\title{
GEOLOGIC STUDIES IN ALASKA by the U.S. Geological Survey during 1987
}

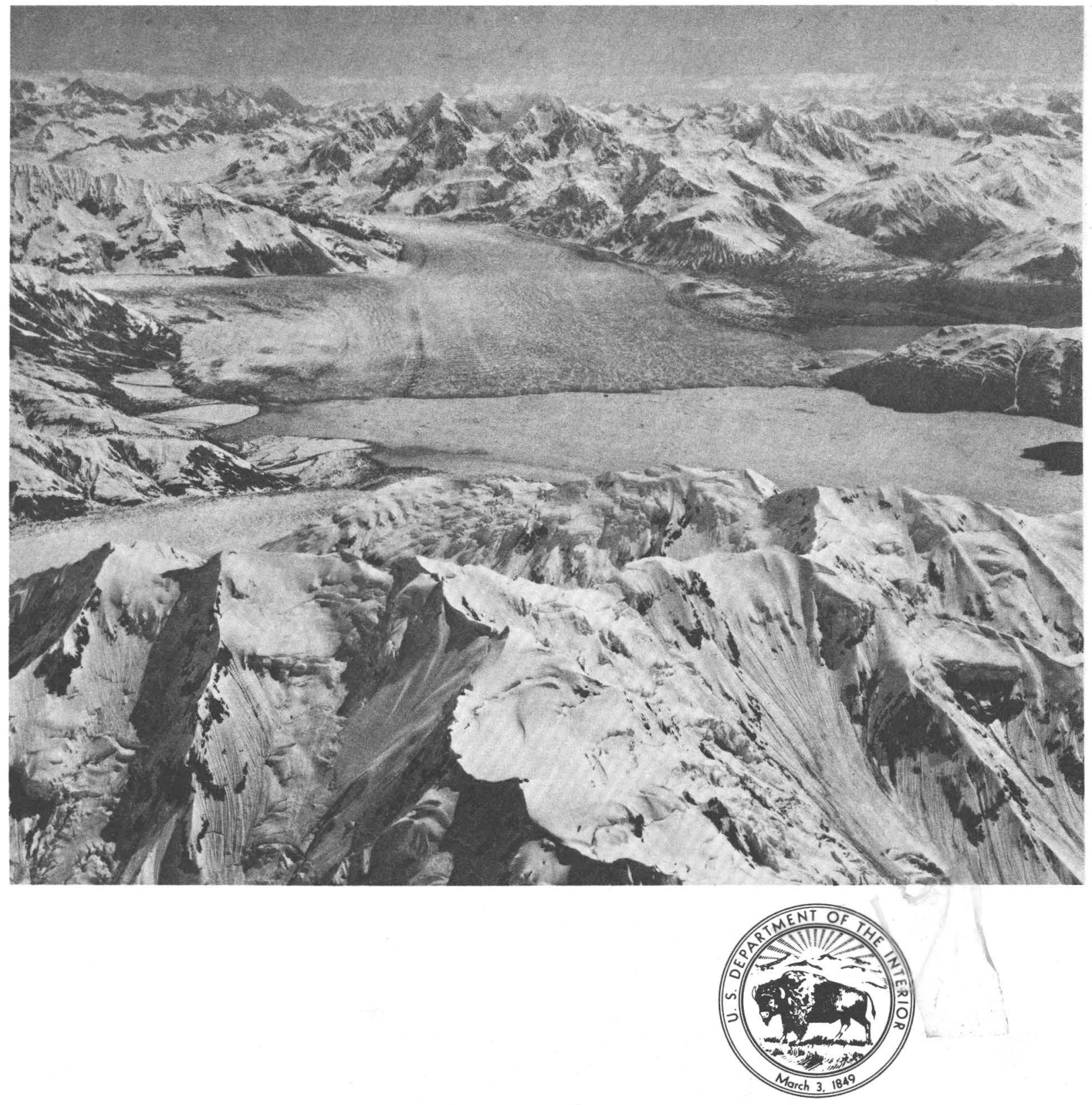

U.S. Geological Survey Circular 1016 
Front cover: View northeast to terminus of Hubbard Glacier, June 13, 1986. Glacier has advanced to tip of Gilbert Point (right center of photograph), blocking Russell Fiord. Photograph by L.R. Mayo.

Back cover: Terminus of Hubbard Glacier from Osier Island, January 12, 1986. Photograph by L.R. Mayo. 


\section{Geologic Studies in Alaska by the U.S. Geological Survey during 1987}

JOHN P. GALLOWAY and THOMAS D. HAMILTON, Editors

U.S. GEOLOGICAL SURVEY CIRCULAR 1016 
DEPARTMENT OF THE INTERIOR

DONALD PAUL HODEL, Secretary

U.S. GEOLOGICAL SURVEY

Dallas L. Peck, Director

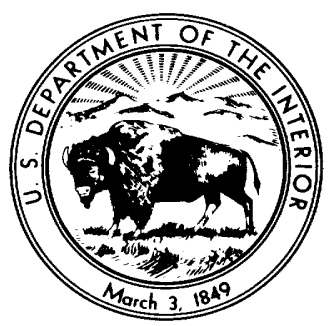

Any use of trade names and trademarks in this publication is for descriptive purposes only and does not constitute endorsement by the U.S. Geological Survey

Library of Congress Catalog Number 76-608093

UNITED STATES GOVERNMENT PRINTING OFFICE, WASHINGTON : 1988

Free on application to the Branch of Distribution

U.S. Geological Survey

Federal Center, Box 25425

Denver, CO 80225

Publication authorized by the Director, U.S. Geological Survey, March 30, 1988 


\section{CONTENTS}

Introduction

John P. Galloway and Thomas D. Hamilton, editors 1

\section{ARTICLE OF SPECIAL INTEREST}

Advance of Hubbard Glacier and Closure of Russell Fiord, Alaska--Environmental Effects and Hazards in the Yakutat Area

Lawrence R. Mayo 4

\section{NORTHERN ALASKA}

A Major Unconformity Between Upper Ordovician and Lower Devonian Strata in the Nanook Limestone, Shublik Mountains, Northeastern Brooks Range

Robert B. Blodgett, David M. Rohr, Anita G. Harris, and Rong Jia-yu 18

Ostracode and Molluscan Assemblages from the Late Neogene Nuwok Member of the Sagavanirktok Formation, North Slope

El isabeth M. Brouwers and Louie Marincovich, Jr. 24

Nearshore Marine Environments of the Alaskan Beaufort Sea During Deposition of the Flaxman Member of the Gubik Formation

L. David Carter, Elisabeth M. Brouwers, and Louie Marincovich, Jr. 27

Stromatolite- and Coated-Grain-Bearing Carbonate Rocks of the Western Brooks Range Julie A. Dumoulin 31

Off-Platform Silurian Sequences in the Ambler River Quadrangle Julie A. Dumoul in and Anita G. Harris 35

Late Wisconsin Eolian Activity and Related Alluviation, Central Kobuk River Valley Thomas D. Hamilton, John P. Galloway, and Eduard A. Koster 39

Decollements in the Endicott Mountains Allochthon, North-Central Brooks Range J.S. Kelley and Diedra Bohn 44

A Thermal Cross Section for the Permafrost and Hydrate Stability Zones in the Kuparuk and Prudhoe Bay Oil Fields

Arthur H. Lachenbruch, S. Peter Galanis, Jr., and Thomas H. Moses, Jr. 48

\section{EAST-CENTRAL ALASKA}

A Late Silurian Age Determination for the Limestone of the Lost Creek Unit, Livengood

C-4 Quadrangle, East-Central Alaska

Robert B. Blodgett, Ning Zhang, Allen R. Ormiston, and Florence R. Weber 54

A Comparative Petrologic Study of Sandstone from the Wilber Creek, Cascaden Ridge, and Wickersham Units in the Livengood Quadrangle

$$
\text { L.D. Gergen, J.E. Decker, and George Plafker } 57
$$

Tertiary Gold-Bearing Gravel at Livengood, Alaska

Susan M. Karl, Thomas A. Ager, Karl Hanneman, and Steve D. Teller 61

Reconnaissance Geochemical Investigations of the White Mountains National Recreation Area, East-Central Alaska

Thomas D. Light, Gregory K. Lee, Richard B. Tripp, and Elizabeth A. Bailey 64 
Ultramafic Rocks of the Livengood Terrane

Robert A. Loney and Glen . R. Himmelberg 68

Mineral Resource Assessment for Part of the White Mountains National Recreation Area Richard B. McCammon, Thomas D. Light, and C. Dean Rinehart 71

Stratigraphy, Sedimentology, and Structure of the Wickersham Terrane in the Cache Mountain Area, EastCentral Alaska

Thomas E. Moore and Warren J. Nokleberg 75

Gold Mineralization by Metamorphic Fluids in the Chandalar District, Southern Brooks Range--Fluid Inclusion and Oxygen-Isotopic Evidence

Scott C. Rose, William J. Pickthorn, and Richard J. Goldfarb 81

\section{WEST-CENTRAL ALASKA}

Factor Analysis of the NURE Stream-Sediment and Lake-Sediment Geochemical Data from the Iditarod Quadrangle John E. Gray, Sarah C. Smith, and Richard J. Goldfarb 86

Glacial Geologic History of the Salmon Lake Area, Seward Peninsula Darre 11 S. Kaufman, David M. Hopkins, and Parker E. Calkin 91

Lahar Deposit in the Iditarod Volcanies, Southwestern Iditarod Quadrangle Robert G. McGimsey and Marti L. Miller 95

Right-Lateral Offset Solution for the Iditarod-Nixon Fork Fault, Western Alaska Marti L. Miller and Thomas K. Bundtzen 99

Geologic Setting and Petrography of the Phyllite and Metagraywacke Thrust Panel, North-Central Alaska John M. Murphy and W.W. Patton, Jr. 104

\section{SOUTHERN ALASKA}

Middle Pennsylvanian Plutonic Rocks Along the Southern Marg in of the Wrangellia Terrane John N. Aleinikoff, George Plafker, and Warren J. Nokleberg 110

Source of the Sanford Volcanic Debris Flow, South-Central Alaska Donald H. Richter, Henry R. Schmol1, and Dana J. Bove 114

Hydrocarbon Source Potential and Thermal Maturity of the Sanctuary Formation (Middle Miocene), Northern Foothills of the Alaska Range Richard G. Stanley 117

Mineralogy and Stage Assignment of Some Tertiary Coal from the Tikishla Park Drill Hole, Anchorage, Alaska G.D. Stricker, M.E. Brownfield, L.A. Yehle, and J.A. Wolfe 121

\section{SOUTHWESTERN ALASKA}

Petrogenesis of the Crooked Mountains Pluton, Bethel Quadrangle: A Preliminary Report

Thomas P. Frost, James P. Calzia, Ronald W. Kistler, and Davison V. Vivit 126

Geochemical Anomalies in the Eastern Katmai Region of the Alaska Peninsula

Richard J. Goldfarb, John E. Gray, and R.B. Tripp 132

\section{SOUTHEASTERN ALASKA}

Relative Timing of Porphyroblast Growth, Foliation Development, and Ductile Shear in Pelitic Metamorphic Rocks from the Juneau Area, Southeastern Alaska

Robert L. Bauer, Glen R. Himmelberg, David A. Brew, and Arthur B. Ford 138 
A Reexamination of the Contacts and other Features of the Gravina Belt, Southeastern Alaska David A. Brew and Susan M. Karl 143

Megafossils (Buchia) Indicate Late Jurassic Age for Part of Kelp Bay Group on Baranof Island, Southeastern Alaska

David A. Brew, Susan M. Karl, and John W. Miller 147

Major-Element Geochemistry of Metabasalts of the Juneau-Haines Region, Southeastern Alaska Arthur B. Ford and David A. Brew 150

Petrography of Sandstones of the Orca Group from the Southern Trans-Alaskan Crustal Transect (TACT) Route and Montague Island

L.D. Gergen and George Plafker 156

$\mathrm{H}_{2}$ S-Rich Vein-Forming Fluids at the Sumdum Chief Gold Mine, Southeastern Alaska

Richard J. Goldfarb, Albert H. Hofstra, Gary P. Landis, and David L. Leach 160

New K-Ar Ages for Plutons on Western Chichagof Island and on Yakobi Island

Susan M. Kar 1, Bruce R. Johnson, and Marvin A. Lanphere 164

Geochemistry and Petrography of Lamprophyre Dike Rocks in the Coast Mountains, Southeastern Alaska John S. Lull and George Plafker 169

Alteration Zoning and Origin of the Alaska-Juneau Gold Deposit

Rainer J. Newberry and David A. Brew 174

\section{OFFSHORE}

Construction of an Arctic Barrier Island by Alternating Sea-Ice Pileup and Overwash P.W. Barnes and Erk Reimnitz 180

Sea-Floor Feeding Traces of Gray Whales and Walrus in the Northeast Chukchi Sea R. Lawrence Phillips and Mitche $11 \mathrm{~W}$. Colgan 183

Late Cretaceous Sediments from the Northeast Chukchi Sea

R. Lawrence Phillips, LedaBeth G. Pickthorn, and Douglas M. Rearic 187

Evidence for Sea-Ice Impact on Icy Reef, Beaufort Sea Coast

Erk Reimnitz and P.W. Barnes 190

\section{BIBLIOGRAPHIES}

Reports about Alaska in USGS Publications Released in 1987 compiled by Ellen R. White 194

Reports about Alaska in Non-USGS Publications Released in 1987 Which Include USGS Authors compiled by Ellen R. White 201

SUBJECT INDEX 208

AUTHOR INDEX 213

AUTHORS' ADDRESSES 214 



\title{
Geologic Studies in Alaska by the U.S. Geological Survey during 1987
}

\author{
By John P. Galloway and Thomas D. Hamilton, editors
}

\section{Introduction}

This volume is a continuation of the annual United States Geological Survey (USGS) Circulars reporting results of work in progress on earth science investigations in Alaska. The series began in 1975 under the title "The United States Geological Survey in Alaska--Accomplishments during $19 \mathrm{xx}^{\prime \prime}$ and has continued since 1986 under the present title. The 40 short papers and the feature article presented here report on some of the geologic studies undertaken in Alaska during 1987 by the USGS, cooperating agencies, and universities.

The reports presented here begin with an article of special interest followed by papers related to the five regional subdivisions of Alaska and to areas offshore on the Alaska continental shelf (fig. 1). Regional papers are presented in sequence from north to south. This year, a keynote article of special interest is devoted to a topic that was prominent in the news during 1987: the advance of Hubbard Glacier and its damming of Russell Fiord near the community of Yakutat in southern Alaska. This report, which deals with a particularly dynamic and hazardous aspect of Alaska's environment, is given a greater depth of coverage than the other papers in this volume. Photographs on the front and back covers illustrate some aspects of Hubbard Glacier's activities.

The 40 other reports in this volume provide a representative sample of current USGS research in Alaska. The topies range widely from mineral resources, including fossil fuels (eight papers), to paleontology, petrology of igneous, metamorphic, and sedimentary rocks, structural geology, and Quaternary geology (four or five reports each). Other papers cover coastal hazards, geochronology, and marine geology.

Two bibliographies following the reports of investigations cover (1) reports about Alaska in USGS publications released in 1987 and (2) reports about Alaska by USGS authors in outside publications in 1987. Author and subject indexes and author addresses are appended at the back of the volume. A bibliography and index of the short papers in past USGS Circulars devoted to Geological Research and Accomplishments in Alaska (1975-1986) has recently been published as USGS Open-File Report 87-420.

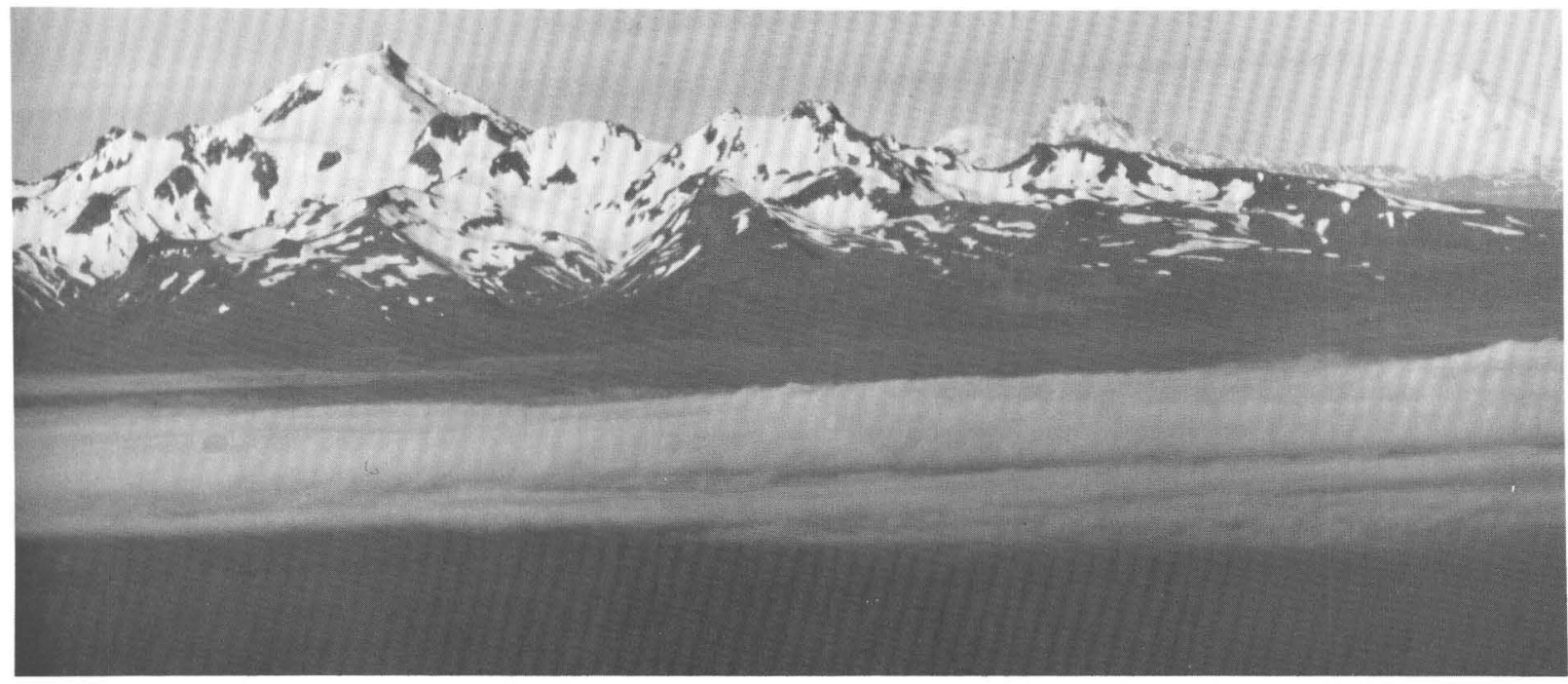

View southwest across Cold Bay to four of Alaska's many volcanoes (from left to right): Frosty Peak and its northwest slope; smooth, snow-covered Roundtop Mountain; "mouse-eared" Isanotski Peaks; and the classic cone of Shishaldin Volcano. 


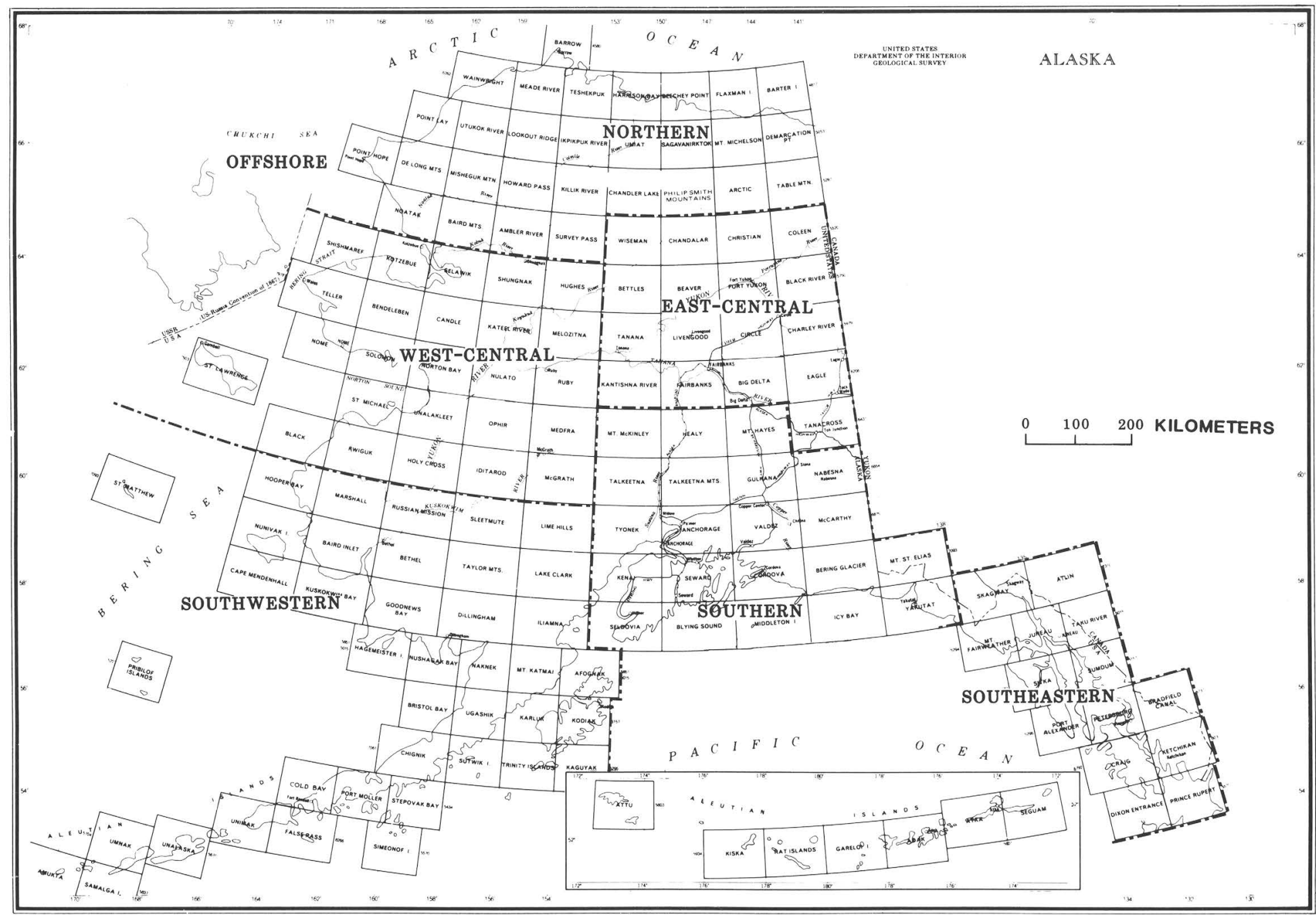

Figure 1. Regions of Alaska as used in this circular and outlines of 1:250,000-scale quadrangles. 


\section{ARTICLE OF SPECIAL INTEREST}

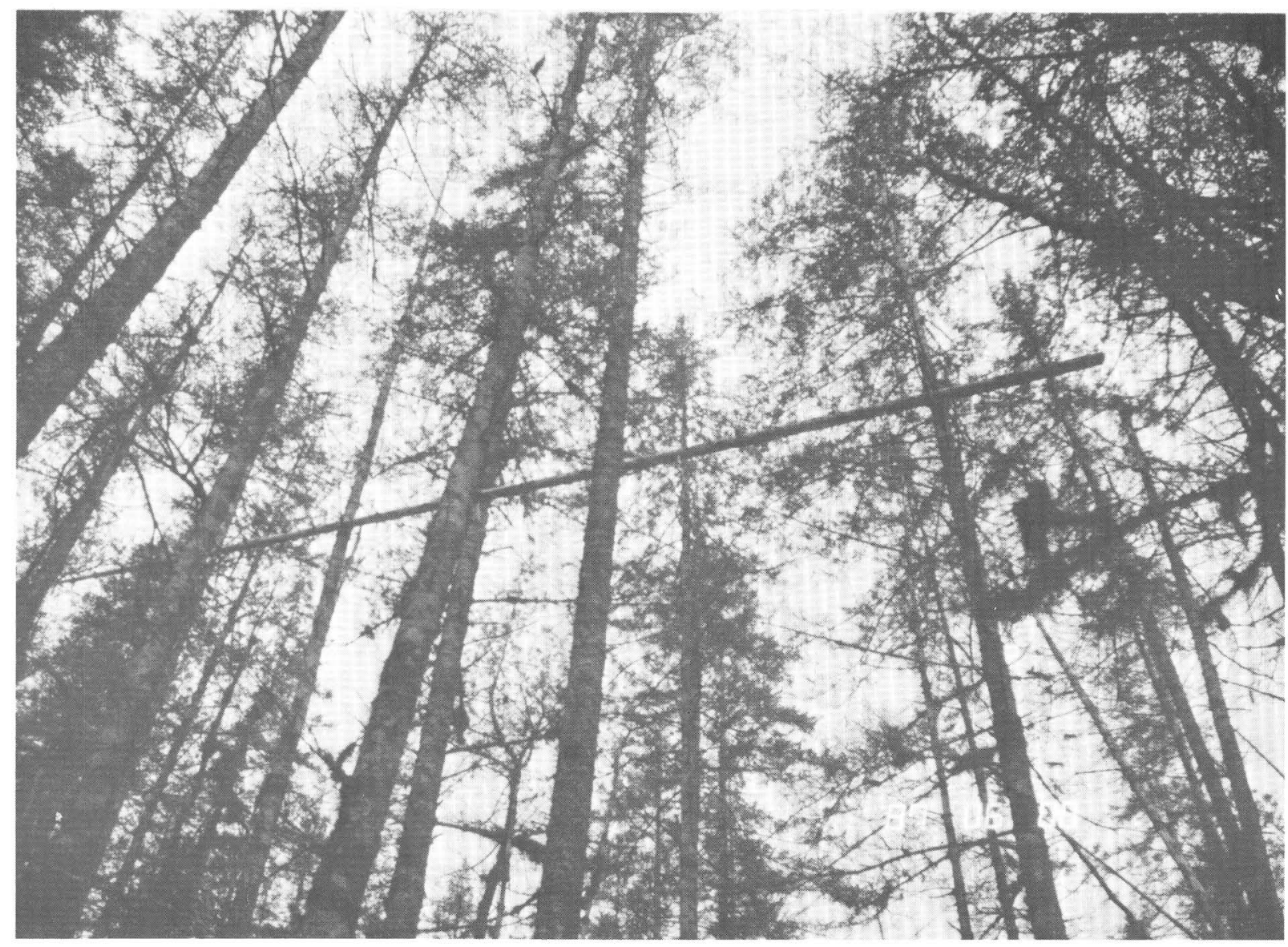

Driftwood log at height of about $15 \mathrm{~m}$ in forest of Sitka spruce at south end of Russell Fiord. Log was stranded by sudden outburst of Russell Lake, which is described in following article. Photographed June 8, 1987, by L.R. Mayo. 


\section{Advance of Hubbard Glacier and Closure of Russell Fiord, Alaska- Environmental Effects and Hazards in the Yakutat Area}

By Lawrence R. Mayo

\section{Introduction}

Hubbard Glacier originates in the Icefield Ranges of Yukon Territory, Canada, and in the St. Elias Mountains of Canada and Alaska. It flows south and southeast for about $120 \mathrm{~km}$ through the St. Elias Mountains into Disenehantment Bay and Russell Fiord near Yakutat (fig. 1). Hubbard Glacier is the largest North American ice stream that presently calves into tidewater. It covers an area of about $3,400 \mathrm{~km}^{2}$ and extends to sea level from an altitude of about 5,800 meters on the flank of Mount Logan, Canada's highest peak.

The terminus of Hubbard Glacier has fluctuated through a distance of more than $60 \mathrm{~km}$ within the past 1,000 years (fig. 1). Earlier advances that repeatedly dammed and released a very large lake in the Russell Fiord basin are recorded by ancient lake sediments that span the past 7,000 years (George Plafker, U.S. Geological Survey, written commun., 1987).

In a study of glacier-dammed lakes of Alaska, it was predicted that Hubbard Glacier would again block Russell Fiord by about 1991 (Post and Mayo, 1971). The temperature and salinity of Russell Fiord consequently were studied by Reeburgh and others (1976) to provide background data in anticipation of a future conversion of the fiord into a lake. They recognized that such a lake could potentially overflow at its south end, causing severe flooding near the town of Yakutat (fig. 1).

Historical records show that Hubbard Glacier has advanced 2 to $3 \mathrm{~km}$ during the past century (the actual distance varies along the terminus). In May 1986, this progressive advance carried it across the entrance of Russell Fiord, where it formed a massive ice dam. Rapid rise in the surface level of the newly created Russell Lake submerged forests to a height of $26 \mathrm{~m}$ and threatened to overflow into the Situk River, a highly productive and economically important salmon stream near Yakutat (fig. 1).

Many glaciers of southern Alaska are subject to major advances and retreats. These events have impacts on lakes, streams, and coastal morphology; on forests and wildlife; and on human ecology. Continuing studies of Hubbard Glacier by the U.S. Geological Survey and other State and Federal agencies are aimed at documenting the mechanism and impacts of the recent Hubbard Glacier advance and reconstructing the history of the glacier's earlier fluctuations. Knowledge obtained from these studies can be used to predict future changes and their environmental effects for Hubbard Glacier and other tidewater glaciers. This paper summarizes the geologic history and recent advance of Hubbard Glacier, its effects, and the implications for assessments of glacier changes throughout southern Alaska.

\section{Glacier history}

Varved lake deposits dating $6,310 \pm 110$ and $4,890 \pm 100 \mathrm{yr}$ B.P. are interbedded with alluvium and glacial till in deltas near the south end of Russell Fiord (George Plafker, U.S. Geological Survey, and J.J. Clague, Geological Survey of Canada, written commun., 1987). These deposits indicate that major advances of Hubbard Glacier or possibly of neighboring glaciers blocked Russell Fiord during middle Holocene time, a period when glaciers throughout the world are generally believed to have been less extensive than at present.

Plafker and Miller (1958) have shown that Hubbard Glacier advanced to the mouth of Yakutat Bay about 1130 A.D. ( \pm 160 years) and deposited the moraine upon which the present town of Yakutat is situated (fig. 1). A distributary ice stream of presumably the same age flowed southeast, filled Russell Fiord with ice, and deposited a terminal moraine at the south end of the fiord. The glacier subsequently retreated to an unknown position, then readvanced into the head of Yakutat Bay by about 1700 A.D. (Plafker and Miller, 1958) (fig. 1).

Hubbard Glacier retreated again after 1700 A.D. During that retreat, Alessandro Malaspina, an Italian explorer who worked for Spain, entered Yakutat Bay in 1791. Malaspina carried a map showing the possible western end of the elusive "Northwest Passage" at the head of the bay (Tarr and Butler, 1909). His observations within the bay indicate that the glacier had retreated at least $20 \mathrm{~km}$ since 1700 A.D., but beyond that point the bay was blocked by "perpetual frost." Malaspina named Disenchantment Bay for his frustrated hopes of finding a navigable passage. Tarr and Butler (1909) concluded that Malaspina's "perpetual frost" was probably only tightly packed floating icebergs rather than the terminus of Hubbard Glacier because the explorers did not report calving from the terminus of the glacier, which would have been an unforgettable hazard to their small boat.

In 1890, I.C. Russell, the first modern scientist to examine the Yakutat Bay region and the first member of the U.S. Geological Survey to study glaciers in Alaska, provided an accurate description of 


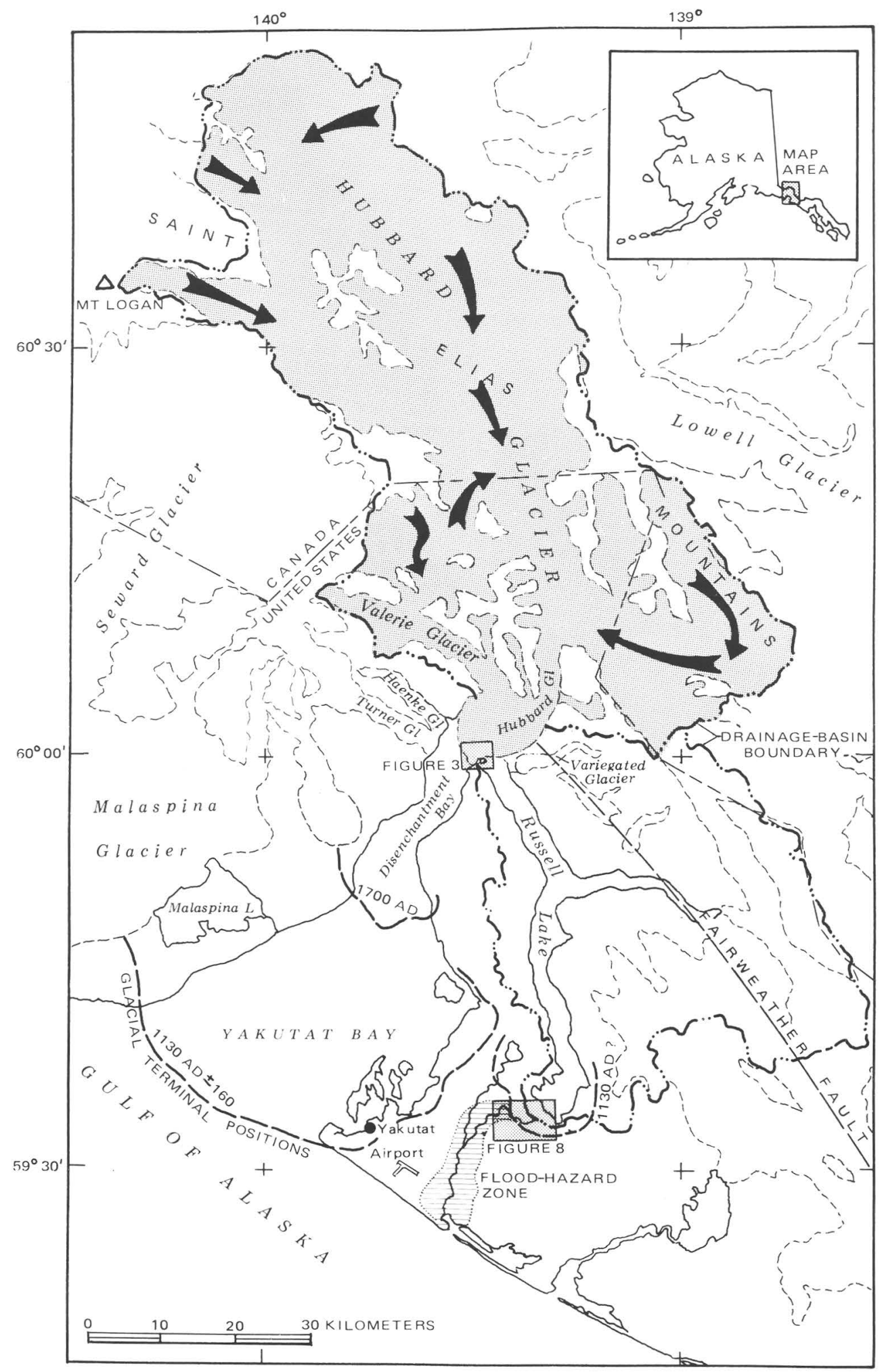

Figure 1. Hubbard Glacier system, showing flow directions (arrows), extent of advances about 1130 A.D. and 1700 A.D., and flood-hazard zone along Situk River. Dashed lines indicate glacier margins. 
the position and features of Hubbard Glacier. His small-scale map and drawing of Hubbard Glacier (Russell, 1891) shows the glacier's terminus approximately $2 \mathrm{~km}$ from Osier Island, leaving open the mouth of a large fiord to the east. That position indicated approximately $28 \mathrm{~km}$ of retreat since the 1700 A.D. advance. Russell probably observed Hubbard Glacier near its maximum recessional position.

In 1891, Russell (1893) traveled into the fiord that later was named after him (Gannett, 1902) and recognized from the pioneer vegetation and fresh shoreline features along its walls that the fiord had been the site of a recent glacier-dammed lake.

An ethnographic description of this lake was given in 1952 to Frederica de Laguna $(1972$, p. 287) by Harry K. Bremner, a Tlingit Indian of Yakutat, whose father had witnessed the outburst of the lake as a child. Bremner stated: "About the middle of the last century ... people were near the lake picking strawberries... That was what my father was doing. Every time he came back to the boat, he found that it was going dry, so he would push it off into deeper water before going back for another load. When this happened a few times he realized that the water was really going down. Everybody ran and got into the canoes and started down the stream. Suddenly a big mass of salt water rushed downstream. Everybody got away safely. There was still enough water in the stream for the canoes. But after that, Situk River was just a little one."

Elders in Yakutat believe that this event occurred about 1860 (Elaine Abraham, oral commun., 1986). This is supported by annual rings of a spruce tree on the former lake bed, which indicate that the tree began growth in 1885 .

During the 96 years since Russell's observations, Hubbard Glacier has readvanced about $2 \mathrm{~km}$ across the fiord entrance at the head of Disenchantment Bay (fig. 2).

\section{Dynamies of Hubbard Glacier}

From 1961 to 1986, Hubbard Glacier approached Gilbert Point near Osier Island (fig. 2), and the rate of glacier advance increased locally as it entered progressively shallower water at the entrance to Russell Fiord (fig. 3).

Most glaciers advance and retreat synchronously as a result of climatic variations which produce changes in the rate of snow accumulation or ice melting (Nye, 1960). Tidewater glaciers, however, are an exception. Glaciers that terminate in seawater can advance asynchronously and over long distances due to the forward movement of protective submarine terminal moraines (fig. 4A; Post, 1975). These glaciers can also retreat rapidly by calving into the ice-scoured and -deepened fiords behind the moraines if they recede only a short distance from the protective moraines against which they formerly were grounded (fig. 4B). The asynchronous behavior of tidewater glaciers is well illustrated by Columbia Glacier, which is now in rapid retreat (Meier and others, 1985) while Hubbard Glacier is advancing. Glaciers that end in deep lakes, such as Portage Glacier southeast of
Anchorage, behave in a similar way (Mayo and others, 1977).

Hubbard Glacier is in the early phase of a major new advance that began about 100 to 150 years ago. The glacier has a strong positive ice balance because its last recession resulted in the loss by rapid calving of most of its ablation zone. At present, 95 percent of Hubbard Glacier is above the local snowline or equilibrium line altitude (ELA) at $1,000 \mathrm{~m}$ altitude (fig. 4), and therefore is within the accumulation zone. A glacier that has fully advanced to an equilibrium position typically has about 60 to 70 percent of its total area within its accumulation zone (Meier and Post, 1962).

The current advance of Hubbard Glacier is controlled by the movement of a submarine moraine at the ice terminus, which was discovered by ice radar and fathometer surveys (Mayo, 1987). The glacier terminus is in shallow water that varies from 0 to $50 \mathrm{~m}$ deep at the crest of this moraine. The fiord is $205 \mathrm{~m}$ deep $2 \mathrm{~km}$ in front of the moraine crest, and the glacier bed is $320 \mathrm{~m}$ below sea level $2 \mathrm{~km}$ behind the moraine crest (fig. 5). The shallow water at the moraine limits the rate of ice calving (Brown and others, 1982). The process of displacement of the moraine into Disenchantment Bay by Hubbard Glacier is demonstrated by the fact that the glacier bed is now more than $300 \mathrm{~m}$ below sea level at the position where the glacier terminus had been mapped in 1895 by the International Boundary Commission (1952).

\section{Recent glacier advance and lake formation}

Photographs taken during repeated overflights of Hubbard Glacier in April and May 1986 by residents of Yakutat show that the glacier was advancing rapidly across the entrance of Russell Fiord at a rate of approximately $10 \mathrm{~m}$ per day and that submarine deposits were being raised above sea level by the plowing action of the glacier. Closure of the mouth of Russell Fiord was completed on May 29, 1986, and the newly-formed Russell Lake began filling (fig. 6). Although Hubbard Glacier advanced toward the terminus of Variegated Glacier to the east, the two glaciers remained separated by a stream flowing between them. Hubbard Glacier began to overrun Osier Island during the remainder of 1986, but stopped short of the summit of the island (figs. 2 and 3 ).

Scientists of the U.S. Geological Survey, the U.S. Forest Service, and the University of Alaska initiated research projects during the summer of 1986 in cooperation with the National Park Service, the City of Yakutat, and the National Geographic Society. Their studies included determination of the causes of Hubbard Glacier's behavior, measurements of the rate of filling of Russell Lake, precision remapping of the Yakutat Forelands, estimation of the flooding of the Situk River should Russell Lake overflow, and archeology in areas potentially subject to flooding.

The rapid ice advance in 1986 was caused by a weak and short-duration surge of Valerie Glacier, a tributary of Hubbard Glacier (fig. 1). The surge, which had a measured flow rate of $36 \mathrm{~m} / \mathrm{d}$ in June 1986, produced unusual crevassing and marginal wrench faults in Valerie Glacier. The rapid advance of 
Hubbard Glacier resulted in the plowing of shallow marine sediments between the glacier and the shore at the entrance to Russell Fiord. These sediments were pushed above sea level and calving losses at the terminus were eliminated, which then resulted in continuing advance. (Mayo, 1987). The surge ended in late June 1986, and no further rapid advance of Hubbard Glacier took place after that time.

At the same time that significant advance was occurring in shallow water near Gilbert Point (fig. 3 ), advance was negligible at locations along the terminus of Hubbard Glacier where the water was more than $200 \mathrm{~m}$ deep in front of the moraine. This indicates that the rate of advance along the terminus of advancing tidewater glaciers is related inversely to the amount of subglacial sediment required to fill the fiord in front of the moraine. The location of the Hubbard Glacier ice dam in 1986 was controlled by the presence of shallow unconsolidated deposits on bedrock near the glacier terminus; but the timing of the closure in 1986 was controlled by the weak surge of the Valerie tributary of Hubbard Glacier. The bedrock core of

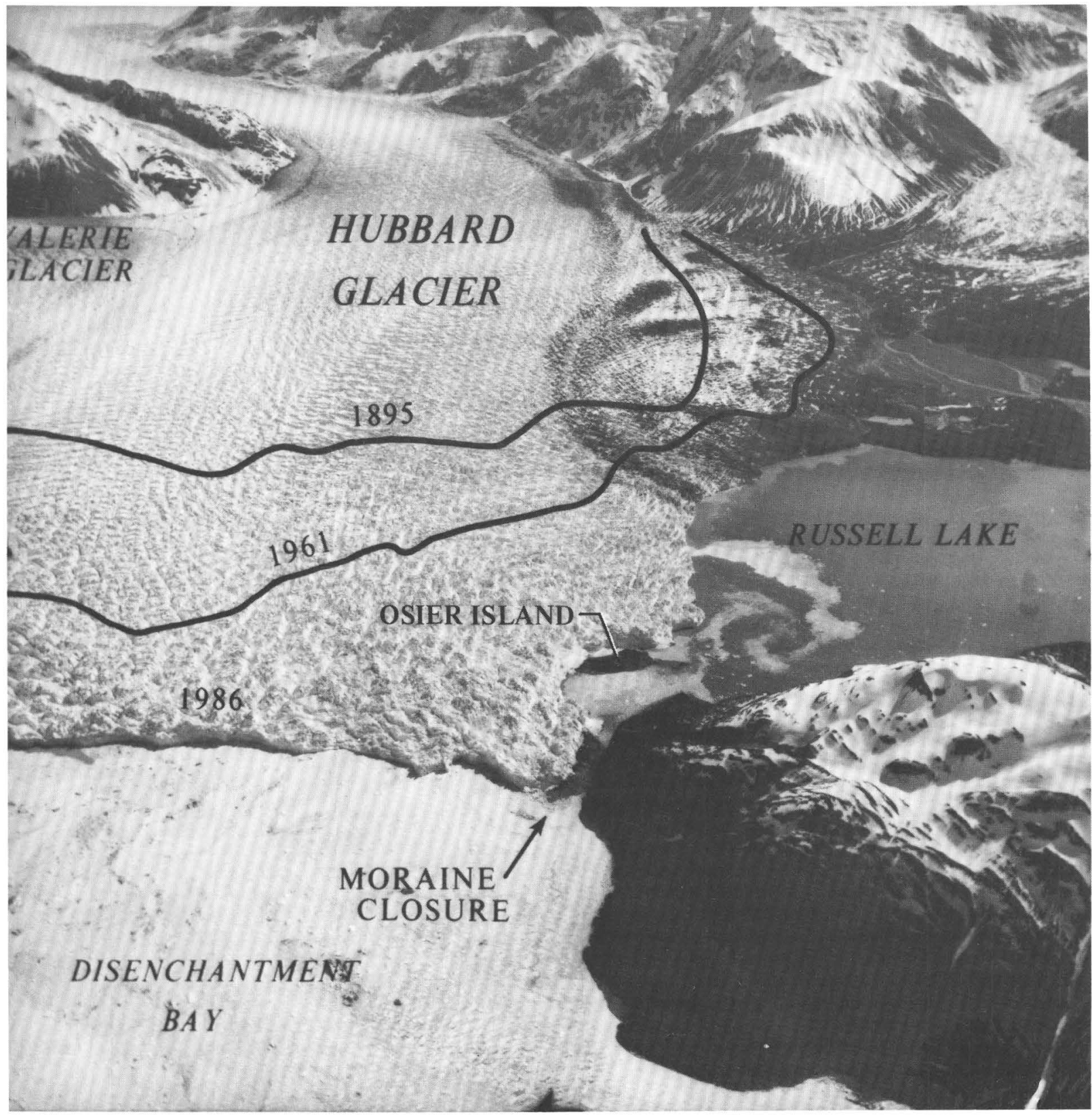

Figure 2. View east to terminus of Hubbard Glacier June 13, 1986. Glacier position in 1895 from International Boundary Commission (1952); position in 1961 from U.S. Geological Survey Mount St. Elias (A-4) and (A-5) 1:63,360 quadrangle maps. Gilbert Point is in the right foreground. 
Osier Island served as a buttress against rapid ice flow and terminus advance in June 1986 (fig. 2).

During the summer of 1986 , Russell Lake rose rapidly (fig. 6), inundating about $33 \mathrm{~km}^{2}$ of forested land adjacent to the blocked fiord. Half of its drainage basin is occupied by glaciers, and ice melt and rainfall runoff from these glaciers produced about 80 percent of the runoff feeding the lake. The lake area, beginning at $195 \mathrm{~km}^{2}$, was equal to about 10 percent of the basin area, so the measured lake rise during the summer of 1986 of $25.5 \mathrm{~m}$ (based on data of Seitz and others, 1986) was equivalent to an average about $2.5 \mathrm{~m}$ liquid runoff from the basin. Very high runoff rates, $3.8 \mathrm{~m}$ per year at Bering Glacier east of Hubbard Glacier, had been calculated from observed glacier equilibrium line altitudes (Mayo, 1986), but the simple volumetric measurement of runoff into Russell Fiord is the first direct data obtained for a large basin with glaciers in this part of Alaska.

As Russell Lake rose in the summer of 1986 , several consequences were possible: (1) the lake could overflow and burst out through the new moraine formed from submarine sediments plowed against Gilbert Point by Hubbard Glacier at the north end of Russell Fiord, (2) the lake could overflow onto the Yakutat Foreland at the south end of Russell Fiord, or (3) the lake could burst out through the ice dam. Hubbard Glacier did not advance fully to the bedrock ridge at the entrance to Russell Fiord. The marine sediments plowed from the fiord in April and May 1986 were trapped between the glacier ice and the ridge, forming a moraine (fig. 2). As the glacier pushed forward, the moraine was squeezed and deformed

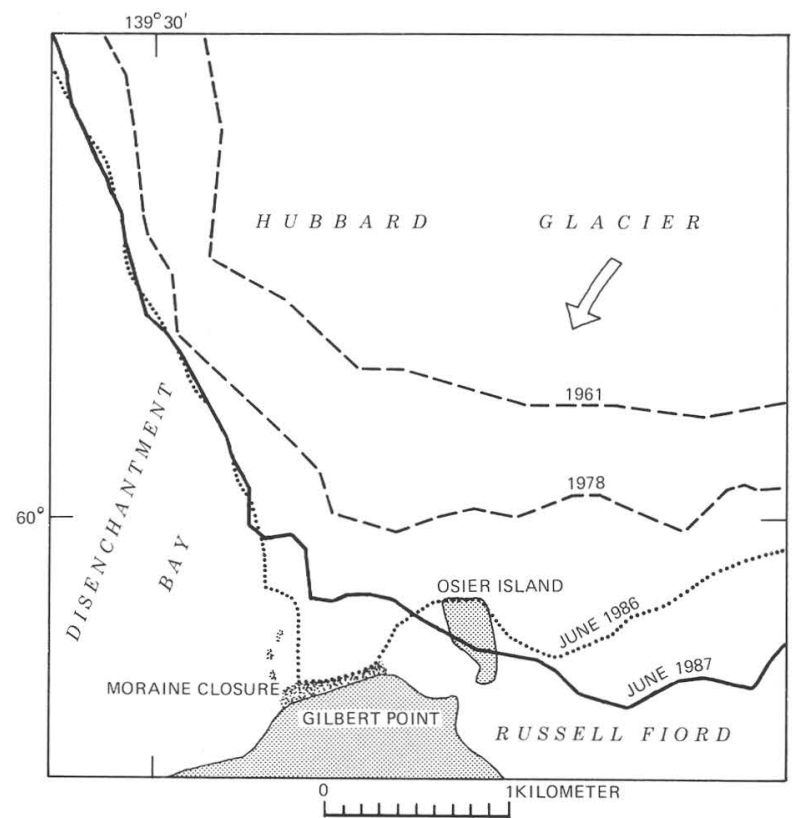

Figure 3. Terminal positions of Hubbard Glacier from 1961 to June 1987 at entrance of Russell Fiord. Glacier position in 1961 from maps cited in figure 2; position in 1978 from Krimmel and Sikonia (1986). Arrow indicates direction of flow. See figure 1 for location. upward. The overflow point on the moraine rose at a rate that was faster than the filling rate of the lake (fig. 7), and overflow therefore did not occur.

Potential lake overflow sites also exist at the south end of Russell Fiord, $50 \mathrm{~km}$ beyond the terminus of Hubbard Glacier. The lowest site is situated $39 \mathrm{~m}$ above sea level in a recently reforested channel in the moraine at the head of Old Situk Creek (fig. 8). The overflow channel contains a lag deposit of boulders derived from the moraine, and is undoubtedly the channel used over a century ago by the Tlingit Indians to gain access by boat into Russell Lake. Remapping of the Yakutat Foreland (fig. 8) was undertaken as a joint project by the U.S. Forest Service and the U.S. Geological Survey in 1986 to obtain precise altitude data in areas possibly subject to flooding from the potential filling and overflow of Russell Fiord (fig. 1).

Before overflow could occur across the moraine at either end of the lake, the lake burst out through the 500-m-wide ice dam, which proved to be too narrow to contain Russell Lake. The calving rate from the Disenchantment Bay side of the ice dam exceeded the lateral deformation rate of the dam, causing it to become progressively narrower (eventually only $150 \mathrm{~m}$ wide; see fig. 9). Small ponds of meltwater trapped in crevasses at the edge of the ice dam indicated that water pressure in the dam was higher than at Russell Lake; this increased the calving rate into
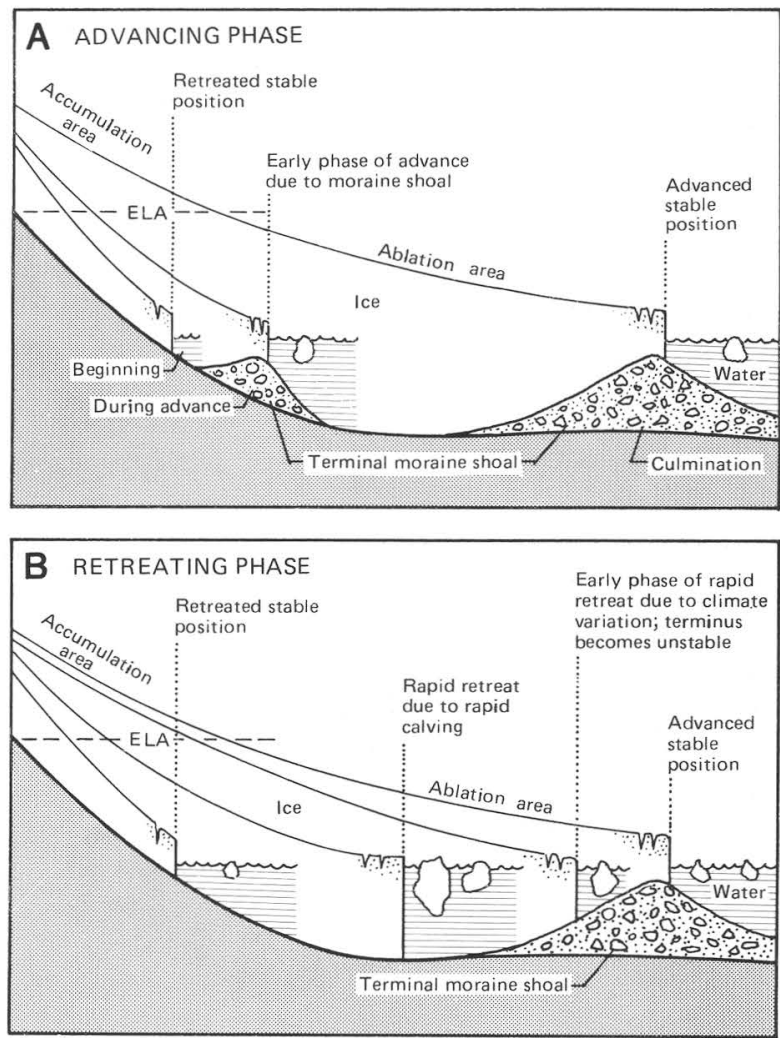

Figure 4. Cycle of advance and retreat of a tidewater glacier. ELA (equilibrium-line altitude) is position on glacier where annual snow accumulation equals annual snow melt. 
Disenchantment Bay, resulting in a deep embayment in the ice dam during September and early October.

During the afternoon of October 7, 1986, lake water began flowing through the maze of crevasses in the ice dam, carrying with it small fragments of ice. In the late evening of the same day between $10: 15$ and 10:45 p.m. Standard Alaskan Time, when the lake height peaked at $25.5 \mathrm{~m}$ above sea level and with 5.3 $\mathrm{km}^{3}$ of water stored, the ice dam failed. Thunderous calving every few seconds for several hours during the night indicated that failure occurred by progressive collapse of massive ice blocks into the outburst channel (fig. 10). At the same time, the channel widened by erosion of alluvial fan deposits and highly jointed bedrock on Gilbert Point.

Measurements of lake height were obtained during the outburst at a site located $8 \mathrm{~km}$ from the failing ice dam (Seitz and others, 1986). The maximum
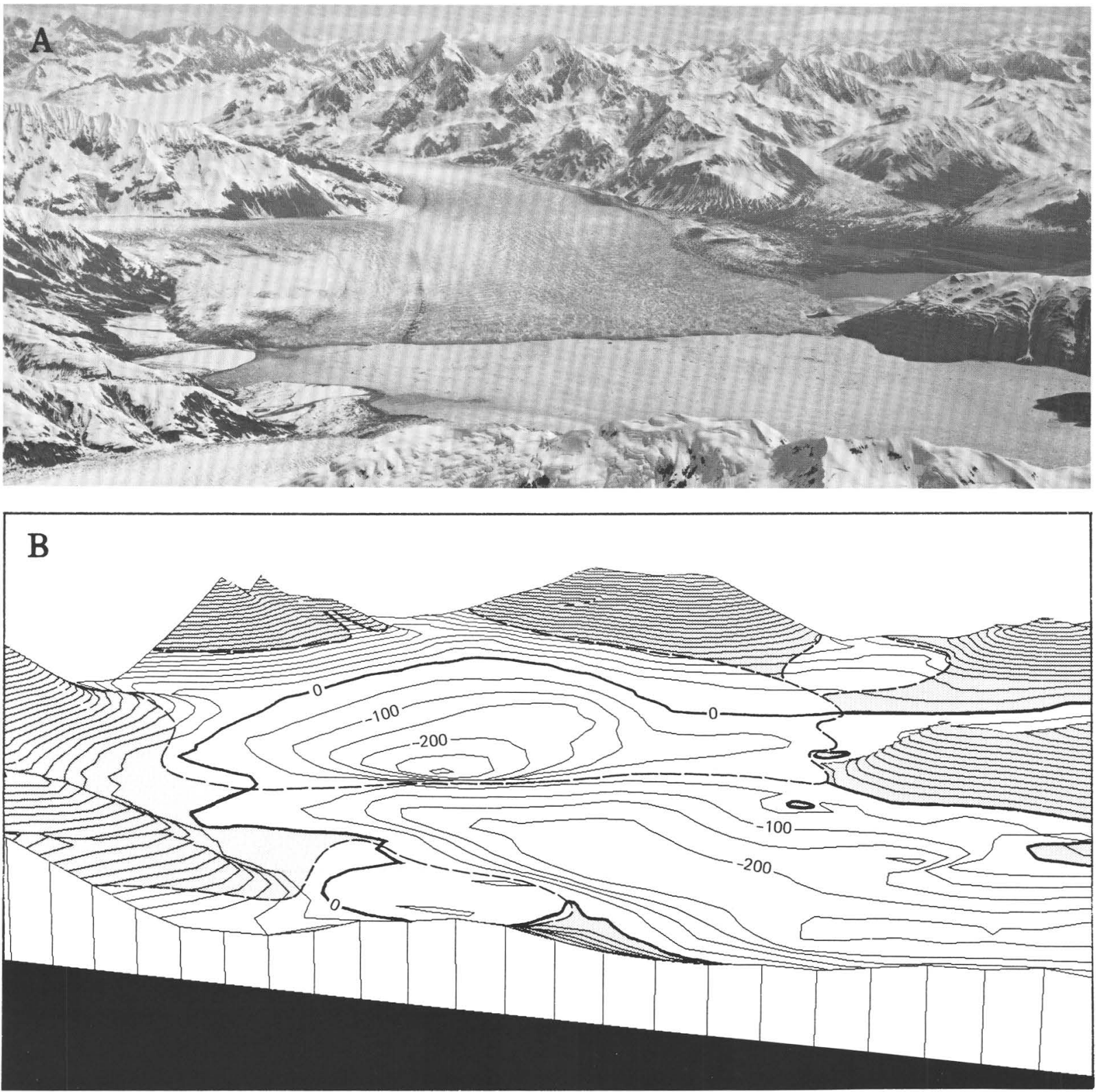

Figure 5. View northeast showing surface and bed of Hubbard Glacier. A, Photograph taken June 13, 1986. Turner Glacier in lower left corner; Gilbert Point and Russell Lake near right margin. B, Computer-drawn perspective contour map showing exposed land (shaded), glacier limits (dashed lines), bed of Hubbard Glacier (unshaded) and fiord bottom (unshaded). Contour interval 50 m; altitudes above and below mean sea level. Note submarine moraine at Hubbard Glacier terminus. 
discharge rate took place between 1 and 2 a.m. on October 8, when the lake dropped $1.68 \mathrm{~m}$. Assuming that the entire lake surface fell equally, the average discharge rate during the interval was $104,500 \mathrm{~m}^{3}$ per second, which greatly exceeded the highest measured rate of flow of the Yukon River, Alaska's largest river $\left(29,000 \mathrm{~m}^{3} / \mathrm{s}\right.$, Jones, 1983$)$. The lake area at that time was $224 \mathrm{~km}^{2}$.

Russell Lake poured into Disenchantment Bay (fig. 11) with a velocity measured at $11 \mathrm{~m} / \mathrm{s}$ at dawn, which was about 4 hours after the time of peak discharge. The momentum of the outburst flood carried the turbulent water 5 to $6 \mathrm{~km}$ across Disenchantment Bay to the west shore where it washed against the terminus of Turner Glacier.

The peak flow rate of the "Russell River" may be the greatest water discharge to occur in North America and the largest glacier outburst in the world measured during the past few centuries (table 1), but was much less than the estimated peak discharge of 15 to $17 \mathrm{million} \mathrm{m}^{3} / \mathrm{s}$ from late Pleistocene Glacial Lake Missoula when it burst out into the Columbia River between 16,000 and 12,000 years ago ( $\mathrm{O}^{\prime}$ Connor and Baker, 1987; Baker, 1973), creating the Channeled Scablands of eastern Washington. Prior to the 1986 outburst of Russell Lake, the greatest known historical outburst was from the June 5, 1976, failure of the Teton Dam, Idaho, which was $65,000 \mathrm{~m}^{3} / \mathrm{s}$ (Ray and Kjelstrom, 1978, Costa, 1985). The largest known historic glacier outbursts in Alaska have been from Chakachamna Lake, which is dammed by Barrier Glacier at Mount Spurr volcano, and from Berg Lake, which is dammed by Bering and Stellar Glaciers.

Russell Lake had not fully emptied by 9 p.m. on October 8 when observations stopped, but was still 2 to $3 \mathrm{~m}$ higher than the water surface in Disenchantment Bay. A normal tidal current was observed flowing from Russell Fiord on the morning of October 9, indicating that the outburst had ceased. The outburst of the lake probably had continued until about 3 a.m. on October 9, when the projected lake height recession was equal to the predicted tide level in Disenchantment Bay. The total outburst period therefore was approximately 28 to 30 hours.

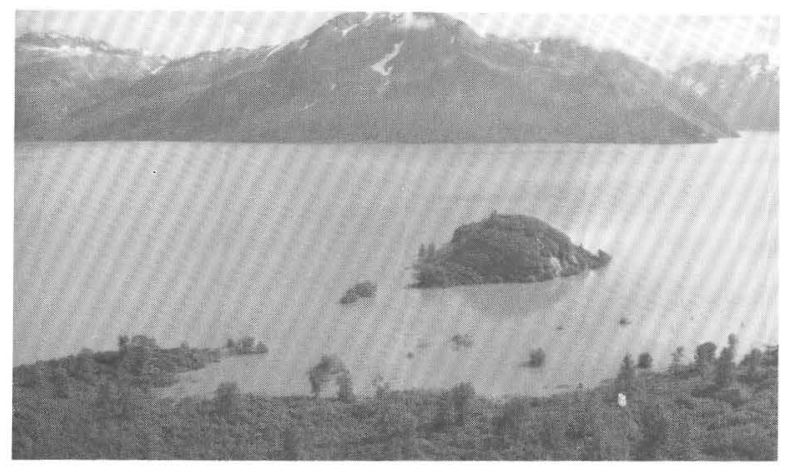

Figure 6. View southeast across Russell Lake showing flooded forest, August 28, 1986. Lake height was $20 \mathrm{~m}$ above sea level at this time.
The outburst eroded the shore of Russell Fiord back by as much as $300 \mathrm{~m}$ in the vicinity of the failing ice dam. Most of the erosion was from an alluvial fan, most of which was swept into Disenchantment Bay, but as much as $50 \mathrm{~m}$ of the highly jointed bedrock also was eroded. Only a small remnant of the terminal moraine remained, and individual boulders of marble as large as $15 \mathrm{~m}$ in diameter had been carried away. Before the outburst, Osier Island had been mantled with glacial till and marine gravel, but these deposits and some bedrock were eroded and generally only small alder roots remained in bedrock fissures. Shrimp found near the top of Osier Island could have been derived only from the bed of Russell Fiord, where they were probably swept up by water turbulence in the lake during its outburst.

Vegetation that had been inundated by the lake was severely damaged. Mud and stones dropped from icebergs that had been floating in the lake had accumulated in tree branches as a form of "arboreal diamicton" (fig. 12), and icebergs that had been floating near the shore of Russell Lake remained grounded in alder forests well above sea level (fig. 13). A brown algal slime covered all vegetation to a height of about $15 \mathrm{~m}$ above sea level at the south end of the former lake, and some logs that had been floating were caught high in tree limbs (see photo on p. 3). By October 1987, one year after the lake had drained, all alder and devil's club vegetation that had been inundated was dead. Other vegetation, including spruce, hemlock, willows, and grasses, that had been flooded for less than a month had partially recovered, but was dead where inundated for longer periods. Several species of horsetails (Equisetum) were already recolonizing the floor of the dead forest in the summer of 1987.

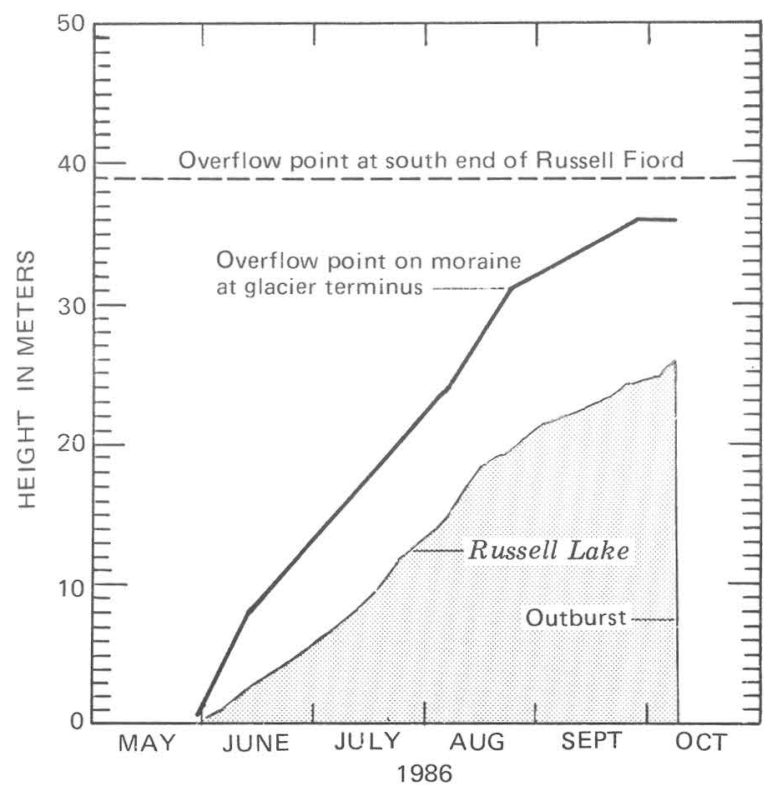

Figure 7. Height of potential overflow point on Hubbard Glacier moraine (measured by aneroid altimeter) and height of Russell Lake (data from Seitz and others, 1986), May to October 1986. 
Table 1. Peak discharges of largest known historic glacial lake outbursts

[Sources: Russell and Berg Lakes, D.C. Trabant, and L.R. Mayo, U.S. Geological Survey, unpub. data; Lake George, U.S. Geological Survey, 1964, 1971, and unpub. data; other lakes, J.E. Costa, 1985, and J.E. Beget, 1986]

\begin{tabular}{lcrl}
\hline \multicolumn{1}{c}{ Location } & \multicolumn{3}{c}{$\begin{array}{c}\text { Peak } \\
\text { discharge } \\
\left(\mathrm{m}^{3} / \mathrm{s}\right)\end{array}$} \\
& Date & Reference \\
\hline 1. Russell Lake, Alaska & 1986 & 104,500 & See text \\
2. Grimsvatn, Iceland & 1934 & 50,000 & Thorarinsson, 1957 \\
3. Chong Kumdan, India & 1929 & 22,650 & Gunn, 1930 \\
4. Berg Lake, Alaska & 1983 & 17,000 & Trabant and Mayo, unpub. \\
5. Chakachamna Lake, Alaska & 1971 & 13,300 & Lamk, 1972 \\
6. Lake George, Alaska & 1958 & 10,200 & USGS, 1964 \\
7. Lake George, Alaska & 1961 & 10,100 & USGS, 1971 \\
8. Lake George, Alaska & 1957 & 9,430 & USGS, unpub. \\
9. Lake George, Alaska & 1960 & 9,290 & USGS, 1964 \\
10. Lake George, Alaska & 1949 & 8,100 & USGS, unpub. \\
11. Gietro, Switzerland & 1818 & 8,000 & Haeber1i, 1983 \\
12. Lake George, Alaska & 1953 & 7,700 & USGS, unpub. \\
13. Lake George, Alaska & 1954 & 7,450 & USGS, unpub. \\
14. Lake George, Alaska & 1955 & 7,300 & USGS, unpub. \\
15. Lake George, Alaska & 1956 & 7,100 & USGS, unpub. \\
16. Lake George, Alaska & 1965 & 6,680 & USGS, 1971 \\
17. Standline Lake, Alaska & 1984 & 6,100 & Sturm and Benson, 1986 \\
18. Lake George, Alaska & 1964 & 6,100 & USGS, 1971 \\
& & & \\
\hline
\end{tabular}

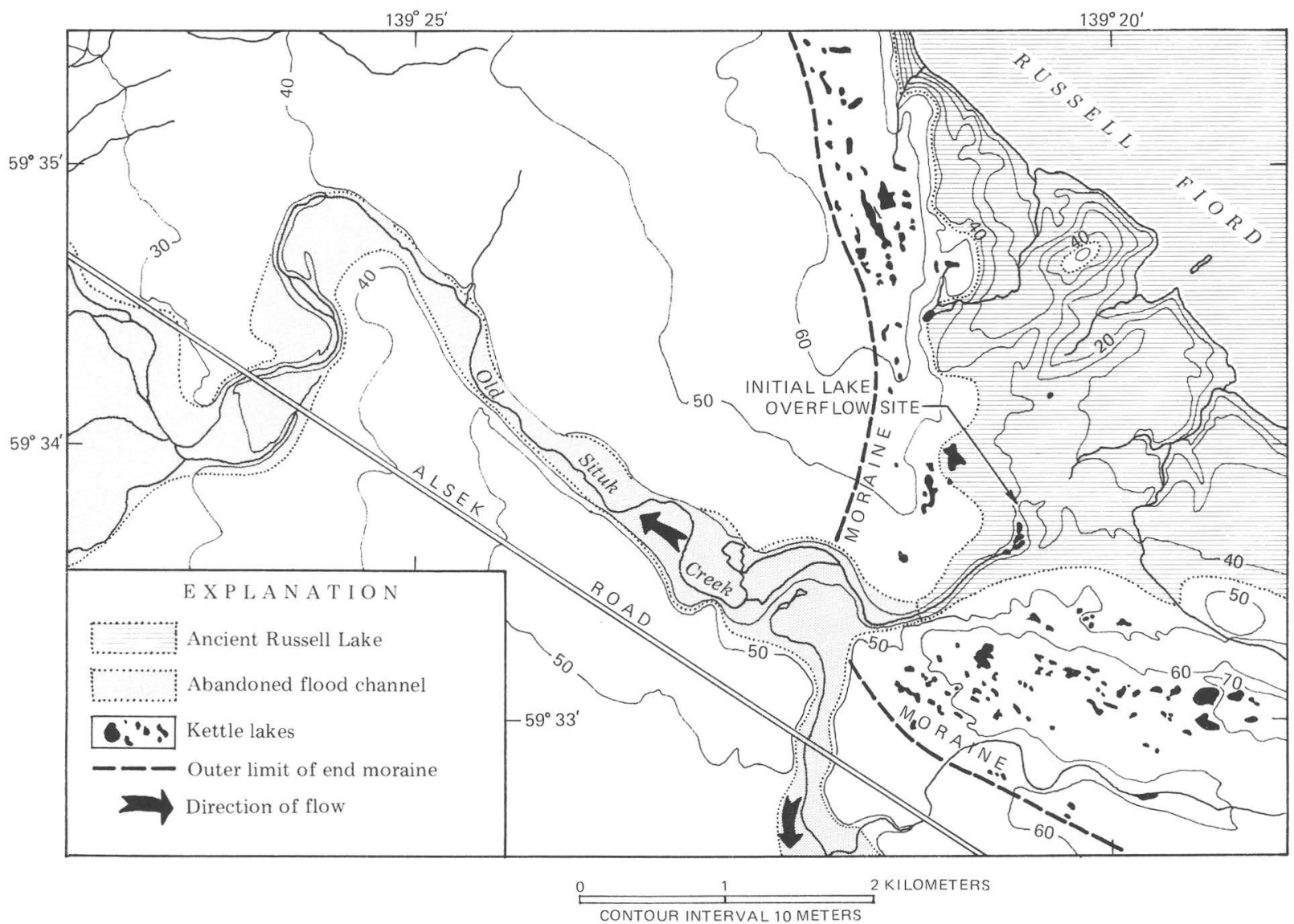

Figure 8. Situk River overflow site $22 \mathrm{~km}$ east of Yakutat at south end of Russell Fiord. Initial overflow point altitude is $39 \mathrm{~m}$ above sea level. Areas subject to flooding by Russell Lake extend to $45 \mathrm{~m}$ elevation. Abandoned flood channel is that of previous overflow of Russell Lake prior to about 1860. Abandoned shoreline and flood channel interpreted from map and aerial photographs. 
The terminus of Hubbard Glacier readvanced during the winter of 1986-1987, overriding most of Osier Island during January. However, it retreated about the same amount during the following summer. At the present time, Hubbard Glacier shows no evidence of rapidly reclosing Russell Fiord. However, the steepened bedrock ridge at Gilbert Point exhibits incipient landslide scarps, which suggests that approximately $500,000 \mathrm{~m}^{3}$ of rock could slide into the narrow opening into Russell Fiord south of the glacier terminus (W.O. Powell, U.S. Forest Service, written commun., 1987). Although that amount of rock would probably not dam the entrance, it could reduce the calving rate of Hubbard Glacier and thereby might lead to rapid reclosure by the ice.

Haenke Glacier, which now enters Disenchantment Bay about $1 \mathrm{~km}$ from the terminus of Hubbard Glacier, surged during 1986-1987: it emerged from the mountains in February 1987 and advanced into Disenchantment Bay by June. Rock debris carried by the Haenke Glacier is entering Disenchantment Bay near the calving terminus of Hubbard Glacier. This additional sediment will decrease the water depth in the bay, which in turn could increase the advance rate of part of the terminus of Hubbard Glacier.

\section{Glacial events and environmental effects: 1988 and beyond}

Hubbard Glacier has advanced for the past 100 to 150 years by moving a submarine moraine into Disenchantment Bay. The glacier will continue to advance, reclosing Russell Fiord in a few years. Hubbard Glacier is capable of sustaining this strong advance because of its unusually large accumulation area compared with its ablation area. In addition, landslides from Gilbert Point or debris deposited by the surging Haenke Glacier could rapidly decrease water depth and calving rate at the terminus of Hubbard Glacier, further increasing its rate of advance. Velocity of Hubbard Glacier is being monitored by satellite telemetry (Trabant, 1986) to provide data essential for assessing its future rate of advance.

The exact nature of future events at Hubbard Glacier is uncertain, but some elements are predictable. When the advancing glacier closes Russell Fiord again, the ice dam can be expected to be wider than it was in 1986 because the glacier currently is advancing along its entire terminus (fig. 3 ). In addition, the overriding of Osier Island in 1987 is evidence that the glacier is becoming thicker at that location. If the ice dam is wider and higher than it was in 1986, it may also be stronger; consequently Russell Lake may rise higher than it did in 1986.

The future Russell Lake could rise to the level of the channel at the south end of Russell Fiord and overflow through it into the Situk River, or it could burst out again by either of two processes. An outburst could occur between Osier Island and Gilbert Point, as it did in 1986, or it could take place through the main mass of Hubbard Glacier north of Osier Island if the rising lake floats the ice free from the fiord floor. In the latter case, a large amount of ice could be carried away by the outburst, leaving a truncated glacier terminus in deep water behind the protective moraine. The stability of the glacier then would be threatened because it could retreat catastrophically by rapid calving into deep water.

If Russell Lake were to overflow into the Situk River, which would occur about 12 to 18 months after the lake began to fill, the lake's surface would continue to rise several meters higher than the initial

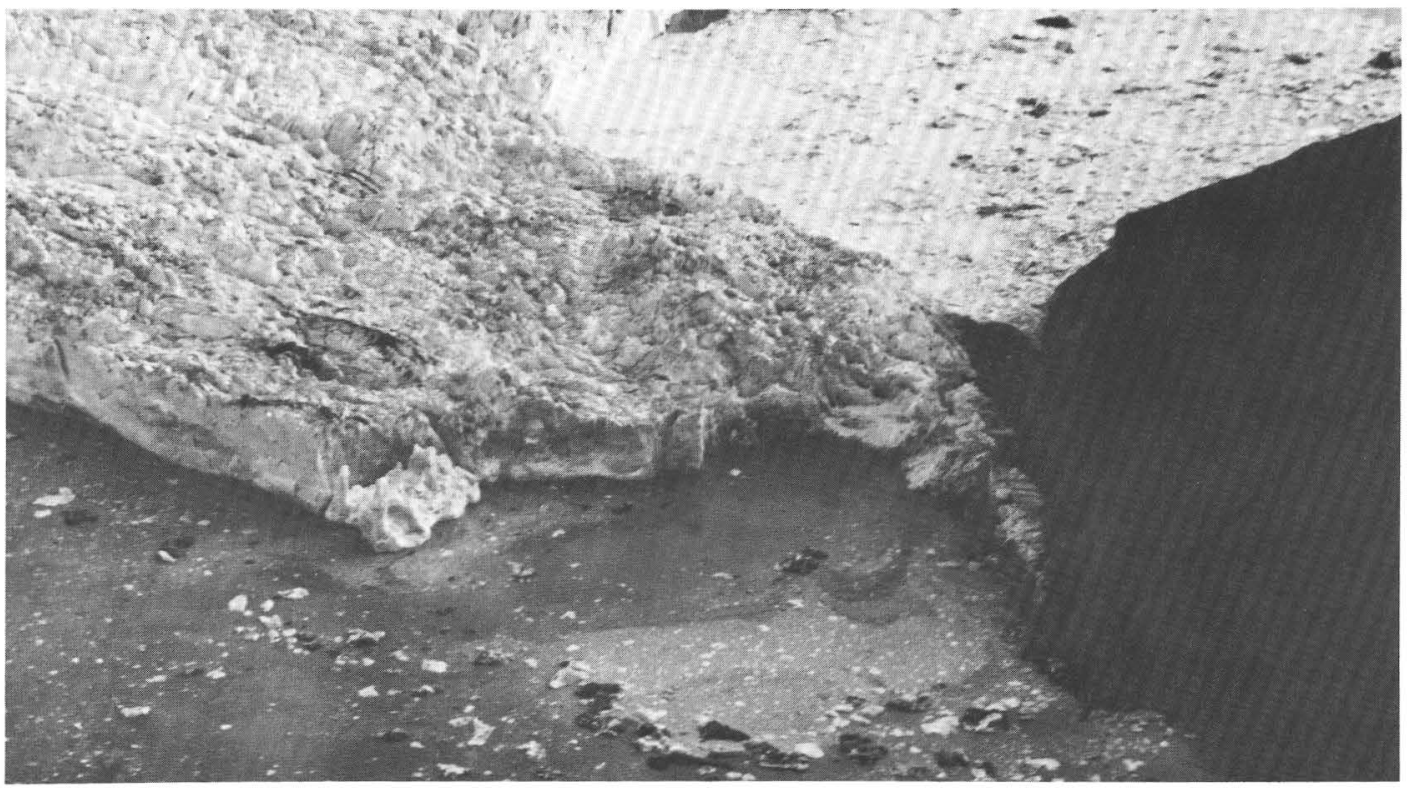

Figure 9. Hubbard Glacier ice dam on October 7, 1986, 10:47 a.m., about 12 hours before its failure. View looking east. 
overflow point by an amount equal to the depth of water in the overflowing river. The lake basin would thus fill to a height of about $45 \mathrm{~m}$ above mean sea level. The extent of the zone of flooding along the river, interpreted from channel scars visible on aerial photographs, is shown in figure 8. The limits of the flood-hazard zone on the Yakutat Foreland closer to the Gulf of Alaska (fig. 1) also is evident on aerial photographs, but future flooding may not be restricted to the former flood channel. The land surface may have been differentially uplifted by tectonic activity, most notably the 1899 Yakutat earthquake, (Tarr and Martin, 1906), and the basin size and runoff rate may not be the same in the future as they were during the last overflow into the Situk River. Although the main channel extends west along Old Situk Creek, a smaller distributary channel extends south at the moraine front (fig. 8), and it also could carry water during times of high future flow.

The average discharge of water from the Russell Fiord basin can be estimated using a runoff model that is based on the observed equilibrium line

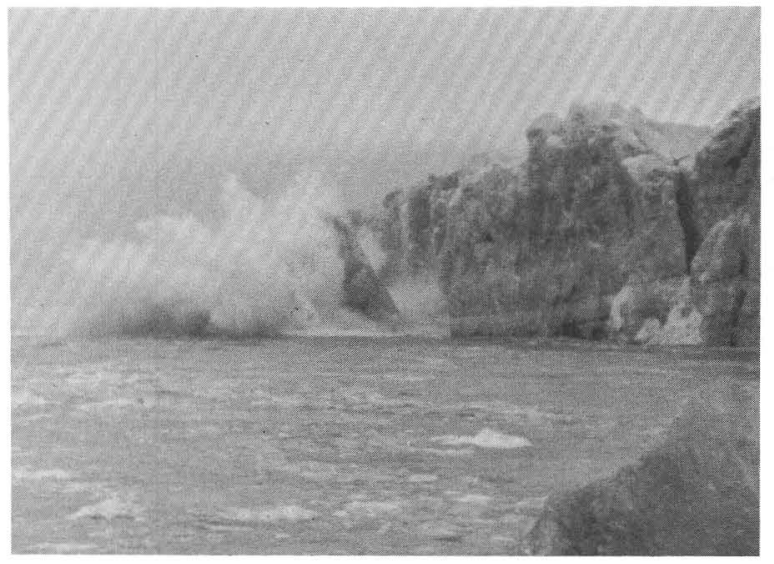

Figure 10. Hubbard Glacier ice dam disintegrating during outburst of Russell Lake; October 8, 1986, 1:56 p.m.

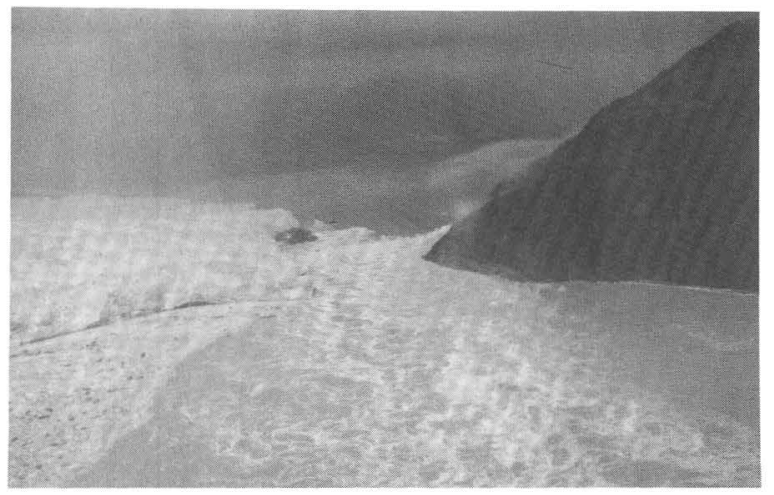

Figure 11. Outburst of Russell Lake and flow of "Russell River" into Disenchantment Bay; October 8, 1986, 9:01 a.m. Discharge rate at that time was approximately $77,000 \mathrm{~m}^{3} / \mathrm{s}$, and water speed in outburst channel was measured at $10.8 \mathrm{~m} / \mathrm{s}$ soon after photograph was taken. altitudes of glaciers (Mayo, 1986). The estimated average discharge would be about $220 \mathrm{~m}^{3} / \mathrm{s}$, and the peak flow each year could be about five times greater (a normal relationship for rivers in Alaska). Unusual flooding events could be even greater. In contrast, the flow of the Situk River during a rainy period in October 1987 was about $30 \mathrm{~m}^{3} / \mathrm{s}$, and the average discharge rate may be only 10 to $15 \mathrm{~m}^{3} / \mathrm{s}$. An orderof-magnitude increase in the flow of the river can be expected to destroy the forest in the revegetated channels, possibly creating sizable log jams that would further intensify the flooding. High flow probably would also cause erosion of soils and sediments, resulting in additional turbidity of the water. Because its basin is dominated by glacier runoff, Russell Lake would contain a significant concentration of suspended clay-size particles that would pass into the river. Changes in both flow and turbidity would affect the highly prized fish resources of the Situk River. Flooding would eradicate sections of the Alsek Road (fig. 8), inundate a small airfield, and affect subsistence fish camps, but at the same time would

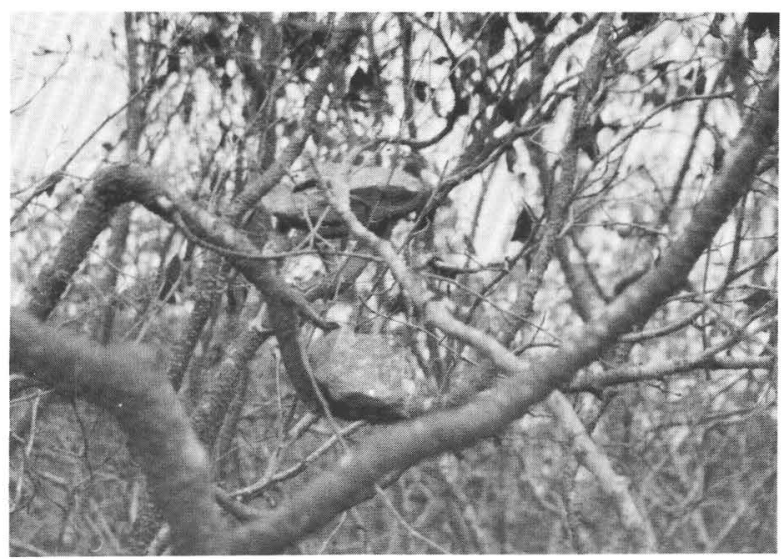

Figure 12. Rocks and mud deposited on alders from icebergs that had been floating in Russell Lake. Photograph taken October 9, 1986.

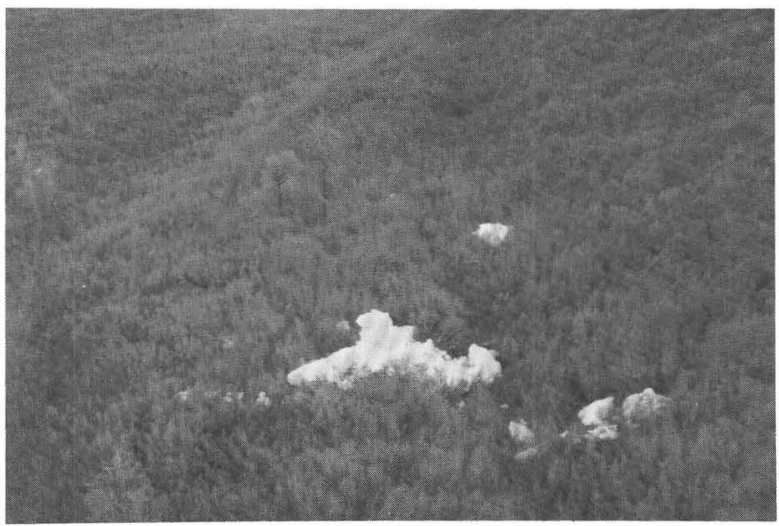

Figure 13. Icebergs stranded in mud-covered forest that had been flooded by Russell Lake. Photograph taken October 9, 1986. 
create a new route by which both boats and fish could enter Russell Lake. During times of combined high tide and high river discharge, the Yakutat Airport, the primary point of access to the Yakutat area, might be subject to minor flooding.

Russell Fiord remains unfrozen at the present time owing to tidal inflow during the winter, but Russell Lake would probably develop winter ice with a cover of snow. The ice and snow cover would increase albedo locally as well as decrease the amount of heat provided by that body of water to the air during severe winter weather. These factors could cause the temperature of air blowing across Russell Fiord to be colder than at present during winter and spring.
After closure of Russell Fiord, tidal flux into Yakutat Bay would be reduced by the amount of water that presently cycles in and out of Russell Fiord. The resulting decrease in tidal currents in Yakutat Bay could cause a decrease in the rate of iceberg flushing from the bay. Migratory fish, which enter Russell Fiord from Yakutat Bay at present, would be blocked by Hubbard Glacier. However, a new path into Russell basin via the Situk River would become available after the lake filled.

The advance of Hubbard Glacier and creation of Russell Lake might also increase water pressure on the Fairweather fault (fig. 1), a plate boundary transform fault, where the fault crosses the Nunatak Arm of
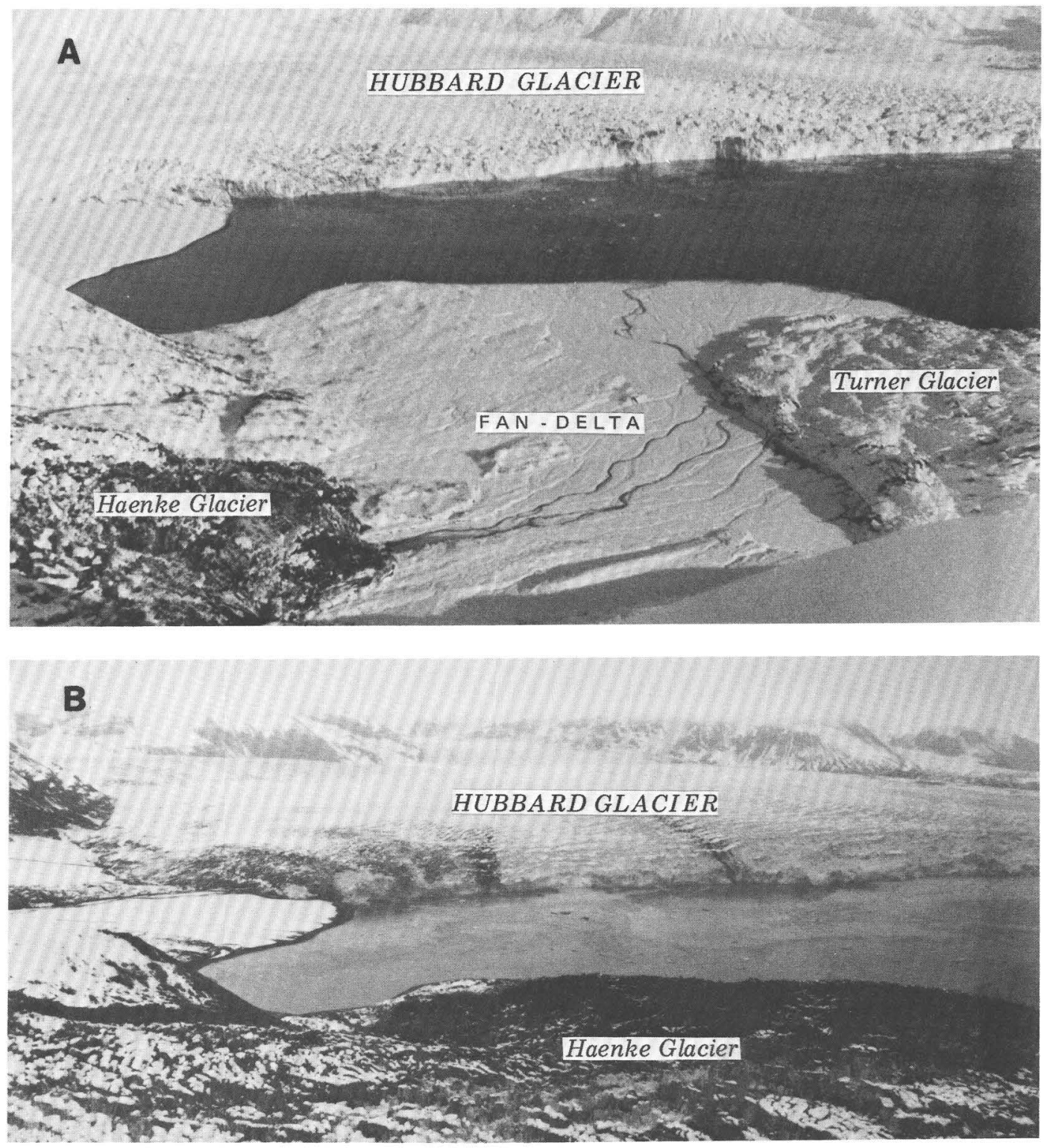

Figure 14. Terminus of surging Haenke Glacier: A, February 13, 1987; B, June 19, 1987. Haenke Glacier surged over fan-delta and terminus of Turner Glacier to become Alaska's newest tidewater glacier. 
Russell Fiord (John Lahr, U.S. Geological Survey, oral commun., 1987). In addition the fiord would be converted into a lake with fresh water "floating" on residual, probably sulfate-rich and anoxic, seawater (Reeburgh and others, 1976). This would produce a drastic change in the ecosystem of the fiord.

\section{Conclusions}

The recent advance of Hubbard Glacier provides a large-scale example of the environmental and economic problems that can result from dynamic glacier fluctuations in Alaska. As glaciers advance and retreat, new glacier-dammed lakes can be formed, drainage basin boundaries can change substantially, the flow regime and quality of rivers can change, and fisheries and forests can be impacted. These changes can, in turn, alter transportation, economic, and recreational activities of people in the regions affected.

Detection of a submerged moraine beneath the terminus of the advancing Hubbard Glacier and the discovery of at least four major glacier advances and recessions during the past 7,000 years strengthens the hypothesis of Post (1975) regarding the behavior of tidewater glaciers. Ongoing studies at Hubbard Glacier suggest that the rate of advance of tidewater glaciers is controlled by the rate of sediment transport by the glacier to its calving terminus, by submarine mass wasting at the moraine front, and by the depth of water in front of the submarine moraine. Measurement of the rate of rise of Russell Lake in 1986 confirmed previously estimated very high runoff rates for the region that had been based on primarily observed equilibrium-line altitudes of glaciers.

\section{Acknowledgments}

Investigations of the Hubbard Glacier and Russell Lake were carried out within the Wrangell-St. Elias National Park and Preserve, administered by the U.S. Department of Interior's National Park Service, and the Tongass National Forest, administered by the U.S. Department of Agriculture's Forest Service. The full cooperation of both agencies greatly faciliated this study. Richard Martin and Clarence Summers of the National Park Service provided permits and equipment. Michael Barton, Kenneth Roberts, Helen Clough, Jere Christner, Bud Tomlinson, David Wood, James Wolfe, William Powell, Patrick Thrasher, and Clarence Rayson of the U.S. Forest Service provided permits, funding, photographs, technical information, equipment, and full support in Yakutat for the investigation. Rod March, Dennis Trabant, and Paul Brooks of the USGS, and Gail Mayo assisted with work at Hubbard Glacier; Donald Thomas and Benjamin Kirkpatrick, USGS, measured the decline of Russell Lake under difficult storm conditions during the night of the outburst. Larry and Caroline Powell of Yakutat made available their library and photographs of the Yakutat area, and discussed extensively with me the effects of Hubbard Glacier's advance. Stimulating discussions with all of the above individuals and with many other residents of Yakutat helped develop a full appreciation of the broad environmental implications of the advance of Hubbard Glacier.
Helen Clough, U.S. Forest Service, Frederica de Laguna, Bryn Mawr College, Thomas Hamilton, USGS, and Gerd Wendler, University of Alaska, provided helpful reviews of this paper. Maps and line drawings were prepared by Robert Gilmore, USGS.

\section{REFERENCES CITED}

Baker, V.R., 1973, Paleohydrology and sedimentology of Lake Missoula flooding in eastern Washington: Geological Society of America Special Paper 144, 79 p.

Beget, J.E., 1986, Comment on "Outburst floods from Glacial Lake Missoula" by G.K.C. Clarke, W.H. Mathews, and R.T. Pack: Quaternary Research, v. 25, p. 136-138.

Brown, C.S., Meier, M.F., and Post, Austin, 1982, Calving speed of Alaska tidewater glaciers, with application to Columbia Glacier, Studies of Columbia Glacier, Alaska: U.S. Geological Survey Professional Paper $1258-\mathrm{C}, 13$ p., 6 plates.

Costa, J.E., 1985, Floods from dam failures: U.S. Geological Survey Open-File Report 85560,54 p.

de Laguna, Frederica, 1972, Under Mount Saint Elias: The history and culture of the Yakutat Tlingit: Smithsonian Contributions to Anthropology, Part 1, v. 7, 547 p.

Gannett, Henry, 1902, Geology and paleontology, in Harriman Alaska Expedition: New York, Doubleday, Page, v. 2, p. 260-261.

Gunn, J.P., 1930, The Shyok flood, 1929: The Himalayan Journal, v. 2, p. 35-47.

Haeberli, Wilfried, 1983, Frequency and characteristics of glacier floods in the Swiss Alps: Annals of Glaciology, v. 4, p. 85-90.

International Boundary Commission, 1952, Establishment of the boundary between Canada and the United States, Tongass Passage to Mount St. Elias: Washington, D.C., U.S. Department of State, $365 \mathrm{p}$.

Krimmel, R.M., and Sikonia, W.G., 1986, Velocity and surface altitude of the lower part of Hubbard Glacier, Alaska, August 1987: U.S. Geological Survey Open-File Report 86-549, $13 \mathrm{p}$.

Jones, S.L., 1983, Floods from small drainage basins in Alaska: U.S. Geological Survey Open-File Report 83-285, 60 p.

Lamke, R.D., 1972, Floods of the summer of 1971 in south-central Alaska: U.S. Geological Survey Open-File Report, 88 p.

Mayo, L.R., 1986, Annual runoff rate from glaciers in Alaska; a model using the altitude of glacier mass balance equilibrium, in Kane, D.L., Cold Regions Hydrology Symposium: American Water Resources Association Technical Publication Series TPS-86-1, p. 509-517.

-.-- 1987, Cause of the advance of Hubbard Glacier, Alaska: American Association Advancement of Science, Arctic Science Conference, 1987, Proceedings, p. 49. 
Mayo, L.R., Zenone, Chester, and Trabant, D.C., 1977, Reconnaissance hydrology of Portage Glacier Basin, Alaska-1972: U.S. Geological Survey Hydrological Investigations Atlas HA583,2 sheets.

Meier, M.F., and Post, A.S., 1962, Recent variations in mass net budgets of glaciers in western North America: International Association of Hydrological Sciences, no. 58, p. 63-77.

Meier, M.F., Rasmussen, L.A., and Miller, D.S., 1985, Columbia Glacier in 1984: Disintegration underway: U.S. Geological Survey Open-File Report 85-81, 21 p.

Nye, J.F., 1960, The response of glaciers and ice-sheets to seasonal and climatic changes: Royal Society, Proceedings, Series A, v. 256, no. 1287, p. 559-84.

O'Connor, J.E., and Baker, V.R., 1987, Peak flood discharges from late Pleistocene Glacial Lake Missoula [abs.]: Geological Society of America Abstracts with Programs, v. 19, no. 7, p. 792 .

Plafker, George, and Miller, Don, 1958, Glacial features and surficial deposits of the Malaspina district, Alaska: U.S. Geological Survey Miscellaneous Geological Investigations Map I-271., scale 1:125,000.

Post, Austin, 1975, Preliminary hydrography and historic terminal changes of Columbia Glacier, Alaska: U.S. Geological Survey Hydrologic Investigations Atlas HA-559.

Post, Austin, and Mayo, L.R., 1971, Glacier dammed lakes and outburst floods in Alaska: U.S. Geological Survey Hydrological Investigations Atlas HA-455, 10 p., 3 sheets.

Ray, H.A., and Kjelstrom, L.C., 1978, The flood in southeastern Idaho from the Teton Dam failure of June 5, 1976: U.S. Geological Survey Open-File Report 77-765, 48 p.

Reeburgh, W.S., Muench, R.D., and Cooney, R.T., 1976, Oceanographic conditions during 1973 in Russell Fjord, Alaska: Estuarine and Coastal Marine Science, p. 129-145.

Russe11, I.C., 1891, An expedition to Mount St. Elias, Alaska: National Geographic Magazine, v. 3, p. 53-204.

Russel1, I.C., 1893, Second expedition to Mount St. Elias, in Powell, J.W., Thirteenth annual report of the United States Geological Survey to the Secretary of the Interior, 1891-'92; Part II--Geology: Washington, D.C., Government Printing Office, p. 7-91.

Seitz, H.R., Thomas, D.S., and Tomlinson, Bud, 1986, The storage and release of water from a large glacier-dammed lake: Russell Lake near Yakutat, Alaska, 1986: U.S. Geological Survey Open-File Report 86-545, $10 \mathrm{p}$.

Sturm, Matthew, and Benson, C.S., 1986, A history of jokulhlaups from Strandline Lake, Alaska, U.S.A.: Journal of Glaciology, v. 31 , no. 109 , p. 272-280.

Tarr, R.S., and Butler, B.S., 1909, The Yakutat Bay region, Alaska; Physiography and glacial geology: U.S. Geological Survey Professional Paper 64, $183 \mathrm{p}$.

Tarr, R.S., and Martin, Lawrence, 1906, Recent changes of level in the Yakutat Bay region, Alaska: Geological Society of America Bullet in, v. 17, p. 29-64.

Thorarinsson, Sigurdur, 1957, The jokulhlaup from the Katla area in 1955 compared with other jokulhlaups in Iceland: Reykjavik, Museum of Natural History Miscellaneous Papers, no. 18, p. 21-25.

Trabant, D.C., 1986, Glacier motion by telemetered satellite navigation positions: American Association Advancement of Science, Arctic Science Conference, 1987, Proceedings, p. 51 .

U.S. Geological Survey, 1964, Compilation of records of surface waters of Alaska, October 1950 to September 1960: U.S. Geological Survey Water-Supply Paper 1740, 86 p.

U.S. Geologica1 Survey, 1971, Surface water supply of the United States 1961-65; art 15. Alaska: U.S. Geological Survey Water-Supply Paper 1936,342 p.

Reviewers: Helen Clough, T.D. Hamilton, Frederica de Laguna, and Gerd Wendler

Geologic Studies in Alaska by the U.S. Geological Survey during 1987: John P. Galloway and Thomas D. Hamilton, editors, U.S. Geological Survey Circular 1016. 


\section{NORTHERN ALASKA}

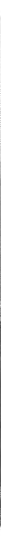

View north across Little Kobuk Sand Dunes to Jade Mountains and other peaks of western Brooks Range. See article by Hamilton and others. Photograph by J.P. Galloway. 


\title{
A Major Unconformity Between Upper Ordovician and Lower Devonian Strata in the Nanook Limestone, Shublik Mountains, Northeastern Brooks Range
}

\author{
By Robert B. Blodgett, David M. Rohr, Anita G. Harris, and Rong Jia-yu
}

Field studies during 1987 helped to characterize a major unconformity separating Upper Ordovician and Lower Devonian strata within the uppermost part of the Nanook Limestone in the Mt. Michelson C-3 quadrangle, northeastern Brooks Range. Two sections (fig. 1) that include the unconformity were measured, and the unconformity was traced between them. Responsibility for the paleontologic results reported here is: Blodgett and Rong, brachiopods; Harris, conodonts; and Rohr, gastropods.

The Nanook Limestone was named by Dutro (1970), who recognized eight informal members and suggested that the entire formation was of Middle Devonian age. Because an angular unconformity separates the Nanook Limestone from the overlying Endicott Group, member 8, the uppermost and thickest member of the Nanook Limestone, is variably preserved. Dutro (1970) gave the thickness for this member as $218 \mathrm{~m}$ in its type section, but farther to the east it thickens to about $625 \mathrm{~m}$.

Blodgett and others $(1986 \mathrm{a}, \mathrm{b})$ recognized the presence of Late Cambrian, Early Ordovician, Middle and (or) Late Ordovician, and late Early Devonian (Emsian) and (or) early Middle Devonian (Eifelian) faunas within member 8 of the Nanook Limestone. In addition, one locality (in section $87 \mathrm{NA}-1$ of this report) was suggested as possibly being of Early Silurian age. Additional studies of the faunas from member 8 of the Nanook now show that both Middle and Late Ordovician faunas are present and that the Devonian strata, lying unconformably on Upper Ordovician strata, are entirely of late Early Devonian (Emsian) age. The suggested Lower Silurian (Llandoverian) strata are now known to be of Late Ordovician age.

Measured section $87 \mathrm{NA}-1$ is $76.2 \mathrm{~m}$ thick (fig. $2)$. The base of the section is at a vertical fault zone at the west end of the traverse. The top of the section is at a covered interval separating the highest exposed beds of member 8 from the overlying beds of the Kayak Shale. An unconformity is present $39.6 \mathrm{~m}$ above the base of the section. The beds below the unconformity are lighter (light brown to medium gray) than the overlying dark-brown to dark-gray strata. Beds immediately above the surface of the unconformity are reddish. Conodonts recovered throughout the section have a color alteration index (CAI) of 4 , indicating that the rocks reached burial temperatures of at least $200{ }^{\circ} \mathrm{C}$.

A conodont sample from $1.6 \mathrm{~m}$ above the base of the section (USGS colln. 10630-CO, fig. 2) produced a monospecific collection of Aphelognathus aff. A. divergens Sweet (figs. $3 \mathrm{~A}-\mathrm{E}$ ), indicating a Richmondian-Gamachian age and a warm, possibly very shallow water depositional environment. Collections relatively abundant in representatives of Aphelognathus divergens and A. shatzeri Sweet, to the virtual exclusion of other conodonts, are also characteristic of an 80-meter, massive, burrowmottled dolostone in the Baird Group of the Hub Mountain area, northeast Baird Mountains quadrangle, western Brooks Range (Dumoulin and Harris, 1987). A single specimen of Phragmodus n. sp. of Barnes (1974) (fig. 3F), together with specimens of Aphelognathus sp. indet., were recovered from $6.1 \mathrm{~m}$ above the base of the section (USGS colln. 10631-CO). Phragmodus n. sp. is known from lower Maysvillian strata in the Canadian Arctic Islands and also occurs in strata of that age in the central Brooks Range (Chandalar D-6 quadrangle, USGS collns. 10582-CO and 10583-CO). Conodonts in overlying collections (USGS colln. 10632$\mathrm{CO}$, in particular) in the Nanook section, however, suggest that this interval is of Richmondian age. Ostracodes were the only other significant faunal element noted this low in the section, and their abundance also suggests a slightly restricted environment.

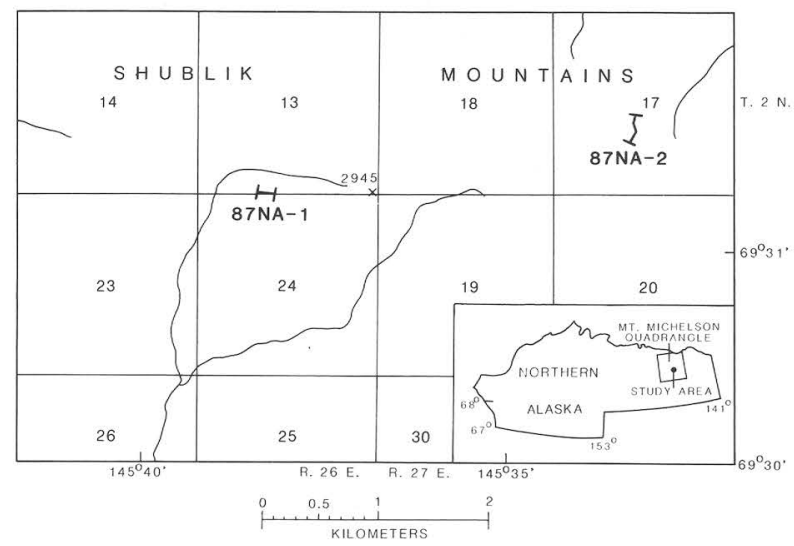

Figure 1. Location of sections (see fig. 2) measured in upper part of member 8 of the Nanook Limestone in Mount Michelson C-3 quadrangle. Base from U.S. Geological Survey, 1955; elevation given in feet. 


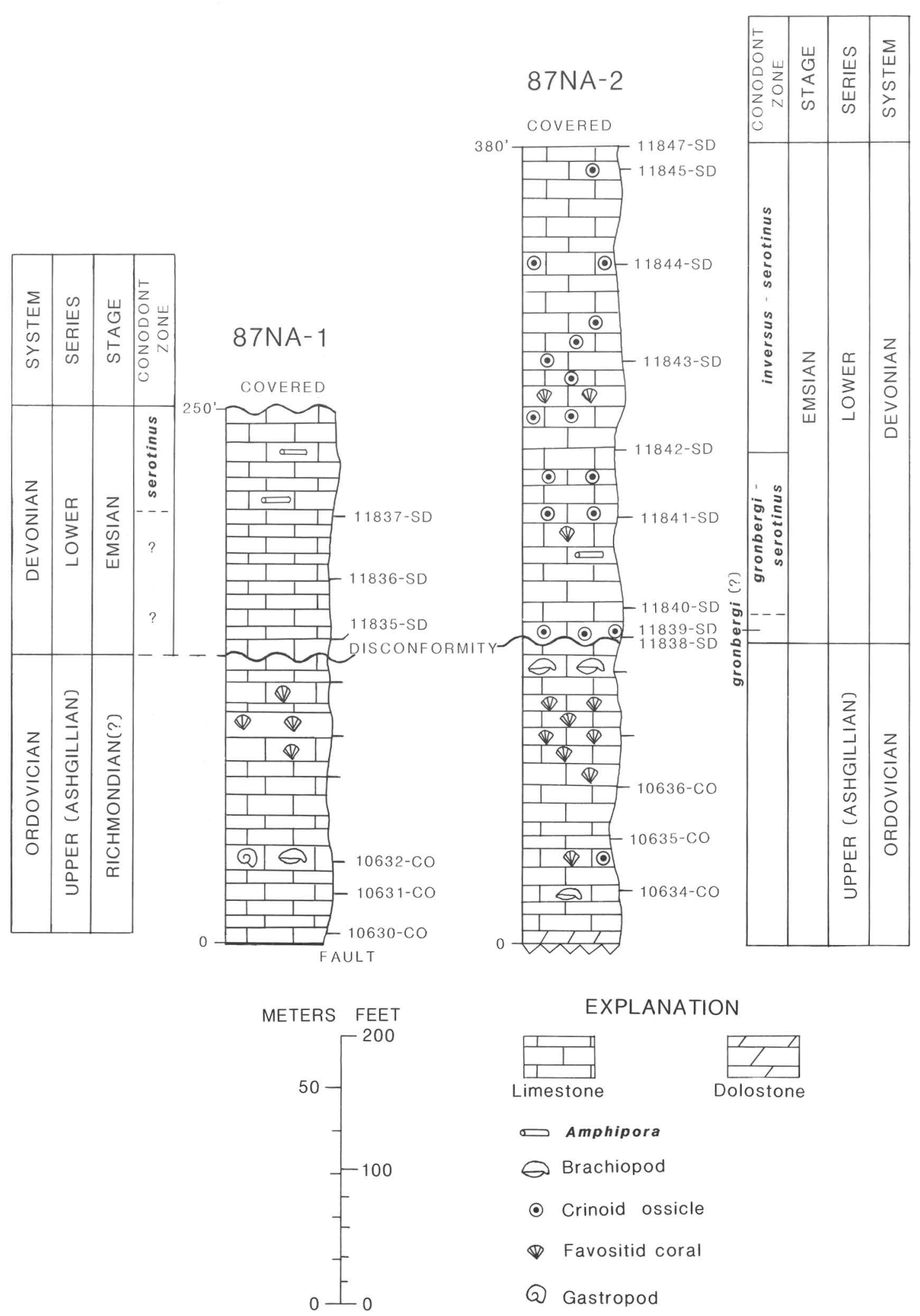

Figure 2. Columnar sections of upper part of member 8 of the Nanook Limestone showing correlation of measured sections $87 \mathrm{NA}-1$ and $87 \mathrm{NA}-2$. Location of sections shown on figure 1. Ticks to right of each column indicate conodont sample. Tick accompanied by USGS collection number indicates that sample yielded relatively biostratigraphically useful conodonts. 
An unusually rich brachiopod-molluscan faunal assemblage was collected 11.0 to $11.3 \mathrm{~m}$ above the base of the section. The brachiopods consist almost exclusively of abundant, disarticulated valves of the pentameracean genus Tscherskidium Nikolaev and Sapelnikov, 1969. Sapelnikov (1985) reported this

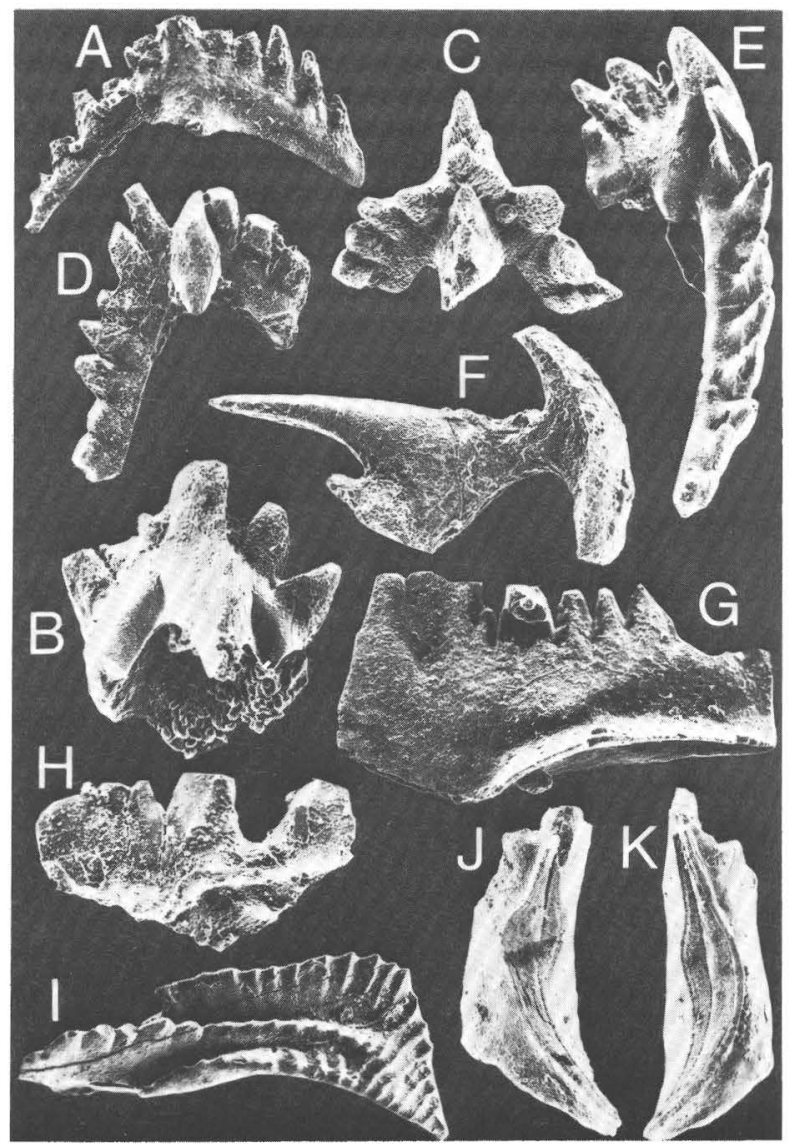

Figure 3. Scanning electron micrographs of Late Ordovician (A-F) and late Early Devonian (G-K) conodonts from uppermost part of the Nanook Limestone, Shublik Mountains, Mount Michelson C-3 quadrangle. A-E, Aphelognathus aff. A. divergens Sweet, USGS colln. 10630-CO, section 87NA-1. A, Lateral view of Pb element, $\times 50$, USNM 423445. B, Posterior view of Sa1 element, $x 50$, USNM 423446. C, Upper view of quadriramate Sa2 element, $\times 50$, USNM 423447. D, Posterior view of Sb element, $\times 50$, USNM 423448. E, Inner lateral view of Sc element, x40, USNM 423449. F, Phragmodus n. sp. of Barnes (1974, pl. 1, fig. 20), lateral view of Sa element, x100, USNM 423450; USGS colln. 10631-CO, section 87NA-1. G, Pandorinellina expansa Uyeno and Mason, lateral view of Pa element, x100, USNM 423451; USGS colln. 11837-SD, section 87NA-1. H, Ozarkodina cf. O. paucidentata Murphy and Matti, lateral view of Pa element, x100, USNM 423452; USGS colln. 11839-SD, section 87NA-2. I, J, Polygnathus inversus Klapper and Johnson, upper (x40, USNM 423453) and lower ( 550 , USNM 423454) views of Pa elements; I from USGS colln. 11843-SD, section 87NA-2; J from USCS colln. 11842-SD, section 87NA-2. K, Polygnathus aff. $P$. perbonus (Philip), lower view of Pa element, x50, USNM 423455; USCS colln. 11839-SD, same collection as $\mathrm{H}$. genus to be restricted to the Ashgillian of northeastern USSR (Kolyma and Chukotka) and, possibly, southern Kazakhstan. Recently, the genus was reported by Rong and Han (1986) from middle Ashgillian strata of Jiangxi Province, east-central China. The new species in the Nanook Limestone (figs. 4A-D) is conspecific with a form identified as Tscherskidium sp. in Rohr and Blodgett (1985, p. 667) from Upper Ordovician (Ashgillian) strata in the Lone Mountain area, McGrath C-4 quadrangle, west-central Alaska. The numerous gastropods at this horizon comprise at least eight species that include Siskiyouspira sp. (figs. 4I-K), Murchisonia? sp. (fig. 4H), Ectomaria ef. E. prisca (Billings, 1859) (fig. 4L), and Maclurites cf. $M$. manitobensis (Whiteaves). The distinctive genus Siskiyouspira Rohr, 1980 is now known from the Upper Ordovician of the northeastern Brooks Range, the Lone Mountain area of west-central Alaska, and the Klamath Mountains of northern California. S. majewskei (Rohr and Blodgett, 1985) from westcentral Alaska is smaller than the Nanook form but, although more poorly preserved, has the same general shape.

Other mollusks present at this level include abundant bivalves and rare orthocone cephalopods. Ostracodes, also abundant in this interval, include the leperditiid genus Sibiritia, previously known only from rocks of Silurian (Llandoverian-early Wenlockian) age (J.M. Berdan, U.S. Geological Survey, oral commun., 1987). Conodonts from this interval (USGS colln. 10632-CO) include: Aphelognathus sp. indet., Pseudobelodina cf. $P$. adentata Sweet, $P$. aff. $P$. vulgaris Sweet, Drepanoistodus suberectus (Branson and Mehl), and Panderodus sp. The age of this assemblage is late Edenian-Richmondian, more probably Richmondian.

Conodont collections at $22.9 \mathrm{~m}, 28.9 \mathrm{~m}$, and $36.6 \mathrm{~m}$ above the base of the section, but still beneath the unconformity, yielded only long-ranging representatives of Panderodus sp. Favositid corals are common to abundant from 22.9 to $36.6 \mathrm{~m}$ above the base.

The upper part of section $87 \mathrm{NA}-1$ contains numerous lenses rich in Amphipora (a sticklike stromatoporoid) which, in the absence of typical openmarine faunal elements, suggests a shallow, somewhat restricted, lagoonal environment. Conodonts recovered at $42.7 \mathrm{~m}$ and $51.8 \mathrm{~m}$ above the base of the section include only long-ranging forms indicative of a Wenlockian-Emsian age range. One collection (USGS colln. 11837-SD), taken $60.9 \mathrm{~m}$ above the base, yielded

Figure 4. Late Ordovician brachiopods and gastropods from upper part of member 8 of the Nanook Limestone. A-D, Tscherskidium n. sp., ventral, posterior, and opposite side views of pedicle valve, x1, USNM 417633, USGS colln. 10632-CO, section $87 \mathrm{NA}-1$. E-G, Eoconchidium sp., side, ventral and dorsal views of pedicle valve, $\times 1.5$, USNM $417634,40.6 \mathrm{~m}$ above base of section 87NA-2. H, Murchisonia? sp., side view, x3, USNM 417635, same collection as A-D. I-K, Siskiyouspira sp., USNM 417636, same collection as A-D; I, oblique side view, x3.5; J, K, apical and basal views, x3. L, Ectomaria cf. E. prisca (Billings, 1859), apertural view, $x 3$, USNM 417637, same collection as AD. 

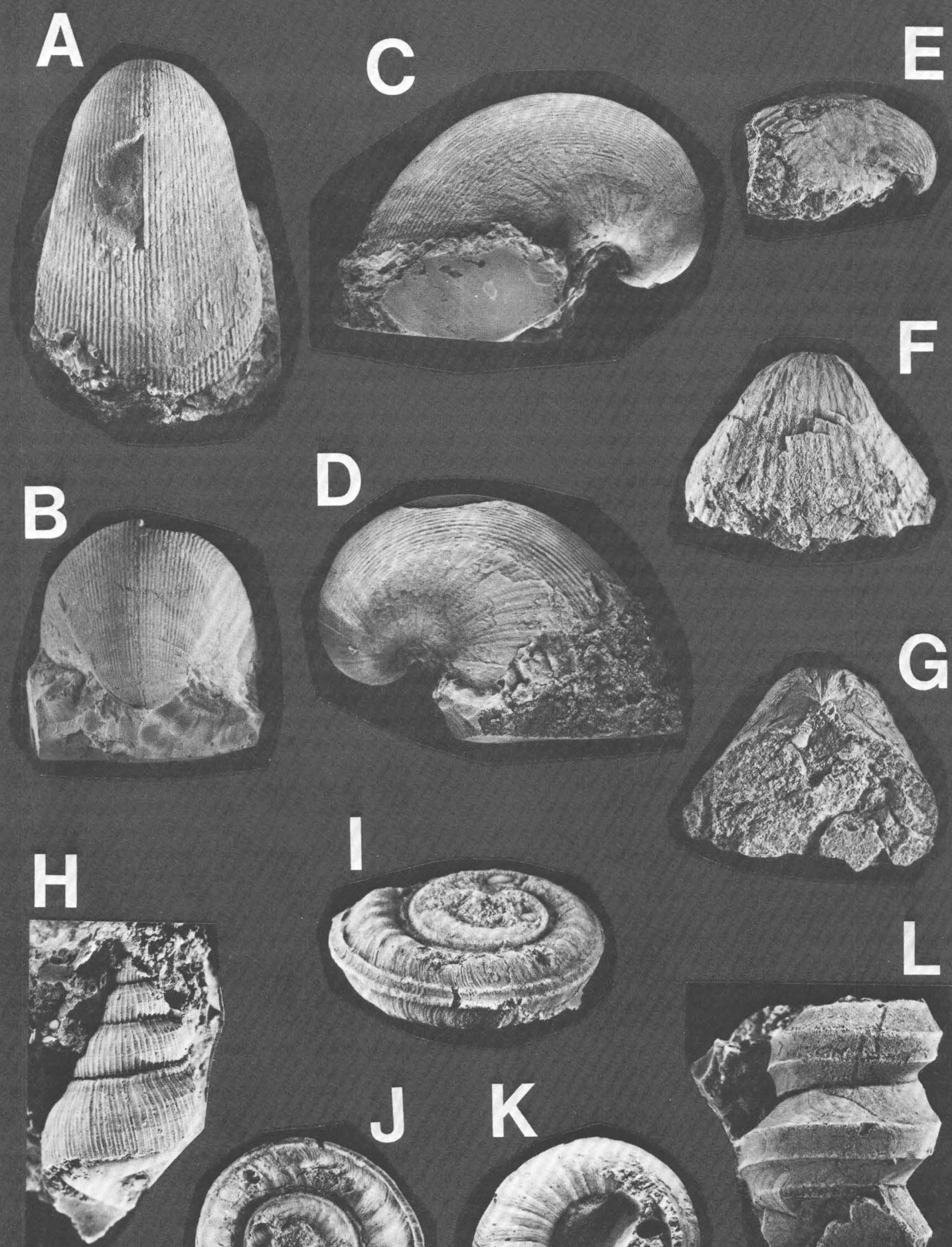

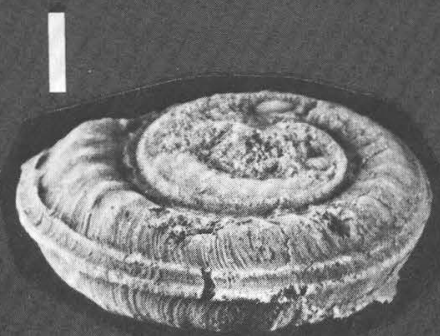

J $\mathbf{K}$
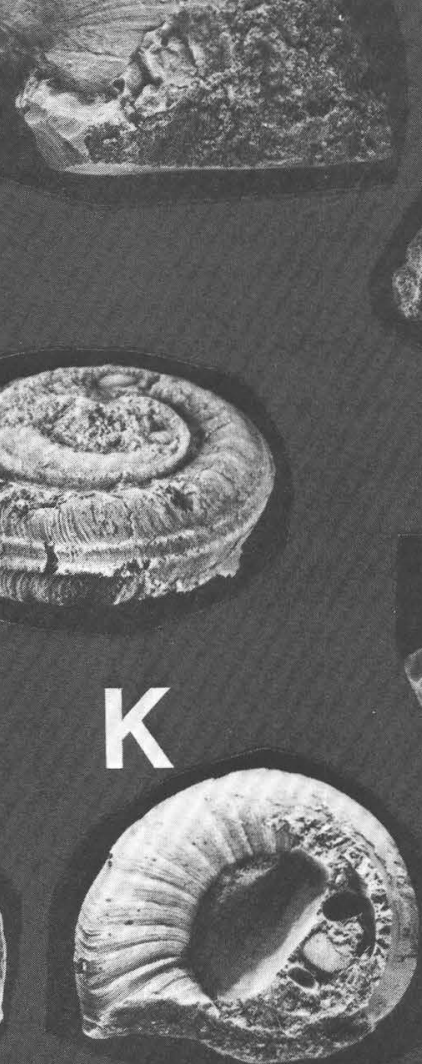

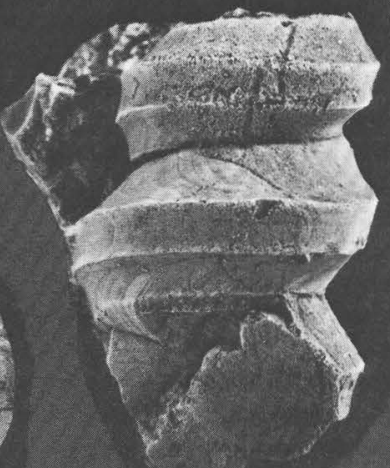


only platform elements of Pandorinellina expansa Uyeno and Mason (fig. 3G), a tropical, relatively cosmopolitan species known to range from the serotinus Zone into the costatus costatus Zone (latest Emsian-earliest Eifelian age). Based on a comparison of thickness between this section and nearby section 87NA-2, we believe that a latest Emsian age is more likely.

Section 87NA-2, which is $115.8 \mathrm{~m}$ thick (fig. 2), is along a north-south-trending ridge. The base of the section is at the base of a prominent yellow dolomitic mudstone bed. Underlying strata were not measured due to inaccessibility. The top of the section is at the north end of a prominent saddle. An unconformity occurs at $44.2 \mathrm{~m}$ above the base of the section. As in section $87 \mathrm{NA}-1$, beds below the unconformity are typically lighter shades of gray or brown, whereas beds above it are characteristically dark gray. All conodonts from section $87 \mathrm{NA}-2$ have a CAI value of 4 , identical to that for section 87NA-1.

Megafossils range from absent to abundant below the unconformity. The brachiopod Tscherskidium n. sp. is present at $7.6 \mathrm{~m}$ and $22.6 \mathrm{~m}$ above the base of the section. Favositid corals are abundant between 23.2 to $36.6 \mathrm{~m}$ above the base. This interval, and its contained corals, is identical to the favositid-rich interval below the unconformity in section 87NA-1. A coquina layer of disarticulated valves of the pentameracean Eoconchidium sp. (figs. $4 \mathrm{E}-\mathrm{G}$ ) occurs $39.6 \mathrm{~m}$ above the base of the section. The genus Eoconchidium Rozman, 1967 was reported by Sapelnikov (1985) from Ashgillian strata of northeastern USSR and Kazakhstan, and, very questionably, from lower Ludlovian strata in Kazakhstan. Conodonts from $7.6 \mathrm{~m}, \mathbf{1 5 . 2} \mathrm{m}$, and $\mathbf{2 2 . 6}$ $\mathrm{m}$ above the base of the section indicate a Middle to Late Ordovician age; those from $30.5 \mathrm{~m}$ and $39.6 \mathrm{~m}$ indicate an even broader range. We place the entire measured part of the section below the unconformity in the Late Ordovician (Ashgillian) on the basis of the presence of the pentameracean genera Tscherskidium and Eoconchidium in its lower and upper parts, respectively. On the basis of paleontologic correlation and lithologic similarities to the Upper Ordovician strata of section $87 \mathrm{NA}-2$, all the beds below the unconformity in section 87NA-1 are also considered to be of Late Ordovician age. In addition, the trilobites reported in Blodgett and others (1986a) as possibly indicating an Early Silurian (Llandoverian) age that were recovered from approximately $22.9 \mathrm{~m}$ above the base of section 87NA-1 are now considered to be of Late Ordovician age.

The part of the section above the unconformity consists of dark-gray lime mudstone and wackestone. Poorly preserved megafossils are present sporadically throughout the section. Two-holed crinoid ossicles, considered an index fossil to Emsian and Eifelian strata, are found throughout the section and form a 0.3-m-thick encrinite bed immediately above the unconformity. The common megafossils include favositid and thamnoporoid tabulate corals and solitary rugose corals. Conodonts recovered from $44.2 \mathrm{~m}$ and 44.5 to $44.8 \mathrm{~m}$ above the base of the section include Polygnathus aff. P. perbonus (Philip) (fig. 3K), suggesting the gronbergi Zone (early Emsian age). Four samples taken from $71.6 \mathrm{~m}$ (USGS colln. 11842-
SD) to $112.8 \mathrm{~m}$ (USGS colln. 11845-SD) above the base of the section produced abundant representatives of $P$. inversus Klapper and Johnson, indicating an inversus Zone through serotinus Zone age range. The highest conodont collection from $115.2 \mathrm{~m}$ (USGS colln. 11847SD) produced abundant specimens of $P$. inversus together with lesser numbers of Pandorinellina steinhornensis miae (Bultynck) and Sannemannia aff. S. glenisteri (Klapper) and is also assigned to an inversus Zone-serotinus Zone interval (middle to late Emsian age). The presence of representatives of Pandorinellina expansa at only $21.9 \mathrm{~m}$ above the unconformity in section $87 \mathrm{NA}-1$, suggests that the interval from at least $71.6 \mathrm{~m}$ to near the top of member 8 at $115.2 \mathrm{~m}$ in section $87 \mathrm{NA}-2$ is within the serotinus Zone.

These biostratigraphic results document the fact that Lower Devonian strata rest unconformably on Upper Ordovician strata in member 8 of the Nanook Limestone. The general parallelism of beds on either side of this boundary indicates a disconformity and suggests that no major tectonic events affected the present area of the Shublik Mountains during Late Ordovician to Early Devonian time. Another significant result is the restriction of the uppermost, Devonian, part of the Nanook Limestone to the Emsian (upper Lower Devonian).

\section{REFERENCES CITED}

Barnes, C.R., 1974, Ordovician conodont biostratigraphy of the Canadian Arctic, in Aitkin, J.D., and Glass, D.J., eds., Canadian Arctic geology: Calgary, Geological Association of Canada and Canadian Society of Petroleum Geologists Special Volume, p. 221-240.

Blodgett, R.B., Clough, J.G., Dutro, J.T., Jr., Ormiston, A.R., Palmer, A.R., and Taylor, M.E., 1986a, Age revisions for the Nanook Limestone and Katakturuk Dolomite, northeastern Brooks Range, in BartschWinkler, Susan, and Reed, K.M., eds., Geologic studies in Alaska by the U.S. Geological Survey during 1985: U.S. Geological Survey Circular 978, p. 5-10.

Blodgett, R.B., Clough, J.G., Dutro, J.T., Jr., Palmer, A.R., Taylor, M.E., and Ormiston, A.R., 1986b, Age revision of the Katakturuk Dolomite and Nanook Limestone, northeastern Brooks Range, Alaska [abs.]: Geological Society of America Abstracts with Programs, v. 18 , no. 2 , p. 87 .

Dumoulin, J.A., and Harris, A.G., 1987, Lower Paleozoic carbonate rocks of the Baird Mountains quadrangle, western Brooks Range, Alaska, in Tailleur, Irv, and Weimer, Paul, eds., Alaskan North Slope geology: Bakersfield, Calif., and Anchorage, Alaska, Pacific Section, Society of Economic Paleontologists and Mineralogists and Alaska Geological Society, v. 1, p. 311-336.

Dutro, J.T., Jr., 1970, Pre-Carboniferous carbonate rocks, northeastern Alaska, in Adkison, W.L., and Brosge, W.M., eds., 
Proceedings of the geological seminar on the North Slope of Alaska: Los Angeles, American Association of Petroleum Geologists, Pacific Section, p. Ml-Ml7.

Rohr, D.M., and Blodgett, R.B., 1985, Upper Ordovician Gastropoda from west-central Alaska: Journal of Paleontology, v. 59, p. $667-673$.

Rong Jia-yu and Han Nai-ren, 1986, Preliminary report on Upper Ordovician (Mid-Ashgillian) brachiopods, Yushan, northeastern Jiangxi (Eastern China), in Racheboeuf, P.R., and Emig, C., eds., Les brachiopodes fossiles et actuels: Actes du ler Congres international sur les Brachiopodes, Brest, 1986, Biostratigraphie du Paleozoique, v. 4, p. 485-491.

Sapelnikov, V.P., 1985, Sistema i stratigraficheskoe znachenie brakhiopod podotryada pentameridin: Moscow, Nauka, 205 p.

Reviewers: A.J. Boucot and J.T. Dutro, Jr.

Geologic Studies in Alaska by the U.S. Geological Survey during 1987: John P. Galloway and Thomas D. Hamilton, editors, U.S. Geological Survey Circular 1016. 


\title{
Ostracode and Molluscan Assemblages from the Late Neogene Nuwok Member of the Sagavanirktok Formation, North Slope
}

\author{
By Elisabeth M. Brouwers and Louie Marincovich, Jr.
}

\begin{abstract}
Neogene marine ostracodes and mollusks previously known only from the type section of the Nuwok Member of the Sagavanirktok Formation at Carter Creek have been recognized at two additional localities on the northeastern Alaskan coastal plain, Barter Island and Manning Point (fig. 1). Ostracodes occur at both new localities, and mollusks only at Manning Point. These fossils provide the first paleontologic correlation of Carter Creek Nuwok strata with other outcrops in northeastern Alaska, and imply that Nuwok strata underlie the coastal plain for at least the 45 kilometers that separate Carter Creek and Manning Point. Additional analysis of the ostracodes and mollusks suggests correlations with faunas in the northwestern Atlantic and provides insights into the marine climate during Nuwok time.
\end{abstract}

The type section of the Nuwok Member consists of $81 \mathrm{~m}$ of interbedded sandstone and siltstone that is exposed in the north limb of the Marsh Creek anticline along the lower reaches of Carter Creek (Morris, 1954; Detterman and others, 1975) (fig. 2). Ostracodes, mollusks and large amounts of wood occur at several horizons. The upper part of the Nuwok sequence also contains sparse calcareous concretions and abundant crystal aggregates of glendonite, an unusual calcite pseudomorph associated with glaciomarine muds (Suess and others, 1982). Correlation of the Barter Island and Manning Point beds with the Nuwok type section at Carter Creek is based on (1) stratigraphic ranges of ostracode and mollusk taxa, (2) the presence of a well cemented, mollusk-rich bed at Manning Point and Carter Creek, and (3) the co-occurrence of glendonites and calcareous concretions at Carter Creek and Manning Point.

Ostracodes at Carter Creek occur in three stratigraphically separate assemblages whose boundaries are marked by pronounced faunal and lithologic changes (fig. 2). Whether these pronounced breaks are local facies changes or unconformities representing significant temporal hiatuses is not yet known.

The basal ostracode assemblage occurs in the lower $5 \mathrm{~m}$ of the Carter Creek section and consists exclusively of extinct species. Species-level morphologic similarities with U.S. East Coast faunas of late Miocene and early Pliocene age imply a common ancestry, although there are no species in common. Nuwok ostracodes assigned to Muellerina, Sarsicytheridea, and Cytheretta are most similar to species from the Miocene part of the Chesapeake Group and the Pliocene Yorktown Formation of Virginia and Maryland. Other species belong to endemic arctic genera (Rabilimis, Paracyprideis) or to cosmopolitan genera of the temperate realm (Cytheropteron).

Living analogs of basal-assemblage species live in environments characterized by uniform temperature and salinity, in depths ranging from the deeper inner shelf to the middle shelf (about 20-50 m). Modern temperature preferences of genera such as Cytheretta and Muellerina suggest mild to cold temperate conditions, which today occur from Cape Hatteras to the Gulf of St. Lawrence in the western Atlantic.

The middle assemblage comprises most of the section at Carter Creek and, like the basal assemblage, consists entirely of extinct species. The minimum age of this assemblage is $3 \mathrm{Ma}$, based on (1) the youngest known occurrence of Rabilimis paramirabilis and Pterygocythereis vannieuwenhuisei in the stratigraphically higher Gubik Formation (Repenning and Brouwers, 1988) and (2) the absence of Pacific ostracodes that migrated north following the opening of Bering Strait at about $3 \mathrm{Ma}$ (Gladenkov, 1981). The maximum age of this assemblage is not known. Ostracode faunas from Manning Point and Barter Island correlate with the middle ostracode assemblage at Carter Creek.

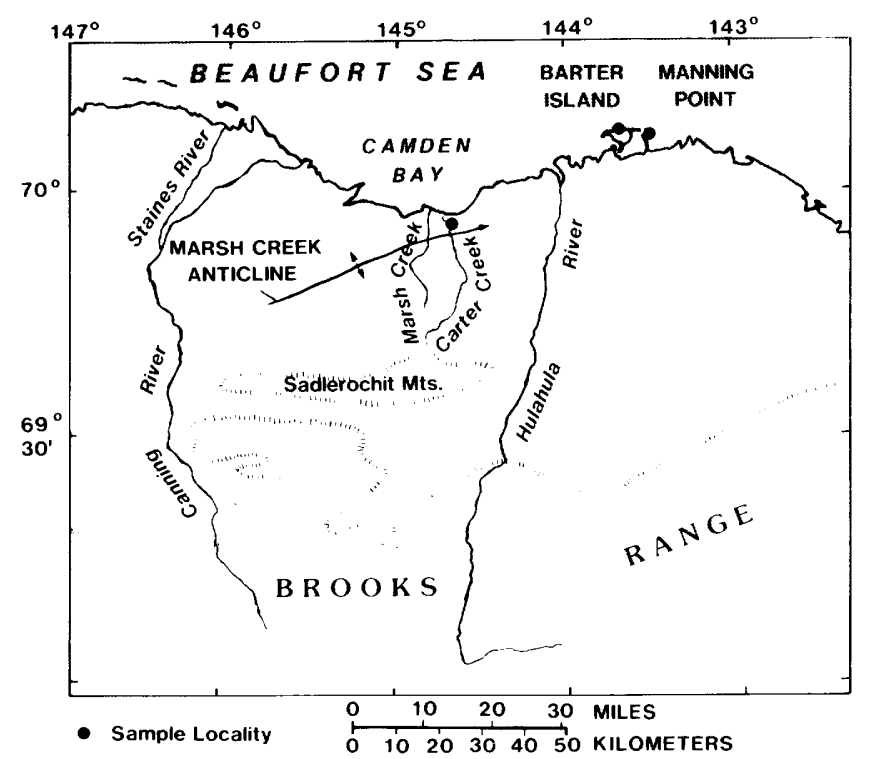

Figure 1. Eastern Arctic Coastal Plain, showing trend of Marsh Creek anticline and location of outcrops studied at Carter Creek, Manning Point, and Barter Island. 
The middle assemblage indicates a cold temperate marine climate, comparable to that of the shallow offshore region of New England and the Gulf of St. Lawrence today. Some genera of the middle assemblage, such as Aurila, are common in temperate waters but do not occur in frigid waters. A shallowing trend is shown by middle-shelf taxa in the lower part of this assemblage and deeper inner-shelf taxa in its upper part. Abundant wood occurs near the top of the assemblage, although nonmarine and estuarine ostracodes are absent. Glendonites and calcareous concretions range through the upper half of the middle assemblage.

The upper assemblage occurs in the basal $10 \mathrm{~m}$ of an upper sand unit, from 63 to $71 \mathrm{~m}$ above the base of the section at Carter Creek (fig. 2); the assemblage consists of both extant and extinct species. The maximum age of the upper assemblage is $2.7 \mathrm{Ma}$, based on the presence of Rabilimis septentrionalis (Repenning and others, 1987). An ancestral species, $R$. paramirabilis, is known to be no younger than 2.8-3.0 $\mathrm{Ma}$ (Colvillian), and the derived species, $R$. septentrionalis, is known to be no older than $2.7 \mathrm{Ma}$ (Bigbendian). Extant species of the upper assemblage are circumpolar in distribution, occurring in subfrigid to frigid waters of the shallow inner shelf.

Carter Creek mollusks occur as two stratigraphically separate assemblages that correspond to the lower and middle ostracode assemblages ( $\mathrm{fig}$. 2). The lower assemblage (the Chlamys nuwokensis zone) and the upper assemblage (the Arctica carteriana zone) have no species in common, but both indicate normal marine salinity, temperate water, and deposition on the deeper inner shelf (about 25-50 m). Whether the difference in faunal composition reflects a hiatus or only two roughly coeval habitats is

\section{CARTER CREEK}

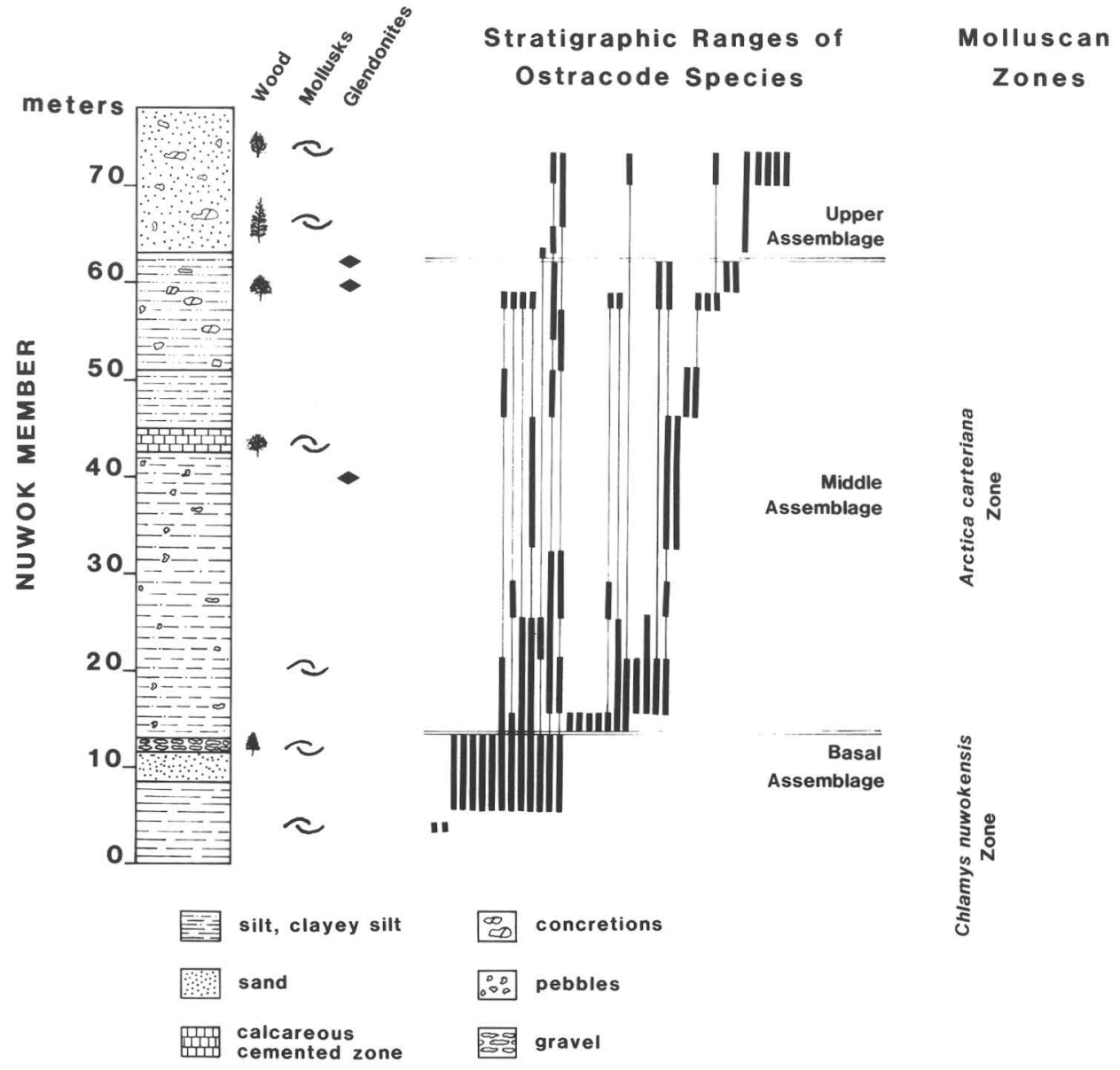

Figure 2. Stratigraphic section of Nuwok Member at type locality at Carter Creek plotted against stratigraphic ranges of ostracode species. Note that the molluscan zones, the Chlamys nuwokensis and Arctica carteriana zones, correspond to basal and middle ostracode assemblages, respectively. 
unknown. Beds at Manning Point contain mollusks referable to the Arctica carteriana zone, the upper molluscan assemblage at Carter Creek.

Similarities of several Nuwok molluscan taxa with warm temperate to tropical Neogene faunas of the eastern United States suggest that provinciality based upon temperature was less developed between the northwestern Atlantic and Arctic Oceans during the Neogene than at present. The presence of even seasonal sea ice during deposition of Nuwok strata is unlikely.

Affinities with Pacific faunas are absent in both molluscan faunas, and both have strong genus-level ties to North Atlantic late Neogene faunas. The Nuwok fauna must predate the first appearance of North Pacific mollusks at approximately $3 \mathrm{Ma}$ in Iceland (Gladenkov, 1981) and in the uppermost member of the Yorktown Formation in Virginia.

Further study of the ties between the Nuwok ostracode and molluscan faunas and late Neogene faunas of the U.S. middle Atlantic coastal plain will provide the basis for more precise correlation and dating of the Nuwok beds.

\section{REFERENCES CITED}

Detterman, R.L., Reiser, H.N., Brosge, W.P, and Dutro, J.T., Jr., 1975, Post-Carboniferous stratigraphy, northeastern Alaska: U.S. Geological Survey Professional Paper 886, 46 $\mathrm{p}$.
Gladenkov, Y.B., 1981, Marine Plio-Pleistocene of Iceland and problems of its correlation: Quaternary Research, v. 15, p. 18-23.

Morris, Robert, 1954, Reconnaissance study of the Marsh Creek anticline, northern Alaska: U.S. Geological Survey Open-file Report 54-146, 6 p.

Repenning, C.A. and Brouwers, E.M., 1988, MidPliocene to Late Pleistocene changes in the Arctic Ocean borderland ecosystem, in Luchterhand, K. and Leopold, E., eds., Longterm restructuring in late Cenozoic terrestrial ecosystems: Evanston, I11., Wm. Caxton Ltd.

Repenning, C.A., Brouwers, E.M., Carter, L.D., Marincovich, Louie, Jr., and Ager, T.A., 1987, The Beringian ancestry of Phenacomys (Rodentia: Cricetidae) and the beginning of the modern Arctic Ocean borderland biota: U.S. Geological Survey Bullet in $1687,31 \mathrm{p}$.

Suess, E., Balzer, W., Hesse, K.-F., Muller, P.J., Ungerer, C.A., and Wefer, G., 1982, Calcium carbonate hexahydrate from organicrich sediments of the Antarctic shelf: Precursors of glendonites: Science, v. 216, p. 1128-1130.

Reviewers: C.A. Repenning and J.A. Wolfe

Geologic Studies in Alaska by the U.S. Geological Survey during 1987: John P. Galloway and Thomas D. Hamilton, editors, U.S. Geological Survey Circular 1016. 


\title{
Nearshore Marine Environments of the Alaskan Beaufort Sea During Deposition of the Flaxman Member of the Gubik Formation
}

\author{
By L. David Carter, Elisabeth M. Brouwers, and Louie Marincovich, Jr.
}

The Flaxman Member of the Gubik Formation (Dinter, 1985) is a glaciomarine mud a few meters thick that occurs along the Beaufort Sea coast and inland to altitudes of about $7 \mathrm{~m}$ (fig. 1). Deposition of the Flaxman Member occurred during an early Wisconsin sea-level highstand that is informally named the Simpsonian transgression (Carter and others, 1986). The Flaxman Member contains ice-rafted erratics of Canadian provenance (Rodeick, 1979), and transportation of the erratics to the Beaufort Sea coast by icebergs records the disintegration of an ice sheet in the Canadian Arctic (Hopkins, 1982). Erratics occur to the southern limit of the deposit, and so were being supplied at the peak of the transgression (Hopkins, 1982). Because the Flaxman Member is a glaciomarine deposit, it differs from any modern sediment accumulations on the inner shelf of the Beaufort Sea; this suggests that some aspects of nearshore marine environments, particularly salinity, temperature, and turbidity, may have been different during the Simpsonian transgression than they are today. We present faunal data from the Flaxman Member that suggest that, at water depths of $20 \mathrm{~m}$ and less, seasonal fluctuations of salinity and temperature were probably similar to the present regime but that water temperatures may have been slightly warmer.

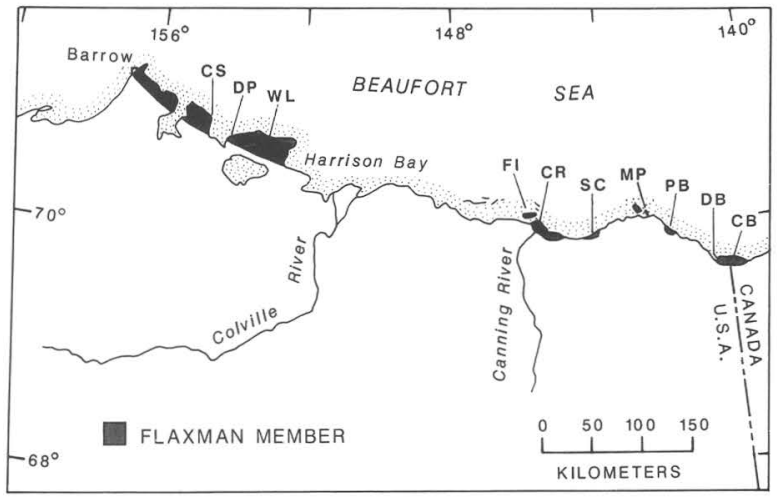

Figure 1. Map of northern Alaska showing distribution of Flaxman Member and locations mentioned in text (CS, Cape Simpson; DP, Drew Point; WL, "Whale Lake"; FI, Flaxman Island; CR, Canning River; SC, Simpson Cove; MP, Manning Point; PB, Pokok Bay; DB, Demarcation Bay; CB, locality near Canadian border).
Our data also suggest that turbidity was high relative to today. At some localities east of Flaxman Island, however, salinities were less than modern values for comparable environments, and we interpret this as indicating a higher influx of fresh water into the marine environment by meltwater from abundant icebergs and an ablating ice sheet.

One of the best exposures of the Flaxman Member is in a coastal bluff near Cape Simpson (figs. 1 and 2), where the glaciomarine mud has been uplifted and anticlinally deformed, probably as a result of pressures generated by the development of nearby oil seeps. The Flaxman Member at Cape Simpson is about $2 \mathrm{~m}$ thick; it disconformably overlies marine sand and is conformably or paraconformably overlain by similar marine sand. A previous account referred to the Flaxman microfauna at Cape Simpson as impoverished (Hopkins and others, 1981), but this resulted from interpreting the upper marine sand as the Flaxman Member and the underlying glaciomarine mud as of last interglacial (Pelukian) age. Thermoluminescence ages for the glaciomarine mud show that it is early Wisconsin in age and support our designation of this unit as the Flaxman Member (Carter and others, 1986). The marine sand above the Flaxman Member is most likely a regressive facies of the Simpsonian

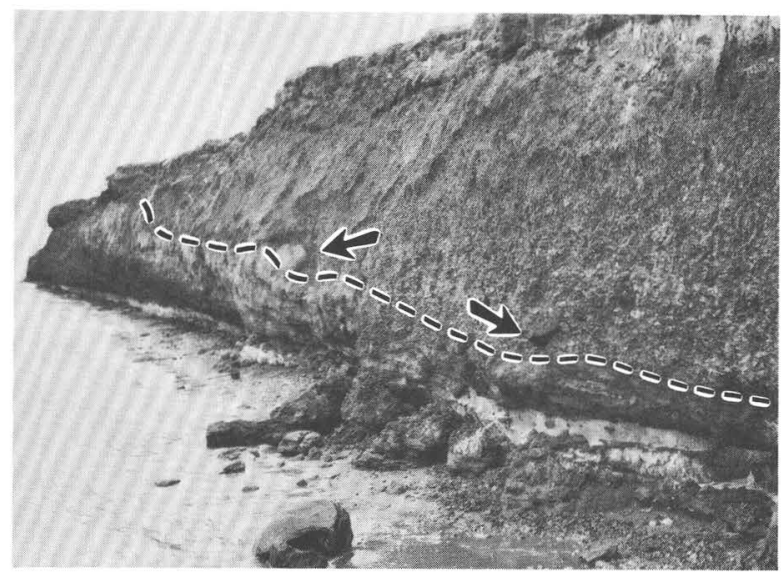

Figure 2. Coastal bluff about $4 \mathrm{~m}$ high near Cape Simpson. Dashed line marks contact between Flaxman Member and underlying marine sand. Arrows point to erratic stones in Flaxman Member. Marine sand that overlies the Flaxman Member is out of view to right. 
transgression, but may represent a younger sea-level highstand. The Flaxman Member contains a sparse but relatively diverse benthic microfauna comprising 15 taxa of marine ostracodes (table 1) and 16 taxa of foraminifers (Hopkins and others, 1981). The ostracode fauna is especially instructive; it contains taxa that occur across the modern inner shelf, but also contains Krithe glacialis and Rabilimis mirabilis, two taxa that today are restricted to environments of normal marine salinity in which there is little seasonal variation in either temperature or salinity (McDougall and others, 1986). Rabilimis mirabilis occurs today only in water depths greater than $20 \mathrm{~m}$ (Brouwers, 1982; McDougall and others, 1986), which is the upper limit of both the pycnocline and halocline (Sharma, 1979; Coachman and Aagaard, 1974).

The mollusk fauna from the Flaxman Member at Cape Simpson is depauperate, consisting only of the bivalves Bathyarca glacialis and Astarte borealis (table 2). Both occur today in the Beaufort Sea, but $B$. glacialis has been found only in water depths greater than $23 \mathrm{~m}$. Thus both the mollusks and ostacodes indicate that the glaciomarine mud at Cape Simpson was deposited below the tops of the halocline and pycnocline, and suggest limited seasonal variability in salinity and density.

In coastal bluffs at Drew Point (fig. 1), Flaxman ostracode faunas contain only euryhaline and eurythermal marine taxa such as Heterocyprideis sorbyana, and Rabilimis septentrionalis, which tolerate the seasonal salinity and temperature variations that occur in modern nearshore, shallow-water environments above the $20-\mathrm{m}$ isobath (McDougall and others, 1986). In these water depths, modern summer temperatures range from -1.5 to $14{ }^{\circ} \mathrm{C}$, and salinity ranges from 0.7 to 31.6 per mil. Winter temperature is generally below $0{ }^{\circ} \mathrm{C}$, ranging from -0.5 to $0.5{ }^{\circ} \mathrm{C}$, and salinity is somewhat higher than in summer, with a range of 21.8 to 31.0 per mil (Sharma, 1979).

The present-day $20-\mathrm{m}$ isobath occurs about 25 $\mathrm{km}$ offshore from Cape Simpson, and the distances from Cape Simpson and Drew Point inland to the inner limit of the Flaxman Member are about $20 \mathrm{~km}$ and 10 $\mathrm{km}$, respectively (Carter, 1983). If we assume that bathymetric equilibrium-profiles during deposition of the Flaxman Member were similar to modern ones, then the glaciomarine mud at Cape Simpson would have been deposited in water depths of about $20 \mathrm{~m}$, and the tops of the pycnocline and halocline would have been at about the same depths as they are today. Additionally, the deposits at Cape Simpson and Drew Point must have been uplifted about $15 \mathrm{~m}$ and 5 to $10 \mathrm{~m}$, respectively. Deposits at the inner limit of the Flaxman Member west of Harrison Bay, however, have not been uplifted (Carter and others, 1986).

Slightly warmer water than at present during deposition of the Flaxman Member is suggested by the presence of the foraminifer Elphidiella groenlandica (Cushman) at Cape Simpson, Drew Point, and informally named Whale Lake (Hopkins and others, 1981; Kristin McDougall, U.S. Geological Survey, written commun., 1980; fig. 1). Elphidiella groenlandica does not live in the Beaufort Sea today, but is common south of Norton Sound (Kristin McDougall, U.S. Geological Survey, oral commun., 1987). Furthermore, the Flaxman marine mammal fauna at Whale Lake includes Eschrictius sp. (gray whale) and Histriophoca fasciata (Zimmermann) (ribbon seal) (Repenning, 1983). Both ribbon seal and gray whale are now only occasional visitors to the Alaskan Beaufort Sea (Moore and Barrowclough, 1984; Rugh and Fraker, 1981), and Repenning (1983) pointed out that their presence as fossils suggests the possibility of warmer waters than at present.

East of Harrison Bay, Flaxman ostracode faunas generally contain the euryhaline and eurythermal taxa characteristic of modern shallow-water faunas (table 1). The molluscan bivalve Cyrtodaria kurriana, present at Demarcation Bay and questionably identified at Canning River, is abundant in modern nearshore sediments of the Beaufort Sea at water depths shallower than $5 \mathrm{~m}$, but has not been found at greater depths (Carey and others, 1984). Thus seasonal variations in temperature and salinity at these two localities during deposition of the Flaxman Member were probably similar to modern values for water depths up to $5 \mathrm{~m}$.

Conditions different from any known modern marine environment of the Alaskan Beaufort Sea are indicated by the presence of the marine ostracode species Pteroloxa cumuloidea, which composes 63 percent of the fauna at Simpson Cove and 29 percent of the fauna at Pokok Bay. The only modern environment in which $P$. cumuloidea has been found is in the nearly fresh-water distributary channel mouths of the Ikpikpuk River delta (E.M. Brouwers and L.D. Carter, unpub. data). It does not occur in environments with slightly higher salinities, such as off the mouths of major rivers and in lagoons and bays (Brouwers, 1982). The Flaxman Member is not a deltaic facies, and the abundant presence of $P$. cumuloidea at Simpson Cove and Pokok Bay is interpreted to mean that there was a greater influx of fresh water into the marine environment than is known to occur anywhere along the coast today. Although Simpson Cove is near the mouth of the Katakturuk River, it is unlikely that during deposition of the Flaxman Member this minor river would have had a discharge larger than the modern major rivers. The Pokok Bay locality is distant from any potentially large source of fresh water. This suggests that a thin surficial layer of nearly fresh water may have been a regional feature of the eastern Beaufort Sea, perhaps generated by higher regional runoff than today, but more probably by meltwater from the icebergs and ablating ice sheet that supplied the erratics in the Flaxman Member.

If the major source of fresh water was meltwater from glacier ice emanating in Canada, we expect that the surface layer of low-salinity water would have thickened eastward. This may be indicated by Pteroloxa venepuncta, which is the only ostracode species identified from the Flaxman Member near the Canadian border. Pteroloxa venepuncta is unknown in modern environments but is believed to have inhabited environments similar to closely related $P$. cumuloidea.

Glaciomarine deposition of the erratics and fine-grained sediment of the Flaxman Member implies higher rates of sedimentation than those of the modern inner shelf, where much of the area may be undergoing net erosion (Reimnitz and others, 1985). The presence of icebergs during deposition of the Flaxman Member 
Table 1. Ostracodes from the Flaxman Member of the Gubik Formation [Number of samples examined in parentheses; \#, dominates assemblage]

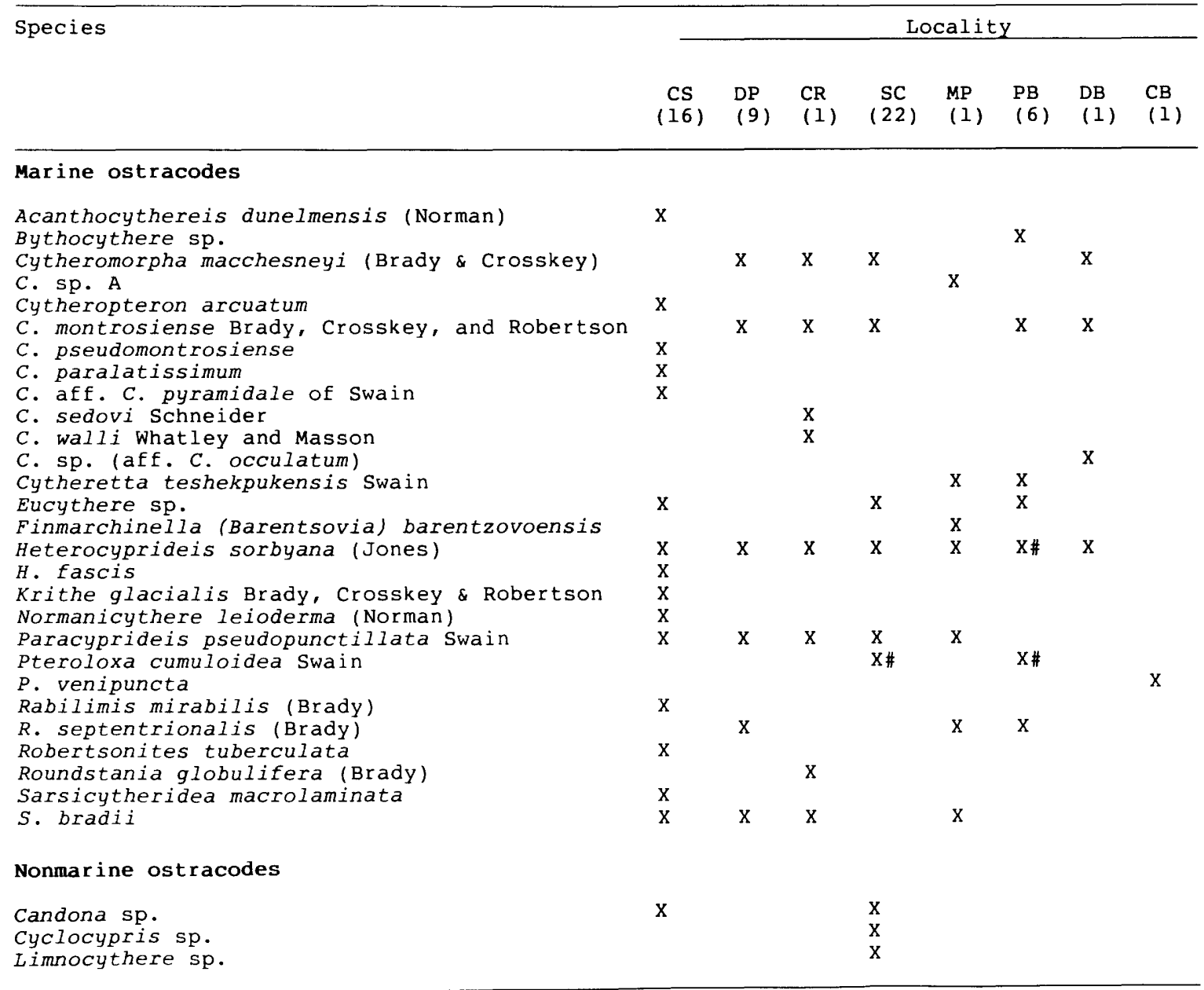

suggests higher rates of ice gouging than would be produced by sea ice alone, which today annually disrupts about 2.7 percent of the sea floor (Barnes and Rearic, 1985). An increase in the rate of sedimentation and (or) ice gouging relative to today must have generated greater turbidity in the water column, and the composition and depauperate nature of the mollusk faunas suggest that this was indeed the case. Only three species of bivalves have been identified from any Flaxman locality (table 2), whereas Carey and others (1984) reported an average of 7.6 species per site at water depths of 5 to $25 \mathrm{~m}$ in modern Beaufort Sea environments. Moreover, 31 species of bivalves have been collected from the modern Beaufort Sea at water depths of $25 \mathrm{~m}$ and less (Carey and others, 1984), whereas the presently known Flaxman bivalve fauna consists of only seven taxa. Species richness on the inner shelf of the western Beaufort Sea is thought to be largely determined by bottom turbulence (Carey and others, 1984), and so the depauperate Flaxman mollusk faunas suggest greater turbidity. Furthermore, all the species presertit in the shallow-water Flaxman faunas east of Cape Simpson are capable of surviving in turbid water. Portlandia arctica, for example, has been found living adjacent to glacier termini where sedimentation rates are exceptionally high (Lubinsky, 1980; Ockelmann, 1958).

In summary, faunal data suggest that during deposition of the Flaxman Member of the Gubik Formation, seasonal fluctuations in temperature and salinity in nearshore marine environments west of Harrison Bay were similar to those of the present day, but average temperatures may have been slightly higher. From Flaxman Island east there may have been a surficial, eastward-thickening sheet of nearly fresh water across much of the nearshore zone during part or all of the open water season. Immediately below this low-salinity layer, seasonal variations in temperature and salinity were probably similar to modern values for water depths less than $5 \mathrm{~m}$. Turbidity was greater across the entire inner shelf than it is today, probably as a result of the relatively higher rates of sedimentation and ice gouging in a glaciomarine sedimentation regime. 
Table 2. Bivalve mollusks from the Flaxman Member of the Gubik Formation

\begin{tabular}{|c|c|c|c|c|c|c|}
\hline \multirow[t]{2}{*}{ Species } & \multicolumn{6}{|c|}{ Locality } \\
\hline & Cs & WL & $\mathrm{CR}$ & sc & MP & DB \\
\hline $\begin{array}{l}\text { Astarte borealis } \\
\text { (Schumacher) } \\
\text { A. montagui (Dillwyn) }\end{array}$ & $\mathrm{x}$ & $\mathrm{x}$ & & & $\mathrm{x}$ & \\
\hline Bathyarca glacialis (Gray) & $\mathrm{X}$ & & & & & \\
\hline $\begin{array}{l}\text { Cyrtodaria kurriana Dunker } \\
\text { Hiatella arctica (Linnaeus) }\end{array}$ & & $\mathrm{x}$ & ?X & & & $\mathrm{x}$ \\
\hline Portlandia arctica (Gray) & & & & $\mathrm{x}$ & & $\mathrm{x}$ \\
\hline $\begin{array}{l}\text { Serripes groeniandicus } \\
\text { (Bruguiere) }\end{array}$ & $\mathrm{x}$ & & & & & \\
\hline
\end{tabular}

\section{REFERENCES CITED}

Barnes, P.W., and Rearic, D.M., 1985, Rates of sediment disruption by sea ice as determined from characteristics of dated ice gouges created since 1975 on the inner shelf of the Beaufort Sea, Alaska: U.S. Geological Survey Open-File Report 85-463, 35 p.

Brouwers, E.M., 1982, Analys is of inner neritic ostracode assemblages from the Beaufort Sea, northern Alaska: Implications for interpreting analogous Quaternary sediments, in Smith, P.A., and Hopkins, D.M., Offshore permafrost studies and shoreline history as an aid to predicting offshore permafrost conditions: U.S. National Oceanic and Atmospheric Administration, Environmental Assessment of the Alaskan Continental Shelf, Annual Report, Task D-9, Research Unit 204 and 273, April 1981 to March 1982 [unpaged].

Carey, A.G., Jr., Scott, P.H., and Walters, K.R., 1984, Distributional ecology of shallow southwestern Beaufort Sea (Arctic Ocean) bivalve Mollusca: Marine Ecology Progress Series, v. 17, p. 125-134.

Carter, L.D., 1983, Engineering-geologic maps of northern Alaska, Teshekpuk Quadrangle: U.S. Geological Survey Open-File Report 83-634, 1 sheet, scale 1:250,000, includes tabular text.

Carter, L.D., Brigham-Grette, Julie, and Hopkins, D.M., 1986, Late Cenozoic marine transgressions of the Alaskan Arctic Coastal Plain, in Heginbottom, J.A., and Vincent, JS., eds., Correlation of Quaternary deposits and events around the Beaufort Sea: Geological Survey of Canada Open File Report 1237, p. 21-26.

Coachman, L.K., and Aagaard, Knut, 1974, Physical oceanography of arctic and subarctic seas, in Herman, Y., ed., Marine geology and oceanography of the arctic seas: New York, Springer-Verlag, p. 1-72.

Dinter, D.A., 1985, Quaternary sedimentation on the Alaskan Beaufort she1f: Influence of regional tectonics, fluctuating sea levels, and glacial sediment sources: Tectonophysics, v. 114, p. 133-161.
Hopkins, D.M., 1982, Abortive glaciations at high latitudes indicated by glaciomarine deposits, Gubik Formation, northern Alaska [abs.]: Geological Society of America Abstracts with Programs, v. 14, no. 7, p. 518.

Hopkins, D.M., McDougall, Kristin, and Brouwers, E1isabeth, 1981, Microfossil studies of Pelukian and Flaxman deposits, Alaska coast of the Beaufort Sea, in Smith, P.A., Hartz, R.W., and Hopkins, D.M., Offshore permafrost studies and shoreline history as an aid to predicting offshore permafrost conditions: U.S. National Oceanic and Atmospheric administration, Environmental Assessment of the Alaskan Continental Shelf, Annual Report, Task D-9, Research Unit 204 and 273, April 1979 to March 1980, Appendix G, p. 6471 .

Lubinsky, Irene, 1980, Marine bivalve molluscs of the Canadian central and eastern Arctic: Faunal composition and zoogeography: Canadian Bulletin of Fisheries and Aquatic Sciences, Bu!let in $207,111 \mathrm{p}$.

McDougall, Kristin, Brouwers, Elisabeth, and Smith, Peggy, 1986, Micropaleontology and sedimentology of the PB borehole series, Prudhoe Bay, Alaska: U.S. Geological Survey Bulletin 1598, 62 p.

Moore, S.E., and Barrowclough, E.I., 1984, Incidental sighting of a ribbon seal (Phoca fasciata) in the western Beaufort Sea: Arctic, v. 37, p. 290.

Ockelmann, K.W., 1958, marine Lamellibranchiata. The zoology of east Greenland: Meddelelser om Gronland Udgiune af Kommissionen for Videnskabelige Undersogelser I Gronland, Bd. 122, Nr. 4, 256 p.

Reimnitz, Erk, Graves, S.M., and Barnes, P.W., 1985, Beaufort Sea coastal erosion, shoreline evolution, and sediment flux: U.S. Geological Survey Open-File Report 85380,66 p.

Repenning, C.A., 1983, New evidence for the age of the Gubik Formation, Alaskan North Slope: Quaternary Research, v. 19, p. 356372 .

Rodeick, C.A., 1979, The origin, distribution, and depositional history of gravel deposits on the Beaufort Sea continental shelf, Alaska: U.S. Geological Survey Open-File Report 79-234, 87 p.

Rugh, D.J., and Fraker, M.A., 1981, Gray whale (Eschrichtius robustus) sightings in eastern Beaufort Sea: Arctic, v. 34, p. 186-187.

Sharma, G.D., 1979, The Alaskan shelf: New York, Springer-Verlag, 498 p.

\section{Reviewers: D.M. Hopkins and Kristin McDouga11}

Geologic Studies in Alaska by the U.S. Geological Survey during 1987: John P. Galloway and Thomas D. Hamilton, editors, U.S. Geological Survey Circular 1016. 


\title{
Stromatolite- and Coated-Grain-Bearing Carbonate Rocks of the Western Brooks Range
}

\author{
By Julie A. Dumoulin
}

Carbonate rocks characterized by locally abundant stromatolites and coated grains have been found at several localities in the Baird Mountains and Ambler River quadrangles (fig. 1). These rocks are part of a belt of metasedimentary and metaigneous rocks that constitutes the southwestern flank of the Brooks Range; all are included in the parautochthon (Schwatka sequence) of Mayfield and others (1983). The rocks have been deformed and metamorphosed to blueschist and greenschist facies, but primary textures and sedimentary structures are locally well preserved.

Abundant stromatolites and (or) coated grains have been found in carbonate rocks west, south, and southeast of Mount Angayukagsraq in the northeastern part of the Baird Mountains quadrangle, west of the Akiak Mountains in the western Ambler River quadrangle, and east of the Redstone River in the central Ambler River quadrangle (fig. 2). These rocks are included in the Paleozoic marble and quartzite unit of Mayfield and Tailleur (1978), and the Kogoluktuk Schist of Hitzman and others (1982). Rocks that may be equivalent to the carbonate sequence discussed here, but which have not yet been closely studied, crop out over a large area that extends east through the Survey Pass quadrangle (S.W. Nelson, U.S. Geological Survey, oral commun., 1987), and into the Wiseman quadrangle (A.G. Harris, U.S. Geological Survey, oral commun., 1987). The stromatolites in the central

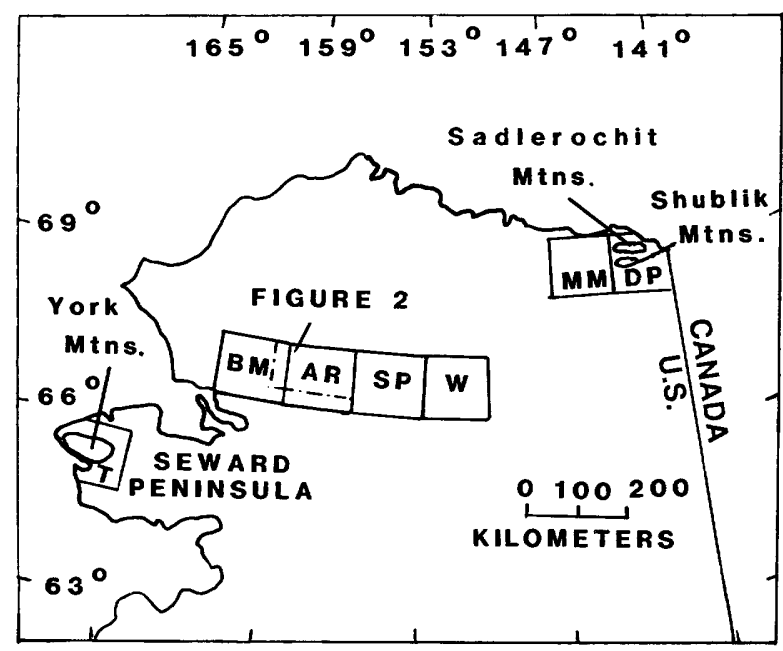

Figure 1. Index map of northern Alaska showing localities discussed in text. Quadrangle designations: AR, Ambler River; BM, Baird Mountains; DP, Demarcation Point; MM, Mount Michelson; SP, Survey Pass; T, Teller; W, Wiseman.
Ambler River quadrangle were first noted by Hitzman and others (1982); all other occurrences are here reported for the first time.

Stromatolites are organosedimentary structures produced through sediment binding, trapping, and (or) precipitation by a microbial community (Krumbein, 1983). Stromatolite morphologies in western Brooks Range rocks range from flat or slightly hummocky tabular sheets a few centimeters thick to laterally linked columnar or club-shaped bodies up to $15 \mathrm{~cm}$ high (fig. 3). At most localities, stromatolitic rocks are intercalated with layers and lenses of dolomitic grainstone and packstone that contain abundant and various coated grains--both ooids and oncoids, according to the usage of Wilson (1975). Ooids are spherical particles less than $2 \mathrm{~mm}$ in diameter with smooth, multiple, concentric laminae assumed to have formed through inorganic chemical precipitation in warm, wave-agitated, saline or hypersaline waters (fig. 4A). Oncoids are characterized by more uneven laminae thought to have formed through biogenic encrustation, typically by algae or cyanobacteria (fig. 4B). The ooid and oncoid grainstone layers are typically crossbedded, but may show parallel lamination or grading. Fenestral fabric is locally well developed. Associated carbonate lithologies include storm-generated flat-pebble conglomerate and carbonate mudstone.

The total thickness of the unit containing the stromatolites and coated grains is difficult to estimate due to structural complexity of the outcrop areas. Maximum thicknesses, on the order of several hundred meters, occur south of Mount Angayukagsraq.

The assemblage of sedimentary features found in these carbonate rocks indicates intertidal to shallow subtidal depositional environments (Wilson, 1975). Modern ooids form in warm, shallow shelf areas of

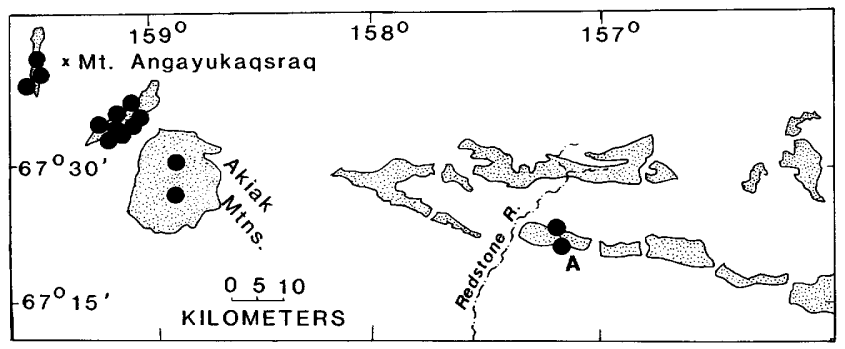

Figure 2. Known locations of stromatolite- and coated-grainbearing carbonate rocks of Baird Mountains and Ambler River quadrangles (solid circles). Extent of lithofacies (stippled pattern) generalized from Mayfield and Tailleur (1978). 
moderate to high wave and current activity; oolitic sands are most abundant in waters less than $10 \mathrm{~m}$, and typically less than $2 \mathrm{~m}$ deep (Choquette, 1978). The Bahama carbonate platform, where tidal channels contain living columnar stromatolites growing in a high-energy environment dominated by ooid sand (Dill and others, 1986), may provide a modern analog for the depositional environment of the western Brooks Range rocks.

In all of the western Brooks Range localities, carbonate rocks containing stromatolites and coated grains are associated with quartzose metasedimentary and metavolcanic rocks. Layers of quartzite and locally calcareous quartz-white mica schist as much as $15 \mathrm{~m}$ thick are intercalated with the carbonate rocks. Quartzose metasedimentary rocks in the central Ambler River area include metaconglomerates with clasts of quartz and chert up to $2 \mathrm{~cm}$ in diameter. Metavolanic rocks include blue amphibole-bearing metabasite that locally preserves pillow breccia and agglomeratic primary textures, and chlorite-albite schist. Southeast of Mount Angayukaqsraq, layers of conglomerate contain mafic clasts in a carbonate

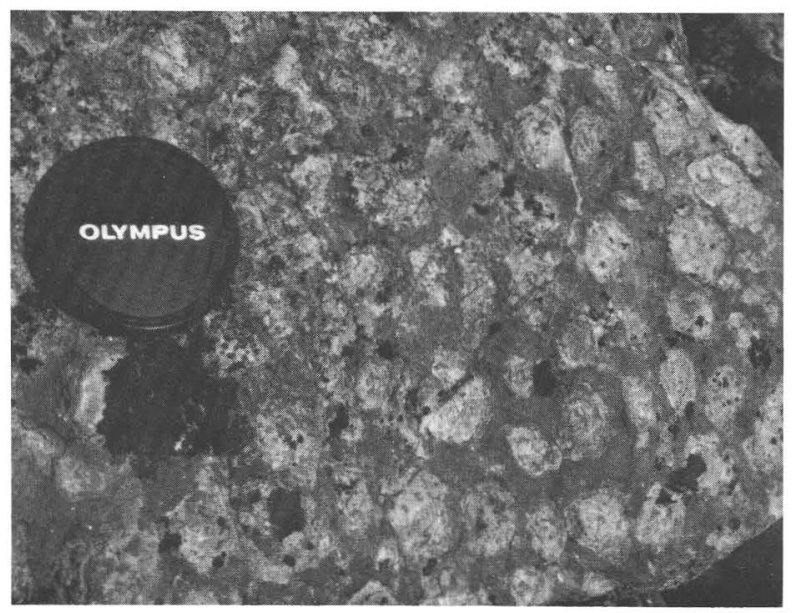

A

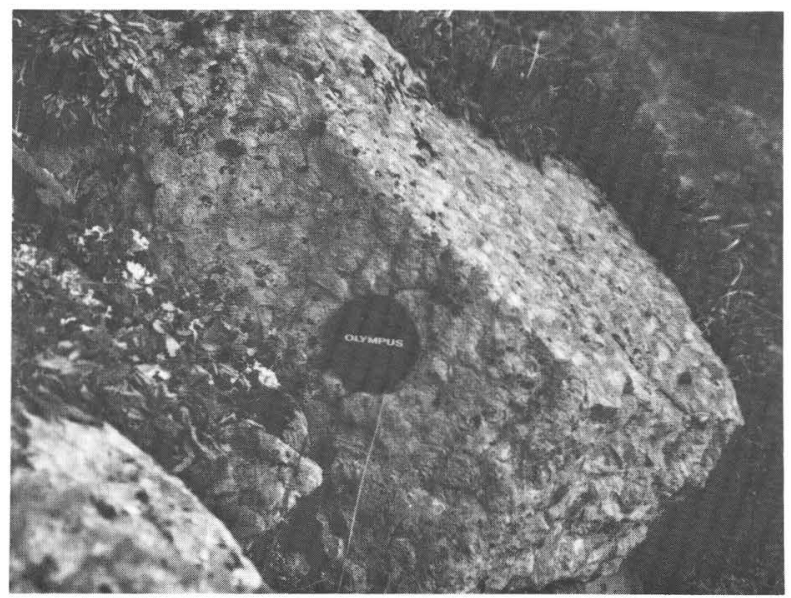

B

Figure 3. Columnar stromatolites, Akiak Mountains area, western Ambler River quadrangle; lens cap is $5 \mathrm{~cm}$ in diameter. A, Top view. B, Side view. matrix; this occurrence suggests that the association of carbonate and metavolcanic rocks is a primary one and not just a later tectonic feature.

The tectonic setting for the association of shallow-water carbonate rocks and mafic metavolcanic rocks may have been a rifted carbonate platform; several episodes of Proterozoic(?) and Paleozoic rifting have been proposed for northwestern Alaska (Schmidt, 1987). The central Ambler River quadrangle contains a carbonate sequence that may have been deposited in a small rift basin (fig. 2, locality A). Stromatolite-bearing, shallow-water carbonate rocks occur adjacent to black carbonate rhythmites with intrastratal deformation (slump folds?). The rhythmites are intercalated with beds of carbonate breccia tens of meters thick containing clasts of white-weathering, locally stromatolitic dolostone in a matrix of black lime mudstone. These rocks are interpreted to be debris flows that formed along a slope bounding a carbonate platform or shelf; the light-colored clasts most likely represent earlycemented shallow-water carbonate lithologies that were eroded and transported into the basin.

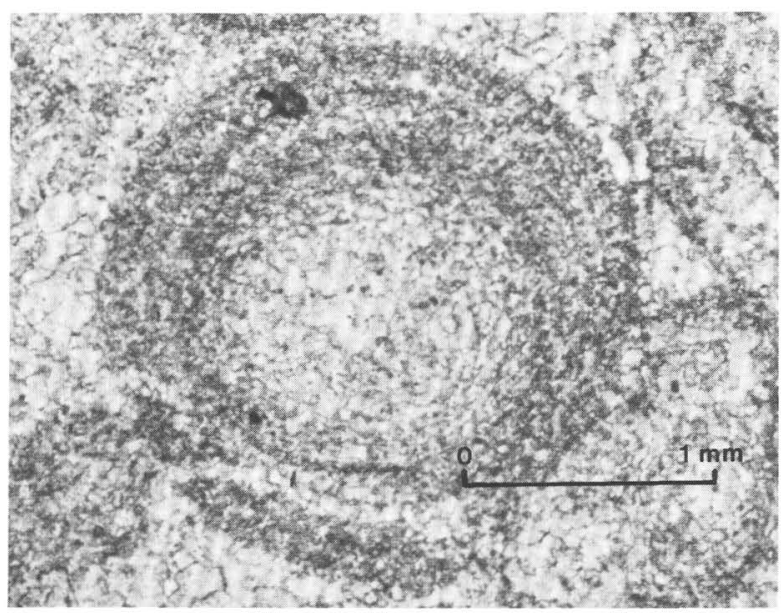

A

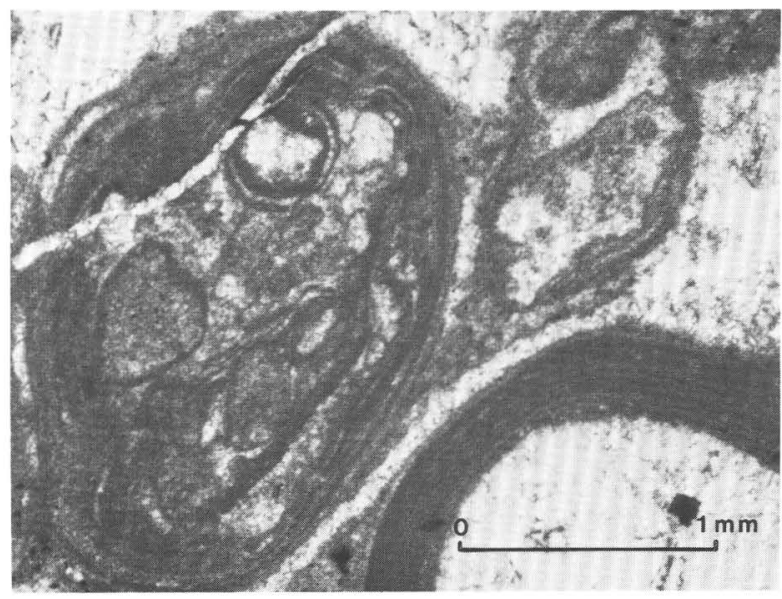

B

Figure 4. Coated grains from southeast of Mount Angayukaqsraq. A, Ooid with smooth, even laminae. B, Oncoid with irregular laminae and multiple nuclei. 
The age of the stromatolite- and coated-grainbearing sequence is uncertain. Stromatolites are known from rocks of Archean age to the present (Krumbein, 1983), and other organic remains (including trace fossils) have not yet been found in this sequence. Relationships with associated rocks suggest that the carbonate rocks with stromatolites and coated grains are early Paleozoic or older in age. In the northeastern Baird Mountains quadrangle, they form a series of thrust sheets imbricated with Proterozoic amphibolite-facies rocks and lower Paleozoic carbonate rocks (Till and others, 1987). The stromatolite- and coated-grain-bearing rocks could represent upper Proterozoic or lowest Paleozoic "cover" of the older Proterozoic "basement." Further, deformed and metamorphosed carbonate rocks of middle or late Paleozoic age in this part of Alaska almost invariably contain at least some megafossil debris (for example, corals and brachiopods). However, the absence of organic remains other than stromatolites in the stromatolite- and coated-grainbearing rocks could be attributed to the fact that both stromatolitic supratidal flats and ooid sand shoals are environments inhospitable to most invertebrates. Both stromatolites and coated grains are rare or absent in carbonate rocks of middle and late Paleozoic age in the western Brooks Range.

Regional correlations of the stromatolite- and coated-grain-bearing rocks are hindered by the lack of age control, but some lithologic correlations can be suggested. The Ordovician argillaceous limestone unit of Sainsbury (1969) is a thick $(1,500 \mathrm{~m})$ Lower Ordovician carbonate sequence that crops out in the York Mountains of western Seward Peninsula (fig. 1). It contains locally abundant coated grains, a variety of stromatolitic morphologies, and some beds rich in quartz silt (Vandervoort, 1985); however, it also contains locally abundant fossils and other carbonate lithologies not seen in the western Brooks Range sequence.

The Katakturuk Dolomite, widely exposed in the Shublik and Sadlerochit Mountains in the northeastern Brooks Range, is a better lithologic match for the western Brooks Range sequence. It is thick (greater than $3,000 \mathrm{~m}$ ) and contains subtidal to intertidal stromatolites of diverse morphologies associated with crossbedded oolitic grainstone and storm-generated intraclastic grainstone (Clough, 1986). The Katakturuk is considered to be Proterozoic in age (Blodgett and others, 1986). A thick sequence of dolostone directly beneath the Katakturuk is associated with basaltic volcanic rocks, but quartzose sedimentary rocks appear to be rare or absent in most of the Katakturuk (K.F. Watts, University of Alaska, written commun., 1987).

If the stromatolite- and coated-grain-bearing carbonate rocks of the western Brooks Range do correlate with the Katakturuk Dolomite, a very extensive carbonate platform existed in northern Alaska during the Proterozoic. A belt of shallowwater carbonates of this size is not unprecedented-the modern-day Great Barrier Reef east of Australia is twice the length of the Brooks Range.

\section{REFERENCES CITED}

Blodgett, R.B., Clough, J.G., Dutro, J.T., Jr., Ormiston, A.R., Palmer, A.R., and Taylor, M.E., 1986, Age revisions for the Nanook Limestone and Katakturuk Dolomite, northeastern Brooks Range, in BartschWinkler, Susan, and Reed, $\vec{K} . M .$, eds., Geologic Studies in Alaska by the U.S. Geological Survey during 1985, U.S. Geological Survey Circular 978, p.5-10.

Choquette, P.W., 1978, Oolite, in Fairbridge, R.W., and Bourgeois, Joanne, eds., The Encyclopedia of Sedimentology: Stroudsburg, Penn., Dowden, Hutchinson, and Ross, p. 510515 .

Clough, J.G., 1986, Peritidal sedimentary facies and stromatolites of the Katakturuk Dolomite (Proterozoic), northeastern Alaska [abs.]: 12th International Sedimentological Congress, Canberra, Australia, p. 64.

Dill, R.F., Shinn, E.A., Jones, A.T., Kelly, K., and Steinen, R.P., 1986, Giant subtidal stromatolites forming in normal salinity waters: Nature, v. 324, p. 55-58.

Hitzman, M.W., Smith, T.E., and Proffett, J.M., Jr., 1982, Bedrock geology of the Ambler District, southwestern Brooks Range, Alaska: Alaska Division of Geological and Geophysical Surveys Geologic Report 75, 2 sheets, scale 1:125,000.

Krumbein, W.E., 1983, Stromatolites--The challenge of a term in space and time: Precambrian Research, v. 20, p. 493-531.

Mayfield, C.F., and Tailleur, I.L., 1978, Bedrock geology map of the Ambler River quadrangle, Alaska: U.S. Geological Survey Open-File Report 78-120A, scale 1:250,000.

Mayfield, C.F., Tailleur, I.L., and Ellersieck, Inyo, 1983, Stratigraphy, structure, and palinspastic synthesis of the western Brooks Range, northwestern Alaska: U.S. Geological Survey Open-File Report 83-779, 53 p.

Sainsbury, C.L., 1969, Geology and ore deposits of the central York Mountains, western Seward Peninsula, Alaska: U.S. Geological Survey Bulletin 1287, 101 p.

Schmidt, J.M., 1987, Paleozoic extension of the western Brooks Range continental margin-Evidence from mineral deposits, igneous rocks, and sedimentary facies [abs.]: Geological Society of America Abstracts with Programs, v. 19, no. 6, p. 477.

Till, A.B., Schmidt, J.M., and Nelson, S.W., 1987, Thrust-involvement of Proterozoic and Mesozoic metamorphic rocks, southwestern Brooks Range, Alaska [abs.]: Geological Society of America Abstracts with Programs, v. 19 , no. 6 , p. 458 .

Vandervoort, D.J., 1985, Stratigraphy, paleoenvironment, and diagenesis of the Lower Ordovician York Mountain carbonates, Seward Peninsula, Alaska: Baton Rouge, Louisiana State University, M.S. Thesis, 141 p. 
Wilson, J.L., 1975, Carbonate facies in geologic history: New York, Springer-Verlag, 471 p.

Reviewers: S.E. Box and Keith F. Watts
Geologic Studies in Alaska by the U.S. Geological Survey during 1987: John P. Galloway and Thomas D. Hamilton, editors, U.S. Geological Survey Circular 1016. 


\title{
Off-Platform Silurian Sequences in the Ambler River Quadrangle
}

\author{
By Julie A. Dumoulin and Anita G. Harris
}

Lithofacies changes in coeval upper Paleozoic rocks have been used to unravel the tectonic history of northern Alaska (for example, Mayfield and others, 1983). Conodont biostratigraphy and detailed petrologic studies are now revealing facies differences in lower Paleozoic rocks that can also be used to constrain their tectono-sedimentary framework (Dumoulin and Harris, 1987). A basic element of basin analysis is the discrimination of shallow-water shelf and platform sequences from deeper water slope and basinal deposits. This report documents several new localities of deeper water, off-platform Silurian deposits in the Ambler River quadrangle and briefly outlines some of their paleogeographic implications.

Mayfield and Tailleur (1978) first described a sequence of metasedimentary rocks from two areas in the north-central Ambler River quadrangle (fig. 1). They recognized "turbidite textures, flute casts, and graded beds" in these rocks and assigned them to the Devonian siltstone and slate unit (fig. 2, unit 1). This unit was considered Devonian in age because it contained favositid corals of Silurian or Devonian age and lay between Mississippian quartz conglomerate (Mc) and carbonate rocks of the Silurian and Devonian Skajit Limestone (Mayfield and Tailleur, 1978). Our recent studies of unit 1 rocks confirm that they are turbidites, but indicate that they are, at least in part, Silurian in age.

A measured section $8 \mathrm{~km}$ east of Kavachurak Creek (fig. 2, locality A) contains more than $25 \mathrm{~m}$ of metasandstone, phyllite, and metalimestone, and a sequence of similar rocks $16 \mathrm{~km}$ to the west is at least $200 \mathrm{~m}$ thick (fig. 2, locality B). The rocks are recrystallized and locally folded, but primary sedimentary features are generally well preserved. Conodonts from these rocks have color alteration indices of 5, indicating the host rock reached temperatures of at least $300{ }^{\circ} \mathrm{C}$. Siliciclastic metasandstone makes up at least 30 percent of unit 1; it is primarily medium to coarse grained and slightly schistose (fig. 3). Most samples contain 5 to 30 percent monocrystalline and polycrystalline quartz clasts, variable (as much as 30 percent) amounts of carbonate detritus, and 5 to 10 percent sedimentary lithic grains (mudstone, siltstone, and phyllite). Other clast types include feldspar (many of the grains are zoned), volcanic lithic grains (most with lathwork textures), and chert. Some chert clasts contain recrystallized radiolarians. About 50 to 60 percent of unit 1 is fine-grained quartzose siltstone and dark-grey to black, light-brown-weathering phyllite, with locally abundant calcareous concretions as much as $30 \mathrm{~cm}$ in diameter. The siliciclastic rocks have many features characteristic of turbidites, including complete to partial Bouma sequences, convolute laminae, flame structures, and a variety of flute, scour, and prod marks. The strata form packages 1 meter to tens of meters thick that coarsen and thicken upward.

Recrystallized, locally dolomitic, limestone layers 5 to $80 \mathrm{~cm}$ thick make up the remaining 10 to 20 percent of unit 1 ; they are intercalated with the siliciclastic rocks and increase in abundance upward. Carbonate rock types include calcirudites containing clasts as large as $10 \mathrm{~cm}$, calcarenites, and calcilutites. The coarser grained layers typically show channelized bases, local grading, and parallel and convolute laminations; clasts are mostly dolostone and limestone, plus a few percent mudstone and quartz. We interpret these rocks as carbonate turbidites and debris flows made up of redeposited shallow-water detritus. The calcilutites probably represent carbonate mud eroded from a slope or platform.

Conodonts recovered from four samples distributed through our 25-m measured section at Locality A are of Middle to early Late Silurian age (Wenlockian to Ludlovian) and represent a normalmarine, relatively warm, shallow-water biofacies (figs. 4A-M). Megafossils recovered from locality A and B include corals, gastropods, bryozoans, brachiopods, conularids, and orthocone cephalopods; they indicate a Silurian or Devonian age (Mayfield and Tailleur, 1978; J.T. Dutro, Jr., U.S. Geological Survey, written

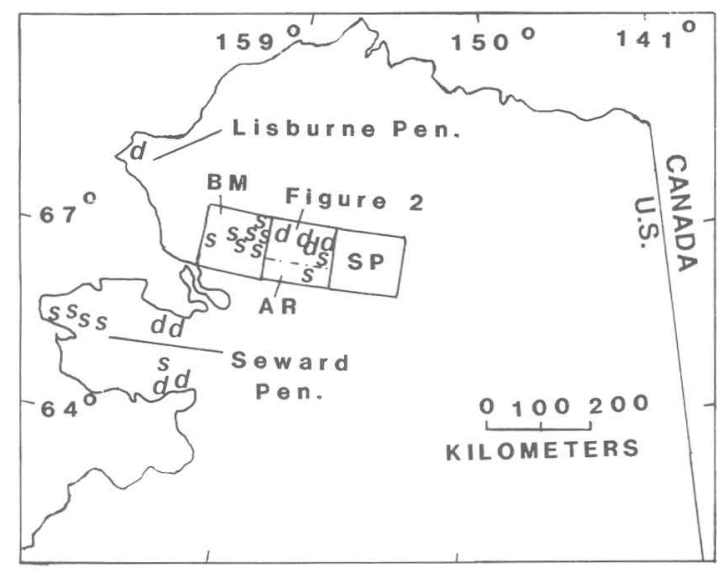

Figure 1. Index map of northern Alaska showing localities discussed in text and general distribution of Silurian shallowwater ( $s$ ) and deeper water (d) lithofacies (from Dumoulin and Harris, 1987, and unpub. data). Quadrangle designations: AR, Ambler River; BM, Baird Mountains; SP, Survey Pass. 


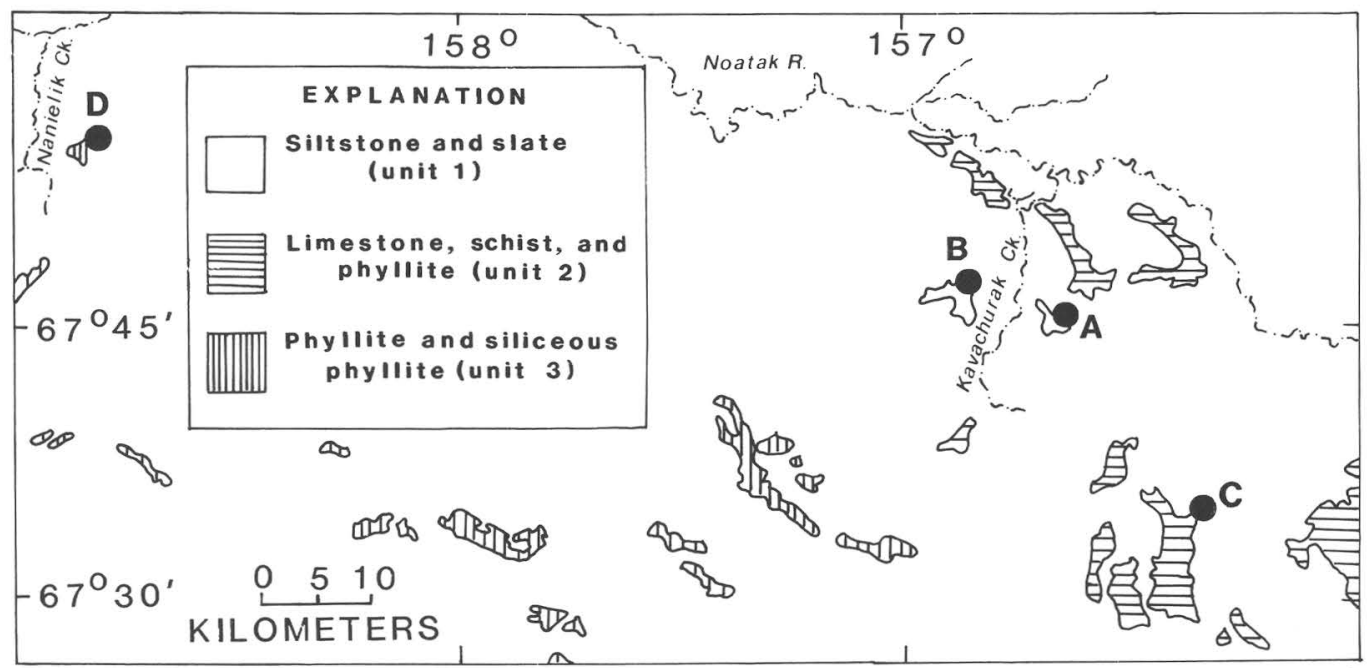

Figure 2. Location of Silurian fossil localities and lithologic units of Mayfield and Tailleur (1978), northern part of Ambler River quadrangle; extent of lithologic units generalized from Mayfield and Tailleur (1978). Letters indicate USGS collection localities referred to in text; A, 11507-SD to 11510-SD; B, 11511-SD; C, 11769-SD; D, 11516-SD. See figure 1 for location.

commun., 1978). Elements of this megafauna as well as the conodonts are characteristic of shallow-water environments, and probably they were hydraulically transported basinward from a platform. We believe that the conodonts found in unit 1 indicate the true age of the unit, however, and were not derived from older rocks because the species association is consistent in age and biofacies throughout the measured section.

The intercalation of siliciclastic and carbonate layers in these Silurian off-platform deposits could reflect sediments derived from two separate source areas--one dominantly siliciclastic and the other dominantly carbonate. Alternatively, hybrid sequences can accumulate in response to sea-level fluctuations (Droxler and Schlager, 1985). Siliciclastic basin deposits tend to accumulate during relative lowstands, when sediment bypasses the platform and shelf and is carried basinward; carbonate basin deposits are favored during highstands, when carbonate production on the platform and shelf is enhanced and terrigenous deposits are trapped near shore.

Rocks lithologically (and perhaps genetically) related to unit 1 crop out across the central and eastern Ambler River quadrangle and make up the Devonian black limestone, calcareous schist, and black siliceous phyllite unit of Mayfield and Tailleur (1978) (fig. 2, unit 2). Unit 2 phyllites contain probable recrystallized radiolarians; rare metasandstones consist mostly of quartz, feldspar, and sedimentary lithic grains. Unit 2 was considered "stratigraphically equivalent" to "less metamorphosed" rocks in the Survey Pass quadrangle that contain Middle and Late Devonian brachiopods by Mayfield and Tailleur (1978). However, several metalimestone layers in unit 2 (locality $\mathrm{C}$ in fig. 2) contain some of the same conodonts (Pelekysgnathus n. sp.) that date unit 1 as Wenlockian to Ludlovian in age. These conodonts are of uniformly small size and were probably winnowed as they were transported basinward from a shallower water environment. Unit 2 may well include rocks of
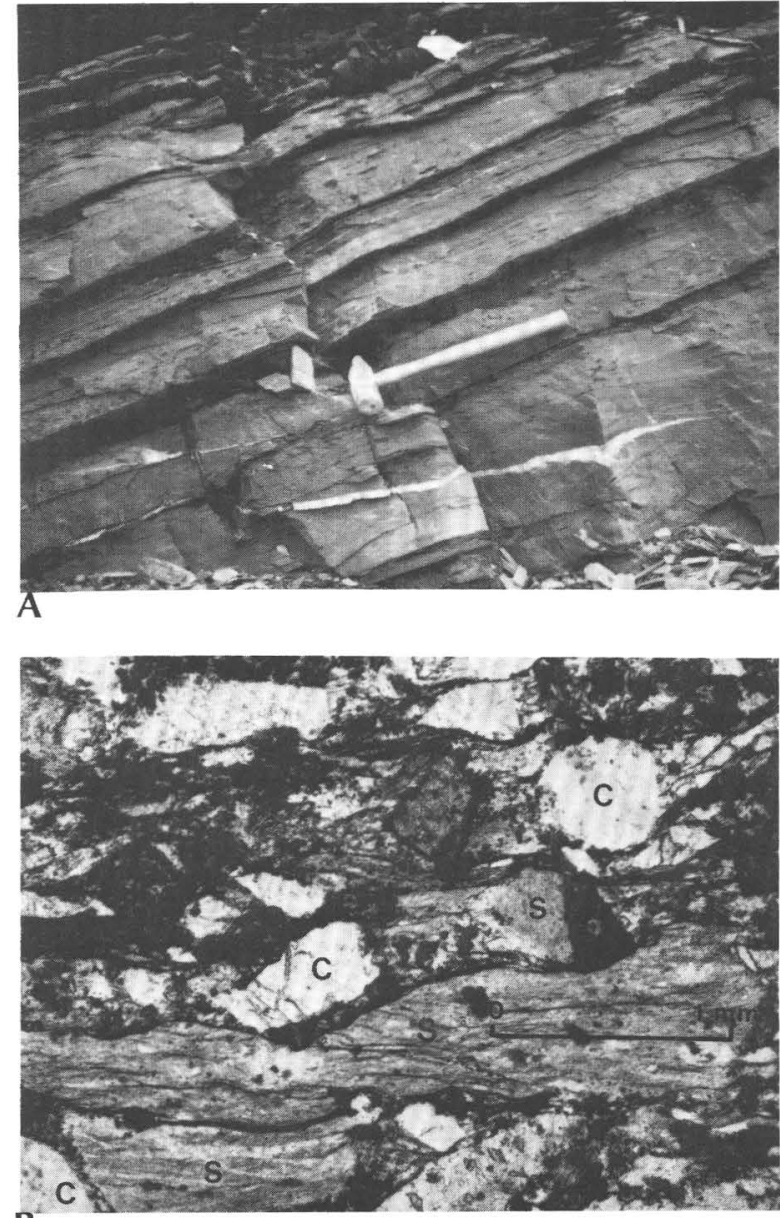

B

Figure 3. Siliciclastic turbidites at locality B. A, Outcrop view. B, Photomicrograph of coarse-grained metasandstone rich in chert (C) and sedimentary lithic (S) clasts. 


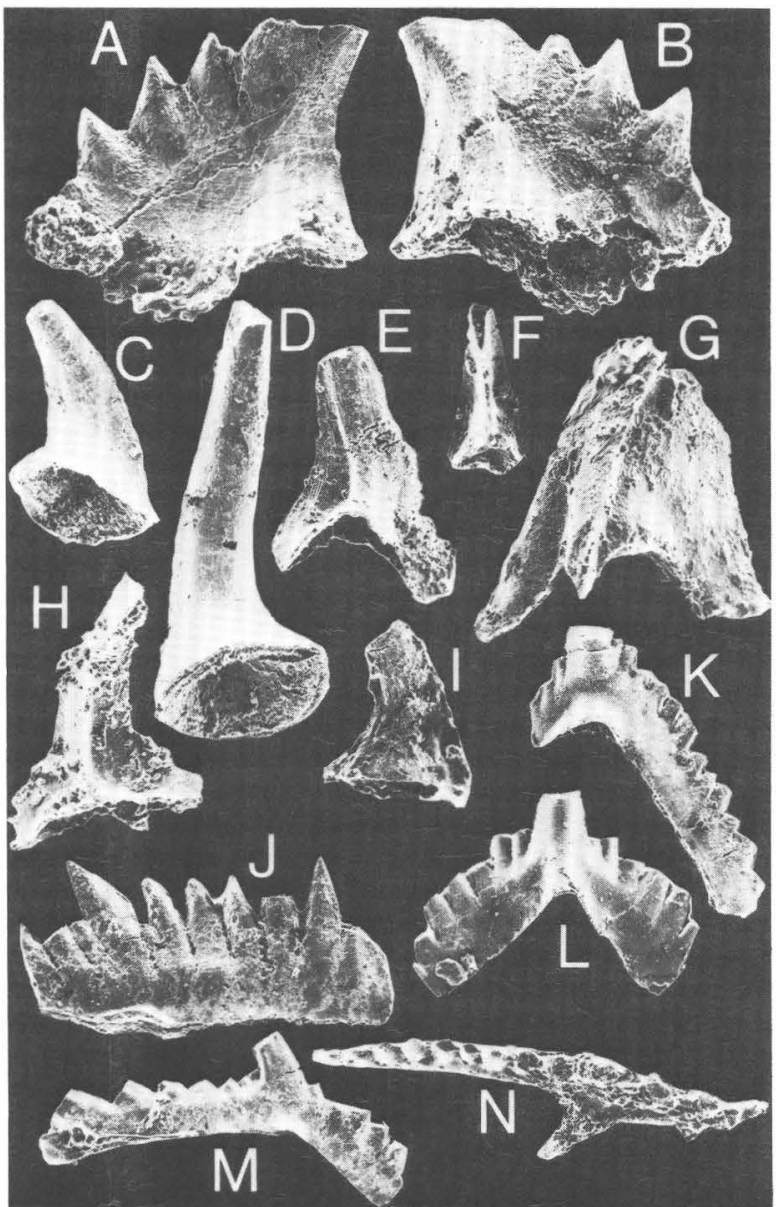

Figure 4. Scanning electron micrographs of Silurian conodonts from off-platform deposits in Ambler River quadrangle. A-I, Pelekysgnathus n. sp., x75, from locality A (fig. 2); C from USGS colln. 11507-SD ( $9 \mathrm{~m}$ above base of section), all others from 11510-SD (25 m above base of section). Although these specimens represent a new species, we believe the composition of the apparatus, which includes $P$ elements and two series of $M$ and $\mathrm{S}$ elements (an alate and a roundiform series) indicates a Wenlockian or Ludlovian age. Thus far, alate $\mathrm{M}$ and $\mathrm{S}$ elements have not been reported from the apparatus of Pelekysgnathus, but it seems likely that such morphotypes would characterize early representatives of the genus. Representatives of Ozarkodina excavata (Branson and Mehl) and Panderodus sp., long-ranging Middle Silurian to Early Devonian forms, are the only other conodonts in the samples which produced Pelekysnathus n. sp. A, B, inner and outer lateral views of $P$ element, USNM 423456. C, D, Postero-lateral views of roundiform $M$ and Sa elements, USNM 423457-423458. E-I, Alate $M(E), S a(F$, posterior view; $G$, antero-lateral view), Sb $(H)$, and Sc (I) elements, USNM 423459-423463. J-M, Ozarkodina excavata (Branson and Mehl), Pa, M, Sa, and Sc elements, x50, USNM 423464-423467, from USGS colln. 11507-SD $(9 \mathrm{~m}$ above base of section, loc. A, fig. 2). N, Pterospathodus pennatus (Walliser), upper view of $\mathrm{Pa}$ element, $\times 50$, USNM 423645, from USGS colln. 11516-SD (fig. 2, loc. D). The presence of this species indicates a range from the celloni Zone to the lower part of the amorphognathoides Zone (very latest Llandoverian). several ages, but at least part of it is of Silurian age and correlative with unit 1 .

Off-platform deposits of Silurian age have also been found in the western Ambler River quadrangle. Middle Silurian (late Wenlockian) graptolites (Claire Carter, U.S. Geological Survey, written commun., 1977) were recovered from the Paleozoic black phyllite and siliceous phyllite unit of Mayfield and Tailleur (1978) (fig. 2, unit 3) east of Nanielik Creek; a possible correlation has been suggested between these rocks and parts of unit 2 (Mayfield and Tailleur, 1978). Black siliceous phyllite in unit 3 (fig. 2, locality D) contains recrystallized radiolarians. Thin interlayers of black, recrystallized limestone at this locality contain conodonts of latest Early Silurian (very latest Llandoverian) age (fig. $4 \mathrm{~N}$ ), slightly older than those found in units 1 and 2.

Off-platform deposits of established Silurian age are not common in northern Alaska whereas shallow-water Silurian deposits are widespread. Shallow-water Silurian sequences occur in several localities in the eastern Ambler River quadrangle (fig. 1 ), and fossiliferous black marble in the southeastern part of the quadrangle contains the same new species of Pelekysnathus (USGS colln. 11381-SD) found in units 1 and 2. Middle to Upper Silurian dolostones in the central and eastern Baird Mountains quadrangle contain conodont assemblages and sedimentary structures indicative of deposition in a range of peritidal environments (Dumoulin and Harris, 1987). Fossiliferous marble in the eastern Baird Mountains quadrangle contains late Early Silurian (late Llandoverian) conodonts (USGS colln. 11768-SD) correlative with those found in unit 3. Other shallowwater carbonate rocks of Silurian age are known from the central and western Seward Peninsula, and from several localities in the central Brooks Range (see summary in Dumoulin and Harris, 1987).

Deep-water deposits of Silurian age in northern Alaska are known from the Seward and Lisburne Peninsulas (fig. 1). On the central Seward Peninsula, the Ordovician to Devonian black metalimestone and marble unit of Till and others (1986) contains probable peri-platform oozes and carbonate turbidites of Middle Silurian age. On the Lisburne Peninsula, strongly deformed, locally calcareous slaty turbidites of the Iviagik Group of Martin (1970) contain Ordovician and late Early Silurian (late Llandoverian) graptolites and conodonts (Grantz and others, 1983). The Lisburne Peninsula turbidites have been correlated with slaty distal turbidites penetrated in wells on the North Slope that contain Ordovician and Silurian graptolites and chitinozoans (Grantz and others, 1983).

Both deep- and shallow-water Silurian deposits of the western Brooks Range are included in the parauthochthon (Schwatka sequence) of Mayfield and others (1983). The proximity of coeval, lithologically and environmentally distinct Silurian deposits in the Baird Mountains-Ambler River area suggests a more complex early Paleozoic paleogeography and (or) tectonic history than has previously been inferred. 


\section{REFERENCES CITED}

Droxler, A.W., and Schlager, W., 1985, Glacial versus interglacial sedimentation rates and turbidite frequency in the Bahamas: Geology, v. 13, p. 799-802.

Dumoulin, J.A., and Harris, A.G., 1987, Lower Paleozoic carbonate rocks of the Baird Mountains quadrangle, western Brooks Range, Alaska, in Tailleur, I.L., and Weimer, Paul, eds., Alaska North Slope Geology: Bakersfield, Calif., Pacific Section, Society of Economic Paleontologists and Mineralogists and Alaska Geological Society, v. 1, p. 311-336.

Grantz, Arthur, Tailleur, I.L., and Carter, Claire, 1983, Tectonic significance of Silurian and Ordovician graptolites, Lisburne Hills, northwest Alaska [abs.]: Geological Society of America Abstracts with Programs, v. 15, no. 5, p. 274.

Martin, A.J., 1970, Structure and tectonic history of the western Brooks Range, De Long Mountains and Lisburne Hills, northern
Alaska: Geological Society of America Bulletin, v. 81, no. 12, p. 3605-3622.

Mayfield, C.F., and Tailleur, I.L., 1978, Bedrock geology map of the Ambler River quadrangle, Alaska: U.S. Geological Survey Open-File Report 78-120A, scale 1:250,000.

Mayfield, C.F., Tailleur, I.L., and Ellersieck, Inyo, 1983, Stratigraphy, structure, and palinspastic synthesis of the western Brooks Range, northwestern Alaska: U.S. Geological Survey Open-File Report 83-779, 53 p.

Ti11, A.B., Dumoulin, J.A., Gamble, B.M., Kaufman, D.S., and Carroll, P.I., 1986, Preliminary geologic map and fossil data, Solomon, Bendeleben, and southern Kotzebue quadrangles, Seward Peninsula, Alaska: U.S. Geological Survey Open-File Report 86-276.

Reviewers: J.T. Dutro, Jr., W.W. Patton, Jr.

Geologic Studies in Alaska by the U.S. Geological Survey during 1987: John P. Galloway and Thomas D. Hamilton, editors, U.S. Geological Survey Circular 1016. 


\title{
Late Wisconsin Eolian Activity and Related Alluviation, Central Kobuk River Valley
}

\author{
By Thomas D. Hamilton, John P. Galloway, and Eduard A. Koster
}

The central Kobuk River valley is located near the south margin of the Brooks Range about $200 \mathrm{~km}$ from the coast (fig. 1). This segment of the valley contains thick sand deposits that were derived primarily from glacial erosion of quartzose rocks within the Brooks Range. Glaciers and meltwater streams transported sandy till and outwash to the south flank of the range; sand then was winnowed from the glacial deposits and redeposited across the Kobuk valley floor by glaciolacustrine, alluvial, and eolian processes (Hamilton, 1984).

Presently active dune fields in the central Kobuk River yalley consist of the Great Kobuk Sand Dunes $\left(62 \mathrm{~km}^{2}\right)$, the Little Kobuk Sand Dunes $\left(8 \mathrm{~km}^{2}\right.$, and the informally named Hunt River dunes $\left(2 \mathrm{~km}^{2}\right)$ opposite the mouth of Hunt River (fig. 1). The Great and Little Kobuk Sand Dunes were built dominantly by southeasterly winter winds, which formed niveo-eolian deposits of interstratified sand and snow (Koster and Dijkmans, 1988). The dunes near Hunt River were built dominantly by northerly winds that funneled through the valley of Hunt River from the low pass at its head. Granulometry and mineralogy of the eolian sands are described by Galloway and Koster (1984) and by J.W.A. Dijkmans (University of Utrecht, The Netherlands) and J.P. Galloway (unpub. data, 1988). Calcretes of the Great Kobuk Sand Dunes have been discussed by Cox and Lawrence (1983), Galloway and others (1985), and Dijkmans and others (1986).

Extensive areas of stabilized and tundracovered or forested dunes in the central Kobuk River valley have been mapped by Fernald (1964), Hamilton

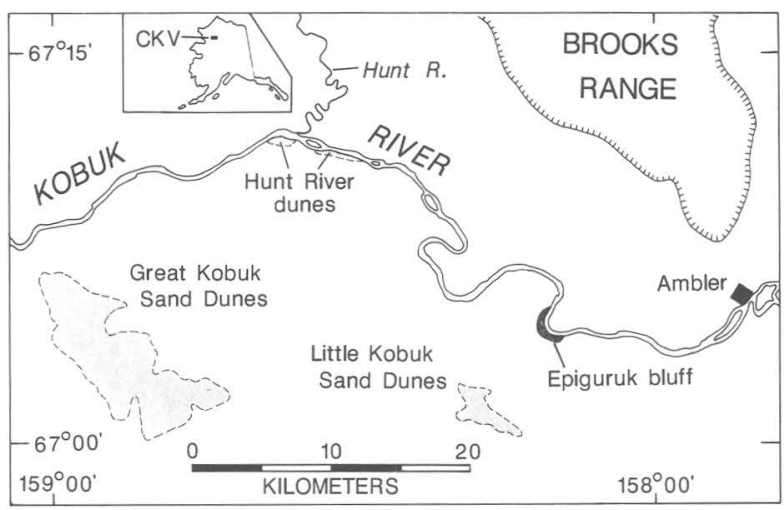

Figure 1. Central Kobuk River valley (CKV), showing location of active dune fields.
(1984), and Kuhry-Helmens and others (1985). These stabilized features cover about $650 \mathrm{~km}^{2}$ of the Kobuk valley floor (Kuhry-Helmens and others, 1985), forming a sand sea (very large dune field) that extends north to Epiguruk bluff on the Kobuk River (fig. 2). Eolian sand, loess, and alluvium at Epiguruk bluff are exposed in an arcuate cutbank about $3 \mathrm{~km}$ long (Hamilton and others, 1984).

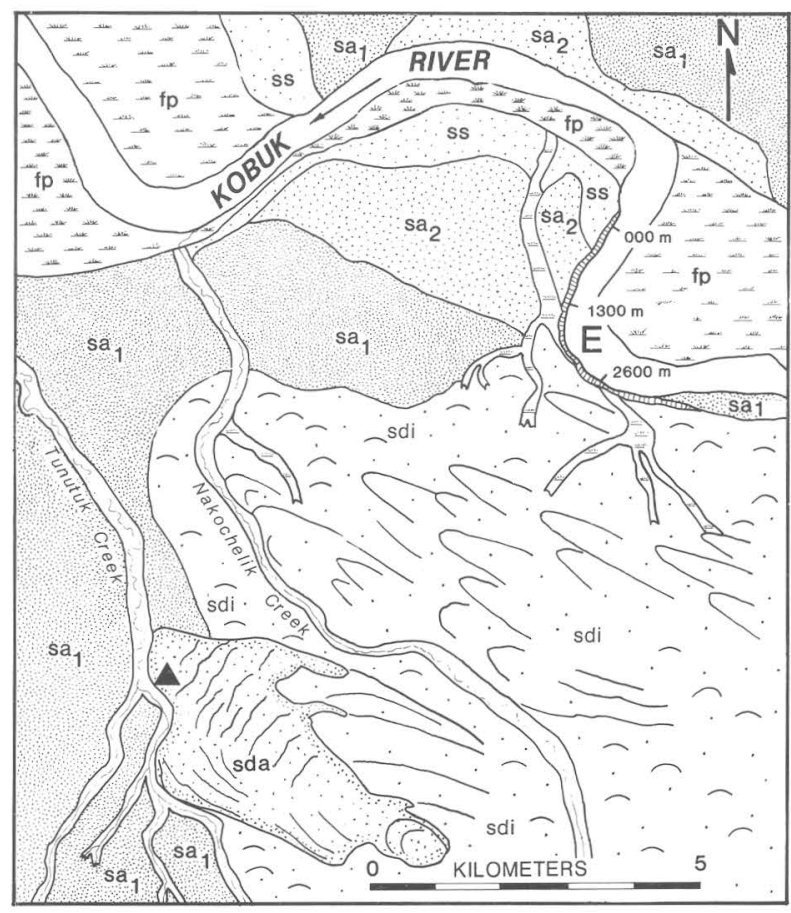

EXPL.ANATION

\begin{tabular}{|c|c|c|c|c|}
\hline$-\mathrm{fp}-$ & Flood plain & sdi & $\begin{array}{l}\text { Inactive } \\
\text { sand dunes }\end{array}$ & $\begin{array}{l}\text { Active } \\
\text { channel }\end{array}$ \\
\hline ss & Slip-off slope & $\mathrm{sa}_{2}$ & $\begin{array}{l}\text { Younger } \\
\text { valley fill }\end{array}$ & $\begin{array}{l}\text { Abandoned } \\
\text { channel }\end{array}$ \\
\hline sda & Little Kobuk & sa 1 & $\begin{array}{l}\text { Older } \\
\text { valley fill }\end{array}$ & $=\underset{\text { bluff }}{\text { Epiguruk }}$ \\
\hline
\end{tabular}

Figure 2. Surficial geology and geomorphology of area around Little Kobuk Sand Dunes and Epiguruk bluff. Meter designations along Epiguruk bluff are positions along surveyed base line. Solid triangle marks exposure at west end of Little Kobuk Sand Dunes. Form lines on dune fields represent transverse, parabolic, and hummocky dune types. 
In this paper, we present stratigraphic evidence and radiocarbon dates which show that (1) a widespread episode of dune formation in the central Kobuk River valley was associated with alluviation of the Kobuk River by $15 \mathrm{~m}$ or more at Epiguruk bluff, and that (2) dune activity and alluviation were broadly synchronous with late Wisconsin (Itkillik II) glaciation of the central Brooks Range as dated by Hamilton (1982) and Hamilton and others (1987). Although late Pleistocene dune-building has been widely reported in Alaska (Hopkins, 1982, and references therein; Carter, 1983), our radiocarbon-dated sections are the first to demonstrate that a distinct episode of dune formation is assignable to the Itkillik II glacial substage of the Brooks Range and to the late Wisconsin glacial episode of Alaska.

At the west end of the Little Kobuk Sand Dunes (fig. 2), an incision up to $20 \mathrm{~m}$ deep formed by headward sapping of a small tributary to Tunutuk Creek (fig. 3) exposes a paleosol within cross-bedded eolian sand. The paleosol typically consists of an A horizon of brownish, organic, structureless very fine sand above a B horizon of oxidized sand about $35 \mathrm{~cm}$ thick that contains cryoturbation structures. In one place, the buried soil forms horizontally laminated deposits of very fine sand and organic-rich silt. The paleosol declines in height toward the east end of the exposure where it forms the floor of a former channel about $3 \mathrm{~m}$ deep (fig. 4). Within the channel floor, the paleosol consists of a $5-\mathrm{cm}$ layer of bryophytic peat, mainly consisting of Scorpidium turgescens, above oxidized sand. Radiocarbon ages of 24,560 \pm 720 and
$24,930 \pm 200$ yr B.P. (I-12,206 and GrN-11.111, respectively) were obtained from peat on the channel floor, and a sample from the organic-rich-silt facies of the paleosol has an age of $24,000 \pm 550 \mathrm{yr}$ B.P. (GrN11.112). The three radiocarbon ages, which broadly overlap at double their counting error (a confidence interval of about 95 percent), indicate that the entire paleosol complex was buried by renewed deposition of eolian sand about 24,000 years ago.

Radiocarbon ages from Epiguruk bluff show a similar history of paleosol formation terminated by accumulation of fluvial and eolian sand derived from the central Kobuk River valley sand sea (Hamilton and others, 1984). Throughout two segments of the bluff (300-600 $\mathrm{m}$ and 2,200-2,600 m), the prominent paleosol illustrated by Hamilton and others (1984, fig. 8) began forming about $34-33 \mathrm{ka}$ (thousand yr B.P.) at heights of 3-5 $\mathrm{m}$ above modern river level (table 1-A). The paleosol later was buried beneath sandy alluvium about $24 \mathrm{ka}$ (table 1-B). The paleosol occurs at a higher level (about 9-12 $\mathrm{m}$ above the river) throughout the segment of the bluff between 1,100 and $1,600 \mathrm{~m}$ (Hamilton and others, 1984, fig. 8). Within this part of the bluff, sandy alluvium was deposited at progressively greater heights up to more than $15 \mathrm{~m}$ above the river between about 23 and $18.5 \mathrm{ka}$ (table 1-C). Eolian sand (unit sdi in fig. 2) extended across the southern part of the bluff area $(1,950-2,600 \mathrm{~m})$ sometime after $19 \mathrm{ka}$; the dunes later became stabilized and were incised by the abandoned channel shown on figure 2. Wood within the channel-filling deposits is dated at about $10.5 \mathrm{ka}$ (table $1-\mathrm{D})$.

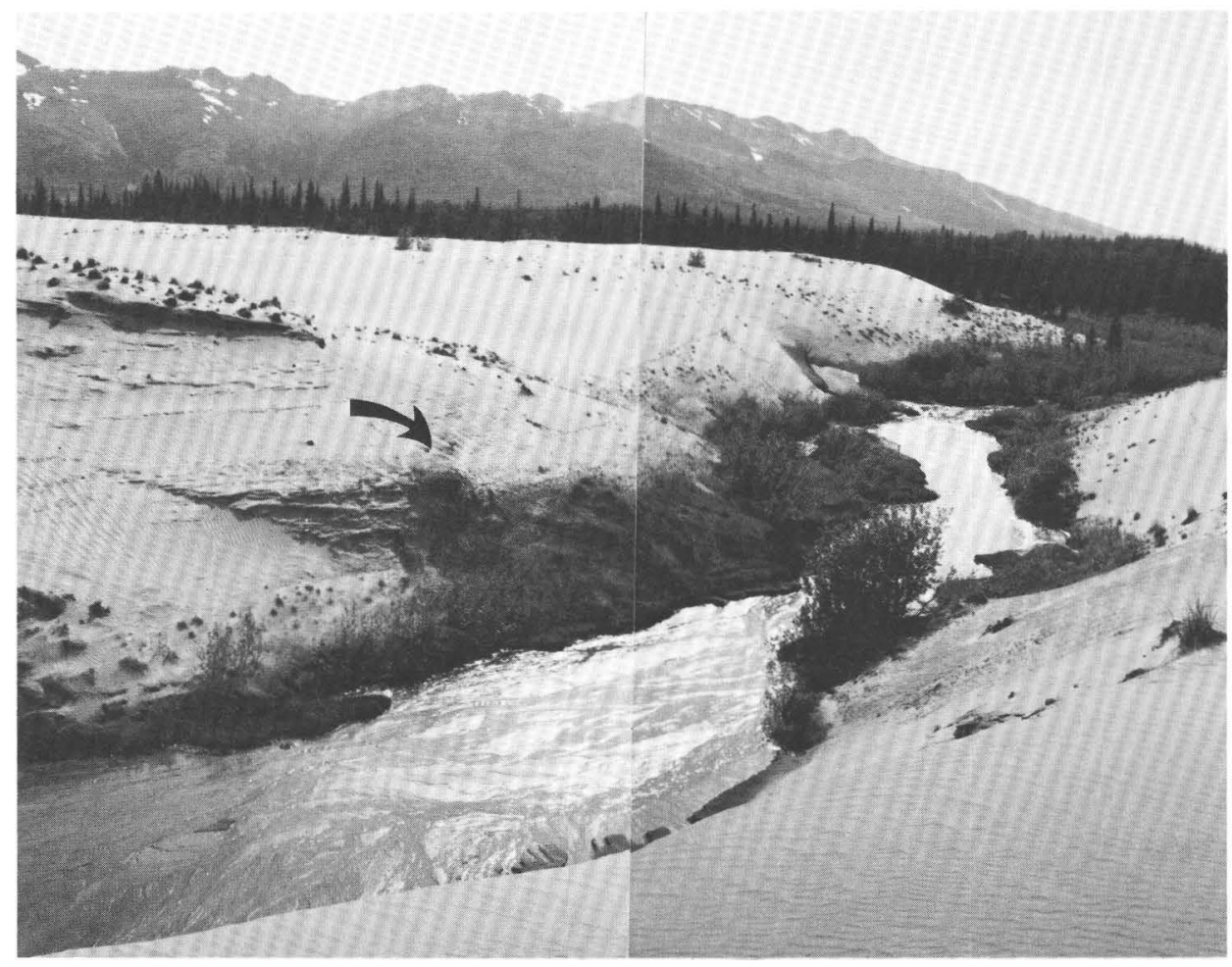

Figure 3. Small tributary to Tunutuk Creek near west edge of Little Kobuk Sand Dunes. Arrow indicates site where radiocarbon samples were taken (I-12,206 and GrN 11.111). 

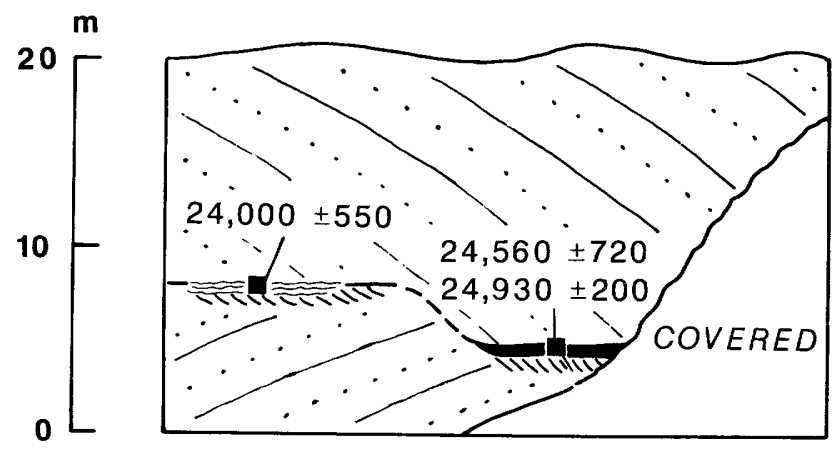

\section{EXPLANATION}

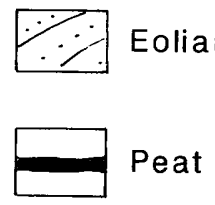

Eolian sand

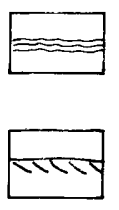

Laminated organic silt

Oxidized horizon

Figure 4. Sketch showing radiocarbon dates and stratigraphic relationships exposed at west end of Little Kobuk Sand Dunes.

The radiocarbon ages from Epiguruk bluff support those from the Little Kobuk Sand Dunes in showing paleosols forming on stable sand surfaces until about $24 \mathrm{ka}$. This suggests that the paleosol in the Little Kobuk Sand Dunes is of regional significance and represents stabilization of the entire dune field during mid-Wisconsin time. The paleosol at the Little Kobuk Sand Dune locality was buried beneath reactivated sand dunes, and active dunes must have reached the Kobuk River at or above Epiguruk bluff at about the same time in order to cause the river to alluviate with well-sorted fine to medium sand (Hamilton and others, 1984).

The William River, which cuts through the Athabascan Sand Dunes of western Canada (Smith and Smith, 1984), provides a modern analog for the alluviating Kobuk River. The bed load of the William River increases forty-fold as it encounters the dune field; its channel pattern changes from meandering to braided, and channel width increases five-fold (Smith and Smith, 1984). In the Kobuk River valley, Kavet and Ahnewetut Creeks exhibit similar broadly braided channel patterns where they intersect the Great Kobuk Sand Dunes. The late Pleistocene Kobuk River similarly developed a broad, shallow channel with westward-directed paleocurrents that lacks point-bar structures and other evidence for meandering flow patterns. Downcutting of the Kobuk River at Epiguruk bluff probably began after about $18.5 \mathrm{ka}$, and development of a broad slip-off slope (fig. 2) indicates that the river had reverted to its meandering channel pattern by about $16 \mathrm{ka}$ (T.D. Hamilton, unpub. data). Our radiocarbon ages from the Little Kobuk Sand Dunes and from Epiguruk bluff show that reactivation of the Kobuk sand sea was synchronous with late Wisconsin glaciation of the central Brooks Range and the north-central Alaska Range (Hamilton, 1982; Ten Brink and Waythomas, 1985), but dune activity evidently began to wane several thousand years before major retreat of glaciers from their end-moraine positions about 13-12 ka (Hamilton, 1986).

A contributing local cause of dune reactivation must have been exposure of the broad Bering Platform by glacioeustatic lowering of sea level (Hopkins, 1982), which would have deprived the central Kobuk River valley of a major source of summer precipitation. However, an extensive sand sea was also active on the Arctic Coastal Plain at this time (Carter, 1981), and this extensive dune field and associated sand wedges suggest a dry, barren, windswept environment with little snow cover in winter (Carter, 1983). The sand seas of the central Kobuk River valley and the Arctic Coastal Plain, together with numerous late Pleistocene dune fields in the Koyukuk River valley (T.D. Hamilton, unpub. field mapping), indicate that aridity was widespread in northern Alaska during the last glaciation and was not localized in regions close to the Bering Platform.

\section{REFERENCES CITED}

Carter, L.D., 1981, A Pleistocene sand sea on the Alaskan Arctic Coastal Plain: Science, v. 211, p. 381-383.

1983, Fossil sand wedges on the Alaskan Arctic Coastal Plain and their paleoenvironmental significance, in Permafrost International Conference Proceedings, 4th, Fairbanks, Alaska, July 1983: Washington, D.C., National Academy Press, p. 109-114.

Cox, G.W., and Lawrence, W.T., 1983, Cemented horizons in subarctic Alaskan sand dunes: American Journal of Science, v. 283, p. 369373.

Di jkmans, J.W.A., Koster, E.A., Galloway, J.P., and Mook, W.G., 1986, Characteristics and origin of calcretes in a subarctic environment, Great Kobuk Sand Dunes, northwestern Alaska, U.S.A.: Arctic and Alpine Research, v. 18, p. 377-387.

Fernald, A.T., 1964, Surficial geology of the central Kobuk River valley, northwestern Alaska: U.S. Geological Survey Bulletin $1181-\mathrm{K}, 31 \mathrm{p}$.

Galloway, J.P., and Koster, E.A., 1984, Comparison of grain-size statistics from two northern Alaska dune fields, in Coonrad, W.L., and Elliott, R.L., eds., The U.S. Geological Survey in Alaska--Accomplishments during 1981: U.S. Geological Survey Circular 868, p. 20-21.

Galloway, J.P., Koster, E.A., ald Hamilton, T.D., 1985, Comments on cemented horizon in subarctic Alaskan sand dunes: American Journal of Science, v. 285, p. $186 \cdot 190$.

Hamilton, T.D., 1982, A late Pleistocene glacial chronology for the southern Brooks Range-Stratigraphic record and regional significance: Geological Society of America Bulletin, v. 93, p. 700-716. 
Table 1. Selected radiocarbon dates from Epiguruk bluff, central Kobuk River Valley

\begin{tabular}{|c|c|c|c|c|}
\hline & $\begin{array}{l}\text { Date and } \\
\text { lab. no. }\end{array}$ & $\begin{array}{l}\text { Material } \\
\text { dated }\end{array}$ & Stratigraphic position & $\begin{array}{l}\text { Height above } \\
\text { river (m) }\end{array}$ \\
\hline \multirow[t]{3}{*}{ D. } & \multicolumn{4}{|c|}{ Channel filling at $1,650-1,950 \mathrm{~m}$} \\
\hline & $\begin{array}{l}10,340 \pm 150 \\
(I-12,462)\end{array}$ & Wood and peat & $\begin{array}{l}\text { Near top of channel filling } \\
\text { (redeposited?) }\end{array}$ & 9 \\
\hline & $\begin{array}{l}10,370 \pm 150 \\
(I-12,438)\end{array}$ & Wood $(\operatorname{Salix})$ & Base of channel filling & 5 \\
\hline \multirow[t]{7}{*}{ C. } & \multicolumn{4}{|c|}{ Fluvial sand above paleosol, $1,100-1,600 \mathrm{~m}$} \\
\hline & $\begin{array}{l}17,370 \pm 280 \\
(I-12,440)\end{array}$ & $\begin{array}{l}\text { Detrital wood } \\
(\text { Salix) }\end{array}$ & $\begin{array}{l}\text { Base of channel filling } \\
\text { (downcutting phase?) }\end{array}$ & 15 \\
\hline & $\begin{array}{l}18,500 \pm 320 \\
(I-13,209)\end{array}$ & $\begin{array}{l}\text { Rooted shrubs } \\
(\text { Salix) }\end{array}$ & Within alluvium & 14.5 \\
\hline & $\begin{array}{l}19,080 \pm 350 \\
(I-13,218)\end{array}$ & $\begin{array}{l}\text { Detrital wood } \\
(\text { Salix) }\end{array}$ & $\begin{array}{l}\text { Within alluvium. Underlies } \\
\text { sand dune }\end{array}$ & 13 \\
\hline & $\begin{array}{l}20,290 \pm 90 \\
(\text { USGS-1449) }\end{array}$ & $\begin{array}{l}\text { Rooted shrubs } \\
(S a I i x)\end{array}$ & Within alluvium & 12 \\
\hline & $\begin{array}{l}2 I, 020 \pm 460 \\
(I-I 3,208)\end{array}$ & $\begin{array}{l}\text { Rooted shrubs } \\
(\text { Salix) }\end{array}$ & Within alluvium & 13 \\
\hline & $\begin{array}{l}23,560 \pm 160 \\
(U S G S-1442)\end{array}$ & $\frac{\text { In }}{(S a i t u}$ roots & Alluvium-paleosol contact & 9 \\
\hline \multirow[t]{5}{*}{ B. } & \multicolumn{3}{|c|}{ Paleosol at $300-600 \mathrm{~m}$ and $2,200-2,600 \mathrm{~m}$} & \multirow[b]{2}{*}{8} \\
\hline & $\begin{array}{l}21,450 \pm 230 \\
\text { (USGS-1653) }\end{array}$ & Peat & Near base of alluvium & \\
\hline & $\begin{array}{l}22,770 \pm 100 \\
(U S G S-1445)\end{array}$ & Peat & Paleosol-alluvium contact & 6 \\
\hline & $\begin{array}{l}24,050 \pm 620 \\
(I-12,471)\end{array}$ & $\begin{array}{l}\text { Rooted shrubs } \\
(\text { Salix) }\end{array}$ & Paleosol-alluvium contact & 8 \\
\hline & $\begin{array}{l}24,290 \pm 720 \\
(G X-1446)\end{array}$ & Wood fragments & $\begin{array}{l}\text { Paleosol-alluvium contact } \\
\text { (From Schweger, 1982) }\end{array}$ & 6 \\
\hline \multirow[t]{3}{*}{ A. } & \multicolumn{3}{|c|}{ Alluvium beneath paleosol } & \\
\hline & $\begin{array}{l}32,830 \pm 730 \\
(U S G S-1661)\end{array}$ & $\begin{array}{l}\text { Detrital wood } \\
\text { and peat }\end{array}$ & Alluvium at base of paleosol & 3 \\
\hline & $\begin{array}{l}33,670 \pm 280 \\
(\text { USGS-1443) }\end{array}$ & $\begin{array}{l}\text { Detrital twigs } \\
(\text { Salix) }\end{array}$ & $\begin{array}{l}\text { Alluvium interstratified with } \\
\text { base of paleosol }\end{array}$ & 5 \\
\hline
\end{tabular}

1984, Surficial geologic map of the Ambler River quadrangle, Alaska: U.S. Geological Survey Miscellaneous Field Studies Map MF-1678, scale 1:250,000. 1986, Correlation of Quaternary glacial deposits in Alaska, in Richmond, G.M., and Fullerton, D.S., eds., Quaternary glaciations in the United States of America: Quaternary Science Reviews, v. 5 (Quaternary Glaciations in the Northern Hemi sphere), p. 171-180.

Hamilton, T.D., Ashley, G.M., Reed, K.M., and Van Etten, D.P., 1984, Stratigraphy and sedimentology of Epiguruk bluff--A preliminary account, in Reed, K.M., and Bartsch-Winkler, Susan, eds., The United States Geological Survey in Alaska-Accomplishments during 1982: U.S. Geological Survey Circular 939, p. 12-15.
Hamilton, T.D., Lancaster, G.A., and Trimble, D.A., 1987, Glacial advance of late Wisconsin (Itkillik II) age in the upper Noatak River valley--A radiocarbon-dated stratigraphic record, in Hamilton, T.D., and Galloway, J. P., eds., Geologic studies in Alaska by the U.S. Geological Survey during 1986: U.S. Geological Survey Circular 998, p. 35-39.

Hopkins, D.M., 1982, Aspects of the paleogeography of Beringia during the late Pleistocene, in Hopkins, D.M., Matthews, J.V., Jr., Schweger, C.E., and Young, S.B., eds., Paleoecology of Beringia: New York, Academic Press, p. 3-28.

Koster, E.A., and Dijkmans, J.W.A., 1988, Niveoeolian deposits and denivation forms with special reference to the Great Kobuk Sand Dunes, northwestern Alaska: Earth Surface 
Processes and Landforms [in press].

Kuhry-Helmens, K.F., Koster, E.A., and Galloway, J.P., 1985, Photo-interpretation map of surficial deposits and landforms of the Kobuk Sand Dunes and part of the Kobuk Lowland, Alaska: U.S. Geological Survey Open-File Report 85-242.

Schweger, C.E., 1982, Late Pleistocene vegetation of eastern Beringia--Pollen analysis of dated alluvium, in Hopkins, D.M., Matthews, J.V., Jr., Schweger, C.E., and Young, S.B., eds., Paleoecology of Beringia: New York, Academic Press, p. 95112 .

Smith, N.D., and Smith, D.C., 1984, William River--An outstanding example of channel widening and braiding caused by bed-load addition: Geology, v. 12, p. 78-82.

Ten Brink, N.W., and Waythomas, C.F., 1985, Late Wisconsin glacial chronology of the northcentral Alaska Range--A regional synthesis and its implications for early human settlements, in Powers, W.R., and others, North Alaska Range Early Man Project: Washington, D.C., National Geographic Society Research Reports, v. 19, p. 15-32.

Reviewers: L.D. Carter and O.J. Ferrians

Geologic Studies in Alaska by the U.S. Geological Survey during 1987: John P. Galloway and Thomas D. Hamilton, editors, U.S. Geological Survey Circular 1016. 


\title{
Décollements in the Endicott Mountains Allochthon, North-Central Brooks Range
}

\author{
By J.S. Kelley and Diedra Bohn
}

Recently compiled mapping and our field observations in the Chandler Lake quadrangle (Kelley, 1988) identify widespread decollements in the Endicott Mountains allochthon in the central Brooks Range (fig. 1). The decollements occur in near-continuously exposed Upper Devonian to Lower Cretaceous strata in the southern Chandler Lake quadrangle. These features are likely sites of extensive and possibly large-scale thrust faulting, thus raising the possibility that the allochthon includes a structural assemblage of strata rather than a simple structural block.

Strata that comprise the Endicott Mountains allochthon were first considered to make up an extensive structural block in the western Brooks Range (Martin, 1970), and the allochton subsequently was traced nearly the breadth of northern Alaska (Mayfield and others, 1983). Martin (1970) described Devonian to Lower Cretaceous strata in an extensive thrust sheet, referred to as the Brooks Range sequence, that extends into the central Brooks Range. Mayfield and others (1983) refined the stratigraphy of Martin (1970), renamed the sequence the Brooks Range allochthon, and suggested that the allochthon extends the breadth of the Brooks Range. In the central Brooks Range, Mull (1979) referred to the Upper Devonian to Lower Cretaceous strata as the Endicott Mountains sequence and subsequently as the Endicott Mountains allochthon (Mull, 1985).

Previous workers have proposed two models for emplacement of the Endicott Mountains allochthon relative to penetratively deformed rocks that crop out south of the Chandler Lake quadrangle. Dutro and others (1976) suggested that the strata of the Endicott Mountains allochthon: (1) could originally have lain north of the penetratively deformed rocks in the Doonerak area or (2) could have been thrust into their present position from south of the penetratively deformed rocks in the Doonerak area. Subsequent workers (Mull, 1982; Mull and others, 1987a; 1987c) argued that the Endicott Mountains allochthon originated south of the Doonerak area and was thrust northward more than $55 \mathrm{~km}$ as a coherent block to its present position north of the Doonerak area.

Our work in the Chandler Lake quadrangle suggests that six major decollements defining five structural blocks occur in the Endicott Mountains allochthon (fig. 2). The areal extent of each decollement ranges from $2,070 \mathrm{~km}^{2}$ to $4,660 \mathrm{~km}^{2}$. Each decollement separates tabular structural blocks that show independent styles of deformation and appear to have formed through delamination of a presumably near-horizontal sedimentary sequence.
The decollements occur within (1) laterally extensive beds possessing low shear strength and (2) lithologic transitions, especially those transitions associated with contrasting shear strengths. Major decollements occur along the base of the Hunt Fork Shale, between the undivided Kanayut Conglomerate and Noatak Sandstone and the Hunt Fork Shale, in the Kayak Shale, and in the Permian and younger strata above the Lisburne Group. Less extensive decollements also occur along the base of the upper part of the Kanayut Conglomerate and between the wacke and shale members of the Hunt Fork Shale.

The basal shale member of the Hunt Fork Shale in the eastern part of the Chandler Lake quadrangle occurs in imbricate blocks, and faults that underlie the blocks sole into a basal thrust that detaches the shale member from unknown substrata. Farther to the west, imbricate fault blocks involving the shale member are not mapped but can be inferred from abrupt thickness changes and localized structural complexities. These features and relationships reflect the presence of an extensive decollement within or along the bave of the Hunt Fork Shale.

Deeply eroded thrust sheets in the southeastern part of the Chandler Lake quadrangle expose an areally limited detachment between the shale and wacke members of the Hunt Fork Shale. Imbricate thrust faults produce multiple repetitions of the shale member independent of the overlying wacke member

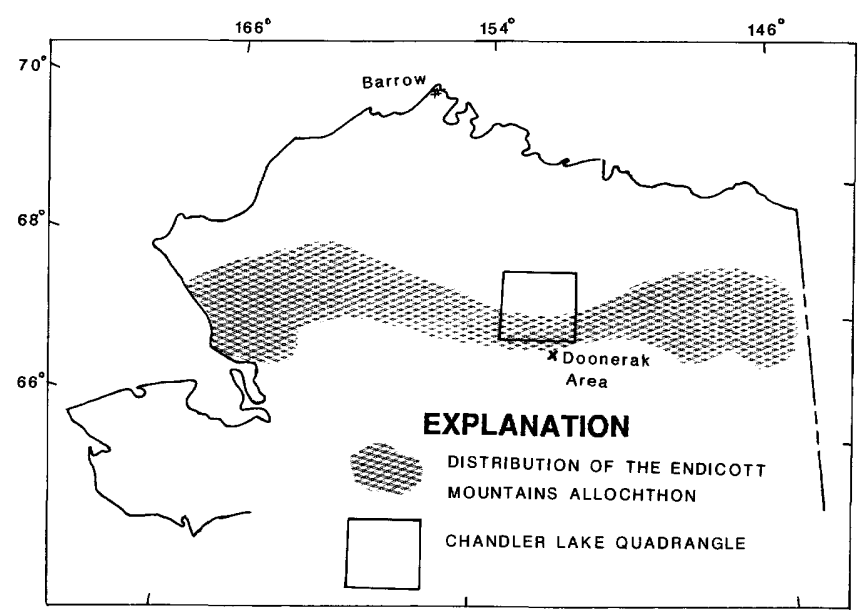

Figure 1. Northern Alaska, showing Chandler Lake quadrangle and distribution of Endicott Mountains allochthon. 
(fig. 3). The décollement between members of the Hunt Fork Shale appears widespread in the southern and southwestern parts of the Chandler Lake quadrangle but not in exposures of Devonian strata farther to the northeast.

An extensive decollement between the Hunt Fork Shale and overlying Noatak Sandstone and Kanayut Conglomerate is exposed in eroded thrust sheets in the southeastern part of the Chandler Lake quadrangle. Multiple repetitions of the Hunt Fork
Shale occur independently of the overlying Kanayut Conglomerate and Noatak Sandstone (fig. 3). The Hunt Fork Shale is structurally complex throughout the exposure of Devonian strata in the Chandler Lake quadrangle, whereas the Kanayut Conglomerate and Noatak Sandstone are not. The decollement produces complex relations in the Noatak Sandstone, typically separating more massive rocks of this unit from thin beds and lenses in gradational contact with the underlying Hunt Fork Shale.
NORTH

RANGE

FRONT
SOUTH

$68^{\circ} \mathrm{N}$

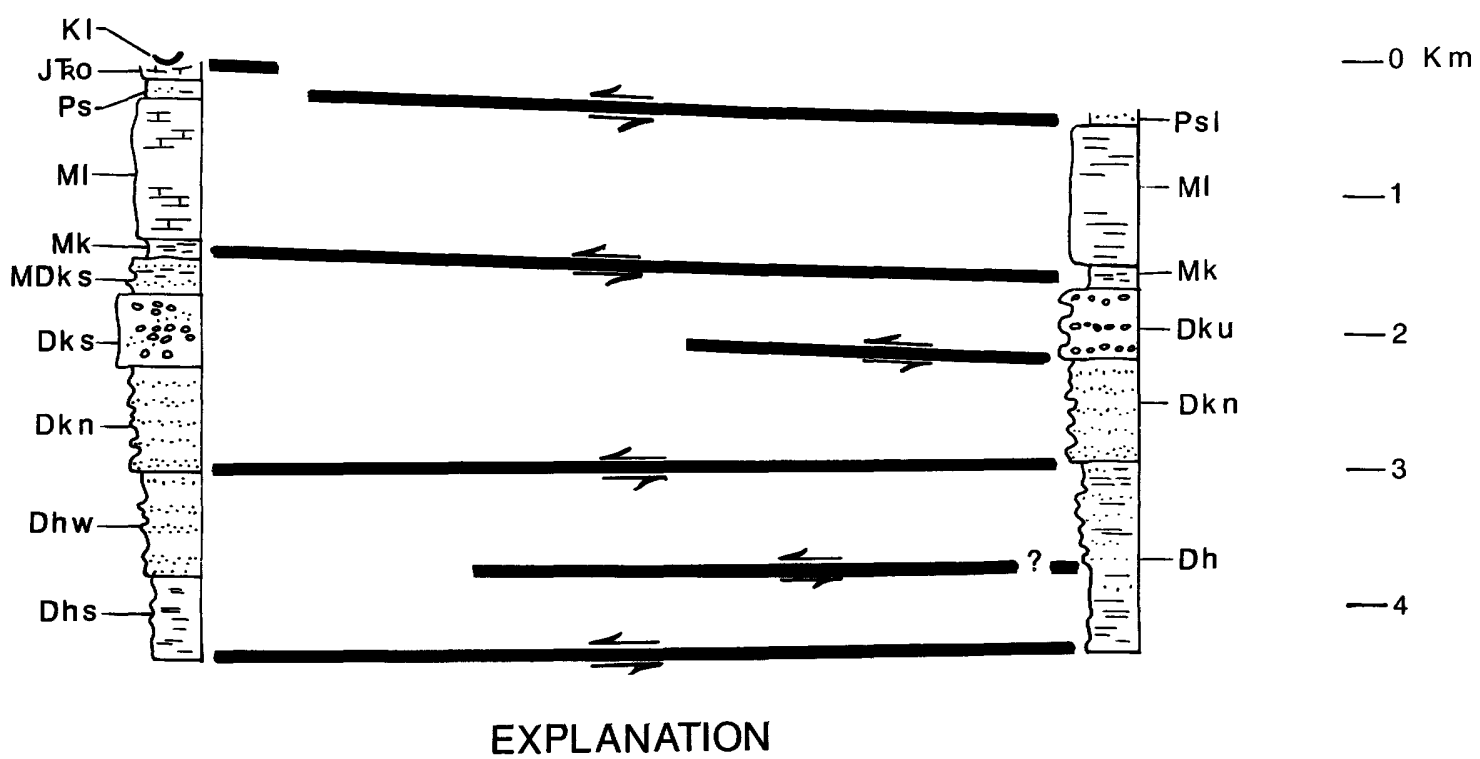

KI Coquinoid limestone (Cretaceous)

Jko Otuk Formation (Jurassic and Triassic)

Ps Siksikpuk Formation of Mull and others (1987a)

Psl Sadlerochit Group, part (Permian)

MI Lisburne Group (Mississippian)

Mk Kayak Shale (Mississippian)

Kanayut Congomerate (Lower Mississippian? and Upper Devonian)

MDks Stuver Member (Lower Mississippian? and Upper Devonian)--Divided into:

Dku Upper part (Upper Devonian)--Mapped in southernmost part of quadrangle only
Dkn Kanayut Conglomerate and Noatak Sandstone, undivided (Upper Devonian)--As mapped, Kanayut Conglomerate consists of the Ear Peak Member

Dh Hunt Fork Shale, undivided (Upper Devonian)--Locally divided into:

Dhw Wacke member

Dhs Shale member

Dks

Shainin Lake Member (Upper Devonian)

Figure 2. North-south transect across southern Chandler Lake quadrangle, showing distribution of décollements in Endicott Mountains allochthon. 

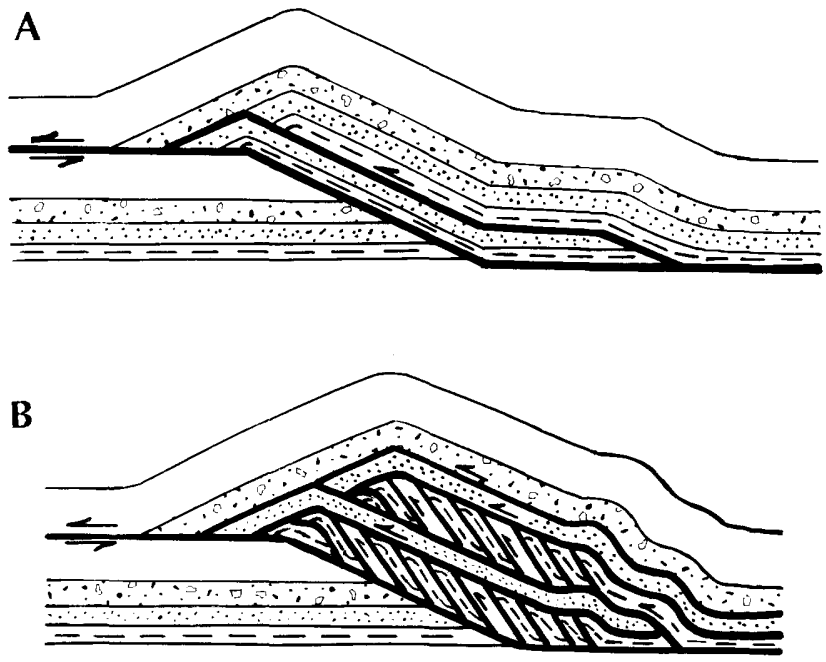

Figure 3. Examples of complex imbrication in thrust sheets. $A$, Imbrication involving a single décollement. B, Imbrication and development of duplexes involving two décollements. Arrows show relative movement.

Where present, the upper part of the Kanayut Conglomerate typically occurs in imbricate fault blocks. The faults underlying the imbricate blocks sole into a décollement at the base of the upper part of the Kanayut Conglomerate. Where the laterally equivalent massive-weathering Shainin Lake and Stuver Members of the Kanayut Conglomerate are present, extensive detachment in the equivalent horizon along the base of the Shainin Lake Member is recognized.

A widespread decollement in the Kayak Shale is indicated by widespread imbricate faulting in the overlying Lisburne Group and structural disruption of the Kayak Shale. Imbricate thrust faults that repeat the Alapah and Wachsmuth Limestones of the Lisburne Group sole into the Kayak Shale. The Kayak Shale is structurally thickened in some localities, nearly removed in others, and elsewhere appears little disturbed.

A décollement occurs above the Lisburne Group over most of the exposure of the Endicott Mountains allochthon in the Chandler Lake quadrangle. Imbricate thrust faults repeat the Lisburne Group, selvages of the Permian Siksikpuk Formation of Mull and others (1987b), and locally part of the Sadlerochit Group. The decollement steps up section along the range front-the Otuk Formation occurs locally along the range front whereas the Siksikpuk Formation is the principal unit that occurs farther south. In the southwestern part of the Chandler Lake quadrangle, where the Alapah and Wachsmuth Limestones are radically thinner than elsewhere and are silicified, the Lisburne Group, Siksikpuk Formation, Otuk Formation, and coquinoid limestone are repeated by imbricate thrust faults that sole into the Kayak Shale.

In summary, the Endicott Mountains allochthon within the Chandler Lake quadrangle is an assemblage of structural blocks separated by extensive décollements. Structural delamination of a probable near-horizontal sedimentary sequence has produced five structural blocks with undetermined amounts of structural transport between blocks. The extensive distribution of the decollements and evidence for extensive faulting however, suggest structural segmentation and telescoping on a scale not previously appreciated in strata assigned to the Endicott Mountains allochthon. Analysis of the structural integrity of the Endicott Mountains allochthon, however, requires construction of retro-deformable regional cross sections that incorporate the decollements recognized here.

\section{REFERENCES CITED}

Dutro, J.T., Jr., Brosge, W.P., Lanphere, M.A., and Reiser, H.N., 1976, Geologic significance of Doonerak structural high, central Brooks Range, Alaska: American Association of Petroleum Geologists Bulletin, v. 60, no. 6, p. 952-961.

Kelley, J.S., 1988, Preliminary geologic map of the Chandler Lake quadrangle: U.S. Geological Survey Open File Report 88-42, 2 sheets, scale 1:125,000.

Martin, A.J., 1970, Structure and tectonic history of the western Brooks Range, DeLong Mountains, and Lisburne Hills, northern Alaska: Geological Society of America Bulletin, v. 81, no. 12, p 3605-3622.

Mayfield, C.F., Tailleur, I.L., and Ellersieck, Inyo, 1983, Stratigraphy, structure, and palinspastic synthesis of the western Brooks Range, northwestern Alaska: U.S. Geological Survey Open-File Report 83-779, 58 p., 5 pl.

Mul1, C.G., 1979, Nanushuk Group deposition and late Mesozoic structural evolution of the central and western Brooks Range and Arctic Slopes, in Ahlbrandt, T.S., ed., Preliminary geologic, petrologic, and paleontologic results of the study of Nanushuk Group rocks, North Slope, Alaska: U.S. Geological Survey Circular 794, p. 5-13.

---- 1982, Tectonic evolution and structural style of the Brooks Range, Alaska: An illustrated summary, in Powers, R.B., ed., Geologic studies of the Cordilleran thrust belt: Denver, Rocky Mountain Association of Geologists, v. 1, p. 1-45.

---- 1985, Cretaceous tectonics, depositional cycles, and the Nanushuk Group, Brooks Range and Arctic Slope, Alaska, in Huffman, A.C., Jr., ed., Geology of the Nanushuk Group and related rocks, North Slope, Alaska: U.S. Geological Survey Bullet in 1614, p. 7-36.

Mul1, C.G., Adams, K.E., and Dillon, J.T., 1987a, Stratigraphy and structure of the Doonerak fenster- and Endicott Mountains allochthon, central Brooks Range, Alaska, in Tailleur, I.L., and Weimer, Paul, eds., Alaskan North Slope geology: Bakersfield, Calif., Pacific Section, Society of Economic Paleontologists and Mineralogists, and Alaska Geological Society, v. 2, p. 663-679. 
Mul1, C.G., Crowder, R.K., Adams, K.E., Siok, J.P., Bodnar, D.A., Harris, E.E., Alexander, R.A., and Solie, D.N., 1987b, Stratigraphy and structural setting of the Picnic Creek allochthon, Killik River quadrangle, central Brooks Range, Alaska: A summary, in Tailleur, I.L., and Weimer, Paul, eds., Alaskan North Slope geology: Bakersfield, Calif., Pacific Section, Society of Economic Paleontologists and Mineralogists, and Alaska Geological Society, v. 2, p. 649-661. Mul1, C.G., Roeder, D.H., Tailleur, I.L., Pessel, G.H., Grantz, Arthur, and May, S.D., 1987c, Geologic sections and maps across Brooks Range and Arctic Slope to Beaufort Sea, Alaska: Geological Society of America, Map and Chart Series $\mathrm{MCH}-28 \mathrm{~S}$, scale $1: 250,000$.

Reviewers: J.Y. Bradshaw and S.W. Nelson

Geologic Studies in Alaska by the U.S. Geological Survey during 1987: John P. Galloway and Thomas D. Hamilton, editors, U.S. Geological Survey Circular 1016. 


\title{
A Thermal Cross Section for the Permafrost and Hydrate Stability Zones in the Kuparuk and Prudhoe Bay Oil Fields
}

\author{
By Arthur H. Lachenbruch, S. Peter Galanis, Jr., and Thomas H. Moses, Jr.
}

The first borehole temperature measurements made under the Department of Energy/Department of Interior, U.S. Geological Survey, North Slope Gas Hydrate Project (DOE Contract No. DE-AI21$83 \mathrm{MC20422)}$ were completed in September 1987. The USGS geothermal logging truck, which was transported to off-road sites on a Rolligon tractor, was used to log ten wells in the Kuparuk, Milne Point, and Prudhoe Bay oil fields to depths totaling $9,550 \mathrm{~m}(31,332 \mathrm{ft})$. Although the data are still being processed, we present here preliminary results along with our earlier equilibrium temperature measurements at Prudhoe Bay (Lachenbruch and others, 1982a). Together these temperature measurements provide a cross section showing the thermal stability fields for permafrost and methane hydrate across the Kuparuk and Prudhoe Bay oil fields (figs. 1 and 2).

Recently logged wells are shown by the solid and open circles west of the Kuparuk River in figure 1; well symbols east of the Kuparuk River mark the sites of our earlier study (Lachenbruch and others, 1982a).
Thickness of the methane hydrate stability zone (HSZ) is based on the assumptions that the material in the pores has hydrostatic pressure and zero salinity. The depths to the top and bottom of the HSZ were determined from the direct temperature measurements (corrected for drilling disturbance where necessary) and the appropriate methane hydrate stability curve (equation 4-4 and table 4-1 of Kuustraa and Hammershaimb, 1983). These depths can easily be adjusted for other conditions of pressure, salinity, or gas composition (see for example Holder and others, 1987). The solid circles in figure 1 denote sites where direct measurements of near-equilibrium temperature were obtained to depths at least as great as the bottom of the HSZ; their overall uncertainties are only a few meters. Where the bottom of the HSZ is extrapolated (open circles, fig. 1), values are enclosed in parentheses when the estimated uncertainty is \pm 30 $50 \mathrm{~m}$, and in square brackets when it is $\pm 50-100 \mathrm{~m}$. At those well sites with no three-digit number for thickness of the HSZ, the measurements were too

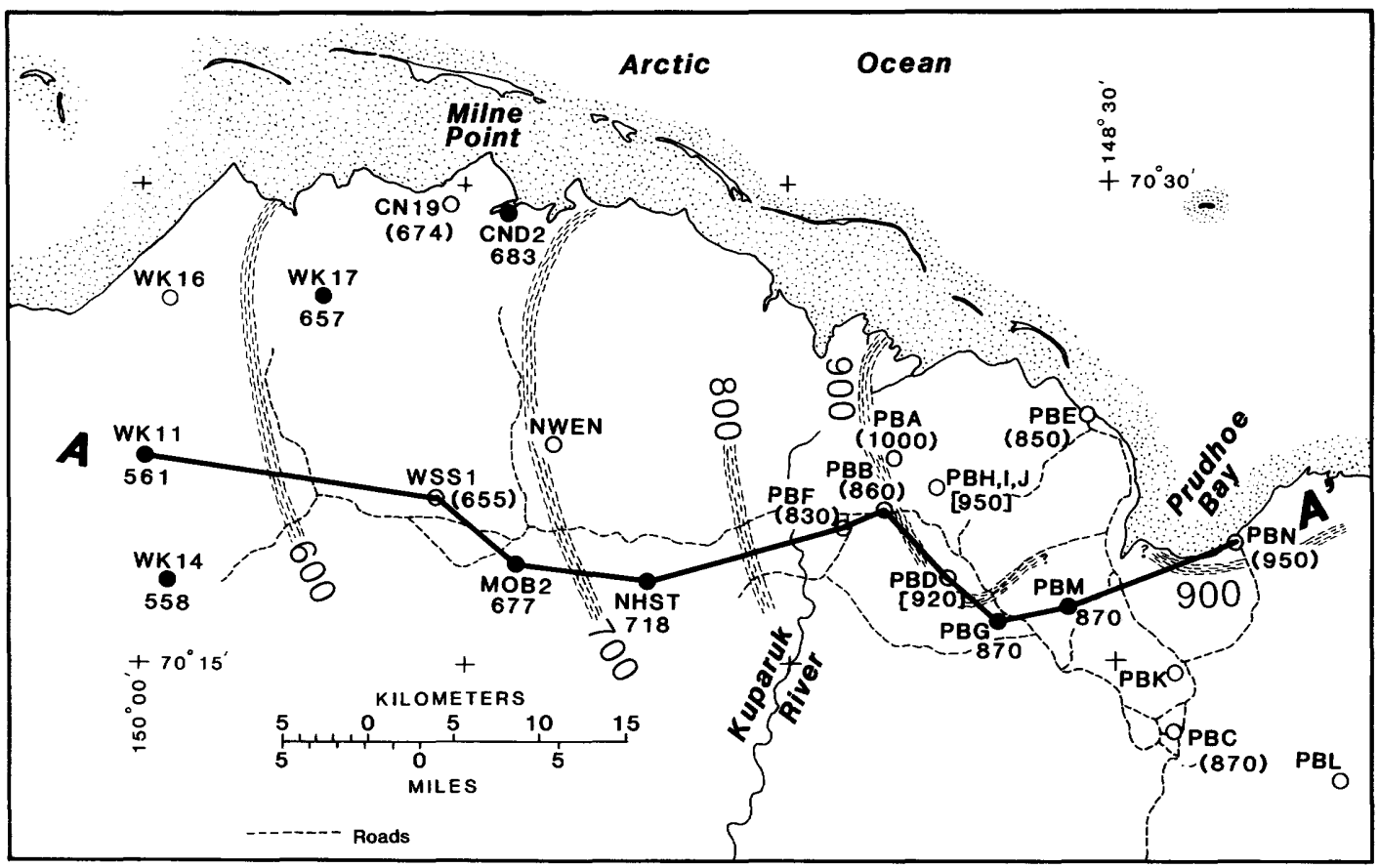

Figure 1. Arctic coastal plain in vicinity of Prudhoe Bay, Kuparuk, and Milne Point oil fields showing location of thermal cross section (figure 2). Numbers near contours and well sites are thickness, in meters, of methane hydrate stability zone (see text for additional explanation). 


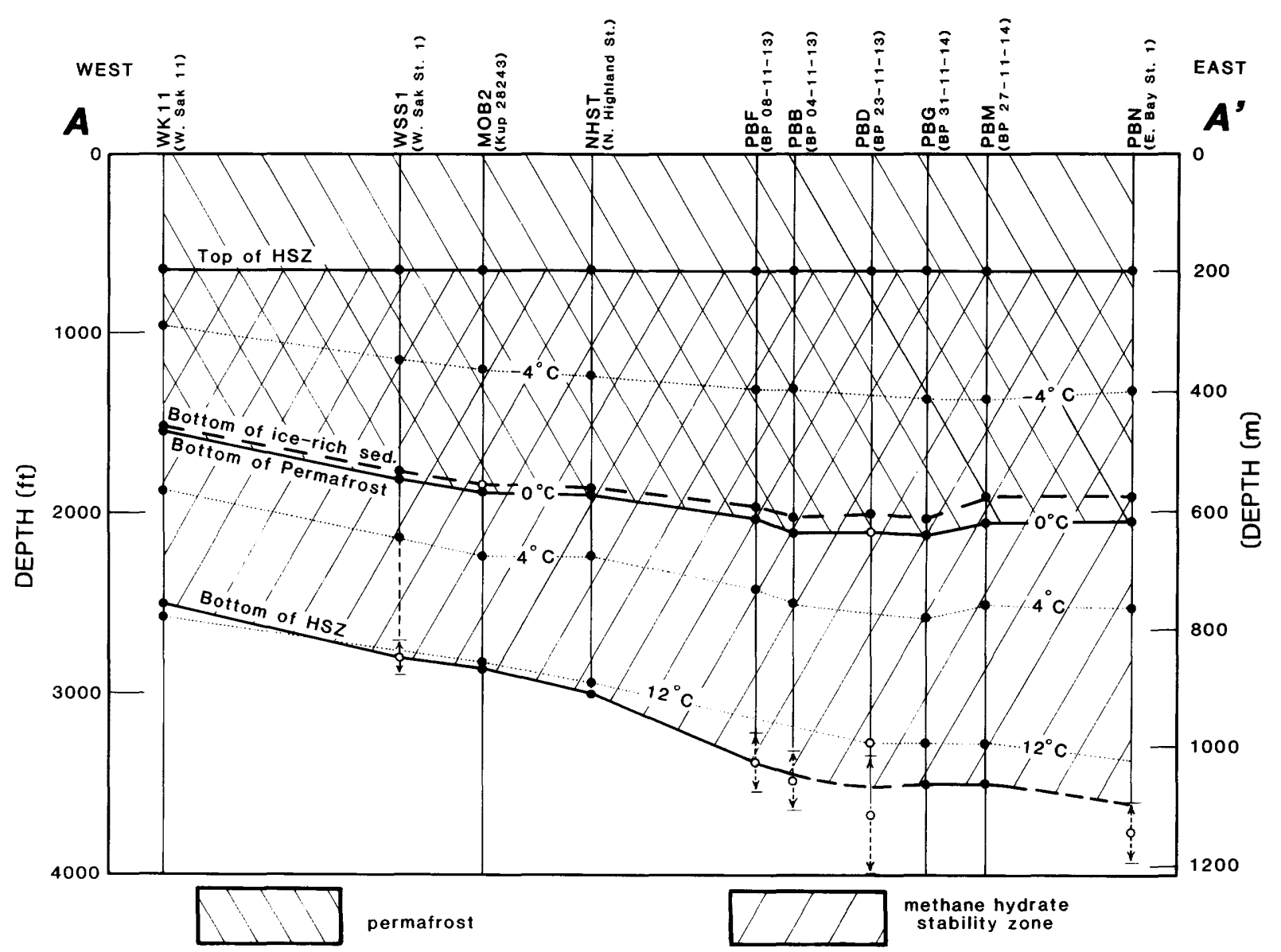

Figure 2. Cross section $A-A^{\prime}$ (see fig. 1) through Kuparuk and Prudhoe Bay oil fields showing zones of methane hydrate stability (HSZ) and permafrost. Operators' designations for holes in parentheses. For further explanation of symbols see text.

shallow or the drilling disturbance was too large to permit a useful estimate; such sites generally provided good values for the depth of permafrost and other isotherms, however.

The zones of methane hydrate stability and permafrost are shown by contrasting patterns in the cross section of figure 2 , and the relation of these zones to temperature profiles is shown for sites near the east and west ends of the section in figure 3 . The base of permafrost (by definition, Muller, 1947) is the $0{ }^{\circ} \mathrm{C}$ isotherm shown as a solid curve in figure 2 . Other selected isotherms $\left(-4{ }^{\circ} \mathrm{C},+4{ }^{\circ} \mathrm{C},+12{ }^{\circ} \mathrm{C}\right)$ are shown by dotted curves. The top of permafrost is generally within a meter of the ground surface and cannot be shown on this scale. Most of the control points for the curves in figure 2 are shown by solid circles, which represent reliable direct measurements and an overall depth uncertainty of only a few meters. Those control points represented by open circles involve some extrapolation and are less reliable.

The dashed curve just above the base of permafrost denoted "base of ice-rich sediments" (fig. 2 ) is the depth of an "elbow" or "gradient break" that commonly occurs in thermal profiles in the Prudhoe Bay region (Lachenbruch and others, 1982a). It is marked by arrows for the wells illustrated in figure 3 .
At this depth, an abrupt downward increase in thermal gradient is caused by the thermal conductivity contrast between interstitial ice (above the break) and interstitial water (below) (Gold and Lachenbruch, 1973). Hence the temperature at the gradient break represents the local freezing-point depression, and as such, it contains important information about pore pressure, capillarity, and chemistry near the base of permafrost. (Other vertical gradient changes, unrelated to the permafrost base and freezing-point depression (e.g., at $280 \mathrm{~m}$ in WK11, fig. 3) will, of course, occur at any lithologic boundaries with a contrast in the abundance of ice or other conductive minerals). As originally pointed out by Stoneley (1970), this depth (when it exists) can be detected also from routine (nonthermal) well logs, a method that has been exploited to map the base of "ice-bonded" or "ice-bearing" permafrost where temperature measurements are not available (for example, Osterkamp and Payne, 1981). An additional step is of ten taken by assuming a value for temperature at the base of ice-rich sediments, the depth of which is estimated from a nonthermal well log. Further assumptions for thermal gradients are then used to construct a thermal profile and to estimate the configuration of the HSZ (for example, Collett, 1983; Holder and others, 1987; Kamath and others, 1987). 
The method can be useful in the Prudhoe Bay area where there is some temperature control and where the meaning of the gradient break is clear because coarse-grained, high-porosity sediments extend above and below the base of permafrost. Over most of the North Slope, however, the hypothetical "base of icerich sediments" is obscure or absent, and these indirect methods of determining thermal regime can be uncertain or misleading (Osterkamp and Payne, 1981; Lachenbruch and others, 1982a, 1987). There is no good substitute for reliable direct temperature measurements.

Even in the restricted area represented by figure 1, direct temperature measurements reveal systematic changes in the thermal gradients and "freezing-point depression," quantities that are assumed to be known in the indirect methods. The isotherms converge to the west (fig. 2) indicating an increasing thermal gradient both in and below permafrost; this results in a westward thinning of both permafrost and the HSZ. These effects are illustreted in figure 3 where the inset gives a scale of increasing thermal gradient (curves a, b, c, and d). From PBM to WK11, the average gradient in permafrost increases roughly from $a$ to $b$ and in the underlying thawed formations from $c$ to $d$. Thermal conditions at WK11 in the Kuparuk oil field are intermediate between those at Prudhoe Bay $100 \mathrm{~km}$ to the east and those at Naval Petroleum Reserve Alaska on the coastal plain 50 to $400 \mathrm{~km}$ farther to the west. At WK11, permafrost depth is about $480 \mathrm{~m}$ compared to more than $600 \mathrm{~m}$ at Prudhoe Bay and 200 to $400 \mathrm{~m}$ in NPRA.

The effects of geographic variations in geothermal gradient can result from corresponding variations in thermal conductivity of the formations or from variation in the rate of heat flow from the earth. The variation in heat flow can, in turn, result from regional changes in deep crustal heat flux or from patterns of fluid circulation in the sedimentary basin (Lachenbruch and others, 1987). There is little doubt that the very deep permafrost and anomalously low thermal gradient at Prudhoe Bay result primarily from the abundance of high-conductivity constituents such as quartz and ice in the porous sands and gravels there (Lachenbruch and others, 1982a). Higher gradients and thinner permafrost in NPRA can be explained in part by a correspondingly greater proportion of low-conductivity constituents such as clay and possibly capillary water in permafrost. However, an important role for heat-flow variations on the North Slope cannot be ruled out and the cause of the trend in figure 2 cannot be established without further study of the properties of the sediment there. In addition to the gradient trends, the new data show that the "bottom of ice-rich sediments" (dashed curve, fig. 2, arrows, fig. 3) is closer to the bottom of permafrost ( $\left({ }^{6} \mathrm{C}\right.$ curve) in the Kuparuk field than in the Prudhoe Bay field indicating that "freezing-point depression" is less in the Kuparuk field. Together these trends have implications for variations in thermal conductivity, heat flow, fluid circulation, pore pressure, and fluid chemistry. Their study can lead to more confident predictions of the configuration of the hydrate stability region and to a better understanding of the geothermal setting of the North Slope Basin.

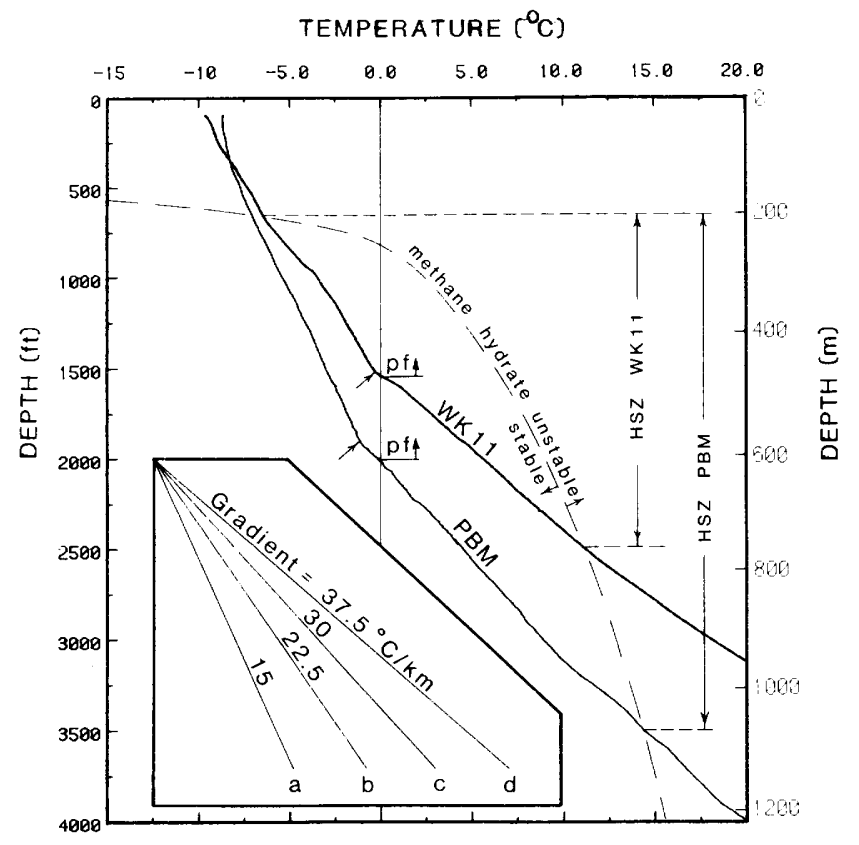

Figure 3. Temperature profiles and their relation to zones of methane hydrate stability (HSZ) and permafrost near west (WK11) and east (PBM) ends of cross section (figures 1 and 2). Base of permafrost is denoted by "pf."

\section{REFERENCES CITED}

Collett, T.S., 1983, Detection and evaluation of natural gas hydrates from well logs, Prudhoe Bay, Alaska, in International Conference on Permafrost, 4th, Fairbanks, Alaska, Proceedings: Washington, D.C., National Academy of Sciences, p. 169-174.

Gold, L.W., and Lachenbruch, A.H., 1973, Therma1 conditions in permafrost--A review of North American literature, in Permafrost--North American Contribution, Second International Conference, Yakutsk, USSR: Washington, D.C., National Academy of Sciences, p. 3-25.

Holder, G.D., Malone, R.D., and Lawson, W.F., 1987, Effects of gas composition and geothermal properties on the thickness and depth of natural-gas-hydrate zones: Journal of Petroleum Technology, September, p. 11471152 .

Kamath, V.A., Godbole, S.P., Ostermann, R.D., and Collett, T.S., 1987, Evaluation of the stability of gas hydrates in northern Alaska: Cold Regions Science and Technology, v. 4, p. 107-119.

Kuustraa, V.A., and Hammershaimb, E.C., 1983, Handbook of gas hydrate properties and occurrence: office of Scientific and Technical Information, U.S. Department of Energy, 234 p.

Lachenbruch, A.H., Sass, J.H., Marshall, B.V., and Moses, T.H., Jr., 1982a, Permafrost, heat flow, and the geothermal regime at Prudhoe Bay, Alaska: Journal of Geophysical Research, v. 87, p. 9301-9316. 
Lachenbruch, A.H., Sass, J.H., Lawver, L.A., Brewer, M.C., and Moses, T.H., Jr., 1982b, Depth and temperature of permafrost on the Alaskan Arctic Slope; preliminary results: U.S. Geological Survey Open-File Report 821039. [Note: Superseded by next-1isted reference.]

Lachenbruch, A.H., Sass, J.H., Lawver, L.A., Brewer, M.C., Marshall, B.V., Munroe, R.J., Kennelly, J.P., Jr., Galanis, S.P., Jr., and Moses, T.H., Jr., 1987, Temperature and depth of permafrost on the Alaskan Arctic Slope, in Tailleur, I.L., and Weimer, Paul, eds., Alaskan North Slope Geology: Bakersfield, Calif., Pacific Section, Society of Economic Paleontologists and Mineralogists, and Alaska Geological Society, v. 50, p. 545-558.

Muller, S.W., 1947, Permafrost, or permanently frozen ground, and related engineering problems: U.S. Engineers office, Strategic Engineering Study Special Report 62, 136 p.

Osterkamp, T.E., and Payne, M.W., 1981, Estimates of permafrost thickness from well logs in northern Alaska: Cold Regions Science and Technology, v. 5, p. 13-27.

Stoneley, Robert, 1970, Discussion, in Adkison, W.L., and Brosge, M.M., eds., Proceedings of the Geological Seminar on the North Slope of Alaska: Los Angeles, Pacific Section, American Association of Petroleum Geologists, p. J2-J4.

Reviewers: L.S. Magoon and T.S. Collett

Geologic Studies in Alaska by the U.S. Geological Survey during 1987: John P. Galloway and Thomas D. Hamilton, editors, U.S. Geological Survey Circular 1016. 



\section{EAST-CENTRAL ALASKA}

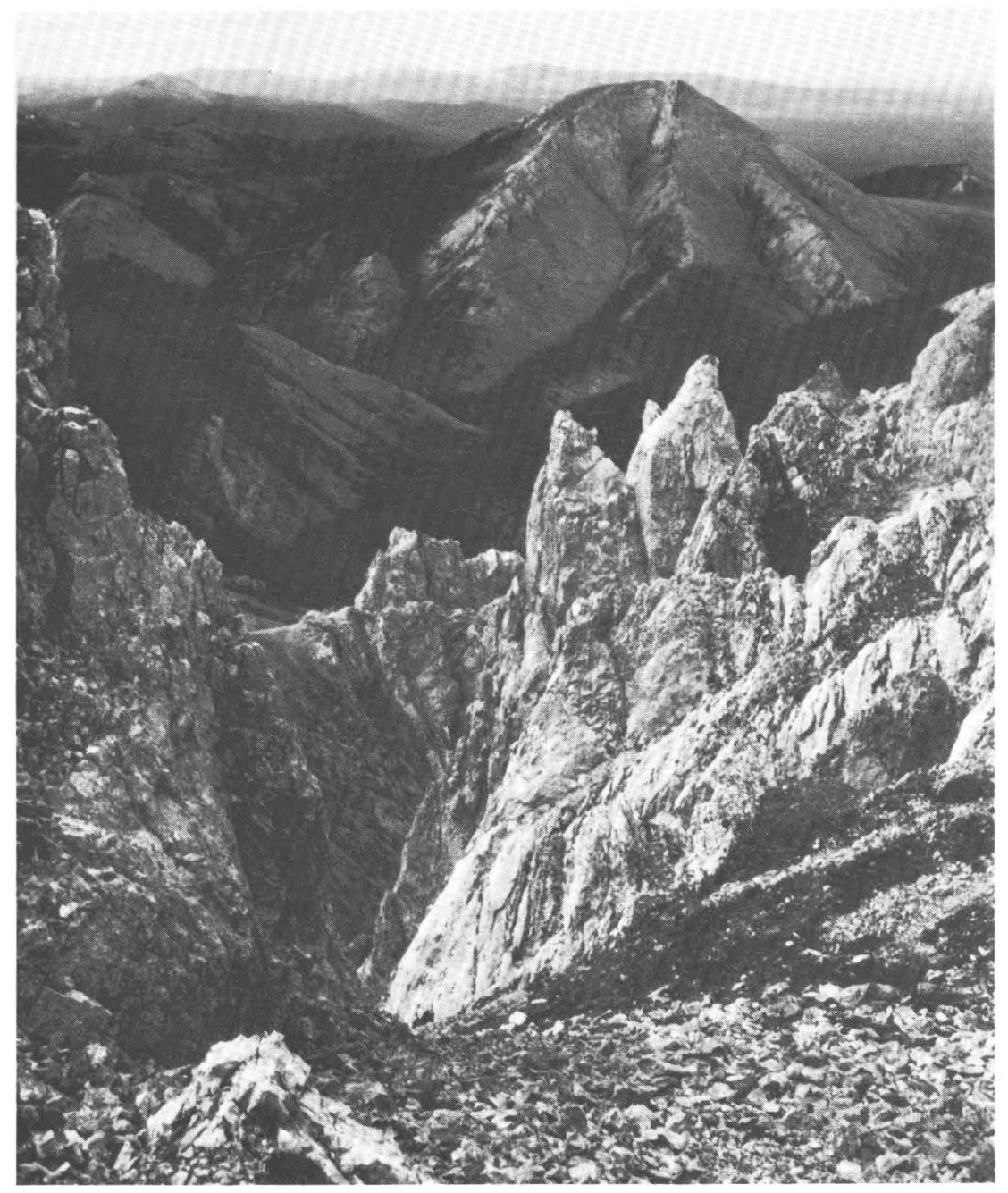

Pinnacles of Devonian limestone in Mt. Schwatka area, Yukon-Tanana Upland. Photograph by F.R. Weber. 


\title{
A Late Silurian Age Determination for the Limestone of the Lost Creek Unit, Livengood C-4 Quadrangle, East-Central Alaska
}

\author{
By Robert B. Blodgett, Ning Zhang, Allen R. Ormiston, and Florence R. Weber
}

The age and stratigraphic relations of a limestone found by R.M. Overbeck in 1918 on a tributary of Lost Creek $14 \mathrm{~km}$ west of Livengood (fig. 1) have long been a matter of conjecture. Mertie (1937, p. 110) placed this locality in the Livengood Chert and used the fossils found there (identified by G.H. Girty as provisionally Late Mississippian in age) to define the age of the formation. New data suggest that, instead, the age of this limestone is Late Silurian.

In the course of geologic mapping of the Livengood 1:250,000 quadrangle (Chapman and others, 1971 ) in the 1960 s and 1970 s the old and new fossil collections were reevaluated (series of written commun. from A.G. Epstein, J.T. Dutro, Jr., W.A. Oliver, Jr., U.S. Geological Survey) and were thought to range in age from Middle Ordovician to Middle Devonian, but with Middle Silurian as the best possibility.

Chapman and others (1980) abandoned the Livengood Chert and named the rocks that had previously been assigned to the lower, predominantly chert unit of that formation the "Livengood Dome Chert"; they established a Late Ordovician age for this new formation based on discovery of graptolites (identified by Claire Carter, U.S. Geological Survey, 1980) in a borrow pit $1.6 \mathrm{~km}$ north of the Lost Creek fossil locality. At that time, the rocks at the Lost Creek locality, because of their differing lithologies, were not assigned to the Livengood Dome Chert.

We carried out new studies of Overbeck's Lost Creek locality between 1985 and 1987. Our purpose was to identify some of the faunal elements found in our newly made collections from the limestone exposure and to redefine the stratigraphic relations of this exposure.

The base of the limestone exposure is $30-45 \mathrm{~m}$ above the bottom of the northwest edge of Hill 1335 (fig. 2), and is situated in the Livengood C-4 quadrangle (lat. $65^{\circ} 30.9^{\prime} \mathrm{N}$., long. $148^{\circ} 51.2^{\prime} \mathrm{W}$.). This locality consists of a massive limestone 12-15 m thick, interbedded with irregularly folded calcareous or silty shale, minor chert, and graywacke. Laterally the limestone body pinches out. The limestone is composed of light-gray lime mudstone and wackestone. Small to medium-sized chert clasts, angular to well rounded, are present both at the base and top of the exposure, and are also abundant in the lateral pinch-out margins. The limestone is interpreted to be a carbonate debris flow within a deeper water clastic unit.
South-dipping shale and claystone underlie the limestone at the downhill (north) end of the exposure. These argillaceous rocks are underlain by tightly folded greenish-gray chert, possibly in unconformable contact. Shale and graywacke turbidites are present uphill from the limestone, but covered intervals make structures difficult to interpret. A northward dip of $85^{\circ}$ was measured in the turbidites, and there is a suggestion of overturned beds. Farther up the hill at a sharp topographic break, chert on the other side of the poorly exposed contact shows different structural attitudes from the graywacke, suggesting the possibility of a fault here between the two lithologies. The uppermost part of Hill 1335 is composed of the Livengood Dome Chert.

Megafossils were collected by Blodgett from the central part of the main limestone exposure. They include, in decreasing order of abundance, brachiopods, crinoidal debris (including articulated columnals), ostracodes, trilobites, rare solitary rugose corals, and possible calcareous algal remains.

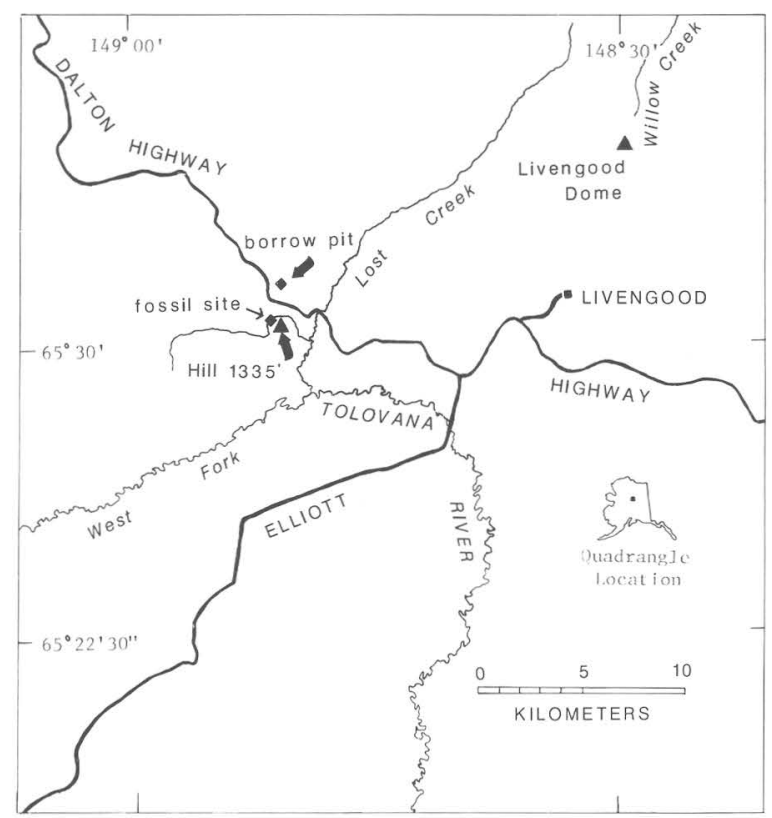

Figure 1. Generalized location map of fossil site and vicinity. 


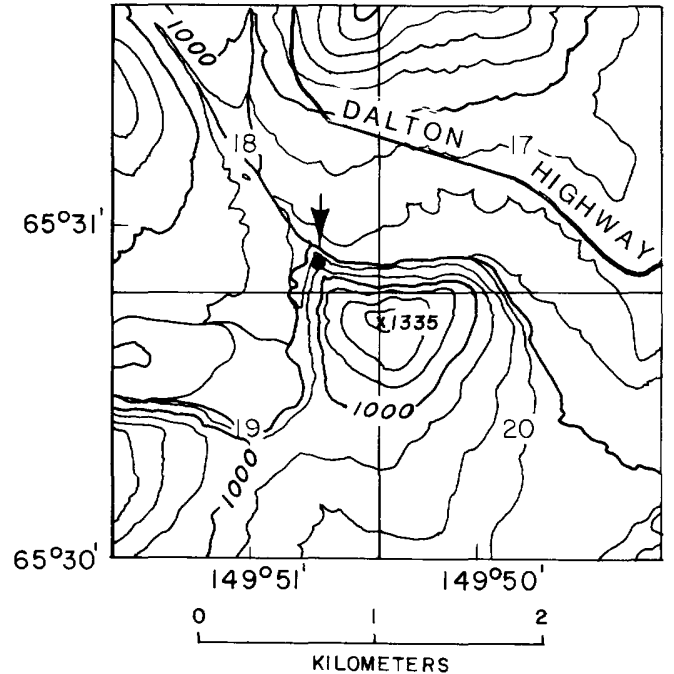

Figure 2. Detailed map showing Hill 1335 and location (arrow) of Lost Creek fossil locality in Livengood C-4 quadrangle. Elevation of hill crest in feet; contour interval 100 feet.

Brachiopods (identified by Zhang and Blodgett) form the most numerous and diverse taxonomic group found at this locality. Taxa present include Lingula sp., Leptaena sp., Severella cf. S. magnificaformis Sapelnikov, 1963, clorindid, Gypidula sp., n. gen.? gypidulinid (aff. Gypidulina), Ancillotoechia cf. A. shannonensis (Amsden, 1949), Spirigerina? sp., Lissatrypa? sp., Eospinatrypa sp. (finely ribbed), Metaplasia ef. M. sp. Lenz, 1970, Janius? sp., and Spirinella sp. Severella magnificaformis Sapelnikov, 1963 is known from the lower Ludlovian of the eastern slope of the Urals. Ancillotoechia shannonensis (Amsden, 1949) occurs in the Brownsport Formation (Ludlovian) of Tennessee. Metaplasia sp. Lenz, 1970 is reported from strata of either late Ludlovian or early Pridolian age in the Road River Formation of the Prongs Creek area, Yukon Territory. The genus Janius is known from Wenlockian to Ludlovian, as well as younger strata. Its presence is listed equivocally here, since it is based on a single deformed fragment. Spirinella is commonly reported from Wenlockian to Ludlovian strata, though a single occurrence of the genus is reported from the Lower Devonian of Nevada. The overall aspect of the brachiopod fauna indicates a Wenlockian to Ludlovian (early to middle Late Silurian) age.

Trilobites (identified by Ormiston) are an uncommon faunal element of this assemblage, and belong to a single species, Contracheirurus n. sp. The genus Contracheirurus was established by Chatterton and Perry (1984) and based upon two species, known only from the Mackenzie Mountains, northwestern Canada. The type species, $C$. zuvegesi Chatterton and Perry, 1984, occurs in lower Wenlockian strata of the Delorme Formation, and the other species, C. n. sp. Chatterton and Perry, 1984, is known from upper Wenlockian or possibly lower Ludlovian strata of the same formation. Although the species from the Lost Creek locality is not conspecific with either described species, the Wenlockian to Ludlovian stratigraphic range of the genus is accordant with ages suggested above for the brachiopods in the Lost Creek fauna.

Several attempts were made to obtain a conodont-based age for the limestone exposed at Lost Creek, but the results (Wenlockian to early Emsian; A.G. Harris, U.S. Geological Survey, written commun., 1987) were less definitive than that based upon the megafauna.

The overall aspect of the fauna is suggestive of a shallow-marine carbonate platform. Because the limestone is interpreted to be a lenticular dehris-flow deposit, it likely was transported dunnslope and deposited in a deeper water environme:t.

Although the limestone is age-equivalent to part of the Road River Formation in east-central Alaska and the Yukon Territory, it is not considered a part of the Livengood Dome Chert. The Livengood Dome Chert is age-equivalent to a stratigraphically lower part of the Road River Formation. Nor is it presently considered a part of the "Amy Creek unit," a dolomite and black chert unit described by Weber and others (1985). The relation of the "Amy Creek unit" to both the Livengood Dome Chert and to the Lost Creek unit remains undetermined at this time.

The collective ranges of our fossils indicates a Late Silurian age for the limestone at the Lost Creek locality. The clastic unit which encloses this limy debris flow must be of the same age. This unit, herein called the "Lost Creek unit," probably represents a hitherto unrecognized but mappable unit present stratigraphically between the Upper Ordovician Livengood Dome Chert and the Middle Devonian Cascaden Ridge unit of Weber and others (1985) and is of intermediate age between these two units. A similar small limestone body present on Willow Creek (north side of Livengood Dome) may also belong in the Lost Creek unit, but these limestone debris flows probably make up only a minor lithology in the Lost Creek clastic rock section.

\section{REFERENCES CITED}

Amsden, T.W., 1949, Stratigraphy and paleontology of the Brownsport (Silurian) of western Tennessee: Peabody Museum of Natural History, Bulletin 5, 138 p.

Chapman, R.M., Weber, F.R., Churkin, Michael, $\mathrm{Jr}$. , and Carter, Claire, 1980, The Livengood Dome Chert, a new Ordovician formation in central Alaska, and its relevance to displacement on the Tintina fault: U.S. Geological Survey Professional Paper 1126-F, $13 \mathrm{p}$.

Chapman, R.M., Weber, F.R., and Taber, Bond, 1971, Preliminary geologic map of the Livengood quadrangle, Alaska: U.S. Geological Survey Open-File Report 71-66, 2 plates.

Chatterton, B.D.E., and Perry, D.G., 1984. Silurian cheirurid trilobites from the Mackenzie Mountains, northwestern Canada: Palaeontographica Abt. A, v. 184, p. 1-78. 
Lenz, A.C., 1970, Late Silurian brachiopoda of Prongs Creek, northern Yukon: Journal of Paleontology, v. 44, p. 480-500.

Mertie, J.B., Jr., 1937, The Yukon-Tanana region, Alaska: U.S. Geological Survey Bullet in 872,276 p.

Sapelnikov, V.P., 1963, Novye predstaviteli zamkovykh brakhiopod iz siluriiskikh otlozhenii urala: Sverdlovsk, Trudy Sverdlovskogo Gornogo Instituta im. V.V. Vakhrusheva (Vyp. 42, Geologiya i polezno iskopaemye urala), p. 15-19.
Weber, F.R., Smith, T.E., Hall, M.H., and Forbes, R.B., 1985, Geologic guide to the Fairbanks-Livengood area, east-central Alaska: Anchorage, Alaska Geological Society, $44 \mathrm{p}$.

Reviewers: A.J. Boucot and S.M. Kar1

Geologic Studies in Alaska by the U.S. Geological Survey during 1987: John P. Galloway and Thomas D. Hamilton, editors, U.S. Geological Survey Circular 1016. 


\title{
A Comparative Petrologic Study of Sandstone from the Wilber Creek, Cascaden Ridge, and Wickersham Units in the Livengood Quadrangle
}

\author{
By L.D. Gergen, J.E. Decker, and George Plafker
}

The Livengood, Manley, White Mountains, and Wickersham tectonostratigraphic terranes of Jones and others (1987) occur within the Livengood quadrangle of east-central Alaska (fig. 1). Rocks of the Livengood terrane include the Livengood Dome Chert (Ordovician) and overlying Amy Creek unit (dolomite, chert, and volcanic rocks), serpentinite, and Devonian Cascaden Ridge unit (fossiliferous shale, sandstone, grit, and minor limestone; Jones and others, 1987). The Manley terrane consists of complexly deformed flyschoid Mesozoic sedimentary rocks assigned to the Wilber Creek unit (Jones and others, 1987). The White Mountains terrane consists of Ordovician volcanic and volcaniclastic rocks and conglomerate of the Fossil Creek unit, overlain by Silurian and Devonian limestone and dolomite, and undated clastic rocks (Jones and others, 1987). The Wickersham terrane includes Precambrian and Cambrian quartz-rich sandstone and grit, shale, and maroon to green slate of the Wickersham unit (Jones and others, 1987). The Wilber Creek, Cascaden Ridge, and Wickersham units are turbidite sequences.

This report presents the first published quantitative data of sandstone petrology of the Wilber Creek, Cascaden Ridge, and Wickersham units. This pilot study was undertaken to determine the feasibility of distinguishing between these units with sandstone petrology and to provide a basis for interpretation of sandstone provenance. The petrologic distinction between sandstones in these units and a knowledge of their source is essential for tectonic and paleogeographic reconstructions in this structurally complex region.

Eight samples were collected for sandstone petrologic study by one of us (Decker) in 1984. Point counts were made on four samples from interbedded graywacke and quartzite within the Wilber Creek unit, two samples from graywacke of the Cascaden Ridge unit, one sample of graywacke from an isolated area that is tentatively correlated with the Cascaden Ridge unit, and one sample from quartzite of the Wickersham unit. The Gazzi-Dickinson point- counting method was employed following the general procedures outlined by Dickinson (1970) and Ingersoll (1978) and discussed by Ingersoll and others (1984). The maximum possible grid spacing was chosen that allowed 500 points to be counted on each slide. One thin section (sample 5) was stained for magnesium (to differentiate dolomite from calcite), but none of the other thin sections were stained. Point-count data for each sample are presented in table 1 and are shown on figure 2 .

Sample 1, from one of the quartzite beds within
the Wilber Creek unit, consists primarily of monocrystalline quartz $\left(\mathrm{Q}_{90} \mathrm{~F}_{7} \mathrm{~L}_{3}\right) ; \quad \mathrm{Qp} / \mathrm{Q}$ (polycrystalline quartz to quartz ratio) is 0.02 (table 1). Lithic clasts, which are uncommon, include impure chert, argillite, and shale. Sample 1 contains moderately to well sorted, subangular to rounded grains, and is predominantly fine sand with some grains ranging from silt to medium-sand size.

Samples 2,3 , and 4 are from the graywacke in the Wilber Creek unit. They contain low proportions of quartz, moderate proportions of feldspar, and moderate to high proportions of lithics $\left(\mathrm{Q}_{9-20} \mathrm{~F}_{25-44}\right.$ $\left.\mathrm{L}_{36-66}\right)$. Qp/Q ranges from 0.04 to 0.24 . Volcanic

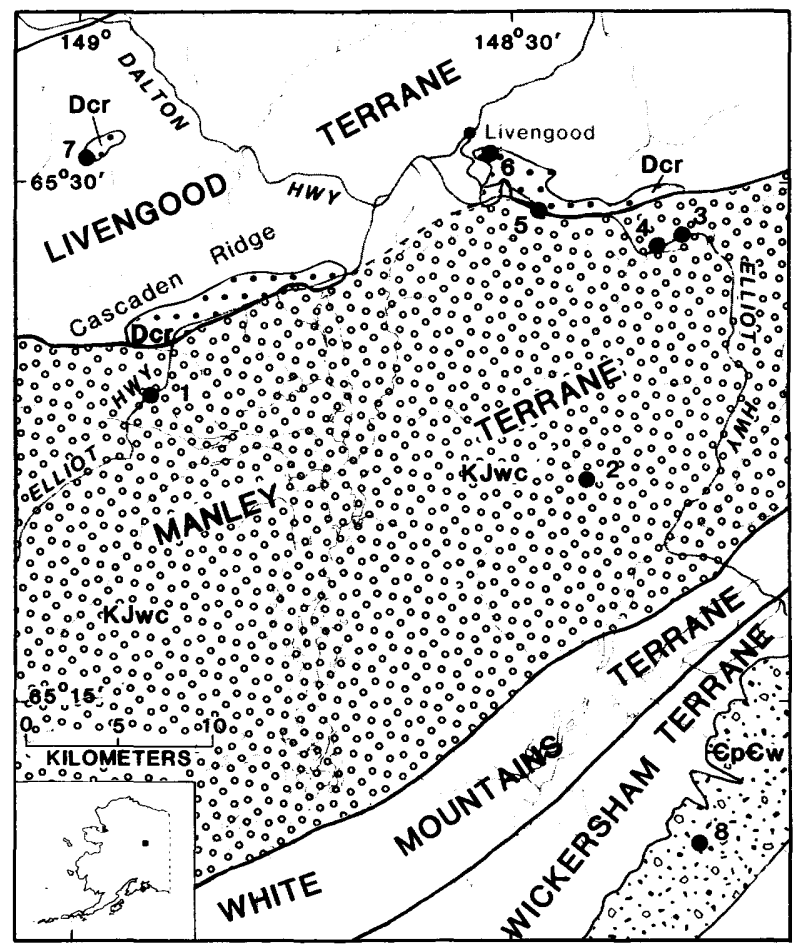

Figure 1. Livengood area showing terrane boundaries (Jones and others, 1987), clastic units of Chapman and others (1971) and Weber and others (1987), and sandstone sample sites. KJWC, Wilber Creek unit (Cretaceous and Jurassic); Dcr, Cascaden Ridge unit (Devonian); $€ p € w$, Wickersham unit (Cambrian and Precambrian). Refer to table 1 for field numbers. 
Table 1. Point-count data for sandstones from the Livengood quadrangle

[Values rounded to nearest whole number and may not sum to 100. QFL, quartz-feldspar-lithic fragments; LmLvLs, metamorphic-volcanic-sedimentary lithic fragments; QpLvmLsm, polycrystalline quartz-volcanic + metavolcanic-sedimentary + metasedimentary lithic grains; QmFLt, monocrystalline quartz-feldspar-L + Qp; $\mathrm{Qp} / \mathrm{Q}$, polycrystalline quartz to quartz ratio; Fmwk\%M, framework percent mica; Fmwk\%D, framework percent dense (excluding opaque minerals), Fmwk\%O, framework percent opaque minerals]

\begin{tabular}{|c|c|c|c|c|c|c|c|c|c|c|}
\hline Unit & $\begin{array}{l}\text { Sample } \\
\text { Number }\end{array}$ & $\begin{array}{l}\text { Field } \\
\text { Number }\end{array}$ & $\begin{array}{l}\text { QFL\% } \\
\text { Q-F-L }\end{array}$ & $\begin{array}{l}{ }^{*} \text { ImLvLs\% } \\
\text { Im-Lv-Ls }\end{array}$ & $\begin{array}{l}\text { *QpLvmLsm\% } \\
\text { Qp-LVm-Lsm }\end{array}$ & $\begin{array}{l}\text { QmFLt\% } \\
\text { Qm-F-Lt }\end{array}$ & $Q p / Q$ & $F m w k \div M$ & Fmwk\%D & Fmwk $\div 0$ \\
\hline $\begin{array}{r}\text { Wilber } \\
\text { Creek }\end{array}$ & $\begin{array}{l}1 \\
2 \\
3 \\
4\end{array}$ & $\begin{array}{l}\text { 84JD356E } \\
\text { 84JD359B } \\
\text { 84JD381A } \\
\text { 84JD382A }\end{array}$ & $\begin{array}{l}90-07-03 \\
14-42-44 \\
09-25-66 \\
20-44-36\end{array}$ & $\begin{array}{l}-\overline{-}- \\
13-58-29 \\
13-67-19 \\
10-65-25\end{array}$ & $\begin{array}{l}-\overline{-}- \\
05-58-37 \\
03-66-31 \\
02-65-33\end{array}$ & $\begin{array}{l}88-07-05 \\
12-42-46 \\
07-25-68 \\
20-44-36\end{array}$ & $\begin{array}{l}.023 \\
.170 \\
.242 \\
.036\end{array}$ & $\begin{array}{c}0 \\
4.1 \\
2.3 \\
3.3\end{array}$ & $\begin{array}{l}0 \\
4.8 \\
1.6 \\
2.6\end{array}$ & $\begin{array}{c}0 \\
0.6 \\
0.6 \\
1.4\end{array}$ \\
\hline $\begin{array}{l}\text { Cascaden } \\
\text { Ridge }\end{array}$ & $\begin{array}{l}5 \\
6\end{array}$ & $\begin{array}{l}\text { 84JD362A } \\
84 \mathrm{JD} 364 \mathrm{D}\end{array}$ & $\begin{array}{l}47-21-32 \\
56-24-20\end{array}$ & $\begin{array}{l}06-05-89 \\
02-05-93\end{array}$ & $\begin{array}{l}15-04-81 \\
38-03-59\end{array}$ & $\begin{array}{l}42-21-38 \\
43-25-32\end{array}$ & $\begin{array}{l}.122 \\
.220\end{array}$ & $\begin{array}{c}0 \\
0.2\end{array}$ & $\begin{array}{l}0 \\
0\end{array}$ & $\begin{array}{l}3.0 \\
0.8\end{array}$ \\
\hline $\begin{array}{c}\text { Cascaden } \\
\text { Ridge(?) }\end{array}$ & 7 & 84JD355D & $17-0-83$ & $01-0-99$ & $17-0-83$ & $0-0-100$ & .985 & 0 & 0 & 5.8 \\
\hline wickersham & 8 & 84JD350A & $99-0-01$ & $-\quad-$ & $-\quad-$ & $99-0-01$ & 0 & 0.2 & 0 & 0 \\
\hline
\end{tabular}

*Not calculated for samples with less than 10 percent lithics

fragments dominate the lithic grains (58 to 67 percent); sedimentary (19 to 29 percent) and metamorphic (10 to 13 percent) grains are subsidiary. Most (49 to 60 percent) of the volcanic grains are altered sufficiently that the original texture is destroyed. However, when grain types can be distinguished, lathwork textures are the most common type ( 22 to 35 percent of total volcanic grains). Sedimentary lithic fragments consist of impure chert (chert containing clay or iron-oxide impurities), argillite, shale, and chert-rich argillite. Most of the metamorphic grains display tectonite fabrics. Opaque minerals compose 0.6 to 1.4 percent of the framework grains. Dense minerals are predominantly epidote; rare amphibole and pyroxene are found in sample 2. Phyllosilicate minerals include chlorite, minor biotite, and rare muscovite and stilpnomelane. Grain size and sorting vary among the samples. Samples 2 and 3 contain very poorly sorted grains ranging from silt to granule or pebble size, whereas sample 4 contains poorly to moderately sorted fine sand, with some grains ranging from silt to medium-sand size. Grains are very angular to subrounded, and the matrix is recrystallized clayey lutum. Samples 2, 3, and 4 are similar to each other in composition but differ markedly from sample 1. Because of their similarity to each other, they may represent the overall composition of the graywacke in the Wilber Creek unit.

Two samples from the Cascaden Ridge unit (samples 5 and 6 ) have moderate to high proportions of quartz, and low to moderate proportions of feldspar and lithics $\left(\mathrm{Q}_{47-56} \mathrm{~F}_{21-24} \mathrm{~L}_{20-32}\right.$; table 1$)$. Twelve to 22 percent of the quartz is polycrystalline (or chert). Sedimentary lithic grains predominate, and only minor amounts of volcanic and metamorphic rock fragments are present $\left(\mathrm{Lm}_{2-6} \mathrm{Lv}_{5} \mathrm{Ls}_{89-93}\right)$. Impure chert composes the highest proportion of the sedimentary lithic fragments (70 to 82 percent). Remaining sedimentary lithic grains consist of argillite, shale, chert-rich argillite, and chert-rich shale. Opaque minerals compose 1 to 3 percent of the framework grains. The samples are predominantly fine-grained sand, but contain some grains ranging from very fine to coarse sand size. They are moderately to well sorted and have angular to subrounded grains. The matrix is recrystallized clayey lutum; sample 5 also has both dolomite and calcite cements.

The remaining sample, tentatively assigned to the Cascaden Ridge unit (sample 7), contains abundant lithic fragments $\left(\mathrm{Q}_{17} \mathrm{~F}_{0} \mathrm{~L}_{83}\right.$; table 1$)$. The lithic part of this sample is almost entirely sedimentary and consists of approximately equal proportions of impure chert (51 percent), and argillite, shale, chert-rich argillite, and chert-rich shale (49 percent). Polycrystalline quartz (chert) makes up 98.5 percent of the total quartz. Six percent of the framework grains are opaque minerals. The sandstone contains very poorly sorted, angular to subrounded grains ranging from very fine sand to granules. Matrix (14.4 percent of the total rock) consists of iron oxides, oxidized iron oxides, and clay. The lithology suggests probable local derivation from nearby outcrops of the Livengood Dome Chert unit, and may represent a lithic-rich endmember composition of the Cascaden Ridge unit.

The quartzite sample from the Wickersham unit (sample 8) consists almost entirely of monocrystalline quartz $\left(\mathrm{Q}_{99} \mathrm{~F}_{0.2} \mathrm{~L}_{0.8}\right.$; table 1$)$. Grains are subrounded to well rounded, range from very fine sand to granule size, and are poorly to moderately sorted. The matrix (4.2 percent of total rock) consists of recrystallized clayey lutum.

Recalculated point-count parameters for the eight samples are plotted on four triangle diagrams (fig. 2). The QFL diagram (fig. 2A) depicts relative proportions of quartz (Q), feldspar (F), and lithic fragments (L). It shows relatively low $Q$ and high $L$ proportions for graywacke of the Wilber Creek unit (samples 2, 3, and 4) compared to the quartzite of the Wilber Creek unit (sample 1), the Cascaden Ridge unit 


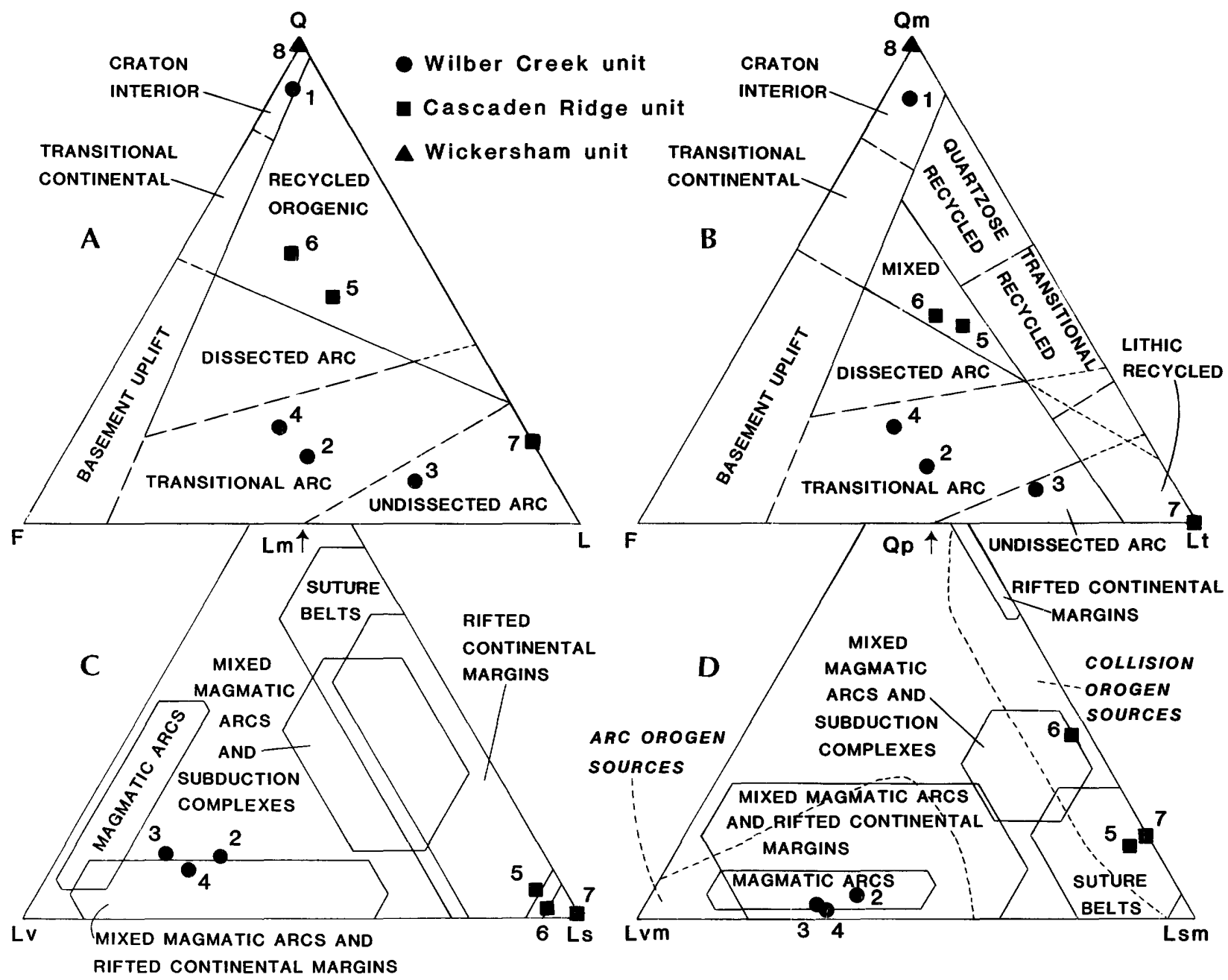

Figure 2. Ternary diagrams for Wilber Creek, Cascaden Ridge, and Wickersham units of Chapman and others (1971) and Weber and others (1987). See text for explanation of abbreviations. A and B, QFL and QmFLt diagrams modified from

(samples 5 and 6), and the Wickersham unit (sample 8). Sample 7, from the Cascaden Ridge(?) unit, contains the highest $\mathrm{L}$ proportions, and sample 8 (Wickersham unit) contains the highest $Q$ and lowest $L$ proportions of the three units.

The QmFLt plot (fig. 2B) shows relative proportions of monocrystalline quartz (Qm), feldspar (F), and lithic fragments plus polycrystalline quartz (Lt). It reveals the predominance of Qm in sample 8 of the Wickersham unit, and in the quartzite (sample 1) of the Wilber Creek unit. Samples of the Cascaden Ridge unit (except sample 7) have higher Qm proportions than graywacke samples of the Wilber Creek unit, and lower Qm proportions than the sample of the Wickersham unit. The lithic-rich end-member sample that is tentatively assigned to the Cascaden Ridge unit (sample 7) is at the Lt apex of the diagram because it is composed of a high proportion of polycrystalline quartz and sedimentary lithic fragments.

The LmLvLs diagram (fig. 2C) depicts relative proportions of metamorphic (Lm), volcanic (Lv), and sedimentary (Ls) lithic fragments. It emphasizes the

Dickinson and others (1983). C, LmLvLs diagram modified from Ingersoll and Suczek (1979); D, QpLvmLsm diagram, showing dashed-line fields from Dickinson and Suczek (1979) and solidline fields from Ingersoll and Suczek (1979).

low proportions of $\mathrm{Lm}$ in the graywacke of the Wilber Creek unit and in the samples of the Cascaden Ridge unit. The greywacke samples of the Wilber Creek unit contain distinctly higher Lv and lower Ls proportions than the samples of the Cascaden Ridge unit.

The QpLvmLsm plot (fig. 2D) shows relative proportions of polycrystalline quartz (Qp), volcanic plus metavolcanic lithic grains (Lvm), and sedimentary plus metasedimentary (Lsm) lithic grains. It shows that the graywacke of the Wilber Creek unit has smaller proportions of $\mathrm{Qp}$ and Lsm and larger proportions of Lvm than the graywacke of the Cascaden Ridge unit.

The four ternary diagrams indicate a probable magmatic-arc provenance for the three graywacke samples of the Wilber Creek unit (fig. 2). Units from adjacent terranes that could have contributed volcanic detritus to the Wilber Creek unit include the Fossil Creek Volcanics of the White Mountains terrane and the Amy Creek unit (dolomite, chert, and volcanic rocks) of the Livengood terrane. Geochemical analysis of major elements of basalt of the Fossil Creek 
Volcanics shows that the basalts are alkalic and therefore are not likely to be island-arc, mid- ocean ridge, or continental tholeiitic basalts (Wheeler and others, 1987). (Compositional differences of volcanic lithic fragments are not distinguishable on the triangle diagrams in figure 2.) However, the lack of carbonate lithic fragments, carbonate matrix, or interbedded carbonate muds within the Wilber Creek unit suggests that the White Mountains terrane is an unlikely magmatic-are source area. Basalt is a minor constituent of the Amy Creek unit and therefore the Livengood terrane is also considered an unlikely source area. Therefore, it is possible that the source area for the Wilber Creek unit is no longer adjacent to the Manley terrane. Fieldwork during 1987 by the TACT project members shows that the quartzites and graywackes of the Wilber Creek unit are locally interbedded, and therefore that different source areas may have existed on opposite sides of the depositional basin.

We draw three preliminary conclusions about the provenance of these few samples from the Livengood quadrangle. (1) The Wilber Creek unit has at least two source areas, one that shed graywacke from a possible magmatic-arc source and another that shed quartzite from a craton interior source; these two source terranes may have been on opposite sides of the depositional basin. (2) Two of the sandstones from the Cascaden Ridge unit have a high proportion of quartz, chert, and sedimentary lithic grains, and may have been derived from a collision orogen source. The other sample consists almost entirely of silicious lithic grains, and may be locally derived from underlying chert units. (3) The quartzite sample from the Wickersham unit is almost exclusively monocrystalline quartz and is compatible with a craton interior provenance.

\section{REFERENCES CITED}

Chapman, R.M., Weber, F.R., and Taber, Bond, 1971, Preliminary geologic map of the Livengood quadrangle, Alaska: U.S. Geological Survey Open-File Map [71-483], 2 sheets, scale 1:250,000.

Dickinson, W.R., 1970, Interpreting detrital modes of graywacke and arkose: Journal of Sedimentary Petrology, v. 40 , no. 2, p. 695707 .

Dickinson, W.R., Beard, L.S., Brakenridge, G.R., Erjavec, J.L., Ferguson, R.C., Inman, K.F., Knepp, R.A., Lindberg, F.A., and Ryberg, P.T., 1983, Provenance of North American
Phanerozoic sandstones in relation to tectonic setting: Geological Society of America Bulletin, v. 94, no. 2, p. 222-235.

Dickinson, W.R., and Suczek, C.A., 1979, Plate tectonics and sandstone compositions: American Association of Petroleum Geologists Bulletin, v. 63, no. 12, p. 2164-2182.

Ingersoll, R.V., 1978, Petrofacies and petrologic evolution of the Late Cretaceous fore-arc basin, northern and central California: Journal of Geology, v. 86, p. 335-352.

Ingersoll, R.V., Bullard, T.F., Ford, R.L., Grimm, J.P., Pickle, J.D., and Sares, S.W., 1984, The effect of grain size on detrital modes: A test of the Gazzi-Dickinson pointcounting method: Journal of Sedimentary Petrology, v. 54, no. 1, p. 103-116.

Ingersol1, R.V., and Suczek, C.A., 1979, Petrology and provenance of Neogene sand from Nicobar and Bengal fans, DSDP Sites 211 and 218: Journal of Sedimentary Petrology, v. 49, no. 4, p. 1217-1228.

Jones, D.L., Silberling, N.J., Coney, P.J., and Plafker, George, 1987, Lithotectonic terrane map of Alaska (west of the 141st meridian): U.S. Geological Survey Miscellaneous Field Studies Map MF-1874-A, scale $1: 2,500,000$.

Weber, F.R., Wheeler, K.L., Dover, J.H., Rinehart, C.D., Blodgett, R.B., Cady, J.W., Kar1, S.M., McCammon, R.B., and Miyaoka, R., 1987, Geologic framework, in Administrative Report on the Mineral Resource Assessment for the White Mountains National Recreation Area, Alaska: U.S. Geological Survey, prepared for the Bureau of Land Management, p. 3-59.

Wheeler, K.L., Forbes, R.B., Weber, F.R., and Rinehart, C.D, 1987, Lithostratigraphy, petrology, and geochemistry of the Ordovician Fossil Creek Volcanics, White Mountains, east-central Alaska, in Hamilton, T.D., and Galloway, J.P., eds., Geologic Studies in Alaska by the U.S. Geological Survey during 1986: U.S. Geological Survey Circular 998, p. 70-73.

Reviewers: T.E. Moore and K.L. Wheeler

Geologic Studies in Alaska by the U.S. Geological Survey during 1987: John P. Galloway and Thomas D. Hamilton, editors, U.S. Geological Survey Circular 1016. 


\title{
Tertiary Gold-Bearing Gravel at Livengood, Alaska
}

\author{
By Susan M. Karl, Thomas A. Ager, Karl Hanneman, and Steve D. Teller
}

Pollen analysis of a sample of organic-rich silt from gold-bearing gravel at Livengood, east-central Alaska, yielded evidence for a late Tertiary (Pliocene?) age for the deposit. This is significant because these gold-bearing gravels were previously thought to be Quaternary in age (Eberlein and Menzie, 1978). Our new information invites reinterpretation of the geomorphic history of the area and of other buried placer deposits in this region of Alaska.

Livengood Creek has historically been the largest placer gold producer in the Tolovana mining district; production through 1987 exceeded 200,000 troy oz $(6,200 \mathrm{~kg})$ (unpub. State of Alaska Records, T.K. Bundtzen, oral commun., January 1988). The present Livengood Creek flows on the south side of the southwest-trending Livengood drainage basin (fig. 1). The original discovery in the district was made in Livengood Creek in 1914 (Brooks, 1916). Soon afterward, more productive auriferous gravel was discovered in deeply buried channels on the north side of the Livengood drainage basin. Auriferous gravel in these deeply buried channels forms a body $10 \mathrm{~km}$ long that is separated from the present Livengood Creek by a discontinuous bedrock ridge $12 \mathrm{~m}$ high. The ancient alluvium in the buried channels is as much as $350 \mathrm{~m}$ wide; it is 3 to $15 \mathrm{~m}$ thick and is covered by 15 to $35 \mathrm{~m}$ of frozen colluvium and silt. Primarily because the surface elevation along the axis of the deposit is 15 to $25 \mathrm{~m}$ higher than the present stream, the deposit has historically been known as the Livengood bench. The base of the ancient gravels, however, is lower than the present stream (fig. 2). No economic gold placers occur in the tributaries on the north side of the valley; however gold has been mined for many years from the modern Livengood Creek and tributaries on the south side of the valley, as well as from the buried channels on the north side.

Livengood Creek and the South Fork of Hess Creek, which is immediately to the northeast, have had a long and complicated geomorphic history. One or more episodes of stream capture were described by Mertie (1917). Local base level has repeatedly shifted up and down, with sequences of downcutting, channel filling, and channel migration, followed by renewed downcutting (Mertie, 1917). During the final stages of valley evolution, a thick section of windblown silt (loess) was deposited and reworked by colluvial and alluvial action. Subsequently, Livengood Creek established a new channel on the south side of the valley, cutting through silt and down into bedrock, so that it became separated from the buried auriferous channels by the bedrock ridge that extends discontinuously from the town of Livengood northeast to the mouth of Amy Creek (Mertie, 1917) (fig. 1). Drilling data that show an abrupt change in depth to bedrock near the mouth of Myrtle Creek suggest that rejuvenation of Livengood Creek may have been influenced by activity on a large north-south-trending normal fault that intersects the Livengood valley at this locality (fig. 1).

Bedrock underlying the buried auriferous channel gravels is pyritic black chert, black siliceous argillite, greenstone, and silicified limestone and dolostone of the Amy Creek unit (Weber and others, 1985). In some places, placer gold has penetrated into decomposed bedrock as much as $60 \mathrm{~cm}$. The character of the gold is quite variable over the length of the deposit: it ranges from light yellow to dark and ironstained, fine to coarse, porous to dense, rounded to angular, and in some places is of mixed varieties. Heavy minerals from pan concentrates include magnetite, ilmenite, hematite, chrome spinel, pyrite, cinnabar, stibnite, and less abundant barite, scheelite, cassiterite, zircon, and uranium-thorium minerals (Mertie, 1917; Eberlein and Menzie, 1978). The source of the gold is believed to be metalliferous quartzcalcite veins that constitute small lodes associated with quartz monzonite dikes of Tertiary(?) age on the south side of the valley (Eberlein and Menzie, 1978). Cambrian mafic and ultramafic intrusive bodies also

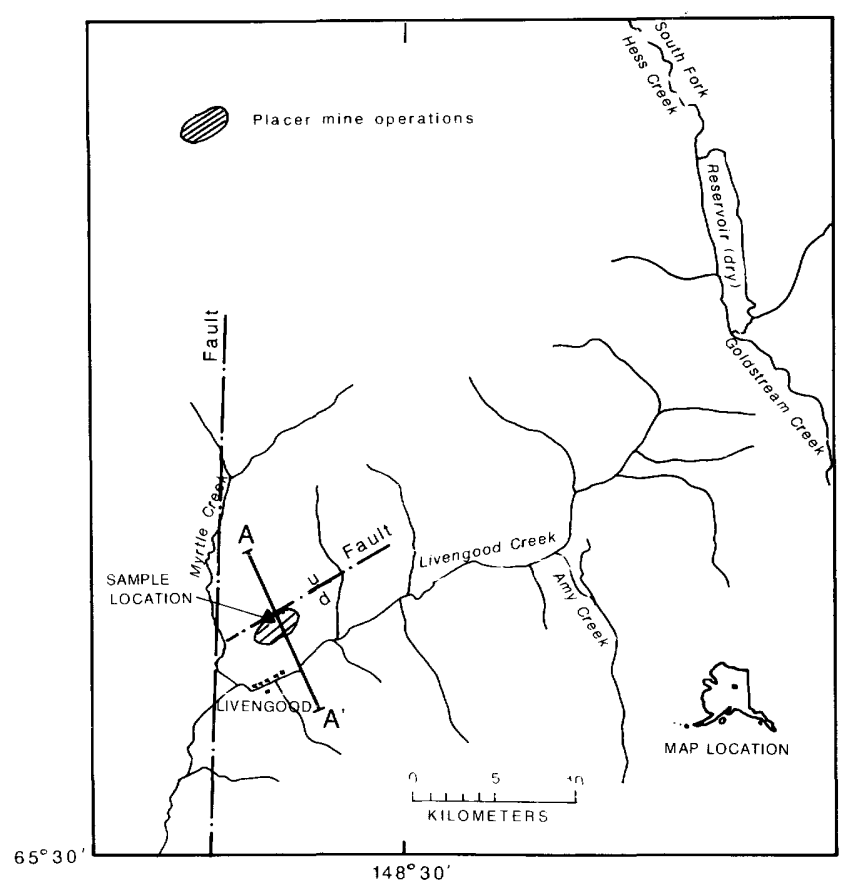

Figure 1. Livengood area, showing faults, drainage features, and location of pollen sample. Cross section A-A' shown on figure 2 . 


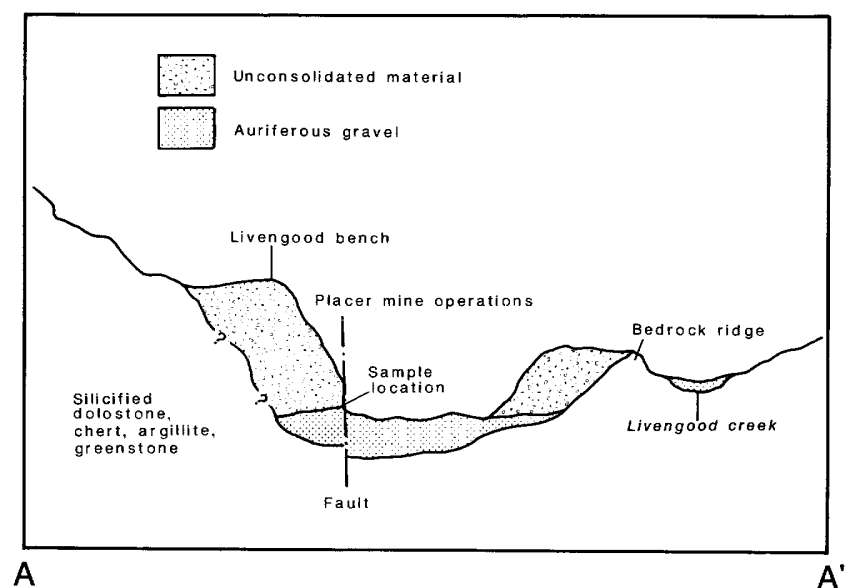

Figure 2. Schematic cross section $A-A^{\prime}$ (see fig. 1) showing bedrock ridge that separates auriferous gravels from present-day Livengood Creek. Diagram not to scale.

occur on the south side of the valley (Weber and others, 1985), and one platinum nugget was reported by Overbeck (1920). Platinum-bearing grains from Amy Creek were reported by Cathrall and others (1987).

We collected a sample for pollen analysis from auriferous gravel in that part of the buried channel on the Livengood bench north of the town of Livengood (figs. 1 and 2) that currently is being mined. The sample was collected from a lens $80 \mathrm{~cm}$ long and 10 $\mathrm{cm}$ thick of dark-brown organic-rich silt which included pieces of woody material up to 0.5 by $1.0 \mathrm{~cm}$ in size (fig. 3). The lens occurs within moderately sorted alluvium of coarse sand to cobble size with poorly defined decimeter-scale lenticular beds; it probably represents a quiet-water deposit behind a bar within a braided channel. The coarse alluvial gravel is subrounded and consists of silicified carbonate, chert, greenstone, argillite, and intermediate intrusive rock, commonly with slightly rusty weathering rinds; clasts of intrusive rock are commonly highly decomposed. The gravel is overlain by approximately $30 \mathrm{~m}$ of frozen silt, stony silt, and organic-rich silt (fig. 3).

The silt sample contained well-preserved pollen and abundant fern spores representing a coniferdominated forest with spruce (Picea), pine ( $P$ inus), and small amounts of hemlock (Tsuga). The sample also contained alder (Alnus), birch (Betula), sedge (Cyperaceae), grass (Gramineae), rare grains of Jacob's ladder (Polemonium), sphagnum moss spores, and several types of fern spores. All other dated pollen and macrofossil assemblages containing pine and hemlock in central and northern Alaska are older than Pleistocene (D.M. Hopkins, University of AlaskaFairbanks, written commun., 1987). The pollen assemblage from Livengood Creek suggests a Pliocene age, but a late Miocene age is also possible (T.A. Ager, unpub. data). The presence of pine and hemlock in this assemblage suggests that the climate at that time was somewhat warmer and more moist than today.

The older, oxidized gravel from which this pollen age was obtained may be correlative with the Cripple Gravel of Pewe (1975), which is the deepest gravel exposed in placer workings in the Fairbanks District. This gravel is found on buried bedrock benches; it contains decomposed clasts of intrusive igneous rock and iron-oxide-coated clasts and is overlain by tan gravel and thick silt deposits. Péwe (1975) inferred the Cripple Gravel to be of late Pliocene and (or) early Pleistocene age.

The Nenana Gravel, found in the Healy area on the north flank of the Alaska Range, probably is late Miocene to early Pliocene in age on the basis of a small megafossil flora (Wolfe and Tanai, 1980). Most of the pollen types found in lignitic horizons in the Nenana Gravel also occur in the Livengood sample. This suggests approximate age equivalency (T.A. Ager, unpub. data). Clasts in the Nenana Gravel also have oxide coatings and include decomposed coarse-grained intrusive rocks. Although possibly time equivalent, the Nenana Gravel, the Cripple Gravel, and the Livengood gravel unit are widely separated in space.

The possibility of older buried channels in the vicinity of known sources of gold has historically been investigated in the Tolovana and other mining districts of central Alaska. Other deeply buried channels are known near Hess Creek north of Livengood and the South Fork of Hess Creek (Brooks, 1916), but these have not yielded significant gold. However, to our knowledge, this is the first major gold placer in interior Alaska that has yielded evidence of a Tertiary age. Our data confirm for the first time the formerly speculative assumption that many of the interior Alaska gold-producing placer deposits may have formed during Tertiary time.

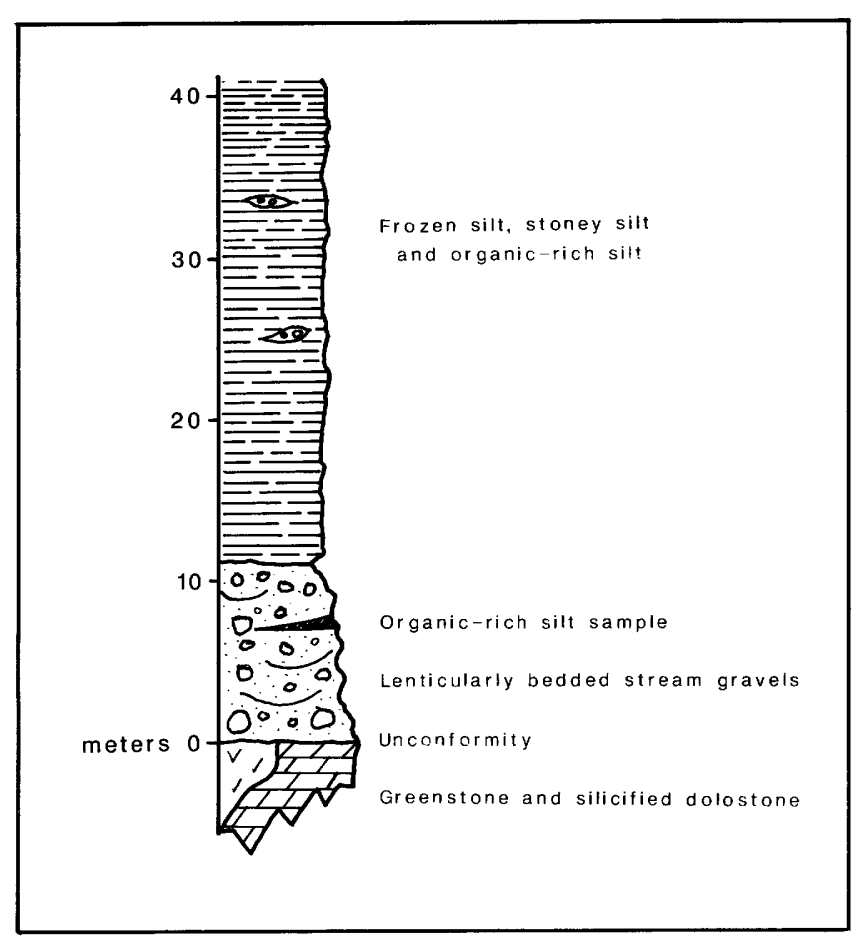

Figure 3. Generalized stratigraphic section at pollen-sample locality on north side of Livengood valley. 


\section{REFERENCES CITED}

Brooks, A.H., 1916, Preliminary report on the Tolovana District: U.S. Geological Survey Bulletin 642, p. 201-209.

Cathrall, J.B., Antweiller, J.C., and Mosier, E.L., 1987, Occurrence of platinum in gold samples from the Tolovana and Rampart mining districts, Livengood quadrangle, Alaska: U.S. Geological Survey Open-File Report 87330,15 p., 1 sheet, scale 1:250,000.

Eberlein, G.D., and Menzie, W.D., 1978, Maps and tables describing areas of metalliferous mineral resource potential of central Alaska: U.S. Geological Survey Open-File Report 78-1-D, 47 p., 2 sheets, scale $1: 1,000,000$.

Mertie, J.B., Jr., 1917, The gold placers of the Tolovana district, Alaska: U.S. Geological Survey Bulletin 662D, p. 260-268.

overbeck, R.M., 1920, Placer mining in the Tolovana district: U.S. Geological Survey Bulletin 712 , p. 178-184.
Péwe, T.L., 1975, Quaternary stratigraphic nomenclature in unglaciated central Alaska: U.S. Geological Survey Professional Paper $862,32 \mathrm{p}$.

Weber, F.R., Smith, T.E., Hall, M.H., and Forbes, R.B., 1985, Geologic guide to the Fairbanks-Livengood area, east-central Alaska: Anchorage, Alaska Geological Society field trip guide, $44 \mathrm{p}$.

Wolfe, J.A., and Tanai, T., 1980, The Miocene Seldovia Point flora from the Kenai Group, Alaska: U.S. Geological Survey Professional Paper $1105,52 \mathrm{p}$.

Reviewers: D.M. Hopkins and F.R. Weber

Geologic Studies in Alaska by the U.S. Geological Survey during 1987: John P. Galloway and Thomas D. Hamilton, editors, U.S. Geological Survey Circular 1016. 


\title{
Reconnaissance Geochemical Investigations of the White Mountains National Recreation Area, East-Central Alaska
}

\author{
By Thomas D. Light, Gregory K. Lee, Richard B. Tripp, and Elizabeth A. Bailey
}

In 1986 and 1987 we conducted a reconnaissance geochemical study of a portion of the White Mountains National Recreation Area (NRA) of east-central Alaska as part of an assessment of the mineral resource potential of that area (fig. 1). The White Mountains NRA lies within the Yukon-Tanana Upland of east-central Alaska. The geologic setting in the vicinity of the White Mountains has been described by Weber and others (1985). The predominant lithologies in the area are Precambrian to Mesozoic quartzitic, pelitic, calcic, and mafic metasedimentary rocks and some metamorphosed mafic and felsic igneous rocks. These rocks are intruded by Cretaceous and Tertiary granitic rocks and minor amounts of intermediate and mafic rocks. Large northeast-southwest-trending thrust faults and strike-slip splays of the Tintina fault zone cross the area (Chapman and others, 1971, F.R. Weber, U.S. Geological Survey, written commun.). The potential for undiscovered mineral resources in the White Mountains NRA is evaluated by McCammon and others (this volume).

During this study, 620 rocks, 461 streamsediment samples, 364 moss-trap-sediment samples, and 340 heavy-mineral concentrates were collected from the White Mountains NRA. All samples were analyzed for 31 elements using a semiquantative, direct-current arc emission spectrographic method (Grimes and Marranzino, 1968). Stream-sediment and moss-trap-sediment samples were also analyzed for $\mathrm{As}, \mathrm{Bi}, \mathrm{Cd}, \mathrm{Sb}$, and $\mathrm{Zn}$ by atomic absorption spectrophotometry using the method of O'Leary and Viets (1986). Analytical data are published in Sutley and others (1987a, 1987b). The nonmagnetic fractions of heavy-mineral concentrates were examined under a binocular microscope to determine the presence of specific ore-related minerals. Identification of unusual or unknown species was confirmed by X-ray diffraction. The analytical data were processed using the USGS STATPAC computer programs (VanTrump and Miesch, 1977) to determine univariate statistics. Nineteen target and pathfinder elements ( $\mathrm{Ag}, \mathrm{As}, \mathrm{Au}$, $\mathrm{B}, \mathrm{Ba}, \mathrm{Be}, \mathrm{Bi}, \mathrm{Cd}, \mathrm{Cu}, \mathrm{Fe}$, La, Mo, Nb, Pb, Sb, Sn, Th, $\mathrm{W}$, and $\mathrm{Zn}$ ) were selected as potential indicators of mineralized areas. The thresholds used to define anomalous concentrations of these selected elements were subjectively determined by visual inspection of histograms and by inflection points in cumulative frequency plots.

The occurrence and distribution of elements and minerals in geochemical samples from the White Mountains NRA were used to determine the areas of anomalous metal concentrations shown in figure 1 and listed in table 1 . In the following paragraphs we discuss these areas in their probable decreasing order of importance based on our current level of information.

The Nome Creek area (area 3; fig. 1 and table 1), which includes Trail and Ophir Creeks, is underlain by greenschist-facies metamorphic rocks of the Precambrian Fairbanks schist unit. Anomalously high concentratons of $\mathrm{Ag}, \mathrm{As}, \mathrm{Au}, \mathrm{Be}, \mathrm{Cu}, \mathrm{Fe}, \mathrm{Pb}, \mathrm{Sb}, \mathrm{Sn}$, and $W$ were observed in samples from this area, and heavy-mineral concentrates collected from its eastern part contained gold, cassiterite, scheelite, pyrite, and arsenopyrite. Approximately $29,000 \mathrm{oz}(900 \mathrm{~kg})$ of gold was recovered prior to 1948 from placer oprations along Nome Creek (U.S. Bureau of Mines file data), and during this study visible gold was observed in numerous samples from the Nome Creek area. Given the abundance of gold observed, we expect that additional placer gold and perhaps lode gold will be found in the Nome Creek area.

Cache Mountain (area 1) is a highly evolved Tertiary granitic intrusion dated at about $58 \mathrm{Ma}$ (Holm, 1975). Fluorite, tourmaline, cassiterite, and scheelite, in addition to high concentrations of $\mathrm{Ag}, \mathrm{B}$, $\mathrm{Be}, \mathrm{Bi}, \mathrm{Cd}, \mathrm{Pb}, \mathrm{Sb}, \mathrm{Sn}$, and $\mathrm{Zn}$, occur in this area. The association of light and transition metals suggests the possible presence of Sn-bearing greisen or vein mineralization in and around the Cache Mountain pluton.

Scattered localities around the periphery of the Victoria Mountain pluton (area 10) contain high values of a wide range of base and precious metals. The abundance of scheelite and cassiterite in streams draining Victoria Mountain suggests the possibility of skarn mineralization in dolomitic rocks along the borders of the intrusion. The continuation of this association of anomalous elements to the north of Victoria Creek may represent dispersion of hydrothermal fluids outward from the pluton along local faults.

Samples from the Warren Creek-Moose Creek area (area 11) contain anomalously high values of $\mathrm{Ag}$, As, B, Ba, Bi, Cd, $\mathrm{Cu}, \mathrm{Fe}, \mathrm{La}, \mathrm{Mo}, \mathrm{Pb}, \mathrm{Sb}, \mathrm{Th}$, and $\mathrm{Zn}$, along with occurrences of pyrite, barite, and sphalerite from Paleozoic to Mesozoic reduced slate, shale, and siltstone. This association suggests the possibility of sedimentary exhalative and (or) epigenetic base-metal sulfide deposits. In addition, high concentrations of base metals in areas of Paleozoic clastic sedimentary and volcanic rocks suggest the possible presence of polymetallic vein deposits peripheral to granitic intrusions to the south (outside our study area).

Anomalous concentrations of As, B, Be, La, Th, and $Y$ were observed in samples from the syenite of 
Roy Creek (area 4). A concentrate sample from Roy Creek contained thorite, allanite, cassiterite, scheelite, and sapphire corundum. One sample from a mineralized fracture zone in the syenite contained greater than 2000 parts per million thorium. Additional fractures containing thorium and rare-earth elements (REE) possibly occur in the syenite of Roy Creek.

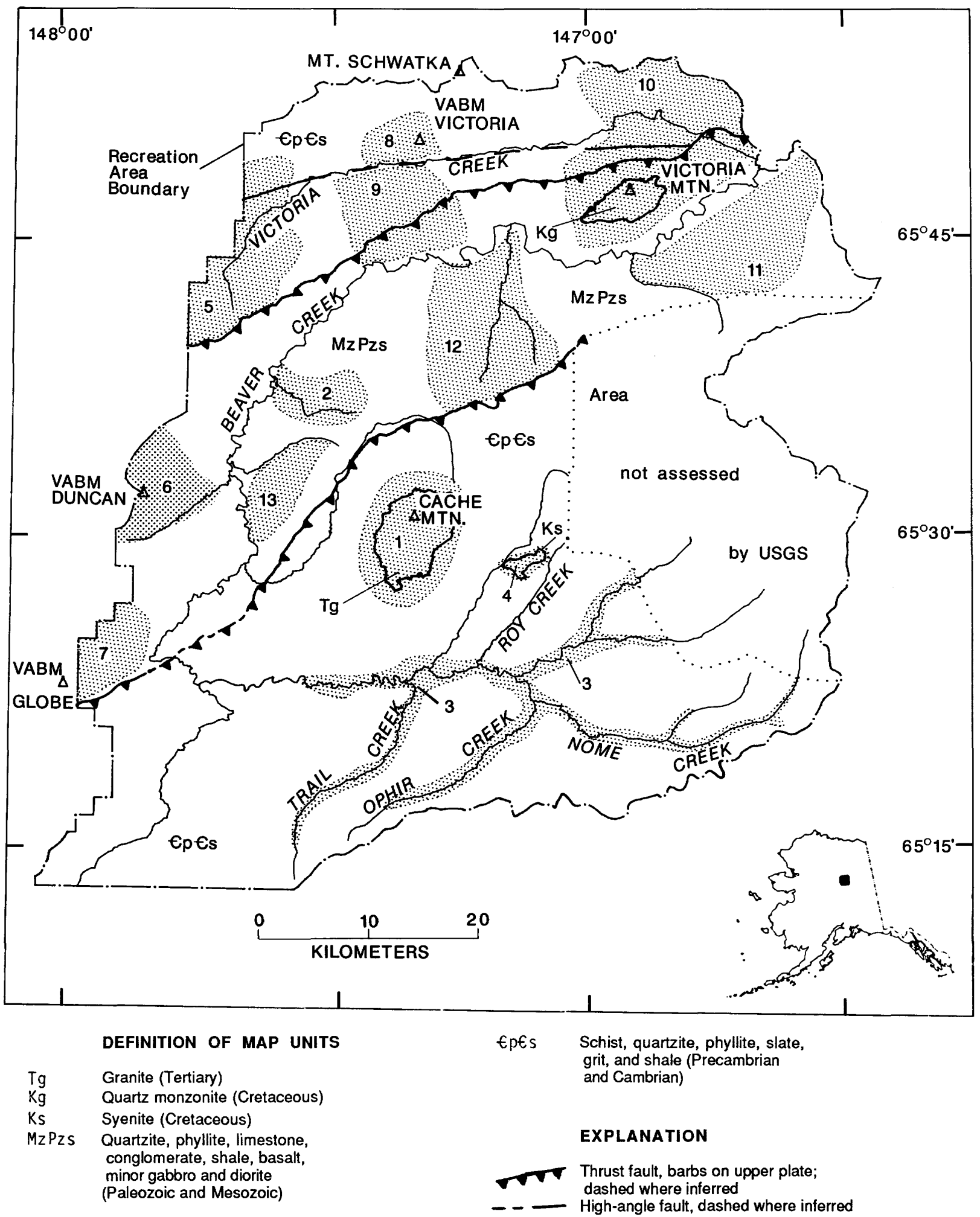

Figure 1. Geochemically anomalous areas (patterned) in White Mountains National Recreation Area. See table 1 for description of numbered areas. VABM, Vertical Angle Bench Mark. 
Table 1. Geochemically anomalous areas in the White Mountains National Recreation Area

laln=allanite, ars=arsenopyrite, bar=barite, cas=cassiterite, cin=cinnabar, cpy=chalcopyrite, cyr=cyrtolite, flu=fluorite, gal=galena, mon=monazite, pyr=pyrite, tour=tourmaline, saph=sapphire, $s c h=s c h e e l i t e, s p h=s p h a l e r$ ite, stib=stibnite, uth=uranothorite]

\begin{tabular}{|c|c|c|c|c|c|}
\hline \multirow{2}{*}{\multicolumn{2}{|c|}{ Area name }} & \multirow[t]{2}{*}{ Bedrock } & \multicolumn{2}{|c|}{ Geochemical anomalies } & \multirow[t]{2}{*}{ Possible source of anomaly } \\
\hline & & & Elements & Minerals & \\
\hline 1. & Cache Mountain & $\begin{array}{l}\text { Granite of } \\
\text { Cache Mountain }\end{array}$ & $\begin{array}{l}\mathrm{Ag}, \mathrm{B}, \mathrm{Be}, \mathrm{Bi}, \mathrm{Cd}, \\
\mathrm{Pb}, \mathrm{Sb}, \mathrm{Sn}, \mathrm{Zn}\end{array}$ & $\begin{array}{l}\text { bar, cas, flu, pyr, } \\
\text { sch, sph, tourveins }\end{array}$ & Sn-bearing greisen or \\
\hline 2. & $\begin{array}{l}\text { Lost Horizon } \\
\text { Creek }\end{array}$ & $\begin{array}{l}\text { Conglomerate, } \\
\text { shale, graywacke }\end{array}$ & $\begin{array}{l}\mathrm{Ag}, \mathrm{Ba}, \mathrm{Cd}, \mathrm{Cu}, \\
\mathrm{Pb}, \mathrm{Zn}\end{array}$ & bar, cin, pyr, sph & Polymetallic veins \\
\hline 3. & Nome Creek & $\begin{array}{l}\text { Fairbanks schist } \\
\text { unit }\end{array}$ & $\begin{array}{l}\mathrm{Ag}, \mathrm{As}, \mathrm{Au}, \mathrm{Be}, \mathrm{Cu} \\
\mathrm{Fe}, \mathrm{Pb}, \mathrm{Sb}, \mathrm{Sn}, \mathrm{W}\end{array}$ & $\begin{array}{l}\text { ars, bar, cas, cin, } \\
\text { gold, pyr, sch }\end{array}$ & Placer $\mathrm{Au}$, vein $\mathrm{Au}$ \\
\hline 4. & Roy Creek & $\begin{array}{l}\text { Syenite of Roy } \\
\text { Creek }\end{array}$ & $\begin{array}{l}\text { As, B, Be, La, Th, } \\
Y\end{array}$ & $\begin{array}{l}\text { aln, cas, sch, saph, } \\
\text { uth }\end{array}$ & Th- and REE-bearing veins \\
\hline 5. & $\begin{array}{l}\text { Upper Victoria } \\
\text { Creek }\end{array}$ & Wickersham unit & $\mathrm{La}, \mathrm{Nb}, \mathrm{Pb}, \mathrm{W}, \mathrm{Zn}$ & $\begin{array}{l}\text { bar, gal, pyr, sch, } \\
\text { sphlymetallic veins }\end{array}$ & Shales and mafic rocks \\
\hline 6. & VABM Duncan & $\begin{array}{l}\text { Conglomerate, } \\
\text { shale, graywacke }\end{array}$ & $\begin{array}{l}\mathrm{Ag}, \mathrm{Cd}, \mathrm{Cu}, \mathrm{Pb}, \mathrm{Sb} \\
\mathrm{Zn}\end{array}$ & $\begin{array}{l}\text { bar, cas, cpy, pyr, } \\
\text { sph, stib shales }\end{array}$ & Polymetallic veins, \\
\hline 7. & VABM Globe & $\begin{array}{l}\text { Limestone, slate, } \\
\text { quartzite, basalt, } \\
\text { mafic sills and } \\
\text { dikes }\end{array}$ & $\mathrm{Ba}, \mathrm{Cu}$, Mo, $\mathrm{w}$ & bar, cas, cin, sch & Polymetallic veins(?) \\
\hline 8 . & VABM Victoria & Wickersham unit & $\begin{array}{l}\mathrm{Ag}, \mathrm{Ba}, \mathrm{Be}, \mathrm{Cd}, \mathrm{La} \\
\mathrm{Nb}, \mathrm{Pb}, \mathrm{Zn}\end{array}$ & $\begin{array}{l}\text { bar, gold, pyr, sch, } \\
\text { sph }\end{array}$ & Polymetallic veins(?) \\
\hline 9. & $\begin{array}{l}\text { Victoria } \mathrm{Cr} . \\
\text { Beaver Creek } \\
\text { Ridge }\end{array}$ & $\begin{array}{l}\text { Dolomite, slate, } \\
\text { grit, mafic and } \\
\text { ultramafic rocks }\end{array}$ & $\begin{array}{l}\mathrm{Ag}, \mathrm{As}, \mathrm{Ba}, \mathrm{Cd}, \mathrm{Pb}, \\
\mathrm{Zn}\end{array}$ & $\begin{array}{l}\text { bar, cas, cin, pyr, } \\
\text { sch }\end{array}$ & Polymetallic veins(?) \\
\hline 10 . & $\begin{array}{l}\text { Victoria Mtn- } \\
\text { Glacier Creek }\end{array}$ & $\begin{array}{l}\text { Quartz monzonite } \\
\text { of Victoria Mtn., } \\
\text { grit, slate, } \\
\text { shale, dolomite }\end{array}$ & $\begin{array}{l}\mathrm{Ag}, \mathrm{As}, \mathrm{Au}, \mathrm{B}, \mathrm{Bi}, \\
\mathrm{Co}, \mathrm{Cu}, \mathrm{Fe}, \mathrm{La}, \mathrm{Mo}, \\
\mathrm{Ni}, \mathrm{Pb}, \mathrm{Sb}, \mathrm{Sn}, \mathrm{Th} \\
\mathrm{w}, \mathrm{Zn}\end{array}$ & $\begin{array}{l}\text { ars, bar, cas, cpy, } \\
\text { gold, pyr, sch, sph, } \\
\text { uth }\end{array}$ & $\begin{array}{l}\text { Skarn, polymetallic } \\
\text { veins }\end{array}$ \\
\hline 11 . & $\begin{array}{l}\text { Warren Creek- } \\
\text { Moose Creek }\end{array}$ & $\begin{array}{l}\text { Slate, quartzite } \\
\text { grit }\end{array}$ & $\begin{array}{l}\mathrm{Ag}, \mathrm{As}, \mathrm{B}, \mathrm{Ba}, \mathrm{Bi} \\
\mathrm{Cd}, \mathrm{Cu}, \mathrm{Fe}, \mathrm{La}, \mathrm{Mo} \\
\mathrm{Pb}, \mathrm{Sb}, \mathrm{Th}, \mathrm{Zn}\end{array}$ & $\begin{array}{l}\text { aln, ars, bar, cyr } \\
\text { flu, gal, mon, pyr, } \\
\text { tour, sch, sph, } \\
\text { stib, uth }\end{array}$ & $\begin{array}{l}\text { Sedimentary exhalative, } \\
\text { polymetallic veins }\end{array}$ \\
\hline 12. & Willow Creek & $\begin{array}{l}\text { Conglomerate, } \\
\text { slate, graywacke, } \\
\text { shale }\end{array}$ & $\begin{array}{l}\mathrm{Ag}, \mathrm{As}, \mathrm{B}, \mathrm{Ba}, \mathrm{Cd}, \\
\mathrm{Cu}, \mathrm{Nb}, \mathrm{Pb}, \mathrm{Sb}, \mathrm{Zn}\end{array}$ & $\begin{array}{l}\text { bar, cas, cin, pyr, } \\
\text { sph, sch }\end{array}$ & Polymetallic veins \\
\hline 13 . & Windy Creek & $\begin{array}{l}\text { Quartzite, slate, } \\
\text { phyllite, shale }\end{array}$ & $\begin{array}{l}\mathrm{Ag}, \mathrm{As}, \mathrm{Cd}, \mathrm{Cu}, \mathrm{Fe}, \\
\mathrm{Mo}, \mathrm{Nb}, \mathrm{Sb}, \mathrm{Pb}, \mathrm{Th} \\
\mathrm{w}, \mathrm{Zn}\end{array}$ & $\begin{array}{l}\text { bar, cin, gal, pyr, } \\
\text { sch, sph, stib }\end{array}$ & Polymetallic veins \\
\hline
\end{tabular}

Samples from Lost Horizon Creek (area 2) and from drainages along the flanks of the ridge between Victoria and Beaver Creeks (area 9) contain high concentrations of $\mathrm{Ag}, \mathrm{Ba}, \mathrm{Cd}, \mathrm{Pb}$, and $\mathrm{Zn}$. Although the source of the metals is not known, the rocks that are potential hosts for sedimentary exhalative mineralization in the Warren Creek-Moose Creek area (area 11) do not occur in these areas. The occurrence of cinnabar together with pyrite and barite in heavymineral concentrates from the Lost Horizon Creek and the ridge between Victoria and Beaver Creeks suggests the presence of epithermal mineralization, possibly in polymetallic veins or channeled along low-angle thrust faults.
Samples from the Windy Creek area (area 13) contain anomalous concentrations of $\mathrm{Ag}, \mathrm{As}, \mathrm{Cd}, \mathrm{Cu}$, $\mathrm{Fe}, \mathrm{Mo}, \mathrm{Nb}, \mathrm{Sb}, \mathrm{Pb}, \mathrm{Th}, \mathrm{W}$, and $\mathrm{Zn}$. The source of the anomalies is unknown. They could be derived from indigenous metals in the underlying JurassicCretaceous flysch or from polymetallic veins formed by the migration of hydrothermal fluids along local faults.

Anomalous concentrations of ore-related elements also occur near the headwaters of Victoria Creek (area 5), near VABM Duncan (area 6), northeast of VABM Globe (area 7), south of VABM Victoria (area 8 ), and along Willow Creek (area 12). There is no known source for these metals, and no evidence of 
epithermal mineralization was observed. Given the lack of evidence for widespread mineralization, we speculate that the metals may be from small fracture fillings caused by the migration of weakly mineralized hydrothermal fluids channeled along loca! faults or that the metals may occur in polymetallic veins.

In summary, geochemical anomalies in the White Mountains NRA and their geologic associations suggest the presence of a wide variety of mineralization types within the study area. Varieties of mineralization include known occurrences of placer gold and Th-REE veins, probably occurrences of lode gold, and possible occurrences of polymetallic veins, sedimentary exhalites, Sn greisen, $\mathrm{W}$ skarn, and ThREE veins.

\section{REFERENCES CITED}

Chapman, R.M., Weber, F.R., and Tabor, Bond, 1971, Preliminary geologic map of the Livengood quadrangle, Alaska: U.S. Geological Survey Open-File Report 71-066, scale $1: 250,000$.

Grimes, D.J., and Marranzino, A.P., 1968, Direct-current arc and alternating-current spark emission spectrographic field methods for the semiquantitative analysis of geologic materials: U.S. Geological Survey Circular 591, 6 p.

Holm, Bjarne, 1975, Bedrock geology and mineralization of the Mount Prindle area, Yukon-Tanana Upland, Alaska: Fairbanks, University of Alaska, M.S. thesis, 55 p.

O'Leary, R.M., and Viets, J.G., 1986, Determination of antimony, arsenic, bismuth, cadmium, copper, lead, molybdenum, silver, and zinc in geologic materials by atomic absorption spectrometry using a hydrochloric acid-hydrogen peroxide digestion: Atomic Spectroscopy, v. 7, no. 1, p. 4-8.

Sutiey, S.J., Ryder, J.T., Light, T.D., and Weber, F.R., 1987a, Analytical results and sample locality map of rock samples from the White Mountains National Recreaton Area, Livengood and Circle quadrangles, eastcentral Alaska: U.S. Geological Survey Open-File Report 87-284, 61 p.

Sutley, S.J., O'Leary, R.M., Lee, G.K., and Light, T.D., 1987b, Analytical results and sample locality map of stream-sediment, moss-trap sediment, and heavy-mineralconcentrate samples from the White Mountains National Recreation Area, Livengood and Circle quadrangles, east-central Alaska: U.S. Geological Survey Open-File Report 87$285,110 \mathrm{p}$.

VanTrump, G., Jr., and Miesch, A.T., 1977, The U.S. Geological Survey RASS-STATPAC system for management and reduction of geochemical data: Computers and Geosciences, v. 3, p. 475-488.

Weber, F.R., Smith, T.E., Hall, M.H., and Forbes, R.B., 1985, Geologic guide to the Fairbanks-Livengood area, east-central Alaska: Anchorage, Alaska Geological Society Guidebook, $44 \mathrm{p}$.

Reviewers: M.S. Allen and M.L. Miller

Geologic Studies in Alaska by the U.S. Geological Survey during 1987: John P. Galloway and Thomas D. Hamilton, editors, U.S. Geological Survey Circular 1016. 


\title{
Ultramafic Rocks of the Livengood Terrane
}

\author{
By Robert A. Loney and Glen R. Himmelberg
}

The ultramafic rocks of the Livengood area are part of a narrow, discontinuous belt of sheared, highly serpentinized ultramafic rocks that extends more than $190 \mathrm{~km}$ from near Manley Hot Springs on the southwest through Livengood to the Beaver Creek area on the northeast (Chapman and others, 1971; Chapman and others, 1982). Foster $(1967,1969)$ called the belt the "Livengood ultramafic trend" and considered it to be a fault-bounded, tectonically emplaced, alpine-type serpentinite. Reconnaissance fieldwork during 1987 generally supports Foster's view, with the assumption that by "alpine-type" he meant serpentinite derived from an ophiolitic harzburgite-dunite complex (Wyllie, 1967). However, the generally poor exposures make it difficult to be certain of many of the details of the belt, particularly the contacts and internal composition.

In the Livengood area, the largest mass of ultramafic rock occurs in Cascadan Ridge about $10 \mathrm{~km}$ southeast of Livengood (localities 10 and 11, fig. 1), but it is poorly exposed at these localities. It appears to be depositionally overlain on the south side of the ridge by the Devonian Cascadan Ridge unit of Weber and others (1985), and on the north side by the Ordovician Livengood Dome Chert. The serpentinite on Cascadan Ridge, although predominant, is cut through by numerous lenticular bodies of gabbro. In the immediate vicinity of Livengood, however, diorite and gabbro dominate, and most serpentinite occurs as small, scattered masses in and around the dioritegabbro bodies.

The serpentinite is largely serpentinized harzburgite (and minor dunite) that had a primary mineralogy consisting of olivine, orthopyroxene (15 to 20 percent), and accessory chromian spinel. Foster (1966) reported minor amounts of clinopyroxene in the ultramafic rocks, but we saw none in the samples we collected. The primary texture, as interpreted from bastite pseudomorphs after orthopyroxene, was anhedral granular with an average orthopyroxene grain diameter of about 3 to $4 \mathrm{~mm}$. Serpentine minerals consist of lizardite and clinochrysotile. The primary mineralogy and texture of the serpentinized harzburgite are characteristic of mantle peridotite of ophiolite complexes.

Similar serpentinite mineralogy and texture, including bastite, was reported by Foster (1969) from the Beaver Creek area at the northeast end of the Livengood ultramafic trend (locality 9, fig. 1), indicating a probable mantle peridotite prototype for that area also. The isolated southwest end of the trend in the Manley Hot Springs area (Serpentine Ridge; locality 12 , fig. 1) has been so intensely recrystallized to antigorite plus magnetite that we could see no relict textures that might further identify its protolith. Tectonic inclusions of rodingitized hornblende-augite gabbro are common, however, and are similar to the disrupted gabbro dikes in the Livengood area. There is nothing in this evidence against the serpentinite being a continuation of the ultramafic rocks of the Livengood area because the difference in mineralogy may be only a product of recrystallization. Antigorite is a higher temperature serpentine mineral than lizardite and chrysotile, which dominate in the Livengood area (Evans and others, 1976; Mellini and others, 1987). The heat source responsible for this recrystallization is not known. Because the serpentinite lies structurally above, and possibly in fault contact with, a poorly dated clastic sedimentary unit of Jurassic or Cretaceous age (Chapman and others, 1982), it was previously included in the Manley terrane rather than the Livengood terrane (Jones and others, 1987).

Near Livengood the serpentinite is intruded by diorite composed largely of brownish-green hornblende and plagioclase, and 10 to $20 \mathrm{~km}$ to the southwest the serpentinite commonly contains disrupted hornblendeaugite gabbro dikes. Some of these dikes have finegrained "chilled" margins, indicating intrusion into the cooler ultramafic rocks. The diorite and gabbro seem petrologically similar, and, in view of the similar $\mathrm{K}-\mathrm{Ar}$ isotopic ages of 518-633 Ma for hornblende (Donald L. Turner, University of Alaska, written commun., 1987), they probably represent the same intrusive event.

Sedimentary and volcanic rocks of Middle Devonian age (Cascadan Ridge unit) on the south side of Cascadan Ridge and the sedimentary rocks of Ordovician age (Livengood Dome Chert) on the north side of the ridge both appear to unconformably overlie the ultramafic rocks. Although ultramafic clasts (serpentinite) have been reported from the conglomerates near the contact with the serpentinite outcrops (Foster, 1966; Weber and others, 1985), our brief search did not substantiate the occurrence of ultramafic clasts. Clasts that appeared to be serpentinite in hand specimen were determined to be chlorite upon X-ray and microprobe analysis. However, the presence of chromian spinel clasts in the conglomerate is highly suggestive of a harzburgite or dunite sedimentary source.

Accordingly, if the above sedimentary and structural relations are valid, the serpentinite would be pre-Ordovician in age, which would be compatible with it being pre-diorite-gabbro $(518-633 \mathrm{Ma})$. It is suggested then that the ultramafic rocks were probably emplaced as part of an ophiolite sometime in the Late Proterozoic (more than $633 \mathrm{Ma}$ ), followed by diorite-gabbro intrusion in the Late Proterozoic to Cambrian interval; they ultimately were eroded and overlapped by sediments in the Ordovician (Livengood 
Dome Chert) and by sedimentary and volcanic deposits in the Middle Devonian (Cascadan Ridge unit). This general structural relationship seems to continue to the northwest to the Beaver Creek area, where a major serpentinite mass is in contact with similar sedimentary rocks along its northwestern contact, but is in fault contact with the Mesozoic sedimentary rocks of the Manley terrane (locality 9, fig. 1). This package of rocks has been called the Livengood terrane (Jones and others, 1987).

The Livengood terrane as thus defined is composed of, in addition to the Proterozoic(?) serpentinized mantle peridotite, Late Proterozoic to Cambrian diorite-gabbroic intrusive rocks, and still later marine sedimentary and volcanic rocks that are unrelated to the partial ophiolite represented by the serpentinite. Thus, in contrast to the probable Mesozoic Kanuti ophiolite terrane (locality 6, fig. 1; Loney and Himmelberg, 1985; Loney and Himmelberg, in press), the Livengood terrane seems not to represent primary emplacement of ophiolite from the mantle, but instead a later, unrelated event. As reflected in figure 1, the Kanuti ophiolite terrane (or equivalent terranes) occurs in widely scattered outcrops as a thrust sheet overlying a lower thrust sheet composed mainly of pillow basalt and radiolarian chert (Angayucham terrane). Such relationships are not present in the ultramafic rocks of the Livengood terrane.

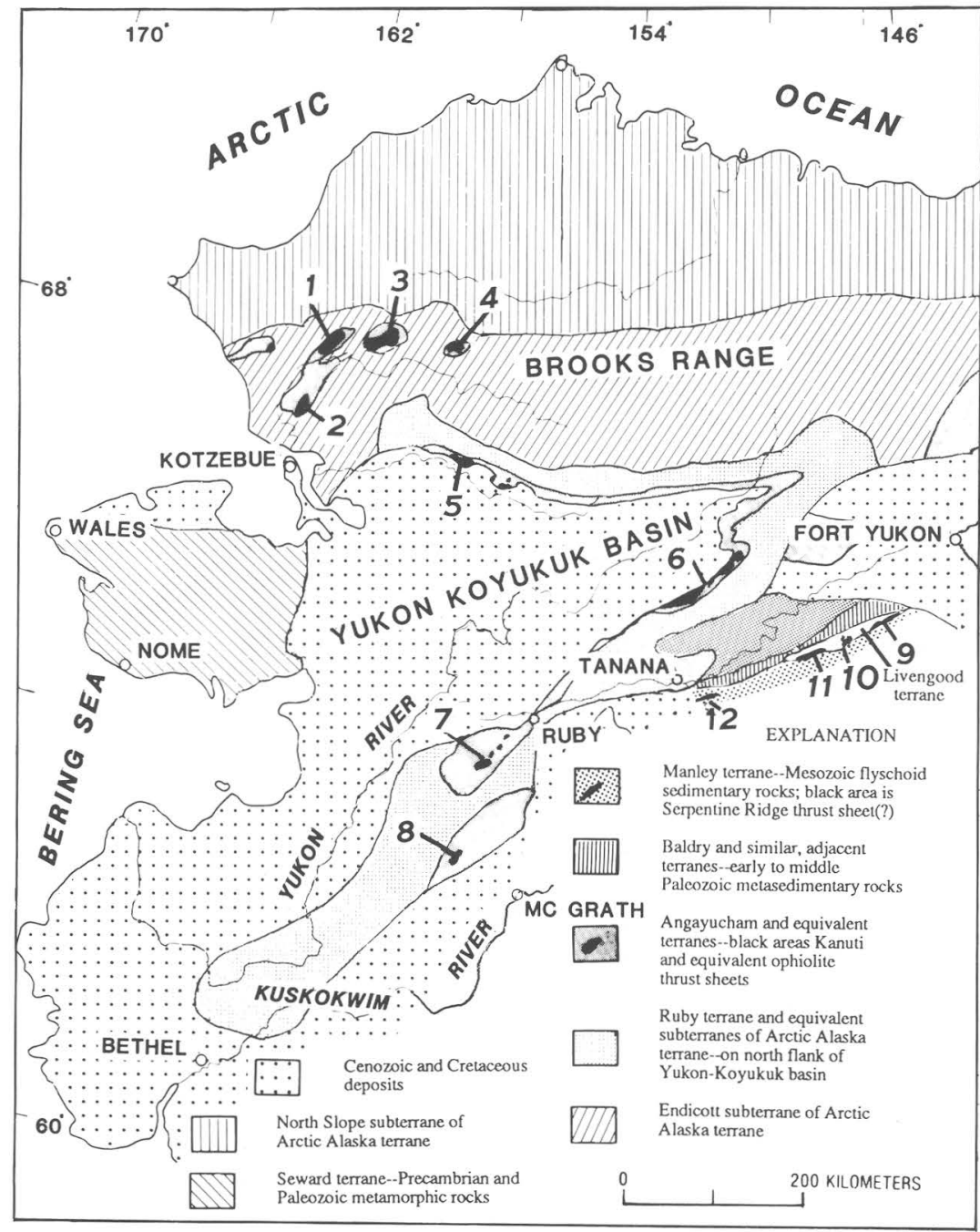

Figure 1. Livengood terrane and ultramafic rocks (10) relative to other major ophiolites and lithotectonic terranes of Alaska (adapted from Patton and others, 1977; and Jones and others, 1987). 1, Avan Hills; 2, Asik Mountain; 3, Misheguk; 4, Siniktanneyak; 5, Jade Mountains; 6, Kanuti; 7, Yuki River; 8, Mount Hurst; 9. Beaver Creek; 10, Livengood; 11, Cascadan Ridge; 12, Manley Hot Springs. 


\section{REFERENCES CITED}

Chapman, R.M., Weber, F.R., and Taber, Bond, 1971, Preliminary geologic map of the Livengood quadrangle, Alaska: U.S. Geological Survey Open-File Report 71-66, 2 sheets, scale $1: 250,000$.

Chapman, R.M., Yeend, W.E., Brosge, W.P., and Reiser, H.N., 1982, Reconnaissance geologic map of the Tanana quadrangle, Alaska: U.S. Geological Survey Open-File Report 82-734, 20 p., 1 sheet, scale 1:250,000.

Evans, B. W., Johannes, W., Oterdoom, H., and Trommsdorff, V., 1976, Stability of chrysotile and antigorite in the serpentinite multisystem: Schweizerische Mineralogische Petrographische Mitteilungen, v. 50, p. 481-492.

Foster, R.L., 1966, The petrology and structure of the Amy Dome area, Tolovana mining district, east-central Alaska: Columbia, Missouri, University of Missouri, $227 \mathrm{p}$.

---- 1967, Tectonic inclusions from a serpentinite, east-central Alaska: U.S. Geological Survey Professional Paper 575-D, p. D120-D122.

--1969, Nickeliferous serpentinite near Beaver Creek, east-central Alaska: U.S. Geological Survey Circular 615, p. 2-4.

Jones, D.L., Silberling, N.J., Coney, P.J., and Plafker, George, 1987, Lithotectonic terrane map of Alaska (west of the 141st meridian): U.S. Geological Survey Miscellaneous Field Studies Map MF-1874-A, scale $1: 2,500,000$.

Loney, R.A., and Himmelberg, G.R., 1985, Distribution and character of the peridotite-layered gabbro complex of the southeastern Yukon-Koyukuk ophiolite belt, Alaska, in Bartsch-Winkler, Susan, and Reed, K.M., eds., The United States Geological Survey in Alaska--Accomplishments during 1983: U.S. Geological Survey Circular 945, p. 46-48.

---- The Kanuti ophiolite terrane, Alaska: Journal of Geophysical Research, p. 1-60. [in press]

Mellini, M., Trommsdorff, V., and Compagnoni, R., 1987, Antigorite polysomatism: Behavior during progressive metamorphism: Contributions to Mineralogy and Petrology, v. 97, p. 147-155.

Patton, W.W., Jr., Tailleur, I.L., Brosge, W.P., and Lanphere, M.A., 1977, Preliminary report on the ophiolites of northern and western Alaska, in Coleman, R.G., and Irwin, W.P., eds., North American ophiolites: Oregon Department of Mineral Industries Bulletin 95, p. 51-57.

Weber, F.R., Smith, T.E., Hall, M.H., and Forbes, R.B., 1985, Geologic guide to the Fairbanks-Livengood area, east-central Alaska: Anchorage, Alaska Geological Society, p. 1-44.

Wyllie, P.J., 1967, Alpine type ultramafic associations, I. Introduction, in Wyllie, P.J., ed., Ultramafic and related rocks: New York, John Wiley, p. 135-136.

Reviewers: Willis Nelson and George Plafker

Geologic Studies in Alaska by the U.S. Geological Survey during 1987: John P. Galloway and Thomas D. Hamilton, editors, U.S. Geological Survey Circular 1016. 


\title{
Mineral Resource Assessment for Part of the White Mountains National Recreation Area
}

\author{
By Richard B. McCammon, Thomas D. Light, and C. Dean Rinehart
}

In 1986 and 1987 the U.S. Geological Survey conducted a mineral resource assessment of most (75 percent) of the White Mountains National Recreation Area (NRA) in east-central Alaska for the Bureau of Land Management. Field mapping, geochemical sampling of stream sediments and rocks, and aeromagnetic, gravity, audiomagnetotelluric, and magnetotelluric studies were carried out within this study area (fig. 1). Results of these multidisciplinary studies were integrated and evaluated to define the areas within the NRA that have the best probability for containing undiscovered mineral resources. The purpose of this report is to present a summary of this resource evaluation, and to enumerate the areas within the NRA that have the highest favorability for mineral endowment.

The White Mountains NRA is a part of the Yukon-Tanana Upland, which is primarily a terrane of quartzitic, pelitic, calcareous, and volcaniclastic metasedimentary rocks with some metamorphosed mafic and felsic igneous rocks that has been intruded by Mesozoic and Cenozoic granitic rocks and minor amounts of intermediate and mafic rocks (Chapman and others, 1971). The major faults in the area are thrust faults and strike-slip fault splays of the Tintina fault zone (F.R. Weber, US Geological Survey, written commun.). Historically, the major mineral resource of the area has been placer gold, which has been recovered in the southern part of the White Mountains NRA since about 1910 (Ellsworth and Parker, 1911). For example, approximately $29,000 \mathrm{oz}(900 \mathrm{~kg})$ of gold was recovered from Nome Creek prior to 1948 (U.S. Bureau of Mines, file data), and exploration and mining activity have continued sporadically to the present. The White Mountains as a whole have been prospected over the years for base and precious metals and, most recently, for uranium (Burton, 1981).

Our assessment of the undiscovered mineral resources of the White Mountains NRA is based on the concept of mineral deposit models, which are defined as the set of attributes common to a particular class of mineral deposit. The mineral deposit models used here (with the exception of high-calcium limestone and thorium- and rare-earth element-bearing (REE) veins) have been described by Cox and Singer (1986). We combined the results of our geological, geochemical, and geophysical studies with all information available from previous investigations to identify areas within the White Mountains NRA that are geologically permissive for the occurrence of mineral deposits and that possess attributes similar to existing models. Both positive and negative evidence (the presence and absence of attributes, respectively) were considered in postulating the occurrence of undiscovered deposits with respect to a particular model.

We determined that there is significant evidence for the occurrence of nine mineral deposit types in the portion of the White Mountains NRA that we evaluated (fig. 1 and table 1). The areas favorable for each of these deposit types were individually assessed to determine the undiscovered resources using a method of Drew and others (1986) as adapted to a computer program known informally as MARK3. This program uses Monte Carlo methods to estimate the contained metal content in undiscovered deposits based on estimates of the number of undiscovered deposits for each deposit type. To use MARK3, subjective probabilistic estimates were made of the number of undiscovered deposits for specific deposit types for each of the tracts identified; a separate estimate was made for the probability that no undiscovered deposits exist (table 1). These estimates were then combined with grade-tonnage data (from Cox and Singer, 1986) as input to MARK3, which, in turn, generated estimates of the contained metal in the undiscovered deposits. In those cases where a metal occurs in more than one model, the estimate of the total contained metal was obtained by convolving the probability distributions of the separate contained metal distributions.

We made probabilistic estimates for the occurrence of undiscovered metallic resources in eight tracts, and for high-calcium limestone in one tract (table 1). Our estimates of the undiscovered resources include the estimate of the mean endowment as well as estimated endowment at the 95 th and 5 th percentile confidence levels. The quantity of undiscovered highcalcium limestone was estimated using a volumetric method (Finch and MeCammon, 1987). Our analysis depends on two critical assumptions. First, in order to make use of existing grade-tonnage data, we assume that future discovery of the types of mineral deposits considered in our assessment will be of similar size and grade as those deposits described in the model. Second, our estimates are based on present knowledge about the deposit types and would be modified by improved knowledge of present deposit types and future recognition of new deposit types.

Tracts evaluated as favorable for resource occurrence are outlined in figure 1, and geochemically anomalous areas in the White Mountains NRA, that include these tracts are described by Light and others (this volume). Tract 1 encompasses the silica-rich leucogranite of Cache Mountain and is permissive for 
the occurrence of tin greisen. The granite contains anomalously high tin values, but does not appear to be composed of multiple intrusions. We estimate a 10 percent probability of an undiscovered tin greisen deposit (table 1). Small veins or breccia zones bearing thorium and rare-earth oxides (REO) are associated with syenite in tract 2 . We estimate a 10 percent probability for undiscovered Th/REE vein deposits in this area. Scheelite and base metals in stream sediments suggest the possibility of tungsten skarn deposits in thin carbonate lenses near the Victoria Mountain pluton (tract 3 ), where we estimate a 5 percent probability for the occurrence of undiscovered skarn deposits. Based on the presence of sulfides, proximity to felsic intrusions, and a geologic setting similar to the Keno Hill-Galena Hill area in the Yukon Territory, we estimate a $\mathbf{5 0}$ percent probability for at least one polymetallic vein deposit in tract 5 .

Intrusion of buried Cretaceous or Tertiary granitic plutons inferred from aeromagnetic lows (Cady and Weber, 1983) may have caused hydrothermal remobilization of gold to form gold-bearing veins and stringers in tract 6 (Light and others, 1987). We estimate a 10 percent probability of one or more lode

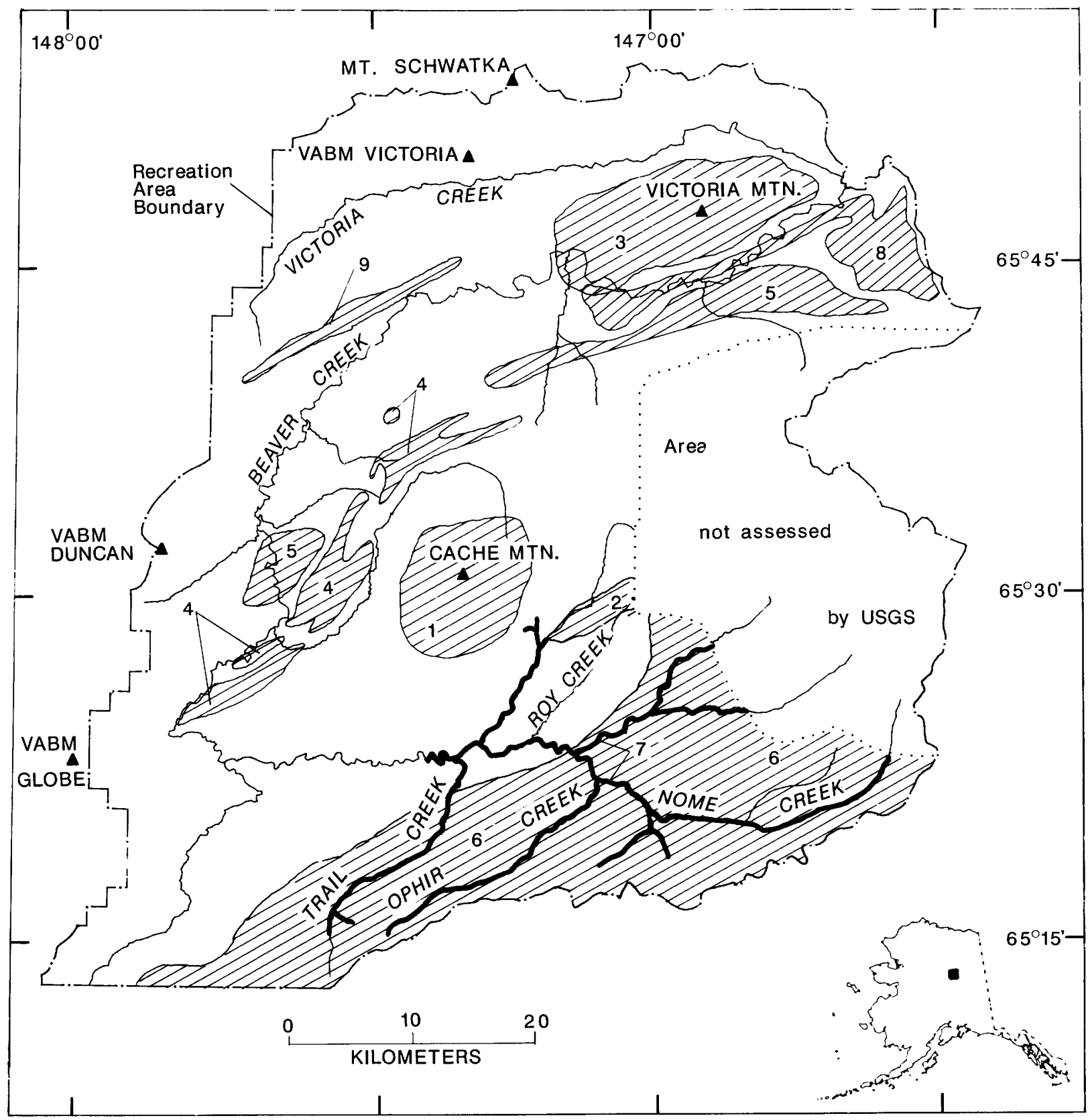

Figure 1. White Mountains National Recreation Area showing tracts with potential for undiscovered mineral resources (indicated by pattern and heavy-line drainage). Part of NRA indicated as "not assessed by USGS" was assessed by Alaska Division of Geological and Geophysical Surveys. Numbers refer to table 1. VABM, Vertical Angle Bench Mark. 
Table 1. Probabilistic estimates for resource endowment, White Mountains NRA

$[(1)$, probability that one or more deposits exist; (2), given the existence of undiscovered deposits, the number of deposits will equal or exceed the indicated number at the $0.9,0.5$, or 0.1 probability level]

\begin{tabular}{|c|c|c|c|c|c|}
\hline Tract & Deposit model & Probability(l) & $\frac{\text { Expect }}{0.9}$ & $\frac{\operatorname{ted}}{0.5}$ & $\frac{\text { number }(2)}{0.1}$ \\
\hline 1 & Sn greisen & 0.1 & 1 & 1 & 1 \\
\hline 2 & Th/REE veins & .1 & 1 & 1 & 1 \\
\hline 3 & W skarn & .05 & 1 & 1 & 1 \\
\hline 4 & High-calcium limestone & 1.0 & - Not & \multicolumn{2}{|c|}{ applicable- } \\
\hline 5 & Polymetallic vein & .5 & 1 & 1 & 2 \\
\hline 5 & Lode Au & .1 & 1 & 1 & 2 \\
\hline 7 & Placer Au & .5 & 1 & 2 & 3 \\
\hline 8 & Sedimentary exhalative ( $\mathrm{Zn}, \mathrm{Pb})$ & .1 & 1 & 1 & 1 \\
\hline 9 & $\begin{array}{l}\text { Serpentine-hosted asbestos/ } \\
\text { stratiform mafic-ultramafic }\end{array}$ & 0 & O & & \\
\hline
\end{tabular}

Table 2. Estimates of undiscovered mineral resources in the White Mountains NRA

[Gold and silver in troy ounces, all other values in short tons $(1$ ton $=909 \mathrm{~kg}$ ). "Probability," probability of endowment at the given confidence level. Estimate for gold at the 95th percentile confidence level based on regression model described by Bliss and others (1987)]

\begin{tabular}{|c|c|c|c|c|c|}
\hline \multirow[t]{2}{*}{ Commodity } & \multirow{2}{*}{$\begin{array}{c}\text { Mean undiscovered } \\
\text { endowment }\end{array}$} & \multicolumn{4}{|c|}{ Probability } \\
\hline & & 95 & percent & 5 & percent \\
\hline Gold & 46,000 & & 6,500 & & 94,000 \\
\hline Silver & $4,200,000$ & & 0 & 14, & 000,000 \\
\hline Zinc & 310,000 & & 0 & 1, & 200,000 \\
\hline Lead & 180,000 & & 0 & & 520,000 \\
\hline Tin & 500 & & 0 & & 1,100 \\
\hline Tungsten & 2,100 & & 0 & & 0 \\
\hline Thorium & 7,000 & & 0 & & 25,000 \\
\hline REO & 6,000 & & 0 & & 32,000 \\
\hline \multicolumn{6}{|l|}{ High-calcium } \\
\hline Iimestone & 27 billion & & 8.4 billion & 45 & billion \\
\hline
\end{tabular}

gold deposits within this area. We estimate a 50 percent probability that one or two placer gold deposits (and a 10 percent probability of three or more placer deposits) remain along Nome, Trail, and Ophir Creeks (tract 7). Tract 8 contains sulfides in tuffaceous rocks, dark argillite, and conglomerate in a geologic setting similar to the Selwyn Basin, Yukon Territory; we estimate a 10 percent probability for at least one sedimentary-exhalative $\mathrm{Pb}-\mathrm{Zn}$ deposit in this tract. Tract 9 encompases a mafic and ultramafic complex that is a permissive environment for serpentine-hosted asbestos or stratiform chromite deposits. However, the complex is relatively thin and has been well explored, and we do not consider it to be a potential resource for asbestos, chromium, or nickel.

The largest potential resource within our study area is high-calcium limestone, which is generally defined as having a minimum of 93 percent $\mathrm{CaCO}_{3}$. Ten grab samples taken from the Tolovana Limestone, which composes the core of the White Mountains (tract 4), averaged 98.6 percent $\mathrm{CaCO}_{3}$. These 10 samples contain a higher average percentage of carbonate than
99 percent of 2,829 high-calcium limestones from Alaska, Idaho, Oregon, and Washington that have been analyzed by Hill and others (1972). Based on a volumetric method of Finch and McCammon (1987), we estimate that 27 billion tons may be present within the White Mountains NRA, but a comprehensive sampling program would need to be undertaken to determine more accurately the extent and thickness of the highcalcium layers within the Tolovana Limestone and to refine our preliminary estimate.

With the exception of gold and high-calcium limestone, the probability that undiscovered resources exist within the White Mountains NRA is considered to be low (table 1), and the size of the deposits that might exist is considered to be small. Therefore, our estimate of commodity endowment at the 95 percent confidence level is zero for all commodities except gold and high-calcium limestone (table 2). Gold is an exception because of its known occurrence within placer deposits in the White Mountains NRA and the virtual certainty that additional placer resources are present. 


\section{REFERENCES CITED}

Bliss, J.D., Orris, G.J., and Menzie, W.D., 1987, Changes in grade, volume, and contained gold during the mining life-cycle of gold placer deposits: Canadian Institute of Mining, v. 80, no. 903, p. 75-80.

Burton, P.J., 1981, Radioactive mineral occurrences, Mt. Prindle area, Yukon-Tanana Uplands, Alaska: Fairbanks, University of Alaska, M.S. thesis, 72 p.

Cady, J.W., and Weber, F.R., 1983, Aeromagnetic map and interpretation of magnetic and gravity data, Circle quadrangle, Alaska: U.S. Geological Survey Open-File Report 83$170-\mathrm{C}$, scale $1: 250,000$.

Chapman, R.M., Weber, F.R., and Tabor, Bond, 1971, Preliminary geologic map of the Livengood quadrangle: U.S. Geological Survey Open-File Report 71-66, scale $1: 250,000$.

Cox, D.P., and Singer, D.A., 1986, Mineral deposit models: U.S. Geological Survey Bulletin 1693, 379 p.

Drew, L.J., B1 iss, J.D., Bowen, R.W., Bridges, N.J, Cox, D.P., DeYoung, J.H., Jr., Houghton, J.C., Ludington, S., Menzie, W.D., Page, N.J, Root, D.H., and Singer, D.A., 1986, Quantitative estimation of undiscovered mineral resources--A case study of U.S. Forest Service Wilderness Tracts in the Pacific Mountain System: Economic Geology, v. 81, p. 80-88.

El1sworth, C.E., and Parker, G.L., 1911, Placer mining in the Yukon-Tanana region: U.S. Geological Survey Bullet in 480, p. 153-172.

Finch, W.I., and McCammon, R.B., 1987, Uranium resource assessment by the Geological Survey--Methodology and plan to update the National Resource Base: U.S. Geological Survey Circular 994, 31 p.

Hil1, T.P., and Werner, M.A., 1972, Chemical composition of sedimentary rocks in Alaska, Idaho, Oregon, and Washington: U.S. Geological Survey Professional Paper 771, $319 \mathrm{p}$.

Light, T.D., Cady, J.W., Weber, F.R., McCammon R.B., and Rinehart, C.D., 1987, Sources of placer gold in the southern part of the White Mountains Recreation Area, EastCentral Alaska, in Hamilton, T. D., and Galloway, J.P., eds., Geologic studies in Alaska by the U.S. Geological Survey during 1986: U.S. Geological Survey Circular 998, p. 67-69.

Reviewers: J.D. B1iss and W.J. Nokleberg

Geologic Studies in Alaska by the U.S. Geological Survey during 1987: John P. Galloway and Thomas D. Hamilton, editors, U.S. Geological Survey Circular 1016. 


\title{
Stratigraphy, Sedimentology, and Structure of the Wickersham Terrane in the Cache Mountain Area,
} East-Central Alaska

\author{
By Thomas E. Moore and Warren J. Nokleberg
}

The Wickersham terrane is a small terrane of continental affinity that lies between the northern margin of the metamorphosed Yukon-Tanana terrane and the southern limit of the lower grade White Mountains, Manley, and Livengood terranes in central Alaska (fig. 1). The Wickersham terrane is interpreted by Jones and others $(1984,1986,1987)$ to have an unknown or "suspect" origin because of its position outboard, or south of a possible suture bounding the Manley terrane and the North American craton. However, Wheeler and others (1987) and Pessel and others (1987) interpreted the Wickersham terrane as a stratigraphic link between the higher grade terranes to the south and the less metamorphosed terranes to the north in central Alaska. Despite its critical position for tectonic reconstructions of central Alaska, little is known about the sedimentologic and structural character of the Wickersham terrane. During the 1987 field season of the Trans-Alaska Crustal Transect (TACT) geologic studies project, we collected sedimentologic and structural data from the Cache Mountain area (fig. 2) in order to ascertain the stratigraphy and environment of deposition of the Wickersham terrane. Our observations suggest that, at least locally, the Wickersham terrane is a gently southward-dipping homoclinal succession of turbidites with a stratigraphic succession opposite from that previously described.

The Wickersham terrane, originally called the Beaver terrane by Churkin and others (1982), was distinguished by Jones and others (1984) on the basis of its quartz-rich composition and sedimentary character. Geologic mapping by Chapman and others (1971), Smith and Pessel (1987), and F.R. Weber (U.S. Geological Survey, written commum., 1987) shows that the terrane consists of two major units in the vicinity of Cache Mountain. The structurally lower unit consists primarily of gray, maroon, and green slate that contains local units of quartzose sandstone and granule to pebble conglomerate; thinner and less abundant beds of dolomite and dark micritic limestone are also present. The upper unit consists primarily of thick-bedded quartzose sandstone and granule to pebble conglomerate which locally is intercalated with sparse, thinner units of gray or green slate. Sandstone in both units consists dominantly of monocrystalline and polycrystalline quartz with minor feldspar and metamorphic rock fragments (Pessel and others, 1987). Weber and others (1985) informally called these units the "maroon and green slate member" and the "basal grit unit," respectively, of the Wickersham unit and considered them to be overlain by the "Takoma bluff member," which is not exposed in the Cache Mountain area. The thickness of the two lower members is estimated at about $3,000 \mathrm{~m}$ by F.R. Weber (written commun., 1987) and more than $7,000 \mathrm{~m}$ by Pessel and others (1987, fig. 2.8). The contact between the two lower units in the study area was shown as conformable, but overturned, by Chapman and others (1971) and as a thrust fault by F.R. Weber (written commun., 1987) and Smith and Pessel (1987).

Although lacking the pervasive metamorphic minerals and foliation of the Yukon-Tanana terrane, both of the units of the Wickersham terrane display a weak to prominent slaty cleavage in fine-grained rocks and schistosity in coarser grained rocks. Metamorphic minerals are mainly chlorite, white mica, and quartz. The metamorphic fabric is weakly developed and dips southeastward in the northwestern part of the terrane, but appears to generally increase in prominence toward the southeast where it changes orientation to a gentle northward dip. The increasing strain gradient and general similarity of composition led Weber and others (1985) and Pessel and others (1987) to conclude that the Wickersham terrane is the less deformed and metamorphosed sedimentary cover for the YukonTanana terrane which lies to the south. Chapman and

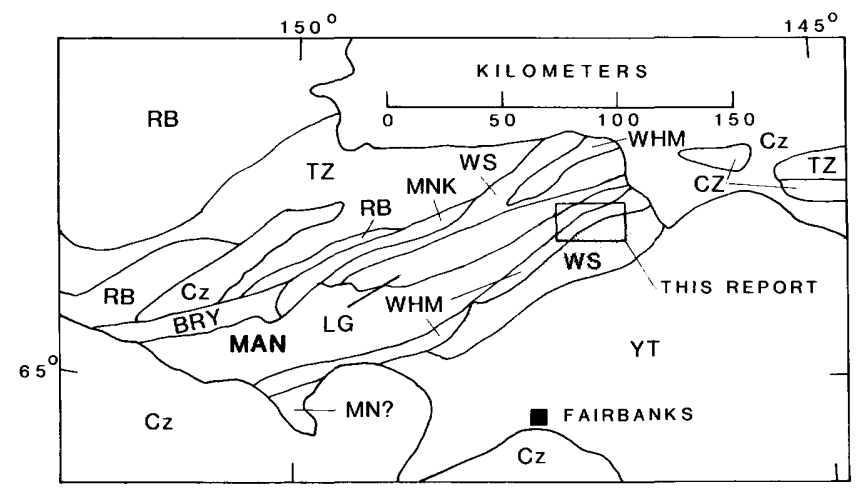

Figure 1. Map showing terranes of east-central Alaska. Abbreviations: RB, Ruby terrane; TZ, Tozitna terrane; BRY, Baldry Mountain terrane; MNK, Minook terrane; WS, Wickersham terrane; WHM, White Mountains terrane; LG, Livengood terrane; MAN, Manley terrane; MN, Minchumina terrane; $C Z$, Crazy Mountains terrane; YT, Yukon-Tanana terrane; $\mathrm{Cz}$, Cenozoic successor basin deposits. 
others (1971), however, showed this contact as a northdipping fault which Churkin and others (1982) postulated to be a major structural break separating the two terranes. Foster and others (1987) also interpret this contact as a fault. The northern margin of the Wickersham terrane is nearly everywhere mapped as a high-angle fault by all workers, though it was interpreted as a faulted unconformity by Pessel and others (1987), Wheeler and others (1987), and F.R. Weber (written commun., 1987).

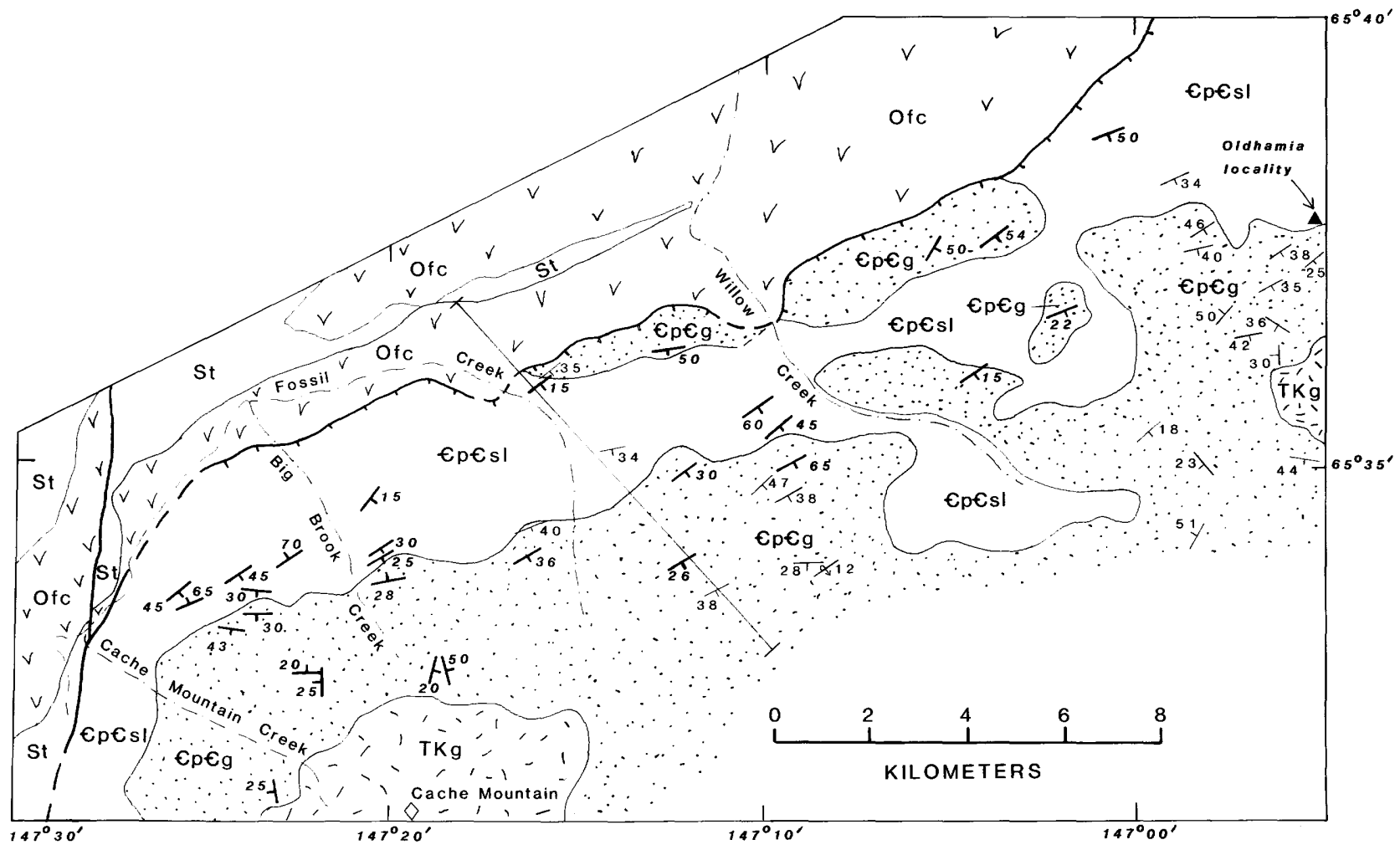

A. NW

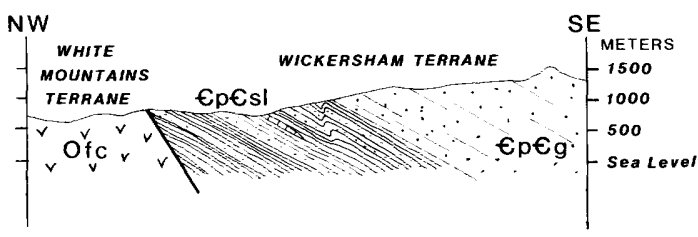

EXPLANATION
B. NW

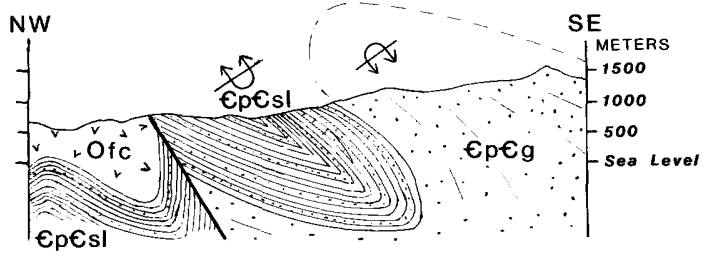

C. NW

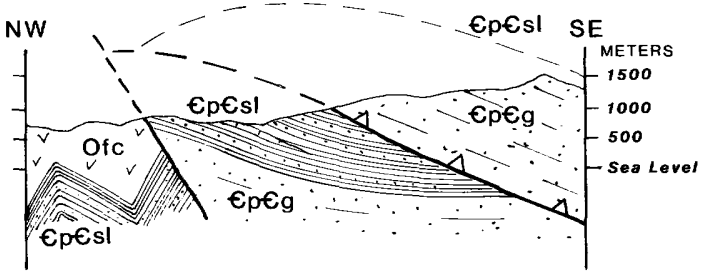

Figure 2. Geologic map of Wickersham terrane in vicinity of Cache Mountain, Livengood C-1 and Circle C-6 quadrangles. Geologic mapping modified from F.R. Weber (U.S. Geological Survey, written commun., 1987) in Livengood C-1 quadrangle and Smith and Pessel (1987) in Circle C-6 quadrangle. Heavy symbols show bedding attitudes from this study; lighter symbols show bedding attitude data compiled from F.R. Weber (written commun., 1987) and Smith and Pessel (1987). Contact between units Ep€sI and $€ p € g$ is interpreted as conformable although shown as a thrust fault by F.R. Weber (written commun., 1987) and Smith and Pessel (1987). G.H. Pessel (written commun., 1987) and Michael Churkin (unpub. field notes and oral commun., 1988) reported overturned bedding not shown in region east of long $147^{\circ}$. Cross sections show three differing interpretations along line of section shown on map; see text for details. 
Because of the regional south-dipping foliation surfaces developed in the northwestern half of the terrane, Chapman and others (1971) hypothesized that strata of the terrane form a southwest-trending, northwesterly vergent, map-scale recumbent fold (fig. 2, cross section B). This structural interpretation suggests that the grit unit, now structurally higher, was emplaced northward over the maroon and green slate unit. The structural model of Chapman and others (1971) concluded that the grit unit is older and occurs at a stratigraphically lower position than the maroon and green slate unit.

The age of the strata of the Wickersham terrane is based on the occurrence of the Early Cambrian or possibly Late Proterozoic trace fossil Oldhamia (Hof mann and Cecile, 1981) near the top of the maroon and green slate unit at the locality shown on figure 2 (Foster and others, 1983). Utilizing the structural model and stratigraphic interpretation of Chapman and others (1971), most workers (for example, Smith and others, 1987) have considered this fossil locality to date strata near the top of the Wickersham terrane, implying that the grit unit is no younger than Early Cambrian and may be Late Proterozoic in age.

In order to better understand the sedimentary history and structure of the Wickersham terrane, we examined this terrane in short traverses at about 20 localities in the vicinity of Cache Mountain (fig. 2). In general, we found that sandstones of both the structurally lower maroon and green slate unit and structurally higher grit unit display Bouma sequences which we interpret as evidence of deposition by turbidity currents. Sedimentary structures observed include graded bedding, erosional bases, ripup clasts, parallel lamination, ripple cross lamination and possible sole markings including load casts. In many locations, cleavage and schistosity surfaces are parallel or acutely oblique to sedimentary bedding and tend to obscure sedimentary structures, particularly in the finer grained rocks. These features confirm the interpretation of Pessel and others (1987) and F.R. Weber (written commun., 1987) that the succession consists largely of turbidites and allows description of the strata by the classification system of Mutti and Ricci Lucchi (1978).

The maroon and green slate unit consists mainly of slaty and phyllitic siltstone, shale, and sandstone, locally displays distinctive maroon and green coloration, but is generally gray. A dark-gray micritic limestone, about $3 \mathrm{~m}$ thick, and thin diabase dikes were observed at two localities. The sandstone-toshale ratio of the unit is low, probably on the order of $1: 100$, but this is difficult to estimate because of poor outcrop. Locally, however, sandstone-to-shale ratios are as high as $2: 1$. These sandstone-rich intervals are as thick as $3 \mathrm{~m}$ and contain fine- to coarse-grained sandstone in graded beds 5 to $20 \mathrm{~cm}$ thick. Where examined, these sandstone beds display abbreviated Bouma sequences that appear to be laterally continuous (facies D) although similar, but laterally discontinuous beds (facies $E$ ) were observed at one location. At another location, the sandstone intervals appeared to be organized into multiple 3-m-thick thinning- and fining-upward sequences.

The structurally higher grit unit consists largely of thick packages (greater than $5 \mathrm{~m}$ ) of sandstone and has an overall sandstone-to-shale ratio greater than 10. The sandstone intervals generally are medium to coarse grained, but commonly include granule to fine-

\section{A. Maroon and green slate unit}

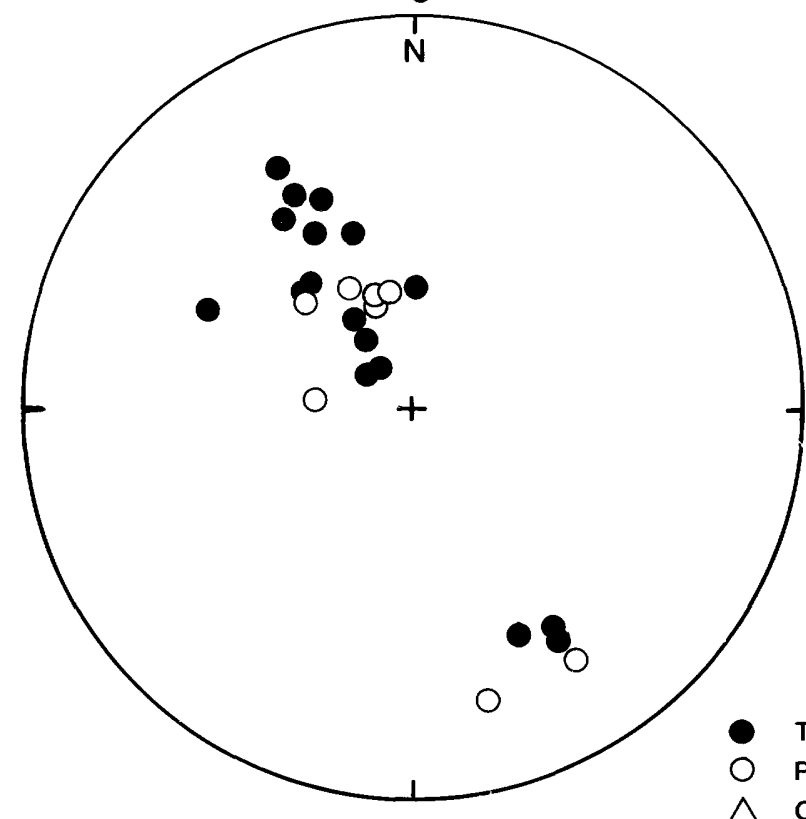

B. Grit unit

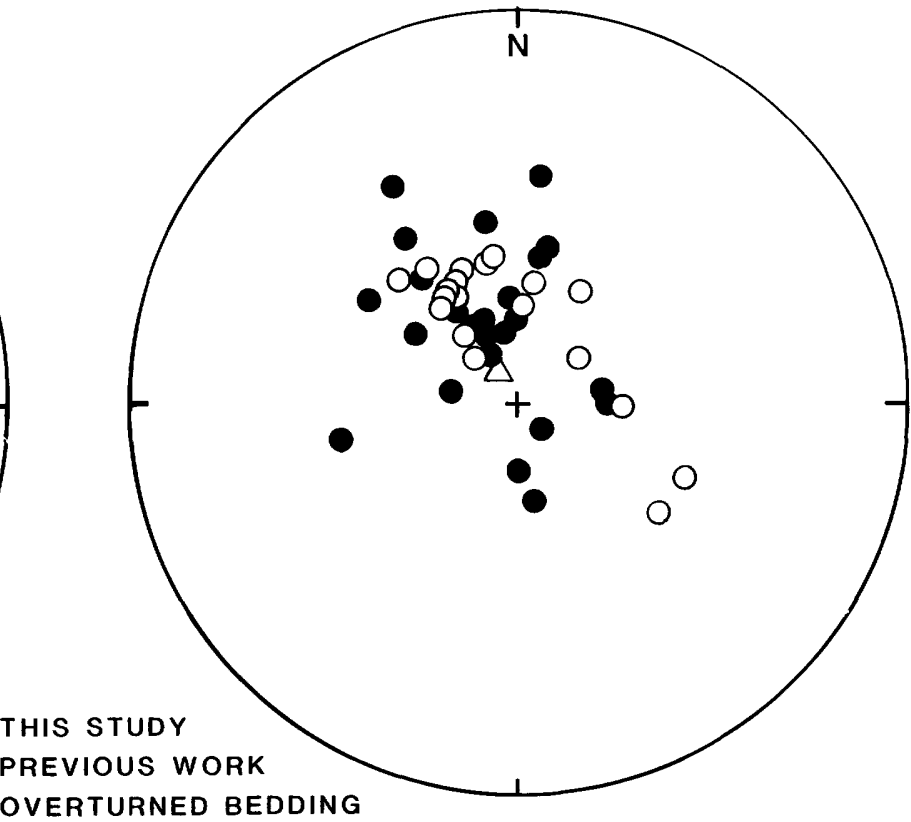

Figure 3. Lower hemisphere stereogram projections showing poles to bedding for rocks of maroon and green slate unit (A) and the grit unit (B) of the Wickersham terrane. Data from Smith and Pessel (1987), F.R. Weber (written commun., 1987), and this study. Some of the data reported by Smith and Pessel (1987) are now considered to be possibly overturned by G.H. Pessel (oral commun., 1988). 
pebble conglomerate. Some of these units have channelized basal contacts, but most do not display internal sedimentary structures and instead appear massive throughout. In one location, thin discontinuous siltstone laminae were observed within a thick sandstone package, suggesting that most of the sandstone-conglomerate packages consist of amalgamated sandstone beds (facies A and B). Finer grained intervals, 3 to $25 \mathrm{~m}$ thick, separate the sandstone-conglomerate packages. The finer grained intervals have sandstone-to-shale ratios of $3: 1$ to $1: 1$ and consist of interbedded fine to medium-grained sandstone and slaty siltstone and shale. The sandstone beds are 10 to $100 \mathrm{~m}$ thick and commonly display complete to incomplete Bouma sequences and erosional bases (facies $C$ and $D$ ). Some thin ripple cross laminated sandstone beds appear to be laterally discontinous, suggesting the presence of facies $E$ turbidites within these intervals.

The contact between the structurally lower maroon and green slate unit and the overlying coarser grained grit unit is generally easily identified and mapped. We examined this contact in several places, and found it to be generally conformable and gradational. North of Cache Mountain, an interval of facies $A$ and $B$ turbidites 10 to $20 \mathrm{~m}$ thick occurs within maroon and green slate and phyllite about $50 \mathrm{~m}$ below the mapped contact. This sandstone interval appears to thin upward toward the slate below the contact. Likewise, east of Willow Creek and near the northern margin of the Wickersham terrane, part of the grit unit is mapped as outliers in the maroon and green slate unit. The sandstone units at this location dip moderately to the southeast and compose welldeveloped megasequences $10 \mathrm{~m}$ thick that thin and fine upward. These sandstone intervals are separated by apparently conformable gray, green, and maroon slaty intervals of somewhat greater thickness. Where examined, the sandstone intervals displayed sharp, erosional conglomeratic bases of facies $A$ and $B$ turbidites which succeeded upward into facies C, D, and $\mathrm{E}$ turbidites. Ripple cross lamination at the top of the sequence suggests paleotransport generally toward the southeast. On the basis of existing mapping and our observations, it appears that these sandstone units are laterally discontinuous over distances of 1 to $5 \mathrm{~km}$ and are encased by fine-grained strata of the maroon and green slate unit.

Bedding attitude data at 26 locations where sedimentary structures such as graded bedding, erosional basal contacts, and ripple cross lamination allowed identification of sedimentary facing directions, are plotted in figure 3 along with comparable data reported by Smith and Pessel (1987) and F.R. Weber (written commun., 1987) for the Wickersham terrane. These data are internally consistent and show that strata from both units of the Wickersham terrane have an average strike and dip of about N. $55^{\circ}$ E. and $30^{\circ} \mathrm{SE}$, respectively. A few bedding attitudes from the Wickersham grit and
A.

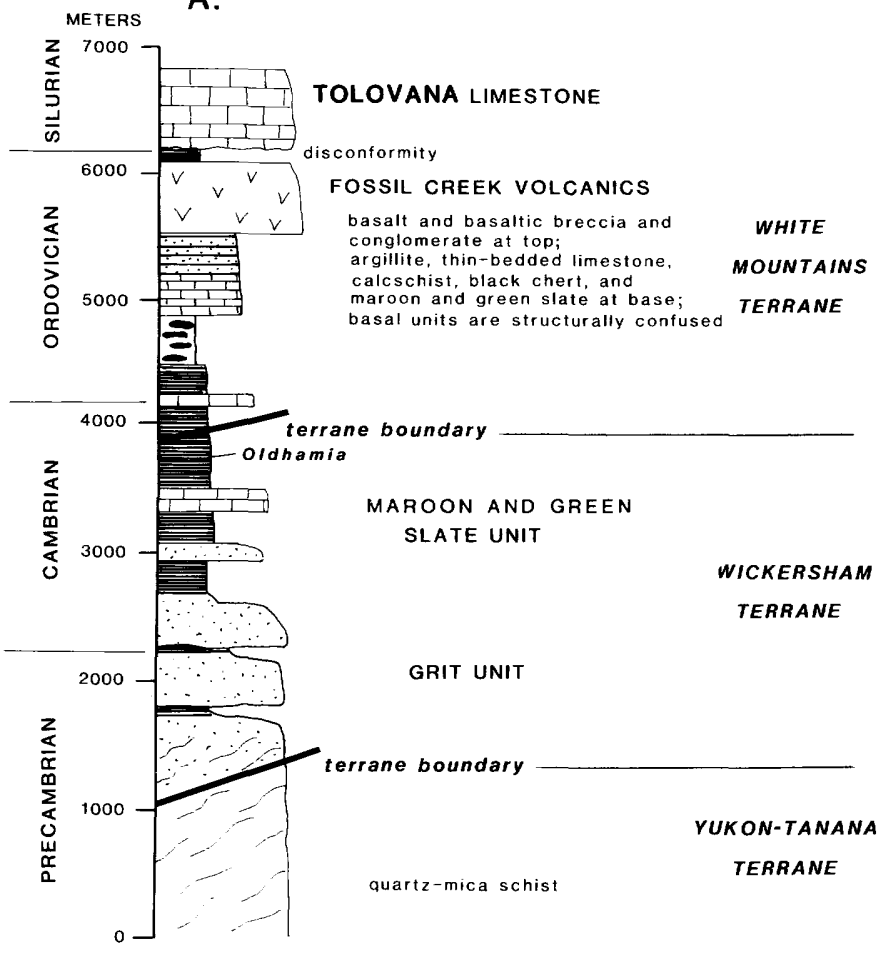

B.

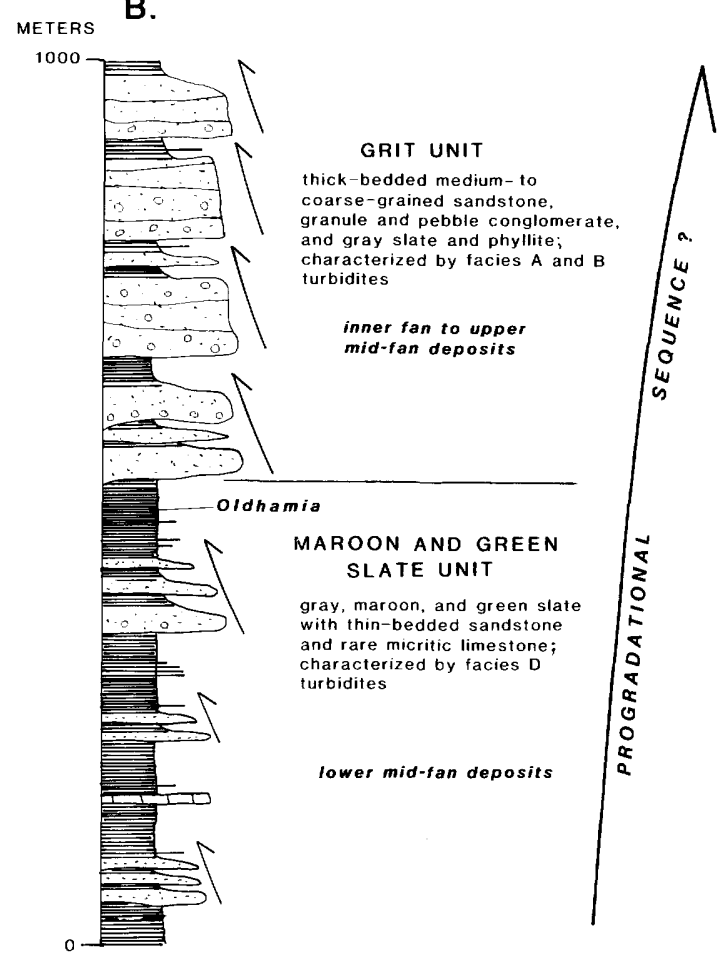

Figure 4. Schematic stratigraphic columns. A, Reconstructed stratigraphy for east-central Alaska preferred by Pessel and others (1987) and F.R. Weber (written commun., 1987) showing stratigraphic relationships between Yukon-Tanana, Wickersham, and White Mountains terranes. Diagram also shows possible stratigraphic position of terrane boundaries mapped by Jones and others (1984); B, Column summarizing our stratigraphic and sedimentologic interpretations in Cache Mountain area. Arrows pointing up and to left indicate sandstone thinning- and finingupward megasequences commonly considered indicative of midfan turbidite deposition. 
maroon and green slate units, however, appear to cluster about average orientations of N. $35^{\circ} \mathrm{E}$. and $25^{\circ}$ $\mathrm{NW}$ and $\mathrm{N} .60^{\circ}$ E. and $75^{\circ} \mathrm{NW}$, respectively, but our field observations indicate that most of these data represent the short limbs of upright folds. The northwestward dips may be variable because of the contrast in thickness and competence of the bedding involved in the two units. Also, inspection of the maps of other workers suggests that some steep northwesterly dips are associated with the major fault bounding the northern margin of the Wickersham terrane, whereas others are located adjacent to the Late Cretaceous or early Tertiary granitic plutons that intrude the terrane. We found neither overturned bedding nor any bedding with dips steeper than $70^{\circ}$, although F.R. Weber (written commun., 1987) showed one overturned bed with a southeasterly dip of $12^{\circ}$ northwest of Cache Mountain in the grit unit. In view of our data, we believe that the overturned facing direction determined in the Cache Mountain area must be viewed as local rather than regional in extent. Nearly all of the data shown in figure 3 were collected along the axis of the large recumbent fold shown in the cross section of Chapman and others (1971) (fig. 2, cross section $B$ ). Because such a fold would require steep and overturned bedding, these data appear to argue against a recumbent fold structural interpretation.

Taken together, the presence of mostly upright facing directions, apparently conformable bedding attitudes in both units, and presence of a gradational contact between the maroon and green slate unit and the grit unit suggest that the Wickersham terrane in the Cache Mountain area consists of a southeastdipping homoclinal succession of turbiditic strata (fig. 2 , cross section A). Furthermore, these data indicate that the structurally lower maroon and green slate unit should be interpreted as lying conformably beneath the coarser grained grit unit in this area (fig. 4B). If representative of the enire terrane, this stratigraphic interpretation would conflict with that reported by Chapman and others (1971), Weber and others (1985), Smith and Pessel (1987) and Pessel and others (1987). Our sedimentologic and stratigraphic data suggest that the strata of the Wickersham terrane in the Cache Mountain area comprise a quartz-rich, upwardcoarsening submarine-fan complex that prograded into a basin on, or adjacent to, a continent during Cambrian time (fig. 4B). Pessel and others (1987) concluded independently that the Wickersham terrane east of the area was deposited in a submarine-fan system.

Although the contact between the maroon and green slate unit and the grit unit is locally tectonized or faulted, and dip reversals are locally present along the contact, we found no evidence of a regional fault contact between the units as mapped by Smith and Pessel (1987) and F.R. Weber (written commun., 1987). However, this contact is commonly concealed, and it may be permissable to interpret the contact as a bedding-plane thrust fault. If such a fault exists, it may have small displacement, assuming the stratigraphy proposed above. In contrast, the stratigraphic interpretation of Weber and others (1985) and Smith and Pessel (1987) would require substantial displacement across the hypothetical bedding plane fault in the Cache Mountain area. Cross section C (fig. 2) shows a structural model interpreting this contact as a large-scale duplex that is compatible with their stratigraphy and the bedding facing direction data repoted here. This model predicts the presence of the grit unit at depth beneath the maroon and green slate unit and hangingwall and footwall cutoffs and other features of fold-thrust belts, none of which have been observed by us in the Cache Mountain area. Additionally, this model would require a decollement at depth, either within the grit unit or perhaps at the contact between the Wickersham and Yukon-Tanana terranes. Although not shown by Smith and Pessel (1987), Michael Churkin (unpub. field notes and personal commun., 1988) and G.H. Pessel (written commun., 1988) report overturned beds and isoclinal folds east of the Cache Mountain area (east of long. $147^{\circ}$ on fig. 2). These features may be evidence for a higher degree of strain and a different deformational style in the Wickersham terrane east of our study area. Alternatively, the grit unit may be viewed as one or more depositional wedges of relatively proximal coarser grained clastic strata that interfinger with and are encased by the finer grained and relatively more basinal strata of the maroon and green unit. G.H. Pessel (written commun., 1988) reports that the sandstone-to-shale ratio in the grit unit east of our study area is substantially lower than we have found for that unit, suggesting that lateral as well as vertical facies changes exist within the terrane. Large-scale interfingering of the units is consistent with the variable stratigraphic relationships between the two mapped units discussed here but may not require faults of significant displacement within the study area. Pell and Simony (1987) recently described a similar stratigraphic interpretation for the grit and finer grained units of the Windermere Supergroup in British Columbia with which the strata of the Wickersham terrane are commonly correlated (for example, Tempelman-Kluitt, 1984; Weber and others, 1985).

\section{REFERENCES CITED}

Chapman, R.M., Weber, F.R., and Tabor, Bond, 1971, Preliminary geologic map of the Livengood quadrangle, Alaska: U.S. Geological Survey Open-File Report 483, 2 sheets, scale 1:250,000.

Churkin, Michael, Jr., Foster, H.L., Chapman, R.M., and Weber, F.R., 1982, Terranes and suture zones in east central Alaska: Journal of Geophysical Research, v. 87, p. 3718-3730.

Foster, H.L., Laird, Jo, Keith, T.E.C., Cushing, G.W., and Menzie, W.D., 1983, Preliminary geologic map of the Circle quadrangle, Alaska: U.S. Geological Survey Open-File Report 83-170A, scale 1:250,000.

Foster, H.L., Keith, T.E.C., and Menzie, W.D., 1987, Geology of east-central Alaska: U.S. Geological Survey Open-File Report 87-188, $59 \mathrm{p}$.

Hofmann, H.J. and Cecile, M.P., 1981, Occurrence of Oldhamia and other trace fossils in lower Cambrian (?) argillites, Niddery Lake map area, Selwyn Mountains, Yukon Territory: 
Geological Survey Canada Paper 81-1A, p. 281-290.

Jones, D.L., Silberling, N.J., and Coney, P.J., 1986, Collision tectonics in the cordillera of western North America: Examples from Alaska, in Coward, M.P., and Ries, A.C., eds., Collision tectonics: Geological Society of London, Special Publication 19, p. 367-387.

Jones, D.L., Silberling, N.J., Coney, P.J., and Plafker, George, 1984, Lithotectonic terrane maps of the North American Cordillera, Part A--Lithotectonic terrane map of Alaska, sheet 1 of 4: U.S. Geological Survey OpenFile Report 84-523, scale $1: 2,500,000$.

Jones, D.L., Silberling, N.J., Coney, P.J., and Plafker, George, 1987, Lithotectonic terrance map of Alaska (West of the $41 \mathrm{st}$ Meridian): U.S. Geological Survey Miscellaneous Field Studies Map MF-1874-A, scale $1: 2,500,000$.

Mutti, Emiliani, and Ricci Lucchi, Franco, 1978, Turbidites of the Northern Apennines: Introduction to facies analysis: International Geology Review, v. 20, p. 125166.

Pell, J., and Simony, P.S., 1987, New correlations of Hadrynian strata, southcentral British Columbia: Canadian Journal of Earth Sciences, v. 24, p. 302-313.

Pessel, G.H., Reifenstuhl, R.R., and Albanese, M.D., 1987, Regional geology, in Smith, T.E., Pessel, G.H., and Wiltse, M.A., eds., Mineral assessment of the Lime Peak-Mt Prindle area, Alaska: Fairbanks, Alaska
Department of Natural Resources, Division of Geological and Geophysical Surveys, p. 2-1 to $2-26$.

Smith, T.E., and Pessel, G.H., 1987, Bedrock geologic map of the Lime Peak-Mt. Prindle area, east-central Alaska: Alaska Division of Geological and Geophysical Surveys, Report of Investigations 87-4, plate 2-1A, scale $1: 63,360$.

Tempelman-Kluitt, Dirk, 1984, Counterparts of Alaska's terranes in Yukon, in Symposium of Cordilleran geology and mineral exploration; Status and future trends: Vancouver, Geological Association of Carada. p. 41-44.

Weber, F.R., Smith, T.E., Hall, M.H., and Forbes, R.B., 1985, Geologic guide to the Fairbanks-Livengood area, east-central Alaska: Anchorage, Alaska Geological Society, 44 p.

Wheeler, K.L., Forbes, R.B., Weber, F.R., and Rinehart, C.D., 1987, Lithostratigraphy, petrology, and geochemistry of the Ordovician Fossil Creek Volcanics, White Mountains, east-central Alaska, in Hamilton, T.D., and Galloway, J.P., eds., Geologic studies in Alaska by the U.S. Geological Survey during 1986: U.S. Geological Survey Circular 998, p. 70-73.

Reviewers: H.L. Foster and R.M. Chapman

Geologic Studies in Alaska by the U.S. Geological Survey during 1987: John P. Galloway and Thomas D. Hamilton, editors, U.S. Geological Survey Circular 1016. 


\title{
Gold Mineralization by Metamorphic Fluids in the Chandalar District, Southern Brooks Range- Fluid Inclusion and Oxygen-Isotopic Evidence
}

\author{
By Scott C. Rose, William J. Pickthorn, and Richard J. Goldfarb
}

The Chandalar mining district is located $320 \mathrm{~km}$ north of Fairbanks in the southern Brooks Range (fig. 1). The four gold-quartz lodes examined in this study (Mikado, Summit, Envelope, Little Squaw) have seen limited production, but placers in drainages surrounding the lode deposits have produced more than 40,000 oz $(1,244 \mathrm{~kg})$ of gold (Heiner and Wolff, 1968). Bedrock in the district consists of pelitic schist of Devonian age that is locally intruded by Devonian (?) dikes and sills of mafic to intermediate composition (Chipp, 1970). These rocks were subjected to two periods of upper greenschist-facies metamorphism during the Cretaceous; northeast-vergent thrust faulting accompanied the second metamorphic event (Chipp, 1970; Dillon, 1982).

The gold-quartz lodes are localized in subparallel high-angle shear zones that trend N. $60^{\circ}$ W. These features cut across metamorphic fabric and were clearly emplaced within the metasediments after peak metamorphism. Veins consist of both high-grade ribbon quartz, and low-grade to barren milky quartz. Vein mineralogy is consistent within all lodes. Quartz is the dominant gangue mineral with minor carbonate; the most abundant sulfide minerals are arsenopyrite, galena, stibnite, pyrite, pyrrhotite, and sphalerite. Gold replaces galena, sphalerite, and arsenopyrite and also occurs as isolated grains in quartz.

We conducted fluid inclusion and oxygen-isotope studies to determine the physical and chemical nature of the fluids responsible for ore genesis. Fluid inclusion data can provide important constraints on the pressure, temperature, and composition of ore fluids, and oxygen-isotope data can help identify the source and exchange history of these ore fluids.

A previous fluid inclusion study of some of these deposits (Ashworth, 1983) identified variable gas-to-liquid ratios in fluid inclusions and concluded that boiling of ore fluids led to gold deposition. Our study has also identified variable gas-to-liquid ratios in similar samples. We interpret these as secondary inclusions formed by necking down (Roedder, 1984) of former primary inclusions. We see no evidence for trapping of immiscible fluids or boiling. Ore-stage quartz is often a banded, ribbon-type quartz that forms by repeated episodes of dilation, quartz precipitation, and subsequent shearing. This repeated shearing results in numerous zones of necked, secondary inclusions. The common spatial association between gold grains and ribbons of wallrock suggests that chemical reactions between the ore fluids and the wallrocks may have played a role in destabilizing goldbisulfide complexes.

Primary and (or) pseudosecondary fluid inclusions found in unstrained quartz from the four lode deposits were chosen for microthermometric study (fig. 2). They range from less than 5 micrometers to greater than 70 micrometers in maximum dimension. Only one type of primary fluid inclusion has been identified in both the high-grade ribbon quartz and the low-grade milky quartz. These fluid inclusions generally contain three phases at room temperature; $\mathrm{CO}_{2}$ vapor, $\mathrm{CO}_{2}$ liquid, and water. Some inclusions have only two phases at room temperature, $\mathrm{CO}_{2}$ liquid, and water liquid, but generate a $\mathrm{CO}_{2}$ vapor phase upon cooling a few degrees. The inclusions have consistent $\mathrm{CO}_{2}: \mathrm{H}_{2} \mathrm{O}$ volume ratios of 0.30 to 0.35 . Similar relationships were observed in a limited number of fluid inclusions in sphalerite from the Mikado mine. The small range in clathrate melting temperatures and $\mathrm{CO}_{2}$ homogenization temperatures along with the consistent gas-to-liquid ratios for all the lodes indicate trapping of a one-phase fluid under similar pressures and temperatures. There is no evidence of fluid immiscibility or boiling in these samples.

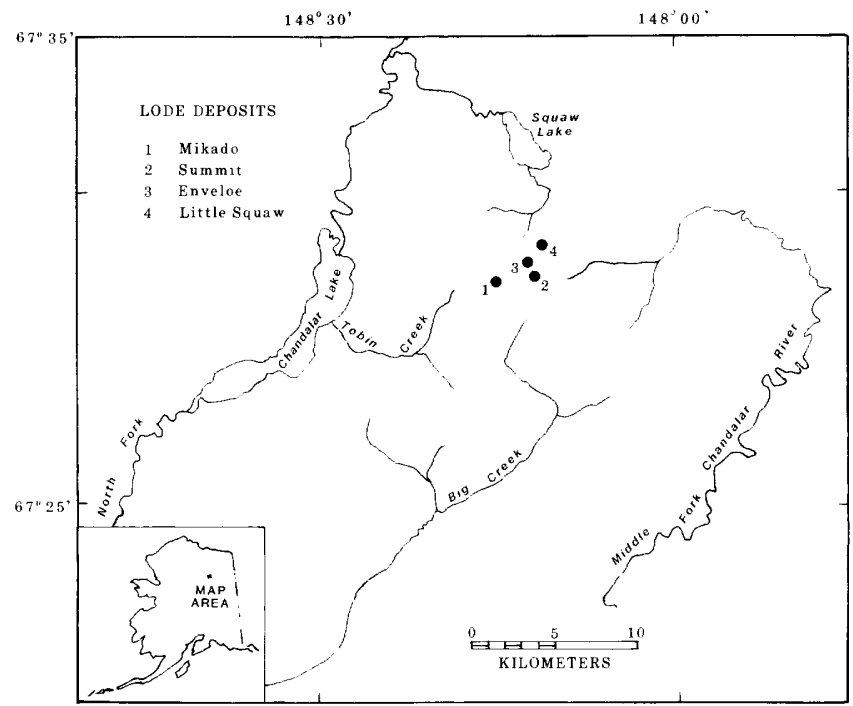

Figure 1. Location of the lode-gold mines examined in the Chandalar district. 
Melting of solid $\mathrm{CO}_{2}$ ranges from the triple point for pure $\mathrm{CO}_{2}$ of $-56.6{ }^{2} \mathrm{C}$ to $-58.2{ }^{\circ} \mathrm{C}$ (fig. $2 \mathrm{~A}$ ). Depression of the melting temperature below $-56.6{ }^{\circ} \mathrm{C}$ is evidence of minor amounts of $\mathrm{CH}_{4}$ and (or) $\mathrm{N}_{2}$ in the gas phase (Roedder, 1984). Clathrate melting temperatures ranged from $8.4{ }^{\circ} \mathrm{C}$ to $10.8{ }^{\circ} \mathrm{C}$ (fig. 2B) for all studied inclusions. The melting temperatures above $10.0{ }^{\circ} \mathrm{C}$ indicate that a few mole percent $\mathrm{CH}_{4}$ definitely occurs in some inclusions. Depression of the temperature below $10.0^{\circ} \mathrm{C}$ results from the presence of salt and perhaps minor $\mathrm{N}_{2}$ within the fluids. Homogenization of $\mathrm{CO}_{2}$ occurs between $22.8{ }^{\circ} \mathrm{C}$ and $27.6{ }^{\mathrm{C}}$ (fig. 2C), corresponding to densities between 0.79 and $0.76 \mathrm{~g} / \mathrm{cm}^{3}$, respectively. Final homogenization occurred at temperatures between $265{ }^{\circ} \mathrm{C}$ and $300^{\circ} \mathrm{C}$ (fig. 2D), representing minimum estimated temperatures of mineralization.

Using relationships from Swanenburg (1980) and Burruss (1981), the bulk density and composition of the fluid inclusions can be estimated. Inclusions generally contain approximately 86 to 88 mole percent $\mathrm{H}_{2} \mathrm{O}, 12$ to 14 mole percent $\mathrm{CO}_{2}, 0.6-0.7$ mole percent $\mathrm{CH}_{2}$, $<3-3.5$ mole percent $\mathrm{N}_{2}$, and $<3.0$ equivalent weight percent $\mathrm{NaCl}$. These compositions were used to select an appropriate solvus for the fluids, and to select isochores which help constrain the pressuretemperature environment of ore deposition. A minimum trapping pressure of $75 \mathrm{MPa}$ (750 bars) is defined by the final homogenization temperature and the experimentally determined solvus for a 12 to 14 mole percent $\mathrm{CO}_{2}$ fluid (Swanenberg, 1980). Maximum trapping pressures and temperatures of $56 \mathrm{GPa}(5.6$ kbar) and $470{ }^{\circ} \mathrm{C}$ were determined by intersecting the fluid inclusion isochores (Brown and Lamb, 1986) with the albite + epidote $=$ oligoclase line. This reaction boundary defines the upper limit of regional metamorphism in the vicinity of the Chandalar district (Ashworth, 1983). The true trapping pressure must lie on the isochores somewhere between the $\mathrm{CO}_{2}-\mathrm{H}_{2} \mathrm{O}$ solvus and the reaction line.

Seven samples were analyzed in our preliminary oxygen-isotope study (table 1): two high-grade ribbon quartz samples and four barren milky quartz samples from the lode deposits; and one concordant metamorphic segregation quartz sample taken approximately $300 \mathrm{~m}$ from any discordant gold-bearing vein. The $\delta^{18} \mathrm{O}$ values for high-grade and barren quartz from the gold lodes are relatively constant,
COP MELT TEMPERATURE

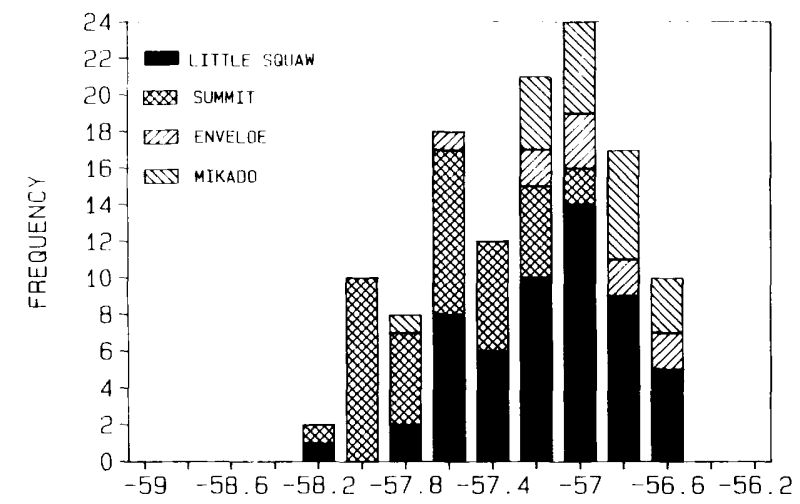

A

TEMPERATURE $\left({ }^{\circ} \mathrm{C}\right)$

\section{CO2 HOMOGENIZATION TEMPERATURE}

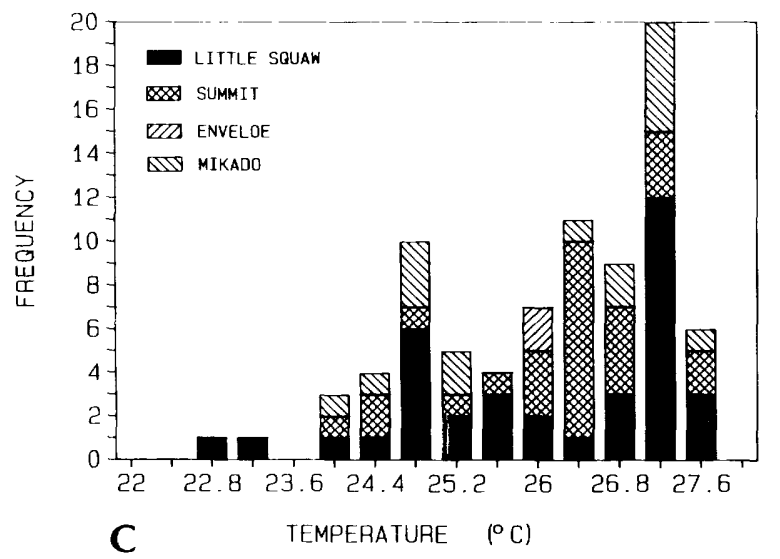

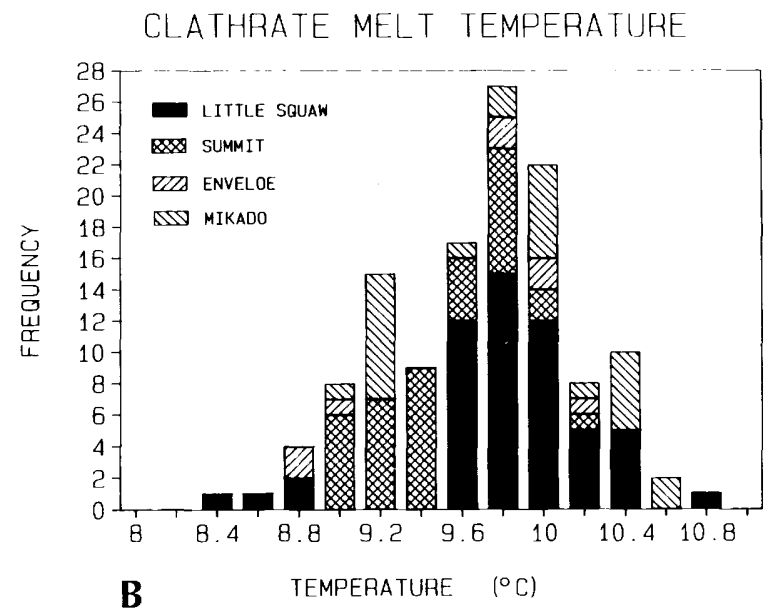

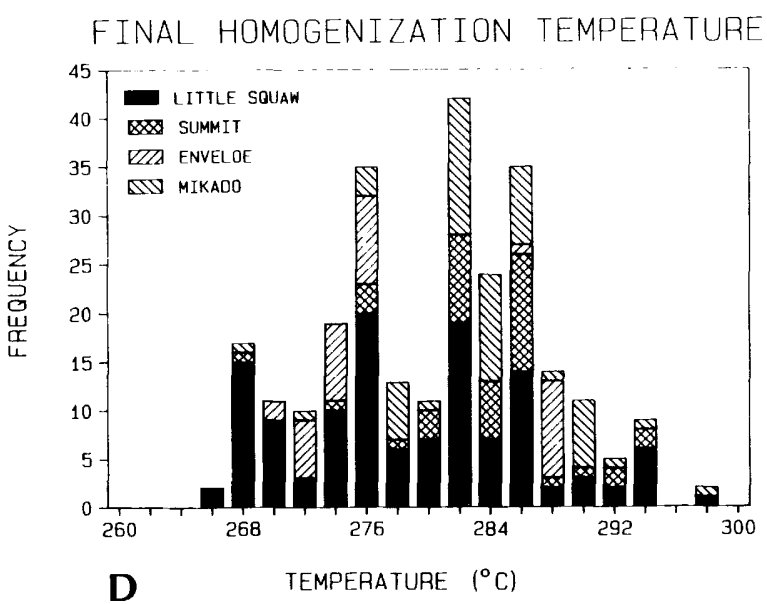

Figure 2. Histograms of microthermometric data from primary fluid inclusions. 
Table 1. Oxygen isotope data from quartz veins

[Fluid values calculated using temperature of $280^{\circ} \mathrm{C}$ and quartz-water fractionation equation of Clayton and others (1972)]

\begin{tabular}{lcc}
\hline Sample & Description & $\delta^{18} \mathrm{O}$ quartz \\
(permil) & $\begin{array}{c}\delta^{18} \mathrm{fluid} \\
\text { (permil) }\end{array}$
\end{tabular}

\begin{tabular}{llcc}
\hline Little Squaw & High-grade ribbon qtz & 15.6 & 7.4 \\
Mikado & High-grade ribbon qtz & 15.6 & 7.4 \\
Mikado & Barren milky qtz & 15.9 & 7.7 \\
Enveloe & Barren milky qtz & 16.1 & 7.9 \\
Summit & Barren milky qtz & 16.1 & 7.9 \\
Little Squaw & Barren milky qtz & 15.4 & 7.2 \\
Summit & Segregation qtz & 18.4 & --- \\
\hline
\end{tabular}

ranging from +15.4 per $\mathrm{mil}$ to +16.1 per mil. The estimated $\delta^{18} \mathrm{O}$ values of the vein-forming fluids, ranging from +7.2 per mil to +7.9 per mil, were calculated using an average fluid inclusion homogenization temperature of $280^{\circ} \mathrm{C}$ and the quartzwater fractionation equation of Clayton and others (1972). The isotopically heavy values are consistent with those for other mesothermal gold deposits within the northern North American Cordillera (Gamble and others, 1985; Nesbitt and others, 1986; Goldfarb and others, 1987) and are significantly heavier than in most epithermal gold systems (Ohmoto, 1986). The actual source for the fluids is still uncertain. However, if the ore-forming fluids were deeply circulating meteoric waters with required initial $\delta D$ values at least as light as -150 per mil, they would require an oxygen shif $t$ of more than 25 per mil. We doubt that such a large shift is likely with the relatively high water-to-rock ratio required to produce the thick, high-grade veins. Using relationships from Field and Fifarek (1985), water-torock ratios of less than 0.1 would be required at 300 ${ }^{\circ} \mathrm{C}$ if meteoric fluids were invoked for ore genesis at the Little Squaw lode prospect. Thus we believe that the isotopically heavy ore fluids are more likely derived from deep crustal sources.

The isotope compositions and fluid inclusion compositions are similar to $\mathrm{C}-\mathrm{O}-\mathrm{H}$ fluids commonly observed in medium-grade metamorphic rocks (Crawford and Hollister, 1986). Such fluids are inferred to have been released during devolatilization reactions, and reflect compositions buffered by the surrounding mineral assemblages. Gold is believed to have been mobilized from the pelitic metasediments by these metamorphic fluids.

Wood and Walther (1986) documented fluid-torock ratios of $6: 1$ in greenschist-to amphibolite-grade metamorphosed pelitic rocks. In the Chandalar area, thrust faults may have channelized large volumes of the fluids released during Cretaceous metamorphism, resulting in even higher concentrations of fluids. We suggest a hydraulic fracturing model similar to the model proposed by Ashworth (1983) for the formation of the gold lodes of the Chandalar district. Rapid uplift due to tectonic unloading results in a decrease in lithostatic pressure. When the fluid pressure exceeds confining pressure, hydraulic fracturing and the release of metamorphic fluids will occur. Decreasing pressure-temperature and changing redox conditions, in part due to wallrock reactions, are the most likely parameters controlling deposition of gold by the hydrothermal fluids.

\section{REFERENCES CITED}

Ashworth, K.K., 1983, Genesis of gold deposits of the Little Squaw Mines, Chandalar mining district, Alaska: Bellingham, Western Washington University, M.S. thesis, 98 p.

Brown, P.E., and Lamb, W.M., 1986, Mixing of $\mathrm{H}_{2} \mathrm{O}-\mathrm{CO}_{2}$ in fluid inclusions; Geobarometry and Archean gold deposits: Geochimica et Cosmochimica Acta, v. 50, p. 847-852.

Burruss, R.C., 1981, Analysis of phase equilibria in $\mathrm{C}-\mathrm{O}-\mathrm{H}-\mathrm{S}$ fluid inclusions, in Hollister, L.S., and Crawford, M.L., eds., Short Course in fluid inclusions: Applications to petrology: Mineralogical Association of Canada, Short Course Handbook, v. 6, p. 39-74.

Chipp, E.R., 1970, Geology and geochemistry of the Chandalar area, Brooks Range, Alaska: Alaska Division of Mines and Geology Report $42,39 \mathrm{p}$.

Clayton, R.N., O'Neil, J.R., and Mayeda, T.J., 1972 , Oxygen isotope exchange between quartz and water: Journal of Geophysical Research, v. 77, no. 17, p. 3057-3067.

Crawford, M.L., and Hollister, L.S., 1986, Metamorphic fluids: The evidence from fluid inclusions, in Walther, J.V., and Wood,

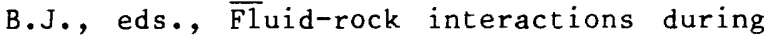
metamorphism, advances in physical geochemistry, v. 5: New York, SpringerVerlag, p. 1-35.

Dillon, J.T., 1982, Source of lode and placer gold deposits of the Chandalar and Upper Koyukuk districts, Alaska: Alaska Division of Geological and Geophysical Surveys, Alaska Open-file Report 158, 22 p.

Field, C.W., and Firarek, R.M., 1985, Light stable-isotope systematics in the epithermal environment, in Berger, B.R., and Bethke, P.M., eds., Geology and geochemistry of epithermal systems: Society of Economic Geologists, Reviews in Economic Geology, v. 2, p. 99-128. 
Gamble, B.M., Ashley, R.P., and Pickthorn, W.J., 1985, Preliminary study of lode gold deposits, Seward Peninsula, in BartshWinkler, Susan, ed., The United States Geological Survey in Alaska: Accomplishments during 1984: U.S. Geological Survey Circular 967, p. 27-29.

Goldfarb, R.J., Nelson, S.W., Berg, H.C., and Light, T.D., 1987, Distribution of mineral deposits in the Pacific Border Ranges and Coast Mountains of the Alaskan Cordillera, in Elliot, I., and Smee, B.W., eds., Geoexpo/87, Exploration in the North American Cordillera: Association of Exploration Geochemists, p. 19-41.

Heiner, L.E., and Wolff, E.N., 1968, Mineral resources of northern Alaska: Mineral Industry Research Laboratory, University of Alaska, Report 16, 306 p.

Nesbitt, B.E., Murowchick, J.B., and Muehlenbachs, K., 1986, Dual origins of lode gold deposits in the Canadian Cordillera: Geology, v. 14, p. 506-509.

Ohmoto, Hiroshi, 1986, Stable isotope geochemistry of ore deposits, in Valley, J.W., Taylor, H.P., and $0^{\prime}$ Neal, J.R., eds.,
Stable isotopes in high temperature geological processes: Mineralogical Society of America, Reviews in Mineralogy, v. 16, p. 491-556.

Roedder, Edwin, 1984, Fluid inclusions, in Ribbe, P.H., ed., Mineralogical Society of America: Reviews in Mineralogy, v. 12, 644 p.

Swanenberg, H.E.C., 1980, Fluid inclusions in high-grade metamorphic rocks from $S$. W. Norway: Geologica Ultraiectina, University of Utrecht, Netherlands, no. 25, 147 p.

Wood, B.J., and Walther, J.V., 1986, Fluid flow during metamorphism and its implications for fluid-rock ratios, in Walther, J.V., and Wood, B.J., eds., Fluid-rock interactions during metamorphism, advances in physical geochemistry, v. 5: New York, SpringerVerlag, p. 89-108.

Reviewers: Albert Hofstra and John Gray

Geologic Studies in Alaska by the U.S. Geological Survey during 1987: John P. Galloway and Thomas D. Hamilton, editors, U.S. Geological Survey Circular 1016. 


\section{WEST-CENTRAL ALASKA}

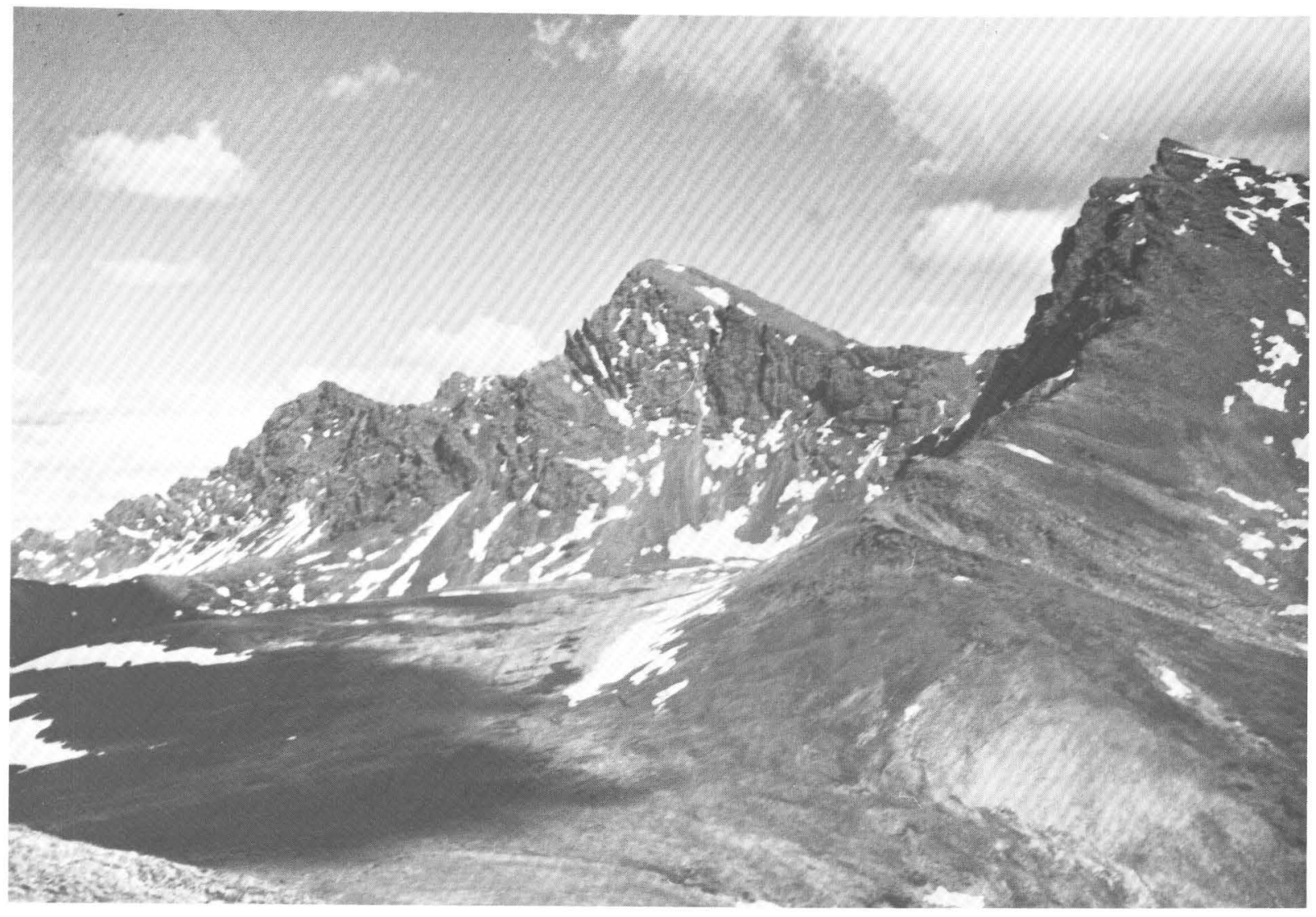

Angayucham terrane in Jade Mountains. Mafic-ultramafic thrust panel (high ridge) resting in thrust contact on phyllite-metagraywacke thrust panel, low area in foreground and middle distance. See article by Murphy and Patton. Photograph by W.W. Patton, Jr. 


\title{
Factor Analysis of the NURE Stream-Sediment and Lake-Sediment Geochemical Data from the Iditarod Quadrangle
}

\author{
By John E. Gray, Sarah C. Smith, and Richard J. Goldfarb
}

The U. S. Department of Energy conducted a reconnaissance geochemical study of the Iditarod quadrangle, that was completed in 1981 and was part of the National Uranium Resource Evaluation (NURE) program. During the study, 888 stream-sediment and 505 lake-sediment samples were collected to assess the uranium resource potential of the quadrangle. Composite stream-sediment samples were collected from small first-order streams. These samples were as evenly distributed throughout the quadrangle as possible, averaging approximately one sample per 23 $\mathrm{km}^{2}\left(9 \mathrm{mi}^{2}\right)$. However, in swampy areas streamsediment sampling was usually not possible and lakesediment samples were collected instead. All samples were analyzed at the Los Alamos National Laboratory by various methods including $\mathrm{X}$-ray fluorescence, instrumental neutron-activation, arc-source emission spectrography, and delayed-neutron counting (NURE, 1983). The U.S. Geological Survey is currently in the process of evaluating the mineral resource potential of the Iditarod quadrangle as part of an AMRAP (Alaskan Resource Mineral Appraisal Program) study. The purpose of this paper is to use the NURE data to identify areas of potential mineralization in the this quadrangle.

$\mathrm{R}$-mode factor analysis was used to identify the major geochemical associations in the stream and lake-sediment data sets. This technique groups elements into "factors". Different types of mineral deposits and rock lithologies have different geochemical signatures that can be identified with this method. A six-factor model was selected to account for the stream-sediment data (table 1).

The first three stream-sediment factors are related to bedrock geochemistry in the quadrangle. Factor 1 contains high loadings for $\mathrm{Ce}, \mathrm{Eu}, \mathrm{Lu}, \mathrm{Sm}$, Th, $\mathrm{U}, \mathrm{Zr}, \mathrm{Hf}$, and $\mathrm{Na}$. Samples with high scores onto this factor (fig. 1) correlate with the distribution of intermediate to felsic igneous rocks including monzonites in the Beaver Mountains (Bundtzen and Laird, 1982) and felsic dikes in the Crooked Creek area (Miller and Bundtzen, 1987). Factor 2, which contains high loadings for $\mathrm{Cr}, \mathrm{Co}, \mathrm{V}, \mathrm{Sc}, \mathrm{Ni}$, and $\mathrm{Mg}$, represents a mafic rock association. Samples with the highest scores for factor 2 are found in the north-central part of the quadrangle near resistant ridges that are underlain by mafic volcanic rocks (fig. 1). A correlation between $\mathrm{Pb}, \mathrm{Cs}$, and $\mathrm{Cl}$ defines factor 3 . This association is most likely a reflection of partitioning of these elements into feldspars and micas (and perhaps also apatite in the case of $\mathrm{Cl}$ ) in more alkalic igneous rocks. Samples with the highest factor 3 scores cluster in watersheds underlain by quartz monzonite and syenite.

Factor 4 includes high positive loadings for $\mathrm{Al}$, $\mathrm{Ba}, \mathrm{Ca}, \mathrm{Dy}, \mathrm{K}$, and $\mathrm{Ti}$. This factor is interpreted to be representative of refractory minerals and organic and clay-rich sediments retained in marshy lowland areas. Such lowands are prevalent in the western part of the quadrangle.

Factor 5 has high positive loadings for $\mathrm{Fe}, \mathrm{Mn}$, and As. This factor is thought to delineate areas with high geochemical favorability for epithermal preciousmetal occurrences. Samples with the highest scores for this factor occur near areas of known preciousmetal lode or placer activity (such as the Moore, Ganes, and Crooked Creek mining areas). In addition, samples with high scores for this factor are also found in previously unrecognized locations, as indicated on figure 1. In some cases, these samples are spatially related to intermediate to felsic igneous rocks, such as near monzonites in the Flat area and felsic dikes in the Crooked Creek area. Although $\mathrm{Sb}$ and $\mathrm{W}$ were eliminated from the factor analysis because most samples were below the detection limit for these elements, samples with high factor 5 scores of ten show anomalous concentrations of one or both of these elements. This is especially true of $\mathrm{Sb}$ in the Crooked Creek area and $\mathrm{W}$ and $\mathrm{Sb}$ in the Flat and Moore Creek areas. Only one anomalous silver value is reported in the NURE data, and it occurs in a stream sediment sample in Ganes Creek in the eastern Beaver Mountains. There are no gold values above the detection limit in the NURE stream-sediment data set. Therefore, although there are numerous areas of placer activity in the quadrangle, the association of gold with factor $\mathbf{5}$ is poorly documented.

High positive loadings for $\mathrm{Cu}$, and to a lesser degree $\mathrm{Cs}$ and $\mathrm{Ni}$, characterize factor 6 . This factor association is interpreted to be representative of copper-rich base-metal mineralization. Samples with the highest scores onto factor 6 of ten correlate with igneous rocks of intermediate to felsic composition, especially in the Beaver Mountains. Bundtzen and Laird (1982) identified several localities of copper mineralization in the Beaver Mountains, most of which had associated anomalous $\mathrm{Ag}$, and less commonly anomalous $\mathrm{Pb}, \mathrm{As}, \mathrm{Sb}, \mathrm{Zn}$, and $\mathrm{Sn}$. Other areas with high scores onto this factor are shown on figure 1.

The geochemical results from lake sediments collected during the NURE project were also examined using R-mode factor analysis. A five-factor model 
Table 1. Factor loadings for the stream sediments

[Total variance explained by the 6 -factor model equals 72 percent. Loadings less than 0.30 have been omitted]

\begin{tabular}{lllllll}
\hline Element & 1 & 2 & Factors & & 5 & 6 \\
\hline
\end{tabular}

\begin{tabular}{|c|c|c|c|c|c|c|}
\hline Al & -- & -- & -- & 0.87 & -- & -- \\
\hline As & -- & -- & 0.30 & -- & 0.72 & -- \\
\hline $\mathrm{Ba}$ & -- & -- & -- & .80 & -- & -- \\
\hline $\mathrm{Ca}$ & -- & -- & -- & .60 & -- & -- \\
\hline $\mathrm{Ce}$ & 0.82 & -- & -- & .37 & -- & -- \\
\hline $\mathrm{Cl}$ & -- & -- & .63 & -- & -- & -- \\
\hline Co & -- & 0.75 & -- & -- & .38 & -- \\
\hline $\mathrm{Cr}$ & -- & .89 & -- & -- & -- & -- \\
\hline Cs & -- & -- & .56 & -- & .32 & 0.37 \\
\hline $\mathrm{Cu}$ & -- & -- & -- & -- & -- & .82 \\
\hline Dy & .45 & -- & -- & .76 & -- & -- \\
\hline $\mathrm{Eu}$ & .70 & -- & -- & -- & -- & -- \\
\hline $\mathrm{Fe}$ & -- & .33 & -- & -- & .77 & -- \\
\hline $\mathrm{Hf}$ & .82 & -- & -- & -- & -- & -- \\
\hline K & .30 & .32 & -- & .69 & -- & -- \\
\hline La & .48 & -- & .45 & -- & -- & -- \\
\hline $\mathrm{Lu}$ & .67 & -- & -- & -- & -- & -- \\
\hline Mg & -- & .83 & -- & -- & -- & -- \\
\hline $\mathrm{Mn}$ & -- & .45 & -- & -- & .63 & -- \\
\hline $\mathrm{Na}$ & .68 & .31 & -- & .44 & -- & -- \\
\hline $\mathrm{Ni}$ & -- & .78 & -- & -- & -- & .32 \\
\hline $\mathrm{Pb}$ & -- & -- & .55 & -- & -- & -- \\
\hline Sc & .50 & .62 & -- & .44 & -- & -- \\
\hline $\mathrm{Sm}$ & .71 & -- & -- & -- & -- & -- \\
\hline Th & .82 & -- & -- & .35 & -- & -- \\
\hline $\mathrm{Ti}$ & .37 & -- & -- & .76 & -- & -- \\
\hline U & .59 & .36 & .32 & .43 & -- & -- \\
\hline V & .44 & .62 & -- & .41 & -- & -- \\
\hline $\mathrm{Zr}$ & .74 & -- & -- & .40 & -- & -- \\
\hline \multicolumn{7}{|c|}{$\begin{array}{l}\text { Percent of } \\
\text { total variance } \\
\text { explained by }\end{array}$} \\
\hline factor & 39 & 12 & 7 & 5 & 5 & 4 \\
\hline
\end{tabular}

was used for evaluating these data (table 2). However, the relatively poor proximity of the lake-sediment samples to well-exposed bedrock in the quadrangle makes interpretation of these factor analysis results difficult.

Factor 1 is thought to be related to high organics and clays in the lake sediments and is therefore analogous to factor 4 for the stream sediments. Samples with high scores for this factor are most prevalent in the western part of the Iditarod quadrangle where there are abundant marshy lowlands (fig. 2).

Factor 2 is similar to factor 5 in the stream sediments and may be a precious-metal association. Only one anomalous gold value occurs in the NURE lake-sediment data. This sample is located just west of Swinging Dome in the western part of the quadrangle (fig 2). The bedrock geology is poorly exposed in this area, but appears to be predominantly intermediate to felsic volcanic rocks (Miller and Bundtzen, 1987). If there is a close association of gold mineralization with these volcanic rocks, it is not well understood at this time.

Lake-sediment factor 3 is similar to the intermediate to felsic rock factor (factor 1) for the stream sediments. It is difficult to obtain any useful information from this factor, because most of these lakes are spatially removed from bedrock exposures.

Factor 4 for the lake sediments is a base-metal association and is similar to factor 6 for the stream sediments. As with the stream sediment factor 6, samples with the highest scores for this factor occur in lakes in the Beaver Mountains where base metal mineralization has been recognized.

Factor 5 for the lake sediments is analogous to the mafic rock association that characterizes factor 2 in the stream sediments. The distribution for this factor is also similar to that of stream sediment factor 2 in the north-central part of the quadrangle.

Factor analysis of the geochemical results from the NURE project stream and lake sediments does appear to be useful for targeting potential areas of 


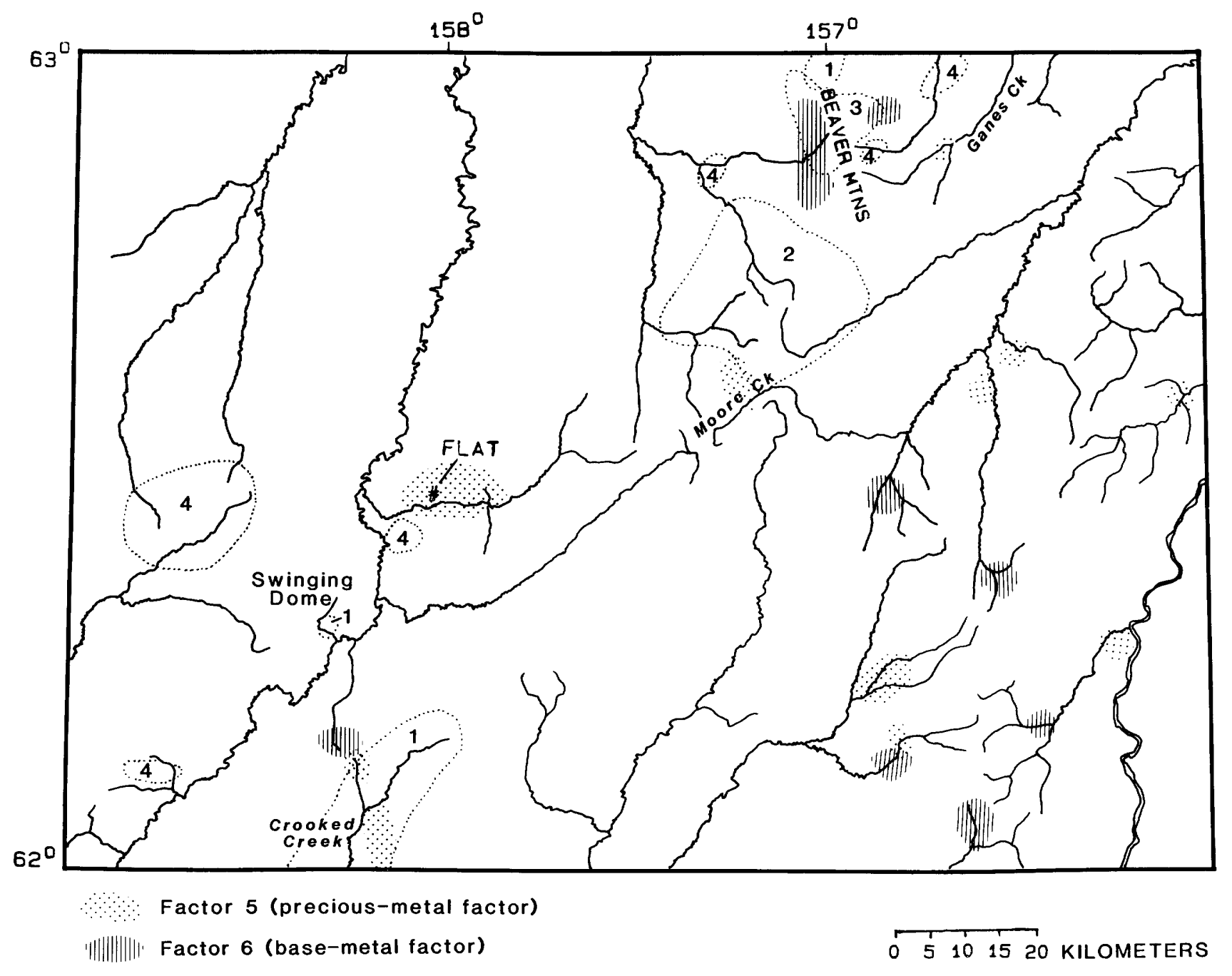

Figure 1. Iditarod quadrangle showing distribution of stream-sediment factors (1-6). Stipple and line patterns are for factors 5 and 6 as indicated.

mineralization in the Iditarod quadrangle. A basemetal and a precious-metal association have been identified in both data sets. Base-metal associations are commonly correlative with intrusive rocks of intermediate composition and are somewhat analogous to porphyry copper systems. The precious-metal factors appear to be related to epithermal deposits that are, in some cases, proximal to known igneous activity. However, rare anomalous gold and other pathfinder elements makes interpretations of mineralization factors somewhat difficult. The lake sediments are not evenly distributed throughout the quadrangle and are not as useful as the stream sediments for delineating areas of potential mineralization.

\section{REFERENCES CITED}

Bundtzen, T.K., and Laird, G.M., 1982, Geologic map of the Iditarod $\mathrm{D}-2$ and eastern $\mathrm{D}-3$ quadrangles, Alaska: Alaska Division of Geological and Geophysical Surveys, Geologic Report 72, 1 sheet, scale $1: 63,360$.

Miller, M.L., and Bundtzen, T.K., 1987, Geology and mineral resources of the Iditarod quadrangle, west-central Alaska, in Sachs, J.S., ed., U.S.G.S. research on mineral resources 1987--programs and abstracts: U.S. Geological Survey Circular 995, p. 46. 47 .

National Uranium Resource Evaluation Project (NURE), 1983, The geochemical atlas of Alaska: Los Alamos National Laboratory publication GJBX-32 (83).

Reviewers: D.E. Detra and S.C. Rose

Geologic Studies in Alaska by the U.S. Geological Survey during 1987: John P. Galloway and Thomas D. Hamilton, editors, U.S. Geological Survey Circular 1016. 


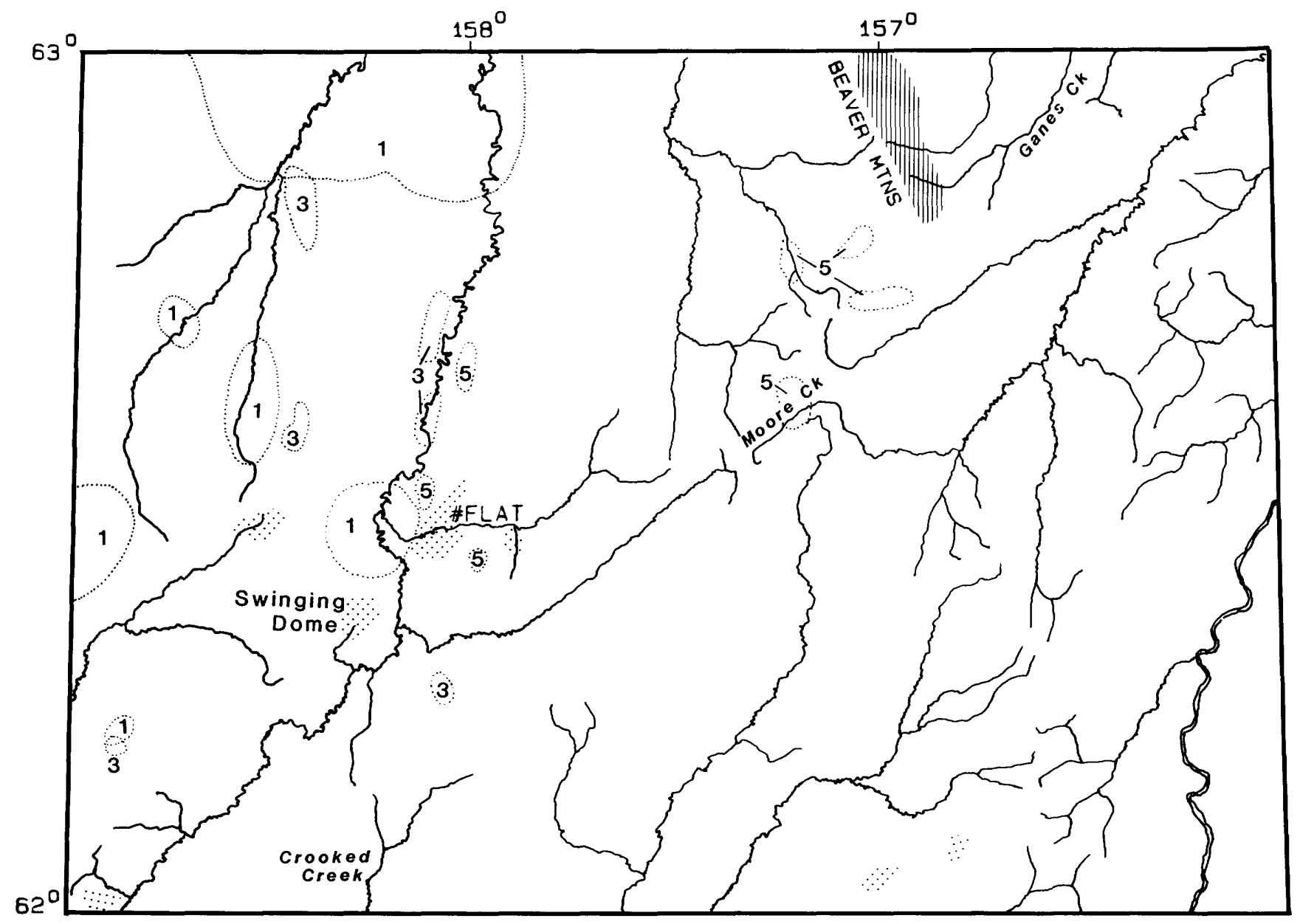

Factor 2 (precious-metal factor)

Factor 4 (base-metal factor)

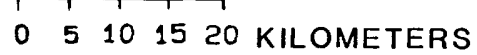

Figure 2. Iditarod quadrangle showing distribution of lake-sediment factors (1-5). Stipple and line patterns are for factors 2 and 4 as indicated. 
Table 2. Factor loadings for lake sediments

[Total variance explained by the 5 -factor model equals 77 percent. Loadings less than 0.30 have been omitted]

\begin{tabular}{|c|c|c|c|c|c|}
\hline \multicolumn{6}{|c|}{ Factors } \\
\hline Element & 1 & 2 & 3 & 4 & 5 \\
\hline Al & 0.85 & -- & -- & -- & -- \\
\hline As & -- & 0.87 & -- & -- & -- \\
\hline $\mathrm{Ba}$ & .83 & -- & -- & -- & 0.34 \\
\hline $\mathrm{Ca}$ & .74 & -- & -- & -- & -- \\
\hline $\mathrm{Ce}$ & .64 & -- & 0.53 & -- & .45 \\
\hline $\mathrm{Cl}$ & -- & -- & -- & -- & -.81 \\
\hline Co & -- & .41 & .39 & -- & .59 \\
\hline $\mathrm{Cr}$ & .40 & -- & .39 & -- & .68 \\
\hline Cs & -- & .40 & .30 & 0.62 & -- \\
\hline $\mathrm{Cu}$ & -- & -- & -- & .53 & -- \\
\hline Dy & .88 & -- & -- & -- & -- \\
\hline $\mathrm{Eu}$ & .55 & -- & .60 & -- & -- \\
\hline $\mathrm{Fe}$ & .50 & .50 & .31 & -- & .43 \\
\hline $\mathrm{Hf}$ & .54 & -- & .64 & -- & .36 \\
\hline $\mathrm{K}$ & .75 & -- & -- & -- & .31 \\
\hline $\mathrm{Lu}$ & .31 & -- & .74 & -- & -- \\
\hline $\mathrm{Mg}$ & .45 & -- & -- & -- & .65 \\
\hline $\mathrm{Mn}$ & .56 & .62 & -- & -- & -- \\
\hline $\mathrm{Na}$ & .80 & -- & .37 & -- & -- \\
\hline $\mathrm{Ni}$ & -- & -- & -- & .37 & .66 \\
\hline $\mathrm{Pb}$ & -- & -- & -- & .74 & -- \\
\hline Sc & .69 & -- & .36 & -- & .42 \\
\hline $\mathrm{Sm}$ & -- & -- & .75 & -- & -- \\
\hline Th & .58 & -- & .55 & -- & .44 \\
\hline $\mathrm{Ti}$ & .81 & -- & -- & -- & .36 \\
\hline $\mathrm{U}$ & .69 & -- & -- & -- & .34 \\
\hline V & .51 & -- & -- & -- & .57 \\
\hline $\mathrm{Zr}$ & .73 & -- & .34 & -- & .35 \\
\hline $\begin{array}{l}\text { Percent of } \\
\text { total } \\
\text { variance } \\
\text { explained }\end{array}$ & & & & & \\
\hline by factor & 56 & 8 & 5 & 4 & 4 \\
\hline
\end{tabular}




\title{
Glacial Geologic History of the Salmon Lake Area, Seward Peninsula
}

\author{
By Darrell S. Kaufman, David M. Hopkins, and Parker E. Calkin
}

In the Salmon Lake area of southwestern Seward Peninsula (fig. 1), glacial deposits formed by four ice advances of Pleistocene age are clearly exhibited; they lie in close proximity to one another and are accessible by unpaved road from Nome. Recent refinements in the area's glacial chronology (Kauf man and Hopkins, 1986; Calkin and others, 1987) are combined in this paper with our detailed field mapping during 1983-87, our quantitative relative-age data on moraines, and a significant new radiometric age. These data provide a new perspective on an area that has been described in reconnaissance studies since the turn of the century (Brooks, 1901; Hopkins, 1953).
The Salmon Lake area encompasses the rugged, ice-sculptured peaks and valleys of the eastern Kigluaik Mountains and extends to the rolling uplands beyond. It includes two major valley systems, occupied by Grand Central River and Crater Creek, that preserve an extensive glacial record. This glacial record can be correlated with the youngest four Pleistocene events of the regional glacial sequence described by Kaufman and Hopkins (1986)--the Nome River, Stewart River, Salmon Lake, and Mount Osborn glacial advances. During the oldest glacial episodes, the most recent of which is the Nome River glaciation, ice carved broad U-shaped troughs and advanced south
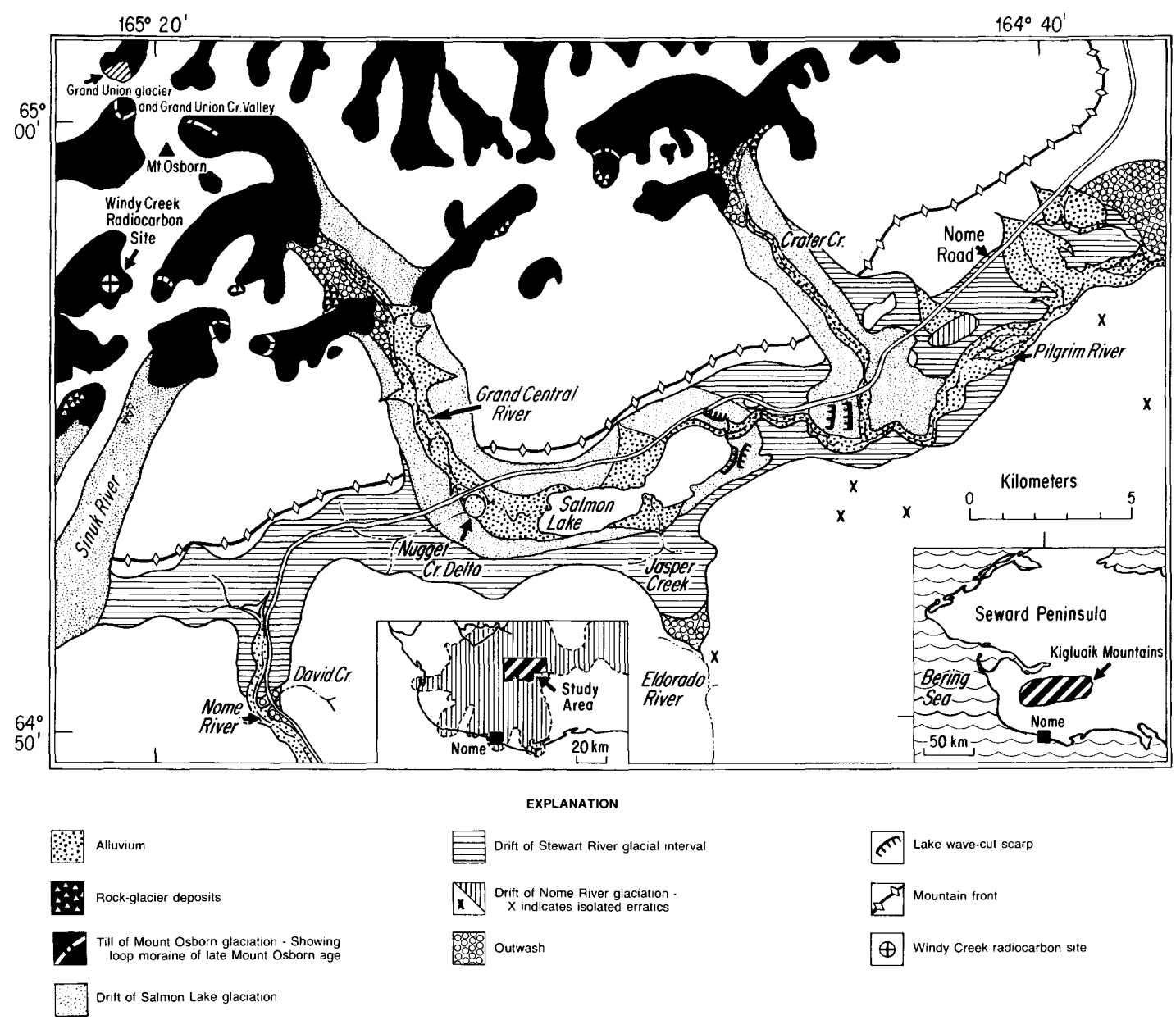

Figure 1. Generalized surficial geologic map of principal study area, Kigluaik Mountains. Center insert map shows inferred extent of Nome River age glaciers. 
more than $60 \mathrm{~km}$ to points beyond the present-day northern coast of the Bering Sea. Subsequent glacier advances affected an area nearly an order of magnitude less extensive. During the two earliest of these advances, the Stewart River and the Salmon Lake, glaciers flowed short distances beyond the mountain front. The most recent major ice advance, the Mount Osborn, was restricted to the highest tributary valleys.

Drift of Nome River age, believed to be more than 0.8 m.y. old (Kaufman and Hopkins, 1986), is recognized in only a few small tracts in the Salmon Lake area. The nearly featureless drift (table 1) is mantled by a thick blanket of frozen, wind-blown silt that supports a continuous cover of cottongrass (Eriophorum vaginatum) tussocks. Erratic boulders found scattered on frost-rived bedrock and in the beds of river channels record glacial activity considerably beyond the drift limit. South of Pilgrim River, erratics dating to the Nome River glaciation and probably older glacial episodes have been mapped up to an altitude of $290 \mathrm{~m}$.

Kaufman and Hopkins (1986) named the Stewart River glacial interval for moraine complexes, thought to be older than the last interglacial interval, situated 5 to $10 \mathrm{~km}$ beyond the limits of younger Salmon Lake drift deposits on the south side of the Kigluaik Mountains. Ice occupying the Grand Central River valley flowed beyond the mountain front forming a large, tri-lobed piedmont glacier (fig. 1). On the west, the glacier topped a low divide at the Nome River valley, merged with ice from the Sinuk River valley, and flowed south to terminate at David Creek, leaving a conspicuous moraine and adjacent outwash plain. A second tongue flowed south a short distance into Eldorado River valley, depositing a low moraine that forms the drainage divide at the head of that valley. The east margin of the former ice tongue is marked by a sharp-crested lateral moraine at an altitude of $245 \mathrm{~m}$ in the valley of Jasper Creek. A train of erratic boulders can be traced up the western wall of Eldorado River valley to a similar altitude. The eastern lobe of ice from Grand Central River valley coalesced with ice flowing from Crater Creek valley, then moved northeastward down the valley of the Pilgrim River to form a multiple-crested moraine near the lower course of Homestake Creek. Although more complex than most, the morphology is typical of moraines of Stewart River age as summarized in table 1 . The generally smooth terrain is punctuated by solitary, gravelly ridges and hillocks that commonly are armored by pebbly gravel.

The Salmon Lake glaciation is represented by extensive lobate moraines deposited by glaciers that advanced to within several kilometers of the former Stewart River glacial limit. In several places, glaciers failed to top drainage divides traversed by older ice. Hopkins' (1953) type locality for drift of Salmon Lake age is the morainal complex at the east end of Salmon Lake. This moraine delineates the terminus of a broad valley glacier that flowed from Grand Central River valley but did not merge with ice originating from the valley of Crater Creek.

Textural and morphologic differences distinguish the moraines of Salmon Lake age generated by the two independent glaciers in the valleys of Grand Central River and Crater Creek. The Crater Creek moraine is exceptionally bouldery and displays abundant primary microrelief. In contrast, the moraine east of Salmon Lake is largely composed of sandy gravel and is devoid of microrelief features. These disparities can partly be attributed to differences in transport distance and composition of valley-filling sediments. The Crater Creek moraine was deposited by a glacier nearly half the length of the glacier that occupied Grand Central River valley. Furthermore, the walls of the narrow Crater Creek valley were probably more severely undercut, thus delivering abundant rockfall debris to the glacier. The Grand Central glacier, on the other hand, flowed through a broad valley underlain by fine-grained alluvial and possibly lacustrine sediments, and incorporated these into its end moraine.

During the Salmon Lake glaciation, ice from Crater Creek valley advanced to block the Pilgrim River valley and impounded a shallow proglacial lake

Table 1. Select morphologic data derived from topographic profiles of moraines in the Kigluaik Mountains [Group mean values \pm 1 standard deviation are shown; see Kaufman (1987) for a complete discussion of methodology]

\begin{tabular}{lcccc}
\hline \multicolumn{1}{l}{$\begin{array}{l}\text { Morphologic } \\
\text { parameter }\end{array}$} & Mount Osborn & Salmon Lake & Stewart River & Nome River \\
\cline { 2 - 5 } Axial crest mean slope (deg) & $6.4 \pm 1.7$ & $5.0 \pm 1.6$ & $3.2 \pm 1.0$ & $0.4 \pm 0.0$ \\
$\begin{array}{l}\text { Axial crest slope standard } \\
\text { deviation (deg) }\end{array}$ & $6.4 \pm 2.6$ & $5.6 \pm 1.3$ & $4.5 \pm 1.6$ & $0.5 \pm 0.0$ \\
$\begin{array}{l}\text { Cross section mean slope (deg) } \\
\text { Crest width (m) }\end{array}$ & $9.8 \pm 1.1$ & $8.6 \pm 2.3$ & $4.7 \pm 1.2$ & $1.7 \pm 0.2$ \\
Number of moraines studied & $19.5 \pm 5.5$ & $25.4 \pm 12.4$ & $39.3 \pm 12.0$ & $410.0 \pm 5.0$ \\
\hline l Mean and standard deviation of slope angles were calculated by slope-frequency analysis.
\end{tabular}


at an altitude of about $150-\mathrm{m}$. Poorly defined shoreline scarps of this lake extend around the western side of the Crater Creek moraine and are notched into both sides of the Salmon Lake moraine (fig. 1). A delta exposed in the banks of an artificially diverted channel of Nugget Creek at the west end of Salmon Lake is also graded to the $150-\mathrm{m}$ shoreline. A section measured on the south bank of the channel (fig. 2) revealed more than $1.5 \mathrm{~m}$ of deltaic foreset gravel overlain by about $1 \mathrm{~m}$ of horizontally bedded gravel and a thin $(0.3 \mathrm{~m})$ layer of eolian sand from which a set of ice-wedge pseudomorphs originates. The eolian sand is in turn overlain by about $2 \mathrm{~m}$ of cobbly gravel, possibly outwash of Mount Osborn age, and about $0.8 \mathrm{~m}$ of eolian silty sand containing fine-grained tephra from the $3,400-4,000 \mathrm{yr}$ B.P. eruption of Aniakchak Crater (Riehle and others, 1987). A second set of icewedge pseudomorphs extends downward from the capping silty sand.

The presence up-glacier from the Salmon Lake moraine of deltas and shoreline scarps of a proglacial lake dammed by the Crater Creek glacier indicate that the maximum advances of the Grand Central River and Crater Creek glaciers during Salmon Lake time were asynchronous. The proglacial lake probably caused an early and rapid calving retreat of the Grand Central River glacier. Furthermore, because a large portion of this glacier spans a narrow altitude range, a small change in snowline altitude would have greatly altered its accumulation area. As snowline rose following the Salmon Lake maximum, a large area that had previously lain in the accumulation zone no longer nourished the glacier. An equivalent rise of snowline in the shorter and steeper Crater Creek valley would have had a less significant effect upon that glacier's accumulation area.
The Salmon Lake glaciation is older than 40,000 yr B.P. and has long been considered of early Wisconsin age (Kaufman and Hopkins, 1986). However, our data do not exclude the possibility that it predates the last major interglaciation. Relative-age data from the Salmon Lake area and other places in the Kigluaik Mountains provide only a relative chronology for the glacial sequence (Kaufman, 1987, Calkin and others, 1987, tables 1 and 2). The data show that differences in postdepositional modification between moraines of Salmon Lake and Stewart River age are greater than the difference between those of Salmon Lake and Mount Osborn age, suggesting that successively older advances were separated by intervals of increasing duration.

The Mount Osborn glaciation is represented by sharply defined moraines enclosing freshly eroded walls of tributary valleys throughout the Kigluaik Mountains. Trimlines developed during Mount Osborn time are prominent on many valley walls and are traceable into terminal moraines that delimit former glaciers about $3 \mathrm{~km}$ long. All tributary valleys of Grand Central River and Crater Creek were occupied during Mount Osborn time, but the glaciers failed to fill the major trunk valleys that contained ice during the preceding Salmon Lake glaciation.

Based on similarities in weathering characteristics, the Mount Osborn glaciation has been correlated with the Itkillik II glaciation of the Brooks Range (Hamilton and Hopkins, 1982), dated by Hamilton $(1982,1986)$ as occurring between 25,000 and 11,500 yr B.P. A new radiocarbon age of $11,530 \pm \mathbf{4 5 0}$ yr B.P. (I-15,041) on peat collected by W.B. Whitford (State University of New York, Buffalo, written commun., 1987) from a shallow cirque of Windy Creek (fig. 1) indicates that this west-facing cirque was ice-

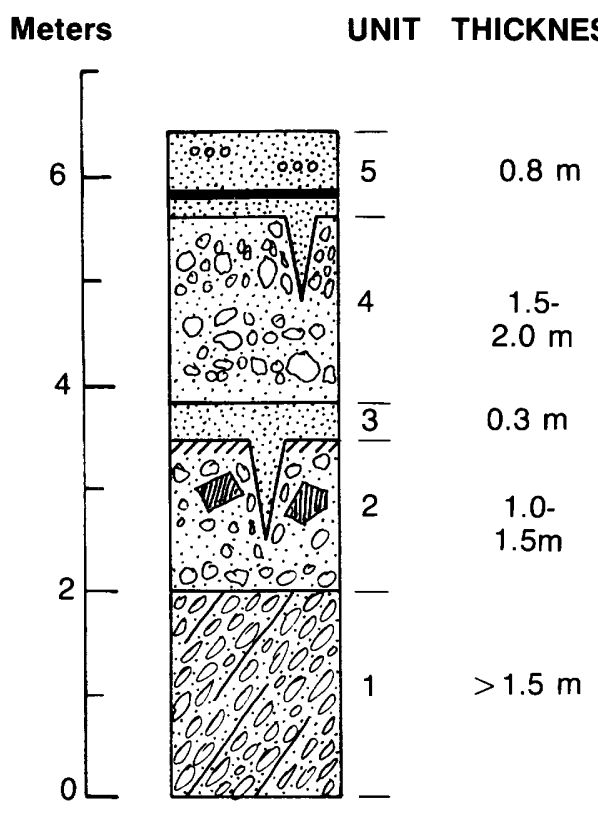

\section{DESCRIPTION}

SILTY SAND AND TEPHRA (EOLIAN). Very fine sand and silt with rare pebbles; grayish brown to light olive gray. Thin $(1-3 \mathrm{~cm})$ fine-grained, pale yellowish brown tephra at $70 \mathrm{~cm}$ depth

COARSE GRAVEL (OUTWASH). Crudely stratified and imbricated pebbles, cobbles, and rare boulders in coarse, moderate brown matrix of sand and granules; cut by ice-wedge pseudomorphs

SAND (EOLIAN?). Thin $(1-2 \mathrm{~cm})$ beds of alternating fine and coarse sand

GRAVEL (ALLUVIAL). Horizontally bedded pebbly sandy gravel; contains blocks, $0.5-1.0 \mathrm{~m}$, of stratified fine sand and silt; cut by ice-wedge pseudomorphs; possible buried soil at top

GRAVEL (DELTAIC). Steeply dipping $\left(25^{\circ}-30^{\circ}\right)$, beds $10-15 \mathrm{~cm}$ thick, of clean, cobble-pebble gravel and coarse sand; top of unit at approximately $150 \mathrm{~m}$ altitude

Figure 2. Stratigraphic section from Nugget Creek delta; location shown on figure 1. 
Table 2. Select surface-boulder weathering characteristics for deposits ranging in age from Salmon Lake glaciation to Holocene, in the Kigluaik Mountains

[Group mean values \pm 1 standard deviation are shown; data from B.]. Przybyl, State University of New York, Buffalo, written commun., 1987]

\begin{tabular}{lcccc}
\hline \multirow{2}{*}{$\begin{array}{l}\text { Surface-boulder } \\
\text { weathering } \\
\text { parameter }\end{array}$} & Holocene & Recessional Osborn & Mount Terminal & Salmon Lake \\
\cline { 2 - 5 } & $1.78 \pm 0.26$ & $2.27 \pm 0.11$ & $2.31 \pm 0.08$ & $2.65 \pm 0.15$ \\
Roundness index & $>150$ & $54.4 \pm 11.0$ & $55.0 \pm 15.7$ & $24.6 \pm 10.2$ \\
Frequency (per $\left.100 \mathrm{~m}^{2}\right)$ & $64.5 \pm 18.5$ & $18.1 \pm 4.4$ & $15.3 \pm 4.0$ & $10.4 \pm 3.2$ \\
Protrusion (cm) & 2 & 10 & 12 & 16 \\
Number of sites & & & &
\end{tabular}

${ }^{I}$ Calculated as a weighted mean by assigning values to each roundness catagory as follows;

1 , angular; 2 , subangular; 3 , subrounded; 4 , rounded.

free by $11,500 \mathrm{yr}$ B.P. Because the cirque was last occupied by ice during Mount Osborn time, the radiocarbon age supports our correlation of the Mount Osborn with the Itkillik II glaciation.

Another set of distinctive moraines is found in several north-facing cirques of the study area. The moraines are situated well up-valley from Mount Osborn terminal moraines, and about $1 \mathrm{~km}$ beyond the headwalls of cirques that presently lack glacier ice. They bear a discontinuous sod cover, a dense growth of lichens on boulders, and consist of low, solitary ridges that form nearly complete semicircles. Subsurface and surface-boulder weathering characteristics of these distinctive loop moraines and nearby recessional moraines are indistinguishable from the outermost moraines of Mount Osborn age (table 2). These moraines evidently record a glacial stillstand or readvance late during the Mount Osborn glaciation. However, they are distinctly older than the pair of Holocene moraines flanking the glacier at the head of Grand Union Creek (fig. 1 and table 2).

\section{REFERENCES CITED}

Brooks, A.H., 1901, A reconnaissance of the Cape Nome and adjacent gold fields of Seward Peninsula, Alaska in 1900, in Brooks, A.H., Richardson, G.B., Collier, A.J., and Mendenhal1, W.C., Reconnaissance in the Cape Nome and Norton Bay regions, Alaska in 1900: U.S. Geological Survey, p. 1-180.

Calkin, P.E., Przybyl, B.J., and Kaufman, D.S., 1987, Latest Quaternary glaciation, Kigluaik Mountains, northwestern Alaska [abs.]: Geological Society of America Abstracts with Programs, v. 19, no. 1, p. 8 .

Hamilton, T.D., 1982, A late Pleistocene glacial chronology for the southern Brooks Range-Stratigraphic record and regional significance: Geological Society of America Bulletin, v. 93, p. 700-716.
---- 1986, Late Cenozoic glaciation of the central Brooks Range, in Hamilton, T.D., Reed, K.M., and Thorson, R.M., eds., Glaciation in Alaska--The geologic record: Anchorage, Alaska Geological Society, p. 950 .

Hamilton, T.D., and Hopkins, D.M., 1982 , Correlation of northern Alaskan glacial deposits--A provisional stratigraphic framework, in Coonrad, W.L., ed., The United States Geological Survey in Alaska-Accomplishments during 1980: U.S. Geological Survey Circular 844, p. 15-18.

Hopkins, D.M., 1953, Seward Peninsula, in Péwé, T.L., ed., Multiple glaciation in Alaska--A progress report: U.S. Geological Survey Circular 289, p. 10-11.

Kaufman, D.S., 1987, Morphometric analysis of Pleistocene glacial deposits in the Kigluaik Mountains, northwestern Alaska: Seattle, University of Washington, M.S. thesis, $50 \mathrm{p}$. Kaufman, D.S., and Hopkins, D.M., 1986, Glacial history of the Seward Peninsula, in Hamilton, T.D., Reed, K.M., and Thorson, R.M., eds., Glaciation in Alaska--The geologic record: Anchorage, Alaska Geological Society, p. 51-78.

Riehle, J.R., Meyer, C.E., Ager, T.A., Kaufman, D.S., and Ackerman, R.E., 1987, The Aniakchak tephra deposit, a late Holocene marker horizon in western Alaska, in Hamilton, T.D., and Galloway, J.P., eds., Geologic studies in Alaska by the U.S. Geological Survey during 1986: U.S. Geological Survey Circular 998, p. 19-22.

Reviewers: J.E. Beget and T.D. Hamilton

Geologic Studies in Alaska by the U.S. Geological Survey during 1987: John P. Galloway and Thomas D. Hamilton, editors, U.S. Geological Survey Circular 1016. 


\title{
Lahar Deposit in the Iditarod Volcanics, Southwestern Iditarod Quadrangle
}

\author{
By Robert G. McGimsey and Marti L. Miller
}

A volcanic field, termed the Iditarod Volcanics (Miller and Bundtzen, this volume), forms a prominent upland southeast of the Iditarod River in the southwestern part of the Iditarod quadrangle (fig. 1). The Iditarod Volcanics consists of two informal map units--lower and upper--which range in overall age from Late Cretaceous to early Tertiary. The heterogeneous lower unit, which is composed mainly of breccias and pyroclastic rocks, underlies mafic and intermediate lava flows of the upper unit. The volcanic field is bounded to the northwest by the Iditarod-Nixon Fork strike-slip fault and by unconsolidated Quaternary deposits. Interbedded sandstone, siltstone, and shale composing the turbidite sequence of the upper Lower and Upper Cretaceous Kuskokwim Group (Bundtzen and Laird, 1983; Cady and others, 1955) crop out south and east of the volcanic belt. Extensive colluvial and vegetative cover in this area of low relief conceals the exact nature of the contact between the Kuskokwim Group and the

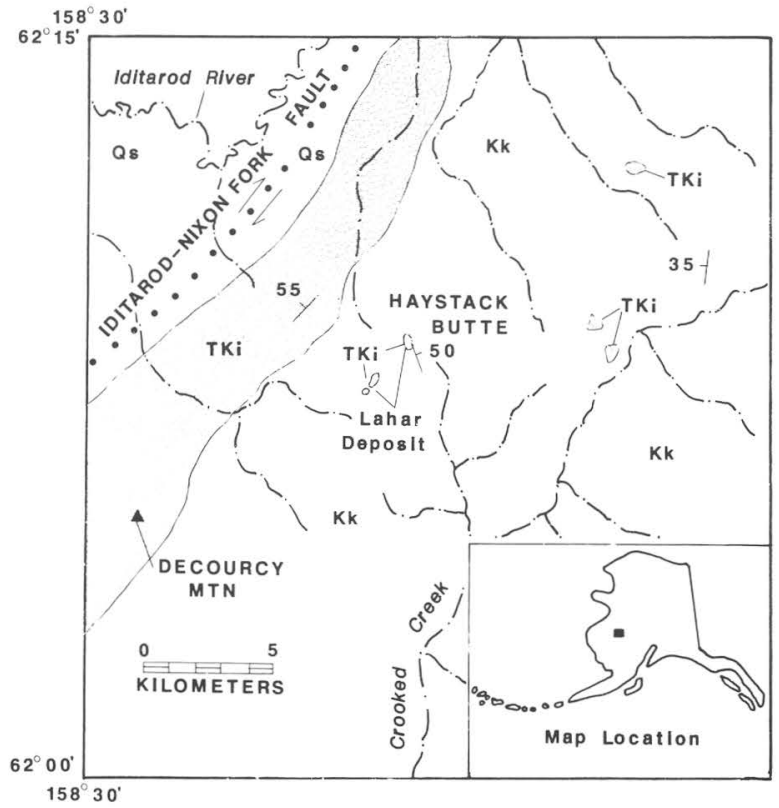

Figure 1. Generalized geologic map of Iditarod A-5 quadrangle. Map-unit symbols are: Qs, surficial deposits (Quaternary); TKi, Iditarod Volcanics (lower Tertiary and Upper Cretaceous); Kk, Kuskokwim Group (Upper and Lower Cretaceous), sedimentary rocks.
Iditarod Volcanics. Both sequences are broadly folded with fold axes generally oriented northeast-southwest. Isolated exposures of volcaniclastic deposits and minor mafic lava flows assigned to the Iditarod Volcanics apparently overlie the Kuskokwim Group as outlying erosional remnants southeast of the main volcanic field (fig. 1). One such deposit occurs about 3 $\mathrm{km}$ east of the main volcanic field where it forms a cluster of three steep-sided, hummocky spires that rise prominently above the surrounding terrain (fig. 2). The most conspicuous of these is Haystack Butte. The other two outcrops, located $2 \mathrm{~km}$ southwest of Haystack Butte, contain ungraded and nonbedded matrix-supported clasts of volcanic rock, sandstone, and shale randomly distributed in an unsorted clay- to sand-sized matrix that appears to be tuffaceous, though devitrified. Both outcrops contain a continuum of grain sizes from clay to boulders.

Two distinct types of clasts are present. The first type, which occurs primarily in the southernmost outcrop, is subrounded to well-rounded elongate clasts that range in size from large cobbles to boulders as much as $75 \mathrm{~cm}$ in maximum dimension. These clasts consist mainly of fine-grained lithic sandstone and minor shale, similar to that of the subjacent Kuskokwim Group (fig. 3); their smoothness and degree of rounding suggests that they formed in a fluvial environment.

The second type of clast ranges in size from small pebbles to small cobbles, are angular to subrounded, and consist dominantly of porphyritic volcanic rock and subordinate fine-grained lithic sandstone. Many of the volcanic rock clasts are from mafic and intermediate lava flows, as indicated by pilotaxitic textures and the presence of feldspar and clinopyroxene phenocrysts; some clasts are substantially more altered than others and contain abundant iron-oxide minerals. Some of the cobblesized sandstone clasts are angular and display no evidence of fluvial rounding but instead resemble fragments of talus. The matrix consists mainly of poorly sorted lithic clasts in an apparently devitrified tuff (fig. 4). Subordinately included are subrounded to subangular grains of quartz and feldspar and equant clinopyroxene and plagioclase. The fine-grained part of the matrix contains microlitic feldspar, and a few shard-like structures are still recognizeable despite pervasive diagenetic alteration (fig. 4B). Clast and grain boundaries are commonly oxidized, and interstitial pore spaces are filled by matrix material indicating that the deposit was water saturated and probably warm. Lack of interstitial secondary mineralization suggests that oxidation is a primary 


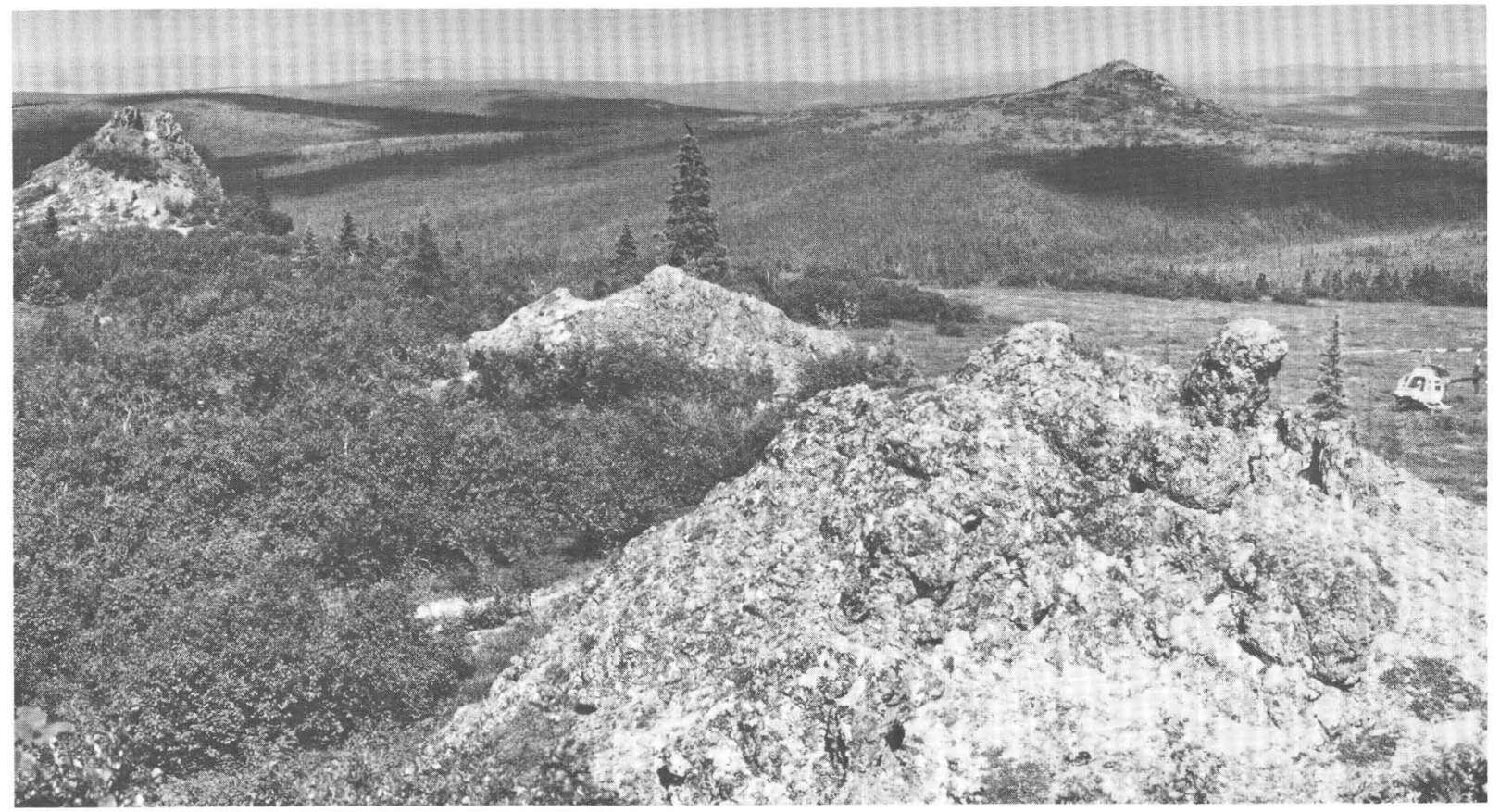

Figure 2. View north showing outcrops of lahar deposit. Distant knob in upper right is Haystack Butte.

feature rather than a consequence of diagenesis (T.E.C. Keith, U.S. Geological Survey, written commun., 1987).

Haystack Butte consists mainly of poorly sorted, matrix-supported, subangular to subrounded clasts of intermediate volcanic rock, sandstone, and shale. As in the neighboring outcrops, volcanic clasts outnumber those of sedimentary origin. Clast size ranges from coarse sand to small pebbles; the matrix is poorly sorted, altered, devitrified lithic tuff very similar to that in the other two outcrops. The deposit also lacks any discernible internal structures such as grading and bedding. The main difference between the Haystack Butte outcrop and those to the southwest is that the larger well-rounded clasts of sedimentary rocks are not present at Haystack Butte.

We interpret the outcrops to be remnants of a volcanic debris flow rather than fluvial deposits because of the lithology and physical characteristics of the clasts and matrix, their internal structures, and areal distribution of the deposit. Most clasts are of volcanic rock, which is typical of lahars (Fisher and Schmincke, 1984), and sedimentary rock clasts are minor. Many of the sedimentary rock clasts are highly angular, and therefore unlikely to have been transported by fluvial processess. The finest part of the matrix also lacks the granularity typical of fluvial sedimentary deposits, and the presence of altered microlitic structures and a few shard-like relies suggests that it originally was tuffaceous. The deposit

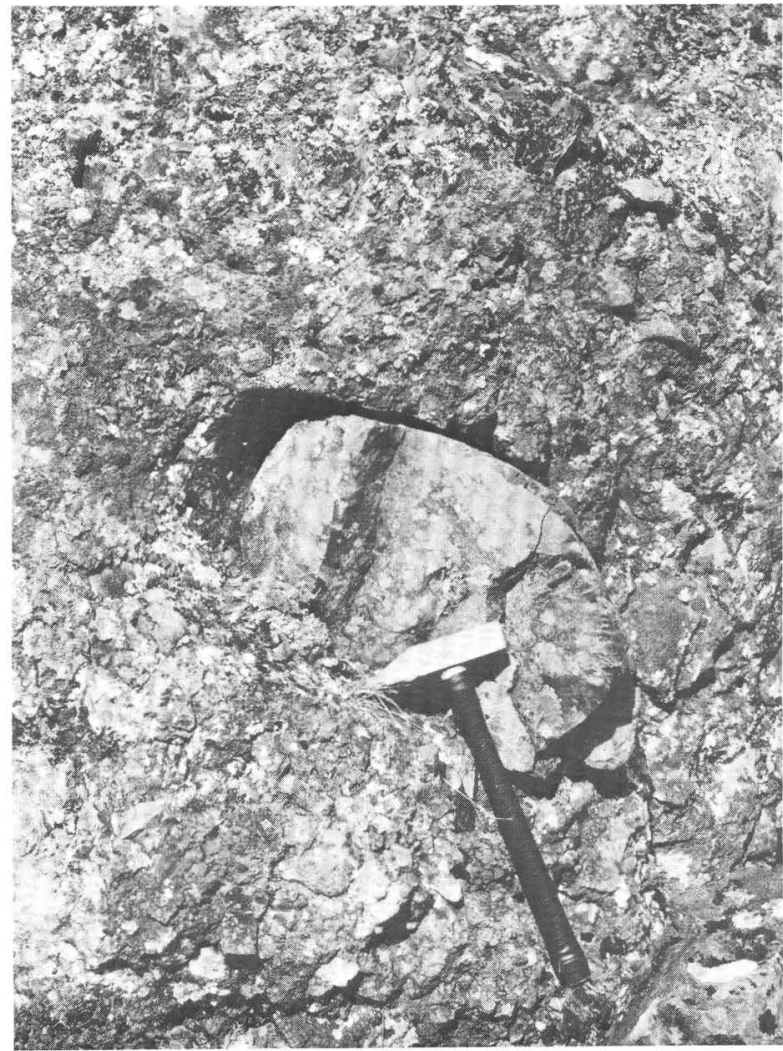

Figure 3. Well-rounded 50-cm-long sandstone clast in poorly sorted tuffaceous matrix. From southernmost outcrop of those shown in figure 1. 


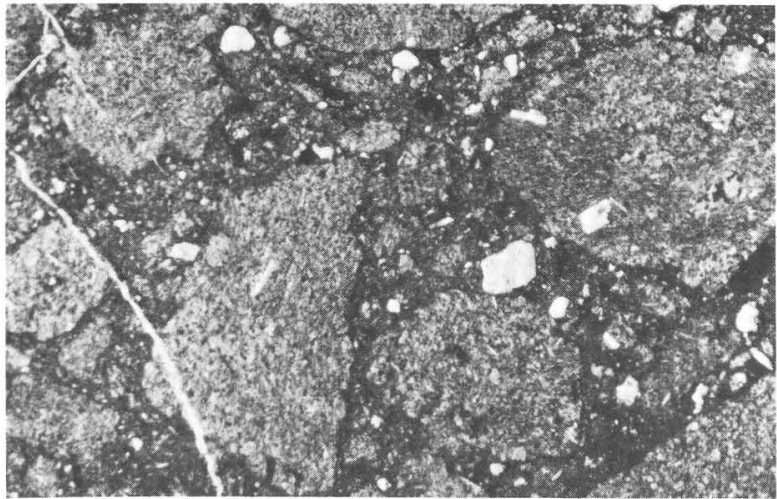

A

MILLIMETER

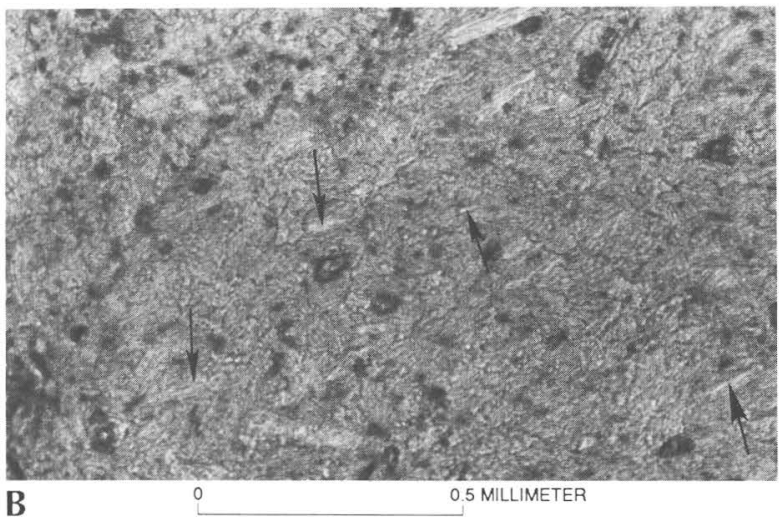

Figure 4. Photomicrographs of matrix of lahar deposit. A, Continuum of grain sizes from clay to sand. B, Finer portion of matrix; presence of relict feldspar microlites (arrows) suggests that matrix may originally have been tuffaceous.

lacks any discernible bedding or grading, and poorly sorted clasts of all sizes are randomly distributed in the supporting matrix. Although some lahars have a crude vertical grading and tend to become more graded and better sorted distally from their source (Riehle and others, 1981; Williams and McBirney, 1979, p. 177), they are typically distinguished from fluvial deposits by their lack of internal stratification. Finally, distribution can be an important characteristic in determining the origin of lahars (Crandell, 1971). The outcrops around Haystack Butte are anomalous in that no similar outcrops occur anywhere else in the vicinity, and their limited distribution, though not conclusive in itself, is consistent with our interpretation of the deposit as a lahar. Deposits of fluvial origin would typically be more widely distributed or might form recognizable channel patterns.

A clue to the origin of the lahar may be the presence of the well-rounded large clasts of sedimentary rock that occur in the two southern exposures. The size and shape of the clasts suggest that they were fluvially transported from a source area having at least moderate relief. In order to account for the relatively local extent of these wellrounded clasts in a debris flow-like deposit composed mostly of volcanic material, we envision a channelized lahar that engulfed and incorporated preexisting stream deposits. The Haystack Butte exposures, which contain smaller rounded clasts, might represent a more distal facies of the lahar.

An alternative model is one in which the lahar engulfed an unlithified, isolated or remnant fluvial or glacial deposit. However, it seems unlikely that such a deposit would exist on or near the flanks of an active volcano within the path of a nonconstricted debris flow. It is also doubtful that a lithified deposit containing the clasts could have been eroded by and incorporated in the lahar because lahars tend not to scour and erode the beds over which they travel (Crandell, 1971; Fisher and Schmincke, 1984; Riehle and others, 1981). Therefore a model in which a channelized lahar incorporates stream deposits from a stream bed seems more viable.

Another interesting aspect of the lahar concerns the source of the well-rounded sandstone and shale cobbles and boulders. Megascopically and microscopically, they are very similar to both the sedimentary rocks of the Kuskokwim Group and to sedimentary rocks of Early Cretaceous age (preKuskokwim) that occur $65 \mathrm{~km}$ north of the volcanic field and extend farther to the north and northwest in the Yukon-Koyukuk basin (M.L. Miller, unpub. data; Patton, 1973). Determining the origin of the clasts could prove useful in interpreting the timing of Iditarod volcanism relative to deposition of the Kuskokwim Group. Samples of the shale clasts from the lahar were submitted for palynological and foraminiferal analysis in an attempt to obtain age data, but they proved to be barren of microfossils.

The presence of the lahar and the well-rounded cobbles and boulders within it implies that the source terrane had considerable topographic relief and probably consisted of one or more volcanoes that adjoined or were built upon an upland composed of sedimentary rocks. However, neither vent-facies rocks nor associated plutonic rocks occur within or near the Iditarod Volcanics, and neither the stratigraphy nor the distribution of rocks in this volcanic field indicates a local, centralized source. The source area must have been eroded away, covered by the products of subsequent volcanic activity, or structurally displaced. Interestingly, a similar volcanic sequence and associated plutonic complex occurs in rugged terrain about $90 \mathrm{~km}$ to the northeast across the Iditarod-Nixon Fork fault, and the lack of a source area for the lahar might be explained by rightlateral offset along the fault (Miller and Bundtzen, this volume).

\section{REFERENCES CITED}

Bundtzen, T.K., and Laird, G.M., 1983, Geologic map of the Iditarod D-1 quadrangle, Alaska: Alaska Division of Geological and Geophysical Surveys Professional Report 78, 1 sheet, scale $1: 63,360$. 
Cady, W.M., Wallace, R.E., Hoare, J.M., and Webber, E.J., 1955, The central Kuskokwim region, Alaska: U.S. Geological Survey Professional Paper 268, 132 p.

Crandel1, D.R., 1971, Postglacial lahars from Mount Rainier Volcano, Washington: U.S. Geological Survey Professional Paper 677, 75 p.

Fisher, R.V., and Schmincke, H.-U., 1984, Pyroclastic rocks: New York, SpringerVerlag, $472 \mathrm{p}$.

Patton, W.W., Jr., 1973, Reconnaissance geology of the Northern Yukon-Koyukuk Province, Alaska: U.S. Geological Survey Professional Paper 774-A, $17 \mathrm{p}$.

Riehle, J.R., Kienle, Jurgen, and Emmel, K.S.,
1981, Lahars in Crescent River Valley, Lower Cook Inlet, Alaska: Alaska Division of Geological and Geophysical Surveys Geologic Report 53, $10 \mathrm{p}$.

Williams, Howell, and McBirney, A.R., 1979, Volcanology: San Francisco, Freeman, Cooper and Co., 397 p.

Reviewers: T.E.C. Keith, E.J. Mol1-Stalcup, and J.R. Riehle

Geologic Studies in Alaska by the U.S. Geological Survey during 1987: John P. Galloway and Thomas D. Hamilton, editors, U.S. Geological Survey Circular 1016. 


\title{
Right-Lateral Offset Solution for the Iditarod-Nixon Fork Fault, Western Alaska
}

\author{
By Marti L. Miller and Thomas K. Bundtzen
}

The Iditarod-Nixon Fork fault, a major northeast-southwest-trending strike-slip fault in western Alaska, is marked throughout its $365-\mathrm{km}$ length by aligned streams, fault scarps of Holocene age, and contrasting regional structural grain (fig. 1). Grantz (1966) ascribed probable right-lateral strikeslip (plus possible dip-slip) movement to this vertical to steeply dipping fault, but was unable to firmly establish the amount of offset. Using the geologic mapping of Brown (1926), Grantz (1966) estimated that Cretaceous rocks were offset by $110 \mathrm{~km}$ in a rightlateral sense; when he used the less detailed mapping of Fernald (1960), only $35 \mathrm{~km}$ offset was found. In a more recent paper on the regional geology of western Alaska, Gemuts and others (1983) suggested approximately $80 \mathrm{~km}$ of offset based on the apparent offset of a contact between lower Paleozoic and Cretaceous sedimentary rocks. In the Iditarod quadrangle, which is bisected by the fault on a northeast-southwest diagonal (fig. 1), our work has revealed a distinct volcanic section that we believe firmly documents between 88 and $94 \mathrm{~km}$ of rightlateral movement since the Late Cretaceous. The offset volcanic rocks are shown in figure 1 as the two areas labeled BMVF (for Beaver Mountains volcanic field) and the Iditarod Volcanics, defined herein.

From 1984 to 1986 , under a cooperative agreement between the U.S. Geological Survey and the Alaska Division of Geological and Geophysical Surveys, we mapped the Iditarod quadrangle as part of an AMRAP (Alaska Mineral Resource Assessment Program) study. The study area is largely underlain by interbedded sandstone, shale, and conglomerate of the upper Lower and Upper Cretaceous Kuskokwim Group (fig. 1). Deep-water turbidite-facies rocks dominate, but shallow shoreline-facies rocks are also present. Late Cretaceous to early Tertiary volcano-plutonic complexes locally intrude and overlie the Kuskokwim Group. Comagmatic volcanic rocks of these complexes either overlie or are in fault contact with monzonite plutons; locally, the plutons intrude and partially assimilate the volcanic rocks (Miller and Bundtzen, 1987). The Kuskokwim Group and overlying volcanic rocks have been deformed into broad, open, northeast- to east-west-trending synclines and anticlines. Numerous high-angle faults, the largest of which is the Iditarod-Nixon Fork fault, cut the regional structure at a slightly oblique angle. In two areas along its length (BMVF and the Iditarod Volcanics, fig. 1), the Iditarod-Nixon Fork fault juxtaposes volcanic rocks against Kuskokwim sedimentary rocks. The BMVF north of the fault is the volcanic section of the moderately well exposed volcano-plutonic complex of the Beaver Mountains (fig. 2). The Iditarod Volcanics, south of the fault, consists of a poorly exposed volcanic section in the vicinity of Decourcy Mountain (fig. 2) that is strikingly similar to the BMVF but that lacks exposures of associated plutonic rocks.

The BMVF was first mapped and described by Bundtzen and Laird $(1982,1983)$ and by Bundtzen and others (1987). The dominantly subaerial volcanic section is 350 to $500 \mathrm{~m}$ thick and overlies sedimentary rocks of the Kuskokwim Group. To accommodate the $1: 250,000$ scale of our AMRAP studies, we have combined the original five map units of Bundtzen and others (1987) into two. The basal unit ("tuff" unit $t$, figs. 2 and 3 ), a heterogeneous unit about $250 \mathrm{~m}$ thick, is characterized by lithic and crystal tuff, volcanic breccia, and light-tan to brick-red altered fine-grained andesite to dacite, but it also has minor, apparently interlayered, quartzose sublithic sandstone, shale, and volcaniclastic sediments. The groundmass of volcanic rock samples from this unit is commonly altered to silica + carbonate \pm chlorite. The basal unit is overlain by a unit ("lava-flow" unit mv, figs. 2 and 3 ) that is characterized by lava flows consisting of fine-grained to porphyritic olivine-clinopyroxene basalt, basaltic andesite, and clinopyroxene-plagioclase andesite; volcanic breccia is sometimes present and probably interfingers with the flow rocks. Most of the volcanic rocks are at least in part altered: olivine phenocrysts to serpentinite and (or) iddingsite and groundmass to chlorite \pm carbonate \pm hematite. The lithologic similarity of the quartzose sublithic sandstone and shale interbedded with the basal tuff unit and the lithic to sublithic sandstone and shale of the underlying Kuskokwim Group led Bundtzen and others (1987) to suggest that the contact was conformable. However, no fossils have been found in either unit, and it is possible that the sandstones are not the same and that a disconformity does exist.

The volcanic rocks of the Decourcy Mountain area, on the southeast side of the Iditarod-Nixon Fork fault, were formally designated the Iditarod Basalt by Cady and others (1955). We propose to redefine the formation as the Iditarod Volcanics because rocks of intermediate composition are as common as mafic rocks in the unit. Bedrock in this area is poorly exposed and outcrops are isolated, thus obscuring contact relationships. We estimate the volcanic section to be between 500 and $600 \mathrm{~m}$ thick, and it probably thins outward. We recognize two mappable units within the Iditarod Volcanics that are lithologically identical to the two units of the BMVF, 
thus we have used the same lithologic-unit symbols ("mv" and "t") in both areas (figs. 2 and 3 ). In the Iditarod Volcanics, the basal tuff unit is characterized by lithic tuff, water-laid tuff, and altered lava flows of intermediate composition, but it also includes a volcaniclastic deposit interpreted to be a lahar (see McGimsey and Miller, this volume). Most rocks of this heterogeneous tuff unit are weakly or intensely altered to secondary silica, carbonate, \pm chlorite. In the Iditarod Volcanics, the overlying lava-flow unit is primarily composed of fine-grained to porphyritic olivine-clinopyroxene basalt and lesser plagioclaseclinopyroxene andesite. Volcanic breccia locally interfingers with flow rocks. Alteration of the volcanic rocks is extensive--olivine to serpentinite \pm carbonate or to white mica \pm serpentinite; clinopyroxene to actinolite \pm carbonate; and groundmass to chlorite \pm carbonate. Plagioclase phenocrysts are generally little altered. The nature of the contact between the Iditarod Volcanics and the underlying Kuskokwim sedimentary rocks is enigmatic. Cady and others (1955) interpreted the contact to be disconformable because they believed the base (our tuff unit) was basal breccia. However, in the same paper, they acknowledged that further south the Iditarod Volcanics possibly intertongues with the Kuskokwim Group and might therefore be referred to as a formation of that group. The critical exposures in our study area are ambiguous, and we cannot say whether the contact is conformable or disconformable. Limited radiometric age data from both the BMVF and the Iditarod Volcanics are summarized in

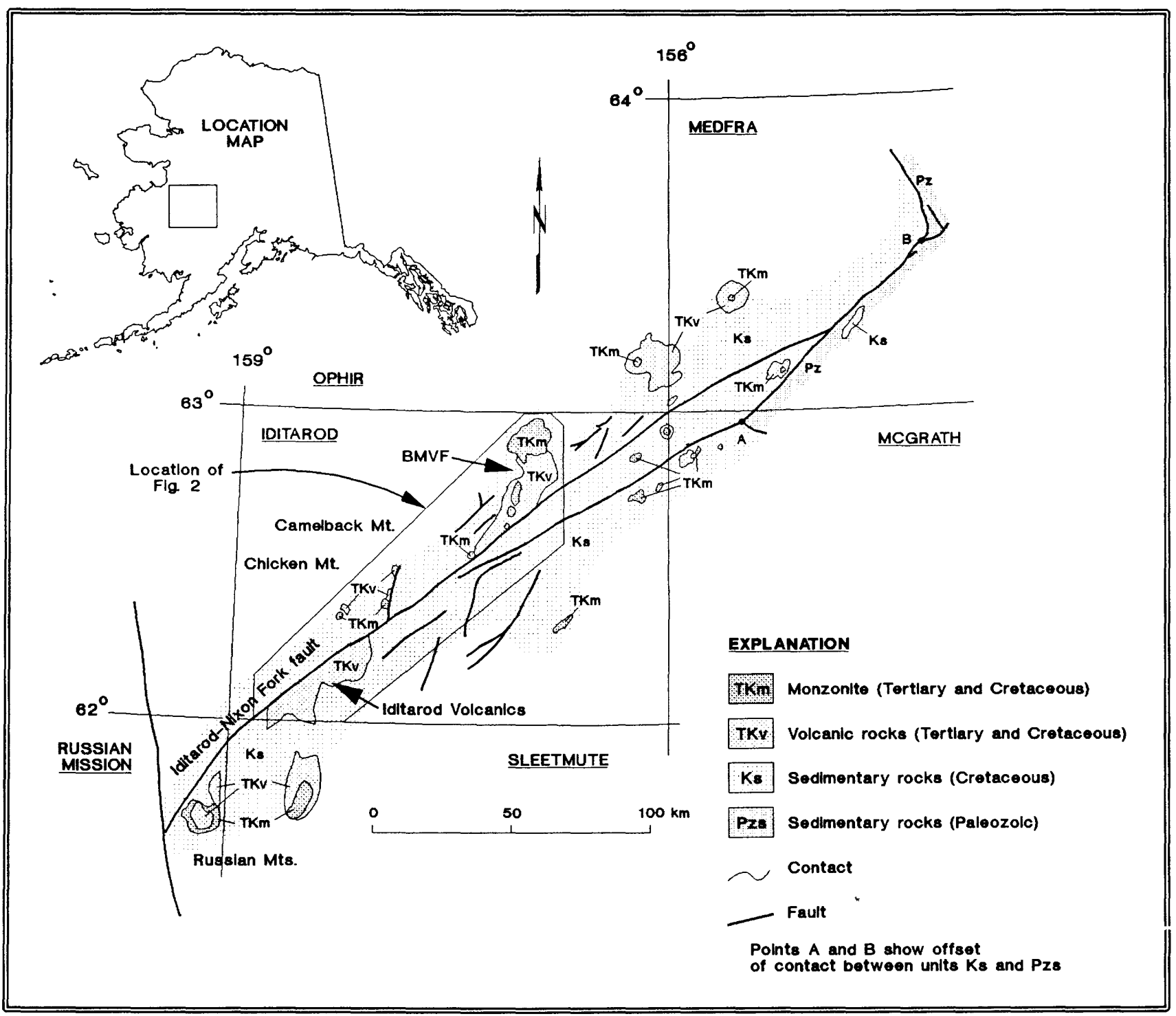

Figure 1. Map showing Iditarod-Nixon Fork fault, proposed offset volcanic rocks of Beaver Mountains volcanic field (BMVF) and Iditarod Volcanics, and associated volcanic rocks and monzonite plutons. Geology modified from Chapman and others (1985) for Ophir quadrangle, Patton and others (1980) for Medfra quadrangle, and Beikman (1980) for Russian Mission and Sleetmute quadrangles. 
table 1. Samples suitable for age determinations have been difficult to obtain due to hydrothermal and thermal effects of underlying plutons throughout the region. Nevertheless, the five ages indicated on table 1 are consistent with field interpretations. In the Decourcy Mountain area, the lower unit of the Iditarod Volcanics yields a $77 \mathrm{Ma}$ age whereas the upper unit yields $66 \mathrm{Ma}$ (minimum age) and $63 \mathrm{Ma}$ ages (fig. 3). In the Beaver Mountains area, the base of the upper unit yields a $76 \mathrm{Ma}$ age whereas its upper part bears a 58 Ma age. Taking into account the limits of analytical error, these ages are in remarkable agreement.

In summary, the lithology, stratigraphic succession, and radiometric ages of the BMVF and the Iditarod Volcanics are very similar. Both sections overlie sedimentary rocks of the Kuskokwim Group and have similar stratigraphic successions. The sequences differ somewhat in the reported nature of the contact with underlying sedimentary rocks of the Kuskokwim Group; however, local unconformities are common in volcanic environments where rapid deposition occurs
(Williams and MeBirney, 1979). We believe that the two sections are the same and that, therefore, they document 88 to $94 \mathrm{~km}$ of right-lateral offset along the Iditarod-Nixon Fork fault.

Several other lines of evidence support our conclusion. First, the Iditarod Volcanics are typical of volcanic rocks associated with volcano-plutonic complexes in west-central Alaska, yet there are no exposed monzonitic plutons spatially associated with these rocks. However, when the right-lateral movement is restored, the Iditarod Volcanics are spatially associated with the monzonites of Camelback Mountain (fig. 1). Second, the amount of movement that we have proposed approximates the offset of the Paleozoic-Cretaceous contact in the Medfra quadrangle (points A and B, fig. 1). Third, when the right-lateral movement is restored, the volcanoplutonic complex of Chicken Mountain in the Iditarod quadrangle and that of the Russian Mountains further to the southwest (fig. 1) line up along a north-south line. The emplacement of the plutons and volcanic

\section{EXPLANATION}

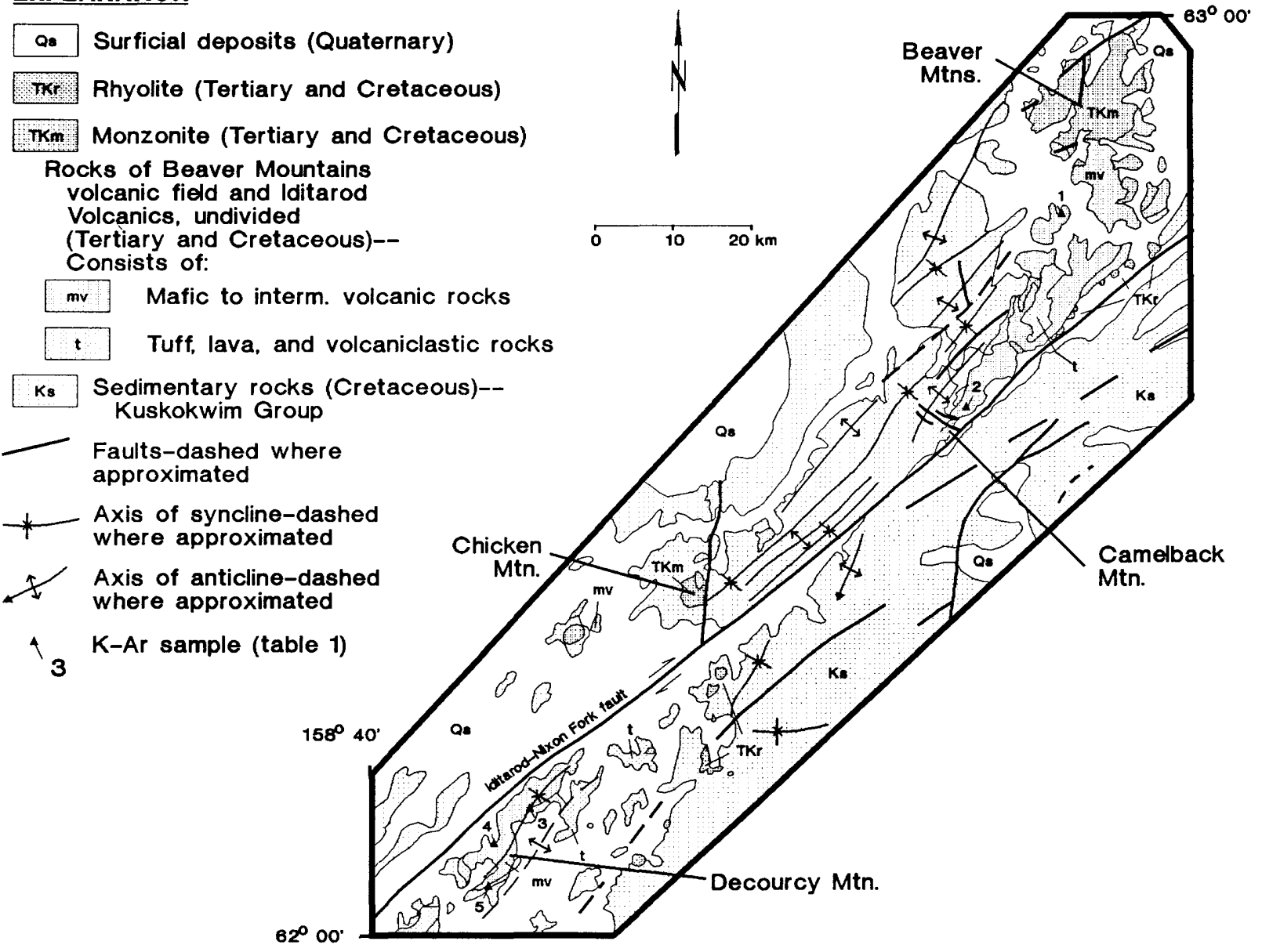

Figure 2. Detailed geologic map of Beaver Mountains volcanic field and Iditarod Volcanics of north-central and southwestern Iditarod quadrangle. 
Beaver Mountains Volcanic Field (BMVF)

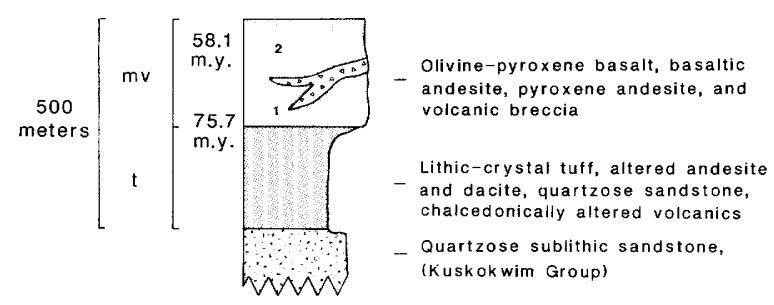

Decourcy Mountain (Iditarod Volcanics)

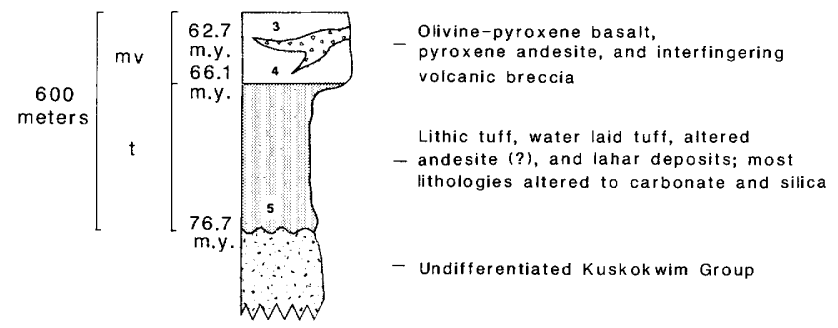

Figure 3. Composite sections of Beaver Mountains volcanic field (BMVF) and Iditarod Volcanics showing stratigraphic subdivisions and locations (1-5, table 1, fig. 1) of K-Ar samples (ages in Ma). mv, mafic to intermediate volcanic rocks; t, tuff, lava, and volcaniclastic rocks. rocks appears to be controlled by high-angle faults (Miller and Bundtzen, 1987), and we have mapped a fault of this type that trends north-south through Chicken Mountain. We suggest that the offset extension of this fault runs along the eastern edge of the Russian Mountains.

Because the volcanic sections are Late Cretaceous to early Tertiary in age, the 88-94 km of movement along the Iditarod-Nixon Fork fault has taken place since that time. Bundtzen and others (1987) reported that a prominent escarpment cuts Quaternary fan-terrace deposits in the Iditarod C-3 quadrangle, strongly suggesting that activity has continued into the Holocene.

\section{REFERENCES CITED}

Beikman, H.M., compiler, 1980, Geologic map of Alaska: U.S. Geological Survey, 2 sheets, scale: $1: 2,500,000$.

Brown, J.S., 1926, The Nixon Fork country: U.S. Geological Survey Bulletin 783-D, p. 97-150.

Bundtzen, T.K., and Laird, G.M., 1982, Geologic map of the Iditarod D-2 and eastern D-3 quadrangles, Alaska: Alaska Division of Geological and Geophysical Surveys Geologic Report 72 , scale $1: 63,360$.

Table 1. Potassium-argon analytical data for volcanic rocks from the Beaver Mountains volcanic field (BMVF) and from the Iditarod Volcanics [Locality numbers are shown on figure 2 . Constants used: $40_{\mathrm{K} / \mathrm{K}}=1.167 \times 10^{-4} \mathrm{~mol} / \mathrm{mol} ; \lambda_{\mathrm{e}}=0.581 \times 10^{-10} \mathrm{yr}^{-1} ; \lambda_{\mathrm{b}}=4.962 \times 10^{-10} \mathrm{yr}^{-1}$ ]

\begin{tabular}{ccccccc}
\hline Map No. & Field $^{2}$ & Rock & Material & $\mathrm{K}_{2} \mathrm{O}$ & Ar rad & $\begin{array}{r}\text { Ar rad } \\
\text { (pct) }\end{array}$ Age \\
(Ma)
\end{tabular}

\begin{tabular}{|c|c|c|c|c|c|c|c|}
\hline$\frac{1}{(82 \mathrm{BT} 392)}$ & $\begin{array}{c}\text { BMVF } \\
\text { (base of } \\
\text { mv) }\end{array}$ & Andesite & $\begin{array}{l}\text { Plagio- } \\
\text { clase }\end{array}$ & $x=0.600$ & 6.68 & 35.3 & $75.7 \pm 2.3$ \\
\hline $\begin{array}{c}2 \\
(84 \mathrm{BT} 277)\end{array}$ & $\begin{array}{l}\text { BMVF } \\
\text { (mV) }\end{array}$ & $\begin{array}{l}\text { Olivine } \\
\text { basalt }\end{array}$ & $\begin{array}{l}\text { Whole } \\
\text { rock }\end{array}$ & $\begin{array}{r}2.653 \\
2.760 \\
x=2.760\end{array}$ & 23.02 & 33.6 & $58.1 \pm 1.9$ \\
\hline $\begin{array}{c}3 \\
(85 \mathrm{BT} 106)\end{array}$ & $\begin{array}{l}\text { Iditarod } \\
(\mathrm{mv})\end{array}$ & $\begin{array}{l}\text { Olivine } \\
\text { basalt }\end{array}$ & $\begin{array}{l}\text { Plagio- } \\
\text { clase }\end{array}$ & $\begin{array}{r}0.582 \\
0.579 \\
\times=0.579\end{array}$ & 5.32 & 79.7 & $62.7 \pm 1.9$ \\
\hline $\begin{array}{c}4 \\
(85 A M 46 A)\end{array}$ & $\begin{array}{l}\text { Iditarod } \\
(\mathrm{mv})\end{array}$ & $\begin{array}{l}\text { Olivine } \\
\text { basalt }\end{array}$ & $\begin{array}{l}\text { Whole } \\
\text { rock }\end{array}$ & $\begin{array}{r}2.120 \\
2.150 \\
x=1.308\end{array}$ & 20.70 & 67.6 & $66.1 \pm 2.0$ \\
\hline $\begin{array}{c}5 \\
(84 \mathrm{BT} 256)\end{array}$ & $\begin{array}{l}\text { Iditarod } \\
\text { (t) }\end{array}$ & Andesite & $\begin{array}{l}\text { Whole } \\
\text { rock }\end{array}$ & $\begin{array}{r}1.303 \\
1.313 \\
x=1.308\end{array}$ & 14.76 & 15.3 & $76.7 \pm 2.3$ \\
\hline
\end{tabular}

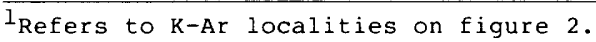

$2_{\mathrm{BMVF}}=$ Beaver. Mountains volcanic field; Iditarod = Iditarod Volcanics. 
---- 1983, Preliminary geology of the northeastern Iditarod C-3 quadrangle, Alaska: Alaska Division of Geological and Geophysical Surveys Report of Investigations 83-13, scale $1: 63,360,6 \mathrm{p}$.

Bundtzen, T.K., Laird, G.M., and Lockwood, M.S., 1987, Geology of the Iditarod C-3 quadrangle, Alaska: Alaska Division of Geological and Geophysical Surveys Professional Report 96, scale $1: 63,360,11$ p.

Cady, W.M., Wallace, R.E., Hoare, J.M., and Webber, E.J., 1955, The central Kuskokwim region, Alaska: U.S. Geological Survey Professional Paper 268, 132 p.

Chapman, R.M., Patton, W.W., Jr., and Mol1, E.J., 1985, Reconnaissance geologic map of the Ophir quadrangle, Alaska: U.S. Geological Survey Open-File Report 85-203, scale $1: 250,000,17 \mathrm{p}$.

Fernald, A.T., 1960, Geomorphology of the upper Kuskokwim region, Alaska: U.S. Geological Survey Bulletin 1071-G, p. 191-279.

Gemuts, I., Puchner, C.C., and Steffel, C.I., 1983, Regional geology and tectonic history of western Alaska, in Symposium on Western
Alaska Geology and Resource Potential Proceedings, February 16 and 17, 1982, Anchorage, Alaska: Journal of the Alaska Geological Society, p. 67-85.

Grantz, Arthur, 1966, Strike-slip faults in Alaska: U.S. Geological Survey Open-File Report 267, 82 p.

Miller, M.L., and Bundtzen, T.K., 1987, Geology and mineral resources of the Iditarod quadrangle, west-central Alaska: U.S. Geological Survey Circular 995, p. 46-47.

Patton, W.W., Jr., Mo11, E.J., Dutro, J.T., Jr., Silberman, M.L., and Chapman, R.M., 1980, Preliminary geologic map of the Medfra quadrangle, Alaska: U.S. Geological Survey Open-File Report 80-811A, scale 1:250,000.

Williams, Howel1, and McBirney, A.R., 1979, Volcanology: San Francisco, Freeman, Cooper and Co., 397 p.

Reviewers: T.E.C. Keith and W.W. Patton, Jr.

Geologic Studies in Alaska by the U.S. Geological Survey during 1987: John P. Galloway and Thomas D. Hamilton, editors, U.S. Geological Survey Circular 1016. 


\title{
Geologic Setting and Petrography of the Phyllite and Metagraywacke Thrust Panel, North-Central Alaska
}

\author{
By John M. Murphy and W.W. Patton, Jr.
}

Exposures of a laterally persistent thrust panel composed of pelitic phyllite and quartzose metagraywacke border the southern Brooks Range and both flanks of the Ruby geanticline in north-central Alaska (fig. 1). The phyllite and metagraywacke thrust panel is the lowest of three thrust panels composing the Angayucham-Tozitna terrane (Patton and others, in press). It is structurally overlain by a laterally extensive thrust panel of imbricated basalt and chert of Devonian to Early Jurassic age, which in turn is overlain by a thrust panel of gabbro and peridotite (Patton and Box, 1985), which are not separated on figure 1. Obduction of the three thrust panels onto the Precambrian to middle Paleozoic miogeoclinal rocks of both the southern Brooks Range and the Ruby geanticline is believed to have occurred in latest Jurassic to Early Cretaceous time due to collision of the intraoceanic Koyukuk arc (Patton and Box, 1985). The purpose of this report is to summarize the distribution, structural position, emplacement history,

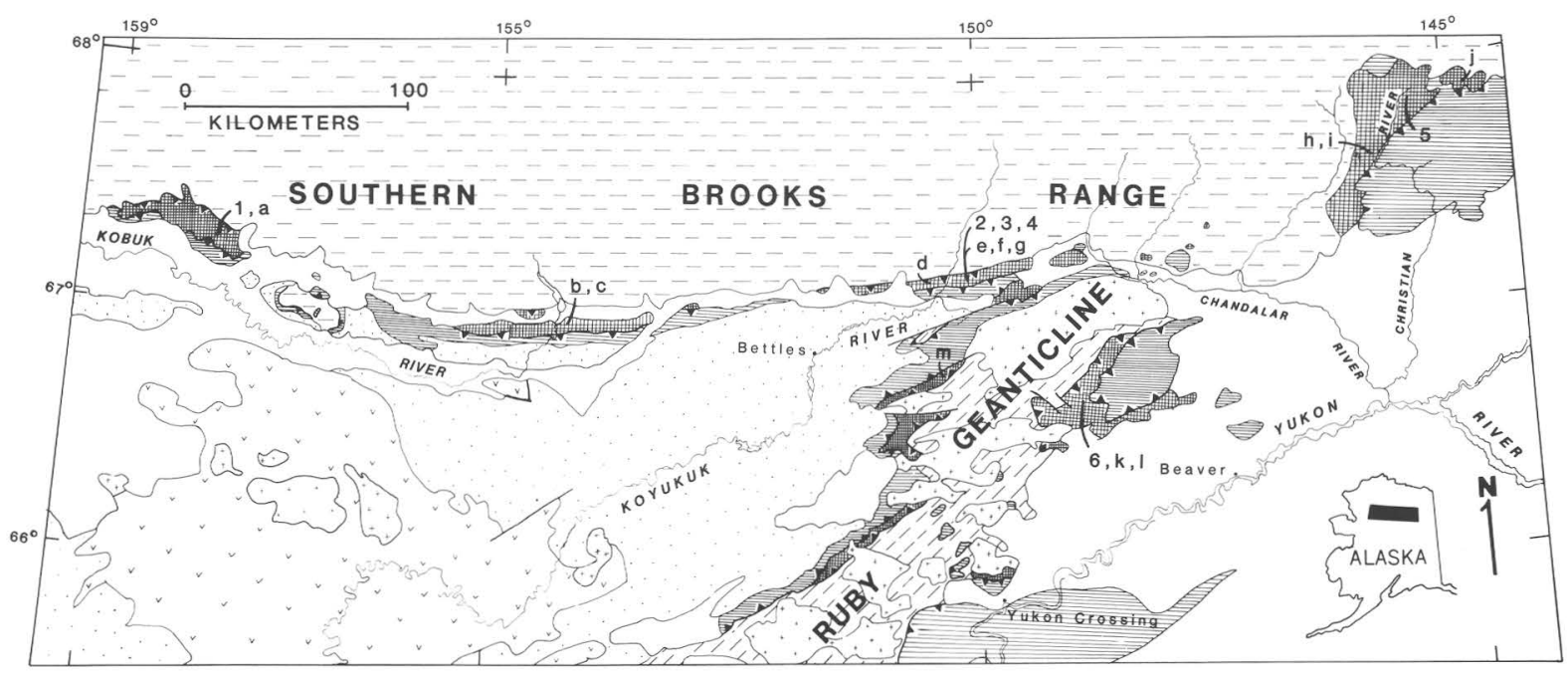

Overlap Assemblages

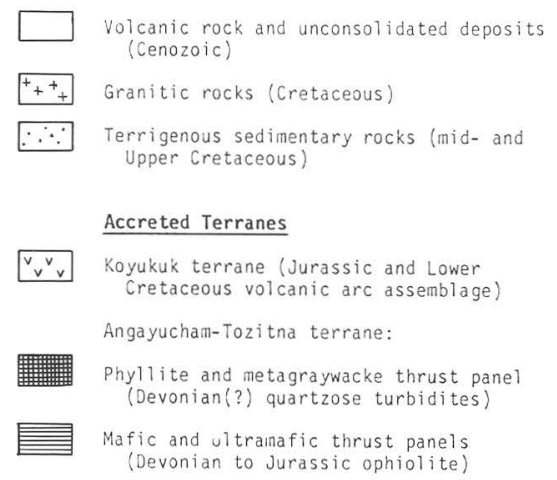

Continental Borderlands

-Z Southern Brooks Range (Precambrian and lower Paleozoic

Ruby Geanticline (Precambrian(?) and lower Paleozoic

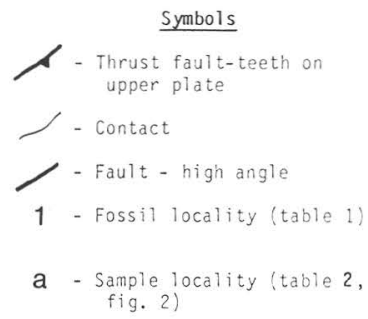

Figure 1. Generalized geologic map of north-central Alaska showing distribution of overlap assemblages, accreted terranes and continental borderlands. Numbers refer to fossil localities given in table 1. Letters refer to petrographic data given in table 2 and plotted on figure 2. Geology modified from W.W. Patton (unpub. data). 
age, sedimentology and petrography of the phyllite and metagraywacke thrust panel.

Our mapping shows that the phyllite and metagraywacke thrust panel can be correlated for more than $500 \mathrm{~km}$ along the southern Brooks Range and for more than $400 \mathrm{~km}$ along both the northeast and southwest flanks of the Ruby geanticline. Sparse fossils have been recovered from the thrust panel, primarily from the southern Brooks Range, but also from the east flank of the Ruby geanticline (fig. 1 and table 1). The maximum range of ages given by these fossils is late Early Devonian to Triassic or Early Jurassic. This large and poorly constrained age range is compatible with regional geologic relations. For example, the youngest possible depositional age of rocks in the thrust panel is Early Cretaceous, constrained by recycled metagraywacke clasts in deposits of Albian age (Dillon and Smiley, 1984), by crosscutting mid-Cretaceous granitic plutons in the Ruby geanticline (Patton and Box, 1985), and by reset $\mathrm{K}-\mathrm{Ar}$ ages of schistose metamorphic rocks of the southern Brooks Range (Turner and others, 1979; Turner, 1984). We believe, however, that only the Devonian fossils give reliable ages because the cherts giving younger ages have been interpreted as faultbounded blocks in the phyllite (table 1, Jones and others, in press). If the nonmarine deposits of the Upper Devonian to Lower Mississippian(?) Kanayut Conglomerate (Nilsen and Moore, 1984) are correlative with the deep marine deposits of the phyllite and metagraywacke thrust panel, then deposition in the thrust panel may have ceased around Mississippian time.

Sedimentary structures within the phyllite and metagraywacke panel are exposed in outcrops along the southern Brooks Range and in borrow pits near the Dalton highway along the Ruby geanticline. These features indicate that original sediment deposition occurred on shale-dominated submarine turbidite systems with abundant fine- to medium-grained turbidites and minor debris flows. The average ratio of phyllite to graywacke is about 4:1. Exposures near the Kobuk, Koyukuk, and Christian Rivers show thinto medium-bedded sandstone beds with erosive bases, shale rip-ups, normal grading, and well-developed Bouma sequences (W.W. Patton, U.S. Geological Survey unpub. field notes, 1970, 1973, 1984; W.P. Brosge, U.S. Geological Survey unpub. field notes, 1962, 1963). At locality 1 (fig. 1 and table 1), impure limestone turbidites and carbonate debris associated with vesicular volcanic flow-breccia contain reworked fossils derived from middle Paleozoic platformcarbonate deposits, suggesting deposition adjacent to a continental margin (Patton and others, in press). The petrography of metagraywacke, discussed below, supports this interpretation. The presence of radiolarian chert interbedded with graywacke turbidites suggests that deposits near the Koyukuk River may have formed in a deep submarine environment (Dillon and others, 1986). For the same area, however, Gottschalk (1987) reports oscillatory ripples and hummocky cross-stratification, both of which indicate deposition above storm-wave base. Because the shallow-marine indicators are limited, we suggest that deposits composing the phyllite and metagraywacke thrust panel are mainly deep-marine turbidites.

Preliminary petrographic studies of 51 thin sections of sandstone from the phyllite and metagraywacke thrust panel resulted in the selection of 13 thin sections from widely separated areas for point-counting. Point counts of over 400 detrital grains per thin section were performed using the traditional method of counting. Criteria for counting focused on decreasing the combined effects of incipient foliation, matrix recrystallization, pressure

Table 1. Fossils from the phyllite and metagraywacke thrust panel

\begin{tabular}{|c|c|c|c|}
\hline $\begin{array}{l}\text { Locality } \\
(\mathrm{fig} \cdot 1)\end{array}$ & Age & $\begin{array}{c}\text { Fossil and host } \\
\text { Iithology }\end{array}$ & Author \\
\hline 1 & $\begin{array}{l}\text { Devonian to Late } \\
\text { Mississippian- } \\
\text { Pennsylvanian(?) }\end{array}$ & $\begin{array}{l}\text { Conodonts reworked } \\
\text { from shallow water in } \\
\text { limestone turbidites }\end{array}$ & $\begin{array}{l}\text { A.G. Harris, } \\
\text { USGS } \\
(1984)\end{array}$ \\
\hline 2 & $\begin{array}{l}\text { Late-Early } \\
\text { Devonian } \\
\text { (Siegian-Emsian) }\end{array}$ & $\begin{array}{l}\text { Palynomorphs in } \\
\text { phyllite }\end{array}$ & $\begin{array}{l}\text { Gottschalk } \\
(1987)\end{array}$ \\
\hline 3 & $\begin{array}{l}\text { Mississippian and } \\
\text { Triassic }\end{array}$ & $\begin{array}{l}\text { Radiolarians in chert } \\
\text { interbedded with } \\
\text { graywacke }\end{array}$ & $\begin{array}{l}\text { Dillon and others } \\
\text { (1986) }\end{array}$ \\
\hline 4 & $\begin{array}{l}\text { Mississippian, } \\
\text { and Triassic- } \\
\text { Early Jurassic }\end{array}$ & $\begin{array}{l}\text { Radiolarians in fault } \\
\text { slices of chert in } \\
\text { phyllite }\end{array}$ & $\begin{array}{l}\text { Jones and others } \\
\text { (in press) }\end{array}$ \\
\hline 5 & $\begin{array}{l}\text { Possible Middle } \\
\text { or Late Devonian }\end{array}$ & $\begin{array}{l}\text { Palynomorphs in } \\
\text { shale }\end{array}$ & $\begin{array}{l}\text { Brosge and Reiser } \\
\text { (1962) }\end{array}$ \\
\hline 5,6 & Probable Devonian & $\begin{array}{l}\text { Plant fragments in } \\
\text { shale and graywacke }\end{array}$ & $\begin{array}{l}\text { Brosge and Reiser } \\
(1962) ; \text { Brosge, } \\
\text { and others (1973) }\end{array}$ \\
\hline 6 & $\begin{array}{l}\text { Probable Late } \\
\text { Devonian }\end{array}$ & $\begin{array}{l}\text { Spiriferid brachiopod } \\
\text { in impure limestone } \\
\text { beds in graywacke }\end{array}$ & $\begin{array}{l}\text { Brosge and others } \\
(1973)\end{array}$ \\
\hline
\end{tabular}


solution, and sorting on bulk rock composition. All sand-size grains $(0.0625-0.5 \mathrm{~mm})$ were counted. Grains smaller than $0.0625 \mathrm{~mm}$ were counted as matrix.

Sandstones from the phyllite and metagraywacke thrust panel are compositionally mature, texturally immature, quartzose litharenites. They consist predominantly of angular to subangular, very fine to medium-grained, moderately sorted grains in pelitic, clay-silt matrix. Matrix ranges between 5 and 25 percent. Framework grains include polygonalpolycrystalline quartz, monocrystalline quartz, unfoliated chert, plagioclase, K-feldspar (microcline), voleanic lithics, sedimentary lithics, metamorphic lithies and plutonie lithics. Voleanic lithics include microlitic and lathwork grains, and greenstone with unfoliated chlorite matrix. Sedimentary lithics are mainly shale and siltstone, with minor recycled quartzchert sandstone. Metamorphic lithics are predominantly quartz-mica schist and gneiss with polygonal internal crystal margins. Minor pelitic phyllite, quartz-tourmaline schist and rare quartzepidote schist also occur. Plutonic lithics are granitic, composed of aggregates of quartz, feldspars and micas. Because of point-counting conventions and the fine grain size of sandstones, amounts of plutonic clasts are underestimated. The unfoliated pelitic gneiss clasts counted as metamorphic lithics probably had plutonic sources. Accessory detrital minerals are white mica, biotite, chlorite, undifferentiated opaques, zircon, tourmaline, sphene, carbonate, myrmekite, and epidote.

Detrital modes from point counts indicate that samples from widely separated areas of the phyllite and metagraywacke thrust panel have similar compositions (table 2). Quartzose grains (including chert) predominate, as single crystals and as plutonic and metamorphic rock fragments. On a QFL provenance diagram (fig. 2A), all samples plot near the $Q$ pole, corresponding to the recycled orogen provenance field of Dickinson (1985). On the QmFLt diagram (fig. 2B) all but two of the samples shift into either the transitional- or lithic recycled-orogen provenance fields when chert and polycrystalline quartz are moved from the $Q$ pole to the Lt pole. Two samples with greater than 10 percent plagioclase overlap slightly into the transitional arc provenance field. These two samples also contain significant lathwork voleanic grains, indicating local volcanic sources.

Although the source areas suggested by provenance diagrams are mainly compressional regimes, including lithic- and transitional-recycled orogens, the unfoliated nature of chert, polycrystalline quartz, and metamorphic lithic fragments suggests that the source region(s) may have been uplifted in a noncompressional (extensional or transform) setting. The textural immaturity of sandstones from the phyllite and metagraywacke thrust panel indicates rapid erosion and redeposition. In contrast, their consistent quartzose compositions indicate compositional maturity, which argues either for intense chemical or physical reworking of a heterogeneous source, or for simpler distribution from a homogeneous source. At present, we consider the source region(s) to have had a limited original composition range, that is, one dominated by granitic plutonic and unfoliated quartzose metamorphic rocks, and by unfossiliferous, unfoliated chert. The source must also have produced abundant pelitic shale, which during deformation became phyllite.

In summary, recent regional geologic compilations and new petrographic data indicate that a laterally persistent thrust panel composed of lowgrade pelitic phyllite and quartzose metagrawacke is the lowest of three internally imbricated thrust panels, composing the Angayucham-Tozitna terrane, that were obducted onto continental platform rocks of both the southern Brooks Range and the Ruby geanticline during latest Jurassic to Early Cretaceous time. The phyllite and metagraywacke thrust panel was deposited as

Table 2. Point-count data for the phyllite and metagraywacke thrust panel

$[\mathrm{Qm}=$ monocrystalline quartz, $\mathrm{Qp}=$ polycrystalline quartz, $\mathrm{C}=$ chert, $\mathrm{P}=$ plagioclase, $\mathrm{K}=$ potassium feldspar, $\mathrm{Lv}=$ volcanic lithics, $\mathrm{Ls}=$ sedimentary lithics, $\mathrm{Lm}=$ metamorphic lithics. $Q^{*}=Q m+Q p+C ; F=P+K ; L^{-}=L v+L s+L m ; L_{t}=L^{-}+Q p+C$. See figure 2 for triangular plots of the data. $Q^{*} F L^{-}$is equivalent to $Q F L$ of Dickinson (1985). Sample localities are plotted on figure 1.]

\begin{tabular}{|c|c|c|c|c|c|c|c|c|c|c|c|c|c|}
\hline Grain type & A & B & c & D & $\mathrm{E}$ & F & G & H & I & $\mathrm{J}$ & K & $\mathbf{L}$ & M \\
\hline inn & 72 & 87 & 94 & 109 & 105 & 70 & 72 & 123 & 167 & 133 & 65 & 38 & 75 \\
\hline up & 167 & 200 & 195 & 85 & 90 & 112 & 102 & 154 & 118 & 135 & 165 & 163 & 244 \\
\hline $\mathrm{C}$ & 57 & 40 & 50 & 103 & 106 & 139 & 85 & 58 & 59 & 95 & 60 & 105 & 49 \\
\hline$P$ & 68 & 22 & 19 & 28 & 31 & 26 & 66 & 1 & 3 & 2 & 12 & 16 & 1 \\
\hline k & - & 3 & 3 & - & 2 & - & - & - & - & - & - & - & - \\
\hline L,V & 12 & 17 & 23 & 22 & 27 & 17 & 75 & 1 & 1 & 5 & 13 & 11 & 2 \\
\hline LS & 12 & 18 & 4 & 28 & 21 & 23 & 22 & 18 & 9 & 16 & 15 & 16 & 18 \\
\hline $\mathrm{Lm}$ & 26 & 32 & 26 & 34 & 29 & 33 & 17 & 50 & 46 & 23 & 73 & 51 & 15 \\
\hline Biotite & - & 4 & - & 3 & 4 & 8 & - & 2 & 10 & 15 & 7 & 1 & 1 \\
\hline White Mica & 2 & 1 & 3 & 5 & 1 & 3 & - & 8 & 11 & 2 & 5 & 3 & 9 \\
\hline Chlorite & - & 3 & 1 & 1 & 1 & 4 & 4 & - & 4 & 3 & - & 2 & - \\
\hline Opaque & 2 & 4 & 2 & 18 & 6 & 3 & 4 & - & 2 & 8 & 1 & 10 & 1 \\
\hline Zircon & 1 & - & - & - & 1 & - & - & - & 3 & 1 & 1 & 2 & - \\
\hline Tourmaline & - & - & - & - & 1 & - & - & 1 & 1 & - & - & - & - \\
\hline Sphene & - & - & - & - & - & 1 & 3 & - & - & - & - & - & $\overrightarrow{0}$ \\
\hline Matrix & 38 & 61 & 39 & 59 & 49 & 48 & 32 & 110 & 69 & 135 & 61 & 40 & 28 \\
\hline Total Points & 457 & 492 & 459 & 495 & 474 & 486 & 482 & 526 & 503 & 573 & 478 & 458 & 443 \\
\hline Total Grains & 419 & 431 & 420 & 436 & 425 & 438 & 450 & 416 & 434 & 438 & 417 & 418 & 415 \\
\hline Pct. Matrix & 8 & 12 & 8 & 12 & 10 & 10 & 6 & 21 & 14 & 24 & 13 & 9 & 6 \\
\hline$Q^{\star}: F: L^{-}$ & $72: 16: 12$ & $78: 6: 16$ & $82: 5: 13$ & $73: 7: 20$ & $73: 8: 19$ & $76: 6: 17$ & $61: 14: 25$ & $91: 0: 9$ & $83: 0: 17$ & $89: 0: 11$ & $72: 3: 25$ & $76: 4: 20$ & $91: 0: 9$ \\
\hline$Q_{m}: F: L_{t}$ & $17: 16: 67$ & $21: 6: 73$ & $23: 5: 72$ & $27: 7: 66$ & $26: 8: 66$ & $17: 6: 77$ & $16: 14: 70$ & $33: 0: 67$ & $42: 0: 58$ & $33: 0: 67$ & $16: 3: 78$ & $10: 4: 86$ & $19: 0: 81$ \\
\hline Skip dist. & $0.4 \mathrm{~mm}$ & $0.5 \mathrm{~mm}$ & $0.4 \mathrm{~mm}$ & $0.5 \mathrm{~mm}$ & $0.4 \mathrm{~mm}$ & $0.4 \mathrm{~mm}$ & $0.5 \mathrm{~mm}$ & $0.3 \mathrm{mtn}$ & $0.4 \mathrm{~mm}$ & $0.4 \mathrm{~mm}$ & 0.4 ann & $0.5 \mathrm{~mm}$ & $0.3 \mathrm{~mm}$ \\
\hline
\end{tabular}




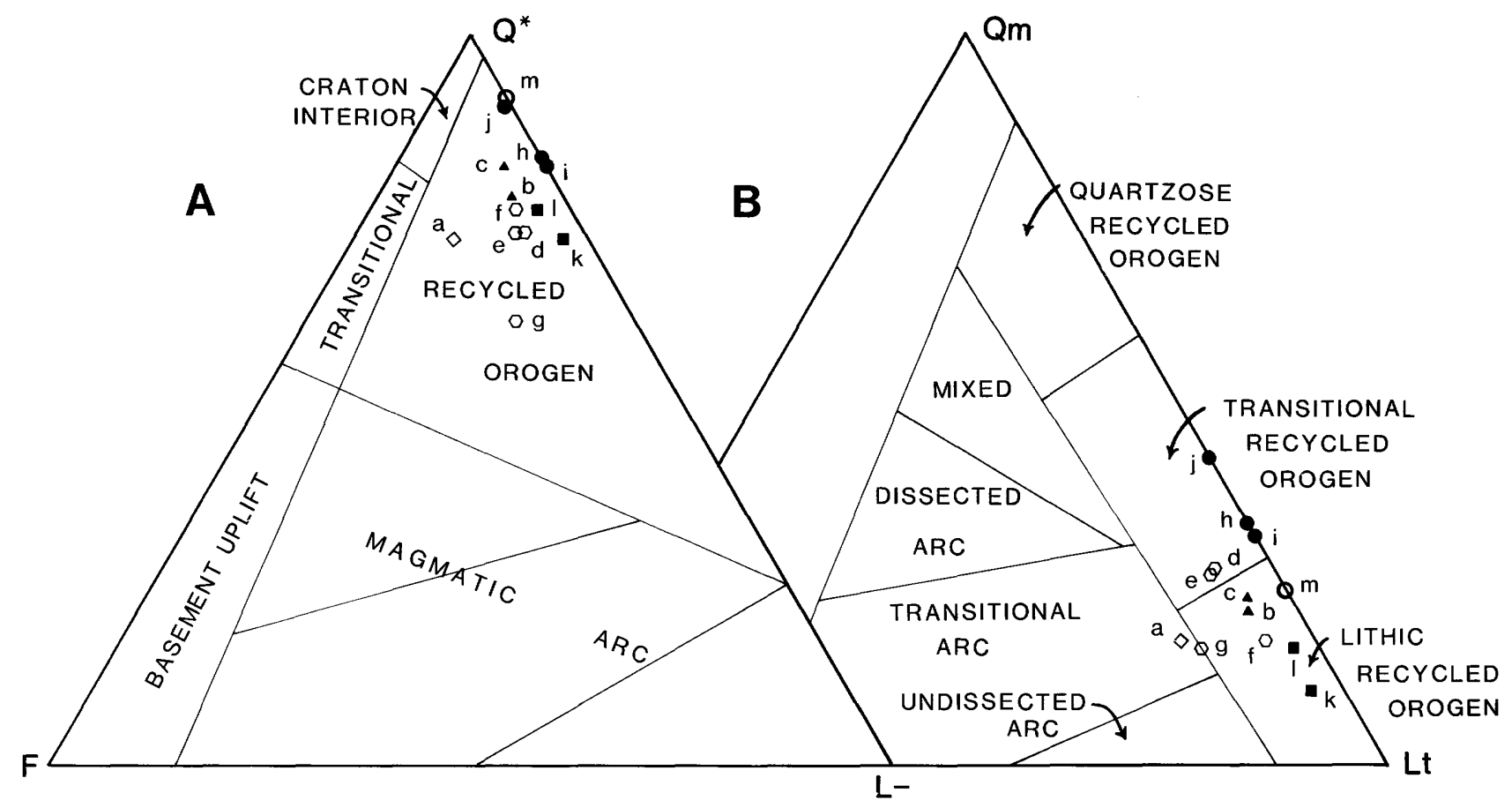

Figure 2. Triangular diagrams showing compositional modes of metagraywacke from phyllite and metagraywacke thrust panel. $\mathrm{Q}^{*} \mathrm{FL}-$ diagram is equivalent to QFL of Dickinson (1985). Provenance fields from Dickinson (1985). Letters correspond to sample data given in table 2 and sample localities on figure 1. See table 2 for explanation of symbols.

continent-derived quartzose turbidites mainly during Devonian time. Compositions of sandstones indicate that sediments were derived from granitic, quartzose metamorphic, unfoliated sedimentary, and minor volcanic sources. The texturally immature sandstones, deposited as turbidites, suggest their rapid transport and deposition. The unfoliated nature of most clasts suggests that the source region was uplifted by extensional processes, perhaps by rifting along a passive continental margin.

\section{REFERENCES CITED}

Brosge, W.P. and Reiser, H.N., 1962, Preliminary geologic map of the Christian quadrangle, Alaska: U.S. Geological Survey Open-File Map 62-229, 2 sheets, scale 1:250,000.

Brosge, W.P., Reiser, H.N., and Yeend, Warren, 1973, Reconnaissance geologic map of the Beaver quadrangle, Alaska: U.S. Geological Survey Miscellaneous Field Studies Map MF525, scale 1:250,000.

Dickinson, W.R., 1985, Interpreting provenance relations from detrital modes of sandstone, in Zuffa, G.G., ed., Provenance of arenites, Proceedings of NATO Advanced Studies Institute on reading provenance from arenites: Amsterdam, D. Reidel, p. 333-361.

Dillon, J.T., Brosge, W.P., and Dutro, J.T., Jr., 1986, Generalized geologic map of the Wiseman quadrangle, Alaska: U.S. Geological Survey Open-File Report 86-219, 2 sheets, scale $1: 250,000$.
Dillon, J.T., and Smiley, C.J., 1984, Clasts from the Early Cretaceous Brooks Range orogen in Albian to Cenomanian molasse deposits of the northern Koyukuk Basin, Alaska [abs.]: Geological Society of America, Abstracts with Programs, v. 16, no. 5, p. 279 .

Gottschalk, R.R., Jr., 1987, Structural and petrologic evolution of the Southern Brooks Range near Wiseman, Alaska: Houston, Rice University, Ph.D. thesis, $263 \mathrm{p}$.

Jones, D.L., Coney, P., Harms, T.A., and Dillon, J.T., [in press], Interpretive bedrock geologic map and supporting radiolarian data from the Angayucham terrane, Coldfoot area, southern Brooks Range, Alaska: U.S. Geological Survey Miscellaneous Field Studies Map MF-.

Nilsen, T.H., and Moore, T.E., 1984, Stratigraphic nomenclature for the Upper Devonian and lower Mississippian(?) Kanayut Conglomerate, Brooks Range, Alaska: U.S. Geological Survey Bulletin 1529-A, 64 p.

Patton, W.W., Jr. and Box, S.E., 1985, Tectonic setting and history of the Yukon-Koyukuk basin, Alaska: Eos [American Geophysical Union Transactions], v. 66, no. 46, p. 1101 .

Patton, W.W., Jr., Box, S.E., Moll-Stalcup, E.J., and Miller, T.P., 198, Geology of west-central Alaska, in Plafker, G., Jones, D.L., and Berg, H.C., ed., Geology of Alaska: Boulder, Colo., Geological Society America, The Geology of North America. 
Turner, D.L. 1984, Tectonic implications of widespread Cretaceous overprinting of $\mathrm{K}-\mathrm{Ar}$ ages in Alaskan metamorphic terranes [abs.]: Geological Society of America Abstracts with Programs, v. 16, no. 5, p. 338 .

Turner, D.L., Forbes, R.B., and Dillon, J.T., 1979, K-Ar geochronology of the southwestern Brooks Range, Alaska: Canadian Journal of
Earth Sciences, v. 16, p. 1789-1804.

Reviewers: S.E. Box and S.M. Kar1

Geologic Studies in Alaska by the U.S. Geological Survey during 1987: John P. Galloway and Thomas D. Hamilton, editors, U.S. Geological Survey Circular 1016. 


\section{SOUTHERN ALASKA}

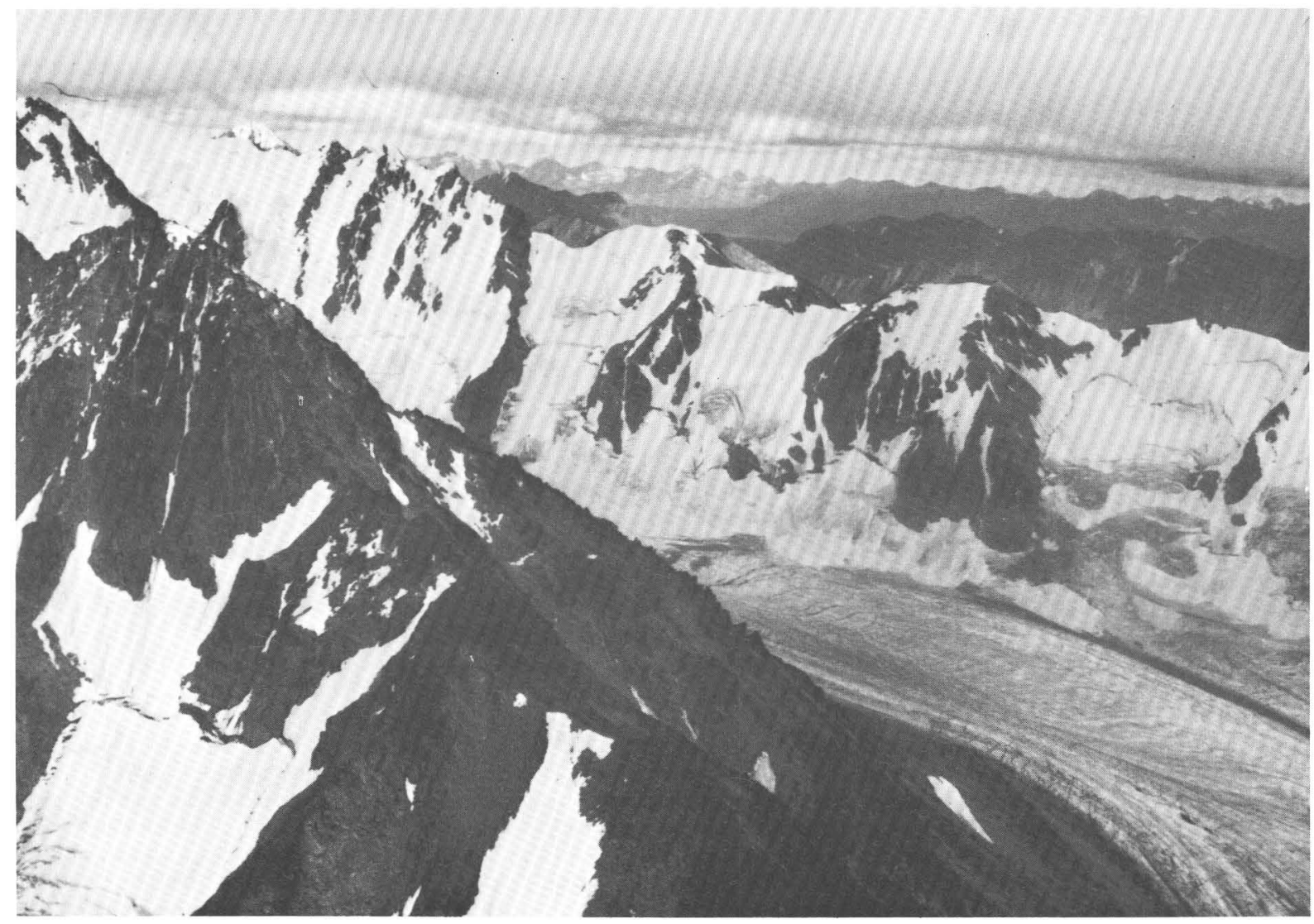

Head of Nenana Glacier, Alaska Range. Photograph by Béla Csejtey. 


\title{
Middle Pennsylvanian Plutonic Rocks Along the Southern Margin of the Wrangellia Terrane
}

\author{
By John N. Aleinikoff, George Plafker, and Warren J. Nokleberg
}

We present two new $\mathrm{U}-\mathrm{Pb}$ ages on zircon and sphene from granitoid rocks along the southern margin of the Wrangellia terrane (Jones and others, 1984). These samples were collected in the northern Chugach and western Wrangell Mountains as part of geologic field studies of the Trans-Alaskan Crustal Transect (TACT) program. Our results document previously unrecognized Middle Pennsylvanian plutonism in this area that may be representative of widespread plutonism of the same general age in adjacent regions of the Wrangellia and Alexander terranes.

In our study area (fig. 1), the Wrangellia terrane, which is part of the allochthonous Wrangellia microplate (Jones and others, 1984), is juxtaposed along the Taral-West Fork faults against Early Jurassic andesitic arc rocks of the Peninsular terrane to the west. Along their southern margins, the Wrangellia and Peninsular terranes are relatively underthrust on the order of $40 \mathrm{~km}$ along the Border Ranges fault by accreted oceanic rocks (schists of Liberty Creek and Iceberg Lake, McHugh Complex, Valdez Group) that make up the Chugach terrane (Nokleberg and others, 1986; Plafker and others, 1985).

Within the Wrangellia terrane, notable differences exist in stratigraphy, plutonism, and metamorphism across the Chitina fault system (fig. 1), a plexus of Early Cretaceous southwest-dipping thrust faults that separate greenschist- to lower amphibolitefacies rocks to the south from relatively unmetamorphosed to lower greenschist-facies rocks to the north (Mackevett, 1978; Gardner and others, 1986). The characteristic Upper Triassic sequences of the Wrangellia terrane, the Nikolai Greenstone and Chitistone Limestone, occur on both sides of the fault. These two parts of the Wrangellia terrane are herein informally referred to as the northern and southern Wrangellia assemblages.

The northern Wrangellia assemblage consists of andesitic rocks (of the Skolai Group) at least as old as Middle Pennsylvanian that are overlain by a Lower Permian marine sedimentary sequence and a distinctive Mesozoic (pre-Middle Jurassic) sequence that includes Triassic tholeiitic basalt, carbonate rocks, and argillaceous sedimentary rocks of oceanic affinities (Mackevett, 1978; Winkler and others, 1981). The metamorphic rocks are intruded by massive to moderately foliated Middle Pennsylvanian syenite and monzonite in the eastern Wrangell Mountains and by quartz diorite to granite (dominantly tonalite and granodiorite) of probable Late Jurassic age.

The southern Wrangellia assemblage consists of penetratively deformed meta-andesite, meta- graywacke, metachert, and abundant linear units of marble and schistose marble as described by MacKevett (1978) and Winkler and others (1981). This assemblage corresponds with the Strelna Formation of Moffit (1938), which is at least in part of Early Pennsylvanian age (Plafker and others, 1985). The metamorphic rocks are intruded by gneissic to mylonitic plutonic rocks of Middle Pennsylvanian age (including those reported on here), and abundant variably foliated plutonic rocks of the Late Jurassic Chitina Valley batholith (MacKevett, 1978; Winkler and others, 1981).

The Middle Pennsylvanian metaplutonic rocks dated in this study are from the southern Wrangellia assemblage (fig. 1). In the Dadina River area (locality of sample 84ANK 069A--hereafter called sample 069), metamorphic rocks that are locally exposed in a narrow belt between the late Cenozoic Wrangell Lavas and associated hypabyssal intrusive rocks on the east and the Quaternary fill of the Copper River basin on the west compose the unnamed metamorphic complex of Winkler and others (1981). In the Chugach Mountains west of the Copper River (locality of sample $84 \mathrm{ANK} 186 \mathrm{~A}-$-hereafter called sample 186), the southern assemblage is exposed as a large thrust sheet remnant that is part of the Haley Creek terrane of Winkler and others (1981). In both areas, metagranodiorite and metagranite compose a relatively minor part of the generally more mafic metaplutonic suites. However, mapping was not sufficiently detailed to determine the areal distribution of these plutons or their relationship to the country rocks.

The dated samples are blastomylonitic to gneissic metagranodiorite. Sample 069 contains about 35 percent plagioclase, 33 percent quartz, 17 percent potassic feldspar, 12 percent biotite, and 3 percent combined epidote, sphene, and iron oxides. Sample 186 contains about 45 percent plagioclase, 30 percent quartz, 15 percent potassic feldspar, and 10 percent epidote with $<1$ percent hornblende altered to epidote, and accessory tourmaline, sphene, and stilpnomelane. Geochemically, the two samples are remarkably similar; they are calc-alkalic with strong enrichment of light relative to heavy rare-earth elements (Plafker and others, 1988).

Six size fractions of zircon and one fraction of sphene were analyzed from each sample. Zircons from sample 069 are euhedral, clear to light brown, and stubby (length-to-width ratio of 1-3); zircons from sample 186 are medium to dark brown, euhedral with some rounded tips, and stubby (length-to-width ratio of 
1-3). The color difference of the two samples is probably due to uranium content. The darker zircons contain about twice as much uranium as the lighter zircons (table 1 ).

Isotopic data (fig. 2) from both samples yield well-defined linear arrays with concordia intercept ages of $310 \pm 29$ and $91 \pm 87 \mathrm{Ma}$ (sample 069) and $309 \pm$ 11 and $101 \pm 70 \mathrm{Ma}$ (sample 186). The coarsest size fraction $(+150$ mesh) has been omitted from each regression because they plot off the discordias in excess of analytical error, suggesting a minor amount of inherited radiogenic lead in these large zircons. Sphene from sample 069 is concordant at about 150 Ma; sphene from 186 has an age of about 200-220 Ma.
The Middle Pennsylvanian metaplutonic rocks in the southern Wrangellia assemblage are recognized in this study as a discrete plutonic suite that predates the dominantly Late Jurassic plutonism in these same areas. The influence of the Jurassic reheating is evident from the $150-\mathrm{Ma}$ age of sphene in sample 069. The somewhat older sphene from sample 186 may reflect another thermal event. Alternatively, the difference in the sphene ages may be due to differential uplift, whereby the sample from the northern Chugach Mountains passed through the closure temperature for the $\mathrm{U}-\mathrm{Pb}$ system in sphene (about $550{ }^{\circ}$ ) about $50 \mathrm{~m} . \mathrm{y}$. earlier than the sample from the Dadina River area. We are unable to

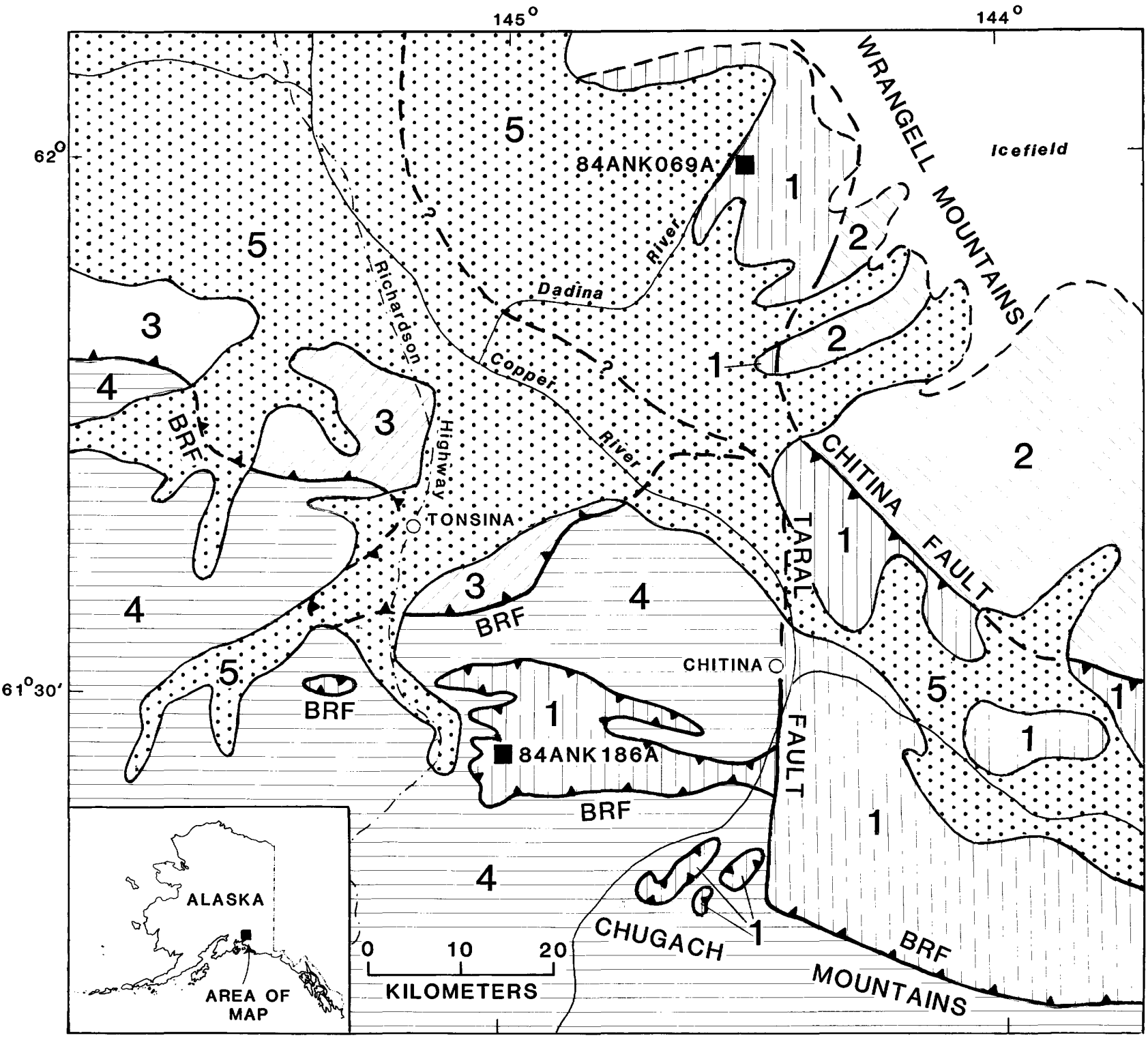

Figure 1. Locations of dated Middle Pennsylvanian metaplutonic rocks (black squares) relative to terranes, major geologic units, and structural features in part of the eastern Wrangell Mountains, northern Chugach Mountains, and Copper River basin. Map units: 1, southern Wrangellia assemblage; 2, northern Wrangellia assemblage; 3, Peninsular terrane; 4, Chugach terrane; 5, unconsolidated deposits. Geology generalized from MacKevett (1978), Winkler and others (1981), Nokleberg and others (1986), Plafker and others (1985), and Plafker (unpub. data). 
Table 1. U-Th-Pb concentration and isotopic composition data from zircon and sphene from metaplutonic rocks of southern Wrangellia assemblage

[Leaders (--) mean not determined. Constants: ${ }^{235} \lambda=9.8485 \mathrm{E}-10 / \mathrm{yr} ;{ }^{238} \lambda=1.55125 \mathrm{E}-10 / \mathrm{yr} ;{ }^{232} \lambda=4.9475 \mathrm{E}-11 / \mathrm{yr} ;{ }^{238} \mathrm{U} /{ }^{235} \mathrm{U}=137.88$ (Steiger and Jäger, 1977 )]

\begin{tabular}{|c|c|c|c|c|c|c|c|c|c|c|c|}
\hline \multirow{3}{*}{$\begin{array}{l}\text { Sample and } \\
\text { traction }\end{array}$} & \multirow{3}{*}{$\begin{array}{l}\text { Woight } \\
\text { (mg) }\end{array}$} & \multirow{2}{*}{\multicolumn{3}{|c|}{$\begin{array}{l}\text { Concentration } \\
\quad(\mathrm{ppm})\end{array}$}} & \multicolumn{3}{|c|}{$\mathrm{Pb}$ composition ${ }^{1}$} & \multicolumn{4}{|c|}{ Ages (Ma) } \\
\hline & & & & & \multirow{2}{*}{$\frac{206 \mathrm{~Pb}}{204 \mathrm{~Pb}}$} & \multirow{2}{*}{$\frac{{ }^{206} \mathrm{~Pb}}{{ }^{207} \mathrm{~Pb}}$} & \multirow{2}{*}{$\frac{206 \mathrm{~Pb}}{208 \mathrm{~Pb}}$} & \multirow{2}{*}{$\frac{{ }^{206} \mathrm{~Pb}}{2{ }^{23} \mathrm{U}}$} & \multirow{2}{*}{$\frac{{ }^{207} \mathrm{~Pb}}{235 \mathrm{U}}$} & \multirow{2}{*}{$\frac{{ }^{207} \mathrm{~Pb}}{{ }^{206} \mathrm{~Pb}}$} & \multirow{2}{*}{$\frac{2{ }^{208} \mathrm{~Pb}}{2^{232} \mathrm{Th}}$} \\
\hline & & $\mathrm{U}$ & Th & $\mathrm{Pb}$ & & & & & & & \\
\hline \multicolumn{12}{|l|}{ 84ANK 069A } \\
\hline$(+150)$ & 14.90 & 756.7 & --- & 31.81 & 34870 & 18.930 & 9.8236 & 267 & 271 & 303 & --- \\
\hline$(-150+200) \mathrm{NMD}$ & 14.95 & 680.0 & --- & 28.42 & 11300 & 18.672 & 10.318 & 266 & 269 & 297 & -- \\
\hline$(-200+250) \mathrm{NMD}$ & 15.70 & 679.1 & --- & 27.60 & 4213 & 17.972 & 10.012 & 257 & 261 & 293 & --- \\
\hline$(-250+325) \mathrm{NMD}$ & 15.11 & 702.9 & -- & 28.66 & 53140 & 19.088 & 10.592 & 262 & 265 & 290 & --- \\
\hline$(-325)$ NMD & 15.01 & 817.0 & --- & 32.38 & 11450 & 18.711 & 10.278 & 253 & 257 & 293 & --- \\
\hline$(-325) \mathrm{Mag}$ & 14.33 & 752.7 & -- & 29.44 & 138700 & 19.153 & 10.648 & 251 & 25 s & 290 & --- \\
\hline sphene & 18.56 & 353.4 & 282.1 & 10.51 & 510.9 & 12.899 & 3.1246 & 151 & 151 & 143 & 147 \\
\hline \multicolumn{12}{|l|}{ 84ANK 186A } \\
\hline$(+150) \mathrm{NM}$ & 7.21 & 1475 & --- & 71.10 & 2134.6 & 16.826 & 5.8123 & 284 & 287 & 310 & --- \\
\hline$(-150+200) \mathrm{NMD}_{2}$ & 2.21 & 1448 & -- & 71.28 & $300 i .8$ & 17.435 & 5.9885 & 293 & 294 & 306 & --- \\
\hline$(-150+200) \mathrm{NMA}^{2}$ & 3.16 & 1498 & --- & 77.69 & 1811.2 & 16.524 & 5.299 & 301 & 301 & 304 & --- \\
\hline$(-200+250)$ NMD & 11.39 & 1634 & --- & 77.26 & 1921.3 & 16.668 & 5.9794 & 280 & 282 & 302 & --- \\
\hline$(-250+325) \mathrm{NMD}$ & 3.46 & 1619 & --- & 75.33 & 2170.5 & 16.943 & 6.0799 & 277 & 279 & 297 & --- \\
\hline$(-400)$ NMD & 11.39 & 1975 & -- & 91.25 & 1557.4 & 16.227 & 6.1461 & 273 & 276 & 295 & --- \\
\hline sphene & 31.27 & 256.4 & 65.49 & 10.92 & 196.2 & 7.9748 & 3.4899 & 201 & 203 & 221 & 246 \\
\hline
\end{tabular}

1 Blank and fractionation corrected. Common lead corrections use values for 310-Ma lead

2 from Stacey and Kramers (1975). Chemical extractions methods modified from Krogh (1973).

2 Abraded.

distinguish between these two hypotheses: if the latter is true, then the ages of the sphenes are only constrained to pre-200 Ma. The lower intercepts of the zircon data suggest a poorly constrained Cretaceous disturbance to the U-Pb systematics. However, because of the large uncertainties, the lower intercept ages may be as old as the 150-Ma sphene. Thus, the $\mathrm{U}-\mathrm{Pb}$ isotopic information obtained in this study indicates intrusion of a suite of Middle Pennsylvanian plutons followed by heating in the Early Jurassic(?), Late Jurassic, and Cretaceous(?).

Middle Pennsylvanian metaplutonic rocks may be part of a belt of lithologically variable plutonic rocks of the same age that is widely exposed in the Wrangellia and adjacent Alexander terranes to the east in Alaska and Canada. Possibly correlative suites within the southern assemblage are: (1) parts or all of the undated gabbro and orthogneiss complex of Mackevett (1978) within the McCarthy area and (2) undated metaplutonic rocks in the metamorphic complex of the Gulkana River along the northern margin of the Copper River basin (Nokleberg and others, 1986). Possibly correlative suites within the northern assemblage are: (1) the monzonitic-granitic complex (Mackevett, 1978), dated with $\mathrm{U}-\mathrm{Pb}$ on zircon at $308 \pm 8 \mathrm{Ma}$ (Gardner and others, in press), that extends from the Wrangellia terrane into the Alexander terrane in the eastern Wrangell Mountains and adjacent parts of Canada ("Icefield Ranges plutonic suite" of Campbell and Dodds, 1985), and (2) a diorite-gabbro-tonalite-anorthosite suite in the eastern Alaska Range that has yielded four $\mathrm{U}-\mathrm{Pb}$ ages on zircon of 290 to $316 \mathrm{Ma}$ (Barker and Stern, 1986). As noted by Barker and Stern (1986), the close association

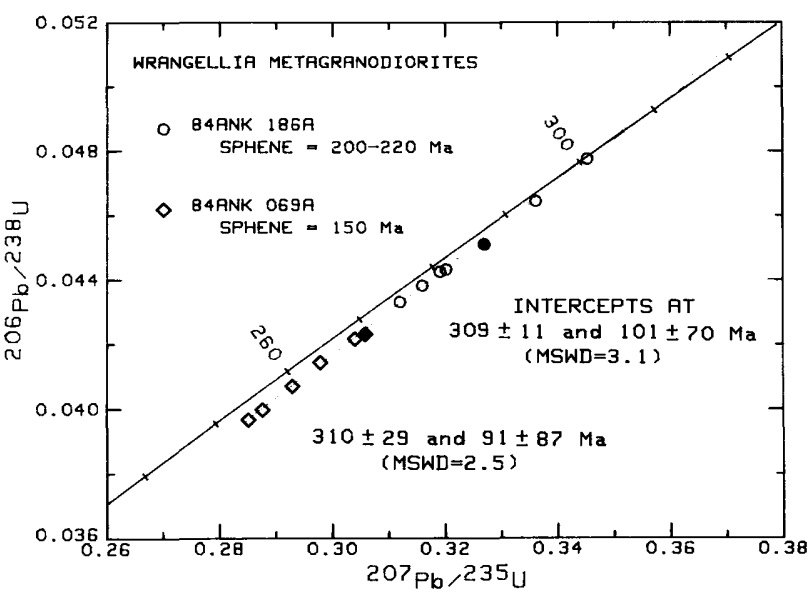

Figure 2. Concordia plot of U-Pb data from zircon from metagranodiorite samples 069 and 186 . Solid black symbols denote values not used in regression calculation.

in time and space of Middle Pennsylvanian plutonism with the lower part of the late Paleozoic andesitic rocks of the Skolai Group suggests that at least some of these plutonic rocks represent shallow to intermediate levels of the Pennsylvanian Skolai magmatic arc. Their widespread distribution indicates that Middle Pennsylvanian plutonic rocks and the metamorphic country rocks that they intrude may constitute the basement for much of the Wrangellia terrane in Alaska. 


\section{REFERENCES CITED}

Barker, Fred and Stern, T.W., 1986, An arc-root complex of Wrangellia, eastern Alaska Range [abs.]: Geological Society of America Abstracts with Programs, v. 18, no. 6, p. 534.

Campbe11, R.B., and Dodds, C.J., 1985, Geology of the Mount St. E1ias map area (115B and C $(E 1 / 2)):$ Canadian Geological Survey Openfile 830,2 sheets, scale $1: 125,000$.

Gardner, M.C., MacKevett, E.M., and McClelland, W.D., 1986, The Chitina fault system of southern Alaska--An Early Cretaceous collisional suture zone [abs.]: Geological Society of America Abstracts with Programs, v. 18 , no. 2 , p. 108 .

Gardner, M.C., Bergman, S.C., MacKevett, E.M., Jr., Plafker, George, Campbell, R.C., Cushing, G.W., Dodds, C.J., McClelland, W.D., and Mueller, P.A., 1988, Middle Pennsylvanian pluton stitching of Wrangellia and the Alexander terrane, Wrangell Mountains, Alaska: Geology, [in press].

Jones, D.L., Silberling, N.J., Coney, P.J., and Plafker, George, 1984, Lithotectonic terrane map of Alaska (west of the 141st meridian), in Silberling, N.J., and Jones, D.L., eds., Lithotectonic terrane maps of the North American cordillera: U.S. Geological Survey Miscellaneous Field Studies Map 1874-A, scale $1: 2,500,000$.

Krogh, T.E., 1973, A low-contamination method for hydrothermal decomposition of zircon and extraction of $\mathrm{U}$ and $\mathrm{Pb}$ for isotopic age determinations: Geochimica et Cosmochimica Acta, v. 37, p. 485-494.

MacKevett, E.M., Jr., 1978, Geologic map of the McCarthy quadrangle, Alaska: U.S. Geological Survey Miscellaneous Investigations Series Map I-1032, scale $1: 250,000$.

Moffit, F.H., 1938, Geology of the Chitina Valley and adjacent area, Alaska: U.S. Geological Survey Bulletin 894, 137 p.

Nokleberg, W.J., Wade, W.M., Lange, I.M., and Plafker, George, 1986, Summary of geology of the Peninsular terrane, metamorphic complex of Gulkana River, and Wrangellia terrane, north-central and northwestern Gulkana quadrangle, in Bartsch-Winkler, Susan, and Reed, Katherine, eds., Geologic studies in Alaska by the U. S. Geological Survey during 1985: U.S. Geological Survey Circular 978, p. 69-74.

Plafker, George, Nokleberg, W.J., and Lull, J.S., 1985, Summary of the 1984 TACT geologic studies in the northern Chugach Mountains and southern Copper River basin, in Bartsch-Winkler, Susan, ed., The U.S. Geological Survey in Alaska: Accomplishments during 1984: U.S. Geological Survey Circular 967, p. 76-79.

---- 1988, Bedrock geology and tectonic evolution of the Wrangellia, Peninsular, and Chugach terranes along the Trans-Alaskan Crustal Transect in the northern Chugach Mountains and southern Copper River basin, Alaska: Journal of Geophysical Research, [in press].

Stacey, J.S. and Kramers, J.D., 1975, Approximation of terrestrial lead isotope evolution by a two-stage model: Earth and Planetary Sciences Letters, v. 26, p. 207221.

Steiger, R.H. and Jäger, E., 1977, Subcommission on Geochronology: Convention on the use of decay constants in geo- and cosmochronology: Earth and Planetary Sciences Letters, v. 36, p. 359-362.

Winkler, G.R., Silberman, M.L., Grantz, Arthur, Miller, R.J., and MacKevett, E.M., Jr., 1981, Geologic map and summary geochronology of the Valdez quadrangle, southern Alaska: U.S. Geological Survey Open-File Report 80$892-A,, 2$ sheets, scale $1: 250,000$.

\section{Reviewers: G.R. Winkler and F. Barker}

Geologic Studies in Alaska by the U.S. Geological Survey during 1987: John P. Galloway and Thomas D. Hamilton, editors, U.S. Geological Survey Circular 1016. 


\title{
Source of the Sanford Volcanic Debris Flow, South-Central Alaska
}

\author{
By Donald H. Richter, Henry R. Schmoll, and Dana J. Bove
}

The Sanford volcanic debris flow occurs in a thick sequence of Pleistocene glaciolacustrine, glacial, and fluvial deposits in the center of the Copper River basin along the northwest flank of the Wrangell Mountains, which are dominated by Pleistocene volcanoes (fig. 1). This extensive volcanic debris flow was first described by Ferrians and others (1958), who referred to it as the Sanford volcanic mudflow, after exposures along the Copper River at the mouth of the Sanford River. They suggested that debris flowed more than $50 \mathrm{~km}$ down the ancestral Sanford and Copper River valleys from the large amphitheater on the southwest face of Mount Sanford $(4,949 \mathrm{~m})$ at the head of Sanford Glacier in the Wrangell Mountains. Nichols and Yehle (1985) described the debris flow in more detail and reiterated that the likely source area was the amphitheater on Mount Sanford. They further suggested that both the amphitheater and the debris flow were the result of a lateral-blast eruption, possibly similar to the 1980 eruption of Mount St. Helens.

During the course of geologic investigations in the western Wrangell Mountains in the summer of 1987, we discovered that the source of the Sanford volcanic debris flow is probably a collapsed dacite dome on the east flank of Mount Drum $(3,661 \mathrm{~m})$. This note briefly describes the debris flow and its source, and speculates on its origin. Although we disagree with Nichols and Yehle as to the source of the debris flow, we are indebted to them for their detailed descriptions of the physical characteristics of the flow, and we base the descriptions that follow mainly on theirs. We did not observe the debris flow near the village of Chistochina (fig. 1), where a questionable occurrence was noted by Nichols and Yehle (1985).

The Sanford volcanic debris flow is exposed discontinuously at elevations between 350 and $615 \mathrm{~m}$ in bluffs along the Copper and lower Sanford Rivers (fig. 1). Near the confluence of the Sanford and Copper Rivers, the debris flow is 1 to $6 \mathrm{~m}$ thick and forms a conspicuous pink bed about $20 \mathrm{~m}$ above river level in the 150-m-high bluffs (O.J. Ferrians, Jr., and H.R. Schmoll, U.S. Geological Survey, written commun., 1957). It conformably overlies fluvial gravel and is disconformably overlain by similar fluvial gravel. This stratigraphic association with fluvial gravel indicates that the debris flow was emplaced during a nonglacial interval, when glacier ice was confined to the higher parts of the Wrangell Mountains as it is today. Two sequences of mainly glaciolacustrine deposits that overlie the gravel indicate that at least two major episodes of glaciation occurred subsequently (Ferrians and others, 1983, p. 151). The debris-flow deposit is weakly indurated and consists dominantly of angular to subrounded volcanic clasts, as large as $3 \mathrm{~m}$ in diameter but commonly 8 to $15 \mathrm{~cm}$, in a matrix of silt and sand. No sorting or bedding is evident. Rounded cobbles of nonvolcanic rock that were probably entrained during flowage are present locally. The volcanic clasts in the debris flow are nearly all pink and gray porphyritic dacite of similar mineralogy. They contain about 10 to 20 percent phenocrysts, 1 to $3 \mathrm{~mm}$ long, consisting chiefly of plagioclase and hornblende and minor, but characteristic, green pyroxene. The gray-colored varieties generally exhibit glassy groundmasses; the darker gray rocks are the most glass rich. All clasts are coated by a thin layer of fine-grained pink matrix material that imparts an overall pinkish cast to the deposit.

The apparent source of the Sanford volcanic debris flow is a collapsed dacite dome at an elevation of about $1,900 \mathrm{~m}$ on the east flank of Mount Drum (fig. 1). The dome was probably similar to, and is arcuately aligned with, the series of dacite domes associated with the second cycle of Mount Drum conebuilding about 200,000 to 300,000 years ago (Richter and others, 1979). The collapsed dome is now a massive pile of dacite rubble, approximately $3.2 \mathrm{~km}$ long by 2.4 $\mathrm{km}$ wide and more than $200 \mathrm{~m}$ thick, that consists of pink and gray, angular to subrounded blocks of dacite in a matrix of pink silt to sand. Individual blocks are up to tens of meters in diameter, but most probably average less than one meter. Lithologically, the remnant dome is a coarse-grained replica of the debris-flow deposits exposed more than $50 \mathrm{~km}$ away. The dacite from the dome is megascopically identical to the dacites in the debris flow, containing 10 to 30 percent phenocrysts of plagioclase and hornblende and minor green pyroxene.

Large boulders of pink dacite occur scattered over volcanic bedrock in at least two known areas in the general vicinity of the dome, a small one $5 \mathrm{~km}$ north of the dome at an elevation of $1,370 \mathrm{~m}$, and a larger one $5 \mathrm{~km}$ east of the dome at an elevation of $1,580 \mathrm{~m}$ (fig. 1). The boulders, especially those in the eastern occurrence, may represent either shorter debris flows or lag deposits remaining after passage of the principal debris flow.

Lack of observable volcanic bombs, pumice blocks, or scoria in the debris-flow deposits or at the collapsed dome suggests that the dome was mature and probably contained very little juvenile magma when it was destroyed. Destruction therefore may have been the result either of a large phreatic explosion caused 
by entry of glacial meltwater into a near-surface subvolcanic heat reservoir, or possibly of a combination of phreatic and renewed magmatic activity. In either case, the explosion-eruption could have formed a vertical debris column which then collapsed to form the rubble dome and the debris flow. Mobility of the debris flow may have been enhanced by cascading down steep mountain flanks into the Sanford valley of which at least the upvalley part was glacier-filled. Based on the size and geometry of other domes in the Mount Drum ringdome complex, the dome may have had an original volume of 4 to $6 \mathrm{~km}^{3}$ which upon collapsing contributed as much as $2 \mathrm{~km}^{3}$ to the debris flow.

The dome is located outside of the boundaries of well-developed lateral moraines that border and extend downvalley from Sanford Glacier and that we attribute to at least two major episodes of glaciation. No evidence of the Sanford volcanic debris flow is found within the boundaries of these moraines, suggesting that the debris flow is older. Evidence of older glaciations, found elsewhere on the slopes of the Wrangell Mountains, is absent in the vicinity of the dome, perhaps obliterated by events associated with dome collapse. These relationships, which suggest that the collapse occurred prior to at least two major episodes of glaciation and subsequent to earlier, more extensive, glaciations, are compatible with the stratigraphic position of the Sanford volcanic debris flow in exposures along the Copper River. The Sanford volcanic debris flow, already useful as a stratigraphic marker in the central Copper River basin, thus may become a much-needed means of correlating between the stratigraphy of the central basin and the moraines of the basin margin as well.

Outcrops within the the amphitheater at the head of the Sanford Glacier (fig. 1), the area previously considered to be the source of the Sanford volcanic debris flow, are nearly inaccessible because of the spectacular 2,900-m-high amphitheater wall. A helicopter reconnaissance revealed that the wall is composed principally of medium to thick lava flows, flow breccias, mudflows, and vent(?) breccias, all probably of andesitic composition, cut by dark-colored dikes and small irregular intrusive masses. Near the top of the wall, a laccolith or mushroom-shaped dome is separated from the underlying flow sequence by as much as $100 \mathrm{~m}$ of thin-bedded pyroclastic rocks or lava

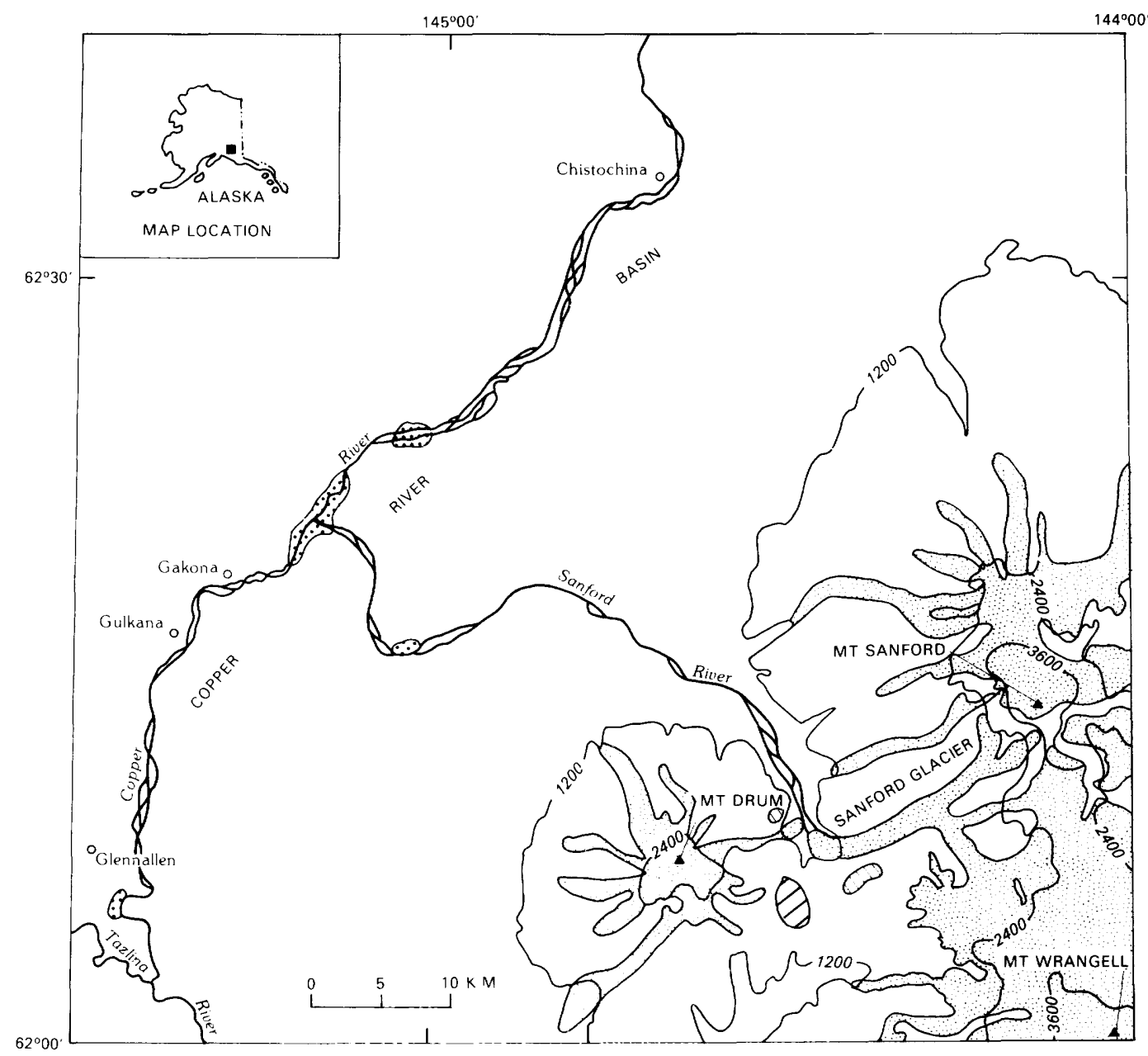

Figure 1. Location of principal exposures of Sanford volcanic debris flow (heavy stipple pattern) and collapsed dacite dome (heavy ruled pattern) believed to be its source. Light ruled pattern, areas of large dacite boulders; light stipple pattern, glaciers and icefields. Contour interval 1,200 m. 
flows. Because the amphitheater wall exhibits a diverse assemblage of volcanic rocks, it is not a likely source of the much more nearly monolithologic Sanford volcanic debris flow.

\section{REFERENCES CITED}

Ferrians, O.J, Jr., Nichols, D.R., and Schmoll, H.R., 1958, Pleistocene volcanic mudflow in the Copper River basin, Alaska [abs.]: Geological Society of America Bulletin, v. 69 , no. 12 , pt. 2 , p. 1563.

Ferrians, O.J., Jr., Nichols, D.R., and Williams, J.R., 1983, Copper River basin, in Pewe, T.L., and Reger, R.D, eds., Guidebook to permafrost and Quaternary geology along the Richardson and Glenn Highways between Fairbanks and Anchorage, Alaska. International Conference on Permafrost, $4 \mathrm{th}$, 1983: Alaska Division of Geological and Geophysical Surveys Guidebook 1, p. 137-175.
Nichols, D.R., and Yehle, L.A., 1985, Volcanic debris flows, Copper River basin, Alaska, in Committee for International Exchange of Landslide Technique, eds., International Conference and Field Workshop on Lands1ides, Proceedings, Fourth: Tokyo, The Japan Landslide Society, p. 365-372.

Richter, D.H., Smith, R.L., Yehle, L.A., and Miller, T.P., 1979, Geologic map of the Gulkana A-2 quadrangle, Alaska: U.S. Geological Survey Geologic Quadrangle Map GQ-1520, scale $1: 63,360$.

Reviewers: J.C. Ratte and L.A. Yehle

Geologic Studies in Alaska by the U.S. Geological Survey during 1987: John P. Galloway and Thomas D. Hamilton, editors, U.S. Geological Survey Circular 1016. 


\title{
Hydrocarbon Source Potential and Thermal Maturity of the Sanctuary Formation (Middle Miocene), Northern Foothills of the Alaska Range
}

\author{
By Richard G. Stanley
}

The middle Miocene Sanctuary Formation, part of the Usibelli Group (Wahrhaftig, 1987), crops out sporadically in the Nenana coal field of the northern foothills of the Alaska Range (fig. 1). The Sanctuary Formation is locally as much as $100 \mathrm{~m}$ thick and consists mainly of mudrocks and fine sandstone that accumulated in a large shallow lake (Wahrhaftig and others, 1969). Worldwide experience indicates that lakebed sediments can be prolific petroleum source rocks (Fouch and Dean, 1982; Tissot and Welte, 1984). With this in mind, 21 samples of mudrocks were collected from six outcrops of the Sanctuary Formation (fig. 1) and analyzed using Rock-Eval pyrolysis, vitrinite reflectance, and thermal alteration index. The results, discussed below, suggest that Sanctuary mudrocks are potential sources of gas and are thermally immature to marginally mature with respect to the oil-generative zone.

Rock samples were collected from exposures in road cuts, stream cuts, headwalls of landslides, and landslide deposits. The samples were taken about 10 to $30 \mathrm{~cm}$ back from the outcrop faces in order to obtain the freshest available material. Splits of the samples were analyzed using Rock-Eval pyrolysis by T.A. Daws (U.S. Geological Survey, Denver, Colo.), vitrinite reflectance by M.J. Pawlewicz (U.S. Geological Survey, Denver, Colo.), and thermal alteration index by Hideyo Haga (Micropaleo Consultants, Inc., San Diego, Calif.).

Rock-Eval pyrolysis is a widely used method of rapidly evaluating the quality and thermal maturity of prospective petroleum source rocks (see, for example, Tissot and Welte, 1984). Pulverized samples of rock are gradually heated from $300{ }^{\circ} \mathrm{C}$ to $550{ }^{\circ} \mathrm{C}$ at $25^{\circ} \mathrm{C}$ per minute in an oxygen-free atmosphere, causing the release of water, carbon dioxide, and hydrocarbons from the rock. Several parameters are measured by the Rock-Eval apparatus (table 1). The quantity $\mathrm{S} 1$ is the amount of hydrocarbons ( $\mathrm{HC}$, measured in milligrams HC per gram of rock, that is released upon initial heating to about $300^{\circ} \mathrm{C}$; this quantity includes the oil and gas already present in the rock. The quantity $\mathrm{S} 2$ (also measured in milligrams HC per gram of rock) is the amount of hydrocarbons generated by pyrolytic degradation of the remaining organic matter in the rock, and is an indicator of the potential of the rock to generate additional oil and gas. Tmax is the temperature--generally about $400{ }^{\circ} \mathrm{C}$ to $500{ }^{\circ} \mathrm{C}--$ at which S2 is at a maximum, and is an indicator of thermal maturity. $\mathrm{S} 3$ is the amount of carbon dioxide (in $\mathrm{mg} \mathrm{CO}_{2}$ per gram of rock) generated during pyrolysis, and is thought to be related to the amount of oxygen in the pyrolyzed organic matter. Additional Rock-Eval parameters include the total organic carbon (TOC) in weight percent; the hydrogen index (HI), defined as the product of 100 times (S2/TOC); and the oxygen index (OI), defined as the product of 100 times (S3/TOC).

Vitrinite reflectance (Ro) and thermal alteration index (TAI) are common methods of assessing thermal maturity. Vitrinite reflectance is determined by measuring the percentage of light reflected by vitrinite, a type of kerogen formed from terrestrial plant material. Thermal alteration index (TAI) is obtained by examining the colors of pollen grains and other organic particles in transmitted light under the microscope (Tissot and Welte, 1984; Waples, 1985).

Analytic results from the Sanctuary Formation are shown in table 1. All but 5 of the 21 samples have total organic carbon (TOC) greater than 0.5 percent, which is generally regarded as the lower limit for potential petroleum source rocks (Tissot and Welte, 1984). Thirteen of the 21 samples have TOC greater

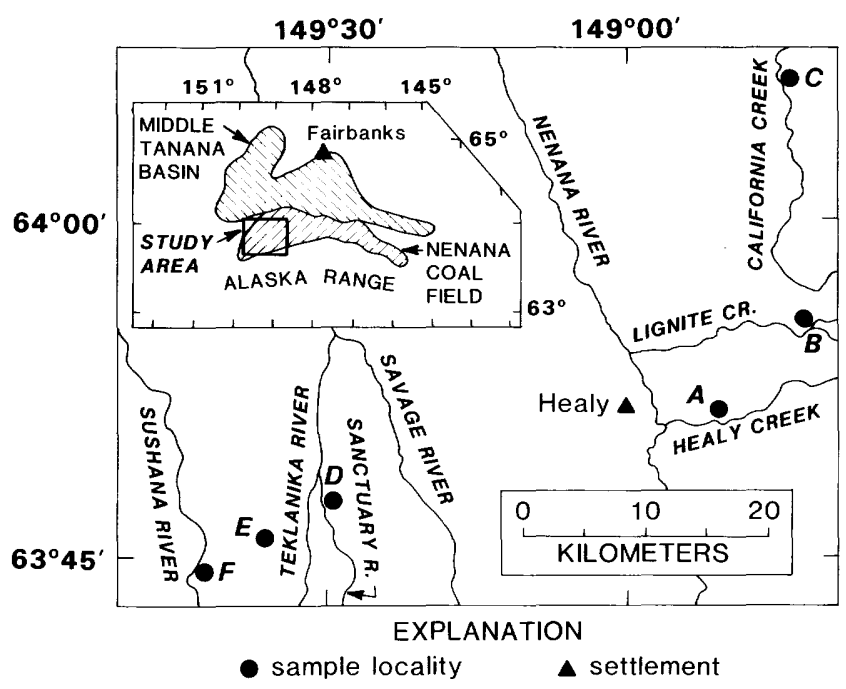

Figure 1. Sample localities in the Sanctuary Formation. Inset shows outlines of middle Tanana basin (Miller and others, 1959) and Nenana coal field (Merritt and Hawley, 1986). A, Suntrana area; B, Sanderson Creek area; C, California Creek; D, Sanctuary River; E, Teklanika River area; F, Sushana River area. 
Table 1. Rock-Eval, vitrinite reflectance (Ro), and thermal alteration index (TAI) data from the Sanctuary Formation [Rock-Eval parameters (TOC, $\mathrm{HI}, \mathrm{OI}$, and so forth) are discussed in the text. See figure 1 for sample locations. NA, not available or not applicable. Tmax values for samples with S2 less than 0.2 were rejected because they are probably unreliable (Peters, 1986)]

\begin{tabular}{|c|c|c|c|c|c|c|c|c|c|c|}
\hline $\begin{array}{c}\text { Sample } \\
\text { No. }\end{array}$ & $\begin{array}{l}\text { Sample } \\
\text { weight } \\
\text { (mg) }\end{array}$ & $\begin{array}{c}\mathrm{Sl} \\
\text { (mg HC/ } \\
\mathrm{g} \text { rock) }\end{array}$ & $\begin{array}{c}\mathrm{S} 2 \\
\text { (mg HC/ } \\
\text { g rock) }\end{array}$ & $\begin{array}{c}\mathrm{S} 3 \\
\text { (mg } \mathrm{CO}_{2} / \\
\mathrm{g} \text { rock) }\end{array}$ & $\frac{\mathrm{S} 1}{\mathrm{~S} 1+\mathrm{S} 2}$ & $\begin{array}{l}\text { s2/s3 } \quad \text { TOC } \\
\quad \text { (wt. pct) }\end{array}$ & $\mathrm{HI}$ & OI & $\begin{array}{l}\operatorname{Tmax} \\
\left({ }^{\circ} \mathrm{C}\right)\end{array}$ & $\begin{array}{l}\text { Median } \\
\text { Ro (\%) }\end{array}$ \\
\hline
\end{tabular}

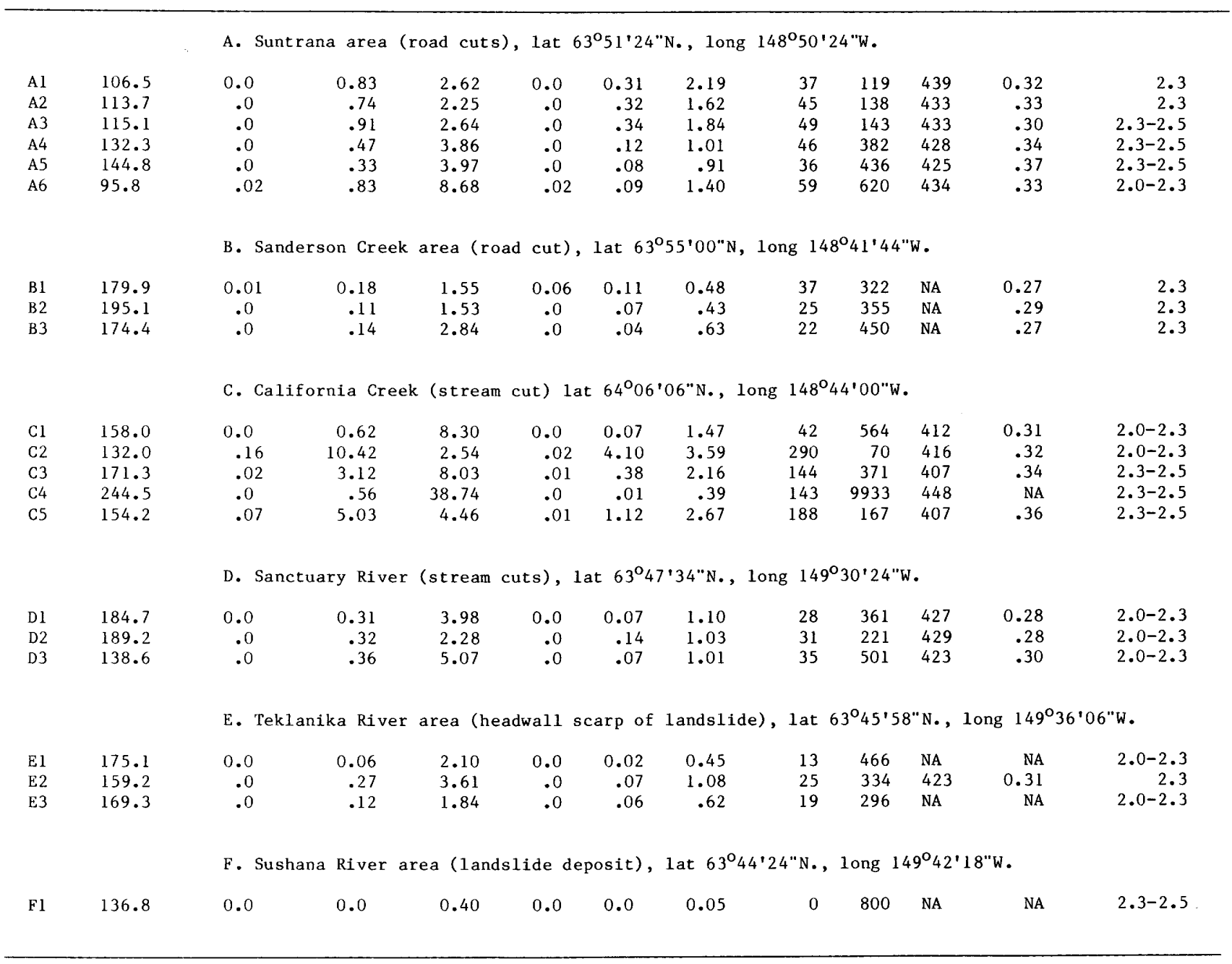

than 1.0 percent, and therefore show good to very good generative potential, according to table 1 of Peters (1986). TOC can be significantly reduced by outcrop weathering (Leythaeuser, 1973; Clayton and Swetland, 1978; Stanley, 1987); therefore, the TOC results from the Sanctuary outcrops (table 1) should be regarded as minimum values.

The relatively high TOC values of the Sanctuary samples contrast with the generally low values of $\mathbf{S 1}$ and S2 (table 1). All of the Sanctuary samples exhibit $\mathrm{S} 1$ less than $\mathbf{0 . 5}$, and all but three samples have $\mathbf{S 2}$ less than 2.5, suggesting poor generative potential by comparison with table 1 of Peters (1986). The reasons for the generally low S1 and S2 are unclear but may be related to (1) surface weathering of the sampled outcrops, (2) initially poor generative potential due to a large proportion of woody (humic) and oxidized (inertinitic) kerogens, and (3) adsorption on clay minerals of the hydrocarbons produced during pyrolysis (Peters, 1986; Stanley, 1987).

The Sanctuary samples (table 1 and fig. 2) exhibit relatively low hydrogen indices (HI) and anomalously high oxygen indices (OI). Nineteen of the 21 samples have HI values less than 150, which indicates that these rocks are "gas-prone," or capable of generating gas but little or no oil (see table 2 of Peters, 1986). Samples C2 and C5 (table 1) have HI values of 290 and 188 , respectively, and therefore are capable of generating oil in addition to gas. The generally low values of HI probably reflect the predominantly woody (humic) origin of the organic matter in the samples; this interpretation is supported by the abundant occurrence of terrestrial plant fragments in the sampled outcrops. Other possible 
causes of low HI include (1) oxidation of organic matter during sedimentation, diagenesis, and outcrop weathering, and (2) adsorption of hydrocarbons onto clay minerals during pyrolysis (Peters, 1986).

Seventeen of the 21 Sanctuary samples have oxygen index (OI) values greater than 150 (table 1 and fig. 2); such values are unusually high (Katz, 1983). Elevated values of OI can be caused by (1) oxidation of organic matter in the samples by outcrop weathering (Peters, 1986; Stanley, 1987); and (2) generation of carbon dioxide during pyrolysis by thermal degradation of carbonate minerals such as calcite, dolomite, and siderite (Katz, 1983; Peters, 1986). Either or both of these problems may have affected the Sanctuary data, because the samples were collected from surface exposures susceptible to weathering, and because the samples were not treated with acid to remove carbonate before pyrolysis.

The Sanctuary samples exhibit relatively low vitrinite reflectance (percent Ro range from 0.27 to 0.37 ), thermal alteration index (TAI range from 2.0 to 2.5 ), and $T \max$ (range from 407 to $448{ }^{\circ} \mathrm{C}$ ). These results indicate that the Sanctuary rocks are thermally immature to marginally mature with respect to the oil-generative zone (fig. 3 ).

In conclusion, limited data from outcrop samples suggest that mudrocks in the Sanctuary Formation are gas-prone and thermally immature to marginally mature. These preliminary interpretations should be tested by further research, including elemental analysis and microscopic examination of organic matter. Speculatively, lacustrine strata similar to the Sanctuary may occur in the subsurface in the middle Tanana basin and other Tertiary sedimentary basins in central Alaska (Miller and others, 1959), and may have generated significant amounts of hydrocarbons.

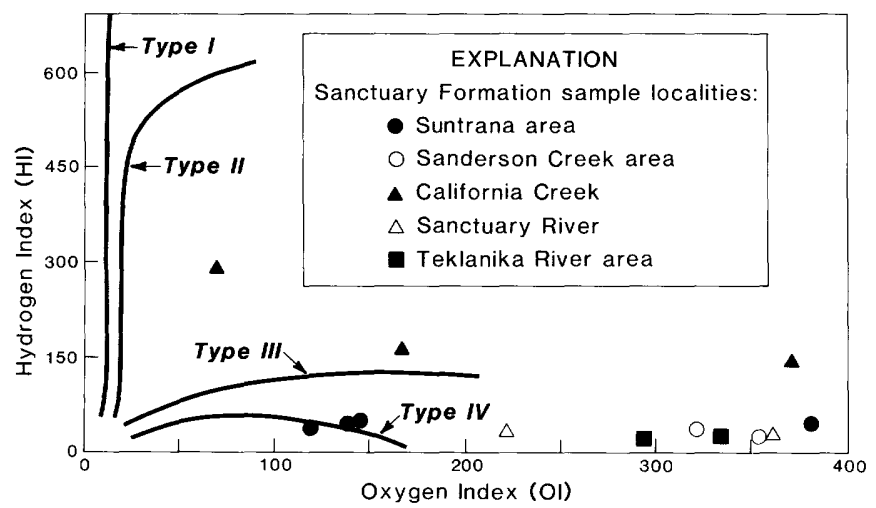

Figure 2. Modified van Krevelen diagram (Peters, 1986) showing idealized kerogen types (solid lines) and results from 13 of 21 samples analyzed from the Sanctuary Formation (table 1). In eight additional samples not shown in this diagram, OI values exceed 400 and $H I$ values are less than 150 . Type I and Type II kerogens are oil-prone while Type III kerogens are gas-prone. Interpretation of Type IV kerogens is controversial; they are variously regarded as oil-prone, gas-prone, or inert (Smyth, 1983; Peters, 1986).

\begin{tabular}{|c|c|c|c|}
\hline Coal Rank & $\begin{array}{l}\text { Rock-Eval } \\
\operatorname{Tmax}\left({ }^{\circ} \mathrm{C}\right)\end{array}$ & $\begin{array}{l}\text { Vitrinite } \\
\text { Reflectance } \\
(\% \text { Ro })\end{array}$ & $\begin{array}{l}\text { Thermal } \\
\text { Alteration } \\
\text { Index } \\
\text { (TAI) }\end{array}$ \\
\hline PEAT & \multirow{2}{*}{\multicolumn{3}{|c|}{ 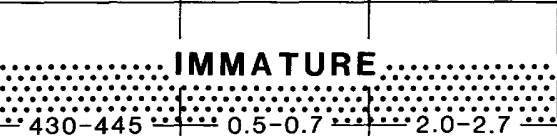 }} \\
\hline $\begin{array}{l}\text { LIGNITE \& } \\
\text { SUB- } \\
\text { BITUMINOUS }\end{array}$ & & & \\
\hline \multirow{3}{*}{ BITUMINOUS } & \multicolumn{3}{|c|}{$\begin{array}{l}\text { OIL-GENERATIVE ZONE } \\
\text { (OIL WINDOW) }\end{array}$} \\
\hline & $-465-475-$ & $-1.2-1.4-$ & $-2.9-3.5$ \\
\hline & \multicolumn{3}{|c|}{ WET-GAS GENERATIVE ZONE } \\
\hline $\begin{array}{c}\text { SEMI- } \\
\text { ANTHRACITE } \\
\& \\
\text { ANTHRACITE }\end{array}$ & \multicolumn{3}{|c|}{$\begin{array}{c}\text { POST-MATURE } \\
\text { (DRY-GAS GENERATIVE ZONE) }\end{array}$} \\
\hline $\begin{array}{c}\text { META- } \\
\text { ANTHRACITE }\end{array}$ & \multicolumn{3}{|c|}{$\begin{array}{l}\text { LOW-GRADE METAMORPHIC } \\
\text { (BARREN) }\end{array}$} \\
\hline
\end{tabular}

Figure 3. Organic geochemical parameters and levels of thermal maturation, compiled from several sources by Stanley (1987). Stippled area shows approximate range of data from the Sanctuary Formation (table 1).

\section{REFERENCES CITED}

Clayton, J.L., and Swetland, P.J., 1978, Subaerial weathering of sedimentary organic matter: Geochimica et Cosmochimica Acta, v. 42 , no. 2 , p. 305-312.

Fouch, T.D., and Dean, W.E., 1982, Lacustrine and associated clastic depositional environments, in Scholle, P.A., and Spearing, Darwin, eds., Sandstone depositional environments: American Association of Petroleum Geologists Memoir $31, \mathrm{p} \cdot 87-114$.

Katz, B.J., 1983, Limitations of "Rock-Eval" pyrolysis for typing organic matter: Organic Geochemistry, v. 4, no. 3/4, p. 195199.

Leythaeuser, Detlev, 1973, Effects of weathering on organic matter in shales: Geochimica et Cosmochimica Acta, v. 37, no. 1, p. 113-120.

Merritt, R.D., and Hawley, C.C., 1986, Map of Alaska's coal resources: Alaska Division of Mining and Geological and Geophysical Surveys Special Report 37, scale $1: 2,500,000$.

Miller, D.J., Payne, T.G., and Gryc, George, 1959, Geology of possible petroleum provinces in Alaska: U.S. Geological Survey Bulletin $1094,131 \mathrm{p}$.

Peters, K.E., 1986, Guidelines for evaluating petroleum source rock using programmed pyrolysis: American Association of Petroleum Geologists Bulletin, v. 70, no. 3, p. 318-329. 
Smyth, Michelle, 1983, Nature of source material for hydrocarbons in Cooper basin, Australia: American Association of Petroleum Geologists Bulletin, v. 67, no. 9, p. 1422-1428.

Stanley, R.G., 1987, Effects of weathering on petroleum-source evaluation of coals from the Suntrana Formation near Healy, Alaska, in Hamilton, T.D., and Galloway, J.P., eds., Geologic Studies in Alaska by the U.S. Geological Survey during 1986: U.S. Geological Survey Circular 998, p. 99-103.

Tissot, B.P., and Welte, D.H., 1984, Petroleum formation and occurrence [2nd ed.]: Berlin, Springer-Verlag, 699 p.

Wahrhaftig, Clyde, 1987, The Cenozoic section at Suntrana, Alaska, in Hill, M.L., ed., Geological Society of America, Cordilleran
Section, Centennial Guide, v. 1, p. 445-450. Wahrhaftig, Clyde, Wolfe, J.A., Leopold, E.B., and Lanphere, M.A., 1969, The coal-bearing group in the Nenana coal field, Alaska: U.S. Geological Survey Bulletin 1274-D, 30 $\mathrm{p}$.

Waples, D.W., 1985, Geochemistry in petroleum exploration: Boston, International Human Resources Development Corporation, 232 p.

Reviewers: C.M. Isaacs and T.J. Wiley

Geologic Studies in Alaska by the U.S. Geological Survey during 1987: John P. Galloway and Thomas D. Hamilton, editors, U.S. Geological Survey Circular 1016. 


\title{
Mineralogy and Stage Assignment of Some Tertiary Coal from the Tikishla Park Drill Hole, Anchorage, Alaska
}

\author{
By G.D. Stricker, M.E. Brownfield, L.A. Yehle, and J.A. Wolfe
}

Anchorage is underlain by a wedge of Quaternary deposits (Miller and Dobrovolny, 1959) that thins eastward from about $300 \mathrm{~m}$ (reinterpreted from Church, 1969, 1970) near Cook Inlet and terminates against the Chugach Mountains where Mesozoic metamorphic rocks crop out (fig. 1). Beneath the Quaternary deposits is a wedge of Tertiary rocks that also thins eastward (Plafker and others, 1982). These rocks are concealed in the Anchorage area, but they crop out along Eagle River about $20 \mathrm{~km}$ northeast of downtown Anchorage (fig. 1) (Wolfe and others, 1966; Magoon and others, 1976). We here present new mineralogic and paleontologic data from a coal horizon within the poorly known Tertiary sedimentary rocks in the subsurface beneath Anchorage.

To inventory and characterize some of the lithofacies underlying Anchorage, a hole $232 \mathrm{~m}$ deep and $150 \mathrm{~mm}$ in diameter was drilled in 1984 and accompanying geophysical studies were completed in 1985 (Yehle and others, 1986). The hole (USGS A-84-1) is located southeast of downtown Anchorage in Tikishla Park (fig. 1), and is steel cased to a depth of about $43 \mathrm{~m}$. Drilling penetrated about $155 \mathrm{~m}$ of Quaternary nonlithified deposits and $76 \mathrm{~m}$ of Tertiary rocks (fig. 2). Sampling was by coring, by collecting cuttings from drilling slurry, and by scraping from the bit assembly itself. Best samples of coal and an underlying siltstone were from a depth of about $167 \mathrm{~m}$, and these were chosen for mineralogic and paleontologic study.

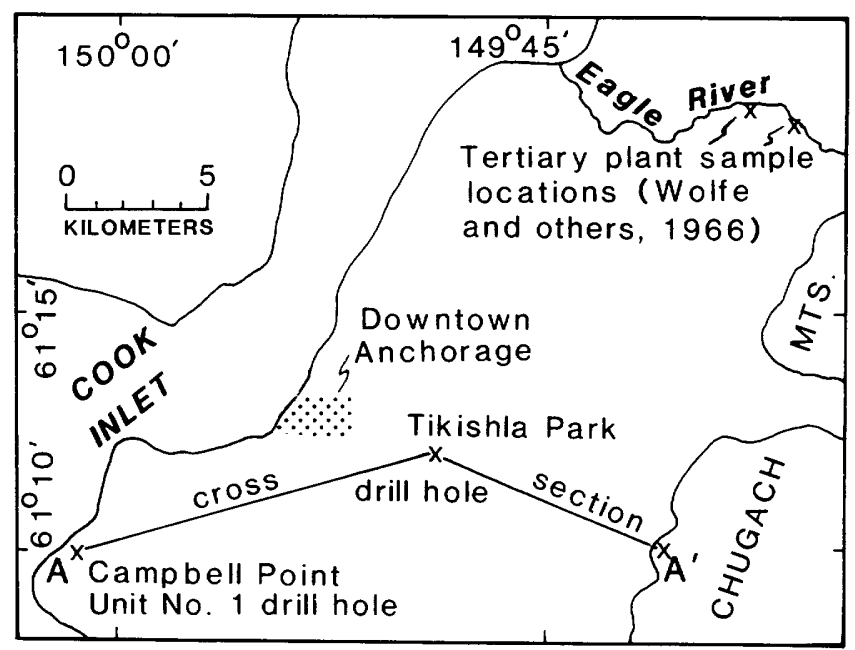

Figure 1. Anchorage area and vicinity, showing Tikishla Park drill hole, plant fossil locations, and line of cross section (figure 3 ).
Our tests and studies included vitrinite reflectance and mineralogy by Stricker and Brownfield and palynology by Wolfe. Mineralogical data were derived from the coal sample by first reducing it to ash by heating to temperatures of $150{ }^{\circ} \mathrm{C}$, following procedures of Gluskoter (1965), and then by interpretation of X-ray diffractograms of the ash. The mean random vitrinite reflectance value of the coal is 0.41 percent, which relates to a coal rank of subbituminous $C$ (Stach and others, 1975). Total ash content of the material was 39.5 percent. The mineral assemblage of the coal ash was determined to be primarily quartz and kaolinite with lesser illite, chlorite, and sodic plagioclase, and trace amounts of apatite and crandallite-group minerals. Composition of the siltstone underlying the coal bed was determined to be dominantly quartz and plagioclase, with some kaolinite and minor illite, chlorite, apatite, and crandallite group minerals.

We are studying minerals of the crandallite group because of their role as indicators of geologic terranes that have elevated levels of volcanic activity (Stricker and others, 1986; Brownfield and others, 1987). This mineral group was previously identified in Alaska coal samples from drill holes (Chleborad and others, 1980; Odum and others, 1983) west of Cook Inlet (P.D. Blackmon, U.S. Geological Survey, written

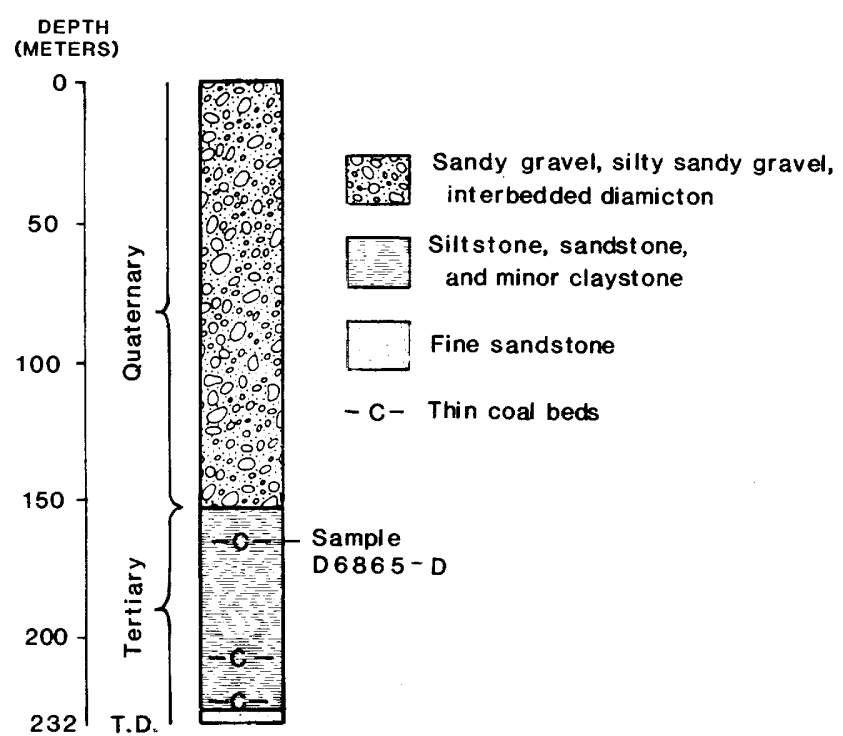

Figure 2. Abbreviated lithologic log of Tikishla Park drill hole, Anchorage, Alaska (modified from Yehle and others, 1986). T.D., total depth. 
commun., June 19, 1981; Stricker and others, 1986; Brownfield and others, 1987). From the presence of crandallite minerals reported here, and from previous work (Stricker and others, 1986; Brownfield and others, 1987), it is becoming apparent that this mineral assemblage has a wider regional and temporal distribution within Tertiary coals than earlier thought probable.

The coal and enclosing sedimentary rocks in the Tikishla Park drill hole were considered by Yehle and others (1986) and Schmoll and Barnwell (1984) to be probably part of the Tyonek Formation and of Tertiary age. This conclusion was based on comparison with outcrops of the nearest similar rocks, those exposed along Eagle River, which were assigned by Wolfe and others (1966) on the basis of plant fossils to the Seldovian Stage (Miocene). Detailed examination of pollen and spores from the coal sample at the $167 \mathrm{~m}$ depth revealed a flora similar to that found in Clamgulchian Stage assemblages by Wolfe and others (1966) at their type locality. Flora present in our sample include: Lycopodium, Osmunda, Taxodiaceaetype, Larix/Pseudotsuga, Picea, Pinus, Tsuga heterophylla-type, Alnus, Betula, Myrica, and Ericaceae. Because the Sterling Formation (Calderwood and Fackler, 1972) contains floral assemblages of the Clamgulchian Stage of latest Miocene extending into Pliocene (Wolfe, 1981), we suggest that the sampled material and probably the underlying rocks penetrated by the drill hole should be assigned to the Sterling Formation rather than to the Tyonek Formation. An earlier interpretation suggesting the presence of the Sterling Formation in the subsurface in the western part of the Anchorage area was published by Church (1969). His geologic cross section included the Yukon Services, Inc.

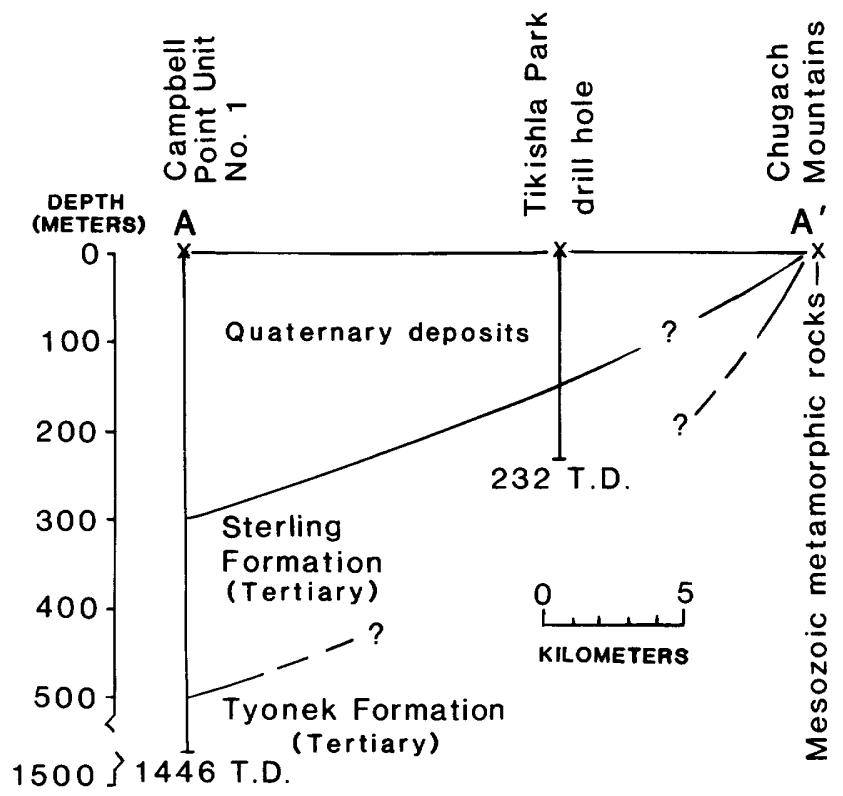

Figure 3. Generalized geologic cross section connecting Campbell Point Unit No. 1 and Tikishla Park drill holes and Chugach Mountains. See figure 1 for location. T.D., total depth.
Campbell Point Unit No. 1 drill hole (fig. 1). The information we present affirms his 1969 interpretation and extends the distribution of the Sterling Formation closer to the Chugach Mountains (fig. 3). A lithologically more varied prism of relatively soft sedimentary rocks exists beneath Anchorage than previously was believed, and we speculate that geologic structures also may be more complex than inferred by earlier workers.

\section{REFERENCES CITED}

Brownfield, M.E., Affolter, R.H., and Stricker, G.D., 1987, Crandallite group minerals in the Capps and $Q$ coal beds, Tyonek Formation, Beluga energy resource area, south-central Alaska, in Rao, P.D., ed., Focus on Alaska's coal '86: Proceedings of the Conference held at Anchorage, Alaska, October 27-30, 1986: Fairbanks, University of Alaska Mineral Industry Research Laboratory, MIRL Report Number 72, p. 142-149.

Calderwood, K.W., and Fackler, W.C., 1972, Proposed stratigraphic nomenclature for Kenai Group, Cook Inlet basin, Alaska: American Association of Petroleum Geologists Bulletin, v. 56, no. 4, p. 739-754.

Chleborad, A.F., Yehle, L.A., Schmoll, H.R., and Gardner, C.A., 1980, Preliminary field geotechnical and geophysical logs from a drill hole in the Capps coal field, Cook Inlet region, Alaska: U.S. Geological Survey Open-File Report 80-393, 17 p.

Church, R.E.(chairman), 1969, South to north stratigraphic correlation section, Anchor Point to Campbell Point, Cook Inlet Basin, Alaska [Cook Inlet Basin stratigraphic study]: Anchorage, Alaska Geological Society, Stratigraphic Committee, Year 1968$69,5 \mathrm{p} 1$.

-.- 1970, South to north stratigraphic correlation section, Campbell Point to Rosetta, and west to east stratigraphic correlation section, Buga River to Wasilla, Cook Inlet Basin, Alaska [Lower Susitna-Knik arm stratigraphic sections]: Anchorage, Alaska Geological Society, Stratigraphic Committee, Year 1969-70, 2 pl.

Gluskoter, H.J., 1965, Electric low-temperature ashing of bituminous coal: Fuel, v. 44, no. 4, p. 285-291.

Magoon, L.B., Adkinson, W.L., and Egbert, R.M., 1976, Map showing geology, wildcat wells, Tertiary plant fossil localities, K-Ar age dates, and petroleum operations, Cook Inlet area, Alaska: U.S. Geological Survey Miscellaneous Geological Investigations Map I-1019, scale $1: 250,000$.

Miller, R.D., and Dobrovolny, Ernest, 1959, Surficial geology of Anchorage and vicinity, Alaska: U.S. Geological Survey Bulletin 1093, $128 \mathrm{p}$.

Odum, J.K., Gardner, C.A., Yehle, L.A., Schmoll, H.R., and Dearborn, L.L., 1983, Preliminary lithologic, geotechnical, and geophysical 
data from drill hole CW-81-2, Chuitna West coal field, Cook Inlet region, Alaska: U.S. Geological Survey Open-File Report 83-78, 12 p.

Plafker, George, Bruns, T.R., Winkler, G.R., and Tysdal, R.G., 1982, Cross section of the eastern Aleutian arc, from Mount Spurr to the Aleutian trench near Middleton Island, Alaska: Geological Society of America, Map and Chart Series MCH-28p, scale 1:1,000,000.

Schmoll, H.R., and Barnwell, W.W., 1984, Eastwest geologic cross section along the DeBarr line, Anchorage, Alaska: U.S. Geological Survey Open-File Report 84-791, $10 \mathrm{p}$.

Stach, E., Taylor, G.H., Mackowsky, M.T., Chandra, D., Teichmüller, M., Teichmüller, R., Murchison, D.G., and Zierke, F., 1975, Textbook of coal petrology: Berlin, Gebrllder Borntraeger, 428 p.

Stricker, G.D., Affolter, R.H., and Brownfield, M.E., 1986, Geochemical characterization of selected coals from the Beluga Energy Resource Area, south-central Alaska: Site of a proposed coal mine [abs.], in Carter, L.M.H., ed., USGS research on energy resources--1986 program and abstracts: U.S. Geological Survey Circular 974, p. 65-66.
Wolfe, J.A., 1981, A chronologic framework for Cenozoic megafossil floras of northwestern North America and its relation to marine geochronology, in Armentrout, J.M., ed., Pacific Northwest Cenozoic biostratigraphy: Geological Society of America, Special Paper 184, p. 39-47.

Wolfe, J.A., Hopkins, D.M., and Leopold, E.B., 1966, Tertiary stratigraphy and paleobotany of the Cook Inlet region, Alaska: U.S. Geological Survey Professional Paper 398-A, $29 \mathrm{p}$.

Yehle, L.A., Odum, J.K., Schmoll, H.R., and Dearborn, L.L., 1986, Overview of the geology and geophysics of the Tikishla Park drill hole, USGS A-84-1, Anchorage, Alaska: U.S. Geological Survey Open-File Report 86-293, 10 p.

Reviewers: S.B. Roberts and H.R. Schmoll

Geologic Studies in Alaska by the U.S. Geological Survey during 1987: John P. Galloway and Thomas D. Hamilton, editors, U.S. Geological Survey Circular 1016. 



\section{SOUTHWESTERN ALASKA}

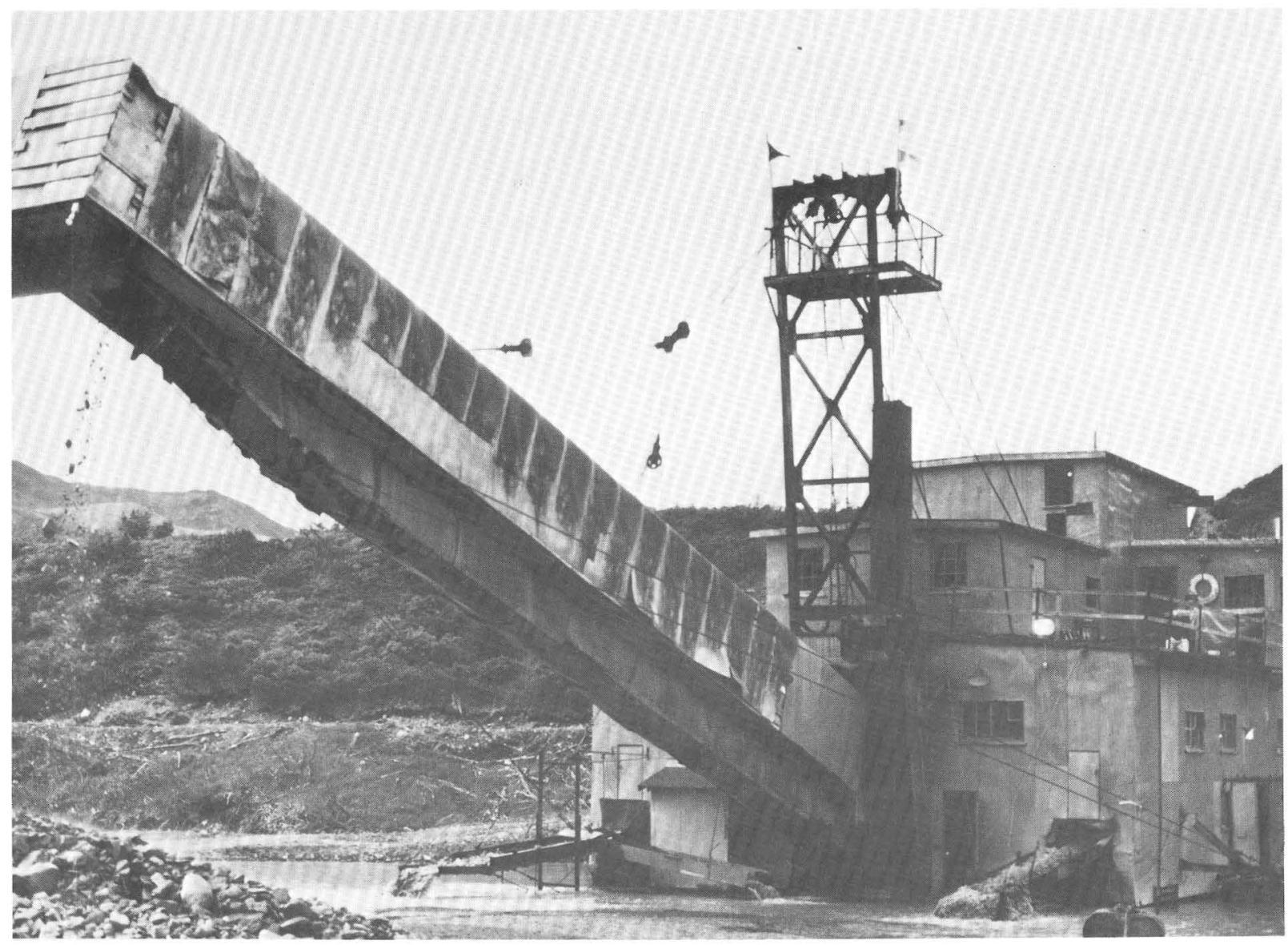

A gold dredge at Nyac (about $95 \mathrm{~km}$ east-northeast of Bethel) disgorges gravel from its tail boom. Photograph by E. Yount. 


\title{
Petrogenesis of the Crooked Mountains Pluton, Bethel Quadrangle: A Preliminary Report
}

\author{
By Thomas P. Frost, James P. Calzia, Ronald W. Kistler, and Davison V. Vivit
}

During the summer of 1987 we began a systematic study of the granitoids between lat. 60 and $61^{\circ} \mathrm{N}$. in the eastern part of the Bethel quadrangle (figs. 1 and 2), as part of the Alaska Mineral Resource Assessment Program. This report presents our initial field results and preliminary petrographic data, along with compositional and isotopic data on samples from a traverse through the Crooked Mountains pluton (fig. 2 ), that pertain to the origin and evolution of southwestern Alaskan granitoids. Field studies were carried out by the first two authors (Frost and Calzia), isotopic analyses were done under the direction of Kistler, and X-ray fluorescence analyses were done by Vivit.

Plutons of the Bethel quadrangle appear to be part of a broad belt of plutonic and volcanic rocks (fig. 1) of Late Cretaceous to early Tertiary age which extend beneath the Bering Sea to the southwest and appear to terminate near the Kaltag fault to the northeast (Wilson, 1977; Shew and Wilson, 1981; Moll and Patton, 1982; Wallace and Engebretson, 1984; Robinson and Decker, 1986; Bergman and Doherty, 1986; Bergman and others, 1987). Plutons emplaced between $63 \mathrm{Ma}$ and $80 \mathrm{Ma}$ are dominantly calc-alkalic and have increasing $\mathrm{K}_{2} \mathrm{O}$ content (at 57.5 percent $\mathrm{SiO}_{2}$ ) with increasing distance from the Gulf of Alaska; plutons emplaced between 45 and $63 \mathrm{Ma}$ do not vary significantly in $\mathrm{K}_{2} \mathrm{O}$ content (at 57.5 percent $\mathrm{SiO}_{2}$ ) throughout the region (Bergman and others, 1987).

Plutons in the Bethel quadrangle cut the accreted Nyac, Goodnews, and Togiak terranes as well as the Albian to Coniacian turbidites of the Kuskokwim Group (fig. 2), but none are known to intrude the Tikchik terrane in the Bethel quadrangle (Hoare and Coonrad, 1959a; Box and Murphy, 1987). Only a few plutons in the quadrangle have been dated radiometrically (table 1 ); the ages determined range between 66 and $120 \mathrm{Ma}$ (Wilson, 1977; Robinson and Decker, 1986; Bergman and Doherty, 1986). Intermediate to rhyolitic flows and domes(?) of Late Cretaceous to early Tertiary age (Hoare and Coonrad, 1959a; Wilson, 1977; Robinson and Decker, 1986), as well as abundant mafic to rhyolitic dikes, cut all other rock types.

Granitoid plutons in the region are typically elliptical in plan and are as large as 8 by $40 \mathrm{~km}$ (fig. 2), although elliptical bodies as small as a few hundred square meters with plutonic textures are scattered throughout the quadrangle. Most plutons are in sharp, discordant contact with their wallrocks and have welldeveloped thermal aureoles as wide as $2 \mathrm{~km}$. The thermally metamorphosed sedimentary and volcaniclastic wallrocks are commonly resistant to erosion and form prominent ridges encircling many of the plutons.

Quartz-rich hornblende-biotite granodiorite, quartz monzodiorite, and granite are the most common plutonic rock types in the Bethel quadrangle, although tonalite, hornblende diorite, and anorthositic hornblende gabbro are also present (Wilson, 1977; Robinson and others, 1986). Most plutons are slightly zoned to unzoned, medium grained, and equigranular, although porphyritic facies are common locally. Finegrained ellipsoidal mafic enclaves, composed of abundant hornblende, biotite, and plagioclase and lesser quartz, potassium feldspar, and sphene, are present in most of the quartz-bearing plutons. Enclaves are typically less than $20 \mathrm{~cm}$ in maximum dimension; most are subequant, although near pluton margins many are strongly flattened. At the

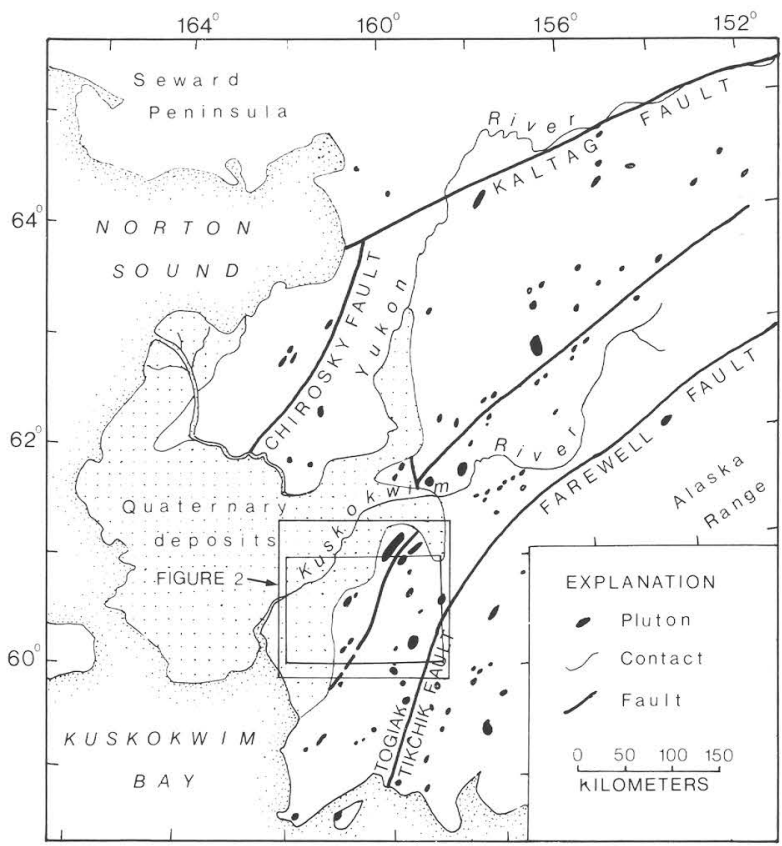

Figure 1. Southwestern Alaska showing distribution of plutonic rocks of Late Cretaceous to early Tertiary age of Kuskokwim Mountains belt. Plutons in Alaska Range and on Seward Peninsula are not shown. Small box in area of figure 2 shows outline of Bethel quadrangle. Adapted from Beikman (1980) and Wallace and Engebretson (1984). 
northwestern margin of the Cripple Mountains pluton (fig. 2), enclaves are most abundant within $50 \mathrm{~m}$ of contact, where they compose about 5 percent of the outcrop.

The Crooked Mountains pluton intrudes Mesozoic intermediate volcanic and volcaniclastic rocks of the Togiak terrane (Box and Murphy, 1987). The rock is predominantly equigranular hornblendebiotite granodiorite and quartz monzodiorite, although it is slightly porphyritic near the pluton margin. The pluton is rimmed on its western side by a homogeneous, medium-grained, equigranular border phase of clinopyroxene quartz diorite which contains prominent, dark-colored, euhedral plagioclase. The border phase is sharply cut by dikes of the main felsic phase of the pluton. Enclaves are present throughout the pluton, although their abundance is typically less than 1 percent of outcrop.

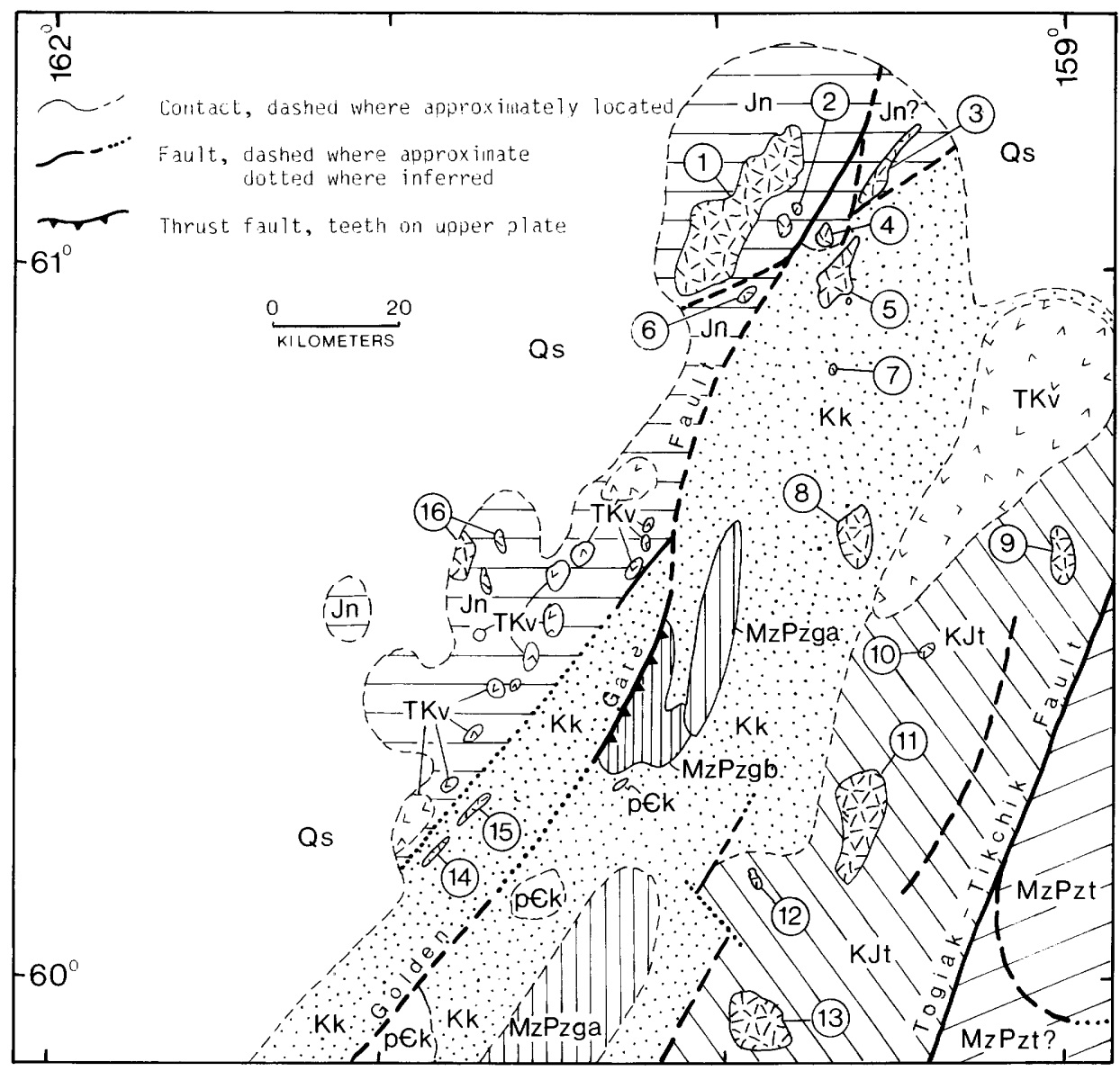

PRE-MID-CRETACEOUS TERRANES

Togiak terrane (Early Cretaceous and (or) Late Jurassic)

KJt Andesitic volcanic rocks, volcaniclastic sedimentary rocks, and tuffaceous

OVERLAP SEQUENCES

Qs Surficial deposits (Quaternary) Late Cretaceous) Basalt to rhyolite flows and domes, includes some hypabyssal rocks

kk Kuskokwim Group (Late and Early Cretaceous)

\section{GRANITOID PLUTONS}

(early Tertiary to Late Cretaceous)

Identified by number, corresponding to numbers in table 1 .

Nyac terrance (Jurassic)

Jn Andesitic volcanic rocks

Goodnews terrane (Mesozoic or Paleozoic)

MzPzga Tuffaceous argillite and chert, some basalt

MzPzgb Foliated metabasite, metachert. and marble

Tikchik terrane (Mesozoic and Paleozoic)

MzPzt Metavolcanic rocks, metachert, graywacke, and $l$ imestone

Kilbuck terrane (Precambrian)

pek Amphibolite facies orthogneiss and quartz-mica schist

Figure 2. Regional geology of Bethel quadrangle and parts of Russian Mission and Goodnews quadrangles (adapted from Hoare and Coonrad, 1959a,b, 1978; Wilson, 1977; Box and Murphy, 1987; Bergman and Doherty, 1986; Bergman and others, 1987; Robinson and Decker, 1986). 
Table 1. Summary of plutonic rocks, Bethel quadrangle region, southwestern Alaska [Numbers key each pluton to figure 1. Hbl, homblende; bio, biotite]

\begin{tabular}{|c|c|c|c|}
\hline Pluton name & Predominant compositions & Age, $\mathrm{Ma}(\mathrm{K}-\mathrm{Ar})$ & References \\
\hline 1. Nyac & $\begin{array}{l}\text { hb1-bio granodiorite and } \\
\text { (porphyritic) biotite } \\
\text { granodiorite and granite }\end{array}$ & $\begin{array}{l}101.1 \pm 3.0(\mathrm{hbl}) \\
108.5 \pm 3.3(\mathrm{bio}) \\
120 \pm 3.6(\mathrm{bio})\end{array}$ & $\begin{array}{l}1,2,4,5 \\
6,8\end{array}$ \\
\hline $\begin{array}{l}\text { 2. Spruce Creek and } \\
\text { Bonanza Creek }\end{array}$ & $\begin{array}{l}\text { fine grained biotie granite } \\
\text { and granodiorite }\end{array}$ & & 2,5 \\
\hline 3. Sawpit Creek & granodiorite (?) & & 2 \\
\hline 4. Fox Creek & $\begin{array}{l}\text { biotite granodiorite, associated } \\
\text { with gabbro (?) and diabase }\end{array}$ & $66.6 \pm 2.0$ (bio) & 2,6 \\
\hline $\begin{array}{l}\text { 5. Mt. Plummer and } \\
\text { Marvel Dome }\end{array}$ & $\begin{array}{l}\text { hbl-bio granodiorite to quartz } \\
\text { monzodiorite }\end{array}$ & & 1,8 \\
\hline 6. Powerplant & $\begin{array}{l}\text { concentrically (?) zoned hbl } \\
\text { diorite to bio-hbl granodiorite }\end{array}$ & & 1,8 \\
\hline 7. Fisher Dome & $\begin{array}{l}\text { porphyritic bio granite, cut by } \\
\text { stibnite-quartz veins }\end{array}$ & & 1,8 \\
\hline 8. Cripple Mountains & bio-hbl granodiorite to granite & & 1,8 \\
\hline 9. Gemuk Mountain & $\begin{array}{l}\text { anorthositic hbl gabbro and } \\
\text { anorthosite (1abradorite) }\end{array}$ & & 1,4 \\
\hline 10. North Fork & hbl-bio granodiorite & & 1,8 \\
\hline 11. Crooked Mountains & $\begin{array}{l}\text { hbl-bio granodiorite, granite, } \\
\text { and quartz monzodiorite }\end{array}$ & $\begin{array}{l}71.7 \pm 2.7 \text { (bio) } \\
73.0 \pm 3.7 \text { (hb1) }\end{array}$ & $1,7,8$ \\
\hline 12. Canyon Creek & $\begin{array}{l}\text { bio-hb1 (cpx) quartz diorite } \\
\text { to granodiorite }\end{array}$ & & 1,8 \\
\hline 13. Mt. Oratio & bio-hbl quartz monzodiorite & $71.1 \pm 2.1$ (bio) & 3,4 \\
\hline 14. Eek River & tonalite and $\mathrm{cpx}$ diorite & & $1,4,8$ \\
\hline 15. Kwethluk River & (porphyritic) two-px diorite & & $1,4,8$ \\
\hline 16. Columbia Creek & hbl-bio granodiorite and granite & & 1,8 \\
\hline
\end{tabular}

References: 1, Hoare and Coonrad (1959a); 2, Hoare and Coonrad (1959b);

3, Hoare and Coonrad (1978); 4, Wilson (1977); 5, Decker and others (1984);

6 , Robinson and Decker (1986); 7, Bergman and Doherty (1986); 8, this report

The compositional variation in the Crooked Mountains pluton indicates that it is of calc-alkalic affinity. The main phase of the pluton is restricted in its compositional range to 69 to 72 percent $\mathrm{SiO}_{2}$ (data normalized anhydrous) and has 4.5 to 5 percent $\mathrm{K}_{2} \mathrm{O}$; trace-element contents exhibit little variation (table 2 , fig. 3). The border phase on the western margin is also homogeneous in all elemental concentrations and has 63.2 to 63.8 percent $\mathrm{SiO}_{2}$ (table 2 and T.P. Frost, unpub. data). All rock types plot in the volcanic arc granites field on $R b$ versus $\mathrm{Y}+\mathrm{Nb}$ and $\mathrm{Nb}$ versus $\mathrm{Y}$ diagrams (Pearce and others, 1984).

The ellipsoidal mafic enclaves are the most variable and erratic in composition of all rock types of the Crooked Mountains pluton (table 2, fig. 3). Silica content is 57.7 to 64.1 percent, $\mathrm{Na}_{2} \mathrm{O}$ content is 5.5 to 5.8 percent, and $\mathrm{K}_{2} \mathrm{O}$ content is 2.2 to 3.8 percent. Rubidium is between 60 and $82 \mathrm{ppm}$; $\mathrm{Sr}$ content is widely variable (fig. 3 ). The compositional variation in the enclaves suggests that they do not represent early mafic cumulates or early differentiates of either the border phase or the main-phase granodiorite (for example, Walawender and Gross, 1986), nor could they all represent a single mafic magma which quenched as enclaves in the magma of the main phase (for example,
Vernon, 1983; Reid and others, 1983; Frost and Mahood, 1987), or residual unmelted material from the source regions of the main phase granodiorite (for example, White and Chappell, 1977). Other origins which have been proposed for similar enclaves in other plutons include liquid immiscibility (for example, Bender and others, 1982), and reequilibrated wallrock inclusions, although these are usually recognizable in the field (for example, Didier, 1973).

Despite the wide variation in major- and traceelement abundances, and the lack of an apparent coherent fractionation trend between enclaves, border phase, and main phase (fig. 3), whole-rock samples of all rock types yield an apparent ${ }^{8} \mathrm{Sr} /{ }^{86} \mathrm{Sr}$ jsochron of $66.6 \pm 7.9 \mathrm{Ma}$, with an apparent initial ${ }^{87} \mathrm{Sr} /{ }^{6} \mathrm{Sr}$ of $0.7036 \pm 0.0002$ (fig. 4). If the apparent isochron is assumed to represent the true age for all rocks analyzed, then the isotopic data suggest that either the enclaves have reequilibrated isotopically with the host magma, or their initial isotopic composition was coincidentally very close to that of the host magma. Barbarin and Bateman (1986) also observed apparent $\mathrm{Sr}$ isotopic equilibration between mafic enclaves and host granitoids in the Sierra Nevada batholith of California. Compositional data suggest that the 
Table 2. Representative analyses, Crooked Mountains pluton, Bethel quadrangle, Alaska (Most X-ray fluorescene (XRF) determinations (except Rb and $\mathrm{Sr}$ ) by D.V. Vivit, USCS. Rb and $\mathrm{Sr}$ (by XRF) and isotopic analyses by A.C. Robinson, USGS, Menlo Park, Calif.]

\begin{tabular}{|c|c|c|c|c|c|c|c|c|c|c|}
\hline \multirow{2}{*}{$\begin{array}{l}\text { Rock type } \\
\text { Sample }{ }^{l}\end{array}$} & \multirow{2}{*}{$\frac{\text { Border }}{046}$} & \multicolumn{3}{|c|}{ Enclaves } & \multicolumn{6}{|c|}{ Main phase } \\
\hline & & 050 & $049-I$ & $043 \mathrm{~A}$ & $043 B$ & 051 & 052 & 039 & 049-H & 041 \\
\hline $\begin{array}{l}\mathrm{SiO}_{2} \\
\mathrm{TiO}_{2} \\
\mathrm{Al}_{2} \mathrm{O}_{3} \\
\mathrm{Fe}_{2} \mathrm{O}_{3} \\
\mathrm{MnO}_{3} \\
\mathrm{MgO} \\
\mathrm{CaO} \\
\mathrm{Na}_{2} \mathrm{O}^{\circ} \\
\mathrm{K}_{2} \mathrm{O} \\
\mathrm{P}_{2} \mathrm{O}_{5} \\
\mathrm{LOI}^{3}\end{array}$ & $\begin{array}{r}62.6 \\
.92 \\
15.3 \\
5.38 \\
.09 \\
2.90 \\
4.24 \\
3.90 \\
3.10 \\
.20 \\
.50\end{array}$ & $\begin{array}{r}56.2 \\
1.22 \\
17.2 \\
7.12 \\
.11 \\
2.80 \\
5.60 \\
5.60 \\
2.22 \\
.28 \\
.37\end{array}$ & $\begin{array}{r}63.2 \\
.78 \\
16.0 \\
4.94 \\
.08 \\
1.90 \\
3.86 \\
5.70 \\
2.44 \\
.22 \\
.13\end{array}$ & $\begin{array}{r}63.3 \\
.78 \\
16.5 \\
4.77 \\
.09 \\
1.10 \\
2.82 \\
5.40 \\
3.64 \\
.26 \\
.75\end{array}$ & $\begin{array}{r}67.6 \\
.52 \\
15.1 \\
3.26 \\
.06 \\
.65 \\
2.02 \\
4.10 \\
4.62 \\
.12 \\
1.87\end{array}$ & $\begin{array}{r}68.0 \\
.52 \\
15.1 \\
3.14 \\
.05 \\
.70 \\
1.92 \\
4.30 \\
4.62 \\
.12 \\
.50\end{array}$ & $\begin{array}{r}68.1 \\
.52 \\
15.0 \\
3.14 \\
.05 \\
.65 \\
1.90 \\
4.40 \\
4.58 \\
.12 \\
.63\end{array}$ & $\begin{array}{r}68.1 \\
.48 \\
15.1 \\
2.95 \\
.05 \\
.60 \\
1.88 \\
4.20 \\
4.66 \\
.10 \\
.88\end{array}$ & $\begin{array}{r}68.7 \\
.52 \\
15.0 \\
3.04 \\
.05 \\
.65 \\
1.88 \\
4.30 \\
4.56 \\
.12 \\
.37\end{array}$ & $\begin{array}{r}71.0 \\
.36 \\
14.1 \\
2.38 \\
.04 \\
.40 \\
1.40 \\
3.90 \\
4.72 \\
.08 \\
.38\end{array}$ \\
\hline Total & 99.1 & 99.0 & 99.3 & 99.4 & 99.9 & 99.0 & 99.1 & 99.0 & 99.2 & 98.8 \\
\hline
\end{tabular}

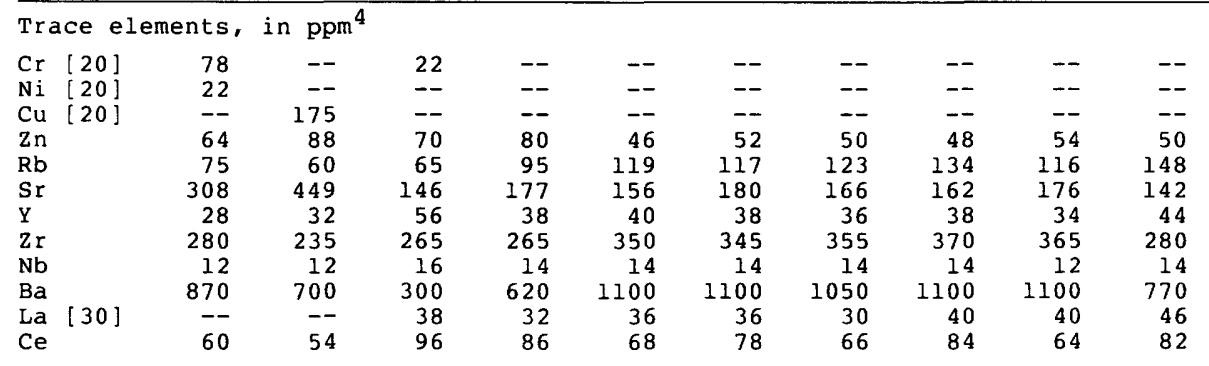

\begin{tabular}{lccccccccccc}
\hline Isotope data & & & & & & & & & \\
$\mathrm{Rb} / \mathrm{Sr}$ & 0.244 & 0.134 & 0.445 & 0.538 & 0.763 & 0.650 & 0.741 & 0.827 & 0.659 & 1.042 \\
$87 \mathrm{Rb} / 86 \mathrm{Sr}$ & .706 & .389 & 1.288 & 1.558 & 2.207 & 1.881 & 2.144 & 2.393 & 1.907 & 3.015 \\
$87 \mathrm{Sr} / 86 \mathrm{Sr}$ & .7043 & .7041 & .7048 & .7050 & .7057 & .7056 & .7055 & .7059 & .7054 & .7066 \\
$\mathrm{Sr}_{\mathrm{i}}$ & .7036 & .7037 & .7035 & .7035 & .7035 & .7037 & .7033 & .7035 & .7034 & .7035
\end{tabular}

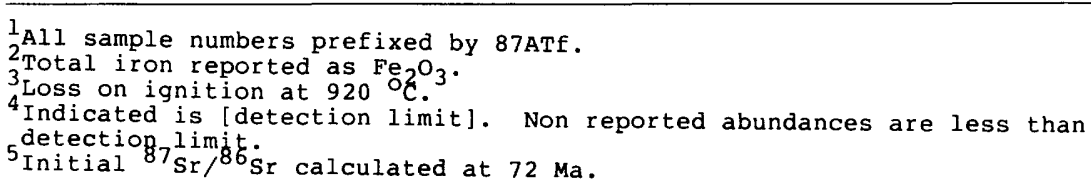

enclaves and border phase are not differentiation products of a single magma, and that the enclaves and the main phase are also not differentiation products of a single magma.

Although the $\mathrm{Sr}$ isotopic data define an apparent isochron for the Crooked Mountains pluton, an age is not assigned to the pluton in this report due to the present uncertainty in the relationship between the origin of the enclaves, their host, and the border phase. The apparent isochron determined for all samples in this study is compatible, within the analytical uncertainty limits, with the $\mathrm{K}-\mathrm{Ar}$ mineral ages of 71.7 to $73.0 \mathrm{Ma}$ determined by Bergman and Doherty (1986). An apparent isochron calculated using only the enclave data is $56.7 \pm 8.6 \mathrm{Ma}$; an apparent isochron calculated using only the main phase data is $69.1 \pm 34.9 \mathrm{Ma}$.

Initial strontium isotopic ratios for the samples from the Crooked Mountains pluton, recalculated using Bergman and Doherty's (1986) K-Ar ages, range from 0.7033 to 0.7037 (table 2), but do not show a systematic difference between enclaves, border phase, and main phase. The low initial $\mathrm{Sr}$ isotopic ratio for the Crooked Mountains pluton suggests that little or no old radiogenic crustal component was involved in its genesis and that Precambrian basement (Hoare and Coonrad, 1959a, 1978; Turner and others, 1983) exposed $40 \mathrm{~km}$ to the west in the Kilbuck terrane (fig. 2) does not extend east beneath the Crooked Mountains. The magma may have had its source in the mantle and (or) in nonradiogenic mafic and intermediate Mesozoic supercrustal rocks.

The chemistry determined for the Crooked Mountains pluton of the Kuskokwim Mountains indicate a subduction-related origin, although the distance to the subduction zone during its emplacement is uncertain. Wallace and Engebretson (1984) and Bergman and Doherty (1986) suggested that Late Cretaceous to early Tertiary magmatism in the Kuskokwim Mountains was part of a very broad magmatic belt from the Alaska Range to the Kaltag fault which developed in response to gently-dipping, rapid subduction of the Kula plate. Bergman and others (1987) have further delineated southwestern Alaska magmatism into a Late Cretaceous (89-66 Ma) calc-alkaline group which formed in response to rapid subduction of the Kula plate, and an early Tertiary (66-45 Ma) group that may not be subduction related, but formed instead by post-subduction lithospheric (including crust) melting. Compositional and isotopic data presented here for the Crooked Mountains pluton are compatible with Bergman and others (1987) conclusions regarding the older magmatic group. 

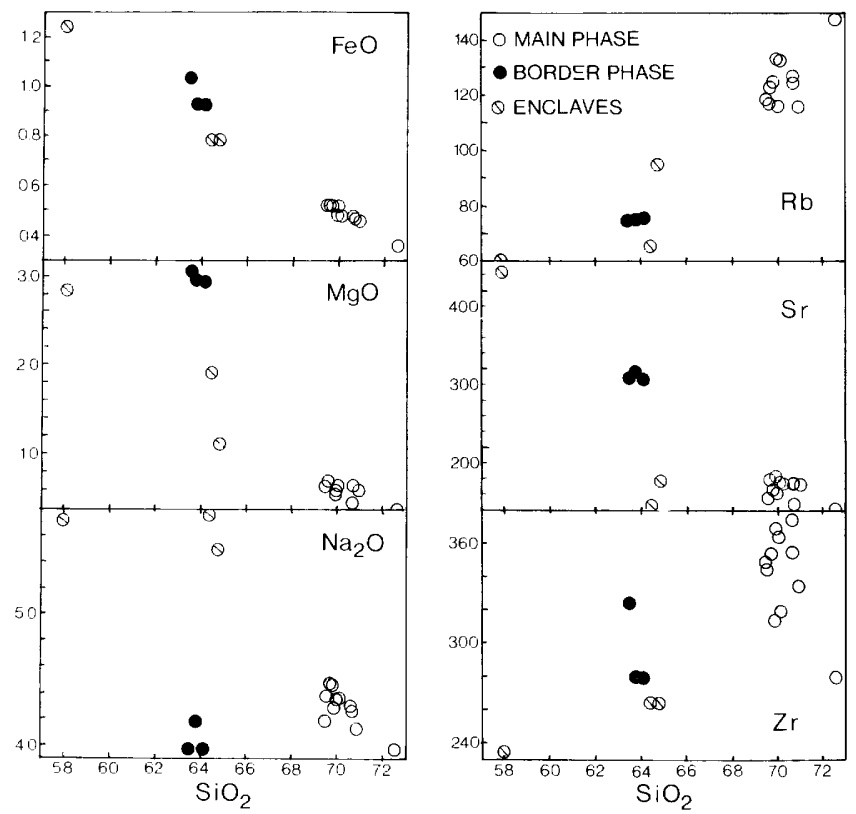

Figure 3. Variation with silica content for selected elements, Crooked Mountains pluton. Major elements in weight percent, trace elements are in parts per million. Total iron reported as FeO. All data recalculated anhydrous. Data from table 2 and D.V. Vivit, written communication. See text for discussion.

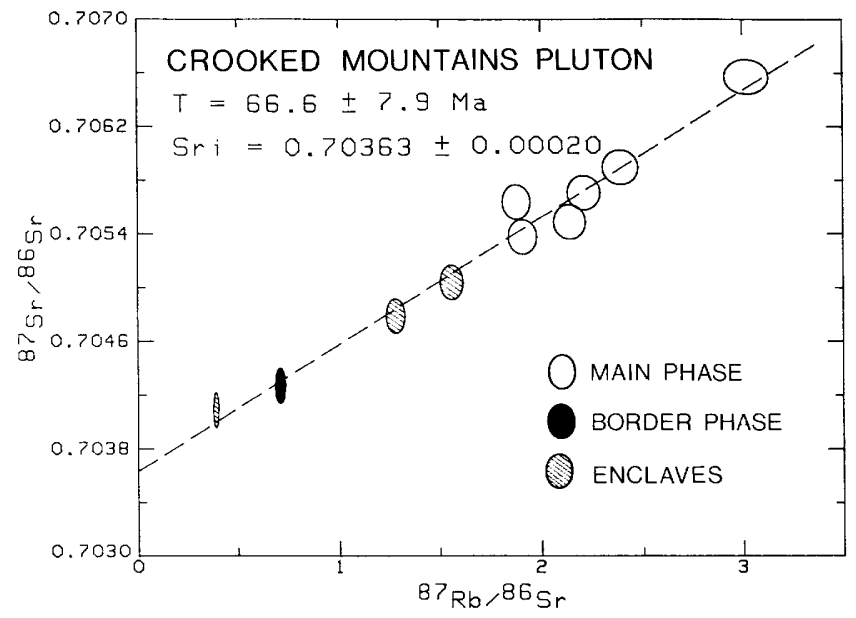

Figure 4. $\mathrm{Rb} / \mathrm{Sr}$ evolution diagram, Crooked Mountains pluton. Ellipse size indicates error in determinations. See text for discussion.
Beikman, H.E., 1980, Geologic map of Alaska: U.S. Geological Survey Special Map, 2 sheets, scale $1: 2,500,000$.

Bender, J.F., Hanson, G.N., and Bence, A.E., 1982, The Cortlandt complex: evidence for large-scale liquid immiscibility involving granodiorite and diorite magmas: Earth and Planetary Science Letters, v. 58, p. 330344.

Bergman, S.C., and Doherty, D.J., 1986 Nature and origin of 50-75 Ma volcanism and plutonism in $W$. and S. Alaska [abs.]: Geological Society of America Abstracts with Programs, v. 18, p. 539.

Bergman, S.C., Hudson, T.L., and Doherty, D.J., 1987, Magmatic rock evidence for a Paleocene change in the tectonic setting of Alaska [abs.]: Geological Society of America Abstracts with Programs, v. 19, p. 586-587.

Box, S.E., and Murphy, J.M., 1987, Late Mesozoic structural and stratigraphic framework, eastern Bethel quadrangle, southwestern Alaska, in Hamilton, T.D., and Galloway, J.P., eds., Geologic studies in Alaska by the U.S. Geological Survey during 1986: U.S. Geological Survey Circular 998, p. 7882 .

Decker, John, Reifenstuhl, R.R., and Coonrad, W.L., 1984, Compilation of geologic data from the Russian Mission A-3 quadrangle, southwestern Alaska: Alaska Division of Geological and Geophysical Surveys, Report of Investigations $84-19$, scale $1: 63,360$.

Didier, J., 1973, Granites and their enclaves: New York, Elsevier, 393 p.

Frost, T.P., and Mahood, G.A., 1987, Field, chemical, and rheologic constraints on mafic-felsic magma interaction in the Lamarck Granodiorite, Sierra Nevada, California: Geological Society of America Bulletin, v. 99, p. 272-291.

Hoare, J.M., and Coonrad, W.L., 1959a, Geology of the Bethel quadrangle, Alaska: U.S. Geological Survey Miscellaneous Investigations Series Map I-285, scale $1: 250,000$.

-.- 1959b, Geology of the Russian Mission quadrangle, Alaska: U.S. Geological Survey Miscellaneous Investigations Series Map I292, scale 1:250,000.

---- 1978, Geologic map of the Goodnews and Hagemeister Island quadrangles region, southwestern Alaska: U.S. Geological Survey Open-File Report 78-9-B, 2 sheets, scale $1: 250,000$.

Mo11, E.J., and Patton, W.W., Jr., 1982, Preliminary report on the Late Cretaceous and early Tertiary volcanic and related plutonic rocks in western Alaska, in Coonrad, W.L., ed., The United States Geological Survey in Alaska: Accomplishments during 1980: U.S. Geological Survey Circular 844, p. 73-75.

Pearce, J.A., Harris, N.B.W., and Tindle, A.G., 1984, Trace element discrimination diagrams for the tectonic interpretation of granitic 
rocks: Journal of Petrology, v. 25, p. 956983.

Reid, J.B., Jr., Evans, O.C., and Fates, D.G., 1983, Magma mixing in granitic rocks of the central Sierra Nevada, California: Earth and Planetary Sciences Letters, v. 66, p. 243-261.

Robinson, M.S., and Decker, John, 1986, Preliminary age data and analytical data for selected igneous rocks from the sleetmute, Russian Missian, Taylor Mountains, and Bethel quadrangles, southwestern Alaska: Alaska Division of Mining and Geological and Geophysical Surveys, Public-Data File 86-99, $8 \mathrm{p}$.

Robinson, M.S., Nye, Chris, and Decker, John, 1986, Preliminary whole rock major oxide and trace element geochemistry of selected igneous rocks from the sleetmute, Russian Mission, and Taylor Mountains quadrangles, southwestern Alaska: Alaska Division of Mining and Geological and Geophysical Surveys, Public-Data File 86-98, 9 p.

Shew, Nora, and Wilson, F.H., 1981, Map and table showing radiometric ages of rocks in southwestern Alaska: U.S. Geological Survey Open-File Report 81-866, 26 p.

Turner, D.L., Forbes, R.B., Aleinikoff, J.N., Hedge, C.E., and McDouga11, Ian, 1983, Geochronology of the Kilbuck terrane of southwestern Alaska [abs.]: Geological
Society of America Abstracts with Programs, v. 15, p. 407 .

Vernon, R.H., 1983, Restite, xenoliths, and microgranitoid enclaves in granites: Journal and Proceedings of the Royal Society of New South Wales, v. 116, p. 77-103.

Wal awender, M.J., and Gross, W.W., 1986, Geochemistry and origin of mafic inclusions in the granitic rocks of the Peninsular Ranges batholith, southern California [abs.]: Geological Society of America Abstracts with Programs, v. 18, p. 194.

Wallace, W.K., and Engebretson, D.C., 1984, Relationships between plate motions and Late Cretaceous to Paleogene magmatism in southwestern Alaska: Tectonics, v. 3, p. 295-315.

White, A.J.R., and Chappel1, B.W., 1977, Ultrametamorphism and granitoid genesis: Tectonophysics, v. 43, p. 7-22.

Wilson, F.H., 1977, Some plutonic rocks of southwestern Alaska, a data compilation: U.S. Geological Survey Open-File Report 77501,9 p.

Reviewers: S.E. Box and E.J. Moll-Stalcup

Geologic Studies in Alaska by the U.S. Geological Survey during 1987: John P. Galloway and Thomas D. Hamilton, editors, U.S. Geological Survey Circular 1016. 


\title{
Geochemical Anomalies in the Eastern Katmai Region of the Alaska Peninsula
}

\author{
By Richard J. Goldfarb, John E. Gray, and R.B. Tripp
}

During the 1983-1985 field seasons, the U.S. Geological Survey conducted a reconnaissance stream sediment geochemical survey of the Alaska Peninsula between lat $58^{\circ}$ and $59^{\circ}$ N. (fig. 1). Stream-sediment samples were collected from areas of active alluvium. Heavy-mineral concentrates were also collected with a standard gold pan at most sediment sites, and any magnetic material within these samples was removed in the laboratory using a magnetic separator. All sediment and nonmagnetic concentrate samples were analyzed for 31 elements using a semiquantitative emission spectrographic method. The methods of collection, processing, localities, and chemical results from these samples were described in detail by Bailey and others (1986). Mineralogical results obtained from the nonmagnetic fraction of the concentrates panned from stream sediments were given by Bennett and Church (1987).

Geologic mapping during the course of the project (J.R. Riehle, U.S. Geological Survey, written commun., 1986) has refined the earlier reconnaissance mapping by Keller and Reiser (1959). The eastern part of the Katmai region is underlain dominantly by Mesozoic siltstone and sandstone of the Naknek and Kaguyak Formations, which, in turn, are overlain by coal-bearing, continental, Tertiary sedimentary beds along much of the eastern edge of the study area. Late Tertiary andesitic and dacitic volcanic rocks of the Aleutian arc crop out over most of the area between Hallo Glacier and Katmai River. Intermediate hypabyssal sills, dikes, and plugs intrude this stratigraphic interval. The western border of the

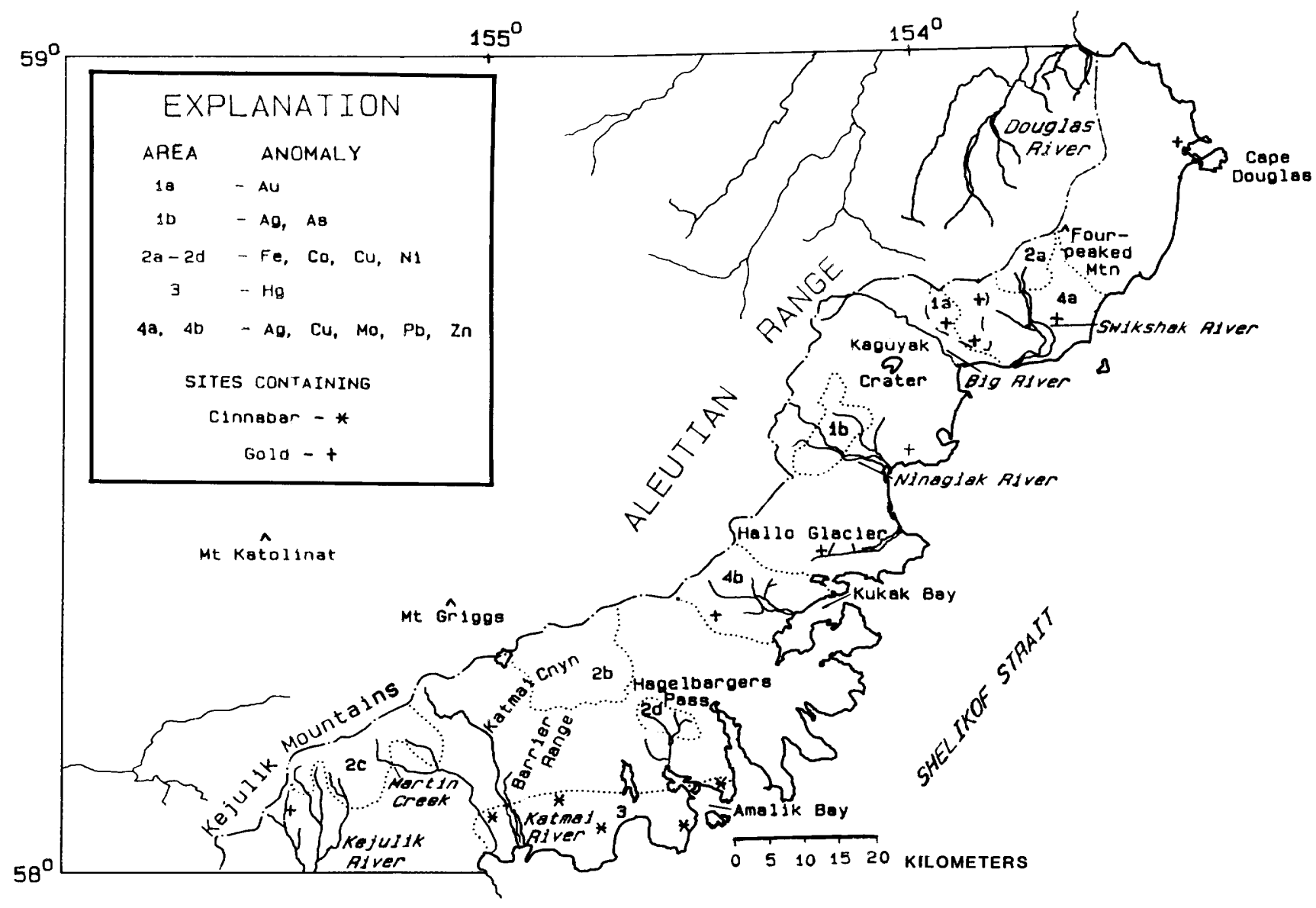

Figure 1. Eastern drainages of Katmai region on Alaska Peninsula, showing distribution of geochemical anomalies. 
study area for this report is the crest of the Aleutian Range. Most of the high peaks are composed largely of Quaternary andesite and dacite that make up the active volcanoes along the continental portion of the Aleutian volcanic arc.

Univariate and multivariate statistical techniques were used to identify anomalous samples collected during the geochemical survey. The basic statistics for the analytical data from the 347 minus80-mesh stream sediments and from the 337 nonmagnetic heavy-mineral concentrates are given in tables 1 and 2. Detection ratios, the number of determinant (noncensored) values divided by the total number of samples analyzed for a given element, describe the degree to which the data are censored. Minimum, median, and maximum values are tabulated to present the range in the geochemical data. The 90th, 95th, and 98th percentiles are also listed to enable the reader to select geochemical thresholds. The geometric mean, geometric deviation, and expected range are computed for those elements with detection ratios greater than 0.15 . According to Miesch (1976), 95 percent of all values for a lognormal distribution fall within an expected range from Geometric Mean/(Geometric Dev.) ${ }^{2}$ to Geometric Mean x (Geometric Dev.) ${ }^{2}$.

Many elements commonly considered to be important pathfinders for mineral occurrences are highly censored within the sediment data. Additionally, visual inspection of histograms of the sediment data showed a relative narrow concentration range for most of the remaining elements. Statistical interpretation of the sediment data provided very limited information that could be used to identify geochemically favorable areas for mineral occurrences. The wider concentration ranges and higher detection ratios for many ore-related elements within the data set from the heavy-mineral concentrates (table 2) provided greater anomaly enhancement. We have therefore relied heavily on this data set for our interpretation.

$\mathrm{R}$-mode factor analysis with Varimax rotation was used to identify the dominant geochemical associations within the log-transformed concentrate data. Before analysis, the more highly censored elements were removed from the data matrix. For each remaining element, values qualified with $\mathbf{N}$ were replaced with 0.5 times the lower determination limit, those with $L$ were replaced with 0.7 times the lower determination limit, and those with $G$ were replaced with 1.3 times the upper determination limit. A fivefactor model that explains 70 percent of the total variance was selected as most appropriate for reducing the concentrate data, and the resulting factor loadings are given in table 3 . Factors 1,3 , and 5 are interpreted to reflect chemical associations within the dominant bedrock lithologies whereas the associations within the other two factors appear to be representative of accumulations of sulfide minerals.

Samples with highest factor 1 scores, and thus enriched in $\mathrm{Ca}, \mathrm{Ti}, \mathrm{B}, \mathrm{La}, \mathrm{V}, \mathrm{Y}$, and (or) $\mathrm{Zr}$, were collected from streams within Mesozoic sedimentary rocks to the west of the Katmai River and within the upper Big River watershed northwest of Kaguyak Crater. The relative abundance of resistate minerals, such as apatite, epidote, rutile, sphene, and zircon, within samples from watersheds underlain by the Mesozoic sedimentary rocks results in the element association characterizing factor 1. Higher background concentrations of $\mathrm{Cr}$ and $\mathrm{Sn}$ within some of these common sedimentary rock-forming minerals distinguishes the region to the west of the Katmai

Table 1. Univariate statistical estimates for elements in 347 sediment samples

[Values for $\mathrm{Fe}, \mathrm{Mg}, \mathrm{Ca}$, and $\mathrm{Ti}$ in percent, all other values in parts per million. Detection ratio, number of samples having determinant concentrations divided by total number of samples analyzed for a given element. $\mathrm{N}$, number of samples in which concentrations could not be detected at lower determination limit. $L$, number of samples in which concentrations were detectable but below lower determination limit. G, number of samples in which concentrations were greater than the upper detection limit. Expected range is distribution of 95 percent of all data expected for log-normal data]

\begin{tabular}{|c|c|c|c|c|c|c|c|c|c|c|c|c|c|}
\hline Element & $\begin{array}{c}\text { Detection } \\
\text { Ratio }\end{array}$ & $\mathrm{N}$ & $\mathrm{L}$ & G & Minimum & Median & $\begin{array}{c}\text { 90th } \\
\text { percentile }\end{array}$ & $\begin{array}{l}\text { 95th } \\
\text { percentile }\end{array}$ & $\begin{array}{c}98 \mathrm{th} \\
\text { percentile }\end{array}$ & Maximum & $\begin{array}{c}\text { Geometric } \\
\text { mean }\end{array}$ & $\begin{array}{l}\text { Geometric } \\
\text { deviation }\end{array}$ & $\begin{array}{l}\text { Expected } \\
\text { range }\end{array}$ \\
\hline $\mathrm{Fe}$ & 1.00 & 0 & 0 & 0 & 1.0 & 7 & 10 & 15 & 15 & 20 & 6.0 & 1.8 & $1.9-19$ \\
\hline $\mathrm{Mg}$ & 1.00 & 0 & 0 & 0 & .7 & 1.5 & 2 & 2 & 3 & 3 & 1.5 & 1.4 & $0.8-2.9$ \\
\hline $\mathrm{Ca}$ & 1.00 & 0 & 0 & 0 & .2 & 1 & 1.5 & 2 & 2 & 3 & 1.0 & 1.5 & $0.4-2.3$ \\
\hline $\mathrm{Ti}$ & .95 & 0 & 0 & 17 & .1 & .7 & 1 & 1 & IG & IG & .6 & 1.7 & $0.2-1.7$ \\
\hline Mn & .99 & 0 & 0 & 1 & 300 & 1,000 & 1,500 & 1,500 & 2,000 & $5,000 \mathrm{G}$ & $931^{\circ}$ & 1.5 & $414-2,095$ \\
\hline $\mathrm{Ag}$ & .03 & 319 & 19 & 0 & $.5 \mathrm{~N}$ & $.5 \mathrm{~N}$ & $.5 \mathrm{~N}$ & $.5 \mathrm{~L}$ & .5 & 2 & - & -- & -- \\
\hline As & .01 & 341 & 5 & 0 & $200 \mathrm{~N}$ & $200 \mathrm{~N}$ & $200 \mathrm{~N}$ & $200 \mathrm{~N}$ & $200 \mathrm{~N}$ & 200 & -- & -- & -- \\
\hline B & .76 & 4 & 79 & 0 & $10 \mathrm{~N}$ & 10 & 50 & 150 & 300 & 1,500 & 16 & 2.6 & $2.4-108$ \\
\hline $\mathrm{Ba}$ & 1.00 & 0 & 0 & 0 & 50 & 300 & 500 & 700 & 1,000 & 1,000 & 262 & 1.9 & $73-946$ \\
\hline $\mathrm{Be}$ & .03 & 238 & 99 & 0 & iN & IN & $1 \mathrm{~L}$ & IL & 1 & 1 & -- & -- & -- \\
\hline $\mathrm{Co}$ & 1.00 & 0 & 0 & 0 & 10 & 30 & 70 & 100 & 100 & 100 & 32 & 2.0 & $8.0-128$ \\
\hline $\mathrm{Cr}$ & .99 & 0 & 1 & 0 & $10 \mathrm{~L}$ & 70 & 150 & 200 & 200 & 300 & 79 & 1.7 & $27-228$ \\
\hline $\mathrm{Cu}$ & 1.00 & 0 & 0 & 0 & 7 & 20 & 50 & 50 & 70 & 500 & 25 & 1.7 & $8.7-72$ \\
\hline La & .04 & 333 & 0 & 0 & $20 \mathrm{~N}$ & $20 \mathrm{~N}$ & $20 \mathrm{~N}$ & $20 \mathrm{~N}$ & 50 & 100 & $\ldots$ & $\cdots$ & -- \\
\hline Mo & .07 & 292 & 29 & 0 & $5 \mathrm{~N}$ & $5 \mathrm{~N}$ & $5 \mathrm{~L}$ & 5 & 10 & 30 & -- & -- & -- \\
\hline $\mathrm{Ni}$ & .99 & 1 & 0 & 0 & $5 \mathrm{~N}$ & 20 & 30 & 30 & 50 & 70 & 19 & 1.5 & $8.4-43$ \\
\hline $\mathrm{Pb}$ & .60 & 34 & 104 & 0 & $10 \mathrm{~N}$ & 10 & 20 & 20 & 30 & 200 & 9.9 & 1.6 & $3.9-25$ \\
\hline Sc & 1.00 & 0 & 0 & 0 & 10 & 20 & 50 & 50 & 50 & 70 & 26 & 1.6 & $10-67$ \\
\hline $\mathrm{Sr}$ & .99 & 2 & 3 & 0 & $100 \mathrm{~N}$ & 200 & 300 & 300 & 500 & 500 & 203 & 1.5 & $90-457$ \\
\hline $\mathrm{v}$ & 1.00 & 0 & 0 & 0 & 70 & 200 & 700 & 1,000 & 1,000 & 1,500 & 273 & 2.1 & $62-1,204$ \\
\hline $\mathrm{Y}$ & 1.00 & 0 & 0 & 0 & 15 & 30 & 30 & 50 & 50 & 50 & 27 & 1.3 & $16-46$ \\
\hline $\mathrm{Zn}$ & .22 & 204 & 66 & 0 & $200 \mathrm{~N}$ & $200 \mathrm{~N}$ & 200 & 300 & 300 & 500 & 129 & 1.5 & $57-290$ \\
\hline $2 r$ & 1.00 & 0 & 0 & 0 & 30 & 100 & 150 & 200 & 300 & 1,000 & 92 & 1.6 & $36-236$ \\
\hline
\end{tabular}


River from the Big River headwaters. Samples with highest scores onto factor 5 are widely distributed over the former area whereas those with anomalously low scores are found in the latter. The $\mathrm{Cr}-\mathrm{Mg}-\mathrm{Mn}-\mathrm{Sc}-$ (-Ba) factor 3 association is characteristic of the Tertiary volcanic units, and samples with high scores onto this factor span across the entire region from Hallo Glacier to the Katmai River.

High factor 2 loadings were calculated for $\mathrm{Co}$, $\mathrm{Cu}, \mathrm{Fe}$, and $\mathrm{Ni}$, a geochemical relationship indicative of abundant pyrite within the collected concentrates. Samples with high scores onto this factor generally contain 20 to 90 percent pyrite and cluster within three areas: (1) the southwest side of Fourpeaked Mountain (shown as area 2a on fig. 1), (2) the entire Katmai Canyon north of the Barrier Range (2b, fig. 1), and (3) the higher elevations of the Kejulik Mountains between Martin Creek and the Kejulik River (2c, fig. 1). In the Fourpeaked Mountain area, both hypabyssal bodies and sandstone within the sampled watersheds are strongly silicified and contained abundant disseminated pyrite. Tertiary intermediate volcanic rocks within Katmai Canyon commonly are strongly silicified, iron-stained, and contain abundant pyrite. Silicified, volcanic breccia float taken near the toe of the glacier at the head of the canyon contained up to 2 ppm Ag, 300 ppm As, 100 ppm Mo, and 6 ppm Sb. The source for most of the pyrite in the Kejulik Mountains is uncertain. However, volcanic rocks within the headwaters of the west branch of Martin Creek are extremely silicified and bleached, and consistently carry 0.3 to $0.5 \mathrm{ppm} \mathrm{Hg}$ and up to $2900 \mathrm{ppm} \mathrm{F}$.

In addition to the three broader areas described above, a few concentrate samples with anomalous factor 2 scores and microscopically visible arsenopyrite were collected from the Hagelbargers Pass area (fig. 1, area 2d). Pyrite-bearing quartz breccia within intermediate volcanic rocks was sampled at two localities southeast of the pass. One sample contained $0.7 \mathrm{ppm} \mathrm{Ag}$ and $0.8 \mathrm{ppm} \mathrm{Au}$, and a second contained $0.25 \mathrm{ppm} \mathrm{Au}$ and $6 \mathrm{ppm} \mathrm{Sb}$.

Samples with highest factor 4 scores contain anomalous amounts of $\mathrm{Ag}, \mathrm{Cu}, \mathrm{Mo}, \mathrm{Pb}$, and (or) $\mathrm{Zn}$. One large cluster of samples includes those from most drainages underlain by sedimentary rocks to the south of Fourpeaked Mountain (fig. 1, area 4a). These samples cover a much more extensive area than the pyrite-rich concentrates described above as spatially associated with hypabyssal rocks on the southwest side of Fourpeaked Mountain. Bennett and Church (1987) listed 10 to 40 percent pyrite, arsenopyrite, chalcopypyrite, sphalerite, galena, wulfenite, and (or) scheelite as occurring within the anomalous samples. A single sample contained visible gold. A second occurrence of widespread concentrates with high factor 4 scores is located to the northwest of Kukak Bay (fig. 1, area 4b), an area underlain by both intermediate volcanic and hypabyssal rocks. Wulfenite, galena, chalcopyrite, and abundant pyrite were identified in many of these samples. Intrusive and volcanic rocks throughout this area show strong sericitic alteration, potassic alteration, and silicification, and they contain abundant disseminated pyrite with lesser arsenopyrite.

Wilson and Cox (1983) described porphyryrelated sulfide mineralization irregularly distributed over the entire Alaska Peninsula. Geochemical signatures within concentrate samples collected across

Table 2. Univariate statistical estimates for elements in 337 nonmagnetic heavy-mineral concentrate samples IValues for $\mathrm{Fe}, \mathrm{Mg}, \mathrm{Ca}$, and $\mathrm{Ti}$ in percent; all other values in parts per million. Column headings same as for table 1]

\begin{tabular}{|c|c|c|c|c|c|c|c|c|c|c|c|c|c|}
\hline Element & $\begin{array}{c}\text { Detection } \\
\text { Ratio }\end{array}$ & $\mathrm{N}$ & $\mathrm{L}$ & G & Minimum & Median & $\begin{array}{c}90 t h \\
\text { percentile }\end{array}$ & $\begin{array}{c}95 \mathrm{th} \\
\text { percentile }\end{array}$ & $\begin{array}{c}98 \mathrm{th} \\
\text { percentile }\end{array}$ & Maximum & $\begin{array}{c}\text { Geometric } \\
\text { mean }\end{array}$ & $\begin{array}{l}\text { Geometric } \\
\text { deviation }\end{array}$ & $\begin{array}{c}\text { Expected } \\
\text { range }\end{array}$ \\
\hline $\mathrm{Fe}$ & 0.99 & 0 & 0 & 1 & 0.5 & 3 & 20 & 30 & 30 & $50 G$ & 3.8 & 2.8 & $0.5-30$ \\
\hline $\mathrm{Yg}$ & 1.00 & 0 & 0 & 0 & .5 & .7 & 3 & 5 & 5 & 7 & .6 & 3.5 & $0.05-7.4$ \\
\hline $\mathrm{Ca}$ & 1.00 & u & 0 & 0 & .1 & 2 & 5 & 7 & 7 & 10 & 2.0 & 2.0 & $0.5-8.0$ \\
\hline $\mathrm{Ti}$ & .72 & 0 & 0 & 95 & .1 & 1 & $2 G$ & $2 G$ & $2 G$ & $2 \mathrm{G}$ & 1.1 & 2.3 & $0.2-5.8$ \\
\hline nth & 1.00 & 0 & 0 & 0 & 50 & 1,000 & 2,000 & 2,000 & 2,000 & 3,000 & 738 & 2.2 & $152-3,572$ \\
\hline $\mathrm{Ag}$ & .20 & 247 & 22 & 1 & IN & IN & 2 & 5 & 20 & $1,000 \mathrm{G}$ & .8 & 3.0 & $0.09-7.2$ \\
\hline As & .12 & 284 & 13 & 0 & $500 \mathrm{~N}$ & $500 \mathrm{~N}$ & 500 & 1,000 & 3,000 & 10,000 & -- & $\ldots$ & \\
\hline $\mathrm{Au}$ & .02 & 327 & 1 & 3 & $20 \mathrm{~N}$ & $20 \mathrm{~N}$ & $20 \mathrm{~N}$ & $20 N$ & 20 & $1,000 \mathrm{G}$ & -- & $\ldots$ & \\
\hline B & .78 & 2 & 58 & 13 & $20 \mathrm{~N}$ & 50 & 2,000 & 5,000 & $5,000 G$ & $5,00 \cup G$ & 93 & 6.1 & $2.5-3,461$ \\
\hline $\mathrm{Ba}$ & .82 & 0 & 30 & 29 & $50 \mathrm{~L}$ & 1,000 & 10,000 & $10,000 \mathrm{G}$ & $10,000 \mathrm{G}$ & $10,000 \mathrm{G}$ & 737 & 6.0 & $20-26,530$ \\
\hline $\mathrm{Be}$ & .01 & 247 & 88 & 0 & $2 \mathrm{~N}$ & $2 \mathrm{~N}$ & $2 L$ & $2 \mathrm{~L}$ & $2 \mathrm{~L}$ & 5 & - & --- & \\
\hline $\mathrm{Bi}$ & .05 & 316 & 3 & 0 & $20 \mathrm{~N}$ & $20 N$ & $20 \mathrm{~N}$ & 20 & 50 & 1,000 & -- & $\cdots$ & \\
\hline $\mathrm{Cd}$ & .014 & 309 & 13 & 0 & $50 \mathrm{~N}$ & $50 \mathrm{~N}$ & $50 \mathrm{~N}$ & $50 \mathrm{~L}$ & 100 & 500 & -- & $-\infty$ & \\
\hline $\mathrm{Co}$ & .87 & 8 & 36 & 1) & $10 \mathrm{~N}$ & 30 & 100 & 150 & 500 & 1,000 & 32 & 2.8 & $4.1-251$ \\
\hline $\mathrm{Cr}$ & .82 & 2 & 59 & 0 & $20 \mathrm{~N}$ & 50 & 200 & 200 & 300 & 1,000 & 51 & 2.6 & $7.5-345$ \\
\hline $\mathrm{Cu}$ & .91 & 0 & 30 & u & $10 \mathrm{~L}$ & 50 & 300 & 500 & 500 & 2,000 & 47 & 3.7 & $3.4-643$ \\
\hline $\mathrm{La}$ & .45 & 177 & 7 & 0 & $50 N$ & $50 N$ & 200 & 300 & 500 & 1,000 & 54 & 2.5 & $8.6-338$ \\
\hline Mo & .20 & 247 & 22 & 0 & $10 N$ & $10 N$ & 20 & 50 & 200 & 1,000 & 7.3 & 2.4 & $1.3-42$ \\
\hline $\mathrm{Nb}$ & .05 & 254 & 67 & 0 & $50 \mathrm{~N}$ & $50 \mathrm{~N}$ & $5 \cup L$ & $50 \mathrm{~L}$ & 50 & 100 & - & $\cdots$ & \\
\hline $\mathrm{Ni}$ & .70 & 87 & 13 & 0 & $10 N$ & 20 & 100 & 200 & 200 & 500 & 21 & 3.3 & $1.9-229$ \\
\hline $\mathrm{Pb}$ & .61 & 64 & 69 & 0 & $20 \mathrm{~N}$ & 20 & 200 & 500 & 1,500 & 5,000 & 40 & 3.9 & $2.6-608$ \\
\hline sb & .01 & 336 & 0 & 0 & $200 \mathrm{~N}$ & $200 \mathrm{~N}$ & $200 \mathrm{~N}$ & $200 \mathrm{~N}$ & $200 \mathrm{~N}$ & 500 & - & $-\infty$ & \\
\hline $\mathrm{Sc}$ & .89 & 25 & 12 & 0 & $10 \mathrm{~N}$ & 50 & 100 & 100 & 100 & 200 & 37 & 2.5 & $5.9-231$ \\
\hline $\mathrm{Sn}$ & .20 & 240 & 30 & 0 & $20 \mathrm{~N}$ & $20 \mathrm{~N}$ & 30 & 50 & 70 & 200 & 13 & 1.7 & $4 \cdot 5-38$ \\
\hline $\mathrm{Sr}$ & .59 & 78 & 60 & 1 & $200 \mathrm{~N}$ & 200 & 700 & 1,000 & 2,000 & $10,000 \mathrm{G}$ & 245 & 2.4 & $43-1,411$ \\
\hline V & .99 & 0 & 1 & 0 & 206 & 150 & 200 & 300 & 300 & 1,000 & 126 & 1.9 & $35-455$ \\
\hline W & .01 & 330 & 3 & 0 & $100 \mathrm{~N}$ & $100 \mathrm{~N}$ & $100 \mathrm{~N}$ & $100 \mathrm{~N}$ & $100 \mathrm{~L}$ & 1,500 & -- & --- & \\
\hline $\mathrm{Y}$ & .99 & 0 & 1 & 0 & $20 \mathrm{~L}$ & 150 & 1,500 & 1,500 & 1,500 & 2,000 & 193 & 3.3 & $18-2,102$ \\
\hline $\mathrm{Zn}$ & .15 & 267 & 21 & 0 & $500 \mathrm{~N}$ & $500 \mathrm{~N}$ & 500 & 2,000 & 5,000 & 20,000 & - & $-\infty$ & \\
\hline $\mathrm{Zr}$ & .34 & 0 & 0 & 223 & 20 & $2,000 \mathrm{G}$ & $2,000 \mathrm{G}$ & $2,000 \mathrm{G}$ & $2,000 \mathrm{G}$ & $2,000 \mathrm{G}$ & 1,699 & 2.5 & $272-10,620$ \\
\hline $\mathrm{Th}$ & .00 & 334 & 3 & 0 & $200 \mathrm{~N}$ & $200 \mathrm{~N}$ & $200 \mathrm{~N}$ & $200 \mathrm{~N}$ & $200 \mathrm{~N}$ & $200 \mathrm{~L}$ & 1, - & $-\infty$ & \\
\hline
\end{tabular}


Table 3. Factor loadings for the first five factors after varimax rotation of the $\log$ transformed concentrate data [Total variance explained by five factors equals 70 percent. Leaders (--), loading less than $10.30 \mid$ that have been omitted]

\begin{tabular}{|c|c|c|c|c|c|}
\hline \multirow[b]{2}{*}{ Element } & \multicolumn{5}{|c|}{ Factors } \\
\hline & 1 & 2 & 3 & 4 & 5 \\
\hline $\mathrm{Fe}$ & -- & 0.89 & -- & -- & -- \\
\hline $\mathrm{Mg}$ & -0.43 & -- & 0.74 & -- & -- \\
\hline $\mathrm{Ca}$ & .61 & -- & -- & -- & -0.34 \\
\hline $\mathrm{Ti}$ & .89 & -- & -- & -- & -- \\
\hline $\mathrm{Mn}$ & -- & -- & .84 & -- & -- \\
\hline $\mathrm{Ag}$ & -- & -- & -- & 0.76 & -- \\
\hline $\mathrm{B}$ & .66 & -- & -- & -- & -- \\
\hline $\mathrm{Ba}$ & -- & -- & -.62 & -- & .31 \\
\hline $\mathrm{CO}$ & -- & .83 & -- & -- & -- \\
\hline $\mathrm{Cr}$ & -- & -- & .55 & -- & .64 \\
\hline $\mathrm{Cu}$ & -- & .67 & -- & .46 & -- \\
\hline La & .79 & -- & -- & -- & -- \\
\hline Mo & -- & -- & -- & .77 & -- \\
\hline $\mathrm{Ni}$ & -- & .88 & -- & -- & -- \\
\hline $\mathrm{Pb}$ & -- & .35 & -- & .76 & -- \\
\hline Sc & .33 & -- & .74 & -- & -- \\
\hline $\mathrm{Sn}$ & -- & -- & -- & -- & .75 \\
\hline V & .69 & -- & .38 & -- & .34 \\
\hline Y & .91 & -- & -- & -- & -- \\
\hline $\mathrm{Zn}$ & -- & -- & -.38 & .53 & -- \\
\hline $\mathrm{Zr}$ & .64 & -- & -.30 & -- & -- \\
\hline $\begin{array}{l}\text { Percent of } \\
\text { total }\end{array}$ & & & & & \\
\hline variance & 21 & 15 & 14 & 11 & 8 \\
\hline
\end{tabular}

many of these systems consist of a widespread $\mathrm{Ag}-\mathrm{As}-$ $\mathrm{Au}-\mathrm{Cu}-\mathrm{Pb}-\mathrm{Zn}$ association surrounding a $\mathrm{Cu}-\mathrm{Mo}-\mathrm{W}$ suite closer to the center of the mineralized systems. Areas delineated in our study by samples with high factor 2 or factor 4 scores (fig. 1) represent localities with highest geochemical favorability for porphyry and epithermal base-metal vein occurrences.

Gold was only detected within nine of the concentrate samples collected within the studied area (fig. 1). This may in part reflect the loss of fine gold during panning or the loss of iron-oxide coated gold grains into the unanalyzed magnetic concentrate fraction. Atomic absorption analysis of samples from 22 of the sites within strongly altered watersheds showed three cases where minor amounts of gold were detected in magnetic concentrate fractions but not in the nonmagnetic fractions or corresponding sediments. Similarly, in two cases, gold was only detected in the sediments and not within either concentrate fraction (R.J. Goldfarb, unpub. data). Three of the nine gold-bearing nonmagnetic concentrates were collected in drainages underlain by Naknek sedimentary rocks between the Swikshak and Big Rivers (fig. 1, area 1a). These samples, which also have anomalous $\mathrm{Ag}, \mathrm{As}, \mathrm{Bi}, \mathrm{Co}, \mathrm{Cu}, \mathrm{Mo}, \mathrm{Pb}, \mathrm{W}$, and $\mathrm{Zn}$ concentrations, identify an area favorable for epithermal gold vein systems. A second target area for epithermal vein systems lies within the Ninigak River watershed (fig. 1, area 1b), where drainages underlain by both sedimentary and volcanic rocks yielded concentrates consistently enriched in $\mathrm{Ag}$ and As and occasionally anomalous in Zn. Five concentrates with microscopically visible cinnabar were collected along the southern edge of the study area, within the sedimentary and volcanic rocks between Amalik Bay and the mouth of the Katmai River (fig. 1, area 3). This area and the Martin Creek region described earlier (within area 2 c) represent two localities with geochemical favorability for shallowlevel $\mathrm{Hg}-\mathrm{Au}$ hydrothermal systems.

\section{REFERENCES CITED}

Bailey, E.A., Sutley, S.J., Arbogast, B.F., Wilson, W.R., and Church, S.E., 1986, Analytical results and sample locality map of stream-sediment and heavy-mineralconcentrate samples from the Mount Katmai quadrangle, and portions of the Naknek, Afognak, and Illiamna quadrangles, Alaska: U.S. Geological Survey Open-File Report 86586, 126 p., scale 1:250,000.

Bennett, G.J. and Church, S.E., 1987, Mineralogy and sample locality map of the nonmagnetic heavy-mineral concentrate samples from the Mount Katmai quadrangle and portions of the Naknek, Afognak, and Illiamna quadrangles, Alaska: U.S. Geological Survey Open-File Report 87-615, 39 p., scale 1:250,000.

Keller, A.S., and Reiser, H.N., 1959, Geology of the Mount Katmai area, Alaska: U.S. Geological Survey Bulletin 1058-G, p. 261298.

Miesch, A.T., 1976, Geochemical survey of Missouri--Methods of sampling, laboratory analysis, and statistical reduction of data: U.S. Geological Survey Professional Paper 954-A, $39 \mathrm{p}$.

Wilson, F.H. and Cox, D.P., 1983, Geochronology, geochemistry, and tectonic environment of porphyry mineralization in the central Alaska Peninsula: U.S. Geological Survey Open-File Report 83-783, 24 p.

Reviewers: S.E. Church and J.E. Kilburn

Geologic Studies in Alaska by the U.S. Geological Survey during 1987: John P. Galloway and Thomas D. Hamilton, editors, U.S. Geologica1 Survey Circular 1016. 



\section{SOUTHEASTERN ALASKA}

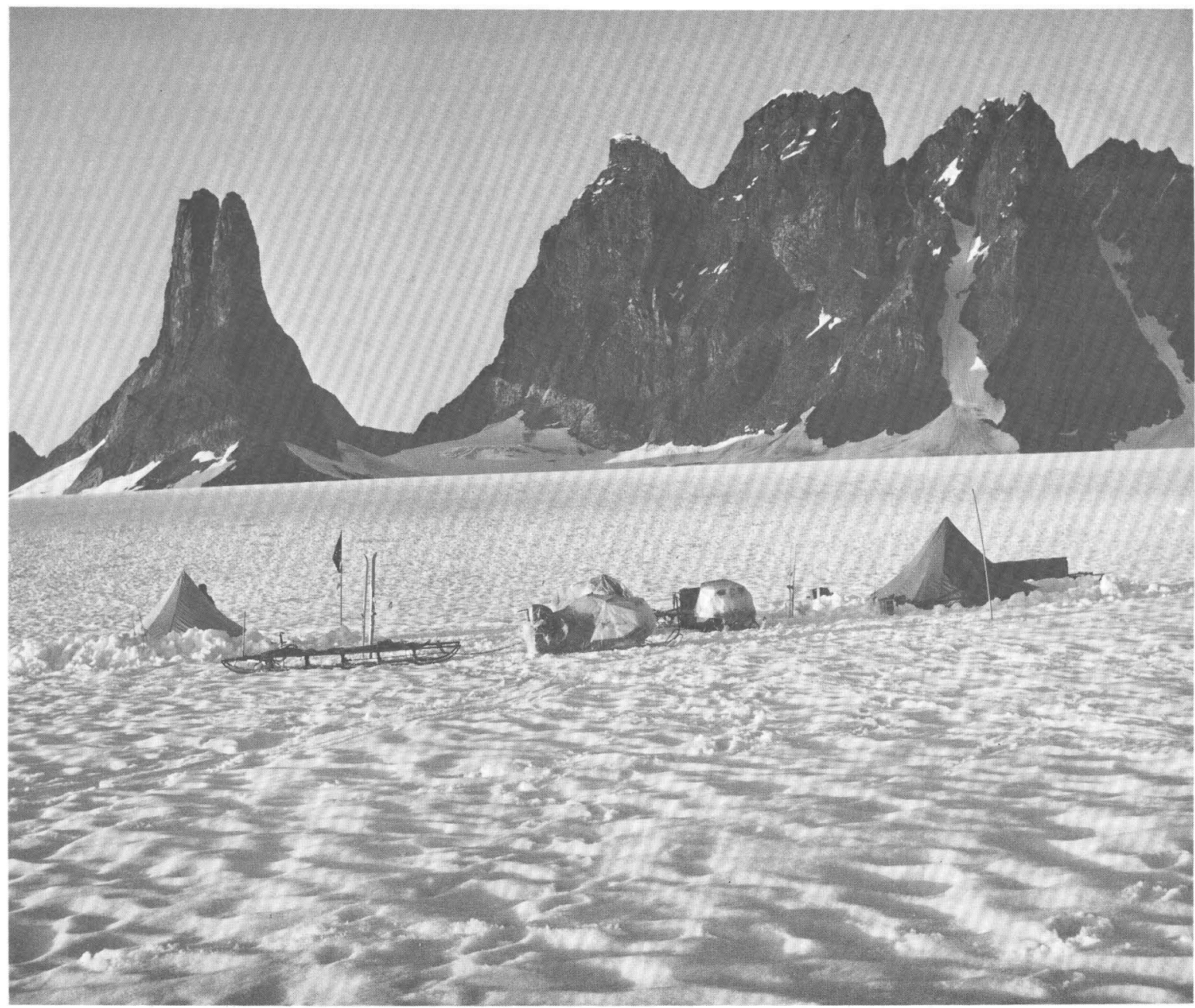

U.S.-Canada boundary peak, Devils Paw (right), highest peak of the Juneau Icefield region (elevation 8,584 feet). Michaels Sword on left. Composed dominantly of Permian(?) and Mesozoic(?) hornfels, showing contact near base with Tertiary (50 Ma) granodiorite. Photograph by A.B. Ford. 


\title{
Relative Timing of Porphyroblast Growth, Foliation Development, and Ductile Shear in Pelitic Metamorphic Rocks from the Juneau Area, Southeastern Alaska
}

\author{
By Robert L. Bauer, Glen R. Himmelberg, David A. Brew, and Arthur B. Ford
}

A regional metamorphic belt containing mineral assemblages that range from the prehnite-pumpellyite metagraywacke facies to the upper amphibolite facies is exposed along the western margin of the Coast plutonic-metamorphic complex in southeastern Alaska. Index mineral isograds in the pelitic rocks were first documented by Forbes (1959) and have been mapped over an extensive area by Ford and Brew (1973, 1977) and Brew and Ford (1977). More recently, the index mineral isograds on Heintzleman and Blackerby Ridges near Juneau (fig. 1) were shown to mark particular model reactions and are thus reaction isograds (Himmelberg and others, 1984a).

Metamorphic textures in the pelitic rocks on Heintzleman and Blackerby Ridges were described by Himmelberg and others (1984b), who noted that an older internal foliation $\left(S_{\mathfrak{i}}\right)$ is commonly preserved in porphyroblasts of biotite and garnet. $\mathbf{S}_{i}$ is locally curved and at $a$ high angle to the later-formed external schistosity $\left(\mathrm{S}_{e}\right)$. Recent work on porphyroblast growth in deforming metamorphic rocks has shown that deformation partitioning between porphyroblasts and matrix (Bell, 1981, 1986) and porphyroblast growth during the development of crenulation foliation (for example, Bell and Rubenach, 1980, 1983; Bell and others, 1986) can produce curved inclusion trails in porphyroblasts that do not require porphyroblast rotation for their formation (Spry, 1969).

In this report we describe metamorphic textures and microfabrics that bear on the relationship between porphyroblast growth and the deformation history of the schists in the Juneau area and are consistent with the observations of Bell and coworkers. Our observations indicate that porphyroblasts of garnet, biotite, kyanite and staurolite grew over and included an early foliation (referred to here as $S_{1}$ ) that was folded and overprinted by a younger crenulation foliation (referred to here as $\mathrm{S}_{2}$ ). Inclusion trails in the garnet and biotite porphyroblasts record stages in the development of the $\mathrm{S}_{2}$ crenulation foliation ( $\mathrm{fig}$. $2)$, and, in cases where $S_{1}$ has been completely overprinted in the rock matrix, these porphyroblasts preserve the only evidence of early $S_{1}$ foliation.

Local late-stage shearing--evident from biotite fish (see fig. 3E for illustration) (Eisbacher, 1970; Lister and Snoke, 1984) and shear bands--has obliterated evidence for $\mathrm{S}_{2}$ in the matrix of some of the rocks. In these rocks the porphyroblasts preserve the only evidence for both $\mathrm{S}_{1}$ and $\mathrm{S}_{2}$. The samples described here were not oriented in the field, thus the relative sense of shear is uncertain. However, our petrographic observations, described below, indicate that this is a post- $S_{2}$ fabric which will require further field study in order to establish its distribution and relationship to previously identified regional deformation features.

This investigation is part of a larger study of the metamorphism and deformation of the rocks near Juneau; as recently summarized by Brew and others (in press), this metamorphic belt evolved in several stages between about $120 \mathrm{Ma}$ and $50 \mathrm{Ma}$. The textures described here are interpreted to have formed during two major tectonothermal events, the first sometime between 120 and $90 \mathrm{Ma}$ and the second sometime between 90 and $70 \mathrm{Ma}$.

Poikiloblastic garnet and biotite from the Juneau area contain quartz and(or) graphite inclusion trails that display a range of forms and relationships to matrix foliations (table 1). These relationships allow interpretation of the generation of foliations in both the porphyroblasts and in the matrix, and of the relative timing of biotite and garnet porphyroblast growth. The six observed relationships and their interpretations are sum marized in table 1.

The first two relationships are relatively uncommon in the Juneau rocks. The type 1 relationship, with straight porphyroblast inclusions continuous into a straight matrix foliation, indicates an $S_{1}$ foliation with no evidence for younger or older foliations. Both biotite and garnet show this relationship in outcrops that are relatively unaffected by the second deformation. The type 2 relationship, with straight porphyroblast inclusion trails in a matrix with a crenulation foliation (fig. 3A), was observed in some small subhedral garnet porphyroblasts that grew early and surrounded inclusions parallel to $\mathbf{s}_{1}$, but stopped growing before the generation of the $\mathrm{S}_{2}$ crenulation foliation in the matrix. Biotite porphyroblasts in the same samples, however, locally include curved inclusion trails, indicating that the biotite grew during the early (stage 2) development of the $\mathrm{S}_{2}$ crenulation foliation in the matrix. This characterizes type 3 relationships, and indicates in this case that the biotite is younger than the coexisting garnet. This relative timing is also indicated by the inclusion of garnet in the biotite (fig. $3 \mathrm{~A}$ ).

The type 3 relationship is much more common in the Juneau area rocks than either the type 1 or type 2 relationships. Curved to distinctly folded inclusion trails, representing various stages in the development of the matrix crenulation foliation, occur in both biotite and garnet. In some cases the inclusion trails 


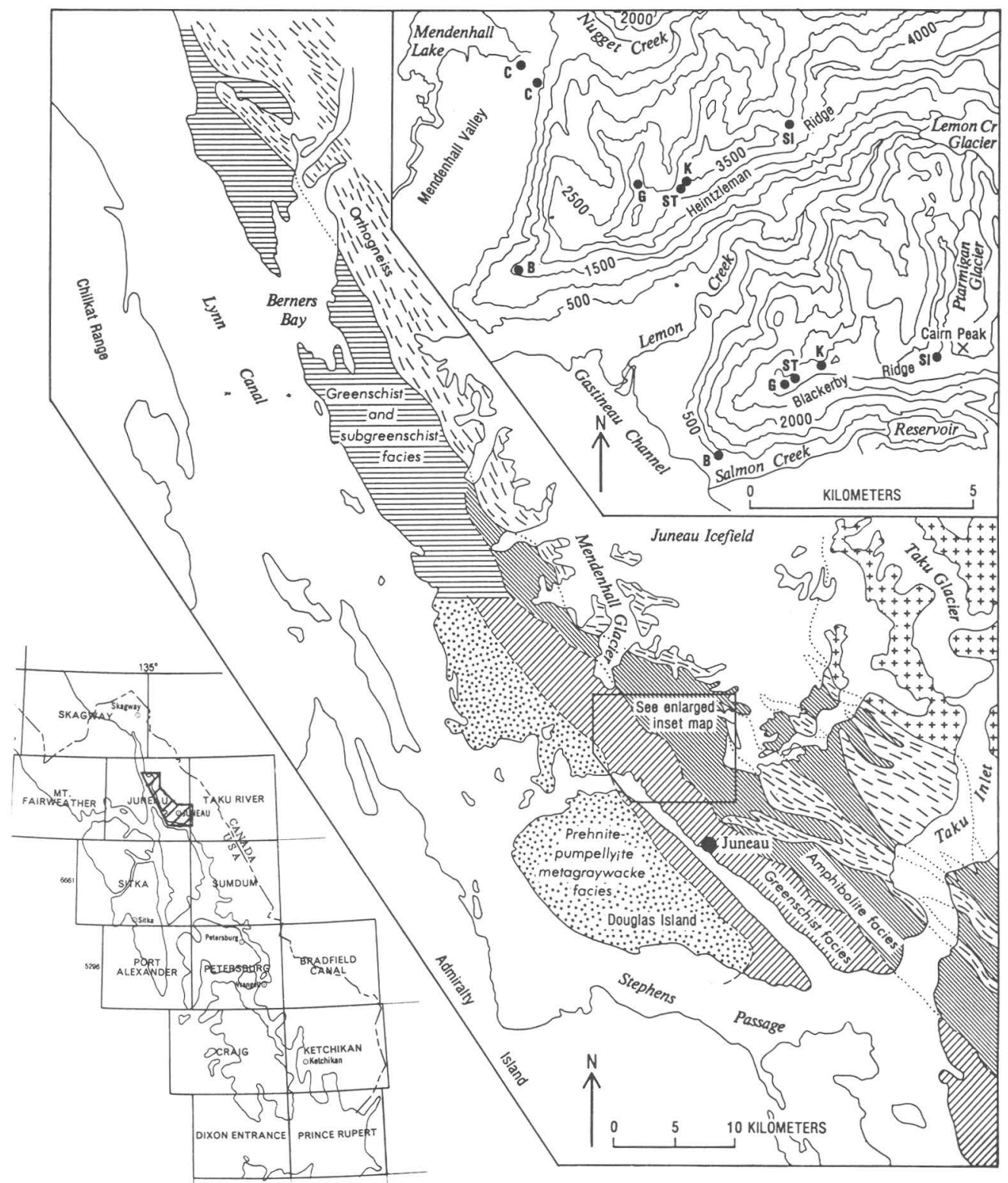

Index map of southeastern Alaska,

showing location of figure 1 .

Figure 1. Sketch map of the Juneau area, showing regional distribution of metamorphic facies and relation to plutonic units of the Coast plutonic-metamorphic complex near Juneau. Dashed-line pattern shows approximate foliation trends in orthogneiss plutons. Crosses denote little-foliated post-tectonic granitic pluton. Inset topographic map (500-ft contours) shows first occurrences in northeastward transects on Heintzleman and Blackerby Ridges of biotite (B), garnet (G), staurolite (ST), kyanite (K), and sillimanite (SI), and occurrences of chloritoid (C). After Himmelberg and others (1984b).

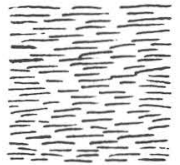

1

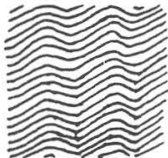

2

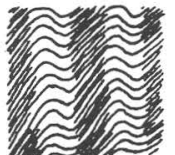

3

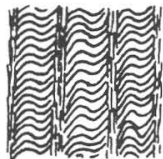

4

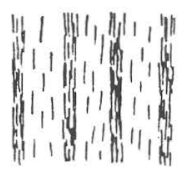

5

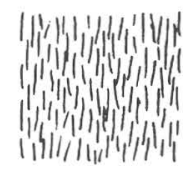

6

Figure 2. Six stages in development of new $\left(\mathrm{S}_{2}\right)$ crenulation foliation, oriented N-S in stages 4,5 and 6, from older $\left(S_{1}\right)$ foliation, oriented E-W in stage 1 (from Bell and Rubenach, 1983). 


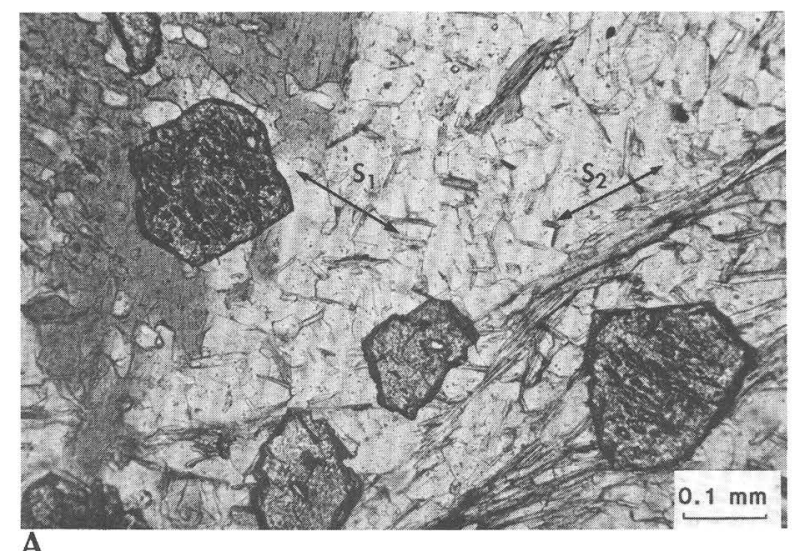

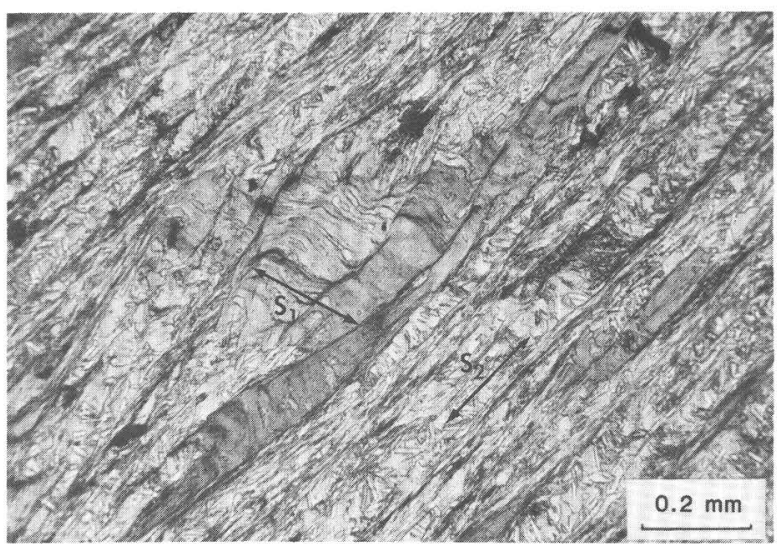

B

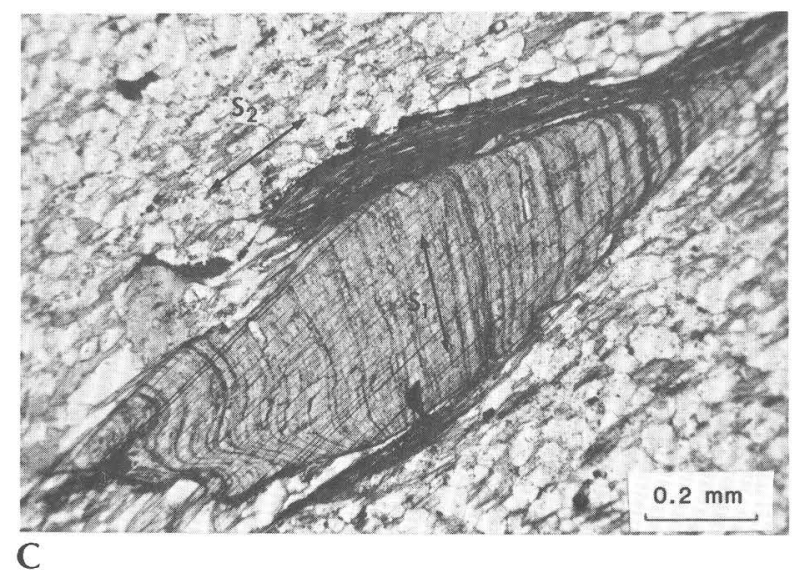

Figure 3. Photomicrographs of Juneau area schists, showing $\mathrm{S}_{1}$ $\mathrm{S}_{2}$ relationships. $\mathrm{A}$, Garnet and biotite porphyroblasts containing straight inclusion trails parallel to $S_{1}$ that are at high angle to $S_{2}$ crenulation foliation in matrix (type 2 relationship). Biotite in other parts of sample show curved inclusion trails indicating that it grew after garnet in this sample (type 3 relationship) (sample 81 SK011A). B, Biotite porphyroblasts containing folded inclusion trails of quartz and graphite parallel to $S_{1}$ (type 3 relationship). $S_{2}$ crenulation foliation in matrix continued to develop after biotite growth resulting in offset of biotite porphyroblasts (sample $83 \mathrm{GH} 020 \mathrm{~A}$ ). C, Biotite porphyroblast containing folded graphite inclusion trails. Inclusion trails are the only remnants of $\mathrm{S}_{1}$ and are sharply

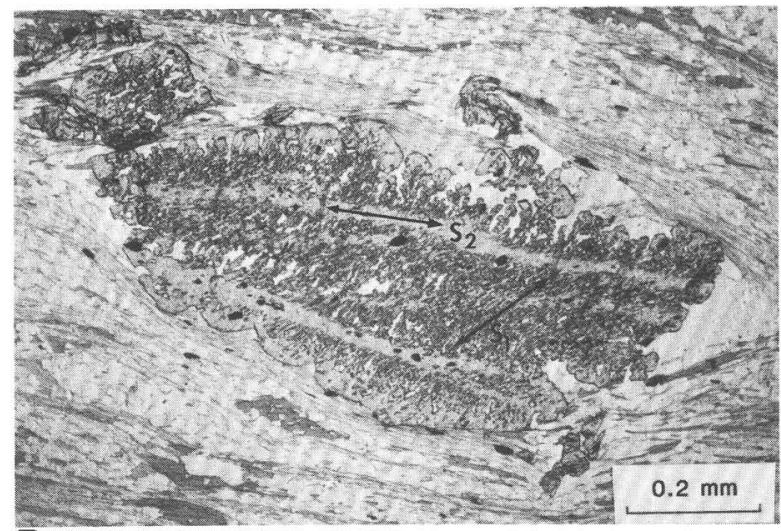

D

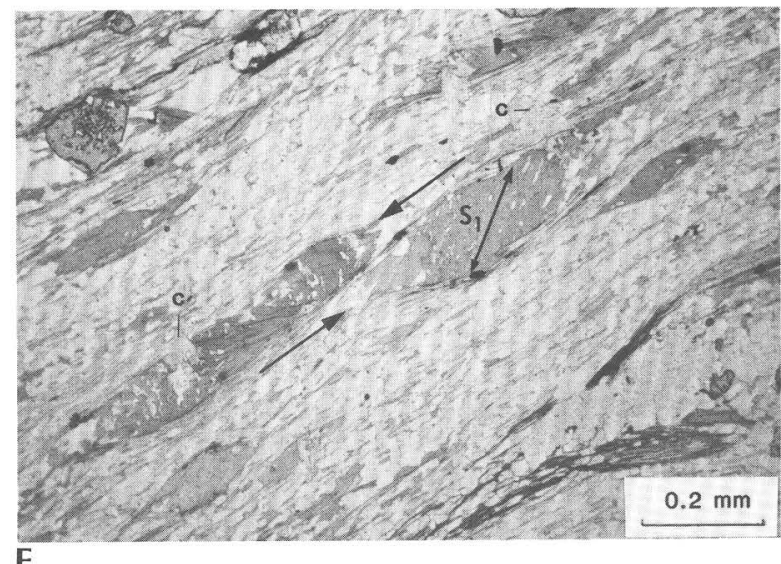

$\mathbf{E}$

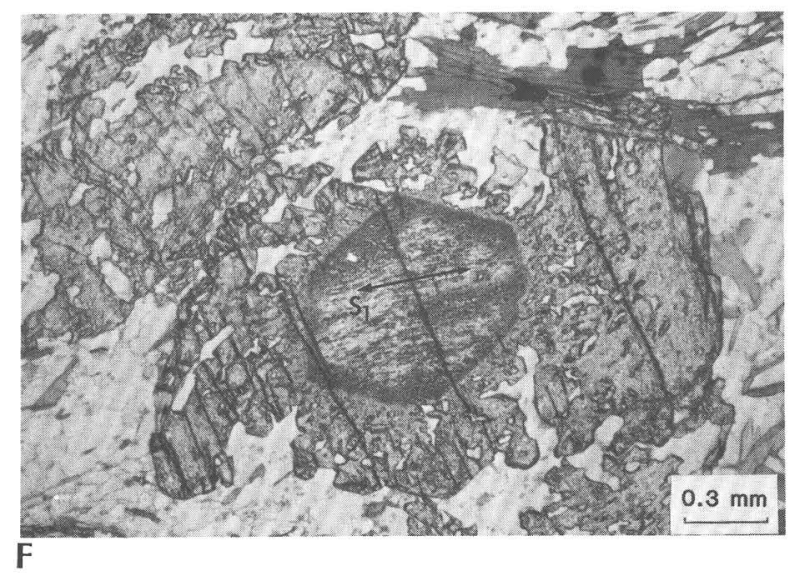

truncated by stage $6 \mathrm{~S}_{2}$ foliation in matrix (type 4 relationship) (sample 81DB020A). D, Garnet porphyroblast containing crenulated (stage 4 ) trails that display both $\mathrm{S}_{1}$ and $\mathrm{S}_{2}$ orientations. Inclusion trails are sharply truncated by shear-induced foliation in matrix that, in this case, is parallel to $S_{2}$ preserved in garnet but overprints $\mathrm{S}_{2}$ in matrix (sample 79GH022A). E, Biotite fish porphyroblasts, containing quartz inclusion trails parallel to $S_{1}$, deformed by left-lateral shear. Undeformed retrograde chlorite (c) grows across sheared boundaries of biotite (sample 79GH022B). F, Garnet porphyroblast consists of outer zone containing curved inclusion trails of quartz that has overgrown euhedral garnet with straight inclusion trails (sample $81 \mathrm{GH} 006(1)$. 
Table 1. Summary of relationships observed between porphyroblast inclusion trails and matrix foliation in pelitic schists from the Juneau area

[See figure 2 for explanation of foliation stages, which are after Bell and Rubenach (1983)]

\begin{tabular}{|c|c|c|c|c|c|c|c|}
\hline \multirow[b]{2}{*}{$\begin{array}{c}\text { Relationship } \\
\text { type no. }\end{array}$} & \multicolumn{3}{|c|}{ Porphyroblast inclusion fabric } & \multicolumn{4}{|c|}{ Matrix fabric } \\
\hline & $\begin{array}{l}\text { Inclusion } \\
\text { trail forms }\end{array}$ & $\begin{array}{c}\text { Foliation } \\
\text { stage(s) }\end{array}$ & $\begin{array}{c}\text { Deformation } \\
\text { features }\end{array}$ & $\begin{array}{l}\text { Foliation } \\
\text { form }\end{array}$ & $\begin{array}{l}\text { Foli } \\
\text { sta }\end{array}$ & $\begin{array}{l}\text { iation } \\
\text { age(s) }\end{array}$ & $\begin{array}{l}\text { Deformation } \\
\text { features }\end{array}$ \\
\hline 1 & Straight & 1 & $\mathrm{~s}_{1}$ & Straight & & 1 & $\mathrm{~s}_{1}$ \\
\hline 2 & Straight & 1 & $\mathrm{~s}_{1}$ & Crenulation & & 4 & $s_{1} \& s_{2}$ \\
\hline 3 & curved & 2 or 3 & $\mathrm{~S}_{1} \& \mathrm{~F}_{2}$ & Crenulation & & 4 & $S_{1} \& S_{2}$ \\
\hline 4 & Curved & 2 or 3 & $\mathrm{~s}_{1} \& \mathrm{~F}_{2}$ & straight & 5 & or 6 & $\mathrm{~s}_{2}$ \\
\hline 5 & $\begin{array}{l}\text { Curved \& } \\
\text { straight }\end{array}$ & 4 & $s_{1} \& s_{2}$ & Crenulation & & 4 & $s_{1} \& s_{2}$ \\
\hline 6 & $\begin{array}{l}\text { Curved \& } \\
\text { straight }\end{array}$ & 4 & $s_{1} \& s_{2}$ & Straight & 5 & or 6 & $\mathrm{~s}_{2}$ \\
\hline
\end{tabular}

are continuous into the adjacent crenulation foliation in the matrix, but in many cases the inclusion trails are truncated by the matrix foliation that continued to develop after porphyroblast growth had ceased (fig. 3B).

When the crenulation foliation continues to develop to stages 5 or 6 , mica grains that parallel $\mathrm{S}_{1}$ and define the crenulations in the matrix become completely aligned parallel to $S_{2}$. The crenulation foliation then becomes a spaced or continuous $\mathrm{S}_{2}$ foliation with no matrix evidence for $S_{1}$. This results in the type 4 relationship (fig. $3 \mathrm{C}$ ). In this case the only evidence for $S_{1}$ is preserved in the curved inclusion trails in the porphyroblasts that are truncated by the matrix foliation. This relationship occurs in both biotite and garnet porphyroblasts in the Juneau rocks.

In many of the rocks from the Juneau area, garnet has overgrown the $S_{2}$ crenulation foliation after new micas were concentrated in zones aligned parallel to $\mathrm{S}_{2}$ and separating microlithons containing asymmetric crenulation of $S_{1}$ (stage 4). Porphyroblasts of this type (fig. $3 \mathrm{D}$ ) contain curved $\mathrm{S}_{1}$ inclusion trails tangential to straight zones parallel to $\mathrm{S}_{2}$ that are relatively inclusion free as a result of overgrowing the mica-rich concentrations that define $\mathrm{S}_{2}$ in the matrix. Such inclusion trails occur in both the type 5 and type 6 porphyroblast-matrix relationships. In the type 5 case, the crenulation foliation in the matrix shows the same stage of crenulation foliation development as that preserved in the porphyroblasts--with both $S_{1}$ and $S_{2}$ preserved. In the type 6 relationship, the foliation in the matrix has progressed to stage 5 or 6 (fig. 2), and the only evidence for $S_{1}$ is in the porphyroblast inclusion trails. Biotite porphyroblasts were not observed in either type 5 or type 6 porphyroblast-matrix relationships, and, with the exception of the coexisting type 2 garnet and type 3 biotite porphyroblast relationships described above, biotite growth in any given sample always began and ended at an earlier crenulation foliation stage than the garnet porphyroblasts.

Late-stage shearing, younger than the $\mathrm{S}_{2}$ foliation, is evident locally from biotite fish (fig. $3 \mathrm{E}$ ), typical of the type II S-C mylonites described by Lister and Snoke (1984), and from shear bands that transect small-scale $\mathrm{F}_{2}$ folds. In some samples the plane of the shear (C-plane) in the matrix is parallel to $\mathrm{S}_{2}$ as defined by inclusion trails in garnet porphyroblasts (fig. 3D). In such cases the shearing could be interpreted to be either (1) a result of continued displacement associated with formation of the crenulation foliation, or (2) a younger shearing event. In other samples, however, the matrix shear sense is opposite that suggested by the asymmetry of the stage 4 crenulation inclusion trails in garnet porphyroblasts, indicating that the shearing is not directly related to the deformation that produced the $\mathrm{S}_{2}$ crenulation foliation. Samples displaying these shear fabrics can be classified as type II S-C mylonites, as defined by Lister and Snoke (1984), but our petrographic observations indicate that earlier S-foliations are not genetically related to the shearing event.

Some of the sheared samples contain elongate garnet porphyroblasts that have rotated and (or) broken up during the shearing. This indicates that shear strains were not completely partitioned around the porphyroblasts (Bell, 1986; and Prior, 1987). Many of the broken porphyroblasts contain subhedral overgrowths of garnet around their broken margins, indicating that garnet continued to grow after the shearing. Undeformed grains of retrograde chlorite grow across the shear foliation in some of the samples (fig. 3E).

In summary, textural interpretations of the relative timing of porphyroblast growth suggest that euhedral to subhedral garnet porphyroblasts grew in some of the schists of the Juneau area at an early stage before or during the very early stages of $\mathrm{S}_{2}$ formation. This was followed by biotite growth during the crenulation stages (stages 2 and 3 ) of $S_{2}$ 
formation. Later stage garnet growth occurred in many of the rocks during the later (stages 3 and 4) development of $\mathrm{S}_{2}$ and was invariably younger than biotite growth in a given sample. In rare samples this later stage of garnet growth has occurred epitaxially over the early euhedral to subhedral garnets (fig. $3 \mathrm{~F}$ ).

The petrographic observations described in this report indicate that amphibolite facies porphyroblasts, generated during the major metamorphic event between 90 and $70 \mathrm{Ma}$ of Brew and others (in press), grew during the progressive development of a crenulation foliation and continued to grow during late-stage shearing under probable waning metamorphic conditions. The $S_{1}$ and $S_{2}$ foliations described here are interpreted to have formed during both the deformational event between 120 and $90 \mathrm{Ma}$ and that between 90 and $70 \mathrm{Ma}$ of Brew and others (in press). The nature and extent of the observed latestage shearing is unclear, but it may be related to the mylonite zone that commonly forms the southwestern contact of the great tonalite sill described by Brew and others (in press).

\section{REFERENCES CITED}

Bel1, T.H., 1981, Foliation development--The contribution, geometry and significance of progressive, bulk, inhomogeneous shortening: Tectonophysics, v. 75, p. 272296.

1986, Foliation development and refraction in metamorphic rocks: Reactivation of earlier foliations and decrenulation due to shifting patterns of deformation partitioning: Journal of Metamorphic Geology, v. 4, p. 421-444.

Bell, T.H., and Rubenach, M.J., 1980 , Crenulation cleavage development--Evidence for progressive bulk inhomogeneous shortening from "millipede" microstructures in the Robertson River metamorphics: Tectonophysics, v. 68, p. T9-T15.

1983, Sequential porphyroblast growth and crenulation cleavage development during progressive deformation: Tectonophysics, v. 92 , p. 171-194.

Bell, T.H., Rubenach, M.J., and Fleming, P.D., 1986, Porphyroblast nucleation, growth and dissolution in regional metamorphic rocks as function of deformation partitioning during foliation development: Journal of Metamorphic Geology, v. 4, p. 37-67.

Brew, D.A., and Ford, A.B., 1977, Preliminary geologic and metamorphic-isograd map of the Juneau B-1 quadrangle, Alaska: U.S. Geological Survey Miscellaneous Field Studies Map MF-846, scale 1:31,680.
Brew, D.A., Ford, A.B., and Himmelberg, G.R., 1988, Evolution of the western part of the Coast plutonic-metamorphic complex, southeastern Alaska, U.S.A., in Daly, S.R., ed., Evolution of metamorphic belts: Geological Society of London Special Paper 32 [in press].

Eisbacher, G.H., 1970, Deformation mechanics of mylonitic rocks and fractured granites in Cobequid Mountains, Nova Scotia, Canada: Geological Society of America Bulletin, v. 81, p. 2009-2020.

Forbes, R.B., 1959, The bedrock geology and petrology of the Juneau Ice Field area, southeastern Alaska: Seattle, University of Washington, Ph.D. Dissertation, $260 \mathrm{p}$.

Ford, A.B., and Brew, D.A., 1973, Preliminary geologic and metamorphic-isograd map of the Juneau B-2 quadrangle, Alaska: U.S. Geological Survey Miscellaneous Field Studies Map MF-527, scale 1:31,680.

1977, Preliminary geologic and metamorphicisograd map of the northern parts of the Juneau A-1 and A-2 quadrangles, Alaska: U.S. Geological Survey Miscellaneous Field Studies Map MF-847, scale 1:31,680.

Himmelberg, G.R., Ford, A.B., and Brew, D.A., $1984 a$, Reaction isograds in pelitic rocks of the Coast plutonic-metamorphic complex near Juneau, in Reed, K.M., and Bartsch-Winkler, Susan, eds., The United States Geological Survey in Alaska: Accomplishments during 1982: U.S. Geological Survey Circular 939, p. 105-108.

1984b, Progressive metamorphism of pelitic rocks in the Juneau area, southeastern Alaska, in Coonrad, W.L., and E1liott, R.L., eds., The United States Geological Survey in Alaska: Accomplishments during 1981: U.S. Geological Survey Circular 868, p. 131-134.

Lister, G.S., and Snoke, A.W., 1984, S-C mylonites: Journal of Structural Geology, v. 6, p. 617-638.

Prior, D., 1987, Syntectonic porphyroblast growth in phyllites: textures and processes: Journal of Metamorphic Geology, v. 5, p. 27-39.

Spry, A., 1969, Metamorphic textures: Oxford, Pergamon Press, $350 \mathrm{p}$.

Reviewers: S.L. Douglass and M.M. Donato

Geologic Studies in Alaska by the U.S. Geological Survey during 1987: John P. Galloway and Thomas D. Hamilton, editors, U.S. Geological Survey Circular 1016. 


\title{
A Reexamination of the Contacts and Other Features of the Gravina Belt, Southeastern Alaska
}

\author{
By David A. Brew and Susan M. Karl
}

The Gravina belt rocks are part of the GravinaNutzotin belt as defined by Berg and others (1972). This report concerns only the part of the belt that is in southeastern Alaska, and we therefore refer to the rocks as the Gravina belt. As defined by Berg and others (1972), the belt consists of flysch, minor nonmarine strata, and interbedded andesitic volcanic rocks; fossil data cited by them indicate a late Middle and Late Jurassic to late Early Cretaceous (Albian) age. On the west side of the belt, the rocks are inferred to depositionally overlie lower Paleozoic and Triassic rocks of the Alexander terrane; at most places on the east side of the belt, they are interpreted to be overthrust by older and more metamorphosed rocks.

The relations of the Gravina belt rocks to adjacent rocks are important both because they are the basis for the argument that the Gravina belt rocks actually overlapped the older rocks on the western (and perhaps the eastern) margins of the Gravina basin and because they constrain post-Gravina fault movements. In this paper we (1) examine the features that led Berg and others $(1972,1978)$ to postulate an overlap relationship; (2) reinterpret the relations of units present in the vicinity of Gravina Island; and (3) interpret the Gravina belt rocks as a lithostratigraphic unit.

For this study, we examined (1) almost all of the localities where Gravina belt rocks have been reported to be in nonfaulted contact with older strata of the Alexander-Wrangellia superterrane or with highly metamorphosed rocks of the western metamorphic belt of the Coast plutonic-metamorphic complex; (2) several localities where fault contacts have been reported by others and we wished to verify the relations; and (3) all nonfaulted and a few faulted contacts where we have unpublished information from our own mapping.

The Gravina belt contacts we examined fall into four main categories: (1) apparent stratigraphic superposition of Gravina belt rocks on older rocks of the Alexander-Wrangellia superterrane; (2) apparent fault contact between the two; (3) apparent gradation from unmetamorphosed (or only somewhat metamorphosed) rocks into metamorphic rocks of the western metamorphic zone (or belt) of the Coast plutonic-metamorphic complex (Brew and Ford, 1984) whose protoliths cannot be identified with certainty; and (4) apparent fault contact between the Gravina belt rocks and metamorphic rocks of the Coast plutonic-metamorphic complex. These categories are used in table 1, listing the five localities most pertinent to this study (and also in a supplemental table of 33 localities that is available from the senior author) to classify the contact localities we have visited (fig. 1).

Our studies reveal no localities where Gravina belt rocks stratigraphically overlie subjacent strata, although at five places we believe that an unconformable relation may exist. Of these, locality 2 (fig. 1) (Redman, 1984) is the most certain, with granitic clasts forming a basal conglomerate that is reported (R.A. Leveille, University of Alaska, oral commun., 1987) to locally fill channels cut in the granitic rock.

Near four of these five localities (2, 5a, 6, 7 on table 1) conglomeratic rocks mapped as part of the Gravina belt contain clasts that are locally derived from nearby rocks of the Alexander-Wrangellia superterrane. (The same relation exists at 13 other localities that are listed in the supplemental table.) This does not necessarily demonstrate overlap of the Gravina belt rocks on the older rocks, but it does demonstrate close proximity of the provenance terrane to the margin of the Gravina belt basin and supports the overlap interpretation. One of the best examples of this is near localities 6 and 7 (fig. 1), where limestone clasts containing Permian fossils like those in place to the west of the contact occur in a large conglomerate unit several kilometers east of the contact.

Although the evidence for unconformable contacts and overlap is not conclusive, we interpret the above local relations together with the regional variation in the inferred substrates to the Gravina belt rocks to indicate that no large lateral movements have occurred along the margins of the Gravina belt rocks during or after their deposition.

In the vicinity of Gravina and Annette Islands, the available evidence (Berg, 1972, 1973; Berg and others, 1972; D.A. Brew and S.M. Karl, unpub. data) indicates that some of the Gravina belt rocks are older and of different affinity than those elsewhere in the belt. All fossils reported from Gravina Island are from the western part of the island and are late Middle or Late Jurassic in age (Berg and others, 1972, p. D3, D5; Berg, 1973); those from Annette Island are of the same age (Berg, 1972). In contrast, from Etolin Island north to the vicinity of Haines, fossils from the belt are dominantly Early Cretaceous in age, although Late Jurassic fossils are present in the Screen Islands (Brew and others, 1984; Berg and others, 1972) and on southeastern Admiralty Island (Loney, 1964). No Middle Jurassic fossils have been reported north of Gravina Island. It is possible that nonfossiliferous rocks equivalent in age to those to the north are present on the eastern part of Gravina Island, on the 
Cleveland Peninsula, and on Revillagigedo Island (D.A. Brew and S.M. Karl, unpub. data; C.M. Rubin, California Institute of Technology, oral commun., 1987; Rubin and Saleeby, 1987). Furthermore, the volcanic rocks in the vicinity of Gravina Island appear to be chemically distinct from the volcanic rocks elsewhere in the belt (compare Berg and others, 1972, with Ford and Brew, this volume; also A.B. Ford, D.A. Brew and J.G. Crock, unpub. data).

These fossil and chemical contrasts indicate that the southern part of the Gravina belt includes an older unit that is apparently not present elsewhere in southeastern Alaska. The major implication is that the unusual Middle and Upper Jurassic section on Gravina and Annette Islands may be overlapped by the dominantly Lower Cretaceous part of the Gravina belt. As mapped (Berg, 1972, 1973), this contact is a high-angle fault on Gravina Island and a depositional contact on Annette Island. We have examined the latter locality (table 1, no. 20) and found the contact to be covered; both we and C.M. Rubin (oral commun., 1987) interpret it most likely to be a fault.

We emphasize here that the Gravina belt rocks, as informally defined by Berg and others (1972), would constitute a lithostratigraphic supergroup if formally defined. No previous effort, including the original definition, establishes this point, but it is clear from our own and previous studies that two separate

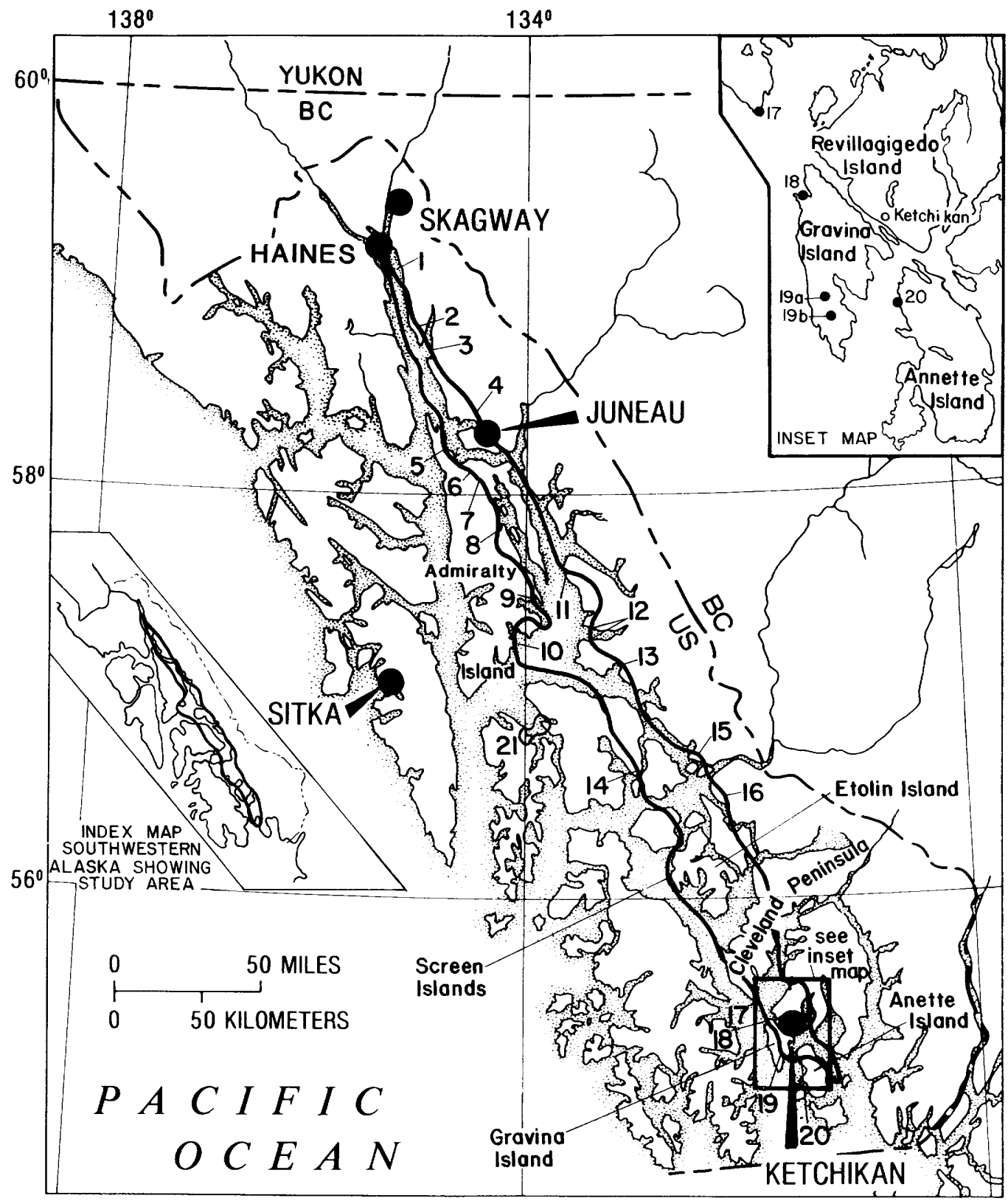

Figure 1. Distribution of Gravina belt rocks in southeastern Alaska (within heavy outline) showing numbered localities referred to in table 1 and the supplemental table. 
Table 1. Compilation of studied localities in southeastern Alaska where Gravina belt rocks are interpreted as likely to be in stratigraphic contact with older rocks of the Alexander-Wrangellia superterrane

\begin{tabular}{|c|c|c|c|c|c|c|c|c|}
\hline $\begin{array}{l}\text { Map } \\
\text { no. }\end{array}$ & $\begin{array}{l}\text { Year(s) } \\
\text { visited }\end{array}$ & $\begin{array}{l}\text { Detailed } \\
\text { examina- } \\
\text { tion? }\end{array}$ & $\begin{array}{l}\text { Is } \\
\text { contact } \\
\text { exposed? }\end{array}$ & $\begin{array}{l}\text { Are field relations compatible } \\
\text { with fault (F) or stratigraphic } \\
\text { relations with Alexander- } \\
\text { Wrangellia superterrane (S); } \\
\text { gradational into metamorphic } \\
\text { rocks (G), and(or) fault } \\
\text { contact with same (D)? }\end{array}$ & $\begin{array}{l}\text { If fault, what type: } \\
\text { vertical (V), high- } \\
\text { angle reverse (R), } \\
\text { thrust (T), high- } \\
\text { angle normal (N), } \\
\text { or low-angle } \\
\text { normal (L) }\end{array}$ & $\begin{array}{l}\text { Alexander- } \\
\text { Wrangellia- } \\
\text { derived } \\
\text { clasts nearby } \\
\text { in Gravina } \\
\text { belt rocks }\end{array}$ & $\begin{array}{l}\text { Source of } \\
\text { data }\end{array}$ & Renarks \\
\hline la & 1969,1985 & Yes & No & $\mathrm{F}, \mathrm{S}$ & $V, R, N$ & Not known & $\begin{array}{l}\text { Plafker and } \\
\text { others, } 1979, \\
\text { this volume }\end{array}$ & $\begin{array}{l}\text { Fossil locality } 78 \mathrm{APr} 136 \\
\text { (see ref.) is Cretaceous, } \\
\text { not Triassic as origin- } \\
\text { ally reported. Locality } \\
\text { is } 1.6 \mathrm{~km} N \text {. of N. end } \\
\text { Dalasuga Is., Skagway } \\
\text { A-1 quad. }\end{array}$ \\
\hline 2 & 1983 & No & Yes? & s & & Yes & Redman, 1984 & $\begin{array}{l}\text { Redman reports stratigra- } \\
\text { phic contact with clasts } \\
\text { of Jualin quartz diorite } \\
\text { in overlapping sediments; } \\
\text { we did not see the actual } \\
\text { contact. }\end{array}$ \\
\hline $5 a$ & 1982 & Yes & No & $\mathrm{F}, \mathrm{S}$ & $\mathrm{V}, \mathrm{R}, \mathrm{N}$ & Yes & $\begin{array}{l}\text { Barker, 1957; } \\
\text { Lathram and } \\
\text { others, } 1965\end{array}$ & $\begin{array}{l}\text { Locality is } 1.6 \mathrm{~km} \text { W. of } \\
\text { Symonds Point, Juneau } \\
\mathrm{B}-3 \text { quad. }\end{array}$ \\
\hline 6 & 1982 & No & Not known & $\mathrm{F}, \mathrm{S}$ & $\mathrm{T}, \mathrm{R} ?$ & Yes & $\begin{array}{l}\text { Lathram and } \\
\text { others, } 1965\end{array}$ & $\begin{array}{l}\text { Contact crosses creek at } \\
\text { Accessible Point. }\end{array}$ \\
\hline 7 & 1982 & No & Yes? & $F, S$ & $\mathrm{~T}, \mathrm{R}$ ? & Yes & $\begin{array}{l}\text { Lathram and } \\
\text { others, } 1965\end{array}$ & $\begin{array}{l}\text { Contact is at base of steep } \\
\text { cliff formed by Triassic } \\
\text { volcanic rocks. }\end{array}$ \\
\hline
\end{tabular}

lithostratigraphic groups are represented in the belt. The Stephens Passage Group of central southeastern Alaska (Lathram and others, 1965) extends both to the south (Brew and others, 1984) and to the north (Brew and Ford, 1986), and the named and unnamed units in the vicinity of Gravino Island (Berg, 1973; Rubin and Saleeby, 1987) comprise a second and informal group. Thus, the Gravina belt rocks are a lithostratigraphic supergroup. Although informal use of the term supergroup is not proposed here, thinking of the Gravina belt rocks in this sense both provides more specific information than does the widely used, but very nonspecific term "belt" and avoids the implication that the belt rocks are a tectonostratigraphic terrane.

In contrast to the original definition of Berg and others (1972), we would characterize the rocks of the Gravina belt as (1) a sequence of dominantly mudstone and sandstone turbidite deposits interbedded and interfingered with lesser amounts of basaltic and hawaiitic flows and breccias, and locally interbedded with significant but minor amounts of both graniticclast-bearing conglomerate and tuffaceous mudstone; and (2) as the metamorphic equivalents of these rocks where gradational relations are present. This conclusion is based on the significant volumes of granitic-clast-bearing conglomerate that are present (Loney, 1964; Lathram and others, 1965; Redman, 1984; and Rubin and Saleeby, 1987), on the findings (Ford and Brew, this volume) that the dominant volcanic rocks are basalts and hawaiites, not andesites, and on the large volumes of slightly metamorphosed fine-grained mixed volcanic and nonvolcanic mudstone locally present as a separate facies within the belt (Brew and others, 1984).

Although this article has focused on the Gravina belt rocks in southeastern Alaska, it is worth noting that possible outliers of the belt have recently been reported in British Columbia to the south (Hill, 1984; Douglas, 1986; Crawford and others, 1987). In addition, current Canadian stratigraphic interpretations now link the Jurassic and Cretaceous Bowser Basin of central British Columbia with rocks on the western side of the Coast plutonic-metamorphic complex; those latter rocks are inferred to be on strike with the aforementioned outliers of the Gravina belt (Wheeler and McFeely, 1987; J.O. Wheeler, Geological Survey of Canada, oral commun., 1987). Such a connection was first suggested by Brew and others (1966).

From our systematic field study of mapped contacts between the rocks of the Gravina belt and older strata, we conclude that (1) none of the contacts visited to date are exposed; (2) most contacts may be interpreted as faults; (3) the best argument for the overlap of the Gravina belt rocks on older strata of the Alexander-Wrangellia superterrane (Berg and others, $1972 ; 1978)$ is the incorporation of clasts from the superterrane in nearby sediments of the Gravina belt; and (4) no evidence exists to suggest that the Gravina belt rocks have been moved laterally large distances. In addition, age and other relations in the vicinity of Gravina Island suggest that some of the Gravina belt rocks there are atypical of the belt as a whole; they may be part of either the Gravina belt or the Alexander terrane, or they may comprise a tectonostratigraphic block or miniterrane that is not exposed elsewhere in southeastern Alaska. Stratigraphically, the Gravina belt rocks are an informal supergroup and should be recognized as such.

\section{REFERENCES CITED}

Barker, Fred, 1957, Geology of the Juneau (B-3) quadrangle, Alaska: U.S. Geological Survey Geologic Quadrangle Map GQ-100, scale $1: 63,360$. 
Berg, H.C., 1972, Geologic map of Annette Island, Alaska: U.S. Geological Survey Miscellaneous Geologic Investigations Map I684 , scale $1: 63,360$.

---- 1973, Geology of Gravina Island, Alaska: U.S. Geological Survey Bulletin 1373, 41 p.

Berg, H.C., Jones, D.L., and Coney, P.J., 1978, Map showing pre-Cenozoic tectonostratigraphic terranes of southeastern Alaska and adjacent areas: U.S. Geological Survey Open-File Report 781085, scale 1:1,000,000.

Berg, H.C., Jones, D.L., and Richter, D.H., 1972, Gravina-Nutzotin belt--tectonic significance of an Upper Mesozoic sedimentary and volcanic sequence in southern and southeastern Alaska, in Geological Survey Research 1972: U.S. Geological Survey Professional Paper 800-D, p. D1-D24.

Brew, D.A., and Ford, A.B., 1984, Tectonostratigraphic terranes in the Coast plutonic-metamorphic complex, southeastern Alaska, in Bartsch-Winkler, Susan, and Reed. K.M., eds., The United States Geological Survey in Alaska: Accomplishments during 1982: U.S. Geological Survey Circular 939, p. 90-93.

---- 1986, Preliminary reconnaissance geologic map of the Juneau, Taku River, At 1 in and part of the Skagway 1:250,000 quadrangles, southeastern Alaska: U.S. Geological Survey Open-File Report 85-395, 23 p.

Brew, D.A., Loney, R.A., and Muffler, L.J.P., 1966, Tectonic history of southeastern Alaska: Canadian Institute of Mining and Metallurgy Special Volume no. 8, p. 149-170.

Brew, D.A., Ovenshine, A.T., Karl, S.M., and Hunt, S.J., 1984, Preliminary reconnaissance geologic map of the Petersburg and parts of the Port Alexander and Sumdum 1:250,000 quadrangles, southeastern Alaska: U.S. Geological Survey Open-File Report 84-405, 2 sheets, 43 p. pamphlet.

Crawford, M.L., Hollister, L.S., and Woodsworth, G.J., 1987, Crustal deformation and regional metamorphism across a terrane boundary, Coast plutonic complex, British Columbia: Tectonics, v. 6, p. 343-361.

Douglas, B.J., 1986, Deformational history of an outlier of metasedimentary rocks, Coast plutonic complex, British Columbia, Canada: Canadian Journal of Earth Sciences, v. 23, p. 813-826.

Hi11, M.L., 1984, Geology of the Redcap Mountain area, Coast plutonic complex, British Columbia: Princeton, N.J., Princeton University, Ph.D. thesis, $216 \mathrm{p}$.

Lathram, E.H., Pomeroy, J.S., Berg, H.C., and Loney, R.A., 1965, Reconnaissance geology of Admiralty Island, Alaska: U.S. Geological Survey Bulletin 1181-R, 48 p., 2 pls., scale $1: 250,000$.

Loney, R.A., 1964, Stratigraphy and petrography of the Pybus-Gambier area, Admiralty Island, Alaska: U.S. Geological Survey Bulletin $1178,103 \mathrm{p}$.

Plafker, George, Hudson, T.L., and Silberling, N.J., 1979, Late Triassic fossils from a sequence of volcanic and sedimentary rocks on the Chilkat Peninsula, southeastern Alaska, in Johnson, K.M., and Williams, J.R., eds., The United States Geological Survey in Alaska--Accomplishments during 1987: U.S. Geological Survey Circular 804B, p. B107-B110.

Redman, Ear1, 1984, An unconformity with associated conglomeratic sediments in the Berners Bay area of southeastern Alaska: Alaska Division of Geological and Geophysical Surveys Professional Report 86, p. $1-4$.

Rubin, C.M., and Saleeby, J.B., 1987, The inner boundary of the Alexander terrane in southern SE Alaska, Part 1: Cleveland Peninsula to southern Revillagigedo Island [abs.]: Geological Society of America, Abstracts with Programs, v. 19, no. 7, p. 826 .

Wheeler, J.0., and McFeely, P., 1987, Tectonic assemblage map of the Canadian Cordillera and adjacent parts of the United States of America: Geological Survey of Canada OpenFile Report 1565.

Reviewers: Bela Csejtey, Jr. and W.J. Nokleberg Geologic Studies in Alaska by the U.S. Geological Survey during 1987: John P. Galloway and Thomas D. Hamilton, editors, U.S. Geological Survey Circular 1016. 


\title{
Megafossils (Buchia) Indicate Late Jurassic Age for Part of Kelp Bay Group on Baranof Island, Southeastern Alaska
}

\author{
By David A. Brew, Susan M. Karl, and John W. Miller
}

Megafossils collected recently on Baranof Island from melange of the Khaz Formation (Kelp Bay Group) are interpreted to indicate that at least part of the unit is Late Jurassic (Tithonian) in age. This collection is important for three reasons: (1) it is the first megafossil collection of any kind reported from Baranof Island, (2) it supplements previous collections from Chichagof Island about $30 \mathrm{~km}$ to the north that indicate a Late Jurassic age for individual displaced blocks in the Khaz Formation, and (3) both the matrix and the enclosed blocks on Baranof Island contain the fossils of Tithonian age, thus implying a Late Jurassic age for the deposition of at least this part of the melange. These main points, together with information on the fossils and on the age of the adjacent Sitka Graywacke, are discussed below.
Saint John Baptist Bay is a 7-km-long, eastsoutheast-trending indentation on the northwest side of Baranof Island (fig. 1). As shown on the reconnaissance map of Loney and others (1975) and on the generalized maps of Plafker and others (1976, 1977), the bay cuts across the regional structural grain and provides good shoreline exposures of the rocks of the Kelp Bay Group. The bay is aligned with an inferred fault that has truncated and (or) offset contacts within the melange (fig. 1).

The Kelp Bay Group is the melange facies of the Chugach terrane in southeastern Alaska (Plafker and others, 1977). East of the head of the bay is the Border Ranges fault (fig. 1), which Plafker and others (1976) showed as separating the Chugach terrane from what we now refer to as the Alexander-Wrangellia

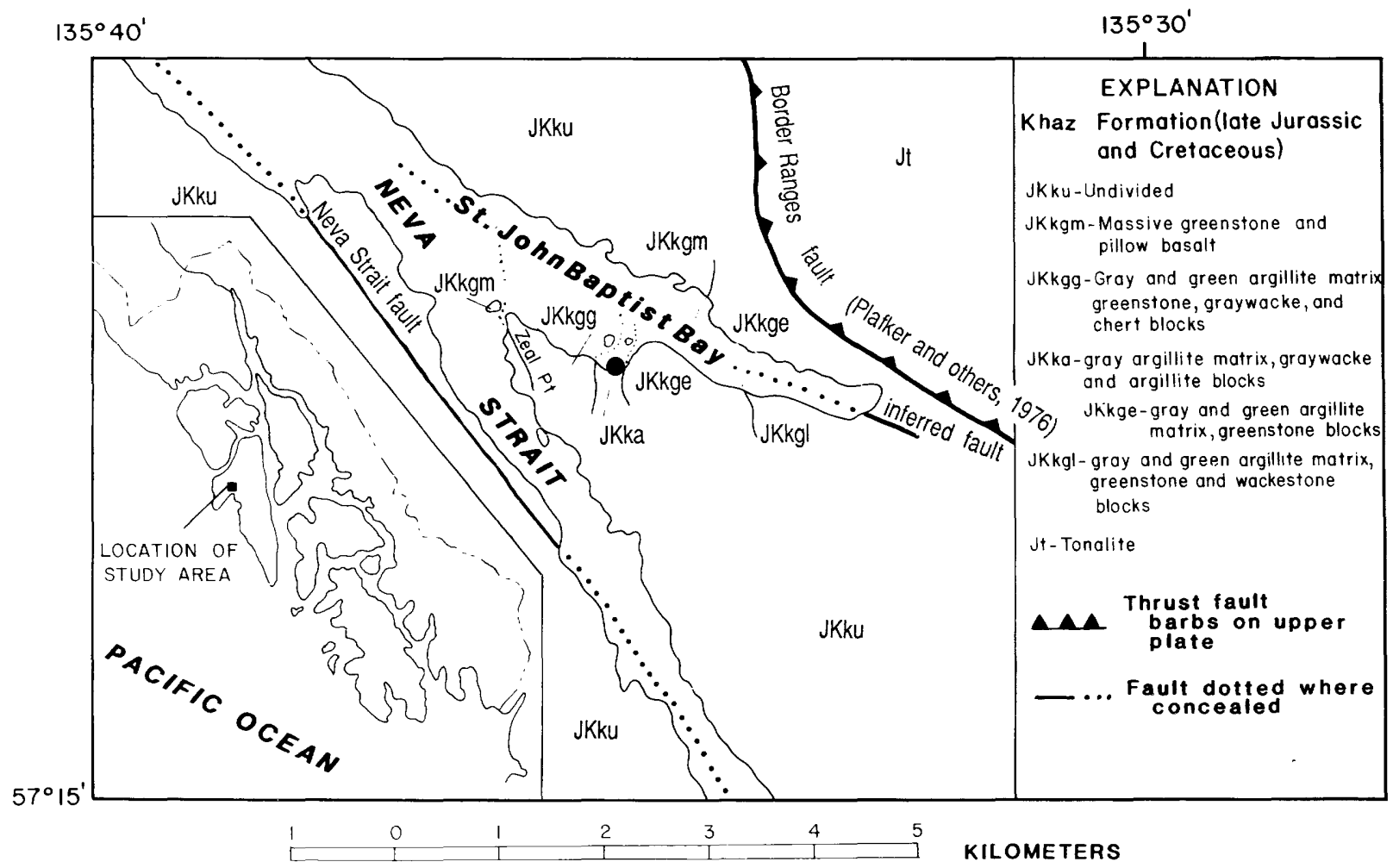

Figure 1. Geologic sketch map of Saint John Baptist Bay, Baranof Island, southeastern Alaska, showing distribution of informal units in the Khaz Formation and location (solid circle) of Buchia fischeriana collection. Geology from Loney and others (1975), modified by D.A. Brew and S.M. Karl (unpub. data). 
superterrane. About $3 \mathrm{~km}$ west of the mouth of the bay (Loney and others, 1975) is the contact of the Kelp Bay Group rocks with the Sitka Graywacke, which is the flysch facies of the Chugach terrane in southeastern Alaska (Plafker and others, 1977).

Recent detailed mapping of the shoreline of Saint John Baptist Bay (D.A. Brew and S.M. Karl, unpub. data) indicates that the Khaz Formation of the Kelp Bay Group (as defined by Karl and others, 1982, and by Johnson and Karl, 1985) is exposed around the entire bay. Generalized informal map units are shown on the sides of the bay in figure 1; their extent to the south and north is not known. On the south side of the bay the Khaz Formation is entirely melange, with blocks of massive dark-gray graywacke, dark-gray argillite, greenish-gray greenstone, and minor limestone enclosed in a deformed matrix of dark-gray argillite. Also present as matrix are units of thinly laminated millimeter- to centimeter-thick layered, light-green and dark-gray argillite that are interpreted to have been interbedded mudstone and tuff. The deformation in the matrix of the melange is shown by conspicuously folded and pulled-apart, thin, discontinuous, 0.5 - to 2.0 -cm-thick layers of light-gray limestone and calcareous argillite and by disrupted layers of the mixed light-green and dark-gray argillite.

The megafossils were found on the south side of the bay about $1.1 \mathrm{~km}$ east-southeast of Zeal Point (fig. 1). They occur in the melange, both in blocks of darkgray argillite a few meters in maximum dimension and also in the enveloping argillite matrix. Their occurrence in the blocks is clear-cut, as they are consistently closely crowded in argillite blocks that do not show the folding and pulling-apart that is common in the matrix. Scattered individuals occur in adjacent argillite that we interpret to be matrix close to the blocks.

Abundant individuals were collected from the blocks and a few individuals from the matrix. The fossils are Buchia fischeriana (d'Orbigny) of Late Jurassic (late Tithonian) age. The same species occurs in large blocks in Khaz Formation melange on Chichagof Island (Decker, 1980b). Unspecified Buchia fossils of Tithonian(?) age were identified and reported by $W$. Connelly (in Decker, 1980b, p. 58) as being in turbidites that may be the matrix of part of the Khaz Formation at an unspecified locality in Slocum Arm on Chichagof Island; this locality was not recovered by other workers in the area, and neither Decker $(1980 \mathrm{a}, \mathrm{b})$ nor Johnson and Karl (1985) proposed a Late Jurassic age for the matrix of the Khaz Formation. Other than the Connelly reference, no fossils have been reported from the melange matrix on Chichagof Island (Johnson and Karl, 1985, p. 5).

Both Decker $(1980 \mathrm{a}, \mathrm{b})$ and Johnson and Karl (1982, 1985) assigned a Cretaceous age to the Khaz Formation on Chichagof Island; we interpret this new locality on Baranof Island to indicate that the unit is at least in part Late Jurassic in age.

This new megafossil collection should be considered in relation to the previously available megafossil and microfossil data from the Khaz Formation on Chichagof and Baranof Islands (table 1). Loney and others $(1975$, p. 20,25$)$ summarized their own and earlier megafossil collections from the Chichagof and Baranof Islands area; at that time the
Buchia collections of Late Jurassic and Early Cretaceous age from Chichagof Island were interpreted to be from the Sitka Graywacke. Since that time re-study of the Chichagof area has resulted in both those and new localities being assigned to the Khaz Formation (Decker, 1980a,b; Johnson and Karl, 1985). As noted above, no megafossils have been reported previously from Baranof Island.

Radiolarians have been recovered from chert in the Khaz Formation at several localities. Plafker and others (1976) reported the occurrence of Valanginian to Hauterivian radiolarians on northern Baranof; that locality (which was reported by D.L. Jones, U.S. Geological Survey, written commun., 1975; and E. Pessagno, University of Texas, written commun., 1977) consists of stream boulders at Old Sitka, north of Sitka (George Plafker, U.S. Geological Survey, oral commun., 1976). One of us (Karl) has identified radiolarians in in situ cherts on northeastern Baranof Island and also at Katlian Bay, which is between the Saint John Baptist Bay and the Old Sitka localities, but poor preservation precluded determination of their age. Radiolarians collected by George Plafker from in situ chert at Katlian Bay in 1975 are also poorly preserved but were dated as possible Late Tithonian to Berriasian by Emile Pessagno (George Plafker, oral commun., 1987). This locality was recollected by Plafker in 1977 and found to contain a Tithonian radiolarian assemblage (George Plafker, oral commun., 1987). Plafker's Katlian Bay chert locality is in what we have mapped as melange consisting of greenstone blocks in a matrix of gray and green argillite.

Our documentation of the age of the blocks and matrix of the melange facies of the Chugach terrane on Baranof Island indicates that the melange there includes blocks of Late Jurassic age in a matrix of the same age. We hypothesize that the Chugach terrane and the Alexander-Wrangellia superterrane were adjacent during the time of melange formation. The volcanic arc we infer to have existed on the Alexander-Wrangellia superterrane in Middle and Late Jurassic time is therefore the likely source for the abundant greenstone and tuffaceous argillite and phyllite in the melange. That arc, which probably was one result of the accretion of the Chugach terrane, persisted into Early Cretaceous time.

Our new information still leaves unanswered the question of the age of the Sitka Graywacke, the flysch facies of the Chugach terrane in southeastern Alaska. It is possible that the Sitka is the same age as the Kelp Bay Group or younger (Decker, 1980b). As noted by Johnson and Karl (1985), there are no fossil localities in the Sitka as it is now mapped. The closest fossil localities in rocks that are lithologically somewhat similar to the Sitka are the Early Cretaceous Inoceramus locality on nearby Emmons Island (Loney and others, 1975; Plafker and others, 1976; Johnson and Karl, 1985), a poorly documented locality with fossils reported to be Early Cretaceous in age in the St. Elias Mountains about $300 \mathrm{~km}$ to the northwest (Sharp and Rigsby, 1956), and Late Cretaceous megafossil and microfossil localities in the Yakutat Group some $200 \mathrm{~km}$ to the northwest (Plafker and others, 1976; George Plafker, written commun., 1987; Rau and others, 1983). The terrane affinity of the first two localities mentioned is uncertain, but that of 
Table 1. Fossil localities in the Khaz Formation, Kelp Bay Group, Chichagof and Baranof Islands, southeastern Alaska ["Matrix," we interpret fossils to be in matrix of melange; "Blocks" indicates we interpret fossils to be in blocks in melange]

\begin{tabular}{|c|c|c|c|c|c|c|}
\hline \multirow[b]{3}{*}{ Age } & \multicolumn{3}{|c|}{ Baranof Island } & \multicolumn{3}{|c|}{ Chichagof Island } \\
\hline & Katlian Bay & Old Sitka & $\begin{array}{l}\text { St. John Baptist } \\
\text { Bay }\end{array}$ & Slocum Arm & & \\
\hline & $\begin{array}{l}\text { G.Plafker, } \\
\text { written, } \\
\text { commun., } 1987\end{array}$ & $\begin{array}{l}\text { Plafker and } \\
\text { others, } 1976\end{array}$ & This paper & $\begin{array}{l}\text { Connelly, } \\
\text { in Decker } \\
\text { 1980a }\end{array}$ & $\begin{array}{l}\text { Decker, } \\
1980 \mathrm{~b}\end{array}$ & $\begin{array}{l}\text { Loney and } \\
\text { others, } \\
1975\end{array}$ \\
\hline \multicolumn{7}{|l|}{ Cretaceous } \\
\hline Hauterivian & & Blocks & & & & \\
\hline Valanginian & & Blocks & & & & \\
\hline Berriasian & & & & & Blocks & Blocks \\
\hline $\begin{array}{l}\text { Jurassic } \\
\text { Tithonian } \\
\text { Tithonian? }\end{array}$ & Blocks & & Matrix and Blocks & Uncertain & Blocks & Blocks \\
\hline $\begin{array}{l}\text { Jurassic or } \\
\text { Triassic }\end{array}$ & & & & & & Blocks \\
\hline
\end{tabular}

the Yakutat Group localities is not. The affinity of the Yakutat Group localities is clearly with the Yakutat terrane, a small tectonostratigraphic terrane with an early history like that of the Chugach terrane and inferred to have been derived from part of the Chugach terrane (Plafker, 1987).

\section{REFERENCES CITED}

Decker, J.E., 1980a, Geologic map of western Chichagof Island, southeastern Alaska: U.S. Geological Survey Open-File Report 80-150, 2 sheets, scale $1: 63,360$.

---- 1980b, Geology of a Cretaceous subduction complex, western Chichagof Island, southeastern Alaska: Stanford, Calif., Stanford University, Ph.D. thesis, 134 p.

Johnson, B.R., and Karl, S.M., 1982, Reconnaissance geologic map of the western Chichagof and Yakobi Islands Wilderness Study Area, southeastern Alaska: U.S. Geological Survey Miscellaneous Field Studies Map MF-1476-A.

---- 1985, Geologic map of western Chichagof and Yakobi Islands, southeastern Alaska: U.S. Geological Survey Miscellaneous Geologic Investigations Map I-1506, scale $1: 125,000,15 \mathrm{p}$. pamphlet.

Karl, S.M., Decker, J.E., and Johnson, B.R., 1982, Discrimination of Wrangellia and the Chugach terrane in the Kelp Bay Group on Chichagof and Baranof Islands, southeastern Alaska, in Coonrad, W.L., ed., The United States Geological Survey in Alaska: Accomplishments during 1980: U.S. Geological Survey Circular 844, p. 124-128.

Loney, R.A., Brew, D.A., Muffler, L.J.P., and Pomeroy, J.S., 1975, Reconnaissance geology of Chichagof, Baranof, and Kruzof Islands, southeastern Alaska: U.S. Geological Survey Professional Paper 792, 105 p.
Plafker, George, 1987, Regional geology and petroleum potential of the northern Gulf of Alaska continental margin, in Scholl, D.W., Grantz, Arthur, and Vedder, J.G., eds., Geology and resource potential of the continental margin of western North America and adjacent ocean basins (Circum-Pacific Council for Energy and Mineral Resources Earth Science Series, v. 6): Houston, Circum-Pacific Council for Energy and Mineral Resources, p. 11/1-11/38.

Plafker, George, Jones, D.L., Hudson, Travis, and Berg, H.C. 1976, The Border Ranges fault system in the Saint Elias Mountains and Alexander Archipelago, in Cobb, E.H., ed., The United States Geological Survey in Alaska: Accomplishments during 1975: U.S. Geological Survey Circular 733, p. 14-16.

Plafker, George, Jones, D.L., and Pessagno, E.A., Jr., 1977, A Cretaceous accretionary flysch and melange terrane along the Gulf of Alaska margin, in Blean, K.M., ed., The United States Geological Survey in Alaska: Accomplishments during 1976: U.S. Geological Survey Circular 751-B, p. B41B43.

Rau, W.W., Plafker, George, and Winkler, G.R., 1983, Foraminiferal biostratigraphy and correlations in the Gulf of Alaska Tertiary province: U.S. Geological Survey $0 i 1$ and Gas Investigations Chart OC-120.

Sharp, R.P., and Rigsby, G.P., 1956, Some rocks of the central St. Elias Mountains, Yukon Territory, Canada: American Journal of Science, v. 254, p. 110-122.

Reviewers: R.A. Loney and George Plafker

Geologic Studies in Alaska by the U.S. Geological Survey during 1987: John P. Galloway and Thomas D. Hamilton, editors, U.S. Geological Survey Circular 1016. 


\title{
Major-Element Geochemistry of Metabasalts of the Juneau-Haines Region, Southeastern Alaska
}

\author{
By Arthur B. Ford and David A. Brew
}

Variably metamorphosed mafic volcanic rocks of greenschist or lower facies are widely distributed in areas of northern southeastern Alaska between Juneau and Haines (fig. 1). Fossils in associated rocks indicate that major basaltic volcanism occurred in three time spans: (1) Silurian and (or) Devonian; (2) Permian(?) and Triassic; and (3) Late Jurassic and Early Cretaceous (Brew and Ford, 1985). Some local units are of unknown age. During regional geological mapping of this area (Brew and Ford, 1985 and unpub. data), we have been systematically sampling the metavolcanic units for geochemical characterization and comparisons. Our studies are in progress, and we here report average major-element compositions of units based on presently available data.

Table 1 shows the compositions of units in different geographic areas west of the Coast Range megalineament (Brew and Ford, 1978) near Juneau (fig. 1). The rocks are strongly recrystallized metabasalts that range from foliated greenstone to greenschist with typical greenschist-facies mineral assemblages of chlorite-epidote-albite-actinolite. Relic phenocrystic augite is common and plagioclase rare.

Metabasalts from the Douglas Island area consist of Upper Jurassic and Lower Cretaceous Douglas Island Volcanies (unit KJsd of Brew and Ford, 1985) and volcanic members of the Seymour Canal Formation that occur on Douglas Island and extend northward to Berners Bay (Brew and Ford, 1985). The Douglas Island Volcanies and Seymour Canal Formation intertongue and thus are approximately coeval; they are at least about $3,000 \mathrm{~m}$ thick. The Seymour Canal Formation is a largely volcanic-derived turbiditic graywacke and slate unit with numerous fossil localities that estabish a Late Jurassic and Early Cretaceous age (Loney, 1964; Brew and Ford, 1985). A previous average major- element composition based on 28 samples was reported by Ford and Brew (1977).

Samples from Glass Peninsula are of the Douglas Island Volcanics on northeastern Admiralty Island (Lathram and others, 1965).

Metabasaltic rocks from Bridget Cove $(10 \mathrm{~km}$ south of Berners Bay) correlate with the Douglas Island Volcanics (Irvine, 1973). They are much less deformed and recrystallized than the rocks on Douglas Island to the south.

Samples from Barlow Cove are of greenschist (Brew and Ford, 1985) with a protolith age considered by Lathram and others (1965) to be Permian and Triassic(?). The rocks were mapped by Barker (1957) as the Barlow Cove Formation of Jurassic(?) to Early Cretaceous(?) age and correlated with the Douglas
Island Voleanics. No fossils have been found in this area.

Table 2 shows average major-element compositions of the metavolcanic units of northern Lynn Canal areas and of areas east of the Coast Range megalineament near Juneau. The rocks are generally well-recrystallized greenstone and greenschist with typical greenschist-facies mineral assemblages of chlorite-epidote-albite-actinolite, and with metamorphic biotite only in areas east of the megalineament near Juneau (Ford and Brew, 1973). Rocks of the Chilkat Peninsula are less altered than those elsewhere.

Samples from the Gastineau Peak area are from a 5-km-wide, northwest-southeast-trending belt adjoining the Coast Range megalineament on the east from Taku Inlet to about $10 \mathrm{~km}$ northwest of Gastineau Peak (Brew and Ford, 1985). The sampling includes the Gastineau volcanic group (of H.M. Eakin and A.C.

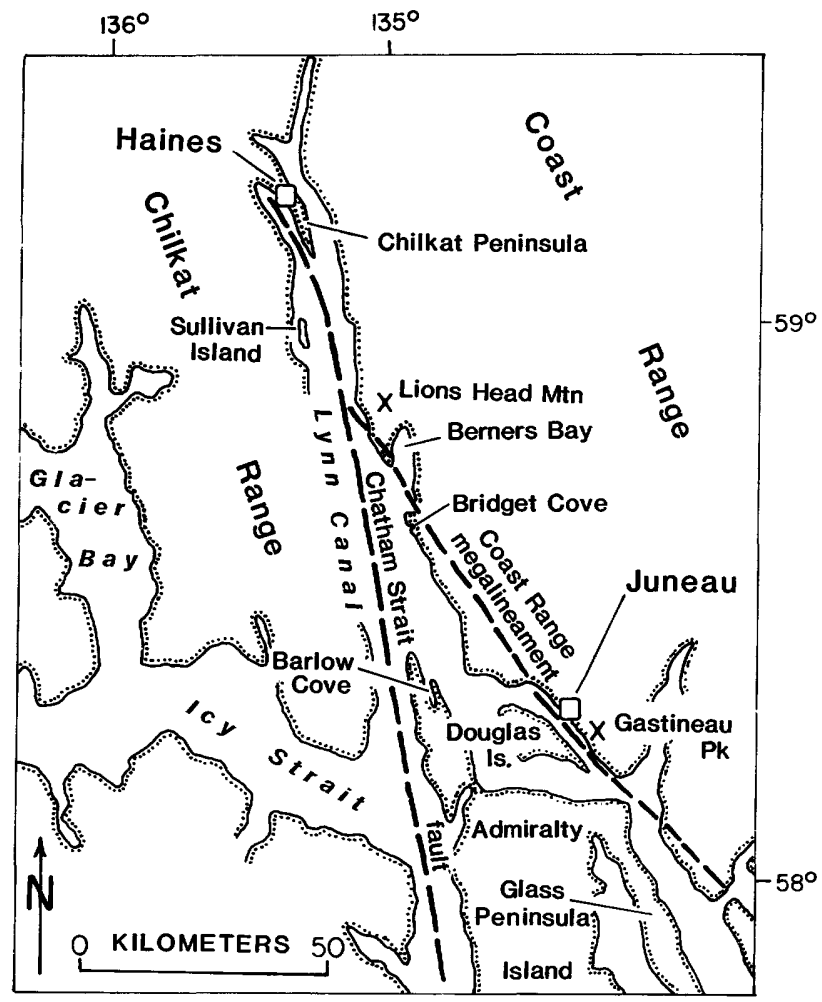

Figure 1. Index map of Juneau-Haines area, southeastern Alaska. 
Table 1. Average major-element content (in weight percent) of Mesozoic metabasalt units of the Juneau area west of the Coast Range megalineament

IAnalyses by $\mathrm{X}$-ray fluorescence except by gravimetric and wet chemical methods for $\mathrm{FeO}$ and volatiles and by rapid rock methods for 28 samples of the Douglas Island unit. Bridget Cove data from Irvine (1973). $\mathrm{Mg}$ value calculated by method of Hughes and Hussey (1976) correcting $\mathrm{Fe}_{2} \mathrm{O}_{3} / \mathrm{FeO}=0.2$ ]

\begin{tabular}{|c|c|c|c|c|}
\hline Figure symbol & $\begin{array}{l}\text { Douglas } \\
\text { Is land } \\
\text { (DI) }\end{array}$ & $\begin{array}{l}\text { Glass } \\
\text { Peninsula } \\
\text { (GLS) }\end{array}$ & $\begin{array}{l}\text { Bridget } \\
\text { Cove } \\
\text { (BGT) }\end{array}$ & $\begin{array}{l}\text { Barlow } \\
\text { Cove } \\
\text { (BLW) }\end{array}$ \\
\hline $\begin{array}{l}\text { Number of } \\
\text { samples }\end{array}$ & 63 & 5 & 7 & 2 \\
\hline $\mathrm{SiO}_{2}$ & 46.9 & 48.3 & 48.2 & 45.8 \\
\hline $\mathrm{Al}_{2} \mathrm{O}_{3}$ & 13.3 & 14.1 & 13.1 & 16.5 \\
\hline $\mathrm{Fe}_{2} \mathrm{O}_{3}$ & 3.6 & 3.1 & 3.34 & 4.6 \\
\hline $\mathrm{FeO}$ & 7.1 & 7.4 & 7.39 & 6.4 \\
\hline MgO & 8.7 & 7.2 & 9.0 & 8.8 \\
\hline $\mathrm{CaO}$ & 10.8 & 11.3 & 10.1 & 10.0 \\
\hline $\mathrm{Na}_{2}$ & 2.2 & 2.9 & 2.6 & 1.9 \\
\hline $\mathrm{K}_{2} \mathrm{O}$ & 1.64 & 1.37 & 2.4 & .20 \\
\hline $\mathrm{H}_{2} \mathrm{O}^{+}$ & 2.87 & 2.66 & 2.71 & 4.25 \\
\hline $\mathrm{H}_{2} \mathrm{O}-$ & .24 & .09 & - & .03 \\
\hline $\mathrm{TiO}_{2}$ & .74 & .77 & .7 & 1.44 \\
\hline $\mathrm{P}_{2} \mathrm{O}_{5}$ & .32 & .32 & .41 & .11 \\
\hline Mno & .17 & .15 & .20 & .16 \\
\hline $\mathrm{CO}_{2}$ & .64 & .31 & .33 & .28 \\
\hline TOTAL & 99.2 & 100.0 & 100.5 & 100.5 \\
\hline Mg value & 65 & 61 & 65 & 65 \\
\hline
\end{tabular}

Table 2. Average major-element content (in weight percent) of Mesozoic and older metabasalt units of the Juneau area east of the Coast Range megalineament and of the northern Lynn Canal area

Analyses by $\mathrm{X}$-ray fluorescence except by gravimetric and wet chemical methods for FeO and volatiles. Mg value, see table 1. Chilkat Peninsula data from Davis and Plafker (1985)]

\begin{tabular}{|c|c|c|c|c|c|}
\hline \multirow[b]{2}{*}{ Figure symbol } & \multirow{2}{*}{$\begin{array}{c}\text { Gastineau } \\
\text { Peak } \\
\text { (GST) }\end{array}$} & \multirow{2}{*}{$\begin{array}{l}\text { Lions Head } \\
\text { Mountain } \\
\text { (LHM) }\end{array}$} & \multirow{2}{*}{$\begin{array}{c}\text { Chilkat } \\
\text { Range } \\
\text { (CHR) }\end{array}$} & \multicolumn{2}{|c|}{$\begin{array}{c}\text { Chilkat } \\
\text { Peninsula }\end{array}$} \\
\hline & & & & ( $\mathrm{CHP})$ & ( $\mathrm{CHL})$ \\
\hline $\begin{array}{l}\text { Number of } \\
\text { samples }\end{array}$ & 23 & 2 & 10 & 13 & 7 \\
\hline $\mathrm{SiO}_{2}$ & 46.1 & 46.8 & 46.6 & 48.9 & 49.7 \\
\hline $\mathrm{Al}_{2} \mathrm{O}_{3}$ & 15.6 & 13.2 & 14.4 & 14.4 & 13.9 \\
\hline $\mathrm{Fe}_{2} \mathrm{O}_{3}$ & 2.8 & 4.8 & 4.0 & 4.5 & 3.9 \\
\hline FeO & 8.7 & 9.7 & 8.1 & 8.2 & 8.8 \\
\hline $\mathrm{MgO}$ & 6.9 & 7.2 & 7.4 & 6.8 & 6.5 \\
\hline $\mathrm{CaO}$ & 10.6 & 8.6 & 9.2 & 10.1 & 10.7 \\
\hline $\mathrm{Na}_{2} \mathrm{O}$ & 2.5 & 3.2 & 2.3 & 2.5 & 2.2 \\
\hline $\mathrm{K}_{2} \mathrm{O}$ & .52 & .27 & .60 & .48 & .59 \\
\hline $\mathrm{H}_{2} \mathrm{O}^{+}$ & 2.56 & 3.01 & 3.45 & 2.11 & 2.13 \\
\hline $\mathrm{H}_{2} \mathrm{O}-$ & .06 & .11 & .12 & .10 & - \\
\hline $\mathrm{TiO}_{2}$ & 1.74 & 2.82 & 1.54 & 1.43 & 2.10 \\
\hline $\mathrm{P}_{2} \mathrm{O}_{5}$ & .39 & .22 & .20 & .17 & .20 \\
\hline $\mathrm{MnO}$ & .18 & .23 & .21 & .21 & .19 \\
\hline $\mathrm{CO}_{2}$ & .68 & .43 & 1.12 & .09 & .07 \\
\hline TOTAL & 99.3 & 100.6 & 99.2 & 100.0 & 101.0 \\
\hline Mg value & 57 & 53 & 58 & 55 & 53 \\
\hline
\end{tabular}


Spencer, quoted by Martin, 1926). The Gastineau contains Late Triassic fossils (Martin, 1926), and other fossils suggest a protolith age range of Early Permian to Late Triassic. Lithologic associations and age constraints are described by Brew and Ford (1985).

The metabasalts from Lions Head Mountain are from a widespread but little-mapped northwestsoutheast-trending greenstone unit between Berners Bay and Lynn Canal. Age information is unavailable, but lithologic comparisons suggest correlation with Upper Triassic metabasalt (Plafker and others, 1979) of the Chilkat Peninsula on approximate strike to the northwest.

Chilkat Range samples are from a little-mapped area of the central Chilkat Range west of Sullivan Island (Brew and Ford, 1985). The unit probably correlates with greenstone and greenschist to south of Silurian and (or) Devonian age.

Samples from the Chilkat Peninsula extend northwestward to near Haines and the upper Chilkat Inlet Davis and Plafker's (1985) sampling of Upper Triassic metabasalt of a 3,000-m-thick sequence at the southern end of the peninsula. Table 2 shows the average of Davis and Plafker's (1985) analyses for comparison.

The original composition of the metavolcanic rocks is uncertain owing to possible major-element mobility in altered volcanic rocks (for example, Rollinson and Roberts, 1986). In this preliminary study we have not attempted a rigorous discrimination of samples that may show chemical migration. However, all samples were plotted on Mullen's (1983) "spilitization" diagram (fig. 2), and any showing unusual sodium enrichment were excluded from the averages of tables 1 and 2. (A small percentage from most units were thereby excluded.) The average compositions of all units lie in the fields of basalt or hawaiite (fig. 3 ) in the IUGS classification of Zanettin (1984), and range from high- $\mathrm{K}$ basalt and absarokite to low- $\mathrm{K}$ calc-alkaline basalt and tholeiite according to Ewart's (1982) classification (fig. 4).

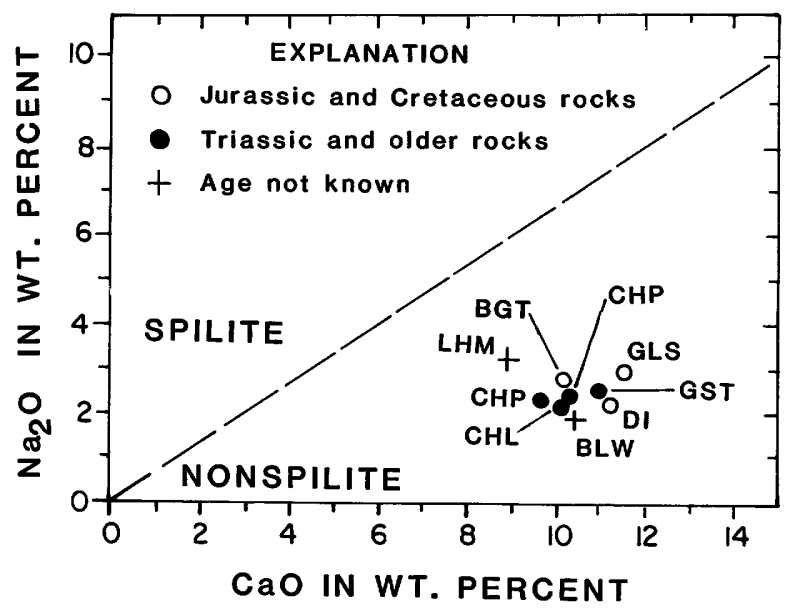

Figure 2. Average composition of metavolcanic units plotted on diagram of Mullen (1983). Normalized volatile free. See tables 1 and 2 for sample-unit symbols.
The average major-element compositions of the metavolcanic rocks of Jurassic to Cretaceous age (Douglas Island Volcanics and equivalents) and those of Triassic and older age differ greatly. The Jurassic to Cretaceous rocks are more magnesian as shown by distinctly higher $\mathrm{Mg}$ values than the older rocks ( $\mathrm{Mg}$ values 61-65, table 1 versus 53-58, table 2). Although $\mathrm{Na}_{2} \mathrm{O}$ contents of the two age groups of rocks are similar (fig. 2), $\mathrm{K}_{2} \mathrm{O}$ content of the Jurassic to Cretaceous rocks is much higher (fig. 4), which accounts for their higher total alkalis in figure 3 . One of the most distinctive differences is the much lower $\mathrm{TiO}_{2}$ content of the Jurassic to Cretaceous rocks (fig. $5)$, as shown in ratios with other oxides in figures 6 and 7. Additionally, in Irvine and Baragar's (1971) classification, the Jurassic to Cretaceous rocks have compositions near or across the tholeiite field boundary and distinctly apart from the tholeitic compositions of the older rocks (fig. 8).

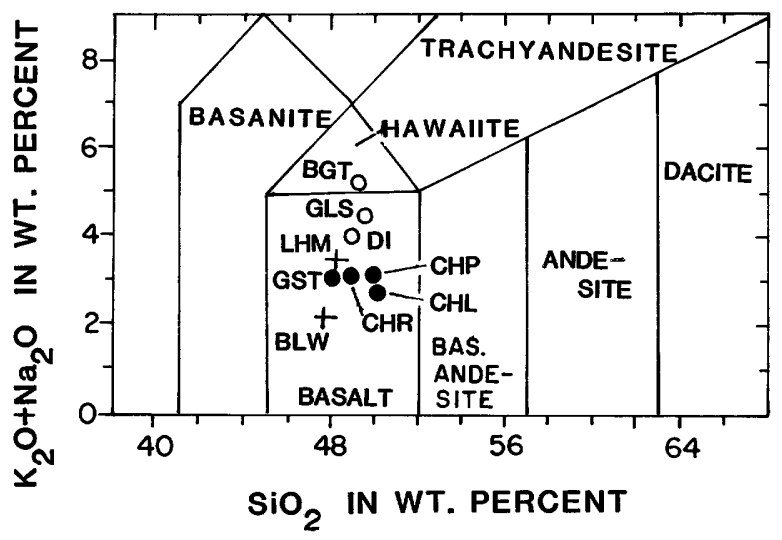

Figure 3. Average composition of metavolcanic units in IUGS classification of Zanettin (1984). Normalized volatile free. Symbols of units as in figure 2 .

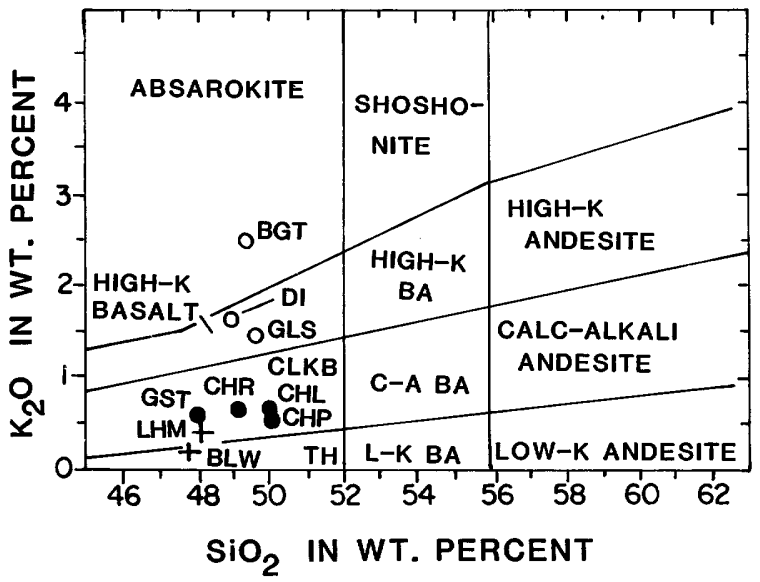

Figure 4. Plot of average $\mathrm{K}_{2} \mathrm{O}$ against $\mathrm{SiO}_{2}$ (normalized volatile free) of metavolcanic units showing rock-type boundaries of Ewart (1982). Symbols of units as in figure 2. TH, low-K tholeiite field and CLKB, calc-alkali basalt field of Ewart (1982). 
The greenstones and greenschists of various ages are generally difficult if not impossible to distinguish on lithological and mineralogical characteristics alone, except that coarse, commonly euhedral, relic pyroxene, where present, and lack of visible plagioclase have been found useful for identifying the Douglas Island Volcanics in our mapping. Correlations of the greenschists of Barlow Cove, the greenstones of Lions Head Mountain, and some greenstone and greenschist of Douglas Island and

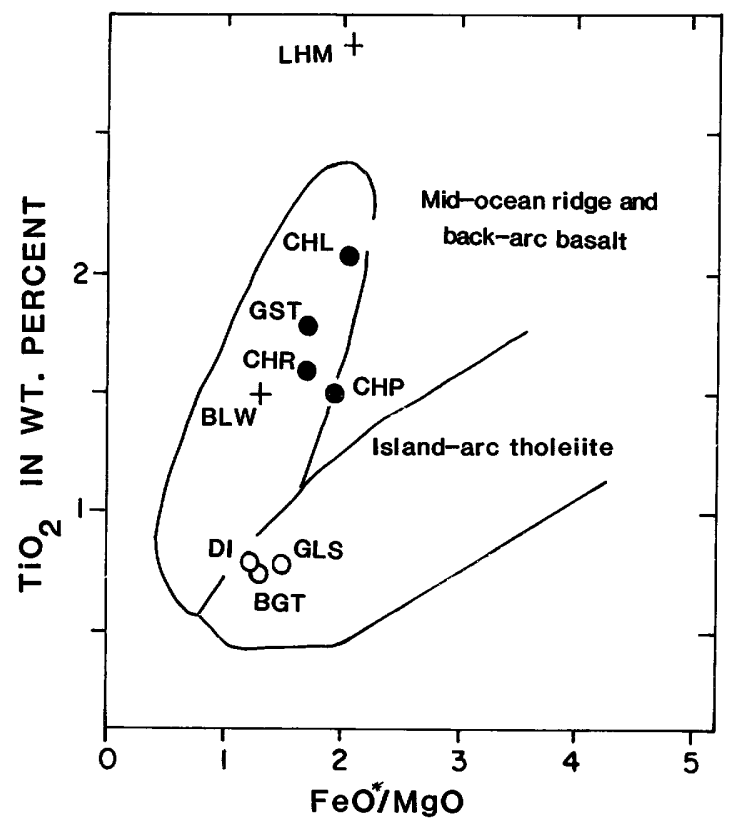

Figure 5. Plot of average $\mathrm{TiO}_{2}$ against $\mathrm{FeO} * \mathrm{MgO}$ (normalized volatile free) of metavolcanic units showing basalt-type fields of Hawkins and others (1985). FeO* equals total iron expressed as FeO. Symbols of units as in figure 2 .

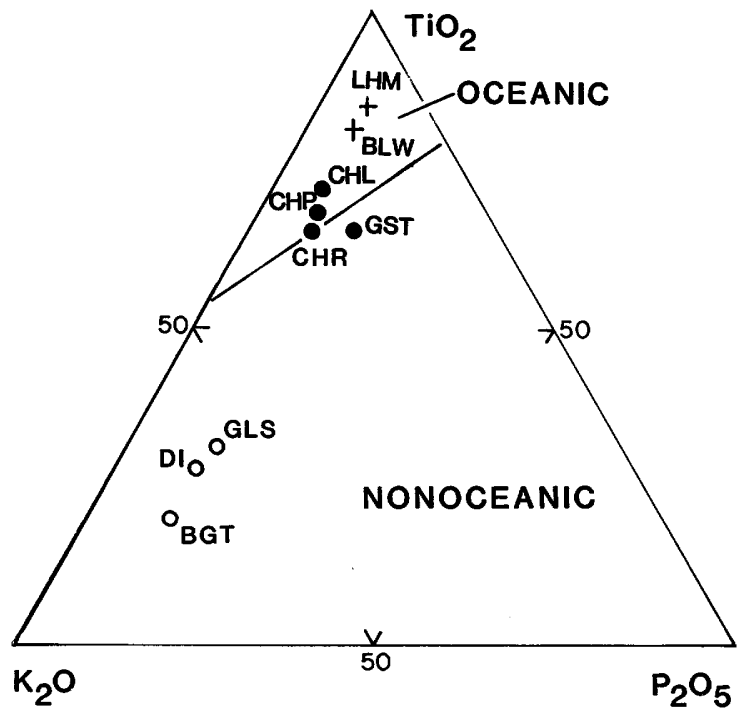

Figure 6. Average composition of metavolcanic units in Pearce and others' (1975) $\mathrm{TiO}_{2}-\mathrm{K}_{2} \mathrm{O}-\mathrm{P}_{2} \mathrm{O}_{5}$ discrimination diagram for oceanic and nonoceanic basalt. Symbols of units as in figure 2 . vicinity are particularly uncertain in the absence of paleontological ages. Using geochemical discriminators shown in figures $3-8$ (as well as some minor elements), we infer that all greenstone and greenschist of Douglas Island and west of the megalineament between Douglas Island and Berners Bay are part of the Jurassic to Cretaceous sequence of metavolcanic and metasedimentary rocks; and that the greenschist of Barlow Cove and greenstone of Lions Head Mountain are geochemically much more like the

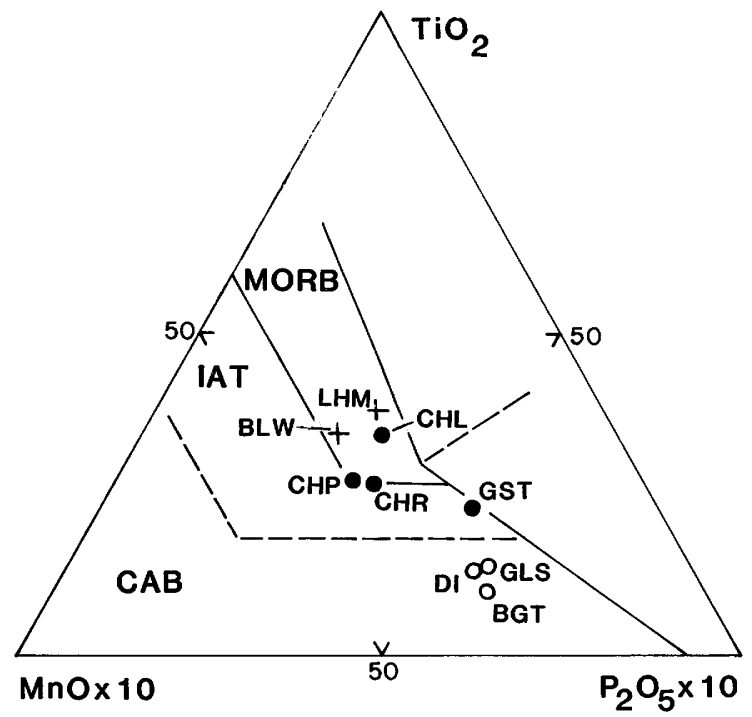

Figure 7. Average composition of metavolcanic units in Mullen's (1983) $\mathrm{MnO}-\mathrm{TiO}_{2}-\mathrm{P}_{2} \mathrm{O}_{5}$ discrimination diagram for oceanic basalt types. MORB, midocean ridge and marginal basin basalt; IAT, island-arc tholeiite; CAB, calc-alkaline basalt. Symbols of units as in figure 2.

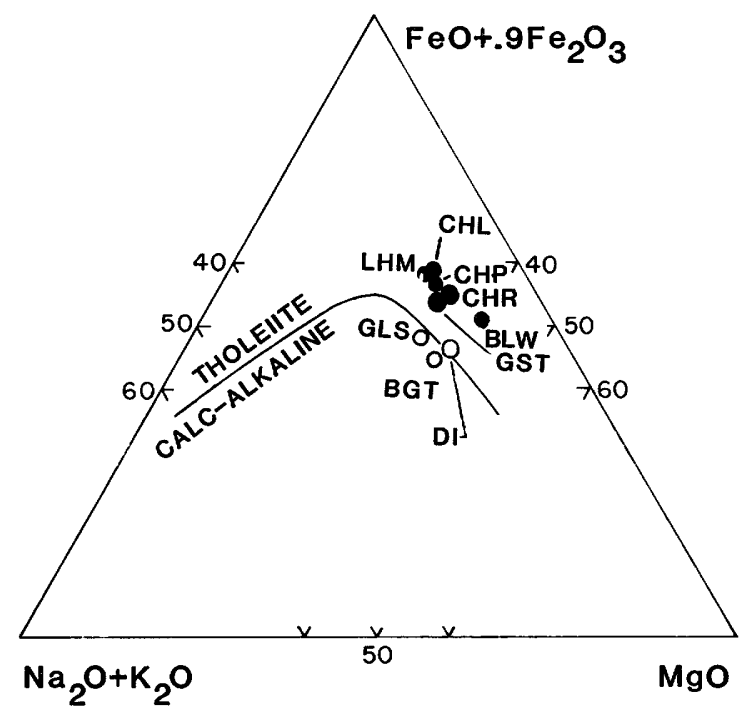

Figure 8. Average composition of metavolcanic units in Irvine and Baragar's (1971) AFM diagram showing tholeiitic and calcalkaline boundary. Note that Bridget Cove rocks (BGT) have alkaline composition (figures 3 and 4). 
metavolcanic rocks of Triassic and older age. The geochemical data are in agreement with Lathram and others' $(1960,1965)$ age reassignment for the greenschist of the Barlow Cove area to Permian and Triassic(?), from Barker's (1957) original correlation with the Douglas Island Volcanics.

The tectonic setting of the basaltic magmatism events in the Juneau-Haines area is difficult to evaluate in terms of major-element chemistry alone. The metavolcanic rocks lie in two markedly distinct groups in Pearce and others' (1975) $\mathrm{TiO}_{2}-\mathrm{K}_{2} \mathrm{O}-\mathrm{P}_{2} \mathrm{O}_{5}$ diagram: the Jurassic to Cretaceous rocks in the field of nonoceanic basalt and the others in or near the field of oceanic basalt (fig. 6). Davis and Plafker (1985) suggested an intraplate or a back-arc or fore-arc extensional setting for the Triassic metabasalt of the southern Chilkat Peninsula. Our data are compatible with that origin and suggest further that, according to the discrimination diagrams of figures 5 and 7 , all the Triassic and older metavolcanic rocks have a similar tectonic setting except possibly the rocks of Gastineau Peak. The many geochemical differences between the Triassic and older rocks on the one hand and the Jurassic to Cretaceous rocks on the other suggest differences in setting or sources of magma. Berg and others (1972) and Panuska and others (1984) included the latter in their "Gravina-Nutzotin belt," a magmatic arc of Jurassic to Cretaceous andesite and flysch in southeastern Alaska. In our study area, however, the rocks of this belt have only basaltic, including alkalic basaltic, composition rather than the andesitic compositions indicated by Berg and others (1972) and Panuska and others (1984). Compositions reported here are those of nonoceanic basalt (fig. 6), as would be expected in a continental-margin magmatic arc, but the rocks are considerably more alkalic (fig. 4) than the calc-alkaline volcanic rocks found in such an orogenic setting (Ewart, 1982), and an origin related to rifting is more likely (Ford and Brew, 1977), perhaps by movements along an ancestral fault of the Coast Range megalineament.

\section{REFERENCES CITED}

Barker, Fred, 1957, Geology of the Juneau (B-3) quadrangle: U.S. Geological Survey Geologic Quadrangle Map GQ-100, scale 1:63,360.

Berg, H.C., Jones, D.L., and Richter, D.H., 1972, Gravina-Nutzotin belt--Tectonic significance of an upper Mesozoic sedimentary and volcanic sequence in southern and southeastern Alaska, in Geological Survey research 1972: U. Geological Survey Professional Paper 800-D, p. D1-D24.

Brew, D.A., and Ford, A.B., 1978, Megalineament in southeastern Alaska marks southwest edge of Coast Range batholithic complex: Canadian Journal of Earth Sciences, v. 15, p. 1763-1772.

1985, Preliminary reconnaissance geologic map of the Juneau, Taku River, Atlin, and part of the Skagway 1:250,000 quadrangles, southeastern Alaska: U.S. Geological Survey Open-File Report 85-395.
Davis, Alice, and Plafker, George, 1985, Comparative geochemistry and petrology of Triassic basaltic rocks from the Taku terrane on the Chilkat Peninsula and Wrangellia: Canadian Journal of Earth Sciences, v. 22, p. 183-194.

Ewart, A., 1982, The mineralogy and petrology of Tertiary-Recent orogenic volcanic rocks: with special reference to the andesiticbasaltic compositional range, in Thorpe, R.S., ed., Andesites: New York, John Wiley and Sons, $724 \mathrm{p}$.

Ford, A.B., and Brew, D.A., 1973, Preliminary geologic and metamorphic-isograd map of the Juneau B-2 quadrangle, Alaska: U.S. Geological Survey Miscellaneous Field Studies Map MF-527, scale 1:31,680.

1977, Chemical nature of Cretaceous greenstone near Juneau, Alaska, in Blean, K.M., ed., The United States Geological Survey in Alaska: Accomplishments during 1976: U.S. Geological Survey Circular 751$\mathrm{B}, \mathrm{P} . \mathrm{B} 88-\mathrm{B} 90$.

Hawkins, J.W., Moore, G.F., Villamor, R., Evans, C., and Wright, E., 1985, Geology of the composite terranes of east and central Mindanao, in Howel1, D.G., ed., Tectonostratigraphic terranes of the CircumPacific region: Houston, Circum-Pacific Council for Energy and Mineral Resources, Earth Science Series, v. 1, p. 437-462.

Hughes, C.J., and Hussey, E.M., 1976, M and $\mathrm{Mg}$ values in igneous rocks: Proposed usage and a comment on currently employed $\mathrm{Fe}_{2} \mathrm{O}_{3}$ corrections: Geochemica et Cosmochimica Acta, v. 40, p. 485-486.

Irvine, T.N., 1973, Bridget Cove volcanics, Juneau area, Alaska: Possible parental magma of Alaskan-type ultramafic complexes: Carnegie Institution of Washington Yearbook 72, p. 478-491.

Irvine, T.N., and Baragar, W.R.A., 1971, A guide to the chemical classification of the common volcanic rocks: Canadian Journal of Earth Sciences, v. 8, p. 523-548.

Lathram, E.H., Loney, R.A, Berg, H.C., and Pomeroy, J.S., 1960, Progress map of the geology of the Juneau quadrangle, Alaska: U.S. Geological Survey Miscellaneous Geological Investigations Map I-276, scale $1: 250,000$.

Lathram, E.H., Pomeroy, J.S., Berg, H.C., and Loney, R.A., 1965, Reconnaissance geology of Admiralty Island, Alaska: U.S. Geological Survey Bulletin 1181-R, $48 \mathrm{p}$.

Loney, R.A., 1964, Stratigraphy and petrography of the Pybus-Gambier area, Admiralty Island, Alaska: U.S. Geological Survey Bulletin $1178,103 \mathrm{p}$.

Martin, G.C., 1926, The Mesozoic stratigraphy of Alaska: U.S. Geological Survey Bulletin, $493 \mathrm{p}$.

Mullen, E.D., 1983, $\mathrm{MnO} / \mathrm{TiO}_{2} / \mathrm{P}_{2} \mathrm{O}_{5}$ : A minor element discriminant for basaltic rocks of oceanic environments and its implications for petrogenesis: Earth and Planetary 
Science Letters, v. 62, p. 53-62.

Panuska, B.C., Decker, J.E., and Berg, H.C., 1984, A preliminary paleomagnetic study of the Gravina-Nutzotin belt, southern and southeastern Alaska, in Coonrad, W.C., and Elliot, R.L., eds., The United States Geological Survey in Alaska: Accomplishments during 1981: U.S. Geological Survey Circular 868, p. 117-120.

Pearce, T.H., Gorman, B.E., and Birkett, T.C., 1975, The $\mathrm{TiO}_{2}-\mathrm{K}_{2} \mathrm{O}-\mathrm{P}_{2} \mathrm{O}_{5}$ diagram: A method of discriminating between oceanic and nonoceanic basalts: Earth and Planetary Science Letters, v. 24, p. 419-426.

Plafker, George, Hudson, Travis, and Silberling, N.J., 1979, Late Triassic fossils from a sequence of volcanic and sedimentary rocks on the Chilkat Peninsula, southeastern Alaska, in Johnson, K.M., and Williams,
J.R., eds., The United States Geological Survey in Alaska: Accomplishments during 1978: U.S. Geological Survey Circular 804B, P. B107-B110.

Rollinson, H.R., and Roberts, C.R., 1986, Ratio correlations and major element mobility in altered basalts and komatites: Contributions to Mineralogy and Petrology, v. 93, p. 89-97.

Zanettin, B., 1984, Proposed new chemical classification of volcanic rocks: Episodes, v. 7 , p. 19-20.

Reviewers: S.E. Box and George Plafker

Geologic Studies in Alaska by the U.S. Geological Survey during 1987: John P. Galloway and Thomas D. Hamilton, editors, U.S. Geological Survey Circular 1016. 


\title{
Petrography of Sandstones of the Orca Group from the Southern Trans-Alaskan Crustal Transect (TACT) Route and Montague Island
}

\author{
By L.D. Gergen and George Plafker
}

The Orca Group is a widespread, thick, strongly deformed and weakly metamorphosed (laumontite and prehnite-pumpellyite facies) flysch and tholeiitic basalt sequence that composes most of the Prince William terrane (Winkler, 1976; Winkler and Plafker, 1981). It is late Paleocene through early middle Eocene in age, based on sparse fossils and the $\mathrm{K}-\mathrm{Ar}$ ages of plutons that intrude the sequence (Plafker and others, 1985). The Prince William terrane is bounded by the Contact fault to the north and west, and by the Chugach-Saint Elias and Ragged Mountain faults to the east (fig. 1). To the south, it extends beneath the continental shelf and possibly beyond (Plafker, 1987).

Five hundred grains on each of 25 thin sections of selected sandstones of the Orca Group were identified using the Gazzi-Dickinson point-counting method (Dickinson, 1970) to place constraints on their provenance. The samples were collected from the area between Prince William Sound and the Copper River for the Trans-Alaska Crustal Transect (TACT) project during 1985 (fig. 1).

Point-count data for sandstones from the Orca Group are presented in table 1 and summarized on figure 2. The sandstones are poorly to moderately sorted, with angular to rounded grains. Medium sand grains predominate, with some grains ranging from silt to pebble size. Average QFL (quartz-feldspar- lithic fragments) percentages are 30-41-29. Quartz is dominantly monocrystalline; polycrystalline quartz is no more than 11 percent of total quartz, averaging 2 percent. Feldspar is mainly plagioclase, which averages 89.4 percent of total feldspar. Rare grains of oligoclase and andesine are present, but most of the plagioclase is altered, and much appears to be albitized. For this reason, original compositions of plagioclase minerals cannot be determined. Average LmLvLs (metamorphic-volcanic-sedimentary lithic fragments) percentages are 20-41-29. The metamorphic lithic clasts are of predominantly tectonite fabrics, with lesser amounts of crystalloblastic textures, and rare schistose grains. Some of the fragments are metavolcanic. Volcanic lithic fragments exhibit lathwork, microlitic, felsitic, hypabyssal, and vitric textures, in decreasing order of abundance. The sedimentary lithic grains consist of argillite, shale, and impure chert. Limestone clasts constituting 2 to 17 percent of total lithic fragments are found in three samples from Montague Island (samples 21, 23, and 25). Dense minerals compose 5 percent or less of total framework grains and include epidote, sphene, garnet, pyroxene, amphibole, and spinel. Phyllosilicate minerals are 0 to 4.8 percent of framework grains and consist of biotite, chlorite, minor muscovite, and rare prehnite. Some of the biotite may be of metamorphic origin.

The QFL diagram (fig. 2A) shows the wide range of feldspar and lithic proportions found in the sandstones of the Orca Group. All of the samples have less than $\mathbf{5 0}$ percent quartz. Lithic constituents form two clusters on the LmLvLs diagram (fig. 2B) based on relative percentages of sedimentary and volcanic grains, with metamorphic lithic grains evenly distributed among the two clusters. The sedimentary cluster is composed of samples that have more than $\mathbf{5 0}$ percent sedimentary and less than 32 percent volcanic lithic fragments. The sedimentary grains, largely argillite and shale, are probably derived from erosion of flysch sequences. The volcanic cluster consists of samples having more than 34 percent volcanic grains (inferred to be derived mainly from an active arc source) and less than 31 percent sedimentary grains. Note that the more lithic-rich samples on the QFL diagram (samples $4,11,14,20,21,23$, and 25) are part of the group of samples that make up the sedimentary cluster on the LmLvLs diagram. The QmPK (monocrystalline quartz- plagioclase- potassium feldspar) diagram (fig. 2C) emphasizes the high proportion of monocrystalline quartz and plagioclase and the low proportion of potassium feldspar. Average QmPK percentages are 42-52-7 (table 1).

Because the samples were not collected from measured sections and because of the complex regional structure, no vertical or horizontal trends within the sequence could be established from the point-count data. Sample data were plotted on triangular diagrams grouped by turbidite facies (Walker and Mutti, 1973), but no apparent trends emerged from the data. Samples were also plotted in four groups (table 1) that represent fault-bounded tectonic blocks: Group A, samples north of the Rude River fault (RRF on fig. 1); Group B, samples from a belt with abundant tholeiitic basalt and breccia south of RRF and north of the Cordova (CF) and Etches (EF) faults; Group C, samples south of CF and EF; and Group D, samples south of the Patton Bay fault (PBF) on Montague Island. Group D samples tend to have higher lithic proportions, and Group A and Group D samples tend to have higher sedimentary lithic proportions than the other groups. 


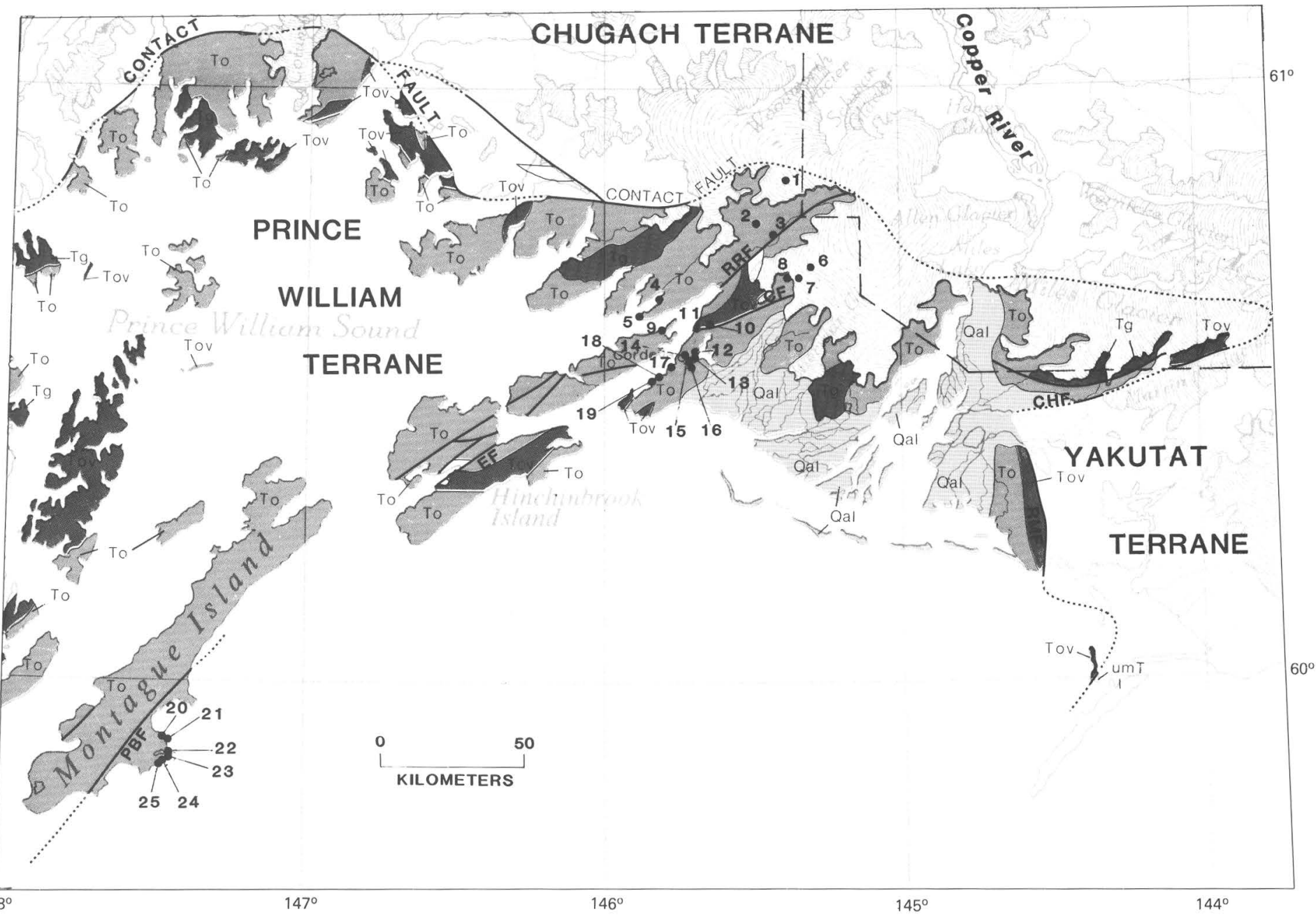

Figure 1. Location map of Prince William Sound region showing distribution of Quaternary alluvial deposits (Qal), the Tertiary Orca Group (To, undifferentiated siliciclastic and volcanic rocks; Tov, volcanic units) and Tertiary intrusive granitic rocks (Tg), faults mentioned in text, and numbered sample localities (refer to table 1 for field numbers). CF, Cordova fault; CHF, Chugach fault; EF, Etches fault; PBF, Patton Bay fault; RMF, Ragged Mountain fault; and RRF, Rude River fault. Faults dotted where concealed. 
Table 1. Point-count data for sandstones of the Orca Group

[QFL, quartz, feldspar, and lithic fragments; LmLvLs, metamorphic,volcanic, and sedimentary lithic fragments; QmPK, monocrystalline quartz, plagioclase, K-feldspar; P/F, plagioclase to feldspar ratio; $\mathrm{Qp} / \mathrm{Q}$, polycrystalline quartz to quartz ratio; Fmwk\%M, framework percent mica; $\mathrm{Fmwk} \% \mathrm{D}$, framework percent dense minerals]

\begin{tabular}{|c|c|c|c|c|c|c|c|c|}
\hline $\begin{array}{l}\text { Sample } \\
\text { Number }\end{array}$ & $\begin{array}{l}\text { Field } \\
\text { Number }\end{array}$ & $\begin{array}{l}\text { QFL } \\
Q-F-L\end{array}$ & $\begin{array}{l}\operatorname{LmLvLs}{ }^{1} \\
\mathrm{Lm}-\mathrm{Lv}-\mathrm{Ls}\end{array}$ & $\begin{array}{l}\mathrm{QmPK} \% \\
\mathrm{Qm}-\mathrm{P}-\mathrm{K}\end{array}$ & $\mathrm{P} / \mathrm{F}$ & $\mathrm{Qp} / \mathrm{Q}$ & Fmwk \&M & Fmwk\&D \\
\hline \multicolumn{9}{|l|}{ Group A } \\
\hline 1 & $85 \mathrm{APr} 78 \mathrm{~A}$ & $37-50-14$ & $24-21-55$ & $42-49-09$ & 0.853 & 0 & 2.7 & 0.7 \\
\hline 2 & 85ANK90A & $30-57-13$ & $15-69-16$ & $34-52-14$ & 0.791 & 0.016 & 1.5 & 5.0 \\
\hline 3 & 85AWK17 & $35-54-11$ & $18-24-58$ & $40-52.09$ & 0.855 & 0 & 1.6 & 0.9 \\
\hline 4 & 85ALu59 & $31-22-46$ & $11-31-58$ & $55-45-0$ & 1.000 & 0.109 & 2.0 & 0.4 \\
\hline 5 & $85 A \operatorname{Pr} 163 \mathrm{~A}$ & $41-32-28$ & $17-16-68$ & $56-43-01$ & 0.987 & 0.010 & 1.8 & 0 \\
\hline \multicolumn{9}{|c|}{ Group B } \\
\hline 6 & $85 \mathrm{APr} 73 \mathrm{~A}$ & $49-44-07$ & $-\quad-\quad-$ & $52-44-04$ & 0.926 & 0.011 & 2.8 & 1.8 \\
\hline 7 & 85ALu4C & $29-56-15$ & $22-52-26$ & $34-65-01$ & 0.984 & 0 & 3.0 & 0.2 \\
\hline 8 & 85ASR40A & $31-62-07$ & $-\quad-\quad-$ & $33-54-13$ & 0.800 & 0.015 & 1.3 & 2.9 \\
\hline 9 & 85ALu69A & $44-30-26$ & $31-56-13$ & $59-41-0$ & 1.000 & 0.033 & 0.8 & 0.6 \\
\hline 10 & 85ALu24 & $41-43-17$ & $18-82-0$ & $49-52-0$ & 1.000 & 0.017 & 1.1 & 1.1 \\
\hline 11 & 85ALu11C & $22-26-51$ & $15-25-60$ & $46-49-05$ & 0.904 & 0.009 & 0.4 & 0.4 \\
\hline \multicolumn{9}{|l|}{ Group C } \\
\hline 12 & 85ALu37A & $22-50-29$ & $03-83-14$ & $29-64-07$ & 0.903 & 0.061 & 1.7 & 2.9 \\
\hline 13 & 85ALu16 & $37-44-19$ & $43-35-23$ & $45-53-02$ & 0.969 & 0.013 & 1.1 & 2.4 \\
\hline 14 & 85ALu31A & $22-25-52$ & $06-11-83$ & $46-44-10$ & 0.811 & 0.028 & 0.2 & 1.4 \\
\hline 15 & 85ALu15 & $28-56-16$ & $28-71-01$ & $33-57-10$ & 0.849 & 0.008 & 2.5 & 3.9 \\
\hline 16 & $85 \mathrm{ALu} 20$ & $26-57-17$ & $26-61-13$ & $31-58-10$ & 0.848 & 0.008 & 2.7 & 2.3 \\
\hline 17 & $85 \mathrm{APr} 66 \mathrm{~A}$ & $35-51-13$ & $40-42-19$ & $40-56-04$ & 0.936 & 0.021 & 3.9 & 4.4 \\
\hline 18 & $85 \mathrm{APr} 62 \mathrm{~A}$ & $40-31-29$ & $10-24-66$ & $55-44-01$ & 0.986 & 0.034 & 2.8 & 0.2 \\
\hline 19 & $85 \mathrm{APr} 59 \mathrm{~A}$ & $36-50-15$ & $11-62-28$ & $42-54-05$ & 0.921 & 0 & 4.8 & 2.5 \\
\hline \multicolumn{9}{|c|}{ Group D } \\
\hline 20 & 85ALu53A & $19-34-46$ & $29-19-52$ & $36-52-12$ & 0.814 & 0 & 0.9 & 0.4 \\
\hline 21 & 85ALu52C & $08-19-74$ & $28-05-67$ & $30-58-12$ & 0.824 & 0 & 0 & 0 \\
\hline 22 & 85ALu44A & $24-45-31$ & $20-70-10$ & $35-60-05$ & 0.923 & 0 & 1.8 & 1.2 \\
\hline 23 & 85ALu46C & $21-22-57$ & $12-17-71$ & $48-42-09$ & 0.819 & 0.054 & 0.2 & 0 \\
\hline 24 & $85 \mathrm{ALu} 48 \mathrm{~B}$ & $18-56-26$ & $19-51-30$ & $24-68-08$ & 0.897 & 0 & 1.9 & 1.9 \\
\hline 25 & 85ALu50B & $16-19-65$ & $05-24-72$ & $45-42-13$ & 0.760 & 0.016 & 1.3 & 0.3 \\
\hline mean & & $30-41-29$ & $20-41-39$ & $42-52-07$ & 0.894 & 0.019 & 1.8 & 1.5 \\
\hline standard & deviation & $10-14-19$ & $10-24-26$ & $10-08-05$ & 0.076 & 0.025 & 1.2 & 1.4 \\
\hline
\end{tabular}

1 Not calculated for samples with less than 10 percent lithics

Otherwise, the sample groups broadly overlap each other when plotted on QFL, LmLvLs, and QmPK diagrams.

Other petrographic studies on sandstones of the Orca Group include those by Winkler (1976), Nelson and others (1985), and Dumoulin (1984). Winkler (1976) examined 59 samples, mainly from Hinchinbrook and Hawkins Islands, that yielded average QFL percentages of 43-46-11, LmLvLs percentages of 7-53-40, Qp/Q of $0.12, \mathrm{P} / \mathrm{F}$ of 0.92 , and framework percent mica of 1.6 percent. He concluded that a composite sedimentary and volcanic terrane such as the Valdez terrane in the Chugach Mountains is a possible source for the detritus in the Orca Group. Nelson and others (1985) analyzed 20 medium-grained sandstones mainly from western Prince William Sound and reported average QFL percentages of 31-41-28. They inferred a magmaticare provenance for the sandstones in the Orca Group with continued dissection of the magmatic are exposing the plutonic roots. Dumoulin (1984) showed no major compositional differences between the detritus in the Orca Group and Valdez Group. She found that average QFL percentages for the eastern part of the Orca Group are 29-51-20, with volcanics dominating the lithic clasts. Detritus of Knight and adjacent islands in Prince William Sound have average QFL percentages of 52-32-16. Dumoulin (1984) concluded that a magmatic-arc provenance was likely and that an important subduction-complex component is suggested by QpLvLs plots for Knight Island area samples. Our study in the vicinity of the TACT route generally confirms previous workers' findings regarding a combined volcanic and sedimentary source for sandstone of the Orca Group.

The two data clusters shown on our LmLvLs diagram (fig. 2B) indicate mixed sources for the sandstones of the Orca Group. The volcanic lithic fragments and unpublished geochemical data indicate first-cycle(?) magmatic-arc derivation. The sedimentary lithic fragments could have been derived from erosion of the Late Cretaceous Valdez Group and correlative units that compose most of the Chugach terrane, and (or) recycling of older Orca Group deposits due to uplift and erosion along the northern margin of the Prince William terrane.

\section{REFERENCES CITED}

Dickinson, W.R., 1970, Interpreting detrita1 modes of graywacke and arkose: Journal of Sedimentary Petrology, v. 40, no. 2, p. 695707.

Dickinson, W.R., Beard, L.S., Brakenridge, G.R., Erjavec, J.L., Ferguson, R.C., Inman, K.F., Knepp, R.A., Lindberg, F.A., and Ryberg, 

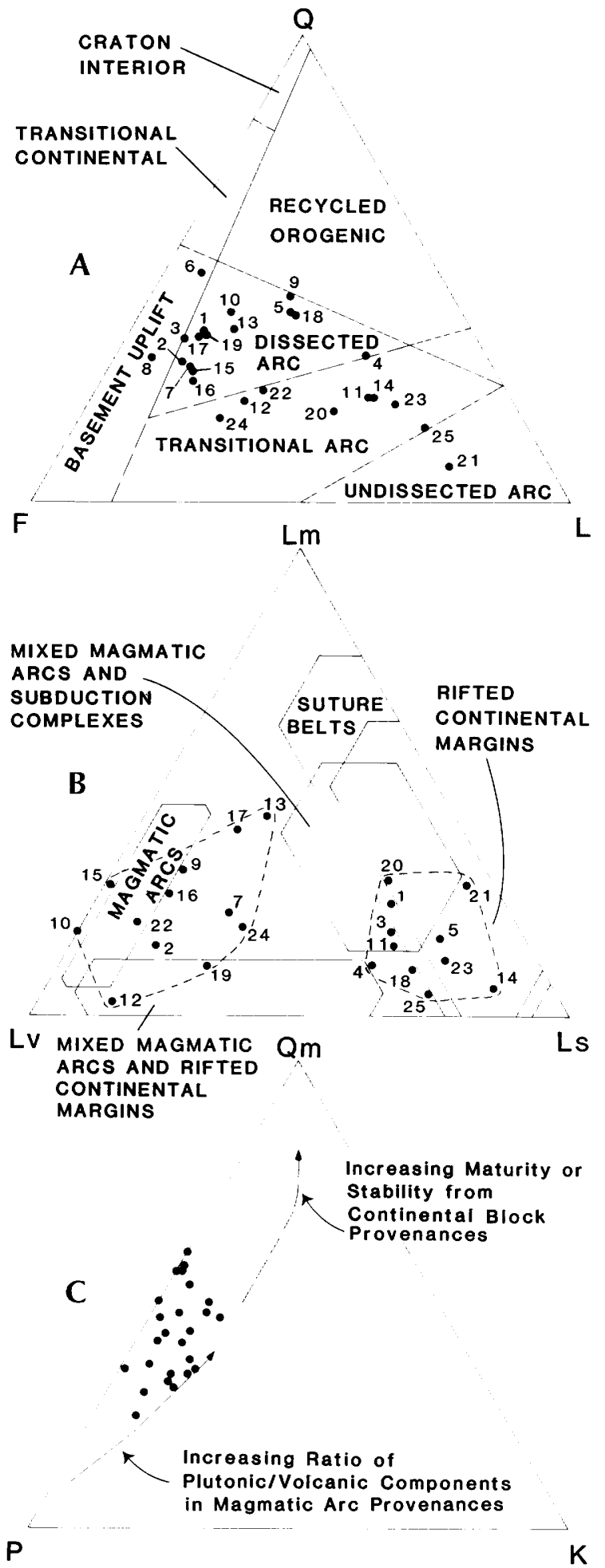

Figure 2. Ternary diagrams for sandstone of the Orca Group. A, QFL (quartz-feldspar-lithic fragments) diagram modified from Dickinson and others (1983). B, LmLvLs (metamorphicvolcanic-sedimentary lithic fragments) diagram modified from Ingersoll and Suczek (1979). Dashed lines delineate dominantly "sedimentary" and "volcanic" clusters. Samples with less than 10 percent lithic grains (6 and 8) were not plotted. C, QMPK (monocrystalline quartz-plagioclase-potassium feldspar) diagram modified from Dickinson and Suczek (1979).
P.T., 1983, Provenance of North American Phanerozoic sandstones in relation to tectonic setting: Geological Society of America Bulletin, v. 94, no. 2, p. 222-235.

Dickinson, W.R., and Suczek, C.A., 1979, Plate tectonics and sandstone compositions: American Association of Petroleum Geologists Bulletin, v. 63, no. 12, p. 2164-2182.

Dumoulin, J.A., 1984, Composition and provenance of sandstone of the Orca and Valdez Groups, Prince William Sound, Alaska [abs.]: Geological Society of America, Abstracts with Programs, v. 16, no. 5, p. 280.

Ingersol1, R.V., and Suczek, C.A., 1979, Petrology and provenance of Neogene sand from Nicobar and Bengal fans, DSDP Sites 211 and 218: Journal of Sedimentary Petrology, v. 49, no. 4, p. 1217-1228.

Nelson, S.W., Dumoulin, J.A., and Miller, M.L., 1985, Geologic map of the Chugach National Forest, Alaska: U.S. Geological Survey Miscellaneous Field Map MF-1645B, scale $1: 250,000$, p. 5-6.

Plafker, George, 1987, Regional geology and petroleum potential of the northern Gulf of Alaska continental margin, in Scholl, D.W., Grantz, Arthur, and Vedder, J.G., eds., Geology and resource potential of the continental margin of western North America and adjacent ocean basins (Circum-Pacific Council for Energy and Mineral Resources Earth Science Series, v. 6): Houston, Circum-Pacific Council for Energy and Mineral Resources, p. 11/1-11/38.

Plafker, George, Keller, Gerta, Barron, J.A., Blueford, J.R., Nelson, S.W., Dumoulin, J.A., and Miller, M.L., 1985, Paleontologic data on the age of the Orca Group, Alaska: U.S. Geological Survey Open-File Report 85429, 22 p.

Walker, R.G., and Mutti, Emiliano, 1973, Turbidite facies and facies associations, in Turbidites and deep-water sedimentation: Anaheim, California, Society of Economic Paleontologists and Mineralogists, Pacific Section, Short Course Lecture notes, p. 119157.

Winkler, G.R., 1976, Deep-sea fan deposition of the Lower Tertiary Orca Group, Eastern Prince William Sound, Alaska, in Miller, T.P., ed., Recent and ancient sedimentary environments in Alaska: Anchorage, Alaska Geological Society, Symposium Proceedings, P. R1-R20.

Winkler, G.R., and Plafker, George, 1981, Preliminary geologic map of the Cordova and Middleton Island quadrangles, Alaska: U.S. Geological Survey Open-File Report 81-1164, scale $1: 250,000$.

Reviewers: J.E. Case and R.L. Detterman

Geologic Studies in Alaska by the U.S. Geological Survey during 1987: John P. Galloway and Thomas D. Hamilton, editors, U.S. Geological Survey Circular 1016. 


\title{
$\mathrm{H}_{2}$ S-Rich Vein-Forming Fluids at the Sumdum Chief Gold Mine, Southeastern Alaska
}

\author{
By Richard J. Goldfarb, Albert H. Hofstra, Gary P. Landis, and David L. Leach
}

The Sumdum Chief mine was the largest gold producer within the southern part of the Juneau gold belt (fig. 1), yielding 24,000 troy oz $(746,000 \mathrm{~g}$ ) of gold and 24,000 troy oz $(746,000 \mathrm{~g})$ of silver between 1890 and 1903 from a mesothermal vein system (Redman and others, 1986). This vein system has an unusual fluid composition that is exceptionally enriched in hydrogen sulfide. The main gold-bearing quartz vein is as much as $1 \mathrm{~m}$ wide and is largely within a fissile graphitic limestone unit of a belt of phyllite and slate (Kimball and others, 1984). A sulfidized felsic dike also hosts some of the quartz veins approximately 150 $\mathrm{m}$ below the main mine workings. Due to the precarious location of these workings, we were only able to sample quartz-vein material cropping out along the lower valley walls and mineralized float undoubtedly fallen from the main workings at higher elevations.

Temperatures of phase changes in fluid inclusions in quartz and sphalerite were determined using a U.S. Geological Survey gas flow microscope stage. All microthermometric measurements were made on fluid inclusions appearing as water-dominant, two-phase systems at room temperature. Some widespread small, dark inclusions and clear, probably empty, one-phase inclusions also were present but were not examined in this study. Most of the fluid inclusions that we studied were pseudosecondary or secondary in origin, trapped along fractures that subsequently healed. Whenever possible, we restricted our microthermometric measurements to inclusions that did not occur along recognizable planes. The more isolated inclusions most likely contain the older fluids, and they were found to contain more dissolved gases than inclusions in secondary planes.

Melting temperatures of ice in the inclusions in both sphalerite and quartz ranged from $-2{ }^{\circ} \mathrm{C}$ to $-6{ }^{\circ} \mathrm{C}$, corresponding to 4 to 9 equivalent weight percent $\mathrm{NaCl}$. These salinities are maximum values because the formation of observed gas clathrates removed water from the residual fluids and lowered the measured melting temperatures. Gas-rich inclusions in sphalerite have clathrate melting temperatures between $10.3{ }^{\circ} \mathrm{C}$ and $11.4{ }^{\circ} \mathrm{C}$, and show melting of solid $\mathrm{CO}_{2}$ at temperatures as low as $-62.5{ }^{\circ} \mathrm{C}$. Both the depression of the $\mathrm{CO}_{2}$ triple point to temperatures below $-56.6{ }^{\circ} \mathrm{C}$ and the presence of clathrate meltings above $10^{\circ} \mathrm{C}$ indicate the presence of other volatiles in the inclusions in addition to $\mathrm{H}_{2} \mathrm{O}$ and $\mathrm{CO}_{2}$. The majority of the measured homogenization temperatures for fluid inclusions in sphalerite ranged from $215^{\circ} \mathrm{C}$ to $290^{\circ} \mathrm{C}$.
Melting of solid $\mathrm{CO}_{2}$ in quartz has not yet been observed, although clathrate melting temperatures ranged from $10.7{ }^{\circ} \mathrm{C}$ to $27.5{ }^{\circ} \mathrm{C}$. Values at the high end of this range are among the highest recorded for any known gold-bearing vein system and indicate an exceptionally anomalous ore fluid composition for some of the vein material at the Sumdum Chief mine. Proximity of these higher values to the $29.5{ }^{\circ} \mathrm{C}$ quadruple point for the $\mathrm{H}_{2} \mathrm{O}-\mathrm{H}_{2} \mathrm{~S}$ system (Touray and Guilhammou, 1984) suggests substantial $\mathrm{H}_{2} \mathrm{~S}$ in the inclusions. Laser Raman microprobe spectroscopy (Wopenka and Pasteris, 1986) confirmed the presence of $\mathrm{H}_{2} \mathrm{~S}$ in these inclusions, as well as $\mathrm{CO}_{2}, \mathrm{~N}_{2}$, and $\mathrm{CH}_{4}$. Relatively isolated, more regularly shaped inclusions in quartz samples yielded homogenization temperatures between $240^{\circ} \mathrm{C}$ and $320^{\circ} \mathrm{C}$. Just prior to homogenization, one 13-micrometer-diameter inclusion decrepitated at $330{ }^{\circ} \mathrm{C}$ and one $18-$ micrometer inclusion decrepitated at $255{ }^{\circ} \mathrm{C}$. Experimental decrepitation data for quartz from Leroy (1979) and Swanenberg (1980) suggests minimum trapping pressures of at least $100 \mathrm{MPa}(1 \mathrm{kbar})$.

Fluid inclusion gas analyses obtained using a quadrupole mass spectrometer (Landis and others, 1987) quantitatively characterize this $\mathrm{H}_{2} \mathrm{~S}$-rich gold system. This technique allows the identification of gas species released from individual fluid inclusions by thermal decrepitation in a dynamically pumped

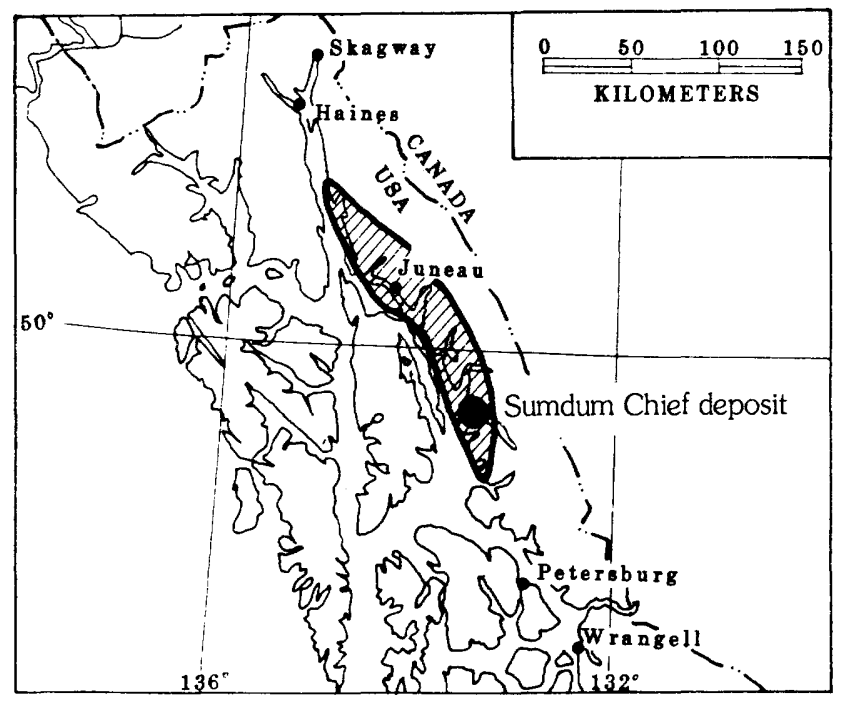

Figure 1. Location of Sumdum Chief gold deposit, southeastern Alaska. Shaded area shows extent of Juneau gold belt. 
vacuum inlet system. Quantitative analyses of individual inclusions from quartz and sphalerite are listed in tables 1 and 2 , which also include bulk analyses of gas released from many inclusions decrepitated within a given temperature range.

Bulk extraction data for quartz are fairly consistent over the entire temperature range. Ranges of volatiles, expressed in mole percent, are 64 to 74 percent for $\mathrm{H}_{2} \mathrm{O}, 8$ to 17 percent $\mathrm{CO}_{2}, 5$ to 7 percent $\mathrm{N}_{2}, 1$ to 3 percent $\mathrm{CH}_{4}$, generally 5 to 6 percent shortchain hydrocarbons (ethane and propane), <2 percent $\mathrm{H}_{2}, 2$ to 4 percent $\mathrm{H}_{2} \mathrm{~S}$, and $<1$ percent $\mathrm{HCl}$ and $\mathrm{Ar}$. Anomalous amounts of short-chain hydrocarbons released between $310^{\circ} \mathrm{C}$ and $340^{\circ} \mathrm{C}$ are also present in analyses of individual inclusions that decrepitated in this temperature range, (such as the burst at $336{ }^{\circ} \mathrm{C}$ ) (table 1). Individual inclusion bursts for the quartz show much wider compositional ranges for $\mathrm{H}_{2} \mathrm{O}, \mathrm{CO}_{2}$, $\mathrm{N}_{2}$, and $\mathrm{H}_{2} \mathrm{~S}$, with as much as 40 percent $\mathrm{CO}_{2}, 25$ percent $\mathrm{N}_{2}$, or 30 percent $\mathrm{H}_{2} \mathrm{~S}$, than do bulk extractions for the same species. Most likely this is due to necking of many of the inclusions. Additionally, individual bursts generally contain lower concentrations of $\mathrm{H}_{2} \mathrm{O}$ and hydrocarbons than observed for the bulk extractions. We suspect many of the smaller inclusions that are only measured through the bulk extractions are relatively enriched in these volatile species. Whether this is indicative of two or more ore-related fluids of varying composition is uncertain. Higher concentrations of $\mathrm{H}_{2} \mathrm{O}$ and hyrocarbons in the bulk analyses also could reflect gradual desorption of these species from vacuum inlet surfaces during heating; high background values are subtracted from individual burst values.
Sphalerite contained fewer fluid inclusions than quartz, probably reflecting differences in the fracture properties of the two minerals. Bulk data are very similar to those for quartz, with slightly less $\mathrm{H}_{2} \mathrm{O}$, slightly more $\mathrm{N}_{2}$ and hydrocarbons, and small amounts of $\mathrm{SO}_{2}$ at about the 1 mole percent level. Similar to quartz, bursts from individual inclusions within sphalerite show increases in $\mathrm{CO}_{2}$ and $\mathrm{N}_{2}$, and decreases in $\mathrm{H}_{2} \mathrm{O}$ and hydrocarbons relative to bulk measurements. The one major difference between the fluids from the quartz and sphalerite is the consistently much lower amount of $\mathrm{H}_{2} \mathrm{~S}$ within inclusions from sphalerite (table 2). Almost all of the individual inclusions contained less than 1 mole percent $\mathrm{H}_{2} \mathrm{~S}$. Much of the sulfur originally within the fluids most likely reacted with $\mathrm{Zn}$ to form the sphalerite.

The presence of significant amounts of $\mathrm{H}_{2} \mathrm{~S}$ in fluid inclusions from minerals in ore deposits is quite rare; the few published accounts of substantial $\mathrm{H}_{2} \mathrm{~S}$ are for deposits formed within diagenetic environments (Touray and Guilhaumou, 1984). Norman and Sawkins (1987), using bulk fluid inclusion data obtained by mass spectrometry, found $\mathrm{H}_{2} \mathrm{~S}$ contents of between 0.01 and 0.0001 mole percent for most ore deposits. Thermodynamic models for gold-rich hydrothermal systems usually indicate $\mathrm{H}_{2} \mathrm{~S}$ and (or) $\mathrm{HS}^{-}$ concentrations between $10^{-2}$ and $10^{-3}$ molal, even where hydrosulfide ligands are believed to form the dominant gold complexes.

Only a handful of studies document $\mathrm{H}_{2} \mathrm{~S}$ concentrations in epigenetic occurrences at the percent level. Norman and Sawkins (1987) discovered 0.9 mole percent $\mathrm{H}_{2} \mathrm{~S}$ in quartz from the Creede,

Table 1. Quantitative analyses (in mole percent) of bulk fluid inclusion gases for ranges of decrepitation temperatures $\left(T_{D}\right)$ and of individual fluid inclusion bursts at specific temperatures for quartz from the Sumdum Chief gold deposit

\begin{tabular}{lllllllllll}
\hline $\mathrm{T}_{\mathrm{D}}\left({ }^{\circ} \mathrm{C}\right)$ & $\mathrm{H}_{2} \mathrm{O}$ & $\mathrm{CO}_{2}$ & $\mathrm{~N}_{2}$ & $\mathrm{CH}_{4}$ & $\mathrm{C}_{\mathrm{n}} \mathrm{H}_{\mathrm{m}}$ & $\mathrm{HCl}$ & $\mathrm{Ar}$ & $\mathrm{H}_{2} \mathrm{~S}$ & $\mathrm{SO}_{2}$ & $\mathrm{H}_{2}$
\end{tabular}

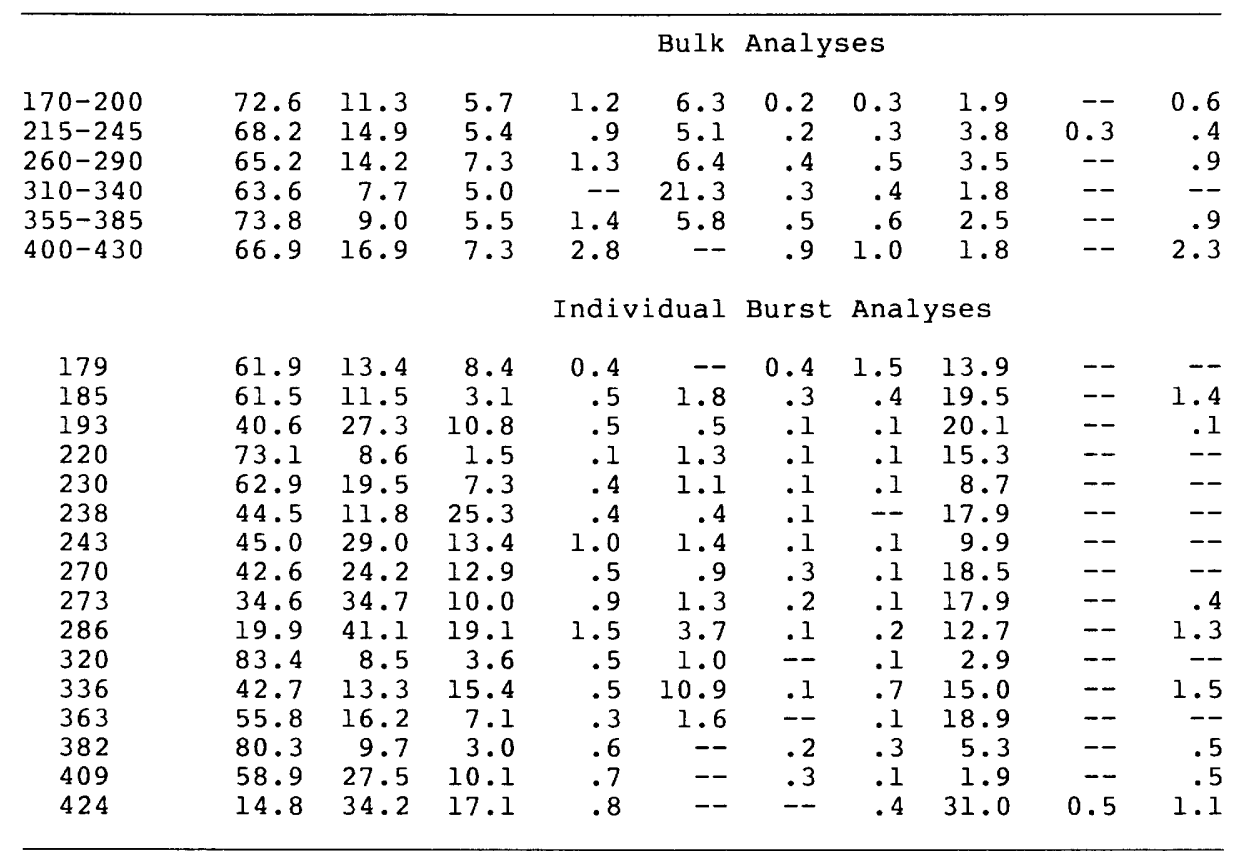


Table 2. Quantitative analyses (in mole percent) of bulk fluid inclusion gases for ranges of decrepitation temperatures $\left(T_{D}\right)$ and of individual fluid inclusion bursts at specific temperatures for sphalerite from the Sumdum Chief gold deposit

\begin{tabular}{|c|c|c|c|c|c|c|c|c|c|c|}
\hline${ }^{\mathrm{T}} \mathrm{D}\left({ }^{\circ} \mathrm{C}\right)$ & $\mathrm{H}_{2} \mathrm{O}$ & $\mathrm{CO}_{2}$ & $\mathrm{~N}_{2}$ & $\mathrm{CH}_{4}$ & $\mathrm{C}_{\mathrm{n}} \mathrm{H}_{\mathrm{m}}$ & $\mathrm{HCl}$ & Ar & $\mathrm{H}_{2} \mathrm{~S}$ & $\mathrm{SO}_{2}$ & $\mathrm{H}_{2}$ \\
\hline & \multicolumn{10}{|c|}{ Bulk Analyses } \\
\hline \multirow[t]{2}{*}{$\begin{array}{l}190-215 \\
230-260\end{array}$} & $\begin{array}{l}58.3 \\
55.8\end{array}$ & $\begin{array}{l}16.0 \\
13.0\end{array}$ & $\begin{array}{l}9.5 \\
8.6\end{array}$ & $\begin{array}{l}2.1 \\
4.9\end{array}$ & $\begin{array}{r}9.1 \\
12.0\end{array}$ & $\begin{array}{r}0.6 \\
.9\end{array}$ & $\begin{array}{r}0.5 \\
.8\end{array}$ & $\begin{array}{r}0.52 \\
.81\end{array}$ & $\begin{array}{l}1.3 \\
1.1\end{array}$ & $\begin{array}{l}2.2 \\
2.1\end{array}$ \\
\hline & \multicolumn{10}{|c|}{ Individual Burst Analyses } \\
\hline $\begin{array}{l}191 \\
195 \\
196 \\
198 \\
202 \\
214 \\
244 \\
277 \\
415\end{array}$ & $\begin{array}{l}49.0 \\
34.3 \\
49.1 \\
68.3 \\
25.9 \\
61.9 \\
37.3 \\
48.2 \\
30.9\end{array}$ & $\begin{array}{l}25.5 \\
41.8 \\
22.4 \\
20.6 \\
37.5 \\
23.7 \\
34.6 \\
24.5 \\
40.5\end{array}$ & $\begin{array}{r}18.1 \\
22.2 \\
21.0 \\
8.0 \\
28.5 \\
12.3 \\
15.6 \\
21.9 \\
16.9\end{array}$ & $\begin{array}{r}1.1 \\
.9 \\
1.2 \\
.3 \\
.9 \\
.8 \\
1.8 \\
1.2 \\
2.4\end{array}$ & $\begin{array}{r}3.3 \\
0.4 \\
.9 \\
1.6 \\
2.1 \\
.8 \\
6.3 \\
3.5 \\
4.0\end{array}$ & $\begin{array}{r}0.6 \\
-- \\
.1 \\
.2 \\
.9 \\
.2 \\
.3 \\
-- \\
1.1\end{array}$ & $\begin{array}{r}0.2 \\
.1 \\
-1 \\
.1 \\
.3 \\
.1 \\
.6 \\
.1 \\
.6\end{array}$ & $\begin{array}{r}0.03 \\
.09 \\
.56 \\
.27 \\
.34 \\
.15 \\
.30 \\
.29 \\
1.32\end{array}$ & $\begin{array}{r}1.0 \\
.2 \\
.2 \\
.6 \\
.5 \\
.1 \\
.8 \\
.3 \\
.6\end{array}$ & $\begin{array}{r}1.0 \\
-- \\
4.5 \\
-- \\
3.1 \\
-- \\
2.3 \\
-- \\
1.6\end{array}$ \\
\hline
\end{tabular}

Colorado, epithermal $\mathrm{Ag}$ system and 3.5 mole percent $\mathrm{H}_{2} \mathrm{~S}$ in quartz from the Cochiti, New Mexico, epithermal Au system. Hofstra and others (1987) described up to 1 mole percent $\mathrm{H}_{2} \mathrm{~S}$ within fluid inclusions at the Jerritt Canyon, Nevada, disseminated gold deposit. Akhmanova and others (1985), using Raman spectroscopy, identified up to 20 mole percent $\mathrm{H}_{2} \mathrm{~S}$ in inclusions from quartz veins cutting metamorphic rocks in the U.S.S.R. Our $\mathrm{H}_{2} \mathrm{~S}$ concentrations within quartz-hosted fluid inclusions are by far the highest yet reported for any of the mesothermal gold vein systems within the accreted terranes of western North America.

Although a few recent measurements on apparently unnecked and unleaked inclusions record relatively high homogenization temperatures $(>\mathbf{3 0 0}$ ${ }^{\circ} \mathrm{C}$ ), the data (excluding the anomalous $\mathrm{H}_{2} \mathrm{~S}$ ) from the Sumdum Chief fluid inclusions are generalfy consistent with those for other mesothermal gold-bearing quartz veins in southern Alaska (Goldfarb and others, in press). Fluid-inclusion and stable-isotope data for these systems are most compatible with a model in which deep-seated fluids are released during devolatilization of subducted crustal material, leach gold from surrounding rocks, and are channelized upward to favorable sites for vein formation. The most likely source for the anomalous $\mathrm{H}_{2} \mathrm{~S}$ is remobilization of sulfur into the metamorphic fluid phase from disseminated sulfides and(or) massive sulfide pods deeper in the sedimentary section. One such sulfide occurrence is exposed at Point Astley, approximately $10 \mathrm{~km}$ northwest of Sumdum Chief, and consists of massive pyrrhotite and sphalerite with abundant porphyroblasts of pyrite (Stowell, 1986). Ferry (1981) pointed out that conversion of disseminated pyrite to pyrrhotite by desulfidization during prograde metamorphism of pelitic schist occurs at all metamorphic grades. If this desulfidization is indeed significant in the vicinity of the Sumdum Chief deposit, then the resulting relatively locally derived $\mathrm{H}_{2}$ S-rich fluid is believed to have mixed with the more regionally derived $\mathrm{H}_{2} \mathrm{O}-\mathrm{CO}_{2}-\mathrm{N}_{2}-\mathrm{C}_{n} \mathrm{H}_{m}$ ore-forming metamorphic fluids sometime during fluid channelization.

\section{REFERENCES CITED}

Akhmanova, M.V., Naumov, V.B., and Sobolev, A.V., 1985, Use of laser Raman microprobe for studies of inclusions in minerals [abs.]: Fluid Inclusion Research, v. 18, p. 3-4.

Ferry, J.M., 1981, Petrology of graphitic sulfide-rich schists from south-central Maine: An example of desulfidization during prograde regional metamorphism: American Mineralogist, v. 66, p. 908-930.

Goldfarb, R.J., Leach, D.L., and Pickthorn, W.J., 1988, Accretionary tectonics, fluid migration, and gold genesis in the Pacific Border Ranges and Coast Mountains, southern Alaska, in Kisvarsanyi, G., and Grant, S.K., eds., North American conference on tectonic control of ore deposits and the vertical and horizontal extent of ore systems: Special Publication of the University of Missouri-Rolla, [in press].

Hofstra, A.H., Landis, G.P., and Rowe, W.A., 1987, Sediment-hosted disseminated gold mineralization at Jerritt Canyon Nevada. IV--Fluid Geochemistry [abs.]: Geological Society of America Abstracts with Programs, v. 19 , no. 7 , p. 704 .

Kimbal1, A.L., Still, J.C., and Rataj, J.L., 1984, Mineral deposits and occurrences in the Tracy Arm-Fords Terror wilderness study area and vicinity, Alaska, in U.S. Geological Survey and U.S. Bureau of Mines, eds., Mineral Resources of the Tracy ArmFords Terror Wilderness Study Area and Vicinity, Alaska: U.S. Geological Survey Bullet in 1525, p. 105-210.

Landis, G.P., Hofstra, A.H., Leach, D.L., and Rye, R.O., 1987, Quantitative analysis of fluid inclusion gases--Application to studies of ore deposits [abs.], in Sachs, J.S., ed., United States Geological Survey Research on Mineral Resources--1987 Program and Abstracts: U.S. Geological Survey 


\author{
Circular 995, p. 38-39. \\ Leroy, Jacques, 1979 , \\ l'étallonaje de la pres \\ inclusions fluides lors de leur \\ décrépitation: Bulletin de Minéralogie, \\ v. 102 , p. 584-593. \\ Norman, D.I., and Sawkins, F.J., 1987, Analysis \\ of volatiles in fluid inclusions by mass \\ spectrometry: Chemical Geology, v. 61, p. \\ $1-10$. \\ Redman, E., Roberts, W.S., Clough, A., and \\ Kurtak, J., 1986, Juneau gold belt area-- \\ Preliminary mine, prospect, sample location \\ maps and descriptions: U.S. Bureau of Mines \\ Open-File Report 85-86, 68 p. \\ Stowell, H.H., 1986, Sphalerite geobarometry in \\ metamorphic rocks and the tectonic history \\ of the Coast Ranges near Holkham Bay, \\ southeastern Alaska: Princeton, N.J., \\ Princeton University, Ph.D. thesis, 263 p.
}

Swanenberg, H.E.C., 1980, Fluid inclusions in high-grade metamorphic rocks from southwest Norway: Geologica Ultraiectina, University of Utrecht, Netherlands, no. 25, 147 p.

Touray, J.C., and Guilhaumou, Nicole, 1984, Characterization of $\mathrm{H}_{2} \mathrm{~S}$ bearing fluid inclusions: Bulletin de Mineralogie, v. 107, p. 181-188.

Wopenka, Brigitte, and Pasteris, J.D., 1986, Limitations to quantitative analysis of fluid inclusions in geologic samples by laser Raman microprobe spectroscopy: Applied Spectroscopy, v. 40, p. 144-151.

Reviewers: J.G. Viets and J.B. McHugh

Geologic Studies in Alaska by the U.S. Geological Survey during 1987: John P. Galloway and Thomas D. Hamilton, editors, U.S. Geological Survey Circular 1016. 


\title{
New K-Ar Ages for Plutons on Western Chichagof Island and on Yakobi Island
}

\author{
By Susan M. Karl, Bruce R. Johnson, and Marvin A. Lanphere
}

Twelve new $\mathrm{K}$-Ar ages for plutons occurring on western Chichagof Island and on Yakobi Island in southeastern Alaska (figs. 1, 2, and 3) confirm or revise ages for some plutons (Johnson and Karl, 1985) and help constrain timing and equivocal field relationships for emplacement of these plutons with respect to each other and to their country rocks. These new ages range from Jurassic to Tertiary (table 1) and show a general younging from east to west (Johnson and Karl, 1985). All of the plutons in the study area are intermediate and calc-alkaline in composition (table 2, figs. 4 and 5), and the Mesozoic plutons are inferred to represent the roots of an arc that developed during the progressive accretion of the Chugach terrane to the Alexander-Wrangellia superterrane (Hudson, 1979; 1983; Brew and Morrell, 1983; Johnson and Karl, 1985).

Most of the plutons on Chichagof Island west of the Peril Strait fault (fig. 1) were considered Cretaceous in age by Loney and others (1975) on the basis of lithologic similarity with dated plutons east of Peril Strait. Some plutons were inferred to be Tertiary in age because they intruded rocks of Cretaceous age. Radiometric ages were reported for two Jurassic plutons by Loney and others (1967, 1975). Because of the difficulty in distinguishing the Jurassic and Cretaceous bodies in the field, Johnson and Karl (1985) extended the age range of the undated plutons to the Jurassic. The ages reported here provide age control for some of the plutons. Samples 1 through 10 are from western Chichagof Island (fig. 1); samples 11 and 12 are from Yakobi Island (fig. 2).

Major element chemical data for representative samples from six different plutons (table 2) show a calc-alkaline trend (fig. 4) consistent with the calcalkaline composition of many other plutons occurring within the Mesozoic and Cenozoic plutonic belts of southern Alaska (Hudson, 1979, 1983). The Tertiary tonalites on Yakobi Island (fig. 2) occur within the Fairweather-Baranof belt of Brew and Morrell (1983) and the Sanak-Baranof belt of Hudson (1983) (fig. 3). The Jurassic and Cretaceous plutons fall within the Muir-Chichagof belt of Brew and Morrell (1983) and the Tonsina-Chichagof belt of Hudson (1983) (fig. 3).

Samples 1 and 2 were collected from the northernmost of three tonalite plutons on western Chichagof Island (fig. 1). This pluton is a locally sheared, fault-bounded intrusive body lying in the Peril Strait fault zone. It was originally considered to be a Tertiary trondjhemite by Loney and others (1975), but samples collected away from the main fault zone plot mostly as tonalites (Johnson and Karl, unpubl. data).

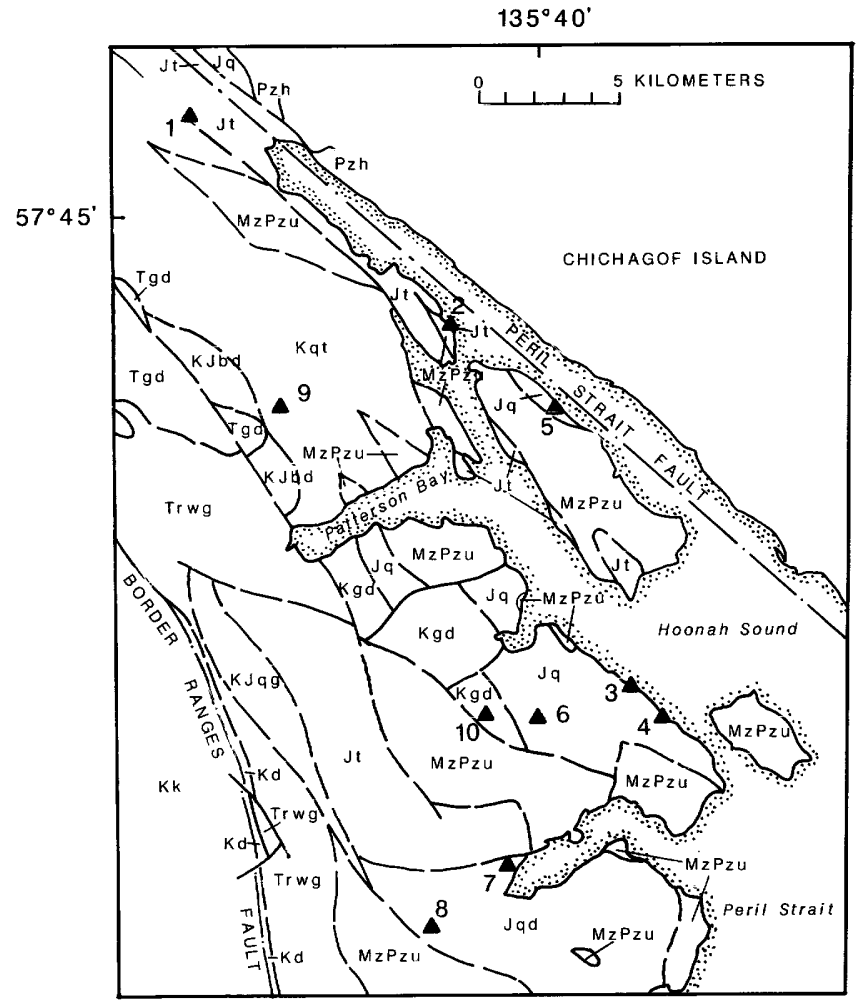

EXPLANATION

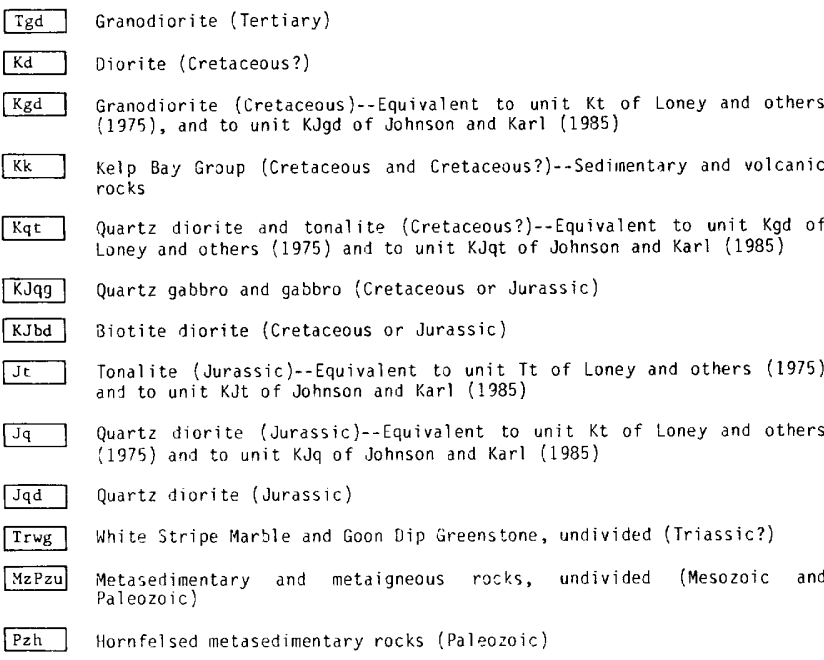

Figure 1. Part of southwestern Chichagof Island, showing geology modified from Johnson and Karl (1985) and locations of dated samples (numbers 1 through 10). 
Color indices of the three plutons range from 2 to 35 . Anhedral green poikilitic hornblende generally, but not always, exceeds partly altered subhedral light- to dark- brown biotite. Accessory minerals include epidote, magnetite, garnet, muscovite, apatite, and sphene. The pluton is equigranular and weakly foliated away from the fault zones. Hornblende from samples 1 and 2, yielded ages of $155 \pm 4.6 \mathrm{Ma}$ and $143 \pm 4.3 \mathrm{Ma}$ respectively; biotite from sample 1 yielded an age of $143 \pm 5.7 \mathrm{Ma}$ (table 1). Based on the hornblende ages we assign a Jurassic age to this pluton (time scale of Palmer, 1983). Because the pluton is entirely fault bounded, we do not know its relationship to adjacent rocks.

Samples $3,4,5$, and 6 are from a quartz diorite pluton that crops out on either side of the Jurassic tonalite in the vicinity of Hoonah Sound (fig. 1). This pluton was considered to be of Cretaceous age by Loney and others (1975). The quartz diorite is medium to dark grayish green and contains more hornblende than biotite with a color index ranging from 25 to 50 ; it contains as much as 5 percent accessory magnetite in places, as well as traces of apatite, epidote, and sphene. Angular to rounded fine-grained mafic inclusions are common, nebulitic to banded gneiss zones occur locally, and the predominant texture is hypidiomorphic equigranular. Pyroxene-cored hornblende crystals are common locally (Johnson and Karl, 1985). The hornblende in the dated samples is anhedral, green, and poikilitic. The biotite is anhedral, light to dark brown, and altered to chlorite, epidote, sericite and sphene. Hornblende ages of our four samples range from $143 \pm 7.8$ to $182 \pm 7.8 \mathrm{Ma}$, and biotite ages range from $148 \pm 4.4$ to $164 \pm 4.9 \mathrm{Ma}$ (table 1). These ages indicate that the pluton was emplaced during Jurassic rather than during Cretaceous time.

Samples 7 and 8 yielding ages of $170 \pm 5.1 \mathrm{Ma}$ and $164 \pm 4.9 \mathrm{Ma}$, respectively (table 1), were collected from a quartz diorite pluton (unit Jgd) which crops out west of Peril Strait (fig. 1). These ages confirm the Jurassic ages reported by Loney and others $(1967,1975)$ for this pluton. The quartz diorite contains hornblende, biotite, and accessory minerals including magnetite, apatite, epidote, sphene, and zircon, with a color index of 30 to 35 . The hornblende is anhedral, green, and poikilitic in places; it also is altered to biotite in places. The pluton is hypidiomorphic, equigranular to seriate, and weakly foliated.

Sample 9 is from quartz diorite and tonalite body on the north side of Patterson Bay (fig. 1) that was thought to be Cretaceous by Loney and others (1975). This pluton is variable in composition, with hornblende greater than biotite in quartz-diorite phases, biotite exceeding hornblende in the tonalites, and a color index ranging from 20 to 55 . The hornblende is subhedral, and pleochroic green and brown. Magnetite, epidote, sphene, chlorite, apatite, zircon and sericite are accessory minerals. Sample 9 yielded an age of $139 \pm 4.2 \mathrm{Ma}$ based on hornblende only. Because the 139-Ma age of this pluton is so close to the Jurassic-Cretaceous boundary, we assign a $\mathrm{K}(?)$ age to this body and recommend further sampling.

Sample 10, from a granodiorite body (fig. 1), was tonalite, with hornblende slightly greater than biotite, but the pluton is mostly medium-gray granodiorite with approximately equal hornblende and biotite. The hornblende that we dated was euhedral, twinned, pale brown to green pleochroic, and contained inclusions of zircon. The biotite from that sample is anhedral, interstitial, and altered to chlorite and sphene. Accessory minerals include magnetite, sphene, epidote, apatite, sericite and zircon. Sample 10 yielded a hornblende-only age of $128 \pm 3.8 \mathrm{Ma}$. This age refines the Cretaceous(?) age assignment of Loney and others (1975) for this pluton to Cretaceous.
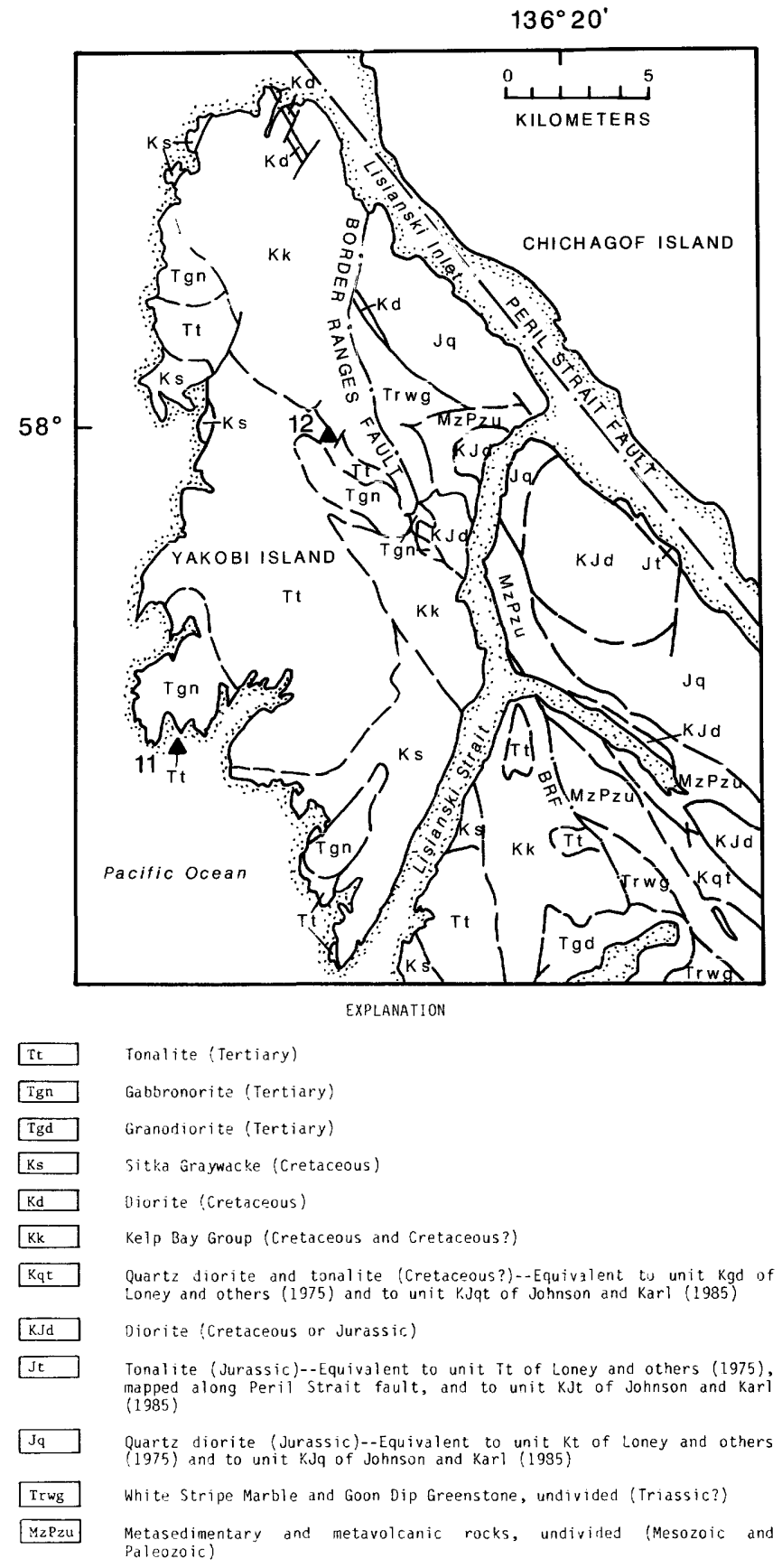

Figure 2. Northwestern Chichagof Island and Yakobi Island, showing geology modified from Johnson and Karl (1985) and locations of dated samples (numbers 11 and 12). 


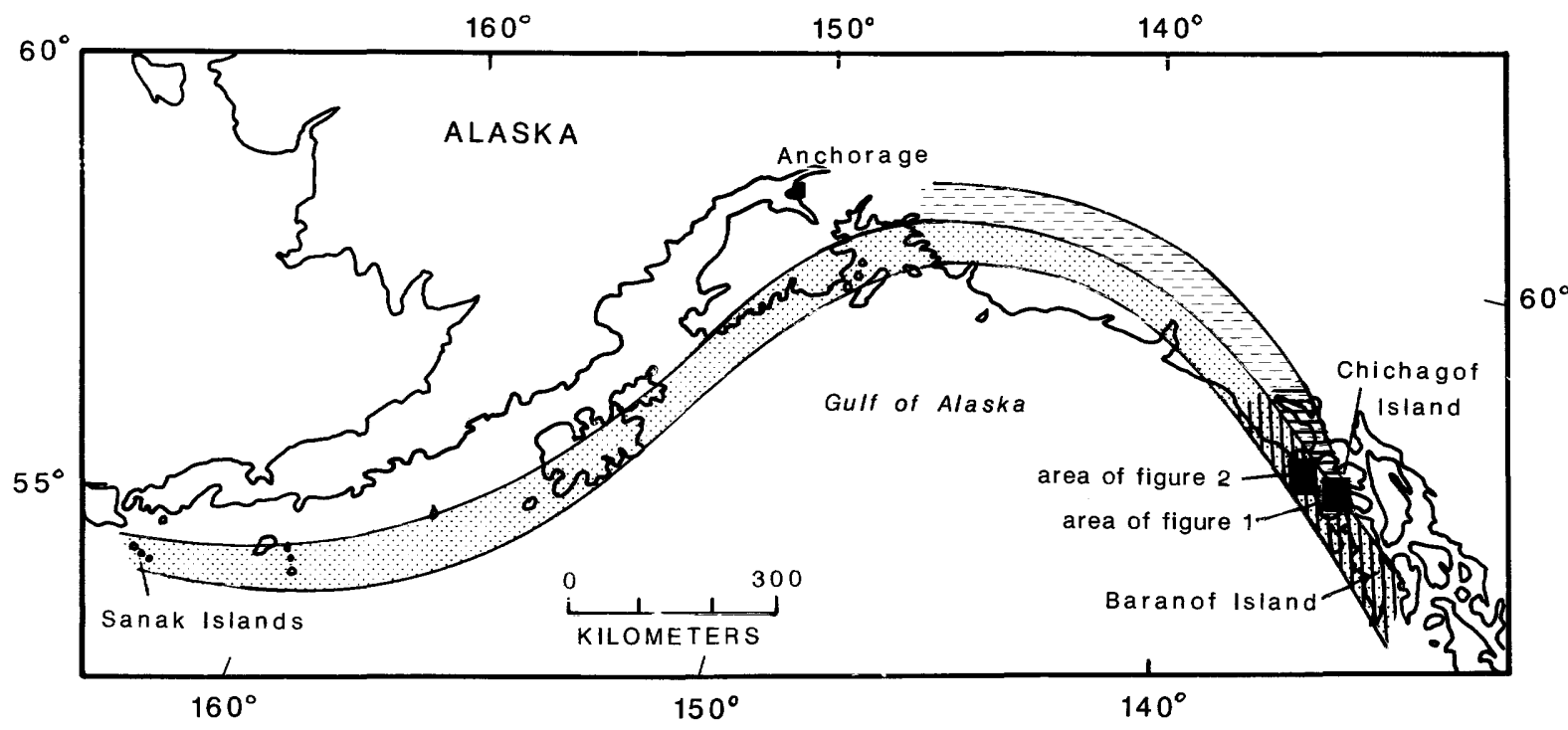

Sanak-Baranof plutonic belt of Hudson, 1983

Fairweather-Baranof plutonic belt of Brew and Morrell, 1983

Tonsina-Chichagof plutonic belt of Hudson, 1983

Muir-Chichagof plutonic belt of Brew and Morrell, 1983

Figure 3. Plutonic belts of Hudson (1983) and Brew and Morrell (1983) in relation to study area (figs. 1 and 2).

The Tertiary ages for samples 11 and 12 from tonalite on Yakobi Island (fig. 2) were reported in Himmelberg and others (1987), but the complete analytical data are reported here for the first time (table 1). The tonalite, which intrudes Cretaceous Sitka Graywacke, has a color index ranging from 5 to 40 , is equigranular to seriate hypidiomorphic, is not foliated but locally has cataclastic textures, and is associated with small gabbronorite bodies (Johnson and Karl, 1985; Himmelberg and others, 1987). Sample 11 contained subhedral, unaltered biotite and traces of subhedral fractured garnet, apatite, muscovite (possibly secondary), magnetite, and zircon. Sample 12 contained anhedral green poikilitic hornblende, subhedral light- to medium-brown biotite, and traces of magnetite, epidote, apatite, and sphene. Ages of $39.6 \pm 1.2 \mathrm{Ma}$ (hornblende) and $41.7 \pm 1.3 \mathrm{Ma}$ (biotite) were obtained on sample 12, and a biotite age of $34.1 \pm$ $1 \mathrm{Ma}$ was measured on sample 11 .

In summary, new radiometric ages (table 1) for 12 granitic rocks confirm some previous age assignments and refine or alter others (see explanations for figs. 1 and 2). These limited data suggest that the oldest Jurassic plutons west of the Peril Strait fault on Chichagof Island are adjacent to the Peril Strait fault. All of the Jurassic and Cretaceous plutons occur in the belt between the Peril Strait fault and the Border Ranges fault (figs 1 and 2) which corresponds to Tonsina-Chichagof belt of Hudson (1983) and the Muir-Chichagof belt of Brew and Morrell (1983). A Cretaceous(?) diorite (Loney and others, 1975; Johnson and Karl, 1985) marks the eastern wall of the Border Ranges fault (fig. 1), and is the farthest west of the Mesozoic plutons. The relationships between these Mesozoic plutons are unclear due to poor exposure and pervasive faulting, but they are all close in space, time, modal composition, and chemistry, suggesting that they are probably related to one another as the roots of a Mesozoic volcanic arc. A Tertiary granodiorite intrudes this Mesozoic belt of plutons (fig. 1) and other Tertiary plutons intrude Cretaceous rocks west of the Border Ranges fault (fig. 2). A wide time gap separates the Mesozoic and Cenozoic plutons, and the Cenozoic plutons are probably not the roots of a volcanic arc. However, the similar calc-alkaline composition of the Mesozoic and Cenozoic plutons, and high silica and alumina content suggesting incorporation of pelitic material, support the interpretation that the Tertiary plutons are related to tectonic accretion (Hudson, 1979; 1983; Brew and Morrell, 1983; Johnson and Karl, 1985).

\section{REFERENCES CITED}

Brew, D.A., and Morrel1, R.P., 1983, Intrusive rocks and plutonic belts of southeastern Alaska, U.S.A.: Geological Society of America Memoir 159, p. 171-193. 
Table 1. Potassium-argon ages and analytical data for plutonic rocks from western Chichagof and Yakobi Islands, Alaska [ Lambda $\mathrm{E}=0.581 \times 10^{-10} \mathrm{yr}^{-1}$, Lambda $\mathrm{B}=4.692 \times 10^{-10} \mathrm{yr}^{-1}, 40 \mathrm{~K} / \mathrm{K}=1.167 \times 10^{-4} \mathrm{~mol} / \mathrm{mol}$. Errors are estimates of the standard deviation of analytical precision]

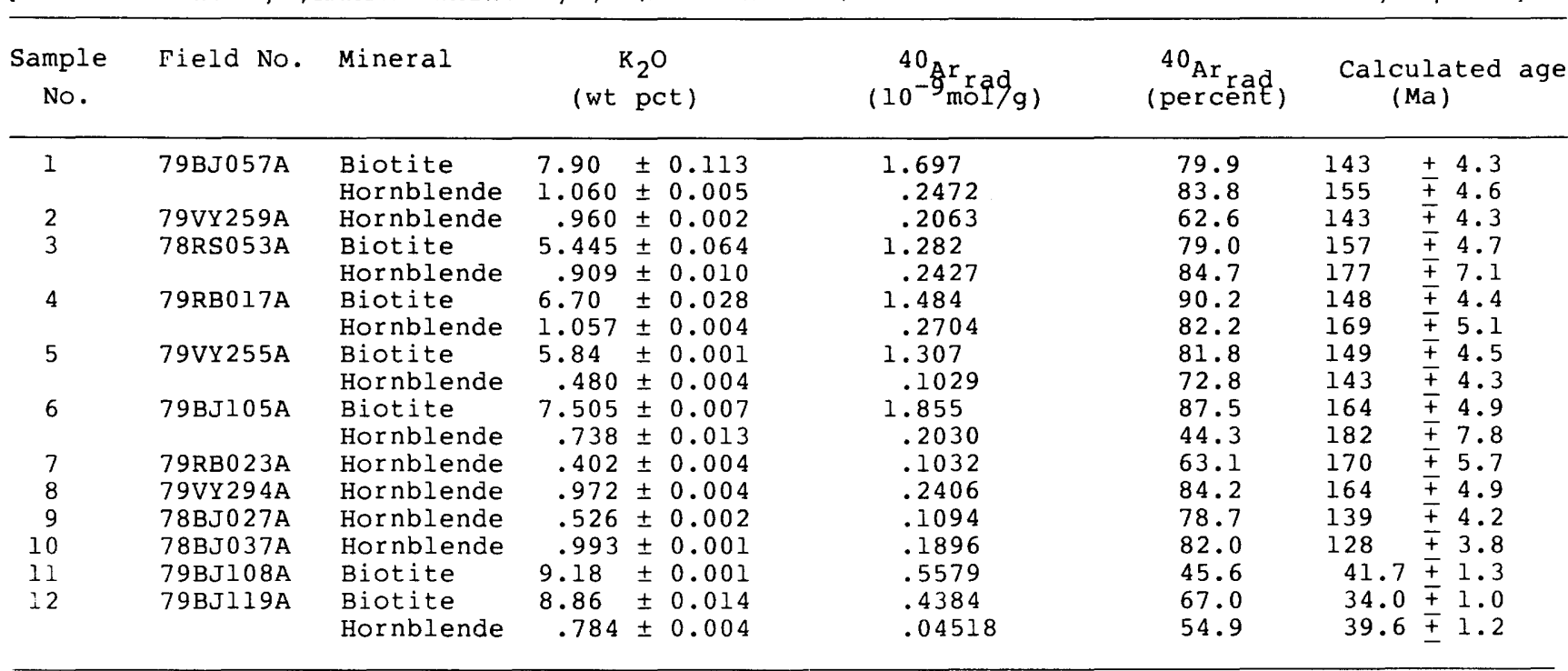

Table 2. Major element chemistry (in percent oxide) for representative samples from several plutons on Chichagof and Yakobi Islands

[T, recalculated to total iron]

\begin{tabular}{lcccccc}
\hline $\begin{array}{l}\text { Field no. } \\
\text { sample no. }\end{array}$ & $\begin{array}{c}78 \mathrm{RS} 053 \mathrm{~A} \\
3\end{array}$ & $\begin{array}{c}79 \mathrm{BJ} 105 \mathrm{~A} \\
6\end{array}$ & $\begin{array}{c}79 \mathrm{VY} 294 \mathrm{~A} \\
8\end{array}$ & $\begin{array}{c}78 \mathrm{BJ} 027 \mathrm{~A} \\
9\end{array}$ & $\begin{array}{c}78 \mathrm{BJ} 037 \mathrm{~A} \\
10\end{array}$ & $\begin{array}{c}79 \mathrm{VY} 294 \mathrm{~A} \\
12\end{array}$ \\
\hline $\mathrm{SiO}_{2}$ & 57.940 & 58.187 & 60.378 & 58.651 & 65.237 & 62.970 \\
$\mathrm{Al}_{2} \mathrm{O}_{3}$ & 19.381 & 18.620 & 18.398 & 22.310 & 17.093 & 15.442 \\
$\mathrm{Fe}_{2} \mathrm{O}_{3}(\mathrm{~T})$ & 6.616 & 6.993 & 6.150 & 3.866 & 4.511 & 7.300 \\
$\mathrm{MgO}$ & 3.267 & 3.390 & 2.805 & 1.635 & 2.175 & 2.286 \\
$\mathrm{CaO}$ & 6.717 & 7.235 & 6.739 & 8.036 & 5.037 & 5.645 \\
$\mathrm{Na}_{2} \mathrm{O}$ & 3.491 & 3.360 & 3.161 & 4.189 & 3.611 & 4.091 \\
$\mathrm{~K}_{2} \mathrm{O}$ & 1.674 & 1.326 & 1.657 & .727 & 1.699 & .963 \\
$\mathrm{TiO}_{2}$ & .670 & .638 & .508 & .404 & .465 & 1.073 \\
$\mathrm{P}_{2} \mathrm{O}_{5}$ & .132 & .111 & .091 & .131 & .091 & .110 \\
$\mathrm{MnO}_{\mathrm{Total}}$ & 98.550 & 98.820 & 98.380 & 99.060 & 98.870 & 99.730 \\
$\mathrm{FeO}$ & 5.954 & 6.293 & 5.535 & 3.480 & 4.060 & 6.570 \\
\hline
\end{tabular}

Himmelberg, G.R., Loney, R.A., and Nabelek, P.I., 1987, Petrogenesis of gabbronorite at Yakobi and northwest Chichagof Islands, Alaska: Geological Society of America Bulletin, v. 98, p. 265-270.

Hudson, Travis, 1979, Mesozoic plutonic belts of southern Alaska: Geology, v. 7, p. 230-234.

---- 1983, Calc-alkaline plutonism along the Pacific rim of southern Alaska: Geological
Society of America Memoir 159, p. 159-169. IUGS Subcommission on the Systematics of Igneous Rocks, 1973, Classification and nomenclature of plutonic rocks, recommendations: Neues Jahrbuch fur Mineralogie Monatshefte, v. 4, p. 149-164.

Johnson, B.R., and Karl, S.M., 1985, Geologic map of western Chichagof and Yakobi Islands, southeastern Alaska: U.S. Geological Survey 

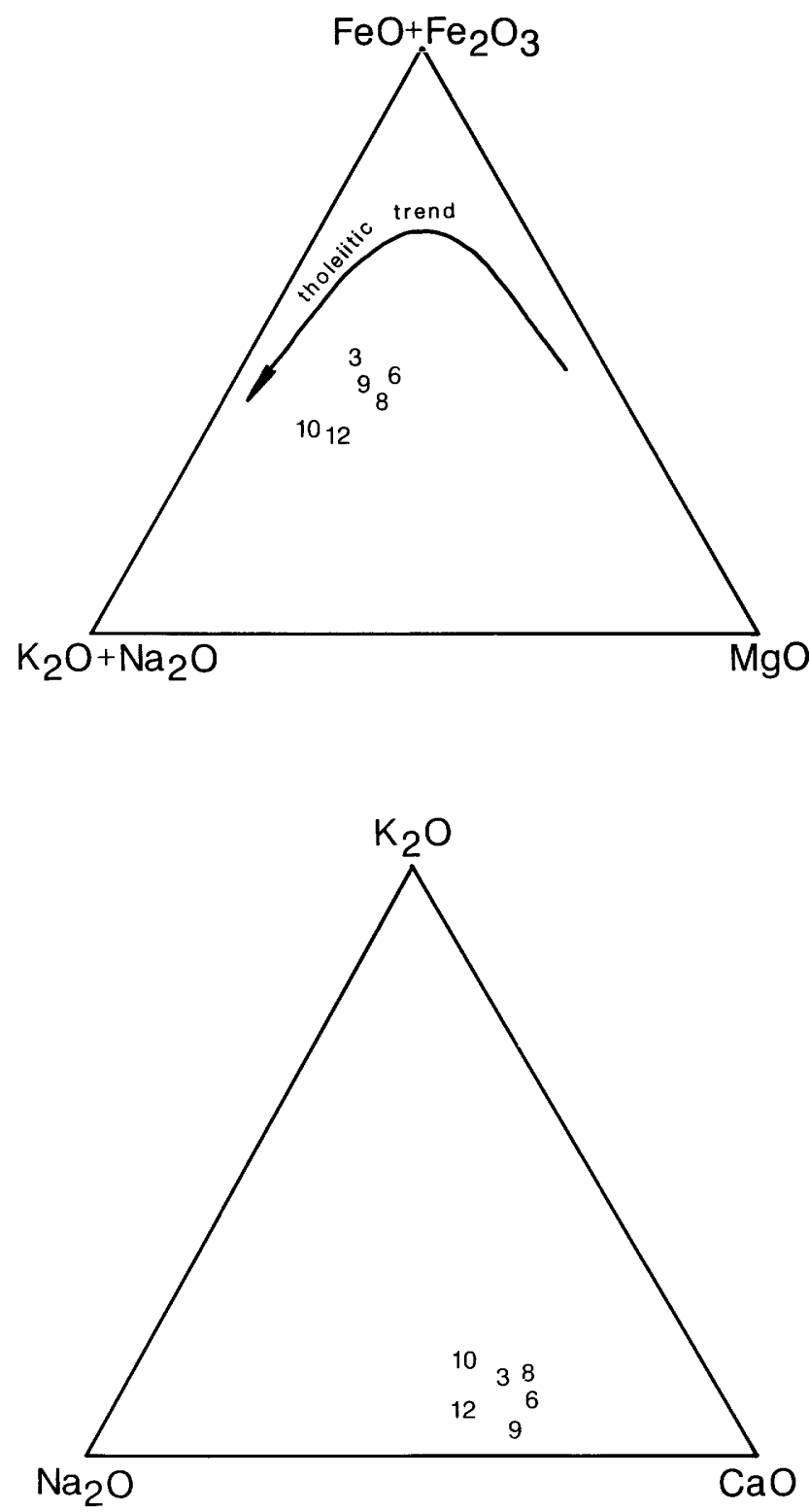

Figure 4. Alkali-iron-magnesium (AFM) and sodium-potassiumcalcium (AKC) diagrams for representative samples from plutons on Chichagof and Yakobi islands. Sample numbers identified on tables 1 and 2.

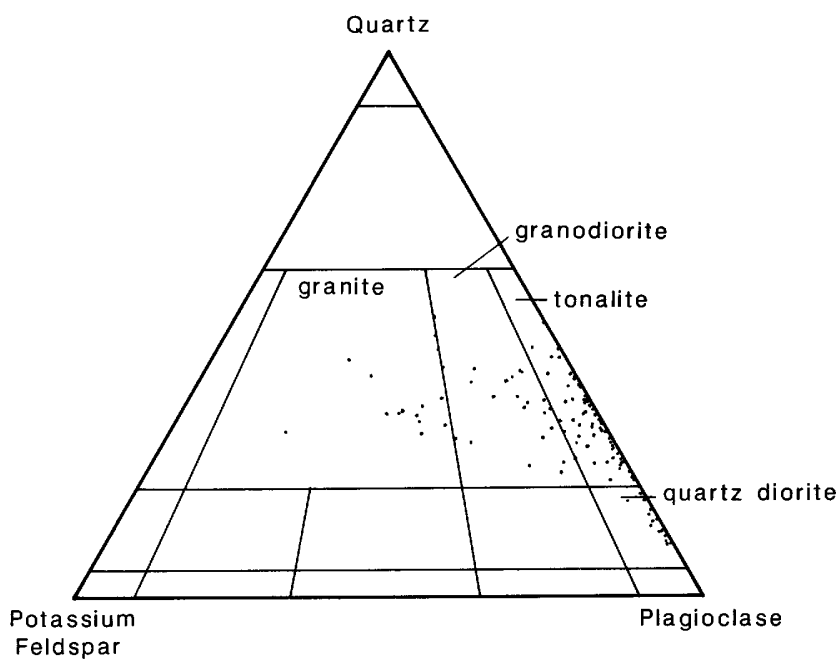

Figure 5. Summary of compositional modes for all samples from plutons on western Chichagof and Yakobi Islands collected during 1978-1980; diagram from IUGS (1973).

Miscellaneous Geologic Investigations Map I1506,15 p., scale $1: 125,000$.

Loney, R.A., Brew, D.A., and Lanphere, M.A., 1967, Post-Paleozoic radiometric ages and their relevance to fault movements, northern southeastern Alaska: Geological Society of America Bulletin, v. 78, p. 511-526.

Loney, R.A., Brew, D.A., Muffler, L.J.P., and Pomeroy, J.S., 1975, Reconnaissance geology of Chichagof, Baranof and Kruzof Islands, southeastern Alaska: U.S. Geological Survey Professional Paper 792, 105 p., 4 pl., scale $1: 250,000$.

Palmer, A.R., 1983, The Decade of North American Geology 1983 Geologic Time scale: Geology, v. 11 , p. 503-504.

Reviewers: D.A. Brew and R.A. Loney

Geologic Studies in Alaska by the U.S. Geological Survey during 1987: John P. Galloway and Thomas D. Hamilton, editors, U.S. Geological Survey Circular 1016. 


\title{
Geochemistry and Petrography of Lamprophyre Dike Rocks in the Coast Mountains, Southeastern Alaska
}

\author{
By John S. Lull and George Plafker
}

A major lamprophyre dike swarm intrudes early Tertiary and older rocks of the Coast Range batholith and surrounding metamorphic rocks in southeastern Alaska. The dikes strike northeast-southwest, are steeply dipping to vertical, and occur throughout the Coast Mountains of southeastern Alaska and British Columbia (Smith, 1973, D.A. Brew, U.S. Geological Survey, oral commun., 1987). In some areas the dikes comprise as much as $\mathbf{2 0}$ percent of the total outerop, indicating substantial northwest-southeast extension during emplacement. Smith (1973) mapped and described the structure, petrography, and majorelement chemistry of lamprophyre dikes in the Prince Rupert-Ketchikan area. This report presents new isotopic, petrographic, and geochemical data for five lamprophyre samples collected along Tracy and Endicott Arms, Behm Canal, and Boca De Quadra in the Ketchikan area of southeastern Alaska (fig. 1).

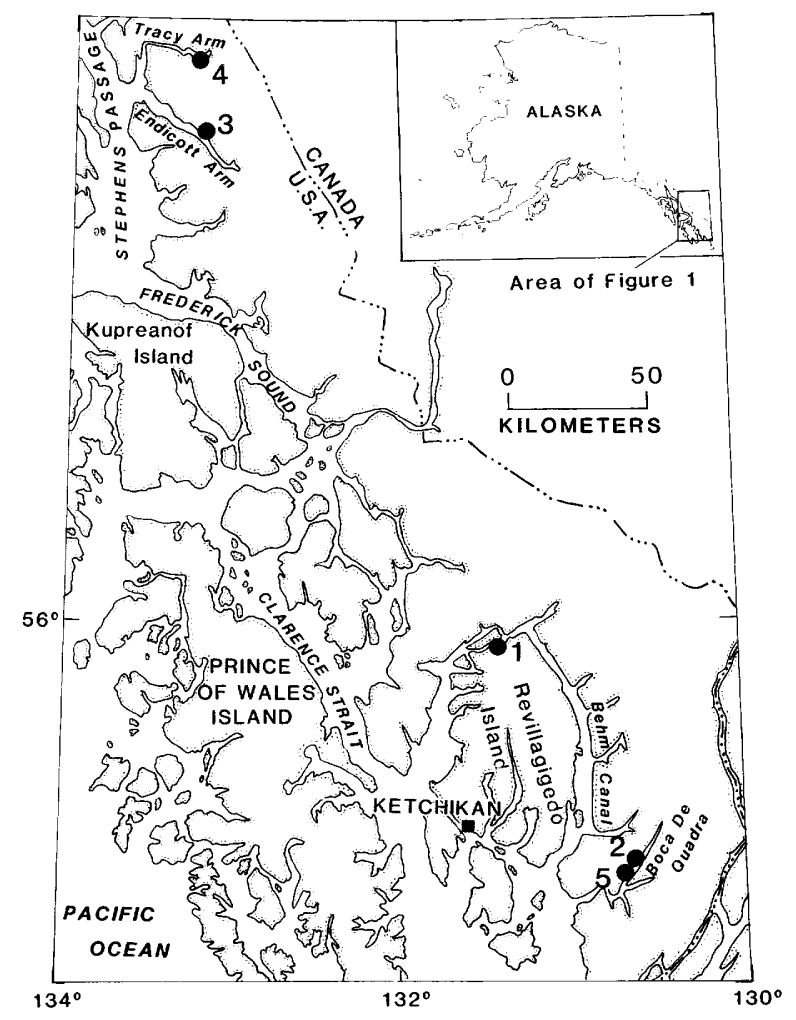

Figure 1. Ketchikan area, southeastern Alaska, showing lamprophyre sample localities. Locality numbers on map correspond to field sample numbers as follows: $1,82 \mathrm{APr} 11 ; 2$, $82 \mathrm{APr} 13 ; 3,82 \mathrm{APr} 7 ; 4,82 \mathrm{APr} 5 ; 5,82 \mathrm{APr} 12$.
Petrographic data for the lamprophyre dike rocks are summarized in table 1 . The rocks are composed essentially of altered plagioclase, brown amphibole (usually in two generations), less abundant clinopyroxene, and rare altered olivine. Secondary hydrous minerals are common. Although the dike rocks are mineralogically and texturally variable, they are very similar chemically. Therefore, the mineralogic and textural variability is ascribed mainly to secondary (deuteric?) processes and differential cooling rates.

Major-oxide and minor-element analyses of five lamprophyre samples are given in table 2. $\mathrm{SiO}_{2}$ averages 50 percent and ranges from 45 to 53 percent (all figures are given in volatile-free weight percent), $\mathrm{K}_{2} \mathrm{O}$ from 0.8 to 2.4 percent, $\mathrm{Na}_{2} \mathrm{O}$ from 2.6 to 4.7 percent, and $\mathrm{TiO}_{2}$ from 1.5 to 1.9 percent. None of the samples are quartz normative; all are olivine normative, and two of the five samples are nepheline normative. The lamprophyres show no iron enrichment on an AFM diagram (fig. 2). Based on normative color

Table 1. Petrographic data for southeast Alaska lamprophyres

\begin{tabular}{|c|c|c|}
\hline $\begin{array}{l}\text { Sample } \\
\text { ido. }\end{array}$ & Texture & $\begin{array}{c}\text { Mineralogy (minerals listed in order } \\
\text { of abundance) }\end{array}$ \\
\hline I & $\begin{array}{l}\text { Panidiomorphic to } \\
\text { intergranular; } \\
\text { fine-grained; } \\
\text { equigranular. }\end{array}$ & $\begin{array}{l}\text { Plagioclase, brown anphibole, clinopyroxene, } \\
\text { magnetite, sericite (after plagloclase), } \\
\text { carbonate, chlorite, apatite. }\end{array}$ \\
\hline \multirow[t]{2}{*}{2} & $\begin{array}{l}\text { Porphyritic (pheno- } \\
\text { crysts } 3-5 \% \text { vol.) }\end{array}$ & Phenocrysts: Brown amphibole, clinopyroxene. \\
\hline & $\begin{array}{l}\text { fine-grained inter- } \\
\text { granular ground- } \\
\text { mass. }\end{array}$ & $\begin{aligned} \text { Groundnass: Piagioclase (altered), brown } \\
\text { amphibole, clinopyroxene, chlorite } \\
\text { inagnetite, quartz }(<1 \%) \text {, apatite. }\end{aligned}$ \\
\hline \multirow[t]{2}{*}{3} & $\begin{array}{l}\text { Strongly porphyritic; } \\
\text { very fine grained } \\
\text { groundmass. }\end{array}$ & $\begin{array}{l}\text { Phenocrysts: Clinopyroxene, olivine (replaced } \\
\text { by sericite, chlorite, talc, } \\
\text { carbonate), piagioclase (altered). }\end{array}$ \\
\hline & & $\begin{array}{l}\text { Groundulass: Plagioclase, clinopyroxene, } \\
\text { inagnetite, pyrite. }\end{array}$ \\
\hline 4 & $\begin{array}{l}\text { Intergranular (<3\% } \\
\text { auphibole micro- } \\
\text { phenocrysts); } \\
\text { fine-grained. }\end{array}$ & $\begin{array}{l}\text { Plagioclase (altered), brown amphibole, magnetite, } \\
\text { chlorite, apatite, quartz }\langle<1 \% \text {. }\end{array}$ \\
\hline \multirow[t]{2}{*}{5} & $\begin{array}{l}\text { Porphyritic; fine- } \\
\text { grained groundmass. }\end{array}$ & $\begin{aligned} \text { Phenocrysts: } & \text { Brown amphibole, mafic (pyroxene?) } \\
& \text { pseudomorphs composed of chlorite, } \\
& \text { epidote, amphibole. }\end{aligned}$ \\
\hline & & $\begin{array}{l}\text { Groundmass: Plagioclase (aitered), brown amphibole, } \\
\text { epidote, chlorite, magnetite, pyrite, } \\
\text { apatite. }\end{array}$ \\
\hline
\end{tabular}


Table 2. Major-oxide (normalized 100 percent volatile-free) and minor-element composition of lamprophyre dike rocks from southeastern Alaska

[See figure 1 for field sample numbers. Major elements analyzed by XRF; Lakewood, Colo.; analysts A.]. Bartel, K. Stewart, and J. Taggart. $\mathrm{H}_{2} \mathrm{O}^{+}, \mathrm{H}_{2} \mathrm{O}^{-}, \mathrm{CO}_{2}$, by rock analysis; Menlo Park, Calif.; analyst: L. Espos. Co, $\mathrm{Cr}, \mathrm{Cu}$, Ni, Sc by optical spectroscopy; Lakewood, Colo.; analyst: M. Malcolm. Ba, Nb, Sr, Zr, Y by XRF; Reston, Va.; analysts: J, Leister, G. Wandless, and R. Johnson]

\begin{tabular}{|c|c|c|c|c|c|c|c|}
\hline Sample No. & 1 & 2 & 3 & 4 & 5 & Average & $\begin{array}{c}\text { Smith }(1973) \\
\text { average }\end{array}$ \\
\hline \multicolumn{8}{|c|}{ Major-oxide composition (weight percent) } \\
\hline $\mathrm{SiO}_{2}$ & 45.21 & 49.32 & 50.31 & 52.74 & 53.13 & 50.14 & 50.71 \\
\hline $\mathrm{Al}_{2} \mathrm{O}_{3}$ & 15.07 & 15.40 & 15.86 & 15.59 & 16.78 & 15.74 & 16.13 \\
\hline $\mathrm{Fe}_{2} \mathrm{O}_{3}$ & 6.26 & 3.51 & 5.03 & 3.20 & 3.01 & 4.20 & 3.31 \\
\hline $\mathrm{FeO}$ & 5.54 & 5.29 & 5.59 & 5.09 & 5.45 & 5.39 & 6.39 \\
\hline MgO & 10.08 & 8.89 & 6.94 & 5.64 & 5.82 & 7.47 & 7.19 \\
\hline $\mathrm{CaO}$ & 12.21 & 9.32 & 7.70 & 7.43 & 7.43 & 8.82 & 8.32 \\
\hline $\mathrm{Na}_{2} \mathrm{O}$ & 2.64 & 3.57 & 3.89 & 4.73 & 3.88 & 3.74 & 3.89 \\
\hline$k_{2} 0$ & .78 & 2.03 & 2.06 & 2.39 & 2.28 & 1.91 & 1.67 \\
\hline $\mathrm{TiO}_{2}$ & 1.58 & 1.57 & 1.70 & 1.89 & 1.37 & 1.62 & 1.43 \\
\hline $\mathrm{P}_{2} \mathrm{O}_{5}$ & .45 & .96 & .73 & 1.19 & .72 & .81 & .78 \\
\hline Mno & .18 & .15 & .20 & .12 & .15 & .16 & .17 \\
\hline $\mathrm{H}_{2} \mathrm{O}^{+}$ & 2.48 & 2.10 & 2.21 & 1.62 & 1.93 & 2.07 & 2.20 (Tota) \\
\hline $\mathrm{H}_{2} \mathrm{O}^{-}$ & .76 & .21 & .85 & .06 & .08 & .39 & $\left.\mathrm{H}_{2} \mathrm{O}\right)$ \\
\hline $\mathrm{CO}_{2}$ & 2.55 & .21 & .75 & .81 & .49 & .96 & .78 \\
\hline
\end{tabular}

Minor-element composition (ppm)

\begin{tabular}{|c|c|c|c|c|c|}
\hline $\mathrm{Sc}$ & 31 & 20 & 24 & 16 & 18 \\
\hline $\mathrm{Cr}$ & 427 & 356 & 218 & 163 & 177 \\
\hline$C_{0}$ & 67 & 46 & 43 & 34 & 33 \\
\hline $\mathrm{Ni}$ & 182 & 155 & 75 & 46 & 51 \\
\hline $\mathrm{Cu}$ & 71 & 42 & 40 & 14 & 36 \\
\hline $2 n$ & 91 & 86.8 & 120 & 168 & 110 \\
\hline $\mathrm{Rb}$ & 12 & 35.4 & 53.8 & 45.7 & 47.8 \\
\hline $5 r$ & 1080 & 1630 & 621 & 963 & 732 \\
\hline$y$ & 23 & 15 & 30 & 21 & 19 \\
\hline $\mathrm{Zr}$ & 194 & 143 & 186 & 316 & 111 \\
\hline $\mathrm{ilb}$ & 21 & 20 & 23 & 15 & - \\
\hline $\mathrm{Sb}$ & .16 & .042 & .119 & .168 & .122 \\
\hline Cs & - & .254 & .961 & .20 & .338 \\
\hline $\mathrm{Ba}$ & 1390 & 1510 & 1030 & 922 & 589 \\
\hline La & 23.1 & 50.8 & 35.3 & 46.0 & 45.0 \\
\hline Ce & 41.2 & 87.4 & 68.6 & 96.5 & 82.0 \\
\hline idd & 21.4 & 38.9 & 35.5 & 48.8 & 31.0 \\
\hline $\mathrm{Sm}$ & 4.23 & 6.57 & 6.69 & 8.37 & 6.18 \\
\hline Eu & 1.53 & 2.05 & 2.21 & 2.51 & 1.85 \\
\hline $\mathrm{Gd}$ & 4.00 & 5.12 & 5.95 & 6.86 & 4.86 \\
\hline $\mathrm{Tb}$ & .620 & .674 & .960 & .976 & .771 \\
\hline Tin & .315 & .265 & .490 & .285 & .345 \\
\hline$Y_{b}$ & 1.84 & 1.60 & 2.79 & 1.66 & 2.15 \\
\hline Lu & .283 & .227 & .403 & .230 & .308 \\
\hline $\mathrm{Ta}$ & .740 & 1.13 & 1.04 & .902 & .895 \\
\hline Th & 2.59 & 3.76 & 2.30 & 7.75 & 4.08 \\
\hline $\mathrm{Hf}$ & 2.46 & 3.04 & 3.58 & 7.09 & 4.00 \\
\hline U & .593 & 1.11 & .77 & 1.48 & 1.10 \\
\hline
\end{tabular}

index and normative plagioclase composition (Irvine and Baragar, 1971), three of the five samples classify as alkali basalt, one as trachybasalt, and one as picrite-basalt. Major-element abundances reported by Smith (1973) for lamprophyres in the Prince Rupert-
Ketchikan area are nearly identical to those of the dike rocks of this study (table 2).

Minor-element data for the lamprophyres are very similar to those of continental flood basalt and contrast strongly with those of mid-ocean ridge basalt 
(MORB). Plots of rare-earth elements (REE), normalized to REE abundances in chondrites, of five lamprophyre samples are shown in figure $3 \mathrm{~A}$. The curves are relatively smooth, and light rare-earth elements (LREE) are strongly enriched relative to heavy rare earth elements (HREE). La ranges from $\mathbf{7 5}$ to 165 times chondrite and Lu ranges from 7 to 12 times chondrite. Sample number 1 shows a slight positive $\mathrm{Eu}$ anomaly, indicating plagioclase accumulation. The spidergram plot (fig. 3B) of incompatible minor elements shows a moderately steep curve (elevated to the left) with $\mathrm{Ba}$ at 85 to 220 times chondrites and $\mathrm{Yb}$ at 7 to 12 times chondrites, a welldefined trough at $\mathrm{Nb}-\mathrm{Ta}$ (except for sample 1), positive peaks at $\mathrm{La}, \mathrm{Sr}$, and $\mathrm{P}$, and a negative peak at $\mathrm{Th}$. On the Ti-Zr-Y discrimination diagram (Pearce and Cann, 1973), four of the samples plot in the continental basalt field and one $\mathrm{Zr}$-enriched sample plots just outside this field (fig. 4A). On a Hf-Th-Ta diagram (Wood, 1980), the lamprophyre samples are not restricted to one field. Two samples plot as calcalkalic arc-rocks, one as "enriched" MORB, and two plot outside all fields (fig. 4B). In contrast to these data, MORB is characterized by flat to LREE-depleted $\mathrm{REE}$ trends, lower $\mathrm{Zr} / \mathrm{Y}$ (reflected in the $\mathrm{Ti}-\mathrm{Zr}-\mathrm{Y}$ diagram), and a spidergram with relatively smooth, flat curves and no $\mathrm{Nb}-\mathrm{Ta}$ trough.

Based on the chemical data, the lamprophyres can be broadly classified as alkali basalts. However, $\mathrm{Hf}, \mathrm{Ta}, \mathrm{Nb}$, and $\mathrm{TiO}_{2}$ abundances are low for alkali basalt. Lack of iron enrichment and the Th-Hf-Ta ratios (fig. 4B) suggest some calc-alkalic character. These rocks therefore appear to be transitional from calc-alkalic basalt to alkali basalt. The Th-Hf-Ta discrimination diagram (fig. 4B) also suggests this possibility.

The youngest rocks intruded by the lamprophyre dikes are plutons of the Quartz Hill-Portland Peninsula area that are radiometrically dated at 19-32 $\mathrm{Ma}$ (Arth and others, in press). The dikes are cut by feeders of Pleistocene volcanic rocks (Smith, 1973). Potassiumargon dates on amphibole from four of the samples

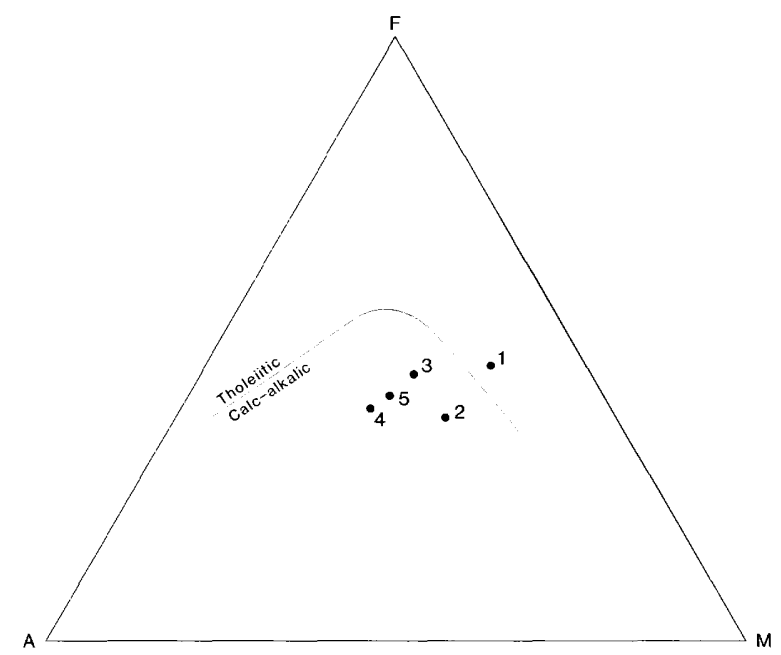

Figure 2. AFM plot for lamprophyres from southeastern Alaska (see figure 1 for field sample numbers). F, FeO*; A, $\mathrm{Na}_{2} \mathrm{O}+\mathrm{K}_{2} \mathrm{O} ; \mathrm{M}, \mathrm{MgO}$. described in this report range from 29 to $47 \mathrm{Ma}$ (table 3 ). The wide spread in age is probably due to extensive alteration and excess argon, resulting in age determinations older than the actual age. Based on chemical similarity, Smith (1973) suggested that the lamprophyres may correlate with Miocene flood basalts of British Columbia.

Smith (1973) made a valid argument for a mantle source for the lamprophyres, and the data in this paper support his conclusion. The lamprophyres clearly could not have been derived from continental crust in southeastern Alaska, and their compositional similarity over a large area suggests derivation from the mantle. The dike rocks are chemically indistinguishable from continental flood basalt, and may well have fed flood basalts which have since been eroded away in southeastern Alaska.

Although the evidence is inconclusive, the possibility of crustal contamination of the lamprophyres is suggested by their mildly alkalic character, the presence of hydrous minerals and altered primary minerals (volatiles may have been derived through heating of crustal rocks), scatter on the Hf-Th-Ta diagram (Wood and others, 1979), and presence of the $\mathrm{Nb}-\mathrm{Ta}$ trough on the spidergram
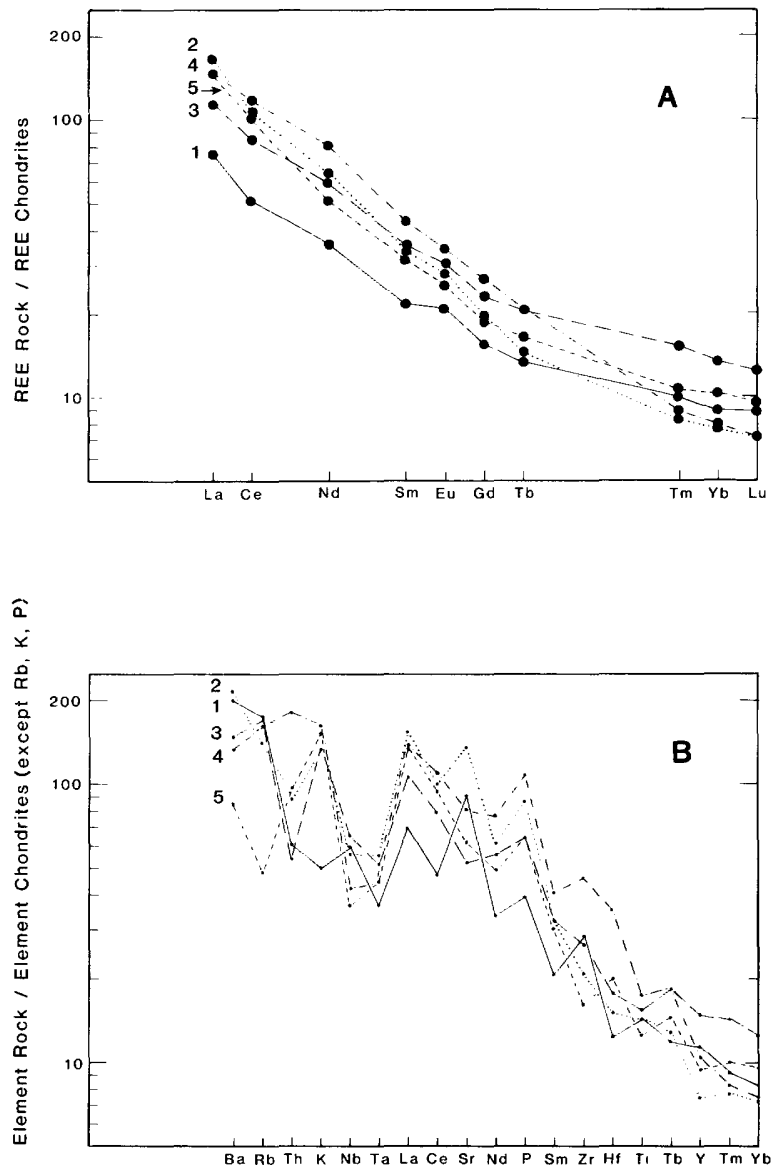

Figure 3. Element abundance diagrams for lamprophyres from southeastern Alaska (see figure 1 for field sample numbers). A, Chondrite-normalized REE plot (chondrite values $X 1.31$, based on Anders and Ebihara, 1982). B, Spidergram plot (Thompson and others, 1983; chondrite normalized following Sun, 1980). 

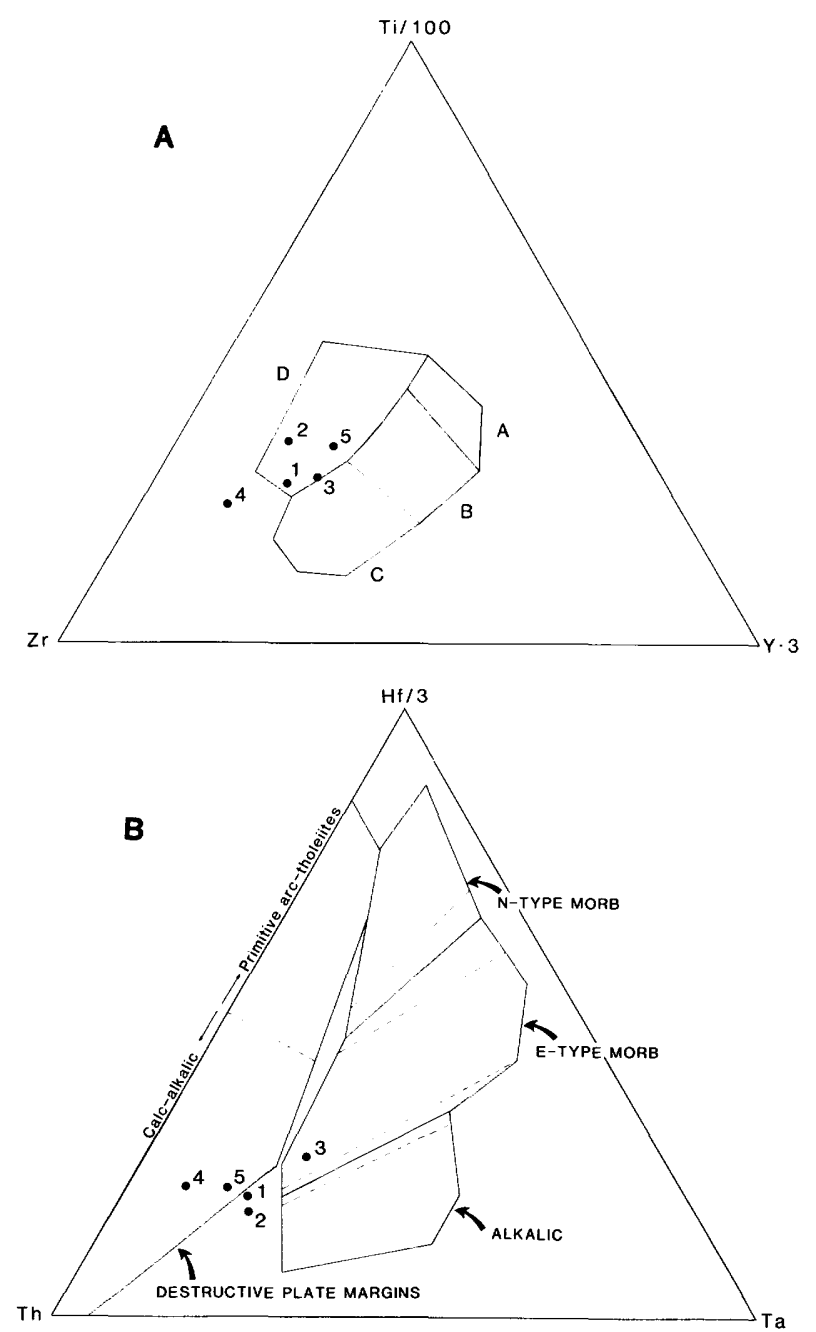

Figure 4. Discrimination diagrams for lamprophyre samples from southeastern Alaska (see figure 1 for field sample numbers). A, Ti-Zr-Y discrimination diagram (Pearce and Cann, 1973). Fields: A, (B), low-K tholeiites; B, ocean-floor basalts; C, (B), calc-alkalic basalts; D, ocean island or continental flood basalts. B, Th-Hf-Ta discrimination diagram (Wood, 1980).
(Thompson and others, 1983). The Nb-Ta trough is also characteristic of subduction-related magmas, but the dikes were not emplaced during subduction. Sample 1 has the most mafic composition and does not exhibit a well-defined $\mathrm{Nb}-\mathrm{Ta}$ trough. If crustal contamination did take place, this sample may represent a relatively uncontaminated member of the lamprophyre suite.

A model proposed by Thompson and others (1983) to explain the chemical characteristics and crustal contamination of continental flood basalt may be applicable to the southeastern Alaska lamprophyres. This model is based on studies of the rise of mafic magmas into rigid crust (Weertman, 1971), heat released by crystallizing dikes (Patchett, 1980, and Turcotte, 1981), and on evidence for an extensive silllike body at about $20 \mathrm{~km}$ depth beneath the Rio Grande Rift (Rinehart and others, 1979). The model calls for the formation of sill complexes of regional extent by ponding of upwelling mafic magma along density discontinuities (such as the base of the crust). The sill complexes feed dike swarms which are eventually vented to the surface. Crystallization and cooling of the sills and dikes release enough heat to locally fuse crustal rocks, allowing contamination of subsequent dikes. The regional extent, composition, and geochemical homogeneity of the lamprophyre dikes in the Coast Mountains of southeastern Alaska and British Columbia appear to be compatible with the proposed model.

\section{REFERENCES CITED}

Anders, Edward, and Ebihara, Mitsuru, 1982 , Solar-system abundances of the elements: Geochimica et Cosmochimica Acta, v. 46, p. 2363-2380.

Arth, J.G., Barker, Fred, and Stern, T.W., 1988, Coast Batholith and Taku Plutons near Ketchikan, Alaska; petrography, geochemistry, and isotopic character: American Journal of Science, Wones volume. [in press]

Irvine, T.N., and Baragar, W.R.A., 1971, A guide to the chemical classification of the common volcanic rocks: Canadian Journal of Earth Sciences, v. 8, p. 523-548.

Table 3. Potassium-argon isotopic data on amphiboles from lamprophyre dike rocks of southeastern Alaska

[Analyst: Krueger Enterprises, Inc., Geochron Laboratories Division, Cambridge, Mass.. See figure 1 for field sample numbers]

\begin{tabular}{cccccc} 
Sample & Percent K & $40_{\mathrm{K}}(\mathrm{ppm})$ & $40_{\mathrm{Ar}}{ }^{(\mathrm{ppm})}$ & $40_{\mathrm{Ar}}{ }^{4} 40_{\mathrm{Ar}}$ tot & $\begin{array}{c}\text { Apparent } \\
\text { age }(\text { Ma) }\end{array}$ \\
\hline 1 & 0.540 & 0.658 & 0.001140 & 0.264 & $29.4 \pm 1.9$ \\
2 & .730 & .891 & .001575 & .393 & $30.0 \pm 1.7$ \\
4 & .582 & .710 & .001996 & .382 & $47.4 \pm 2.6$ \\
5 & .612 & .747 & .001569 & .199 & $35.6 \pm 2.1$
\end{tabular}


Patchett, P.J., 1980, Thermal effects of basalt on continental crust and crustal contamination of magmas: Nature, v. 283, p. 559-561.

Pearce, J.A., and Cann, J.R., 1973, Tectonic setting of basic volcanic rocks determined using trace element analyses: Earth and Planetary Science Letters, v. 19, p. 290300 .

Rinehart, E.J., Sanford, A.R., and Ward, R.M., 1979, Geographic extent and shape of an extensive magma body at midcrustal depths in the Rio Grande Rift near Socorro, New Mexico, in Riecker, R.E., ed., Rio Grande Rift: Tectonics and Magmatism: Washington, American Geophysical Union, p. 237-251.

Smith, J.G., 1973, A Tertiary lamprophyre dike province in southeastern Alaska: Canadian Journal of Earth Science, v. 10, p. 408-420.

Sun, S.S., 1980, Lead isotopic study of young volcanic rocks from mid-ocean ridges, ocean islands and island arcs: Philosophical Transactions Royal Society of London, $v$. A297, p. 409-445.

Thompson, R.N., Morrison, M.A., Dickin, A.P., and Hendry, G.L., 1983, Continental Flood basalts...Arachnids rule $O K$ ?, in Hawkesworth, C.J. and Norry, M.J., eds., Continental basalts and mantle xenoliths, Cheshire, U.K., Shiva, p. 159-185.
Turcotte, D.L., 1981, Some thermal problems associated with magma migration: Journal of Volcanology and Geothermal Research, v. 10, p. 267-278.

Weertman, J., 1971, Theory of water-filled crevasses in glaciers applied to vertical magma transport beneath oceanic ridges: Journal of Geophysical Research, v. 76, p. 1171-1183.

Wood, D.A., 1980, The application of a Th-Hf-Ta diagram to problems of tectonomagmatic classification and to establishing the nature of crustal contamination of basaltic lavas of the British Tertiary Volcanic Province: Earth and Planetary Science Letters, v. 50, p. 11-30.

Wood, D.A., Juron, J.L., and Trenil, Michel, 1979, A re-appraisal of the use of trace elements to classify and discriminate between magma series erupted in different tectonic settings: Earth and Planetary Science Letters, v. 45, p. 326-336.

Reviewers: Fred Barker and Betsy Moll-stalcup

Geologic Studies in Alaska by the U.S. Geological Survey during 1987: John P. Galloway and Thomas D. Hamilton, editors, U.S. Geological Survey Circular 1016. 


\title{
Alteration Zoning and Origin of the Alaska-Juneau Gold Deposit
}

\author{
By Rainer J. Newberry and David A. Brew
}

The Alaska-Juneau (AJ) deposit, located $4 \mathrm{~km}$ east of Juneau (fig. 1), is the largest lode producer of gold in Alaska. This deposit is part of the 150-km-long "Juneau gold belt" of southeastern Alaska, which is responsible for the majority of Alaska's lode gold production. The AJ deposit was described by Wernecke (1932), Twenhofel (1952), and Wayland (1960). Ongoing USGS studies of this deposit (Goldfarb and others, 1986; Newberry and Brew, 1987) have shown it to be an epigenetic deposit and indicate that boiling of $\mathrm{CO}_{2}$-rich fluids probably was an important mechanism of sulfide and gold deposition. Our current studies are focused on understanding the timing and conditions of formation of the deposit as a prerequisite to making a realistic assessment of the undiscovered mineral resources of the area.

Previous interpretations of the source of the AJ deposit ore fluid have included (1) magmatic fluids from the nearby "Coast Range batholith" (Twenhofel, 1952), (2) deeply circulating meteoric waters associated with uplift of the Coast Mountains (Nesbitt and others, 1986), and (3) metamorphic fluids from deeper levels (Goldfarb and others, 1986). After preliminary field mapping (Newberry and Brew, 1987), we undertook petrographic studies, microprobe analysis of selected minerals, and limited age dating to test the various genetic models.

The AJ deposit consists of several quartzankerite-sulfide sheeted vein swarms, each swarm 50$300 \mathrm{~m}$ wide and up to $1 \mathrm{~km}$ long, which occur along a northwest-southeast-trending linear band subparallel to regional structures. These vein swarms together make up the "main ore zone" (figs. 1, 2), which is approximately $4 \mathrm{~km}$ long. The individual veins, the swarms, and the "main ore zone" all cut across the regional foliation and map-unit contacts at a low

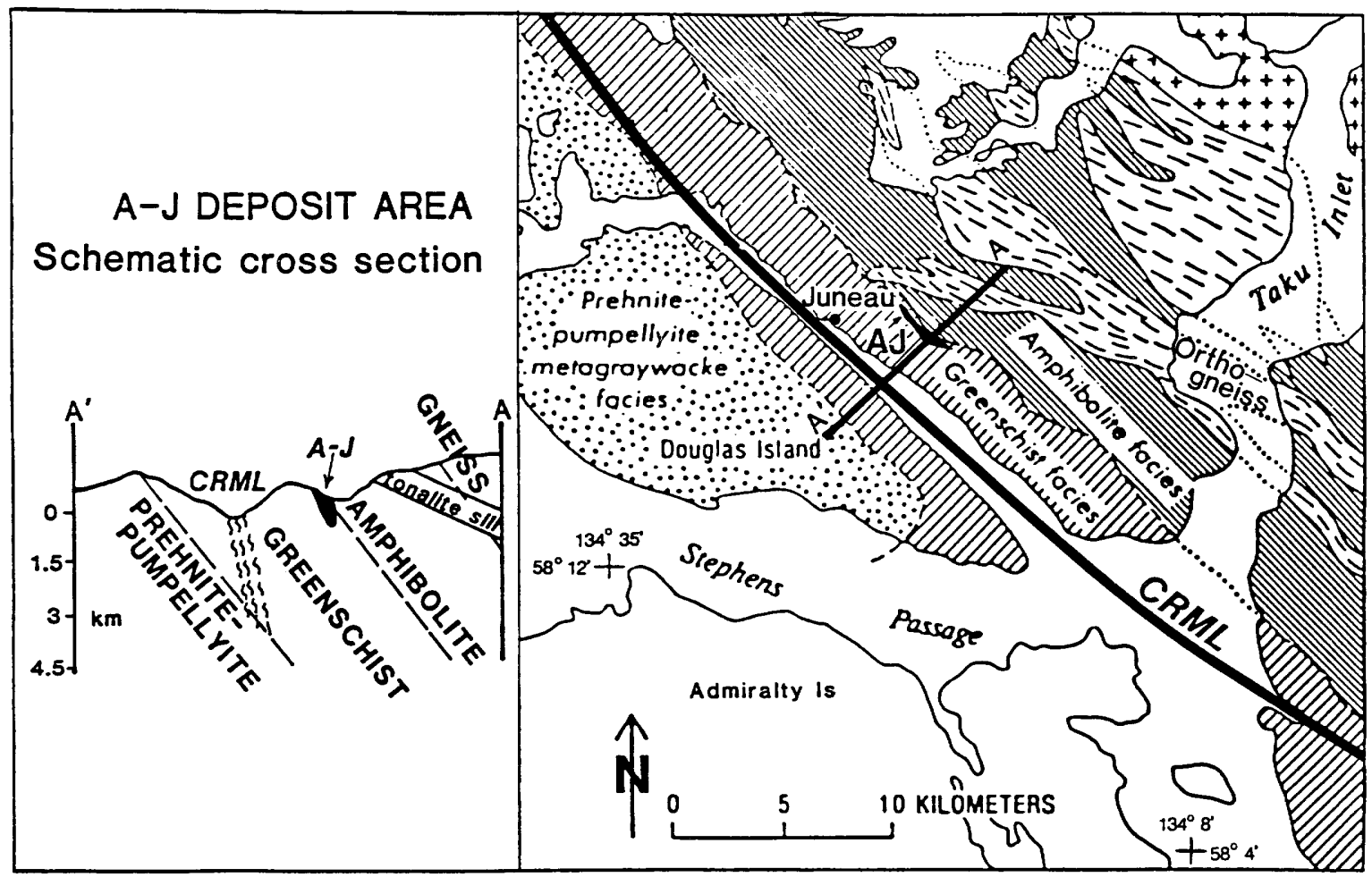

Figure 1. Generalized metamorphic facies map and cross section of Juneau area, showing location of AJ main ore zone (black); modified from Himmelberg and others (1984). Dashed line pattern identifies orthogneiss plutons with dashed lines approximately parallel to foliation. Crosses denote little-foliated post-tectonic granitic pluton. Location of Coast Range Megalineament (CRML) from Brew and Ford (1978). Isograd dips shown on cross section are schematic, taken from topography-isograd relationships shown on Ford and Brew (1977) and Brew and Ford (1977). 
angle, and their emplacement is interpreted to postdate the peak of deformation and metamorphism (Newberry and Brew, 1987).

Field mapping and petrographic studies show that several types of alteration are present in a broad zone that extends up to $1 \mathrm{~km}$ away from the main ore zone. Wallrock opaque minerals define a series of concentric zones surrounding the ore zone (fig. 2), as shown by the relative abundance of (primarymetamorphic?) ilmenite relative to secondary (hydrothermal) pyrrhotite-pyrite. Sulfides are essentially absent in rocks far from the ore zone and increase in abundance as ore veins are approached. Pseudomorphic textures indicate that sulfide minerals replaced ilmenite; released $\mathrm{Ti}$ is present as secondary sphene (far from the ore zone) or rutile (closer to the ore zone). Secondary carbonates show a similar zoning, with calcite the characteristic carbonate mineral far from the ore zone and ferroan dolomite and ferroan magnesite characteristically present in wallrocks of the ore zones. Other zonation includes (1) the presence of arsenopyrite and tourmaline in wallrock in a $100-\mathrm{m}$ zone surrounding the main ore zone, (2) an approximately coincident 10-30 ppb gold halo, and (3) secondary (post-metamorphic) biotite and chlorite in the same zone. The mineralogical changes seen in wallrocks indicate that the hydrothermal fluids added silica, sulfur, carbon dioxide, boron, arsenic, gold, and other elements to rocks surrounding the ore zone.

These secondary minerals in the wallrock of the AJ deposit also show distinct zoning in major-element compositions. Secondary biotite (fig. $2 \mathrm{~B}$ ), chlorite, and tourmaline show decreasing $\mathrm{Fe} / \mathrm{Fe}+\mathrm{Mg}$ as the center of the vein swarms is approached, and ferroan dolomites show progressive decrease in $\mathrm{Fe} / \mathrm{Mn}$ ratios. These changes are probably caused by progressive increases in aqueous sulfur activity toward the center of hydrothermal fluid flux, hence progressive loss of silicate iron at the expense of sulfide iron toward the center of the ore zone. These progressive mineral compositional changes also indicate that major hydrothermal circulation took place in the AJ area.

The fact that mineral zoning at AJ cuts across lithologic boundaries and metamorphic foliation (fig. 2A) indicates that it is a secondary effect that postdates major metamorphism. The large size of the metasomatic aureole also indicates that metasomatic fluid flow was not restricted to the quartz-carbonate veins, and that a large quantity of water passed through the volume of rock enclosing the veins.

The conditions of ore deposition are indicated by compositions of specific sulfide assemblages as shown by microprobe analysis. Pressures estimated from the iron content in inclusion-free sphalerite (Scott, 1973) from sphalerite-pyrite-pyrrhotite assemblages indicate a fluid pressure in the range of 300 to $400 \mathrm{MPa}$ (3-4 kbar) (fig. 3B), slightly below estimated peak metamorphic pressure at the deposit of about 400 to $500 \mathrm{MPa}(4-5 \mathrm{kbar})$ inferred from aluminosilicate geobarometry (G.R. Himmelberg, U.S. Geological Survey, oral commun., 1987; Brew and others, 1987, in press). Of the samples analyzed, higher-iron (low-pressure) sphalerites contain abundant pyrite and pyrrhotite inclusions and lower-iron (highpressure) sphalerites do not contain sulfide inclusions.
Because the high-iron sphalerite samples could have picked up iron from the abundant iron sulfides during cooling (under low-pressure conditions), these samples are probably not indicative of pressure during deposit formation. The inclusion-free samples yield pressures slightly lower than the peak metamorphic pressure; this is compatible with vein formation associated with the metamorphic event, as the vein-forming fluids experienced a pressure intermediate between lithostatic and hydrostatic (approximately 1/3 lithostatic pressure). As discussed below, however, we consider it more likely that these pressure values indicate that vein formation took place after the beginning of postmetamorphic uplift.

Temperatures estimated for the AJ samples from arsenopyrite compositions in arsenopyrite-pyritepyrrhotite assemblages using the method of Kretschmar and Scott (1976) are lower $\left(300^{\circ} \mathrm{C}\right.$ to 380 $\left.{ }^{\circ} \mathrm{C}\right)$ for the veins than for the surrounding wallrocks $\left(380{ }^{\circ} \mathrm{C}\right.$ to $470{ }^{\circ} \mathrm{C}$ ) (fig. $3 \mathrm{~A}$ ). The temperature of the deposit estimated by garnet-biotite geothermometry for the wallrocks is $420{ }^{\circ} \mathrm{C}$. The temperature data indicate that little cooling of the wallrocks took place between the peak of metamorphism at the deposit and formation of the mineralized veins, and the lower temperatures of the veins suggest that the fluids were cooler than the surrounding wallrocks. This difference in temperature may indicate that the AJ hydrothermal fluids were derived from rocks experiencing lower temperatures than the metamorphic rocks enclosing the AJ; it may also indicate cooling of ore fluids caused by enthalpy loss accompanying boiling.

The timing of vein formation relative to peak metamorphism is provisionally estimated by comparing age dates for the two events, keeping in mind that different minerals possess intrinsically different age retention temperatures and that the possible resetting of metamorphic wallrock $\mathrm{K}-\mathrm{Ar}$ ages by the later $50-\mathrm{Ma}$ major intrusive event (Brew and Ford, 1986) has not been fully evaluated (fig. 4). Considering the uncertainties for the various published age estimates and the different age retention temperatures (Lund and others, 1986), it appears that the AJ veins formed within a few million years of the peak metamorphic event, as recorded by the published $\mathrm{K}-\mathrm{Ar}$ ages for metamorphic wallrocks (Forbes and Engels, 1970). Brew and others (1987, in press), however, argue that peak metamorphic conditions were obtained before the emplacement of the $10-\mathrm{km}$-distant $67-\mathrm{Ma}$ syntectonic pluton (fig. 4) dated by Gehrels and others (1984), and therefore the younger $\mathrm{K}$-Ar ages reported by Forbes and Engels (1970) for the metamorphic rocks have been reset by younger thermal events. Brew and others (in press) interpret the age of metamorphism to be somewhere between 90 and $70 \mathrm{Ma}$, but close to 70 Ma. Thus approximately $15 \mathrm{~m} . \mathrm{y}$. may have elapsed between the peak of metamorphism of the deposit and the emplacement of the veins. This interval provides time for several kilometers of uplift and possibly meteoric water incursion. During the 70 to $50 \mathrm{Ma}$ interval, the region underwent rapid uplift (Brew and others, in press). Although no immediately local igneous suite of age similar to the AJ deposit is known, published age determinations (Gehrels and others, 1984) establish that rocks about $18 \mathrm{~km}$ to the northnortheast of the deposit were intruded at $60 \mathrm{Ma}$ and 50 

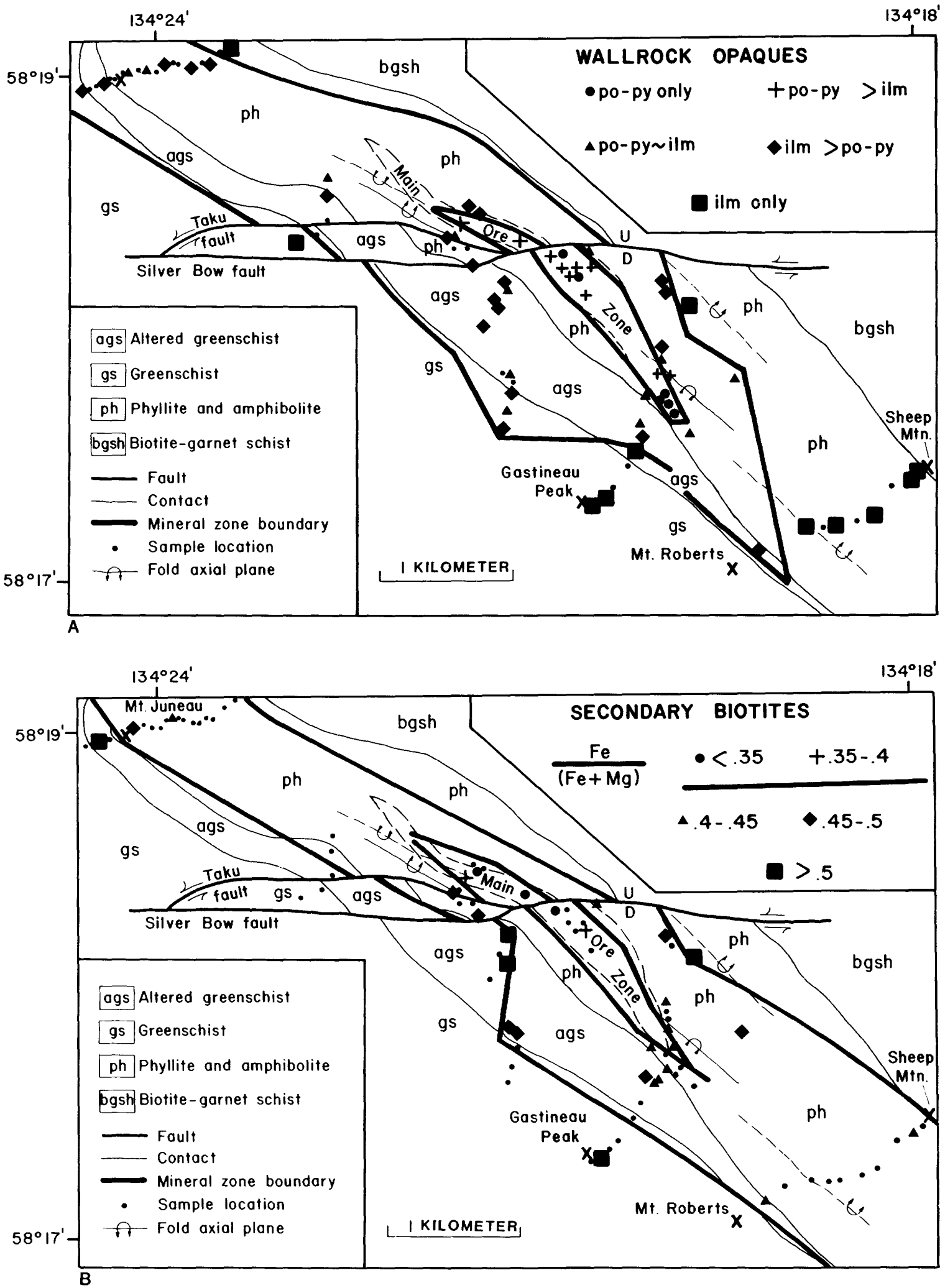

Figure 2. Generalized bedrock geologic map of AJ deposit area (modified from Newberry and Brew, 1987). A, Distribution of relative ilmenite (ilm) and pyrite (py)-pyrrhotite (po) abundances in representative polished thin sections of vein wallrocks. Zone of highest sulfide abundance in wallrocks is approximately coincident with main AJ ore zone (dashed lines). B, Distribution of atomic Fe/Fe+Mg ratios in representative secondary biotites of vein wallrocks (based on microprobe analyses performed at Washington State University). Zone of low-iron secondary' biotites approximately corresponds to main AJ ore zone. Arrows on faults show relative horizontal movement; relative vertical movement shown by $U$ (up) and $D$ (down).

176 Geologic Studies in Alaska by the U.S. Geological Survey during 1987 
$\mathrm{Ma}$, and they may extend closer to the deposit in the subsurface.

Based on extensive regional mapping, Ford and Brew (1973, 1977) and Brew and Ford (1977) have established the existence of regional northwestsoutheast-trending, steeply east-dipping "inverted" metamorphic isograds in the vicinity of the Juneau gold belt (fig. 1): rocks formed at lower temperature and pressure lie structurally below rocks formed at higher temperature and pressure, and both pressure and temperature increase toward the structurally overlying syntectonic great tonalite sill (Brew and others, in press). The rocks that record this metamorphism in the AJ area include several kilometers thickness of calcite-bearing metavolcanic rocks and calcareous phyllite, the carbonate of which presumably was formed by to hydrothermal seawater alteration of the volcanic rocks.

Our preferred scenario for AJ deposit formation, utilizing both regional geologic data and our analytical data, involves upward movement of waters released from the underlying rocks during prograde metamorphism, with the heat source being the structurally overlying syntectonic sill. Dewatering of the low-grade metamorphic rocks could have produced metamorphic waters with high $\mathrm{CO}_{2}$ and moderate $\mathrm{NaCl}$ contents. As the fluids rose, the confining pressure dropped, allowing for $\mathrm{CO}_{2}$ exsolution ("boiling") (Bowers and Helgeson, 1983). The boiling event, indicated by fluid-inclusion investigations (Goldfarb and others, 1986), caused gold deposition through loss of $\mathrm{H}_{2} \mathrm{~S}$ into the vapor phase and consequent destruction of gold bisulfide complexes.

In summary, we suggest that the formation of the AJ deposit is intimately tied to the metamorphic history of the surrounding rocks. The similarity in pressure-temperature conditions of formation, and the
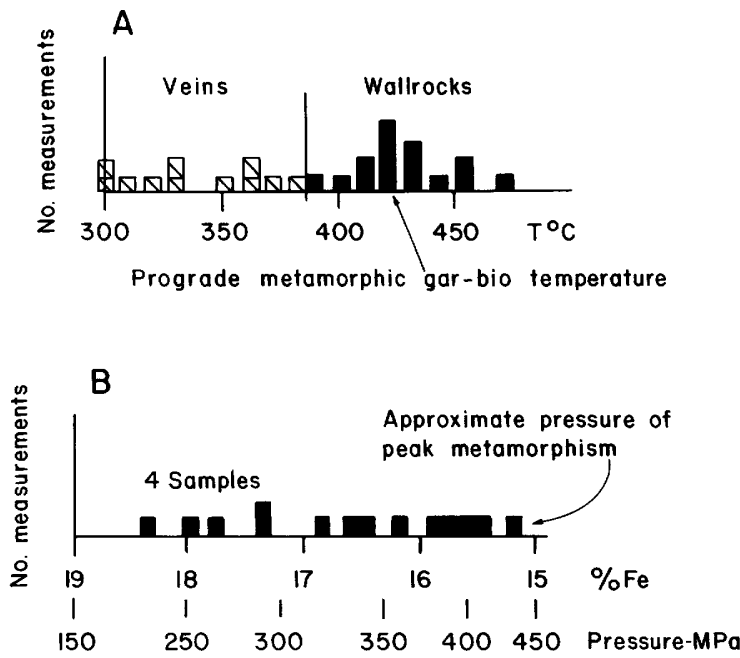

Figure 3. Histograms showing estimated temperatures (A) and pressures (B) of ore deposition in AJ deposit, based on sulfide mineral analyses. Prograde metamorphism biotite-garnet temperature of approximately $420^{\circ} \mathrm{C}$ based on compositions of coexisting garnet and metamorphic biotite in two samples from A) mine. Microprobe analyses performed at Washington State University. short interval between peak metamorphism at the deposit and vein emplacement indicate a close relation. Both meteoric and plutonic fluid sources are considered unlikely, although given the high $\mathrm{CO}_{2}$ flux associated with mineralization, neither can be excluded. The deposit probably was formed from an enormous flux of metamorphically derived hydrothermal fluids, which resulted in the formation of the mineralogical aureole around the deposit. The focusing of water into a relatively small volume probably required some major regional structural focus--such as the Coast Range Megalineament (Brew and Ford, 1978)--as well as a local structural focus.

The implication for mineral resource appraisal in the Juneau area is that only certain rare combinations of metamorphic and structural conditions could have resulted in forming major ore deposits. The need for both a water source (dewatering of rocks at lower metamorphic grade) and a major structural focus implies that the gold belt deposits should be restricted to areas where the Coast Range Megalineament (CRML) intersects the lower greenschist-facies portion of the inverted metamorphic isograd belt. This conclusion is supported by the fact that the gold belt ends some $115 \mathrm{~km}$ to the south, where the CRML cuts into kyanite-grade metamorphic rocks (Brew and others, 1984; Douglass and Brew, 1985).

Zonation around the AJ "main ore body" suggests that it may serve as a guide to ore elsewhere in the Juneau gold belt: arsenopyrite and tourmaline are rare and fine-grained, but ankeritic carbonate and disseminated pyrite-pyrrhotite are common and easily identified.

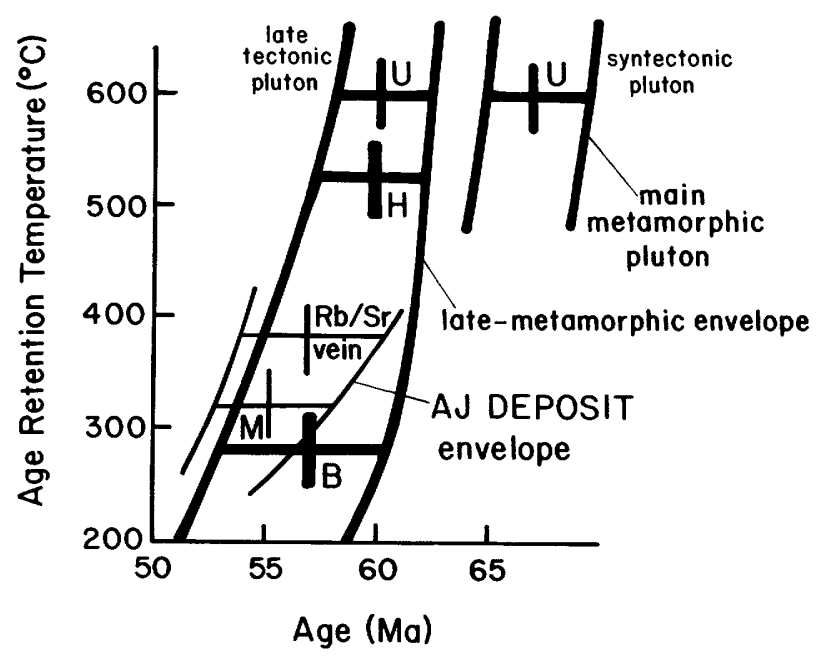

Figure 4. Relative ages of metamorphism (thinner lines) and ore deposition (thicker lines) for rocks of AJ area, plotted as a function of age retention temperature, after Lund and others (1986). Syntectonic Carlson Creek pluton (14 km east-southeast of deposit) and late-tectonic Flat Point pluton (15 km eastnortheast of deposit) $\mathrm{Pb} / \mathrm{U}$ ages (U) from Gehrels and others (1984). Metamorphic hornblende $(H)$ and biotite $(B) \mathrm{K}-\mathrm{Ar}$ ages are from Blackerby Ridge $7 \mathrm{~km}$ north of deposit from Forbes and Engels (1970). Mineralization ages are from vein minerals ( $\mathrm{Rb} / \mathrm{Sr}$ isochron) (R.W. Kistler, U.S. Geological Survey, written commun., 1987) and muscovite K-Ar (M) (D.L. Leach, U.S. Geological Survey, written commun., 1987). 


\section{REFERENCES CITED}

Bowers, T.S., and Helgeson, H.C., 1983, Calculation of the thermodynamic and geochemical consequences of nonideal mixing in the system $\mathrm{H}_{2} \mathrm{O}-\mathrm{CO}_{2}-\mathrm{NaCl}$ on phase relations in geologic systems: Equation of state for $\mathrm{H}_{2} \mathrm{O}-\mathrm{CO}_{2}-\mathrm{NaCl}$ fluids at high pressures and temperatures: Geochimica et Cosmochimica Acta, v. 47, p. 1247-1276.

Brew, D.A., and Ford, A.B., 1977, Preliminary geologic and metamorphic-isograd map of the Juneau B-1 quadrangle, Alaska: U.S. Geological Survey Miscellaneous Field Studies Map MF-846, 1 sheet, scale 1:31,680.

---- 1978, Megalineament in southeastern Alaska marks southwest edge of Coast Range batholithic complex: Canadian Journal of Earth Science, v. 15, p. 1763-1772.

---- 1986, Preliminary reconnaissance geologic map of the Juneau, Taku River, At lin and part of the Skagway 1:250,000 quadrangles, southeastern Alaska: U.S. Geological Survey Open-File Report 85-395, 23 p., 2 sheets, scale $1: 250,000$.

Brew, D.A., Ford, A.B., and Himmelberg, G.R., 1987, Late Cretaceous sedimentation, volcanism, plutonism, metamorphism and deformation in the northern Cordillera, southeastern Alaska [abs.]: Geological Society of America Abstracts with Programs, v. 19 , no. 7 , p. 600 .

---- 1988, Evolution of the western part of the Coast plutonic-metamorphic complex, southeastern Alaska, U.S.A.--A synopsis, in Daly, S.R., ed., Evolution of metamorphic belts: Geological Society of London Special Paper 32 [in press].

Brew, D.A., Ovenshine, A.T., Karl, S.M., and Hunt, S.J., 1984, Preliminary reconnaissance geologic map of the Petersburg and parts of the Port Alexander and Sumdum 1:250,000 quadrangles, southeastern Alaska: U.S. Geological Survey Open-File Report 84-405, 2 sheets, 43 p. pamphlet.

Douglass, S.L., and Brew, D.A., 1985, Polymetamorphism in the eastern Petersburg quadrangle, in Bartsch-Winkler, Susan, ed., The United States Geological Survey in Alaska: Accomplishments during 1984: U.S. Geological Survey Circular 967, p. 89-92.

Forbes, R.B., and Engels, J.C., 1970, $\mathrm{K}^{40} / \mathrm{Ar}^{40}$ age relations of the Coast Range batholith and related rocks of the Juneau Icefield area, Alaska: Geological Society of America Bulletin, v. 81, p. 579-584.

Ford, A.B., and Brew, D.A., 1973, Preliminary geologic and metamorphic-isograd map of the Juneau B-2 quadrangle, Alaska: U.S. Geological Survey Miscellaneous Field Studies Map MF-527.

1977, Preliminary geologic and metamorphic-isograd map of parts of the Juneau A-1 and A-2 quadrangles, Alaska: U.S. Geological Survey Miscellaneous Field Studies Map MF-847.
Gehrels, G.E., Brew, D.A., and Saleeby, J.B., 1984, Progress report on $\mathrm{U} / \mathrm{Pb}$ (zircon) geochronologic studies in the Coast plutonic-metamorphic complex east of Juneau, southeastern Alaska, in Reed, K.M., and Bartsch-Winkler, Susan, eds., The United States Geological Survey in Alaska: Accomplishments during 1982: U.S. Geological Survey Circular 939, p. 100-102.

Goldfarb, R.J., Light, T.D., and Leach, D.L., 1986, Nature of the ore fluids at the Alaska-Juneau gold deposit, in BartschWinkler, Susan, and Reed. K.M., eds., Geologic studies in Alaska by the U.S. Geological Survey during 1985: U.S. Geological Survey Circular 978, p. 92-94.

Himmelberg, G.R., Ford, A.B., and Brew, D.A., 1984, Progressive metamorphism of pelitic rocks in the Juneau area, southeastern Alaska, in Coonrad, W.L., and E1liott, R.L., eds., The United States Geological Survey in Alaska: Accomplishments during 1981: U.S. Geological Survey Circular 868, p. 131-134.

Kretschmar, U., and Scott, S.D., 1976, Phase relations involving arsenopyrite in the system Fe-As-S and their application: Canadian Mineralogist, v. 14, p. 364-386.

Lund, Karen, Snee, L.W., and Evans, K.V., 1986, Age and genesis of precious metal deposits, Buffalo Hump district, central Idaho: Implications for depth of emplacement of quartz veins: Economic Geology, v. 81, p. 990-996.

Nesbitt, B.E., Murowchick, J.B., and Muehlenbachs, K., 1986, Dual origins of lode gold deposits in the Canadian Cordillera: Geology, v. 14, p. 506-509.

Newberry, R.J., and Brew, D.A., 1987, The Alaska-Juneau gold deposits: Remobilized syngenetic versus exotic epigenetic origin, in Hąmilton, T.D., and Galloway, J.P., eds., Geologic studies in Alaska by the U.S. Geological Survey during 1986: U.S. Geological Survey Circular 998, p. 128-132.

Scott, S.D., 1973, Experimental calibration of the sphalerite geobarometer: Economic Geology, v. 68, p. 466-474.

Twenhofel, W.S., 1952, Geology of the AlaskaJuneau lode system, Alaska: U.S. Geological Survey Open-File Report 52-160, 170 p.

Wayland, R.G., 1960, The Alaska Juneau gold ore body: Neues Jahrbuch fur Mineralogie Abhandlungen, v. 94, p. 267-279.

Wernecke, Livingston, 1932, Geology of the ore zones: Engineering and Mining Journal, v. 133 , p. 494-499.

Reviewers: Roger Ashley and Raul Madrid

Geologic Studies in Alaska by the U.S. Geological Survey during 1987: John P. Galloway and Thomas D. Hamilton, editors, U.S. Geological Survey Circular 1016. 


\section{OFFSHORE}

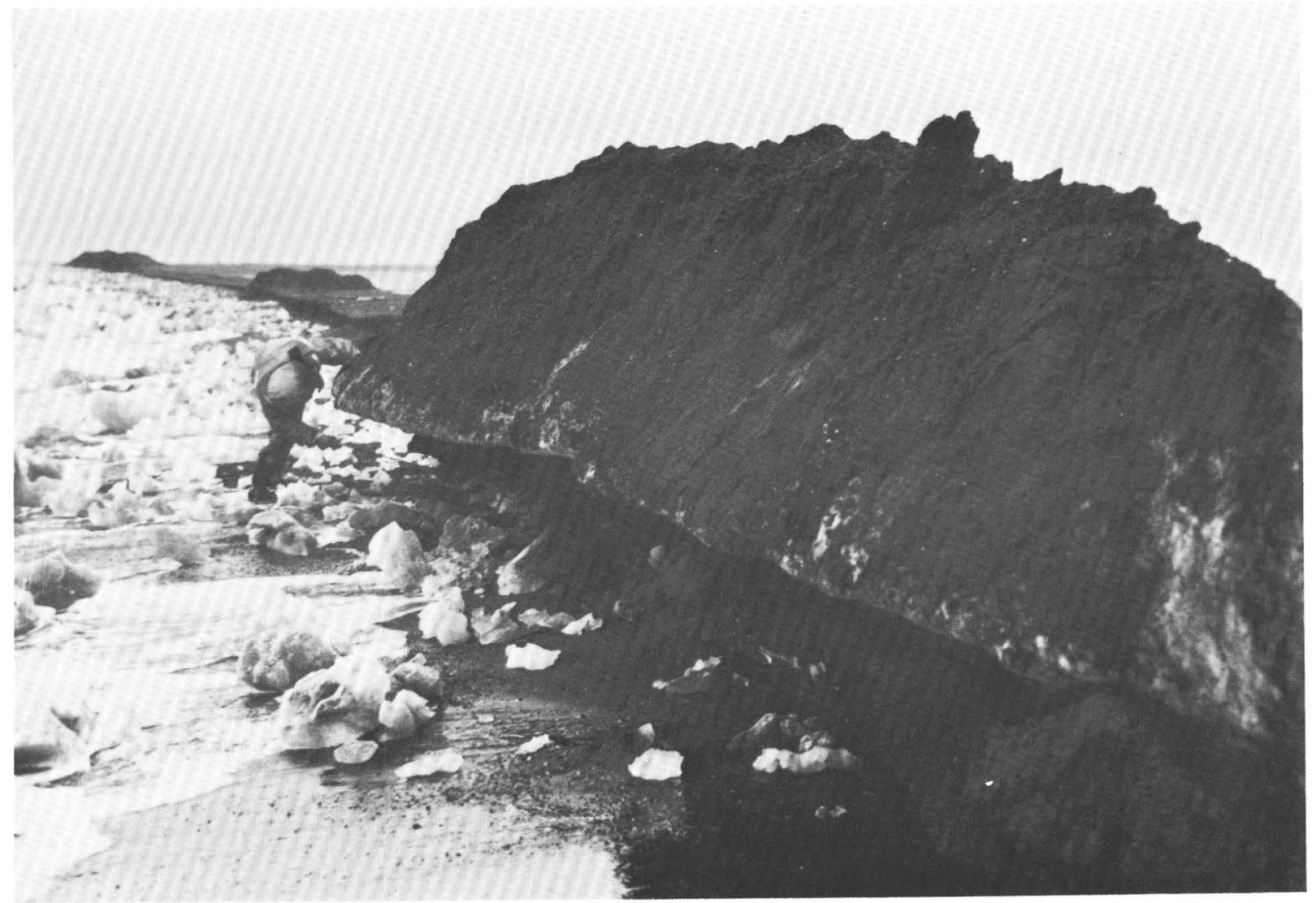

Ice pileup draped with sandy gravel derived from the shoreface along margin of Beaufort Sea. These deposits commonly are a major component of arctic barrier islands. See articles by Barnes and Reimnitz and Reimnitz and Barnes. 'Photograph by Erk Reimnitz. 


\title{
Construction of an Arctic Barrier Island by Alternating Sea-Ice Pileup and Overwash
}

\author{
By P.W. Barnes and Erk Reimnitz
}

Knowledge of northern Alaska's coastal zone-its character, history, and processes--is needed for determinations of State and Federal lands and for the design of coastal structures and pipeline crossings. Such knowledge will also serve in reconstructing ancient high-latitude environments from the geologic record. In this report and its companion (Reimnitz and Barnes, this volume), we discuss the stability, morphology, probable construction mechanism and internal makeup of a unique, sea-ice dominated arctic barrier island from a poorly known stretch of the Alaskan arctic coast. Our evidence implicates sea ice as the sediment-supply agent for the island, and an interaction of alternating ice pileups and overwash as the geologic processes giving the island its unique shape.

Barrier islands form an almost continuous chain fronting the eastern $100 \mathrm{~km}$ of Alaska's low arctic coastal plain. Coalescing alluvial fans form this part of the coastal plain and its extension seaward underneath the continental shelf (Carter and others, 1986; Wolf and others, 1987). A 26-km-long, arcuate barrier island named Icy Reef by John Franklin in 1826 (because of severe coastal ice conditions encountered by his party in mid-summer) is one member of the island chain (fig. 1). Icy Reef blocks the outflow of the Kongakut River from direct access to the sea. Between the river delta and Icy Reef is a shallow lagoon averaging about $500 \mathrm{~m}$ in width and less than 1 $m$ deep (fig. 1 in Reimnitz and Barnes, this volume).

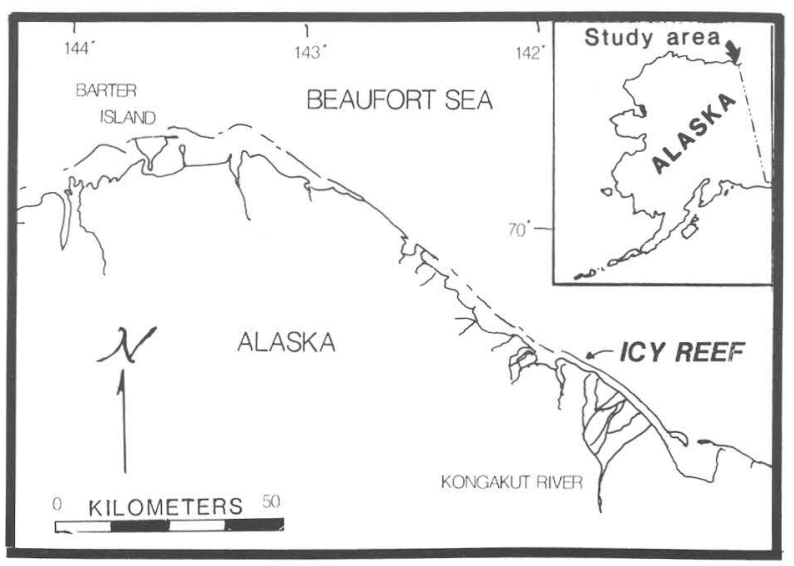

Figure 1. Sketch map of coast and barrier islands in northeastern Alaska showing location of Icy Reef (see Reimnitz and Barnes, this volume, figure 1, for additional detail).
The Kongakut delta is composed of sandy mud whereas the barrier island is constructed of sandy gravel, and therefore, the Kongakut River presently is not considered a major sediment source for Icy Reef. A comparison of the Icy Reef coastline, mapped 30 years apart (about 1950 to about 1980), shows a remarkable stability in the central third of its length, coinciding with an area containing a high hummocky crest that is the focus of this paper.

The low-lying (about $1 \mathrm{~m}$ elevation) eastern and western extremities of Icy Reef are splayed to widths of a few hundred meters and are migrating onshore at rates of $1 \mathrm{~m}$ per year or more, typical of many barrier islands along the arctic coast further to the west (Short and others, 1974; Reimnitz and others, 1988). The stable central third of the island, where widths of 75 to $100 \mathrm{~m}$ prevail, is characterized by a continuous hummocky ridge, up to $4 \mathrm{~m}$ high. We visited this part of the island briefly in 1981 and again in 1987. Piles of sandy gravel 5 to $10 \mathrm{~m}$ in length were found to form hummocky features with crests 1 to $2 \mathrm{~m}$ above the surrounding island (fig. 2). In 1987 the seaward face of the sediment ridge consisted of erosional scarps that exposed three or more horizontal beds of sand and gravel about $25 \mathrm{~cm}$ thick (fig. 3). Laterally these beds vary in thickness and may pinch out. Between the scarps and the sea was a gently sloping $15-\mathrm{m}$-wide sand and gravel beach similar to beaches elsewhere in the Arctic (figs. 2, 3, and 4). The lagoonward slope, which gradually dropped to sea level over distances in excess of $50 \mathrm{~m}$, had formed from a series of overwash fans which originated at saddles along the line of hummocks (fig. 2). Kettle-like depressions (Greene, 1970) up to 3 $\mathrm{m}$ in diameter and $75 \mathrm{~cm}$ deep dotted the lagoonward

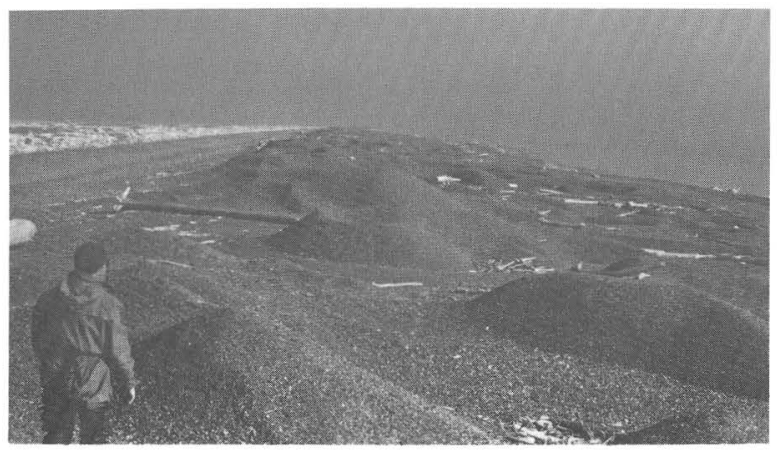

Figure 2. Hummocky crest of Icy Reef in 1981, looking east. Note ice-pushed mounds of sandy gravel and overwash channels in saddles between mounds. 
slope of the island; they commonly contained finegrained sediment and new vegetation. Along the lagoon shore were patches of fine grained, vegetated sediments that contrasted with the sand and gravel seaward on the barrier island. Eolian features were absent on the barrier island. Offshore surficial sediments in water depths to $10 \mathrm{~m}$, which consist of sand and pebbly sand, make up a potential sediment source for the barrier island and hum mocks.

The height and irregular profile of the crest of Icy Reef are unusual for arctic barrier islands (figs. 2 and 4) and suggest a unique explanation. The $30-y r$ stability of the shoreline along the high-crested central one-third of the island may be a part of the explanation, but in itself is not the complete answer. Sea ice must be considered, as it can transport sediment to elevations not normally reached by waves

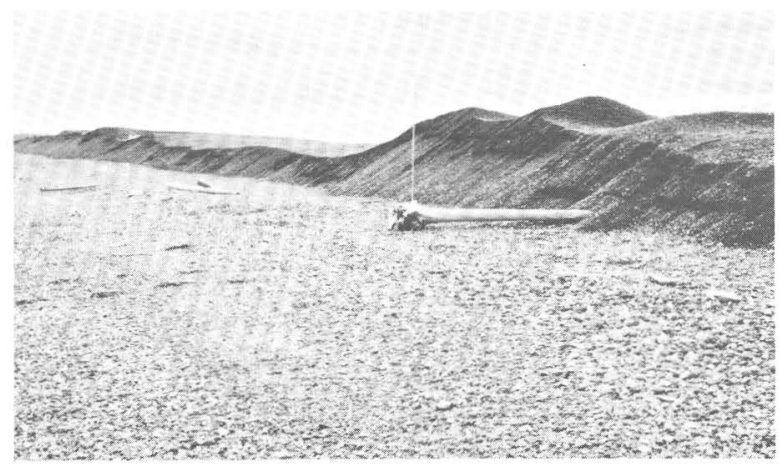

Figure 3. Erosional scarp and hummocky crest of Icy Reef in August 1987, showing several horizontal layers of overwash deposits. Beach deposits reworked by waves and currents in foreground. Offshore is to left; pole is $2.4 \mathrm{~m}$ in length.
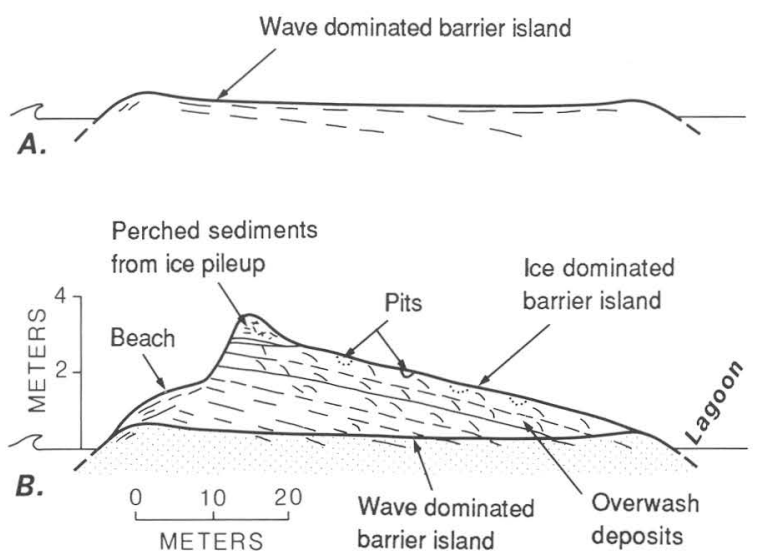

Figure 4. Conceptual cross sections of (A) wave-dominated arctic barrier island (Reindeer Island), "typical" of Beaufort Sea barrier islands; and (B) ice-dominated barrier island (Icy Reef) superimposed on wave-dominated cross section (stippled pattern). Overwash deposits dominate cross sections, but we suggest that ice pileups are responsible for providing material to the islands as demonstrated at Icy Reef.
(Kovacs and Sodhi, 1980). Bulldozing of shoreface material onto arctic beaches by ice has been noted in many instances, and the sediment volumes so contributed in some years may be considerable (Barnes and others, 1982; McLaren, 1982). Harper and others (1985) speculated that onshore transport of sediment by ice is the primary sediment supply for the long, linear, and stable barrier islands of the western Yukon coast, $20 \mathrm{~km}$ east of Icy Reef. Reimnitz and Barnes (this volume) have summarized the evidence for sea ice impacting Icy Reef, and reasoned that ice pileup is a more likely mechanism than ice rideup.

During most pileups, sheets of sea ice break near the ice-flotation line on the shore face in water depths of 1 to $2 \mathrm{~m}$. Continued onshore pushing and piling of ice causes a portion of the broken ice to scoop sand and gravel from the shoreface, resulting in a rubble-pile mixture of sediment and ice. These pileups generally occur within $15 \mathrm{~m}$ of the water's edge and may be up to $10 \mathrm{~m}$ high (Kovacs and Sodhi, 1980). Melting of the ice in these piles releases the incorporated sediment which settles to the underlying surface, forming internally structureless mounds. An abundant supply of coarse material on the shoreface is another requirement for vertical accretion through pileup. Subsequent storms, waves and currents tend to smooth out the hummocky relief and irregularities of ice pileup. Large waves associated with storm surges locally overtop the hummocky ridge, eroding saddles and depositing coalescing fans of overwash sediment. The regionally smooth backslope of Icy Reef has been shaped by such overwash (figs. 2 and 4 ). Kettles form when overwash carries brash ice, which then litters the backslope during fan accretion.

Seaward-facing beaches elsewhere along the Beaufort Sea coast generally retreat between 1 to 10 $\mathrm{m} / \mathrm{yr}$, and therefore the sediment accumulations from intermittent sea-ice pileups are not preserved. The stable part of Icy Reef, where the stratigraphy of the erosional scarp records at least three sedimentation events that could represent alternating ice pileups and smoothing by wave overwash (fig. 3), is an exception. These events have resulted in barrier islands 2 to 3 times as high as islands elsewhere along the Arctic coast (fig. 4).

Rex (1964) and others have noted the virtual absence of ice-disturbance structures in arctic beaches. Those observations were made on normal beach deposits, as in the foreground of figure 3 . Except for the sea-ice kettles on the overwash fans, we too expect that the barrier island at Icy Reef is dominated by hydraulic structures (figs. 3 and 4) except at their highest points. If preserved in the geologic record, steeply dipping, laterally discontinuous overwash fans with pit structures should reflect stable barrier islands in an ice-stressed setting. Such islands, in which the sediment budget is dominated by onshore sediment movement through ice rather than longshore transport, should contain mainly lithologies and clast sizes characteristic of the local offshore, rather than those derived from updrift sediment sources. The dominance of onshore transport from local rather than longshore sediment sources has been suggested by studies of pebble lithologies and sizes in other barrier islands of the Beaufort Sea (Hopkins and Hartz, 1978). 


\section{REFERENCES CITED}

Barnes, P.W., 1982, Marine ice-pushed boulder ridge, Beaufort Sea, Alaska: Arctic, v. 35 , p. 312-316.

Barnes, P.W., Reimnitz, Erk, and Fox, D., 1982 , Ice rafting of fine-grained sediment, a sorting and transport mechanism, Beaufort Sea, Alaska: Journal of Sedimentary Petrology, v. 52, p. 493-502.

Carter, L.D., Ferrians, 0.J., Jr., and Galloway, J.P., 1986, Engineering-geologic maps of northern Alaska coastal plain and foothills of the Arctic National Wildlife Refuge: U.S. Geological Survey Open-File Report 86334,10 p., 2 sheets, scale 1:250,000,

Greene, H.G., 1970, Microrelief of an arctic beach: Journal of Sedimentary Petrology, v. 40, p. 419-427.

Harper, J.R., Collins, Arlene, and Reimer, P.D., 1985, Morphology and processes of the Canadian Beaufort Sea coast [abs.], in Arctic Workshop, Land-Sea Interactions, 14th, Dartmouth, Nova Scotia, p. 110-111.

Hopkins, D.M., and Hartz, R.W., 1978, Coastal morphology, coastal erosion and barrier islands of the Beaufort Sea, Alaska: U.S. Geological Survey Open-File Report 78-1063, $54 \mathrm{p}$.

Kovacs, Austin, and Sodhi, D.S., 1980, Shore ice pile-up: Field observations, models, theoretical analyses: Cold Regions Science and Technology, v. 2, p. 209-288.

McLaren, Patrick, 1982, The coasta1 geomorphology, sedimentology and processes of eastern Melville and western Byam Martin Islands, Canadian Arctic Archipelago: Geological Survey of Canada Bulletin 333, 39 p.

Reimnitz, Erk, Graves, S.M., and Barnes, P.W., 1988, Beaufort Sea coastal erosion, sediment flux, shoreline evolution and the erosional shelf profile: U.S. Geological Survey Miscellaneous Investigations Map I-1182-G, scale $1: 82,000$, with text, 22 p.

Rex, R.W., 1964, Arctic beaches, Barrow, Alaska, in Miller, R.L., ed. Papers in Marine Geology, New York, Macmillan, p. 384-400.

Short, A.D., Coleman, J.M., and Wright, L.D., 1974, Beach dynamics and nearshore morphology of the Beaufort Sea Coast, Alaska, in Reed, J. and Sater, J., eds. The coast and shelf of the Beaufort Sea: Arlington, Va., Arctic Institute of North America, p. 477-488.

Wolf, S.C., Barnes, P.W., Rearic, D.M, and Reimnitz, Erk, 1987, Quaternary seismic stratigraphy of the inner continental shelf north of ANWR, in, Bird K.J. and Magoon, L.B. eds, U. S. Geological Survey Bulletin 1778 , p. $61-78$.

Reviewers: R.L. Phillips and D.M. Rearic

Geologic Studies in Alaska by the U.S. Geological Survey during 1987: John P. Galloway and Thomas D. Hamilton, editors, U.S. Geological Survey Circular 1016. 


\title{
Sea-Floor Feeding Traces of Gray Whales and Walrus in the Northeast Chukchi Sea
}

\author{
By R. Lawrence Phillips and Mitchell W. Colgan
}

Sediments in the northeast Chukchi Sea contain dense to scattered benthic feeding traces of gray whales (Eschrichtius robustus) and walrus (Odobenus rosmarus divergens). This study identifies some of the northernmost feeding grounds of these mammals and sumarizes surface sediment textures, observed feeding traces, and fauna living in or near the feeding areas.

Ice covers the shallow Chukchi Sea for 9 to 10 months a year. As the ice recedes northward in summer, gray whales and walrus move north to feed either adjacent to the ice edge (walrus) or in open water east of the pack ice (gray whales and walrus) where the Alaska Coastal Current is concentrated. Within this region the sea floor exhibits variable relief, deepening northeastward into the Barrow Sea Valley (fig. 1). Along the eastern edge of the Chukchi Sea the northward-flowing Alaska Coastal Current affects the sea floor, producing active sand wave fields, sand ribbons, and extensive gravel lag deposits. All these substrates contain rich faunal communities. The area west of the influence of the coastal current contains sediment varying from muddy fine sand to gravelly sand and muddy gravel; these substrates have less diversified fauna (fig. 2).

Reconnassance geological and geophysical surveys were conducted using the NOAA RV Surveyor

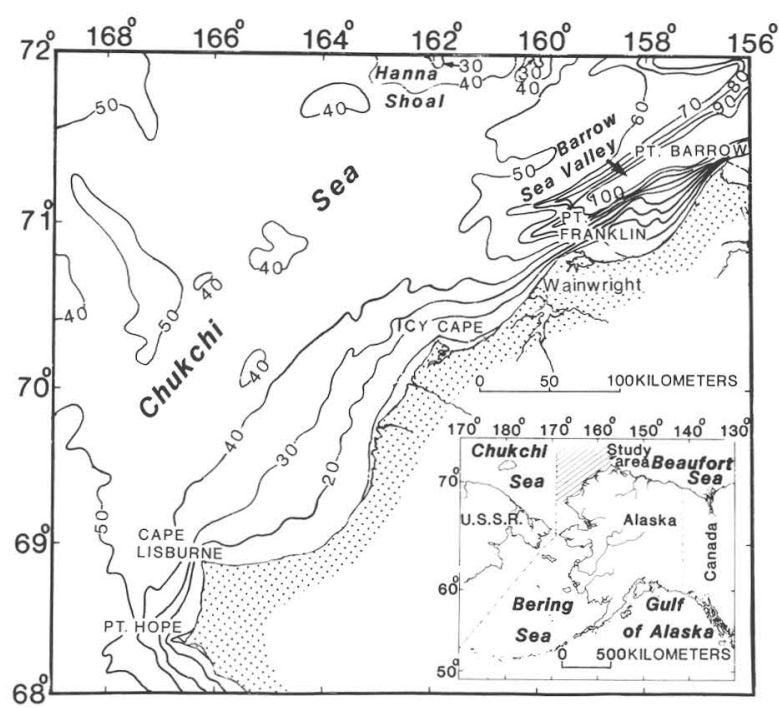

Figure 1. Northeast Chukchi Sea, showing bathymetry in meters (modified from Hill and others, 1984). in 1984 and RV Discoverer in 1985. From sonographs collected during these surveys we identified scattered to dense benthic feeding traces on the sea floor (fig. 2). Television and bottom photographs showed the seafloor surface features in greater detail. Box cores
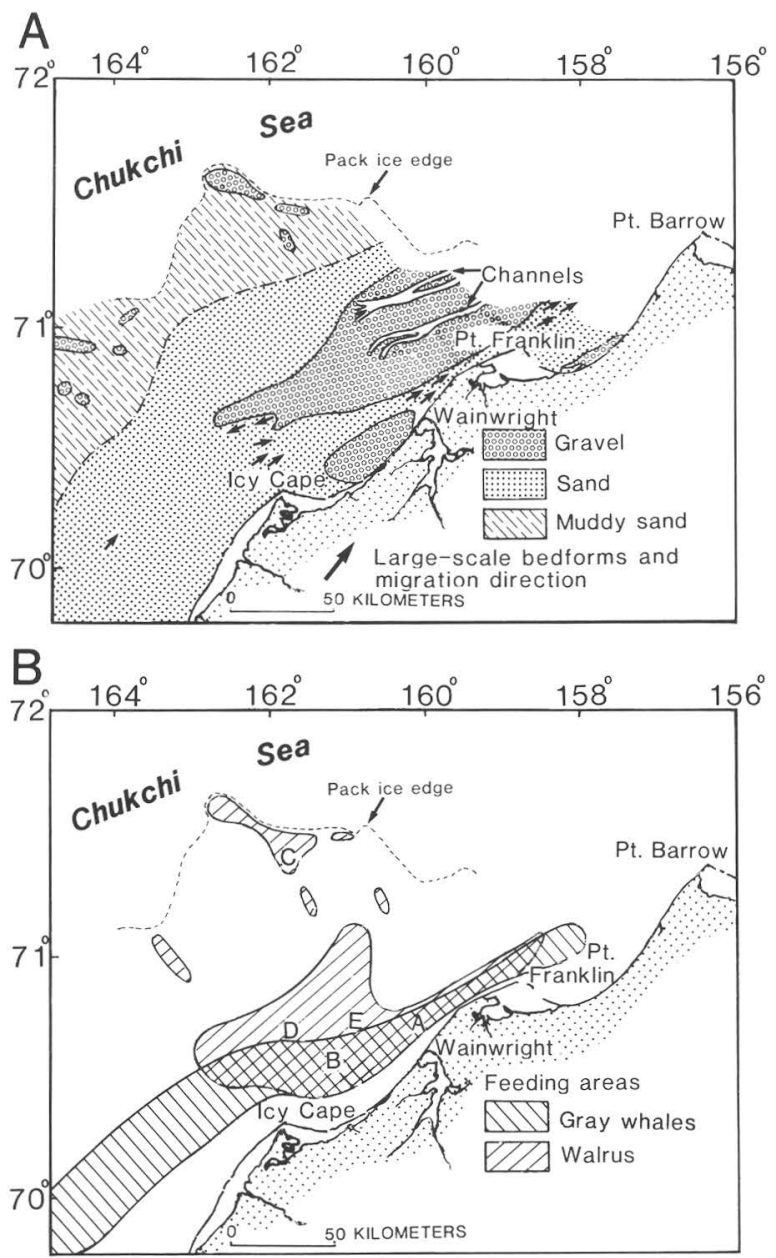

Figure 2. Northeast Chukchi Sea. A, Surface sediment textures. Alaska Coastal Current produces extensive gravel lag deposits within head of Barrow Sea Valley. Sea floor changes to bioturbated sand or muddy sand to west. B, Areas containing benthic feeding traces of gray whales and walrus. Letters indicate locations of sonographs or bottom photographs (see figures 3 to 5 ). 
(four cores per site) and dredges in the gravel-rich areas were taken to sample the sediment and the benthic communities.

Gray whales move north to feed along an openwater corridor between the pack ice and the coast; they reach the vicinity of Barrow and sometimes move into the Beaufort Sea (Maher, 1960). The highest density of gray whales observed in the Chukchi Sea is in the coastal region between Point Hope and Barrow (Ljungblad, 1987). We have observed numerous gray whales concentrated along the eastern side of the Chukchi Sea, especially in the shallow nearshore waters from Icy Cape north to Point Franklin where the Alaska Coastal Current is actively transporting sediment and nutrients.

Gray whales are benthic feeders that produce solitary to multiple sea- floor excavations. They ingest sediment and infaunal invertebrates and filter the sediment through their baleen (Nerini and others, 1980; Nerini 1984; Oliver and Kvitek, 1984; Nelson and others, 1987; Nelson and Johnson, 1984, 1987). Their main food in much of their northern range and especially in the northern Bering Sea is infaunal tubedwelling Ampelisca amphipods (Nerini, 1984, Nelson and others, 1987). However, in the Chukchi Sea their food supply may differ because of opportunistic feeding on both epifaunal and infaunal communities (Ljungblad, 1987). Ljungblad (1987) reported that gray whales apparently were feeding on swarms of epibenthic crustaceans (mysids, amphipods, and shrimp) over a gravel sea floor near Point Hope; on epibenthic isopods north of Cape Lisburne; and on infaunal amphipods southwest of Wainwright.

Gray-whale feeding traces were identified from south of Icy Cape to north of Point Franklin (fig. 2). Observations of sediment plumes surrounding surfacing whales in this region confirm benthic feeding. Serial box cores taken where the whales were feeding show the sediment texture (gravelly sand) and benthic organisms (infaunal tube-dwelling amphipods and two other species of amphipods), and sonographs show dense sea-floor feeding traces (fig. 3). The feeding traces are similar to those initially reported in the Bering Sea by Nerini and others (1980) and Nelson and Johnson (1984). The highest concentration of feeding traces are found at depths of 23 to $34 \mathrm{~m}$ on the inner shelf between Wainwright and Point Franklin. However, a different feeding mode may occur in deeper water where an extensive surficial gravel field exists. Here, the whales may feed on swarming shrimp and amphipods, as suggested by Ljungblad (1987) for the gravel areas near Point Hope, and may not excavate feeding traces.

The benthic feeding traces in sand consist of multiple elliptical pits to solitary elliptical pits 1.0 to $3.8 \mathrm{~m}$ long and 1.0 to $2.5 \mathrm{~m}$ wide (Type I and Type II feeding pits of Nelson and Johnson, 1984, 1987). Most appear to be enlarged and modified by currents. Southwest of Icy Cape, within a region containing small-scale bedforms less than $3 \mathrm{~cm}$ high, solitary and scattered feeding pits are common. Here, the extent of the gray whale feeding is uncertain because the scattered pits may represent "test" feeding areas, or active currents may have filled in most of the feeding traces, or dense carpets of sand dollars (Echinarachnius parma) may restrict whale feeding.
An abundant food supply exists for whales within the coastal region and especially in the shallow regions reworked by active coastal currents. Infaunal and epifaunal organisms observed in sandy substrates on which the whales may be feeding include tubedwelling Ampelisca amphipods, mysids, polychaete worms, isopods, and shrimp. Tube-dwelling amphipods and mysids were abundant in box cores taken in active bedform fields off Point Franklin whereas off Icy Cape epifaunal isopods were very abundant on core surfaces and infaunal amphipods and polychaetes were common. In the gravel-rich areas the whales can feed on shrimp, isopods, mysids, and both epifaunal and infaunal amphipods. Besides benthic feeding the whales may skim the gravel surfaces ingesting swimming prey.

Like the gray whales, walrus during summer tend to concentrate near the Alaskan and the Siberian coasts rather than in the central part of the Chukchi Sea. Most of the walrus that have been observed in the eastern Chukchi Sea were less than $20 \mathrm{~km}$ from the southern pack ice edge with their highest concentrations located offshore between Wainwright
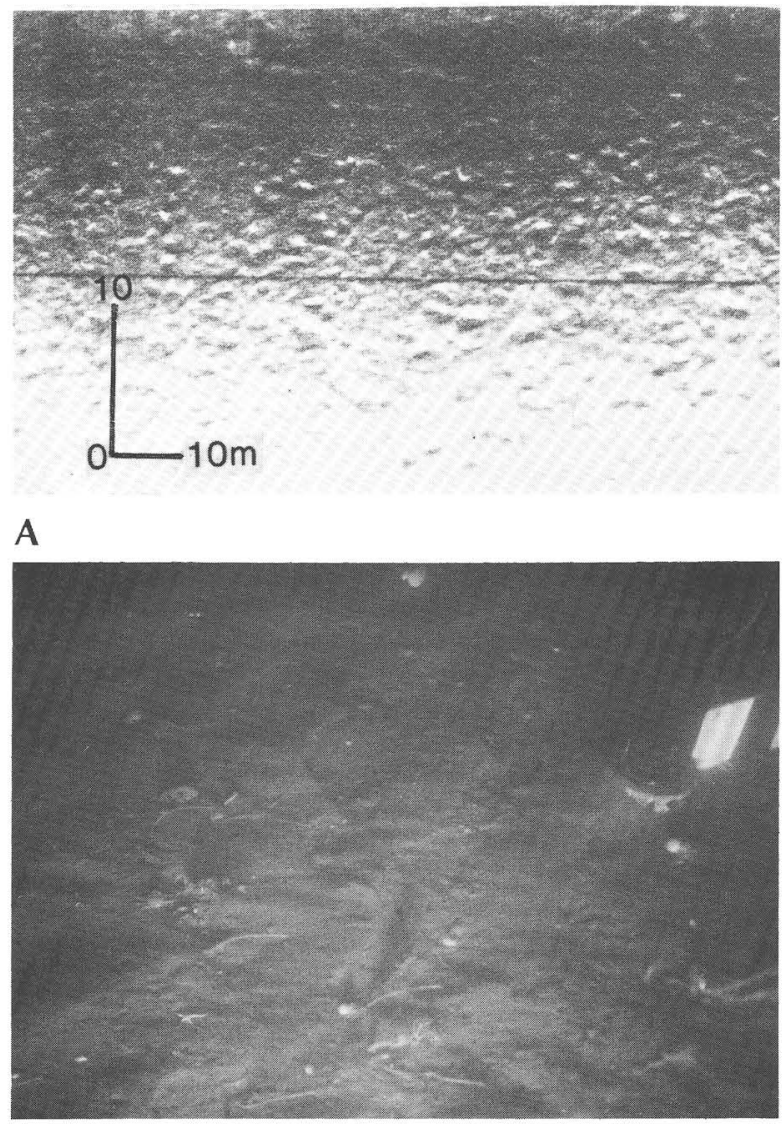

B

Figure 3. Gray-whale feeding pits from a $500-\mathrm{kHz}$ sonograph and associated bedforms. A, Current-modified multiple whale feeding pits in sand at $24 \mathrm{~m}$ depth, locality A. B, Small-scale ripples in coastal current sand at $31 \mathrm{~m}$ depth where whales were observed feeding, locality B. Ripples and inclined stalked bryozoans indicate currents moving from left to right. Stripes on bar scale are $5 \mathrm{~cm}$ wide. 
and Point Barrow (Fay and others, 1984). Studies of benthic feeding traces of walrus show that they excavate an irregular to linear furrow in the sea bed while searching for prey and that the furrows may also contain deeper scattered hydraulic jetted pits (Oliver and others, 1983). Furrow dimensions in shallow water in the northern Bering Sea vary with reported maximum lengths of $64 \mathrm{~m}$ (Oliver and others, 1983) to $200 \mathrm{~m}$ (Nelson and others, 1987). The average furrow widths are $45 \mathrm{~cm}$, and their depths are 10 to $17 \mathrm{~cm}$.

Walrus are opportunistic feeders that consume mainly infaunal prey (primarily pelecypods) but also a variety of epifaunal organisms such as gastropods, sea cucumbers, soft corals, octopus, polychaetes, fish, shrimp, sea pens, amphipods, tunicates, sponges, and crabs (Fay and others, 1984; Fukuyama and Oliver, 1985; Johnson, 1986; and Nelson and others, 1987).

In the eastern Chukchi Sea, where the walrus concentrate in summer, the food supply varies from high diversity and high density in the gravel-rich regions to low diversity and moderate to low density in the sandy regions (fig. 4). The organisms identified in the gravel-rich regions on which walrus may feed include epibenthic sea cucumbers, sea pens, soft corals, sponges, tunicates, isopods, myscids, amphipods, pectens (Chlamys), crabs, gastropods (Neptunia, Boreotrophon, and Buccinum) and brachiopods, whereas the infaunal communities identified consist of polychaetes, amphipods, and a variety of pelecypods (Nucula, Macoma, Mya, Serripes, Astarte, Yoldia, Hiatella, Cyclocardia, and Natica). Macoma and Nucula are the most common living infaunal prey in the gravel-rich regions. The sandy substrate west of the gravel fields contains mainly infaunal organisms including polychaetes, amphipods, Macoma, Yoldia, and Astarte, with Macoma the most abundant prey.

Walrus feeding traces are found to depths of at least $53 \mathrm{~m}$ in the northeast Chukchi Sea. The excavated traces consist of long, narrow, linear

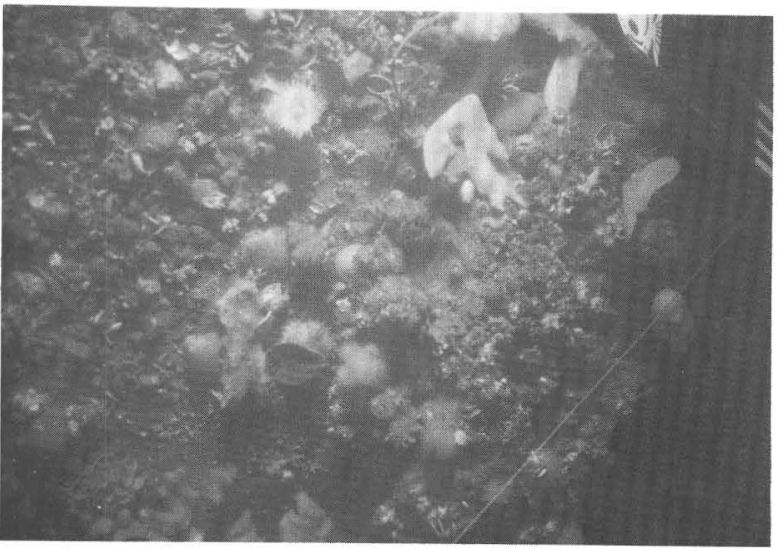

Figure 4. Bottom photograph of typical epifaunal communities on gravel lag at $47 \mathrm{~m}$ depth in Barrow Sea Valley, locality E. Sponges, soft corals, tunicates, crab, brachiopod, anemones, sea urchins, gastropods, bryozoans and barnacles are visible on the gravel surface. furrows; gently curved furrows; irregular furrows in gravel; and multiple overlapping irregular to linear furrows and solitary pits in offshore sand (fig. 5). The sea-floor furrows are less than $50 \mathrm{~cm}$ wide and 2 to 52 $m$ long. These features can be solitary or may occur, especially within the Barrow Sea valley, as linear, parallel multiple traces. They can also appear as dense, overlapping traces with random orientations completely disrupting the sea bed, as for example on the south flank of Hanna Shoal adjacent to the pack ice edge (fig. 5A). Repeated movement of the pack ice harboring abundant numbers of walrus would tend to concentrate feeding within a band to the south of the ice. This appears to be confirmed by the dense feeding pattern observed south of the summer-ice edge position.

In summary, gray whales feed exclusively on infaunal amphipods in the northern Bering Sea but apparently feed on a variety of epifaunal and infaunal prey further to the north. The highest concentration of gray whale benthic feeding traces and food supply underlies the Alaska Coastal Current Water, where the substrate consists of gravel and sand. Walrus feeding traces are found in the same areas as whale feeding traces, but the highest concentrations of walrus feeding traces are identified farther west on the south

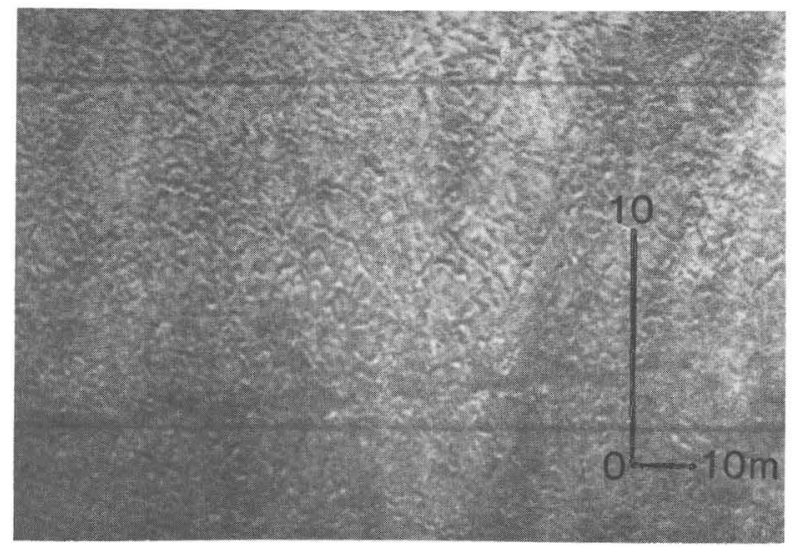

A

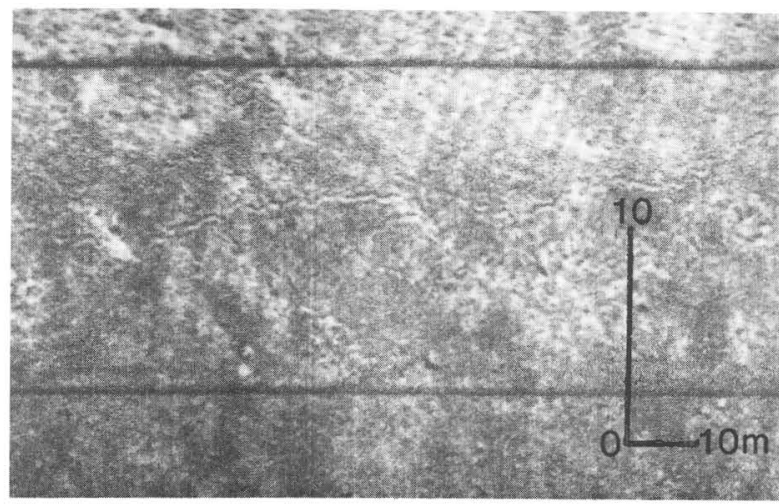

B

Figure 5. Walrus furrows shown on $500-\mathrm{kHz}$ sonographs. A, Dense, multiple walrus furrows in muddy sand at $41 \mathrm{~m}$ depth south of Hanna Shoal, locality C. B, Irregular walrus furrows in gravel at $42 \mathrm{~m}$ depth in Barrow Sea Valley, locality $\mathrm{D}$. 
flank of Hanna Shoal near the pack ice boundary. Both walrus and gray whale feeding traces are readily modified by shelf and storm currents, so the record of benthic feeding identified in the Chukchi Sea probably reflects the minimum area of feeding in this region.

This study was funded in part by the Minerals Management Service through interagency agreement with the National Oceanic and Atmospheric Administration as part of the Outer Continental Shelf Environmental Assessment Program. We thank Captain Peterson and Captain Bradly, the officers, and crew of the RV Discoverer and RV Surveyor for their help.

\section{REFERENCES CITED}

Fay, F.H., Kelly, B.P., Gehnrich, P.H., Sease, J.L., and Hoover, A.A., 1984, Modern populations, migrations demography, trophics, and historical status of the Pacific walrus: U.S. Department of Commerce, Final report, Outer Continental Shelf Environmental Assessment Program, p. 231-375.

Fukuyama, A.K., and Oliver, J.S., 1985, Sea star and walrus predation on bivalves in Norton Sound, Bering Sea, Alaska: Ophelia, v. 24, p. 17-36.

Hi11, E.R., Grantz, Arthur, May, S.D., and Smith, M., 1984, Marine geology atlas Chukchi Sea: U.S. Geological Survey Miscellaneous Investigation Series Map I1182-D.

Johnson, Kirk, 1986, The bizarre diet of walrus: Discovery, v. 19, p. 3-7.

Ljungblad, D.K., 1987, Gray whale distribution in the Chukchi and Bering Seas, in Hale, D.A., ed., Chukchi Sea information update: U.S. Department of Commerce, Outer Continental Shelf Environmental Assessment Program, p. 101-106.

Maher, W.J., 1960, Recent records of the California gray whale (Eschrichtius glaucus) along the north coast of Alaska: Arctic, v. 13 , p. 257-265.

Nelson, C.H., and Johnson, K.R., 1984, Gray whales, tillers of the sea floor, in Clarke, S.H., ed., Highlights in marine geology: U.S. Geological Survey Circular 938, p. 99107 .

---- 1987, Whales and walrus as tillers of the sea floor: Scientific American, v. 255, p. 501-512.

Nelson, C.H., and Johnson, K.R., and Barber, J.H., Jr., 1987, Gray whale and walrus feeding excavation on the Bering shelf, Alaska: Journal of Sedimentary Petrology, v. 57, p. 419-430.

Nerini, M., 1984, A review of gray whale feeding ecology, in Jones, M.L., Swartz, S.L., and Leatherwood, S., eds., The gray whale Eschrichtius robustus: San Francisco, Academic Press, p. 423-450.

Nerini, M.K., Jones, L., and Braham, H.W., 1980, Gray whale feeding ecology, first year final report, March-December, 1980: National Oceanographic and Atmospheric Administration, Outer Continental Shelf Environmental Assessment Program, RU 593, [ contract number R7120828].

O1iver, J.S., and Kvitek, R.G., 1984, Side-scan sonar records and diver observations of the Gray whale (Eschrichtius robustus) feeding grounds: Biology Bulletin, v. 197, p. 264269.

01iver, J.S., Slattery, P.N., O'Connor, E.F., and Lowry, L.F., 1983, Walrus, Odobenus rosmarus, feeding in the Bering Sea: a benthic perspective: Fishery Bulletin, v. 81 , p. 501-512.

Reviewers: J. H. Barber and R. E. Hunter

Geologic Studies in Alaska by the U.S. Geological Survey during 1987: John P. Galloway and Thomas D. Hamilton, editors, U.S. Geological Survey Circular 1016. 


\title{
Late Cretaceous Sediments from the Northeast Chukchi Sea
}

\author{
By R. Lawrence Phillips, LedaBeth G. Pickthorn, and Douglas M. Rearic
}

The shallow epicontinental Chukchi Sea is floored by a thin blanket of sediment, mostly 1 to $2 \mathrm{~m}$ thick but ranging up to $12 \mathrm{~m}$, that overlies folded and faulted bedrock. Only in the northwest part of the study area (fig. 1) does the sediment cover thicken to as much as $64 \mathrm{~m}$ in a series of filled fluvial channels. The thin sediment cover of the Chukchi Sea is the product of ice gouging, storms, shelf currents, and repeated transgressions.

In 1985 we obtained 22 vibracores to a maximum length of $6 \mathrm{~m}$ in the Chukchi Sea using the NOAA RV Discoverer. High-resolution seismic profiles were used to identify sediment thickness and specific core sites which contained thick strata (up to $5 \mathrm{~m}$ sediment) overlying folded bedrock. Stratigraphic investigations identified fresh and altered vitric tephra in 5 cores (Phillips and Colgan, 1987) and a crystal vitric tephra in one additional core (core 67, fig. 2). Core 67 is unique in that a reworked crystal vitric tephra deposited in a shallow marine or beach environment occurs throughout the laminated sand that composes its lowest stratigraphic unit. This paper presents the initial results of potassium-argon dating of biotite from the crystal vitric tephra. We also discuss the deposit's origin and implications of the radiometric age data.

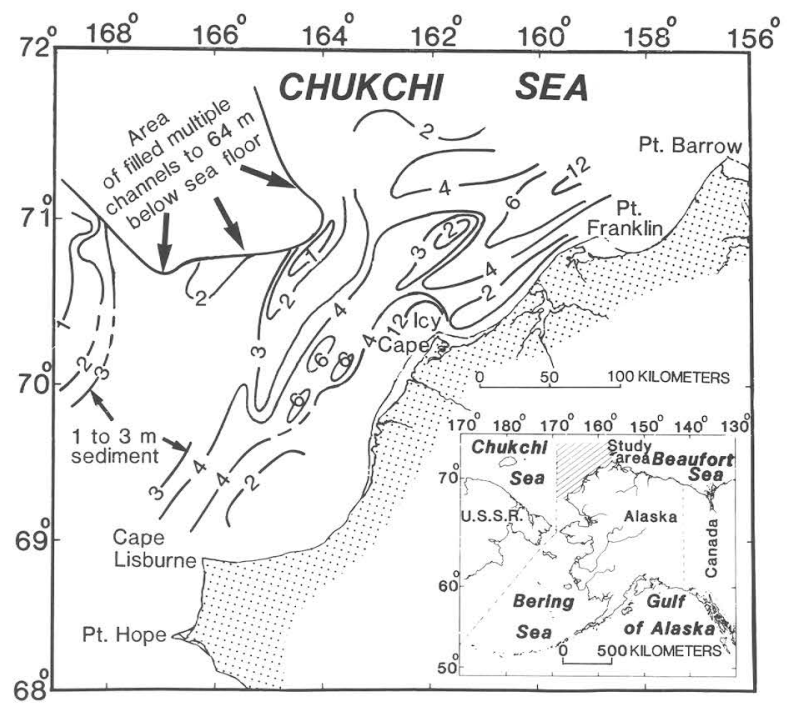

Figure 1. Northeast Chukchi Sea, showing thickness (m) of undeformed sediment overlying folded bedrock. Sediment cover is mainly Quaternary age, but may include flat-lying older strata in some areas. Contours dashed where inferred.
Core site 67 underlies the strong northwardflowing Alaska Coastal Current at $41 \mathrm{~m}$ depth. Three stratigraphic units of unconsolidated sediment are identified in the core (fig. 3). A thin Holocene transgressive sand, $58 \mathrm{~cm}$ thick, forms the uppermost sequence. Underlying the transgressive sand is a 256 cm-thick unit of iron-stained quartz sand, pebbly mud, and brown to black peat containing nonmarine ostracodes of probable Pleistocene age. Well-rounded quartz sand containing granules overlies the basal stratigraphic unit along a sharp irregular contact.

The basal sequence consists of $152 \mathrm{~cm}$ of biotite-rich horizontally laminated sand containing multiple laminae of opaque heavy minerals. Narrow burrows, some filled with heavy minerals, are scattered in the upper $60 \mathrm{~cm}$ of the laminated sand, but this stratigraphic unit contains no fossils. The laminated sand ranges in size from very fine to medium size and exhibits a polymodal size distribution which reflects varying energy conditions and selective grain transport during laminae deposition (fig. 3 ). The sand contains white and clear quartz, zoned plagioclase, altered glassy rock fragments, large brown biotite in books and thin flakes, green hornblende, quartz with biotite, opaque heavy minerals, and clay minerals; its heavy mineral content is 13.4 to 15.7

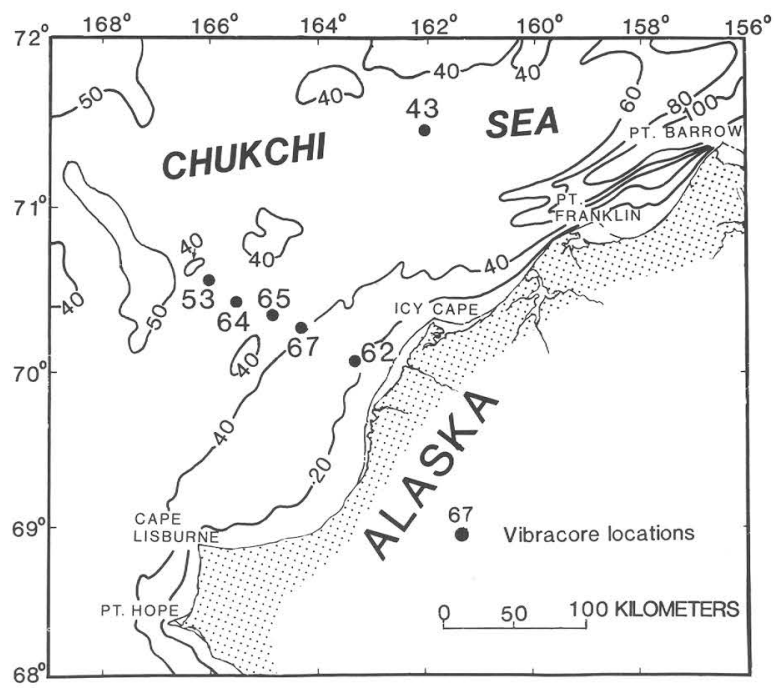

Figure 2. Location of vibracores in northeast Chukchi Sea containing vitric tephra $(53,65)$, altered tephra $(43,62,64)$, and crystal vitric tephra (67). Bathymetric contours in meters. 
percent, the highest values identified in the Chukchi Sea. Clay minerals, which form less than 2 percent of the core, are mainly smectite-illite (89 percent) with minor amounts of kaolinite and chlorite (11 percent).

Potassium-argon dating of biotite in two samples from the top $30 \mathrm{~cm}$ and the bottom $30 \mathrm{~cm}$ of the laminated sand yields ages of $92.1 \pm 1.2$ and $95.2 \pm$ $1.2 \mathrm{Ma}$, respectively (table 1 ). The younger date could possibly reflect some alteration of the biotite rather than a younger age. These dates place the biotite-rich sediments in the Cenomanian stage of the Late Cretaceous (using stage boundaries of Kent and Gradstein, 1985).

The high heavy-mineral content of the sand indicates a high-energy depositional environment in which currents actively concentated both biotite and opaque heavy minerals. Three environments which may produce such laminae are beach, storms, or shelf currents. The specific environment is uncertain, but a beach environment is suggested by the stratigraphic position of this deposit. The occurrence of nonmarine (eolian to fluvial) sediments above the laminated sand suggests an overall regressive sequence. Evidence for storms or shelf currents exists in the present-day regime, and much of the history of the Chukchi Sea apparently is erosional. Either storm or shelf currents, such as the present Alaska Coastal Current which overlies the core site, could produce similar laminae.

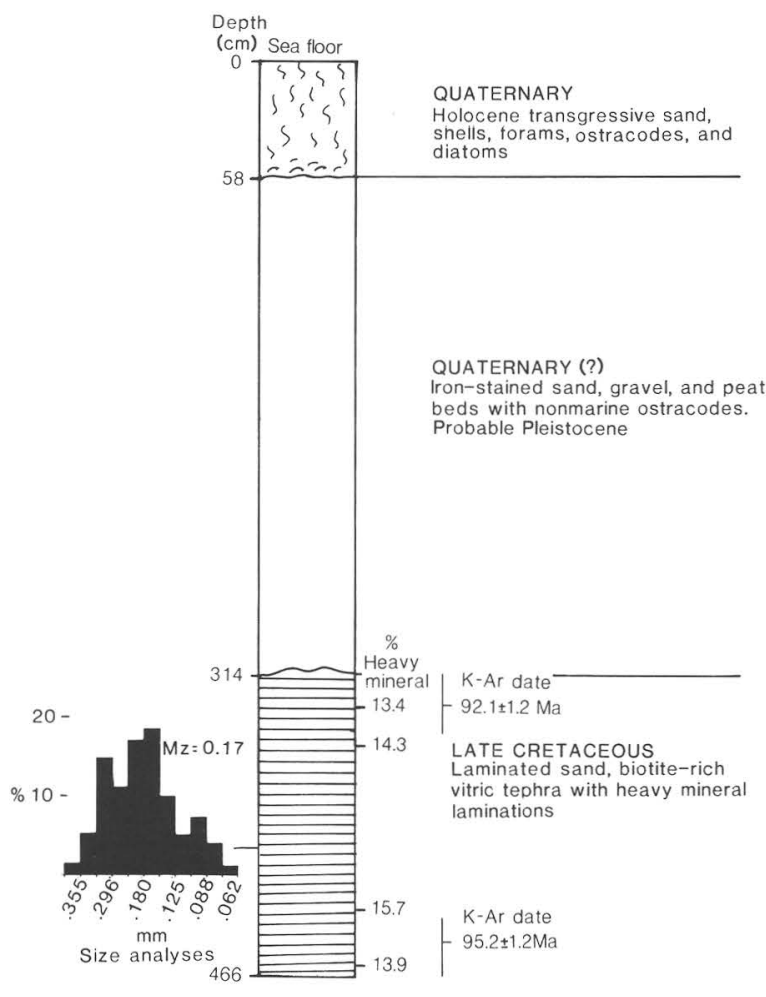

Figure 3. Stratigraphy of core 67 showing three depositional units separated by erosional contacts. Grain-size distribution is of sand fraction.
Any of the three environments--beach, storm, or currents--may have produced the laminated deposit during either the Quaternary or Cretaceous. However, the biotite, which occurs as individual crystals (books), as slightly rounded flakes, and in quartz suggests limited weathering and transport after deposition of the tephra. The relatively unaltered state of the plagioclase and hornblende also support this interpretation. Therefore, the biotite may represent material eroded from a nearby source with limited transport or the deposit may in fact be a primary unit of Cretaceous age.

Biotite in the present Chukchi Sea sediments and in the other vibracore stratigraphic samples is exceedingly limited, and is found only as rare grains in the basal stratigraphic units of two cores containing vitric tephra (cores 53 and 65). Muscovite, however, is common to abundant in all other marine stratigraphic units cored in the Chukchi Sea. If biotite were reworked by Quaternary transgressions one would expect it to be found in more than a single stratigraphic sequence. However, biotite is only abundant in core 67 , thereby suggesting that it is in a primary deposit and that the potassium-argon dates provide a valid Late Cretaceous age for the basal strata at this site.

At the site of core 67, high-resolution seismic profiles show a thin ( 3 to $4 \mathrm{~m}$ ) horizontal sediment cover that overlies gently westward-dipping strata. Although variations in sediment thickness, irregularities in the bedrock surface, and ship movements during anchoring preparatory to coring did not allow exact identification of the sediment thickness at the core site, our studies of the core suggest that Quaternary sediment cover about $3 \mathrm{~m}$ thick overlies about $1.5 \mathrm{~m}$ of bedrock.

The stratigraphic relationship of the reworked tephra grains in core 67 to the other tephras we recovered is uncertain. Both cores 53 and 65 contain identical tephra as indicated by the refractive index of the glass $(1.500 \pm 0.002$, Phillips and Colgan, 1987). The glass shards in core 67 are altered, therefore the refractive index cannot be compared with core 53 and 65. Either the tephra in core 53 and 65 form a blanket deposit over older folded bedrock, or the same bedrock tephra was cored as that at site 67 . The crystal tephra could represent a different phase of the same eruption episode that produced the tephra in cores 53 and 65, but a resolution of this problem must wait for dating of the other tephra deposits. If the crystal tephra in core 67 were related to the vitric tephra in core 53 and 65 , then it would define the stratigraphic age of the upper bedrock surface and will be a very important stratigraphic horizon in the northeast Chukchi Sea.

Late Cretaceous age (Cenomanian) means that the basal strata in core 67 will correlate with the uppermost part of the Nanushuk Group (Niakogon Tongue of the Chandler Formation) and lowermost part of the Colville Group (Seabee Formation) of northern Alaska. Both the Niakogon Tongue of the Chandler Formation and the Seabee Formation contain tephras. The nonmarine Niakogon Tongue of the Chandler Formation contains tephra beds up to $3 \mathrm{~m}$ thick (Brosge and Whittington, 1966). The Seabee Formation consists of fossiliferous marine shale containing numerous bentonite beds up to $1.5 \mathrm{~m}$ thick that yield 
Table 1. Argon analyses and age calculation of biotite from crystal tephra recovered in [Potassium analyses by 1.L. flame photometer using lithium internal standard. Argon analyses by standard techniques of isotope dilution. Ages were calculated using the following constants: $K^{40}$ decay constants: $\lambda_{e}+\lambda_{e}{ }^{\prime}=0.581 \times 10^{-10}$ year $^{-1} ; \lambda_{b}=4.963 \times 10^{-10}$ year ${ }^{-1}$; abundance ratio: $\mathrm{K}^{40} / \mathrm{K}=1.167 \times 10^{-4}$ atom percent]

\begin{tabular}{|c|c|c|c|c|c|}
\hline $\begin{array}{l}\text { Field no. } \\
\text { (see } \\
\text { figure 3) }\end{array}$ & Mineral & $\begin{array}{l}\text { Percent } \\
\mathrm{K}_{2} \mathrm{O}\end{array}$ & $\begin{array}{r}\mathrm{Ar}^{40} \\
\mathrm{rad} \\
(\mathrm{mol} / \mathrm{g})\end{array}$ & $\begin{array}{c}\begin{array}{c}\operatorname{Ar}^{40} \\
\mathrm{rad}\end{array} \\
\begin{array}{c}\text { Ar } \\
\text { total }\end{array}\end{array}$ & $\begin{array}{c}\text { Apparent age } \\
\text { (Ma) }\end{array}$ \\
\hline T30 & Biotite & $\begin{array}{l}8.60 \\
8.55\end{array}$ & $1.167 \times 10^{-9}$ & 0.908 & $92.1 \pm 1.2$ \\
\hline B30 & Biotite & $\begin{array}{l}8.65 \\
8.65\end{array}$ & $1.217 \times 10^{-9}$ & 0.955 & $95.2 \pm 1.2$ \\
\hline
\end{tabular}

potassium-argon ages on biotite of $91.5 \pm 0.9$ to $93.6 \pm$ 1.2 Ma (Lanphere and Tailleur, 1983). The similarities in ages (Late Cretaceous), composition (biotite-rich tephra), and environment (marine) suggest a correlation between the Seabee Formation and the basal sediment in core 67 . It may correlate with part of the Niakogon Tongue of the Chandler Formation as well, but there are no radiometric dates for the tephras.

In summary, six vibracores in the northeast Chukchi Sea penetrated tephra, and one of these cores contain a crystal tephra that was reworked in a beach or high-energy shallow marine environment from a nearby source. Based on potassium-argon dating, the deposit is Late Cretaceous. Although the evidence does not allow a definite assessment of whether the tephras are (1) folded Cretaceous bedrock, (2) a blanket deposit of post-deformation age, or (3) a reworked Quaternary deposit, most of our evidence appears to favor a primary deposit of Cretaceous age.

This study was funded in part by the Minerals Management Service through interagency agreement with the National Oceanic and Atmospheric Administration as part of the Outer Continental Shelf Assessment Program. We thank Captain Peterson, the officers, and crew of the RV Discoveror for their help. We also thank L.F. Espos (USGS) for the potassium analyses and T.L. Vallier (USGS) for petrologic analyses.

\section{REFERENCES CITED}

Brosge, W.P., and Whittington, C.L., 1966, Geology of the Umiat-Maybe Creek region Alaska: U.S. Geological Survey Professional Paper 303-H, p. 501-601.

Kent, D.V., and Gradstein, F.M., 1985, A Cretaceous and Jurassic geochronology: Geological Society of America Bulletin, v. 96, p. 1419-1427.

Lanphere, M.A., and Tailleur, I.L., 1983, K-Ar ages of bentonites in the Seabee Formation, northern Alaska: A Late Cretaceous (Turonian) time-scale point: Cretaceous Research, v. 4, p. 361-370.

Phillips, R.L., and Colgan, M.W., 1987, Vibracore stratigraphy of the northeastern Chukchi Sea, in Hamilton, T.D., and Galloway, J.P., eds., Geologic studies in Alaska by the U.S. Geological Survey during 1986: U.S. Geological Survey Circular 998, p 157-160.

Reviewers: K. J. Bird and T. L. Vallier

Geologic Studies in Alaska by the U.S. Geological Survey during 1987: John P. Galloway and Thomas D. Hamilton, editors, U.S. Geological Survey Circular 1016. 


\title{
Evidence for Sea-Ice Impact on Icy Reef, Beaufort Sea Coast
}

\author{
By Erk Reimnitz and P.W. Barnes
}

In recent investigations of ice impact along the Alaskan coast (Kovacs, 1983, 1984) and global synopses of the phenomenon (Kovacs and Sodhi, 1980; Sodhi and Kovacs, 1984), the distinction is made between (1) rideup, where a sheet of ice may smoothly slide landward across beaches and beyond for distances as much as $185 \mathrm{~m}$, thereby generally conforming to the surface of the land, and (2) pileup, where the icesheet buckles and crumbles at the seaward edge of bottom-fast ice. This ice failure then results in piles of broken ice up to $20 \mathrm{~m}$ high and 10 to $20 \mathrm{~m}$ wide, much of which comes to rest on the beach. Either iceimpact phenomenon is most likely to occur in fall or spring, is over within 15 to 30 minutes at most, and commonly leaves a scar of one form or another, which along stable coastlines may be preserved for decades. Although ice movement onto shore is frequent on a regional scale, it is unpredictable for any particular site and may be likened to a 50-year flood (Sodhi and Kovacs, 1984). Ice rideup is a surficial scraping process mostly over frozen ground; it is unlikely to be arrested at the same place repeatedly, commonly does not result in a mound or ridge of sediment at the terminus, can produce such features no higher and wider than the ice sheet thickness (generally much less than $1 \mathrm{~m}$ ), and therefore is unlikely to raise the elevation of a barrier island. If rideup produces a ridge or mound, this consists of materials scraped largely from the beach surface and tundra, and therefore may include driftwood, soil, and vegetative mat. Ice pileups, on the other hand, recur in a narrow zone; they commonly contain large amounts of sand and gravel from the shoreface dispersed throughout the pile, and each event, therefore, can result in a broad sediment mound 1 to $2 \mathrm{~m}$ high (see Barnes and Reimnitz, this volume). In either case, the natural scars are not easily datable, and no attempts have been made previously to learn about the frequency and severity of ice-encroachment from the fate of manmade objects along the coast. The present study is an attempt to gain such knowledge from objects placed on Icy Reef, a poorly known part of the Beaufort Sea coast. The knowledge will become useful for any future development of the area.

Icy Reef is an arcuate gravel barrier island, 80 to $100 \mathrm{~m}$ wide, that extends for $26 \mathrm{~km}$ along the shores of the Arctic National Wildlife Range, at the south margin of the Beaufort Sea (fig. 1). The island is separated from the Kongakut River delta by a lagoon several hundred meters wide that is generally shallower than $1 \mathrm{~m}$. The Icy Reef setting is unusual for several reasons: (1) The central part of the lagoon is seasonally occupied by a large naled (river icing) (Harden and others, 1977), which never melts entirely. (2) With an unbroken length of $26 \mathrm{~km}$, and a crestal elevation of up to $4 \mathrm{~m}$, Icy Reef is the longest and highest barrier island in the Beaufort Sea. Other more typical barrier islands are only 1 to $2 \mathrm{~m}$ high (Barnes and Reimnitz, this volume). (3) The gravelly crest is hummocky, with over $1 \mathrm{~m}$ of relief, as opposed to the smooth, overwash-shaped nature of barriers. (4) The central, 17-km-long stretch of Icy Reef has remained essentially unchanged in outline from 1951 to 1981 (fig. 1), while other Arctic coastal features have undergone remarkable changes (Reimnitz and others, 1988). Because of its unique character and setting, we believe that much of the knowledge gained from previous studies of lagoons and barrier islands in the Prudhoe Bay area cannot be applied to Icy Reef.

Thirteen towers were erected along Icy Reef for navigational control of hydrographic surveys by the U.S. Coast and Geodetic Survey (C\&GS) in 1952 (fig. 1). Most but not all of these towers were positioned on triangulation stations, and were generally placed on the highest elevation of barrier islands, or several meters to landward. The 1968 edition of C\&GS chart 9478 shows eight of the survey targets as having been destroyed either by 1955 or 1956 . No systematic count has been conducted since, but we believe that none of the survey towers remain standing at this time.

In August 1987, we visited triangulation station EASY, which was established in 1952 (fig. 1). The monument is described as a standard disk on top of an iron pipe projecting $12 \mathrm{~cm}$ above the ground. The reference marks $R M 1$ and RM2 on iron pipes were located within about $15 \mathrm{~m}$ east and south of EASY, with a wooden 4-by-4 inch "witness post" near RM1 (U.S. Department of Commerce, 1977). Remains of the tower were reported near the site in 1972 (U.S. Department of Commerce, 1977), but neither EASY nor its reference marks could be found at that time. During our visit, we found EASY, RM1, and remains of the witness post (fig. 2). They were located at the toe of a subdued erosional scarp 1 to $1.5 \mathrm{~m}$ high, seaward of the hummocky crest of the island. The base of bent RM1 and the stump of the witness post were vertical and obviously in place. The sharp bend in the pipe at the same level as the break of the sound wooden post indicate that both resisted landward shear forces by being held in a surface of frozen sediment rather than in the loose gravel that exists there during summer. The shear plane was slightly above the present beach surface, but more than a meter below the present crest of the island. RM1 was bent toward the base of the 8-m-tall wooden tower $45 \mathrm{~m}$ distant, and the toppled tower was pointing in the same direction as RM1, suggesting to us that both were destroyed by the same type of event. 


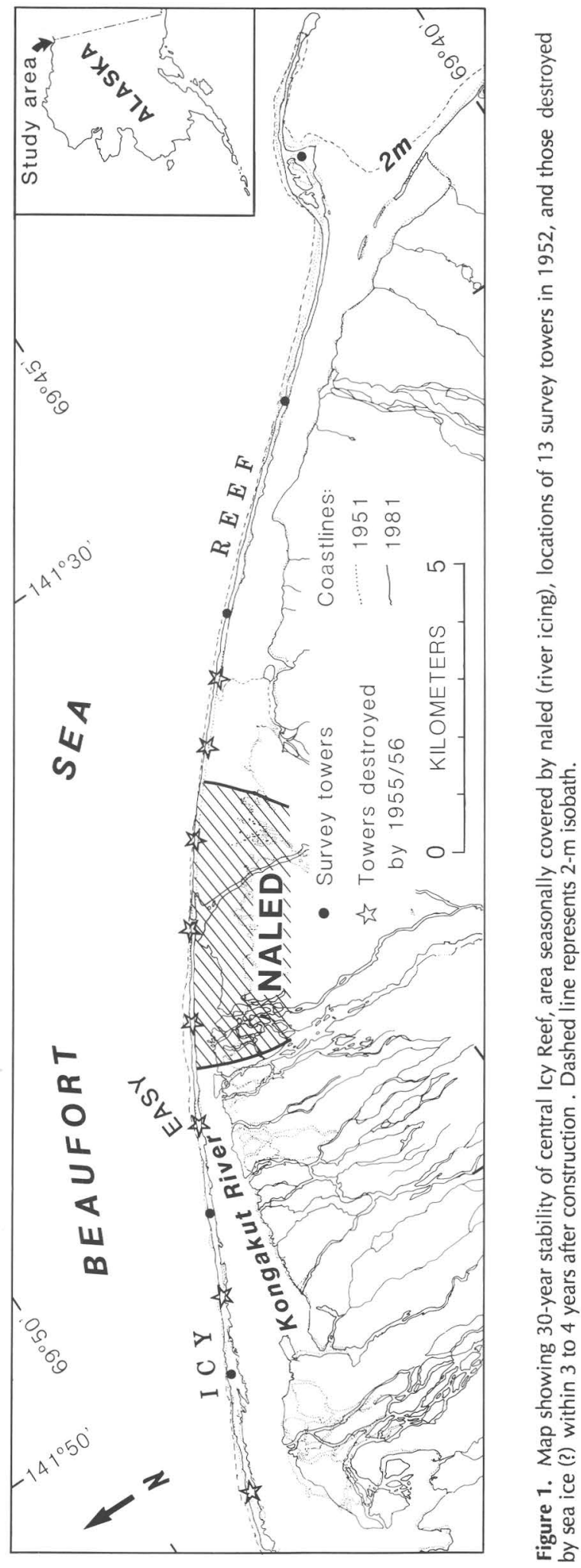

Most survey towers placed on beaches and barrier islands of the Beaufort Sea around 1950 were destroyed before the hundred-year storm surge of 1970 (Reimnitz and Maurer, 1979), whereas the same kinds of towers remain standing on high bluffs between Barrow and Peard Bay along the Chukchi Sea coast. This fact suggests that the destruction was neither from strong winds nor combined icings and winds. Storm waves carrying logs are not believed responsible for destruction of the site for two reasons: (1) the tower lies close to its original location, and (2) the ground was frozen, indicating destruction after freezeup and cessation of wave action. Thus, sea ice most likely damaged the tower and the triangulation station EASY within 3 to 4 years after its construction. We suspect that most of the other towers destroyed on Icy Reef so shortly after construction met a similar fate.

The inability to recover the markers around EASY in 1972 and their rediscovery in 1987 about $1 \mathrm{~m}$ below the present crest of Icy Reef suggest that the station had been buried sometime before 1972 and was exhumed by the eroding sea since then. The hummocky crest of Icy Reef and the buildup of gravel to $4 \mathrm{~m}$, as opposed to the 1- to 2-m level of modern beaches, suggest that sea-ice encroachment added the gravel to the island. The stratigraphy of the gravel deposits exposed in the scarp at EASY suggests repeated deposition and reworking (Barnes and Reimnitz, this volume). Because ice rideup is a subaerial scraping process, unlikely to be arrested at the same place repeatedly, it cannot raise the general elevation of a barrier island. Ice pileups, on the other hand, commonly contain shoreface-derived sand and gravel, which after melting remains as a broad gravel mound. Our evidence thus indicates that much of the old and stable central part of this unusual barrier island has been repeatedly impacted and elevated by ice pileups during the last 35 years.

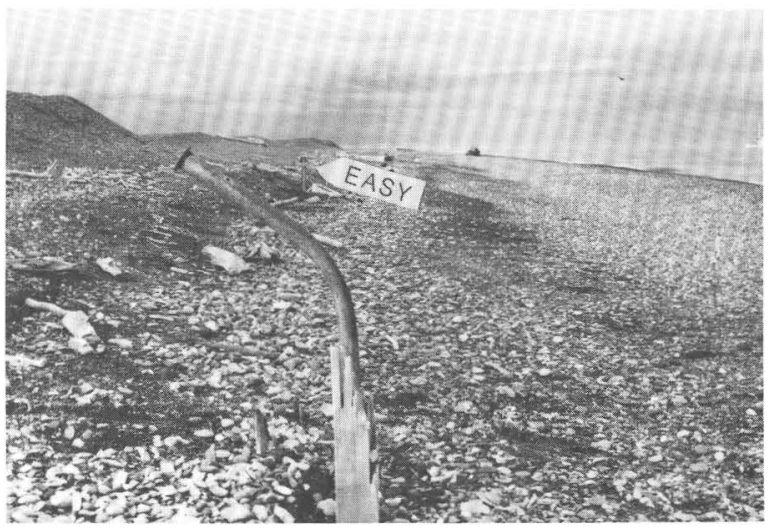

Figure 2. Photograph of triangulation station EASY, bent iron pipe (RM1), and broken witness post on seaward face of Icy Reef in August 1987. Placed in 1952 along the highest part of the island, these markers were first damaged by ice, then buried by gravel from ice pileups, and finally again exhumed by the sea. Ice pileups apparently deposited at least $1 \mathrm{~m}$ of gravel on top of the barrier island since 1952. Note 13-m-long R/V KARLUK for scale. 
Our most intriguing and significant finding is that ice pile-up is an important sediment supply mechanism for Arctic beaches and barrier islands, and can result in net accretion where the coast is stable. Ride-up, on the other hand, is geologically less important because it contributes little to no sediment. This investigation also shows that a comprehensive study of datable artifacts along poorly known stretches of the Arctic coast can provide much insight on its ice hazards and coastal processes.

\section{REFERENCES CITED}

Harden, Deborah, Barnes, P.W., and Reimnitz, Erk, 1977, Distribution and character of naleds in northeastern Alaska: Arctic, $v$. 30 , no. 1 , p. 28-40.

Kovacs, Austin, 1983, Shore ice ride-up and pile-up features, Part 1: Alaska's Beaufort Sea coast: Hanover, N.H., U.S. Army Cold Regions Research and Engineering Laboratory, CRREL Report 83-9, 51 p.

--- 1984, Shore ice ride-up and pile-up features, Part 2: Alaska's Beaufort Sea coast - 1983 and 1984: Hanover, N.H., U.S. Army Cold Regions Research and Engineering Laboratory, CRREL Report 84-26, 29 p.
Kovacs, Austin, and Sodhi, D.S., 1980, Shore ice pile-up: Field observations, models, theoretical analyses: Cold Regions Science and Technology, v. 2, p. 209-288.

Reimnitz, Erk, and Maurer, D.K., 1979, Effects of storm surges on the Beaufort Sea coast, northern Alaska: Arctic, v. 32, no. 4, p. 329-344.

Reimnitz, Erk, Graves, S.M., and Barnes, P.W., 1988, Beaufort Sea coastal erosion, sediment flux, shoreline evolution and the erosional shelf profile: U.S. Geological Survey Miscellaneous Investigations Map I-1182-G, 22 p.

Sodhi, D.S., and Kovacs, Austin, 1984, Forces associated with ice pile-up and ride-up, in Proceedings, International Association for Hydraulic Research, International Symposium on Ice, 7 th, Hamburg, v. IV, p. 239-262.

U.S. Department of Commerce, 1977, Horizontal Control Data: QUAD 691414, Station 1004, National Ocean Survey.

Reviewers: P.R. Carlson and R.L. Phillips

Geologic Studies in Alaska by the U.S. Geological Survey during 1987: John P. Galloway and Thomas D. Hamilton, editors, U.S. Geological Survey Circular 1016. 


\section{BIBLIOGRAPHIES}

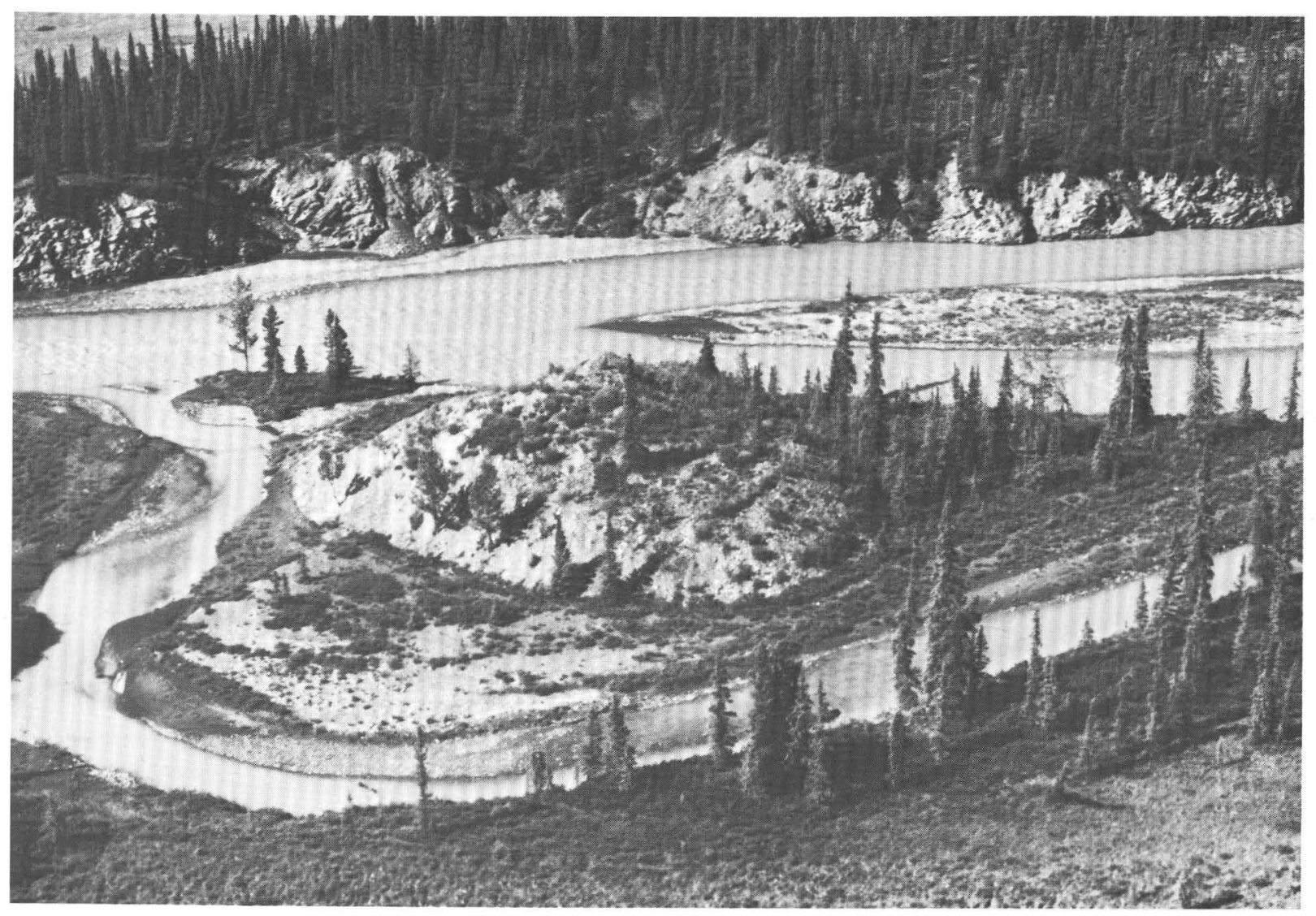

Pingo in channel of Middle Fork Chandalar River, south-central Brooks Range. Stream channel has been forced to bifurcate around the actively growing ice-cored mound. Photograph by T.D. Hamilton. 


\title{
Reports about Alaska in USGS Publications Released in 1987
}

\author{
Compiled by Ellen R. White
}

[Some reports dated 1986 did not become available until 1987; they are included in this listing.]

\section{[Abbreviations used:}

"B 1778" for: Bird, K.J., and Magoon, L.B. eds., Petroleum geology of the northern part of the Arctic National Wildlife Refuge, northeastern Alaska: U.S. Geological Survey Bulletin 1778.

"C 995" for: Sachs, J.S., ed., USGS Research on Mineral Resources - 1987, program and abstracts, third annual V.E. McKelvey Forum on Mineral and Energy Resources: U.S. Geological Survey Circular 995. ellen page

"C 998" for: Hamilton, T.D., and Galloway, J.P., eds., Geologic studies in Alaska by the U.S. Geological Survey during 1986: U.S. Geological Survey Circular 998. (Short papers describing results of recent geologic investigations and lists of published reports.]

Anders, D.E., Magoon, L.B., and Lubeck, S.C., 1987, Geochemistry of surface oil shows and potential source rocks: B 1778, p. 181-198.

Arbogast, B.F., Bailey, E.A., and Frisken, J.G., 1987, Analytical results and sample locality maps of stream-sediment, heavy-mineral-concentrate, and rock samples from the Port Moller, Stepovak Bay, and Simeonof Island quadrangles, Alaska: U.S. Geological Survey Open-File Report 87-502, 122 p., scale l:250,000, 2 pls.

Arbogast, B.F., Madden, Dawn, Hoffman, J.D., and O'Leary, R.M., 1987, Analytical results and sample locality map of stream-sediment, moraine-sediment, and heavy-mineralconcentrate samples from the Anchorage quadrangle, south-central Alaska: U.S. Geological Survey Open-File Report 87-151, 175 p., scale l:250,000, $1 \mathrm{pl}$.

Bailey, E.A., Folger, P.F., Thompson, W.B., Sutley, S.J., Schmidt, J.M., and Karl, S.M., 1987, Analytical results and sample locality map of stream-sediment and heavy-mineral-concentrate samples from the Baird Mountains quadrangle, Alaska: U.S. Geological Survey Open-File Report $87-65,155$ p., scale $1: 250,000,1 \mathrm{pl}$.

Bailey, E.A., Lee, G.K., and Light, T.D., 1987, Semiquantitative emission spectrographic analyses of stream-sediment samples collected in the Livengood and western one-third of the Circle $1^{\circ} \times 3^{\circ}$ quadrangles, Alaska: U.S. Geological Survey Open-File Report 87-264, 74 p., scale 1:250,000, $1 \mathrm{pl}$.

Bailey, E.A., Sutley, S.J., Arbogast, B.F., Willson, W.R., and Church, S.E., 1987, Analytical results and sample locality map of stream-sediment and heavy-mineral-concentrate samples from the Mount Katmai quadrangle, and portions of the Naknek, Afognak, and Iliamna quadrangles, Alaska: U.S. Geological Survey Open-File Report 86-586, 126 p., scale l:250,000, 1 pl.
Barnes, P.W., Graves, Scot, and Reimnitz, Erk, 1987, Beaufort Sea coastal currents: A divergence near Barter Island, Alaska?: C 998, p. 139-142.

Barton, C.C., and Light, T.D., 1987, Structural fabric analysis of the Perseverance Slate and goldbearing quartz veins in the south ore body of the Alaska-Juneau lode system, southeastern Alaska: C 998, p. 110-112.

Barton, H.N., 1987, Sample locality map and results of carrier distillation emission spectrographic analysis of stream-sediment samples from the Chandler Lake quadrangle, Alaska: U.S. Geological Survey Open-File Report 87-21, 7 p., scale $1: 250,000,1 \mathrm{pl}$.

Bartsch-Winkler, Susan and Schmoll, H.R., 1987, Earthquake-caused sedimentary couplets in the Upper Cook Inlet region: C 998, p. 92-95.

Beavan, John, 1987, Crustal deformation measurements in the Shumagin seismic gap, in National Earthquake Hazards Reduction Program; summaries of technical reports v. 24: U.S. Geological Survey Open-File Report 87-374, p. 207-214.

Billington, Selena, and Kisslinger, Carl, 1987, Central Aleutian Islands seismic network, in National Earthquake Hazards Reduction Program; summaries of technical reports v. 24: U.S. Geological Survey Open-File Report 87-374, p. 13-15.

Bird, K.J., and Bader, J.W., 1987, Regional geologic setting and history of petroleum exploration: B 1778, p. 17-25.

Bird, K.J., and Magoon, L.B., eds., 1987, Petroleum geology of the northern part of the Arctic National Wildlife Refuge, northeastern Alaska: U.S. Geological Survey Bulletin 1778, 329 p., 5 pls.

Bird, K.J., and Molenaar, C.M., 1987, Stratigraphy: B 1778, p. 37-59.

Bird, K.J., Griscom, S.B., Bartsch-Winkler, Susan, and 
Giovanetti, D.M., 1987, Petroleum reservoir rocks: B 1778 , p. 79-99.

Blodgett, R.B., Wheeler, K.L., Rohr, D.M., Harris, A.G., and Weber, F.R., 1987, A Late Ordovician age reappraisal for the upper fossil Creek Volcanics, and possible significance for glacioeustasy: C 998, p. 54-58.

Box, S.E., and Murphy, J.M., 1987, Late Mesozoic structural and stratigraphic framework, eastern Bethel quadrangle, southwestern Alaska: C 998, p. 78-82.

Brabets, T.P., 1987, Quantity and quality of urban runoff from the Chester Creek Basin, Anchorage, Alaska: U.S. Geological Survey Water-Resources Investigations Report WRI 86-4312, 58 p.

Brew, D.A., 1987, Cenozoic magmatism in southeastern Alaska: C 998, p. 137.

Brew, D.A., and Ford, A.B., 1987, The Meade Glacier fault--An important tectonic boundary in the northern Cordillera, southeastern Alaska: C 998, p. 113-115.

Brew, D.A., Grybeck, D.J., Cathrall, J.B., Karl, S.M., Koch, R.D., Barnes, D.F., Griscom, A., and Berg, H.C., 1987, Mineral-resource assessment process and results, Petersburg project area, southeastern Alaska [abs.]: C 995, p. 8-9.

Brew, D.A., Himmelberg, G.R., Ford, A.B., and Jachens, R.C., 1987, Ultramafic and mafic sills in the vicinity of the Treadwell gold deposits, Douglas Island, southeastern Alaska: C 998, p. 119-123.

Brewer, M.C., 1987, Surficial geology, permafrost, and physical processes: B 1778, p. 27-36.

Brockman, S.R., Espinosa, A.F., and Michael, J.A., 1987, Digital intensity catalog of earthquakes felt in Alaska and Aleutian Islands, 1786-1981: U.S. Geological Survey Open-File Report 87-68, $12 \mathrm{p}$.

Brown, C.S., Rasmussen, L.A., and Meier, M.F., 1986, Bed topography inferred from airborne radioecho sounding of Columbia Glacier, Alaska: U.S. Geological Survey Professional Paper 1258-G, 26 p.

Bruns, T.R., Fisher, M.A., Carlson, P.R., Rearic, D.M., and Parson, L.M., 1987, GLORIA images obtained in the TACT corridor of the Aleutian convergent margin, northern Gulf of Alaska [abs.]: C 998, p. 170.

Bruns, T.R., Fisher, M.A., Leinbach, W.J., Jr., and Miller, J.J., 1987, Regional structure of rocks beneath the coastal plain: B 1778, p. 249-254.

Bruns, T.R., Mann, D.M., and Sliter, R.W., 1987, Multichannel seismic-reflection profiles collected in 1978 in the eastern Gulf of Alaska: U.S. Geological Survey Open-File Report 87-148, 5 p.

Bruns, T.R., Vallier, T.L., Pickthorn, L.B., and von Huene, Roland, 1987, Volcanic-arc dacite and early Miocene basalt dredged from the Shumagin margin, Alaska: C 998, p. 143-146.

Callahan, J.E., Brougham, G.W., and Bascle, R.J., 1987, Economically recoverable oil resources: $B$ 1778 , p. 299-307.

Campbell, D.L., 1987, Profiles showing models of magnetic structures in accreted terranes of south-central Alaska: U.S. Geological Survey
Miscellaneous Field Studies Map MF-1912, scale $\mathrm{l}: 500,000,2$ sheets.

Carlson, P.R., Marlow, M.S., Parson, L.M., and Somers, M.L., 1987, GLORIA investigation of the Exclusive Economic Zone in the deep Bering Sea: U.S. Geological Survey Open-File Report 87-72, 16 p.

Case, J.E., and Nelson, W.H., 1986, Maps showing aeromagnetic survey and geologic interpretation of the Lake Clark quadrangle, Alaska: U.S. Geological Survey Miscellaneous Field Studies Map MF-1114-E, 2 sheets.

Cathrall, J.B., Antweiler, J.C., and Mosier, E.L., 1987, Occurrence of platinum in gold samples from the Tolovana and Rampart mining districts, Livengood quadrangle, Alaska: U.S. Geological Survey Open-File Report 87-330, 10 p., 1 pl.

Cathrall, J.B., Brosge, W.P., and Dillon, J.T., 1987, Stream-sediment geochemical anomalies in the Doonerak area, Wiseman quadrangle, Brooks Range, Alaska: U.S. Geological Survey Open-File Report 87-139, 6 p.

Cathrall, J.B., Dillon, J.T., Hof $\mathrm{fman}$, J.D., Brosgé, W.P., and Bliss, J.D., 1987, Geochemical maps and evaluation of stream-sediment geochemical data of the Wiseman $1^{\mathbf{O}} \times 3^{\mathbf{O}}$ quadrangle, Brooks Range, Alaska: U.S. Geological Survey Open-File Report 87-12, 67 p., scale l:250,000, 2 pls.

Cathrall, J.B., McDanal, Steve, and Miesch, A.T., 1987, Selected geochemical data and geochemical plots from U.S. Department of Energy - National Uranium Resources Evaluation on sediment samples from the Table Mountain $1^{\circ}$ $x 3^{\circ}$ quadrangle, Brooks Range, Alaska: U.S. Geological Survey Open-File Report 87-424, 55 p.

Church, S.E., 1987, Studies of lead isotopes in sulfide deposits from accreted terranes in the North American Cordillera [abs.]: C 995, p. 12-13.

Church, S.E., Delevaux, M.H., and Gray, J.E., 1987, $\mathrm{Pb}$-isotope data base for sulfides from Alaska, March 1987: U.S. Geological Survey Open-File Report 87-259, 44 p.

Collett, T.S., and Kvenvolden, K.A., 1987, Evidence of naturally occurring gas hydrates on the North Slope of Alaska: U.S. Geological Survey OpenFile Report 87-255, 8 p.

Collett, T.S., Kvenvolden, K.A., Magoon, L.B., and Bird, K.J., 1987, Geochemical and geologic controls of the inferred occurrence of natural gas hydrate in the Kuparuk 2D-15 well, North Slope, Alaska: C 998, p. 24-26.

Cooper, Alan, Hunter, Ralph, Huggett, Quentin, and Harris, Malcolm, 1987, GLORIA study of the Exclusive Economic Zone off Alaska - southern Bering Sea (Bowers basin) initial report for cruise F1-87-BS, 28 June to 27 July 1987: U.S. Geological Survey Open-File Report 87-579, 19 p.

Cooper, Alan, Stevenson, Andrew, Kenyon, Neil, and Bishop, Derek, 1986, GLORIA study of the Exclusive Economic Zone off Alaska - southern Bering Sea: initial report for cruise F4-86-BS, 3 September to 30 September 1986: U.S. Geological Survey Open-File Report 86-596, 19 p.

Cramer, C.H., May, S.D., Hanna, W.F., Grantz, Arthur, and Holmes, M.L., 1986, Reconnaissance magnetic anomaly map of the Chukchi Sea and 
adjacent northwest Alaska: U.S. Geological Survey Miscellaneous Investigations Series, Marine Geology Atlas, Chukchi Sea, I-1182-F, scale $1: 1,000,000,1$ sheet.

Cunningham, K.I., Roberts, A.A., and Donovan, T.J., 1987, Horizontal-gradient magnetic and helium surveys: B 1778, p. 209-218.

Czamanske, G.K., Bennett, P.C., Zientek, M.L., and others, 1986, Comprehensive bibliographies on mineralized and unmineralized layered mafic intrusions in the United States: U.S. Geological Survey Open-File Report 86-589-A, 97 p. [References for Alaska are intermingled with those for other states.]

Davis, A.S., Wong, F.L., Pickthorn, L.-B.G., and Marlow, M.S., 1987, Petrology, geochemistry and age of basanitoids dredged from the Bering Sea continental margin west of Navarin Basin: U.S. Geological Survey Open-File Report 87-407.

Detterman, R.L., Case, J.E., Wilson, F.H., and Yount, M.E., 1987, Geologic map of the Ugashik, Bristol Bay, and western part of Karluk quadrangles, Alaska: U.S. Geological Survey Miscellaneous Investigations Series Map I-1685, scale 1:250,000, 1 sheet.

Detterman, R.L., Wilson, F.H., Yount, M.E., and Miller, T.P., 1987, Quaternary geologic map of the Ugashik, Bristol Bay, and western part of Karluk quadrangles, Alaska: U.S. Geological Survey Miscellaneous Investigations Series Map I1801 , scale 1:250,000, 1 sheet.

Dolton, G.L., Bird, K.J., and Crovelli, R.A., 1987, Assessment of in-place oil and gas resources: $B$ 1778, p. 277-298.

Dubois, G.D., Wilson, F.H., and Shew, Nora, 1986, Map and tables showing potassium-argon age determinations and selected major-element chemical analyses from the Circle quadrangle, Alaska: U.S. Geological Survey Open-File Report 86-392, scale 1:250,000, 1 sheet.

---- 1987, Potassium-argon age determinations from the Port Moller and Stepovak Bay quadrangles, Alaska Peninsula: U.S. Geological Survey OpenFile Report 87-191, scale l:250,000, 1 sheet.

Duttweiler, K.A., 1987, Use of factor analysis in locating base metal mineralization in the Killik River quadrangle, Alaska: C 998, p. 27-30.

Espinosa, A.F., 1987, Seismic hazard studies, Anchorage, Alaska, in National Earthquake Hazards Reduction Program; summaries of technical reports v. 24: U.S. Geological Survey Open-File Report 87-374, p. 547-548.

Fischbein, S.A., 1987, Analysis and interpretation of ice-deformed sediments from Harrison Bay, Alaska: U.S. Geological Survey Open-File Report 87-262, 73 p.

Fisher, M.A., and Bruns, T.R., 1987, Structure of PreMississippian rocks beneath the coastal plain: B 1778 , p. 245-248.

Fogleman, K.A., Page, R.A., Lahr, J.C., and Stephens, C.D., 1987, Earthquake activity around Valdez, Alaska for 1983-1984: U.S. Geological Survey Open-File Report 87-58, 44 p.

Foland, R.L., and Lalla, D.J., 1987, Seismic-reflection data acquisition, processing, and interpretation: B 1778, p. 235-243.
Foley, R.C., 1987, Field surveying and topographic mapping in Alaska: 1947-83: U.S. Geological Survey Circular 991, 98 p., 1 pl. ["A chronological review of surveying activities in Alaska from 1947 to 1983 including a brief description of camp life and some of the hardships and unusual experiences encountered."]

Folger, P.F., Goldfarb, R.J., and Schmidt, J.M., 1987, Preliminary evaluation of geochemical anomalies in the Baird Mountains quadrangle, Alaska: C 998, p. 31-34.

Ford, A.B., and Brew, D.A., 1987, The Wright Glacier volcanic plug and dike swarm, southeastern Alaska: C 998, p. 116-118.

Foster, H.L., and Keith, T.E.C., 1987, Preliminary geology, including the Tintina fault system, of part of the southwestern Charley River quadrangle, Alaska: C 998, p. 59-61.

Foster, H.L., Keith, T.E.C., and Menzie, W.D., 1987, Geology of east-central Alaska: U.S. Geological Survey Open-File Report 87-188, 59 p. [Maps are page-size.]

Foster, H.L., Menzie, W.D., Cady, J.W., Simpson, S.L., Aleinikoff, J.N., Wilson, F.H., and Tripp, R.B., 1987, The Alaska Mineral Resource Assessment Program: Background information to accompany folio of geologic and mineral resource maps of the Circle quadrangle, Alaska: U.S. Geological Survey Circular 986, $22 \mathrm{p}$.

Friesen, W.B., and Howell, D.G., 1987, A mineralogical look at the purple and green phyllitic sheared breccia from the Hammond terrane, Chandalar D-6, Brooks Range, Alaska: U.S. Geological Survey Open-File Report 87-156, 5 p.

Fukuhara, C.R., 1986, Descriptions of plutons in the western part of the Juneau and parts of the adjacent Skagway 1:250,000 quadrangles, southeastern Alaska: U.S. Geological Survey Open-File Report 86-393, 58 p., scale l:250,000, 1 pl.

Galloway, J.P., 1987, A list and index of published radiocarbon dates for Alaska with a bibliography: U.S. Geological Survey Open-File Report 87-517-A, 117 p.

Galloway, J.P., 1987, Radiocarbon date list for Alaska to accompany USGS Open-File Report 87-517A: U.S. Geological Survey Open-File Report 87517-B. [5 $1 / 4^{\prime \prime}$ diskette formatted for IBM-PCs using DOS 2.0 in a standard ASCII format.]

Gamble, B.M., 1987, Gold veins of the Seward Peninsula [abs.]: C 995, p. 23.

Gardner, J.V., Karl, H.A., Huggett, Quentin, and Harris, M., 1986, Cruise report for EEZ-SCAN 86 Cruise F3-86, Zhemchug Canyon and central Aleutian Basin, Bering Sea, August 6, through September 1, 1986: U.S. Geological Survey OpenFile Report 86-597, 12 p.

Gautier, D.L., 1987, Petrology of Cretaceous and Tertiary reservoir sandstones in the Point Thomson area: B 1778, p. 117-122.

Gautier, D.L., Bird, K.J., and Colten-Bradley, V.A., 1987, Relationship of clay mineralogy, thermal maturity, and geopressure in wells of the Point Thomson area: B 1778, p. 199-207.

Gedney, Larry, 1987, Alaska earthquakes, 1983, in Stover, C.W., ed., United States earthquakes, 
1983: U.S. Geological Survey Bulletin 1698, p. 125.

Gehrels, G.E., and Saleeby, J.B., 1986, Geologic map of southern Prince of Wales Island, southeastern Alaska: U.S. Geological Survey Open-File Report 86-275, 33 p., scale 1:63,360, 1 pl.

Glass, R.L., 1987, Groundwater levels in Anchorage, Alaska, 1985: U.S. Geological Survey Open-File Report 87-543, 15 p., 1 pl.

---- 1987, Water resources near Dillingham in the Bristol Bay area, Alaska: U.S. Geological Survey Water-Resources Investigations Report WRI 874141, 27 p.

Goldfarb, R.J., and Smith, S.C., 1987, Geochemical map showing distribution of anomalous element suites in nonmagnetic heavy-mineral concentrates from the Chugach National Forest, Alaska: U.S. Geological Survey Miscellaneous Field Studies Map MF-1645-G, 18 p., scale $\mathrm{l}: 250,000,1 \mathrm{pl}$.

Grantz, Arthur, Dinter, D.A., and Culotta, R.C., 1987, Structure of the continental shelf north of the Arctic National Wildlife Refuge: B 1778, p. 271276.

Hamilton, T.D., and Galloway, J.P., 1987, Geologic studies in Alaska by the U.S. Geological Survey during 1986; introduction: C 998, p. 1.

Hamilton, T.D., and Galloway, J.P., eds., 1987, Geological studies in Alaska by the U.S. Geological Survey during 1986: U.S. Geological Survey Circular 998, 195 p.

Hamilton, T.D., Lancaster, G.A., and Trimble, D.A., 1987, Glacial advance of late Wisconsin (Itkillik II) age in the upper Noatak River Valley--A radiocarbon-dated stratigraphic record: C 998, p. 35-39.

Himmelberg, G.R., Loney, R.A., and Nabelek, P.I., 1987, Petrogenesis of gabbronorite at Yakobi and northwest Chichagof Islands, Alaska [abs.]: C 995, p. 30-31.

Hoffman, J.D., 1987, An application of oblique rotation $\mathrm{R}$-mode factor analysis in the Mount Hayes quadrangle, Alaska: C 998, p. 108.

Jones, D.L., Silberling, N.J., Coney, P.J., and Plafker, George, 1987, Lithotectonic terrane map of Alaska (west of the 141st meridian): U.S. Geological Survey Miscellaneous Field Studies Map MF-1874-A, scale 1:2,500,000, 1 sheet.

Kanamori, Hiroo, 1987, State of stress near seismic gaps, in National Earthquake Hazards Reduction Program; summaries of technical reports v. 24: U.S. Geological Survey Open-File Report 87-374, p. 258-259. [Includes 1986 Andreanof Islands earthquake.]

Karl, H.A., Carlson, P.R., Johnson, K.H., and Rearic, D.M., 1987, Grain-size parameters and constituent grain composition of surface sediment in Navarin basin province, Bering Sea: U.S. Geological Survey Open-File Report 87-64, 32 p.

Karl, H.A., Gardner, J.V., and Huggett, Quentin, 1987, GLORIA images of Zhemchug Canyon and Bering channel-fan system, Bering Sea: C 998, p. 147151.

Karl, S.M., Schmidt, J.M., Folger, Peter, Thompson, Bill, Long, Carl, Goldfarb, Richard, and
Ellersieck, Inyo, 1987, Mineral-resource assessment of the Baird Mountains quadrangle, western Brooks Range, Alaska [abs.]: C 995, p. 33-34.

Keith, T.E.C., Page, N.J, Oscarson, R.L., and Foster, H.L., 1987, Platinum-group element concentrations in a biotite-rich clinopyroxenite suite, Eagle C-3 quadrangle, Alaska: C 998, p. 62-66.

Kelley, J.S., and Foland, R.L., 1987, Structural style and framework geology of the coastal plain and adjacent Brooks Range: B 1778, p. 255-270.

Kisslinger, Carl, 1987, Seismicity patterns and the stress state in subduction-type seismogenic zones, in National Earthquake Hazards Reduction Program; summaries of technical reports v. 24: U.S. Geological Survey Open-File Report 87-374, p. 78-83. ["Aftershocks of the May 7, 1986 earthquake and other Aleutian Islands events," "Coda $Q$ in the Adak region before and after the 1986 Andreanof earthquake"]

Knott, J.M., Lipscomb, S.W., and Lewis, T.W., 1987, Sediment transport characteristics of selected streams in the Susitna River basin, Alaska: data for water year 1985 and trends in bedload discharge: U.S. Geological Survey Open-File Report 87-229, 51 p.

Koch, R.D., Brew, D.A., and Ford, A.B., 1987, Newly discovered molybdenite occurrence near Boundary Creek, Coast Mountains, southeastern Alaska: C 998, p. 124-125.

Krimmel, R.M., 1987, Columbia Glacier, Alaska: Photogrammetry data set $1981-82$ and 1984-85: U.S. Geological Survey Open-File Report 87-219, $104 \mathrm{p}$.

---- 1987, Columbia Glacier in 1986: 800 meter retreat: U.S. Geological Survey Open-File Report 87-207, 7 p.

Krimmel, R.M., and Sikonia, W.G., 1986, Velocity and surface altitude of the lower part of Hubbard Glacier, Alaska, August 1978: U.S. Geological Survey Open-File Report 86-549, 13 p.

Lahr, J.C., Stephens, C.D., Page, R.A., and Fogleman, K.A., 1987, Alaska seismic studies, in National Earthquake Hazards Reduction program; summaries of technical reports v. 24: U.S. Geological Survey Open-File Report 87-374, p. 20-26.

Lamke, R.D., and Bigelow, B.B., 1987, Floods of October 1986 in southcentral Alaska: U.S. Geological Survey Open-File Report 87-391, 31 p.

Lange, I.M., Nokleberg, W.J., Aleinikoff, J.N., and Church, S.E., 1987, Genesis and tectonic setting of volcanogenic massive sulfide deposits, eastern Alaska Range, Alaska [abs.]: C 995, p. 39-40.

Leinbach, W.J., Jr., Miller, J.J., and Lee, M.W., 1987, Seismic-reflection data processing: B 1778, p. 225-233.

Leonard, K.R., and Huber, D.F., 1987, Status of Alaska mineral resources data system: C 998, p. 15-18.

Light, T.D., Cady, J.W., Weber, F.R., McCammon, R.B., and Rinehart, C.D., 1987, Sources of placer gold in the southern part of the White Mountains Recreation Area, east-central Alaska: C 998, p. 67-69.

Lipscomb, S.W., 1987, Sediment-discharge data for the 
lower reach of Campbell Creek, Anchorage, Alaska: May to October 1986: U.S. Geological Survey Open-File Report 87-101, 8 p.

Loney, R.A., and Brew, D.A., 1987, Regional thermal metamorphism and deformation of the Sitka Graywacke, southern Baranof Island, southeastern Alaska: U.S. Geological Survey Bulletin 1779, $17 \mathrm{p}$.

Loney, R.A., Himmelberg, G.R., and Shew, Nora, 1987, Salt Chuck palladium-bearing ultramafic body, Prince of Wales Island: C 998, p. 126-127.

Luedke, R.G., and Smith, R.L., 1986, Map showing distribution, composition, and age of Late Cenozoic volcanic centers in Alaska: U.S. Geological Survey Miscellaneous Investigations Series Map I-1091-F, scale 1:1,000,000, 3 sheets.

Luepke, Gretchen, Molnia, B.F., and Hein, J.R., 1987, Comparison of multiple-year analyses of clay mineralogy of the Copper River System and the Gulf of Alaska: U.S. Geological Survey OpenFile Report 87-153, 1 sheet.

Madden, D.J., and Tripp, R.B., 1987, Geochemical signatures of mineral deposits and rock types as shown in stream sediments from the Chugach and Prince William terranes, Anchorage quadrangle, southern Alaska: U.S. Geological Survey OpenFile Report 87-131, 8 p.

---1 1987, Geochemical signatures of mineral deposits and rock types as shown in stream sediments from the Peninsular terrane, Anchorage quadrangle, southern Alaska: U.S. Geological Survey Open-File Report 87-129, 8 p.

Madden, D.J., Silberman, M.L., and Moore-Nall, Anita, 1987, Ages and geologic relationships in the Willow Creek gold mining district, southwestern Talkeetna Mountains, southern Alaska: U.S. Geological Survey Open-File Report 87-143, 12 p.

Magoon, L.B., Woodward, P.V., Banet, A.C., Jr., Griscom, S.B., and Daws, T.A., 1987, Thermal maturity, richness, and type of organic matter of source-rock units: B 1778, p. 127-179.

Mankinen, E.A., and Plafker, George, 1987, Paleomagnetic evidence for a latest Pliocene and early Pleistocene age of the upper Yakataga Formation on Middleton Island, Alaska: C 998, p. 132-136.

Marinai, R.K., 1987, Petrography and diagenesis of the Ledge Sandstone Member of the Triassic Ivishak Formation: B 1778, p. 101-115.

Marlow, M.S., Carlson, P.R., Dadisman, S.V., Rearic, D.M., Maple, E.J., and Parson, L.M., 1987, GLORIA side-scan and geophysical surveys of the central Bering Sea in 1986: C 998, p. 152-156.

Mayfield, C.F., Ellersieck, Inyo, and Tailleur, I.L., 1987, Reconnaissance geologic map of the Noatak C5, D5, D6, and D7 quadrangles, Alaska: U.S. Geological Survey Miscellaneous Investigations Series Map I-1814, scale 1:63,360, $1 \mathrm{pl}$.

McLean, Hugh, 1987, Petrology and reservoir potential of the Jago River Formation: B 1778, p. 123-126.

Menzie, W.D., Hua, Renmin, and Foster, H.L., 1987, Newly located occurrences of lode gold near Table Mountain, Circle quadrangle, Alaska: U.S. Geological Survey Bulletin 1682, 13 p.

Miller, M.L., and Bundtzen, T.K., 1987, Geology and mineral resources of the Iditarod quadrangle, west-central Alaska [abs.]: C 995, p. 46-47.

Molenaar, C.M., 1987, Introduction: B 1778, p. 3-6.

---- 1987, Principles of petroleum geology and exploration methods: B 1778, p. 7-15.

Molenaar, C.M., Bird, K.J., and Collett, T.S., 1986, Regional correlation sections across the North Slope of Alaska: U.S. Geological Survey Miscellaneous Field Studies Map MF-1907, 1 sheet.

Monger, J.W.H., and Berg, H.C., 1987, Lithotectonic terrane map of western Canada and southeastern Alaska: U.S. Geological Survey Miscellaneous Field Studies Map MF-1874-B, 12 p., scale $1: 2,500,000,1$ sheet.

Moore, E.J., and Addicott, W.O., 1987, The Miocene Pillarian and Newportian (molluscan) stages of Washington and Oregon and their usefulness in correlations from Alaska to California, in Yochelson, E.L., ed., Shorter contributions to paleontology and stratigraphy: U.S. Geological Survey Bulletin 1664, p. A1-A13, 4 pls.

Moriwaki, Yoshiharu, and Idriss, I.M., 1987, Evaluation of ground failure susceptibility, opportunity and potential in Anchorage, Alaskan urban area, in National Earthquake Hazards Reduction Program; summaries of technical reports v. 24: U.S. Geological Survey Open-File Report 87-374, p. 611-615.

Morrissey, S.-T., 1987, Tiltmeter and earthquake prediction program in S. California and at Adak, AK, in National Earthquake Hazards Reduction Program; summaries of technical reports v. 24: U.S. Geological Survey Open-File Report 87-374, p. 416-421.

Mosier, E.L., Cathrall, J.B., Antweiler, J.C., and Tripp, R.B., 1987, Some features of the composition and distribution of geochemical types of placer gold in the Koyukuk-Chandalar mining district, Alaska [abs.]: C 995, p. 50-51.

Mullen, M.W., 1987, Petrology and provenance of sandstones of the Naknek Formation, Alaska Peninsula: C 998, p. 86-90.

Murphy, J.M., 1987, Early Cretaceous cessation of terrane accretion, northern Eek Mountains, southwestern Alaska: C 998, p. 83-85.

Nelson, S.W., Blome, C.D., and Karl, S.M., 1987, Late Triassic and Early Cretaceous fossil ages from the McHugh Complex, southern Alaska: C 998, p. 96-98.

Newberry, R.J., and Brew, D.A., 1987, The AlaskaJuneau gold deposit; remobilized syngenetic versus exotic epigenetic origin: C 998, p. 128131.

Phillips, R.L., and Colgan, M.W., 1987, Vibracore stratigraphy of the northeastern Chukchi Sea: C 998, p.157-160.

Pickthorn, W.J., Goldfarb, R.J., and Leach, D.L., 1987, "Mesothermal" gold--A metamorphic connection? [abs.]: C 995, p. 57.

Reed, K.M., and Marks, J.K., 1987, Bibliography and index of articles in the series of U.S. Geological Survey Circulars devoted to geologic research and accomplishments in Alaska 1975-1986: U.S. Geological Survey Open-File Report 87-420, 110 p. 
Reeder, J.W., and Lahr, J.C., 1987, Seismological aspects of the 1976 eruptions of Augustine Volcano, Alaska: U.S. Geological Survey Professional Paper 1768, 32 p.

Reimnitz, Erk, and Kempema, E.W., 1987, Thirty-fouryear shoreface evolution at a rapidly retreating arctic coastal site: C 998, p. 161-164.

Repenning, C.A., Brouwers, E.M., Carter, L.D., Marincovich, Louie, Jr., and Ager, T.A., 1987, The Beringian ancestry of Phenacomys (Rodentia: Cricetidae) and the beginning of the modern Arctic Ocean borderland biota: U.S. Geological Suyrvey Bulletin 1687, 31 p., 1 pl.

Repetski, J.E., Carter, Claire, Harris, A.G., and Dutro, J.T., Jr., 1987, Ordovician and Silurian fossils from the Doonerak anticlinorium, central Brooks Range, Alaska: C 998, p. 40-42.

Riehle, J.R., Detterman, R.L., Yount, M.E., and Miller, J.W., 1987, Preliminary geologic map of the Mount Katmai quadrangle and portions of the Afognak and Naknek quadrangles, Alaska: U.S. Geological Survey Open-File Report 87-593, scale $1: 250,000,1$ sheet.

Riehle, J.R., Meyer, C.E., Ager, T.A., Kaufman, D.S., and Ackerman, R.E., 1987, The Aniakchak tephra deposit, a late Holocene marker horizon in western Alaska: C 998, p. 19-22.

Riehle, J.R., Yount, M.E., and Miller, T.P., 1987, Petrography, chemistry, and geologic history of Yantarni Volcano, Aleutian Volcanic Arc, Alaska: U.S. Geological Survey Professional Paper 1761, 27 p., scale 1:63,360, 1 pl.

Robbins, S.L., 1987, Gravity interpretation of the coastal plain: B 1778 , p. 219-224.

Rosenblum, Sam, Carlson, R.R., Nishi, J.M., and Overstreet, W.C., 1987, Platinum-group elements in magnetic concentrate from the Goodnews Bay district, Alaska: U.S. Geological Survey Bulletin 1660 .

Sachs, J.S., ed., 1987, USGS Research on Mineral Resources - 1987, program and abstracts, third annual V.E. McKelvey Forum on Mineral and Energy Resources: U.S. Geological Survey Circular 995, 82 p.

Schmidt, J.M., and Folger, P.F., 1987, Organic carbon occurrence and content in carbonate rocks from the Omar copper prospect, Baird Mountains, Alaska: C 998, p. 43-46.

Schmoll, H.R., and Yehle, L.A., 1987, Surficial geologic map of the northwestern quarter of the Tyonek A-4 quadrangle, south-central Alaska: U.S. Geological Survey Miscellaneous Field Studies Map MF-1934, scale l:31,680, 1 sheet.

Seitz, H.R., Thomas, D.S., and Tomlinson, Bud, 1986, The storage and release of water from a large glacier-dammed lake: Russell Lake near Yakutat, Alaska, 1986: U.S. Geological Survey Open-File Report 86-545, 10 p.

Snyder, E.F., compiler, 1987, Activities of the Alaska District Water Resources Division, U.S. Geological Survey, 1987: U.S. Geological Survey Open-File Report 87-38, 24 p.

Sohn, I.G., 1987, Middle and Upper Triassic marine ostracoda from the Shublik Formation, northeastern Alaska, in Yochelson, E.L., ed., Shorter contributions to paleontology and stratigraphy: U.S. Geological Survey Bulletin 1664 , p. C1-C24, 11 pls.

Spicer, R.A., and Parrish, J.T., 1987, Plant megafossils, vertebrate remains, and paleoclimate of the Kogosukruk Tongue (late Cretaceous), North Slope, Alaska: C 998, p. 4748.

Stanley, R.G., 1987, Effects of weathering on petroleum-source evaluation of coals from the Suntrana Formation near Healy, Alaska: C 998, p. 99-103.

---- 1987, Thermal maturity and petroleum-source potential of the Cantwell Formation (Paleocene), Alaska Range: C 998, p. 104-107.

Stephens, C.D., Page, R.A., Fogleman, K.A., and Lahr, J.C., 1987, Southern Alaska seismicity, 1983, in Stover, C.W., ed., United States earthquakes, 1983: U.S. Geological Survey Bulletin 1698, p. 127-130.

Still, P.J., and Brunett, J.O., 1987, Ground-water levels in Alaska, water year 1984: U.S. Geological Survey Open-File Report 87-230, 308 p.

Sutley, S.J., O'Leary, R.M., Lee, G.K., and Light, T.D., 1987, Analytical results and sample locality map of stream-sediment, moss-trap-sediment, and heavy-mineral-concentrate samples from the White Mountains Recreation Area, Livengood and Circle quadrangles, east-central Alaska: U.S. Geological Survey Open-File Report 87-285, 110 p., scale l:63,360, 2 pls.

Sutley, S.J., Ryder, J.T., Light, T.D., and Weber, F.R., 1987, Analytical results and sample locality map of rock samples from the White Mountains Recreation Area, Livengood and Circle quadrangles, east-central Alaska: U.S. Geological Survey Open-File Report 87-284, 61 p., scale l:63,360, 2 pls.

Taber, John, 1987, Seismic monitoring of Shumagin seismic gap, Alaska, in National Earthquake Hazards Reduction Program; summaries of technical reports v. 24: U.S. Geological Survey Open-File Report 87-374, p. 40-41.

Taber, John, and Jacob, K.H., 1987, Analysis of seismic data from the Shumagin seismic gap, Alaska, in National Earthquake Hazards Reduction Program; summaries of technical reports v. 24: U.S. Geological Survey Open-File Report 87-374, p. 300-302.

Taber, John, Luchman, M.A., and Rosen, S., 1987, Earthquake monitoring in the Shumagin seismic gap and eastern Aleutians, Alaska, 1983, in Stover, C.W., ed., United States earthquakes, 1983: U.S. Geological Survey Bulletin 1698, p. 125-127.

Tolson, R.B., Grantz, Arthur, and Mann, D.M., 1987, Multichannel seismic-reflection data from the southern Chukchi Sea: U.S. Geological Survey Open-File Report $87-19,7$ p., scale 1:500,000, 1 pl.

Townshend, J.B., and others, 1987, Preliminary geomagnetic data, College Observatory, Fairbanks, Alaska: U.S. Geological Survey OpenFile Report 87-300 A-I. [Each monthly report has its own letter designation; authorship and page length vary.] 
Tripp, R.B., Crim, W.D., Hoffman, J.D., O'Leary, R.M., and Risoli, D.A., 1986, Mineralogical and geochemical maps showing the distribution of selected minerals and elements found in the minus-80-mesh stream-sediment and related minus-30-mesh heavy-mineral-concentrate samples from the Circle quadrangle, Alaska: U.S. Geological Survey Open-File Report 83-170 F, G, H, 7 p., scale 1:250,000, 6 pls.

U.S. Geological Survey, 1987, Arctic Alaska vegetation and land cover, 1981: U.S. Geological Survey Land Use and Land Cover Map L-0207, scale $1: 250,000$. [Lat. $68^{\circ}$ to $69^{\circ}$, long. $144^{\circ}$ to $147^{\circ}$.]

---- 1987, Beechey Point, Alaska, vegetation and land cover: U.S. Geological Survey Land Use and Land Cover Map L-0211, scale 1:250,000. [Lat. $70^{\circ}$ to $71^{\circ}$, long. $147^{\circ}$ to $150^{\circ}$.]

---- 1987, Pumpage data from public-supply wells at Anchorage, Alaska, 1957-1985: U.S. Geological Survey Open-File Report 86-542, 48 p., 1 pl.

---- 1987, Valdez, Alaska, vegetation and land cover: U.S. Geological Survey Land Use and Land Cover Map L-0209, scale $1: 250,000$. [Lat. $61^{\circ}$ to $62^{\circ}$, long., $144^{\circ}$ to $147^{\circ}$.]

---- 1987, Vegetation and land cover, Tetlin National Wildlife Refuge, Alaska: U.S. Geological Survey Miscellaneous Investigation Series Map I-1813, scale $1: 250,000,1$ sheet [color].

Updike, R.G., 1987, Geologic mapping along the Border Ranges fault zone, Anchorage, Alaska, in National Earthquake Hazards Reduction Program; summaries of technical reports v. 24: U.S. Geological Survey Open-File Report 87-374, p. 588-589.

Updike, R.G., and Carpenter, B.A., 1986, Engineering geology of the Government Hill area, Anchorage, Alaska: U.S. Geological Survey Bulletin 1588, 32 p.

Updike, R.G., and Oscarson, R.L., 1987, An atlas of microfabrics of the Bootlegger Cove Formation, using the scanning electron microscope, rev. Nov. 1986: U.S. Geological Survey Open-File Report 87-60, 19 p., 48 pls.

Vallier, T.L., and Herman, B.M., 1987, Petrology, age, and original tectonic setting of basalt from the St. George basin Cost No. 1 Well, southern Bering
Sea: C 998, p. 165-169.

Walker, K.-M., York, James, Murphy, Dennis, and Sloan, C.E., 1986, Digital data base of lakes on the North Slope, Alaska: U.S. Geological Survey Water-Resources Investigations Report WRI 864143, $13 \mathrm{p}$.

Wheeler, K.L., Forbes, R.B., Weber, F.R., and Rinehart, C.D., 1987, Lithostratigraphy, petrology, and geochemistry of the Ordovician Fossil Creek Volcanics, White Mountains, eastcentral Alaska: C 998, p. 70-73.

White, E.R., compiler, 1987, Reports about Alaska in non-USGS publications released in 1986 which include USGS authors, marked by an asterisk (*): C 998, p. 181-186.

White, E.R., compiler, 1987, Reports about Alaska in USGS publications released in 1986: C 998, p. 172-180.

Wilson, F.H., and O'Leary, R.M., 1987, Tables showing analyses of semiquantitative spectrometry of rock samples collected in the Ugashik, Bristol Bay, and western part of the Karluk quadrangles, Alaska: U.S. Geological Survey Open-File Report 87-419, 34 p.

Wolfe, S.C., Barnes, P.W., Rearic, D.M., and Reimnitz, Erk, 1987, Quaternary seismic stratigraphy of the inner continental shelf north of the Arctic National Wildlife Refuge: B 1778, p. 61-78.

Yeend, Warren, 1987, Placer gold related to mafic schist (?) in the Circle district, Alaska: C 998, p. 74-76.

Yehle, L.A., and Schmoll, H.R., 1987, Surficial geologic map of the Anchorage B-7NE quadrangle, Alaska: U.S. Geological Survey Open-File Report $87-416,20$ p., scale 1:25,000, 2 pls.

1987, Surficial geologic map of the Anchorage B7 NW quadrangle, Alaska: U.S. Geological Survey Open-File Report 87-168, 11 p., scale 1:25,000, 2 pls.

Yount, M.E., Miller, T.P., and Gamble, B.M., 1987, The 1986 eruptions of Augustine Volcano, Alaska: Hazards and effects: C 998, p. 4-13.

Zayatz, M.R., 1987, Petrography of the Baird Mountains schistose lithologies, northwestern Alaska: C 998, p. 49-52. 


\title{
Reports about Alaska in Non-USGS Publications Released in 1987 Which Include USGS Authors
}

\author{
Compiled by Ellen R. White
}

[Some reports dated 1986 did not become available until 1987; they are included in this listing. USGS authors are marked by asterisks (*).]

\author{
Abbreviations used: \\ "North Slope geology" for: Tailleur, Irv, and Weimer, Paul, eds., Alaskan North Slope geology: \\ Bakersfield, Calif., Society of Economic Paleontologists and Mineralogists, Pacific Section \\ "Eos" for: Eos [American Geophysical Union Transactions] \\ "GSA" for: Geological Society of America, Abstracts with Programs
}

*Affolter, R.H., and *Stricker, G.D., 1987, Geochemistry of coal from the Cretaceous Corwin and Chandler Formations, National Petroleum Reserve in Alaska (NPRA): North Slope geology: v. 1, p. 217-224.

*Albert, N.R., Evitt, W.R., and Stein, J.A., 1986, Lacrymodinium, n. gen., a gonyaulacoid dinoflagellate with intercalary archeopyle from the Jurassic and Early Cretaceous of California and Alaska: Micropaleontology, v. 32, no. 4, p. 303-315, pls. 1-2.

*Aleinikoff, J.N., *Dusel-Bacon, Cynthia, *Foster, H.L., and *Nokleberg, W.J., 1987, Lead isotope fingerprinting of tectono-stratigraphic terranes, east-central Alaska: Canadian Journal of Earth Sciences, v. 24, no. 10, p. 2089-2098.

*Arth, J.G., 1987, Regional isotopic variations in the Cretaceous plutons of northern Alaska [abs.]: GSA, v. 19 , no. 6, p. 355 .

Avè Lallemant, H.G., *Kelley, J.S., and Phelps, J.C., 1987, Kinematic analysis of range-front thrust faulting near Anaktuvuk Pass, north-central Brooks Range, Alaska: North Slope geology, v. 2, p. 639-645.

*Barker, Fred, 1987, Cretaceous Chisana Island arc of Wrangellia, eastern Alaska [abs.]: GSA, v. 19, no. 7 , p. 580 .

*Barker, Fred, and *Arth, J.G., 1987, Coast batholith, southeastern Alaska [abs.]: GSA, v. 19, no. 6, p. 356.

*Barnes, D.F., 1987, Gravity anomaly at a Pleistocene lake bed in NW Alaska interpreted by analogy with Greenland's Lake Taserssauq and its floating ice tongue: Journal of Geophysical Research, v. 92, no. 9B, p. 8976-8984.

*Barnes, P.W., *Asbury, J.L., *Rearic, D.M., and *Ross, C.R., 1987, Ice erosion of a sea-floor knickpoint at the inner edge of the stamukhi zone, Beaufort Sea, Alaska: Marine Geology, v. 76, no. 3-4, p. 207-222.
Beard, J.S., and *Barker, Fred, 1987, Gabbro and anorthosite cumulates in the Wrangellia arc-back arc substructure, southern Alaska [abs.]: GSA, v. 19 , no. 7 , p. 583 .

*Berge, P., *Mooney, W.D., and *Murphy, J.M., 1987, Highly-reflective crust identified in a 240channel intermediate-offset seismic reflection experiment in central interior Alaska [abs.]: Eos, v. 68 , no. 44 , p. 1457 .

*Bernstein, L.R., and ${ }^{*}$ Cox, D.P., 1986, Geology and sulfide mineralogy of the Number One orebody, Ruby Creek copper deposit, Alaska: Economic Geology, v. 81, no. 7, p. 1675-1689.

*Bernstein, L.R., and *Cox, D.P., 1987, Geology and sulfide mineralogy of the Number One orebody, Ruby Creek copper deposit, Alaska [abs.]: North Slope geology, v. 1, p. 285. [Reprinted from: Economic Geology, v. 81, p. 1675, 1986.]

*Bird, K.J., 1987, The framework geology of the North Slope of Alaska as related to oil-source rock correlation: North Slope geology, v. 1, p. 121143. [Reprinted from: Magoon, L.B., and Claypool, G.E., eds., 1985, Alaska North Slope oil/rock correlation study: American Association of Petroleum Geologists, Studies in Geology no. 20, p. 3-29.]

*Bird, K.J., 1987, North Slope oil and gas: the Barrow Arch paradox [abs.]: North Slope geology, v. 1, p. 41.

*Blome, C.D., 1987, Paleogeographic significance of lower Mesozoic radiolarians from the Brooks Range, Alaska: North Slope geology, v. 1, p. 371380 .

Boak, J.M., Turner, D.L., Henry, D.J., *Moore, T.E., and Wallace, W.K., 1987, Petrology and K-Ar ages of the Misheguk igneous sequence--an allochthonous mafic and ultramafic complex--and its metamorphic aureole, western Brooks Range, Alaska: North Slope geology, v. 2, p. 737-745.

*Bohannon, R.G., Dobson, M.R., *Edwards, B.D., and 
Jacobs, C.L., 1987, Tectonies of north Pacific Ocean basin: western Aleutian Island region [abs.]: Eos, v. 68, no. 44, p. 1486.

*Box, S.E., 1987, Late Cretaceous or younger SWdirected extensional faulting: Cosmos Hills, Brooks Range, Alaska [abs.]: GSA, v. 19, no. 6, p. 361.

*Box, S.E., and *Patton, W.W., Jr., 1987, Early Cretaceous evolution of the Yukon-Koyukuk basin and its bearing on the development of the Brookian orogenic belt, Alaska [abs.]: North Slope geology, v. 2, p. 833.

*Brew, D.A., 1987, Late Mesozoic and Cenozoic magmatism in the northern Cordillera: southeastern Alaska [abs.]: GSA, v. 19, no. 6, p. 361.

*Brew, D.A., *Ford, A.B., and Himmelberg, G.R., 1987, Late Cretaceous sedimentation, volcanism, plutonism, metamorphism and deformation in the northern Cordillera, southeastern Alaska [abs.]: GSA, v. 19 , no. 7 , p. 600 .

*Brouwers, E.M., Clemens, W.A., Spicer, R.A., *Ager, T.A., *Carter, L.D., and *Sliter, W.V., 1987, Dinosaurs on the North Slope, Alaska: High latitude, latest Cretaceous environments: Science, v. 238, no. 4822, p. 1608-1610.

*Cady, J.W., 1987, Aeromagnetic map of Alaska, lat. $65^{\circ}-68^{\circ}$ N., long. $141^{8}-162^{\circ}$ W. [abs.]: GSA, v. 19 , no. 6 , p. 364 .

----- 1987, Preliminary geophysical interpretation of the oceanic terranes of interior and western Alaska: Evidence for thick crust of intermediate density, in Leitch, E.C., and Scheibner, Erwin, eds., Terrane accretion and orogenic belts: Washington, D.C., American Geophysical Union, Geodynamics Series v. 19, p. 301-305.

*Carlson, P.R., *Cooper, A.K., *Gardner, J.V., *Karl, H.A., *Marlow, M.S., *Stevenson, A.J., Huggett, Q., Kenyon, N., and Parson, L., 1987, GLORIA side-scan imagery of Aleutian basin Bering Sea slope, and abyssal plain [abs.]: American Association of Petroleum Geologists Bulletin, v. 71 , no. 5 , p. 536 .

---- 1987, Long-range sidescan sonar and geophysical survey of the Aleutian Basin: Eos, v. 68, no. 9, p. 122-123.

*Carlson, P.R., *Marlow, M.S., *Rearic, D.R., and Parson, L.M.,1987, The GLORIA view of seafloor processes in Navarinsky and Pervenets Canyons, Bering Sea, Alaska [abs.]: Eos, v. 68, no. 44, p. 1316.

*Carter, L.D., 1987, Late Pleistocene marine transgressions of the Alaskan arctic coastal plain [abs.]: North Slope geology, v. 1, p. 541.

* Carter, L.D., Heginbottom, J.A., and Woo, Ming-ko, 1987, Arctic lowlands, in Graf, W.L., ed., Geomorphic systems of North America: Geological Society of America, Decade of North American Geology, Centennial Special Volume 2, p. 583-628.

*Cochrane, G.R., *Cooper, A.K., *Hunter, R., *Huggett, Q., and Harris, M., 1987, GLORIA side-scan survey of the southwestern Bering Sea basin, Alaska [abs.]: Eos, v. 68, no. 44, p. 1498 .

*Collett, T.S., 1987, Physical parameters controlling gas hydrate stability and distribution on the
North Slope, Alaska [abs.]: American Association of Petroleum Geologists Bulletin, v. 71, no. 5, p. 541.

*Collett, T.S., *Bird, K.J., and *Molenaar, C.M., 1987, Cretaceous and Tertiary (Brookian) depositional style of the Barrow Arch, North Slope, Alaska [abs.]: North Slope geology, v. 1, p. 478.

*Cook, H.E., *Magoon, L.B., *Stanley, R.G., and *Casas, Arturo, 1987, Carbonate submarine fans and aprons in frontier petroleum region-Carboniferous Calico Bluff Formation, eastcentral Alaska [abs.]: American Association of Petroleum Geologists Bulletin, v. 71, no. 5, p. 542.

*Davis, A.S., *Pickthorn, L.G., *Vallier, T.L., and *Marlow, M.S., 1987, Eocene arc volcanism along the Beringian margin: Implications for relocation of the plate boundary to the Aleutian arc [abs.]: Eos, v. 68 , no. 44 , p. 1516 .

Davis, D.M., and *von Huene, Roland, 1987, Inferences on sediment strength and fault friction from structures at the Aleutian trench: Geology, v. 15 , no. 6, p. 517-522.

*Dickinson, K.A., 1987, Profundal sideritic mudstone from an Eocene lake in Alaska [abs.]: American Association of Petroleum Geologists Bulletin, v. 71, no. 8, p. 1003. [Death Valley area, Seward Peninsula]

*Dickinson, K.A., Cunningham, K.D., and *Ager, T.A., 1987, Geology and origin of the Death Valley uranium deposit, Seward Peninsula, Alaska: Economic Geology, v. 82, no. 6, p. 1558-1574.

Dillon, J.T., *Harris, A.G., and *Dutro, J.T., Jr., 1987, Preliminary description and correlation of lower Paleozoic fossil-bearing strata in the Snowden Mountain area of the south-central Brooks Range, Alaska: North Slope geology, v. 1, p. 337345 .

*Dinter, David, 1987, Late Quaternary depositional history of the Alaskan Beaufort shelf [abs.]: North Slope geology, v. 1, p. 541.

*Dumoulin, J.A., and *Harris, A.G., 1987, Cambrian through Devonian carbonate rocks of the Baird Mountains, western Brooks Range, Alaska [abs.]: GSA, v. 19, no. 6, p. 373-374.

1987, Lower Paleozoic carbonate rocks of the Baird Mountains quadrangle, western Brooks Range, Alaska: North Slope geology, v. 1, p. 311336.

*Dusel-Bacon, Cynthia, 1987, Metamorphism in Alaska as a key to its tectonic evolution [abs.]: GSA, v. 19 , no. 7 , p. 649 .

*Dutro, J.T., Jr., 1985, The G. William Holmes Research Station, Lake Peters, northeastern Alaska, and its impact on northern research, in Geological Society of America, Centennial Special Volume 1, p. 301-311.

1987 , A brief history of eighty years of geological exploration in the central Brooks Range, northern Alaska: North Slope geology, v. 1, p. 7-11.

1987, Revised megafossil biostratigraphic zonation for the Carboniferous of northern Alaska: North Slope geology, v. 1, p. 359-364.

*Dutro, J.T., Jr., and *Harris, A.G., 1987, Some stratigraphic and paleontologic constraints on tectonic modelling of the Brooks Range, Alaska 
[abs.]: GSA, v. 19 , no. 6 , p. 374 .

Ehm, Arlen, and ${ }^{*}$ Tailleur, I.L., 1987, Refined names for Brookian age elements in northern Alaska [abs.]: North Slope geology, v. 1, p. 432.

Ekstrom, G., and *Engdahl, E.R., 1987, Earthquake source parameters and stress distribution in the Adak Island region of the central Aleutian Islands [abs.]: Eos, v. 68, no. 44, p. 1352.

*Ellersieck, Inyo, 1987, A structural model of the Brooks Range from the stratigraphic viewpoint [abs.]: GSA, v. 19, no. 6, p. 375 .

*Ellersieck, Inyo, and *Mayfield, C.F., 1987, The western Brooks Range, Alaska: Too much crust [abs.]: North Slope geology, v. 2, p. 736. [Reprinted from: GSA, v. 16 , no. 5 , p. 281, 1984.]

*Emery, P.A., and *Seitz, H.R., 1987, Hubbard Glacier is still on the move: Geotimes, v. 32, no. 5, p. 89.

Farmer, G., *Barker, Fred, and *Plafker, George, 1987, A Nd and Sr isotopic study of Mesozoic and early Tertiary granitic rocks in south-central Alaska [abs.]: GSA, v. 19, no. 6, p. 376.

*Fisher, M.A., *Brocher, T.M., *Plafker, George, and * Nokleberg, W.J., 1987, Midcrustal duplexes below the accreted Chugach terrane of southern Alaska, as revealed by seismic reflection data collected for TACT [abs.]: Eos, v. 68, no. 44, p. 1457.

*Fisher, M.A., *von Huene, Roland, and Smith, G.L., 1987, Reflections from midcrustal rocks within the Mesozoic subduction complex near the eastern Aleutian trench: Journal of Geophysical Research, v. 92, no. 8B, p. 7907-7915.

Folger, P.F., and *Schmidt, J.M., 1986, Geology of the carbonate-hosted Omar copper prospect, Baird Mountains, Alaska: Economic Geology, v. 81, no. 7, p. 1690-1695.

1987, Geology of the carbonate-hosted Omar Copper prospect, Baird Mountains, Alaska [abs.]: North Slope geology, v. 1, p. 286. [Reprinted from: Economic Geology, v. 81, p. $1690,1986$.

*Frederiksen, N.O., and *Schindler, K.S., 1987, Campanian to Maastrichtian pollen biostratigraphy and floral turnover rates, Colville River region, North Slope of Alaska [abs.]: American Association of Petroleum Geologists Bulletin, v. 71 , no. 5 , p. 558 .

*Fuis, G.S., *Ambos, E.L., *Mooney, W.D., *Page, R.A., *Fisher, M.A., *Brocher, T.M., and Taber, J.J., 1987, Crustal structure beneath exposed accreted terranes of southern Alaska: Geophysical Journal of the Royal Astronomical Society, v. 89, no. 1, p. 73-78.

*Fuis, G.S., Beaudoin, B., and *Luetgert, J.H., 1987, Seismic refraction/wide angle reflection data from central Alaska: results of the TACT 1987 field season [abs.]: Eos, v. 68, no. 44, p. 14571458.

*Goldfarb, R.J., *Leach, D.L., *Light, T.D., Paterson, C.J., *Pickthorn, L.B., and *Pickthorn, W.J., 1987, The Juneau gold belt: A mother lode-type system in southeastern Alaska [abs.]: GSA, v. 19, no. 6 , p. 382.

*Goldfarb, R.J., *Leach, D.L., *Miller, M.L., and *Pickthorn, W.J., 1986, Geology, metamorphic setting, and genetic constraints of epigenetic lode-gold mineralization within the Cretaceous Valdez Group, south-central Alaska, in Keppie, J.D., Boyle, R.W., and Haynes, S.J., eds., Turbidite-hosted gold deposits: Geological Association of Canada, Special Paper 32, p. 87105.

*Grantz, Arthur, and *Moore, T.E., 1987, Crustal structure of northern Alaska along geodynamics continent/ocean transect (A-3) [abs.]: GSA, v. 19 , no. 6 , p. 383 .

*Grantz, Arthur, *Dinter, D.A., and *Culotta, R.C., 1987, Geology of the continental shelf north of the Arctic National Wildlife Refuge, northeastern Alaska: North Slope geology, v. 2, p. 759-763.

*Gross, W.K., *Savage, J.C., and *Lisowski, M., 1987, Absence of significant deformation in the Shumagin seismic gap, southwest Alaska, 19801987 [abs.]: Eos, v. 68 , no. 44, p. 1351.

*Hamilton, T.D., 1986, Correlation of Quaternary glacial deposits in Alaska, in Sibrava, V., Bowen, D.Q., and Richmond, G.M.M., eds., Quaternary glaciations in the northern hemisphere: New York, Pergamon, p. 171-180. [In Quaternary Science Reviews, v. 5, no. 1-4.]

*Hampton, M.A., 1986, Geotechnical framework study of the Kodiak Shelf, Alaska, in U.S. Department of Commerce, NOAA, OCSE $\overline{A P}$, Final reports of principal investigators v. 48: Minerals Management Service OCS Study, MMS 86-0065, p. 1-94.

*Hampton, M.A., and *Winters, W.J., 1986, Geotechnical framework study of the northern Bering Sea, Alaska, in U.S. Department of Commerce, NOAA, OCSEAP, Final reports of principal investigators v. 50: Minerals Management Service OCS Study, MMS 86-0112, p. 1-386.

*Hampton, M.A., *Carlson, P.R., *Lee, H.J., and Feely, R.A., 1987, Geomorphology, sediment, and sedimentary processes, in Hood, D.W., and Zimmerman, S.T., eds., The Gulf of Alaska, physical environment and biological resources: U.S. Minerals Management Service, OCS Study MMS 86-0095, p. 93-143.

*Harris, A.G., and *Repetski, J.E., 1987, Ordovician conodonts from northern Alaska [abs.]: GSA, v. 19 , no. 3 , p. 169 .

*Harris, A.G., Lane, H.R., *Tailleur, I.L., and *Ellersieck, Inyo, 1987, Conodont thermal maturation patterns in Paleozoic and Triassic rocks, northern Alaska--Geologic and exploration implications: North Slope geology, v. 1, p. 181191.

*Hildreth, Wes, 1987, New perspectives on the eruption of 1912 in the Valley of Ten Thousand Smokes, Katmai National Park, Alaska: Bulletin of Volcanology, v. 49, no. 5, p. 680-693.

*Hildreth, Wes, and *Fierstein, Judy, 1987, Valley of Ten Thousand Smokes, Katmai National Park, Alaska, in Hill, M.L., ed., Centennial Field Guide, v. 1, Cordilleran Section of the Geological Society of America: Geological Society of America, Decade of North American Geology (DNAG), p. 425-432. 
*Hillhouse, J.W., 1987, Accretion of southern Alaska: Tectonophysics, v. 139, no. 1-2, p. 107-122.

*Himmelberg, G.R., *Loney, R.A., and Nabelek, P.I., 1987, Petrogenesis of gabbronorite at Yakobi and northwest Chichagof Islands, Alaska: Geological Society of America Bulletin, v. 98, no. 3, p. 265279.

Hitzman, M.W., Proffett, J.M., Jr., *Schmidt, J.M., and Smith, T.E., 1986, Geology and mineralization of the Ambler district, northwestern Alaska: Economic Geology, v. 81, no. 7, p. 1592-1618.

*Howell, D.G., and *Wiley, T.J., 1987, Crustal evolution of northern Alaska inferred from sedimentology and structural relations of the Kandik area: Tectonies, v. 6, no. 5, p. 619-631.

*Howell, D.G. *Murray, R.W., *Wiley, T.J., *BoundySanders, Susan, *Kauffman-Linam, Linden, and Jones, D.L., 1987, Sedimentology and tectonics of Devonian Nation River Formation, Alaska, part of yet another allochthonous terrane [abs.]: American Association of Petroleum Geologists Bulletin, v. 71 , no. 5 , p. 569 .

*Huggett, Q.J., Somers, M.L., and Stubbs, A.R., 1987, Interference fringes on GLORIA side-scan sonar images from the Bering Sea and their implications [abs.]: Eos, v. 68, no. 44, p. 1375.

Jones, D.L., *Boundy-Sanders, Susan, *Murray, R.W., *Howell, D.G., and *Wiley, T.J., 1987, Tectonic contacts of miogeoclinal strata in east-central Alaska [abs.]: America Association of Petroleum Geolgists Bulletin, v. 71, no. 5, p. 573.

Kamath, A., Godbole, S.P., Ostermann, R.D., and *Collett, T.S., 1987, Evaluation of the stability of gas hydrates in northern Alaska: Cold Regions Science and Technology, v. 14, no. 2, p. 107-119.

*Karl, H.A., and *Carlson, P.R., 1986, Seafloor hazards and related surficial geology, Navarin Basin province, northern Bering Sea, in U.S. Department of Commerce, NOAA, OC $\overline{C S E A P,}$ Final reports of principal investigators v. 50: Minerals Management Service OCS Study 860112, p. 387-636.

*Karl, H.A., *Vallier, T.L., Masson, D., and Underwood, M.B., 1987, Long-range side-scan sonar mosaic of the western Aleutian arc and trench and the adjacent North Pacific seafloor [abs.]: Eos, v. 68 , no. 44 , p. $1485-1486$.

*Karl, S.M., and *Long, C.L., 1987, Evidence for tectonic truncation of regional east-west trending structures in the central Baird Mountains quadrangle, western Brooks Range, Alaska [abs.]: GSA, v. 19, no. 6, p. 392 .

*Kayen, R.E., and *Lee, H.J., 1987, Arctic Ocean landslides and gas-hydrate decomposition [abs.]: Eos, v. 68 , no. 44 , p. 1285 .

*Kelley, J.S., and *Molenaar, C.M., 1987, Detachment tectonics in the Sadlerochit and Shublik Mountains and applications for exploration beneath the coastal plain, Arctic National Wildlife Refuge, Alaska [abs.]: North Slope geology, v. 2, p. 757 .

*Kelley, J.S., *Brosge, W.P., and *Reynolds, M.W., 1987, Fold-nappes and polyphase thrusting in the north-central Brooks Range, Alaska [abs.]: North Slope geology, v. 2, p. 647.

Kennedy, G.L., Hopkins, D.M., and *Pickthorn, W.J.,
1987, Ikaite, the glendonite precursor, in estuarine sediments at Barrow, arctic Alaska [abs.]: GSA, v. 19 , no. 7 , p. 725 .

*Krimmel, R.M., and *Vaughn, B.H., 1987, Columbia Glacier, Alaska: Changes in velocity 19771986: Journal of Geophysical Research, v. 92, no. 9B, p. 8961-8968.

*Lachenbruch, A.H., *Sass, J.H., Lawver, L.A., *Brewer, M.C., *Marshall, B.V., *Munroe, R.J., *Kennelly, J.P., Jr., *Galanis, S.P., Jr., and *Moses, T.H., Jr., 1987, Temperature and depth of permafrost on the Alaskan arctic slope: North Slope geology, v. 2, p. 545-558.

*Lahr, J.C., and *Stephens, C.D., 1986, Earthquake activity and ground shaking in and along the eastern Gulf of Alaska, in U.S. Department of Commerce, NOAA, OCSEAP, Final reports of principal investigators v. 49: Minerals Management Service, OCS Study MMS 86-0111, p. 29-83.

Lange, I.M., and *Nokleberg, W.J., 1987, Geologic setting, petrology, and geochemistry of stratiform sphalerite-galena-barite deposits, Red Dog Creek and Drenchwater Creek areas, northwestern Brooks Range, Alaska--A reply: Economic Geology, v. 82, no. 4, p. 1079-1081. [See also: Young, L.E., and Moore, D.W., 1987, "***--A discussion": Economic Geology, v. 82, no. 4, p. 1077-1079.]

*Leach, D.L., *Goldfarb, R.J., and *Hofstra, A.H., 1987, Fluid inclusion characteristics of the Juneau gold belt, southeastern Alaska [abs.]: GSA, v. 19 , no. 6 , p. 398 .

*Lee, H.J., and *Schwab, W.C., 1986, Geotechnical framework, northeast Gulf of Alaska, in U.S. Department of Commerce, NOAA, OCSEAP, Final reports of principal investigators v. 48: Minerals Management Service OCS Study, MMS 86-0065, p. 95-547.

*Lisowski, M., *Savage, J.C., and *Burford, R.O., 1987, Strain accumulation across the Fairweather and Totschunda faults, Alaska: Journal of Geophysical Research, v. 92, no. B11, p. 11,55211,560 .

Little, T.A., and *Naeser, C.W., 1987, Implications of apatite and zircon fission track ages for the thermal history of Paleogene rocks along the Border Ranges fault system, southern Alaska [abs.]: GSA, v. 19, no. 7, p. 748 .

*McDougall, Kristin, 1987, Maestrichtian benthic foraminifers from Ocean Point, North Slope, Alaska: Journal of Foraminiferal Research, v. 17, no. 4, p. 344-366.

*Magoon, L.B., and *Anders, D.E., 1987, Petroleum geochemistry of oils and rocks in Arctic National Wildlife Refuge, Alaska [abs.]: American Association of Petroleum Geologists Bulletin, v. 71 , no. 5 , p. 587 .

*Magoon, L.B., *Bird, K.J., 1987, Alaskan North Slope petroleum geochemistry for the Shublik Formation, Kingak Shale, Pebble Shale Unit, and Torok Formation: North Slope geology, v. 1, p. 145-160. [Reprinted from: Magoon, L.B., and Claypool, G.E., eds., 1985, Alaska North Slope oil/rock correlation study: American Association of Petroleum Geologists, Studies in Geology no. 
20, p. 31-48.]

*Mayfield, C.F., *Tailleur, I.L., and *Ellersieck, Inyo, 1987, Stratigraphy, structure, and palinspastic synthesis of the western Brooks Range, northwestern Alaska [abs.]: North Slope geology, v. 2, p. 735. [Reprinted from: USGS Open-File Report 83-779, p.1, 1983.]

Mechan, G.A., and *Fuis, G.S., 1987, Ray equation migration of wide-angle reflections from southern Alaska: Journal of Geophysical Research, v. 92, no. B1, p. 407-420.

Meier, M.F., and *Post, Austin, 1987, Fast tidewater glaciers: Journal of Geophysical Research, v. 92, no. 9B, p. 9051-9058. [Columbia Glacier]

*Miller, T.P., and *Smith, R.L., 1987, Late Quaternary caldera-forming eruptions in the eastern Aleutian arc, Alaska: Geology, v. 15, no. 5, p. 434-438.

*Molenaar, C.M., *Bird, K.J., and Kirk, A.R., 1987, Cretaceous and Tertiary stratigraphy of northeastern Alaska: North Slope geology, v. 1, p. 513-528.

*Molenaar, C.M., Mull, C.G., and Swauger, D.A., 1987, Geologic features of Ignek Valley and adjacent mountains, northeastern Alaska, in Hill, M.L., ed., Centennial Field Guide, v. $\overline{1}$, Cordilleran Section of the Geological Society of America: Geological Society of America, Decade of North American Geology (DNAG), p. 473-478.

*Molnia, B.F., *Luepke, Gretchen, and *Hein, J.R., 1987, Synoptic clay mineralogy of the Copper River drainage system, Alaska [abs.]: GSA, v. 19, no. 7 , p. 775-776.

*Moore, T.E., 1987, Geochemical and tectonic affinity of basalts from the Copter Peak and Ipnavik River allochthons, Brooks Range, Alaska [abs.]: GSA, v. 19 , no. 6 , p. 434 .

---- 1987, Geochemistry and tectonic setting of some volcanic rocks of the Franklinian assemblage, central and eastern Brooks Range, Alaska: North Slope geology, v. 2, p. 691-710.

Moore, T.E., *Brosge, W.P., Churkin, Michael, Jr., and Wallace, W.K., 1987, Pre-Mississippian accreted terranes of northeastern Brooks Range, Alaska [abs.]: North Slope geology, v. 2, p. 711.

*Moore, T.E. Roeske, S.M., and *Grantz, Arthur, 1987, Crustal structure of central Alaska along geodynamics continent/ocean transect (A-3) [abs.]: GSA, v. 19 , no. 6 , p. 434 .

Mull, C.G., Roeder, D.H., *Tailleur, I.L., Pessel, G.H., *Grantz, Arthur, and *May, S.D., 1987, Geologic sections and maps across Brooks Range and Arctic Slope to Beaufort Sea, Alaska: Geological Society of America Map and Chart Series MCH28S, 1 sheet.

*Nelson, C.H., and *Johnson, K.R., 1987, Whales and walruses as tillers of the sea floor: Scientific American, v. 256, no. 2, p. 112-117. [Study area is NE Bering Sea]

*Nelson, C.H., *Johnson, K.R., and *Barber, J.H., Jr., 1987, Gray whale and walrus feeding excavation on the Bering shelf, Alaska: Journal of Sedimentary Petrology, v. 57, no. 3, p. 419-430.

Nelson, R.E., and *Carter, L.D., 1987, Paleoenvironmental analysis of insects and extralimital Populus from an early Holocene site on the Arctic Slope of Alaska, U.S.A.: Arctic and Alpine Research, v. 19, no. 3, p. 230-241.

*Nelson, S.W., and *Koski, R.A., 1987, The Midas Mine--A stratiform $\mathrm{Fe}-\mathrm{Cu}-\mathrm{Zn}-\mathrm{Pb}$ sulfide deposit in Late Cretaceous turbidite near Valdez, Alaska [abs.]: GSA, v. 19 , no. 6 , p. 436 .

*Nelson, S.W., *Miller, M.L., and *Dumoulin, J.A., 1987, Resurrection Peninsula and Knight Island ophiolites and recent faulting on Montague Island, southern Alaska, in Hill, M.L., ed., Centennial Field Guide, v. 1, Cordilleran Section of the Geological Society of America: Geological Society of America, Decade of North American Geology (DNAG), p. 433-438.

*Newberry, J.T., Laclair, D.L., and Fujita, Kazuya, 1986, Seismicity and tectonics of the far western Aleutian Islands: Journal of Geodynamics, v. 6, no. 1-4, p. 13-32.

Nilsen, T.H., and *Moore, T.E., 1987, Tectonic significance of the Kanayut Conglomerate and related middle Paleozoic deposits, Brooks Range, Alaska [abs.]: North Slope geology, v. 2, p. 711.

*Nokleberg, W.J., and *Plafker, George, 1987, Structure and tectonics of southern Alaska along the Trans-Alaska Crustal Transect (TACT) [abs.]: Eos, v. 68 , no. 44 , p. 1456 .

*Orth, D.J., 1987, North Slope geographic-name sources for geologic nomenclature: North Slope geology, v. 2, Appendix 3, p. 847-854. [Reprinted from: Adkison, W.L., and Brosge, M.M., eds., 1970 , Proceedings of the Seminar on the North Slope of Alaska: Los Angeles, Calif., American Association of Petroleum Geologists, Pacific Section, p. R1-R10.]

*Page, R.A., *Stephens, C.D., *Lahr, J.C., and *Fogleman, K.A., 1987, The transition between the Aleutian and Wrangell Wadati-Benioff zones, southern Alaska [abs.]: Eos, v. 68, no. 44, p. 1456-1457.

*Parrish, J.T., 1987, Lithology, geochemistry, and depositional environment of the Triassic Shublik Formation, northern Alaska: North Slope geology, v. 1, p. 391-396.

*Patton, W.W., Jr., *Stern, T.W., *Arth, J.G., and Carlson, Christine, 1987, New $\mathrm{U} / \mathrm{Pb}$ ages from granite and granite gneiss in the Ruby geanticline and southern Brooks Range, Alaska: Journal of Geology, v. 95 , no. 1, p. 118-126.

Petersen, J.K., Kawasaki, Koji, Osterkamp, T.E., and *Scott, J.H., 1987, Nuclear well-logging in permafrost [abs.]: North Slope geology, v. 2, p. 570.

*Phillips, Larry, *Barnes, Peter, *Reimnitz, Erk, and *Hunter, Ralph, 1986, Geologic processes and hazards of the Beaufort and Chukchi Sea shelf and coastal regions, in U.S. Department of Commerce, NOAA, OCSEAP, Final reports of principal investigators v. 52: Minerals Management Service OCS Study, MMS 86-0114, p. 343-820.

*Phillips, $\quad$ R.L., 1986, Current-dominated sedimentation in the northeastern Chukchi Sea, Alaska [abs.], in Knight, R.J., and McLean, J.R., eds., Shelf sands and sandstones: Calgary, Alberta, Canadian Society of Petroleum Geologists, p. 336-337.

*Phillips, R.L., 1987, Late Cretaceous to early 
Tertiary deltaic to marine sedimentation, North Slope, Alaska [abs.]: American Association of Petroleum Geologists Bulletin, v. 71, no. 5, p. 601.

*Pickthorn, W.J., 1987, Stable isotope characteristics of the Juneau gold belt, Alaska [abs.]: GSA, v. 19 , no. 6 , p. 440 .

Plumley, P.W., and *Tailleur, I.L., 1987, Paleomagnetic results from the Sadlerochit and Shublik Mountains, eastern North Slope, Alaska [abs.]: North Slope geology, v. 2, p. 580.

Roeske, S.M., *Moore, T.E., and *Grantz, Arthur, 1987, Crustal structure of southern Alaska along geodynamics continent/ocean transect (A-3) [abs.]: GSA, v. 19, no. 6, p. 444.

*Ryan, H.F., and *Scholl, D.W., 1987, Deformational effects and the lateral transport of arc basement rocks along the central Aleutian oblique convergence zone [abs.]: Eos, v. 68, no. 44, p. 1486.

*Sable, E.G., and *Stricker, G.D., 1987, Coal in the National Petroleum Reserve in Alaska (NPRA): framework geology and resources: North Slope geology, v. 1, p. 195-215.

*Schmidt, J.M., 1986, Stratigraphic setting and mineralogy of the Arctic volcanogenic massive sulfide propsect, Ambler district, Alaska: Economic Geology, v. 81, no. 7, p. 1619-1643.

1987, The Ambler sequence at Arctic Ridge, Ambler district, Alaska, in Hill, M.L., ed., Centennial Field Guide, v. 1, Cordilleran Section of the Geological Society of America: Geological Society of America, Decade of North American Geology (DNAG), p. 463-468.

*Scholl, D.W., and *Stevenson, Andrew, 1987, Ocean margin tectonics and North Pacific paleoceanography--wonderments about the effects of the Pacific-Bering Sea connection [abs.]: International Conference on Pacific Neogene Stratigraphy, 4th, Berkeley, Calif., 1987, Abstract Volume, p. 95-97.

*Sloan, C.E., 1987, Water resources of the North Slope, Alaska: North Slope geology, v. 1, p. 233252.

Spicer, R.A., *Wolfe, J.A., and *Nichols, D.J., 1987, Alaskan Cretaceous-Tertiary floras and arctic origins: Paleobiology, v. 13, no. 1, p. 73-83.

*Stanley, R.G., 1987, Petroleum resource potential and thermal maturity of Cantwell Formation (Paleocene), central Alaska Range: A reconnaissance study [abs.]: American Association of Petroleum Geologists Bulletin, v. 71 , no. 5 , p. 617-618.

*Tailleur, I.L., 1987, Arguments for Cretaceous instead of Devonian plutonism in the Brooks Range, northern Alaska [abs.]: North Slope geology, v. 2, p. 724. [Reprinted from: GSA Abstracts with Programs, v. 16, p. 336, 1984.]

*----- 1987, One presumptive paleogeography for the Phanerozoic of what is now the North American Arctic [abs.]: North Slope geology, v. 2, p. 831. [Reprinted from: GSA, v. 16, p. 336.]

*----- 1987, A rationalization of the Koyukuk "crunch," northern and central Alaska [abs.]: North Slope geology, v. 2, p. 832. [Reprinted from: American Association of Petroleum
Geologists Bulletin, v. 64, p. 792, 1980.]

1987, What Brooks Range collision, continental margins? [abs.]: GSA, v. 19, no. 6, p. 456.

*Tailleur, Irv, and Weimer, Paul, eds., 1987, Alaskan North Slope geology: Bakersfield, Calif., Society of Economic Paleontologists and Mineralogists, Pacific Section, 2 v., 3 pls.

*Till, A.B., *Schmidt, J.M., and *Nelson, S.W., 1987, Thrust-involvement of Proterozoic and Mesozoic metamorphic rocks, southwestern Brooks Range, Alaska [abs.]: GSA, v. 19, no. 6, p. 458 .

*Torresan, M.E., and *Schwab, W.C., 1987, Fabric and its relation to sedimentologic and physical properties of near-surface sediment, Shelikof Strait and Alsek prodelta, Alaska: Journal of Sedimentary Petrology, v. 57, no. 3, p. 408-418.

Underwood, M.B., *Karl, H.A., *Vallier, T.L., and Masson, D., 1987, Sedimentation within the Amchitka-Attu corridor of the Aleutian trench [abs.]: Eos, v. 68, no. 44, p.1486.

*Vallier, T.L., *Karl, H.A., and Underwood, M.B., 1987, Geologic framework of the western Aleutian arc and adjacent North Pacific seafloor [abs.]: Eos, v. 68 , no. 44, p. 1486.

*Wahrhaftig, Clyde, 1987, The Cenozoic section at Suntrana, Alaska, in Hill, M.L., ed., Centennial Field Guide, v. 1, Cordilleran Section of the Geological Society of America: Geological Society of America, Decade of North American Geology (DNAG), p. 445-450.

Walker, K.-M., York, James, and *Murphy, Dennis, 1987, Identifying water sources on the North Slope, Alaska for geologic exploration [abs.]: North Slope geology, v. 1, p. 253.

*Walters, R.A., and Dunlap, W.W., 1987, Analysis of time series of glacier speed; Columbia Glacier, Alaska: Journal of Geophysical Research, v. 92, no. 9B, p. 8969-8975.

*Wiley, T.J., and *Howell, D.G., 1987, Three formations interpreted as westerly scoured submarine fans, Kandik area, east-central Alaska [abs.]: Eos, v. 68 , no. 44 , p. 1457 .

*Wiley, T.J., *Howell, D.G., *Kauffman-Linam, Linden, *Boundy-Sanders, Susan, *Murray, R.W., and Jones, D.L., 1987, Kandik basin stratigraphy, sedimentology, and structure [abs.]: American Association of Petroleum Geologists Bulletin, v. 71 , no. 5 , p. 627 .

*Wilson, F.H., and *Shew, Nora, 1987, K-Ar age discordancy in Quaternary volcanic rocks [abs.]: Eos, v. 68 , no. 44 , p. 1287 .

*Wolfe, J.A., and Tanai, Toshimasa, 1987, Systematics, phylogeny, and distribution of Acer (maples) in the Cenozoic of western North America: Journal of the Faculty of Science, Hokkaido University, Japan, Series IV Geology and Mineralogy, v. 22, no. 1, 246 p. [Includes sections on Alaska.]

*Wolfe, J.A., and Upchurch, G.R., Jr., 1987, North American nonmarine climates and vegetation during the Late Cretaceous: Palaeogeography, Palaeoclimatology, Palaeoecology, v. 61, no. 1-2, p. 33-77. [Includes section on Alaska.]

*Woodward, P.V., 1987, Regional evaluation of formation fluid salinity by SP log, Ivishak Sandstone, North Slope, Alaska [abs.]: American 
Association of Petroleum Geologists Bulletin, v. 71 , no. 5 , p. 629 .

*Zen, E-an, 1986, Magmatic-epidote-bearing tonalitic plutons in the western Cordillera and their tectonic significance [abs.], in International Mineralogical Association, General Meeting, 14th, Stanford University, Stanford, Calif., 1986,
Abstracts with Programs, p. 279.

*Zierenberg, R.A., and *Schmidt, J.M., 1987, Subsurface mineralization and sulfur isotope systematics at the Red Dog $\mathrm{Zn}-\mathrm{Pb}-\mathrm{Ag}$ deposit, Noatak district, Alaska [abs.]: GSA, v. 19, no. 7, p. 905 . 


\section{Subject Index}

COAL

Mineralogy and Stage Assignment of Some Tertiary Coal from the Tikishla Park Drill Hole, Anchorage, Alaska G.D. Stricker, M.E. Brownf ield, L.A. Yehle, and J.A. Wolfe 121

\section{ECONOMIC}

$\mathrm{H}_{2}$ S-Rich Vein-Forming Fluids at the Sumdum Chief Gold Mine, Southeastern Alaska Richard J. Goldfarb, Albert H. Hof stra, Gary P. Landis, and David L. Leach 160

Reconnaissance Geochemical Investigations of the White Mountains National Recreation Area, East-Central Alaska Thomas D. Light, Gregory K. Lee, Richard B. Tripp, and Elizabeth A. Bailey 64

Mineral Resource Assessment for Part of the White Mountains National Recreation Area Richard B. McCammon, Thomas D. Light, and C. Dean Rinehart 71

Alteration Zoning and Origin of the Alaska-Juneau Gold Deposit Rainer J. Newberry and David A. Brew 174

Gold Mineralization by Metamorphic Fluids in the Chandalar District, Southern Brooks Range--Fluid Inclusion and Oxygen-Isotopic Evidence

Scott C. Rose, William J. Pickthorn, and Richard J. Goldfarb 81

\section{GEOCHEMISTRY}

Geochemical Anomalies in the Eastern Katmai Region of the Alaska Peninsula Richard J. Goldfarb, John E. Gray, and R.B. Tripp 132

Factor Analysis of the NURE Stream-Sediment and Lake-Sediment Geochemical Data from the Iditarod Quadrangle

John E. Gray, Sarah C. Smith, and Richard J. Goldfarb 86

Tertiary Gold-Bearing Gravel at Livengood, Alaska Susan M. Kar 1, Thomas A. Ager, Kar 1 Hanneman, and Steve D. Teller 61

Reconnaissance Geochemical Investigations of the White Mountains National Recreation Area, East-Central Alaska

Thomas D. Light, Gregory K. Lee, Richard B. Tripp, and Elizabeth A. Bailey 64

\section{GEOCHRONOLOGY}

Petrogenesis of the Crooked Mountains Pluton, Bethel Quadrangle: A Preliminary Report Thomas P. Frost, James P. Calzia, Ronald W. Kistler, and Davison V. Vivit 126

New K-Ar Ages for Plutons on Western Chichagof Island and on Yakobi Island Susan M. Kar 1, Bruce R. Johnson, and Marvin A. Lanphere 164

\section{GEOPHYSICS}

A Thermal Cross Section for the Permafrost and Hydrate Stability Zones in the Kuparuk and Prudhoe Bay Oil Fields

Arthur H. Lachenbruch, S. Peter Galanis, Jr., and Thomas H. Moses, Jr. 48 


\section{MARINE}

Construction of an Arctic Barrier Island by Alternating Sea-Ice Pileup and Overwash

P.W. Barnes and Erk Reimnitz 180

Nearshore Marine Environments of the Alaskan Beaufort Sea During Deposition of the Flaxman Member of the Gubik Formation

L. David Carter, Elisabeth M. Brouwers, and Louie Marincovich, Jr. 27

Sea-Floor Feeding Traces of Gray Whales and Walrus in the Northeast Chukchi Sea

R. Lawrence Phillips and Mitchell W. Colgan 183

Late Cretaceous Sediments from the Northeast Chukchi Sea

R. Lawrence Phillips, LedaBeth G. Pickthorn, and Douglas M. Rearic 187

Evidence for Sea-Ice Impact on Icy Reef, Beaufort Sea Coast

Erk Reimnitz and P.W. Barnes 190

\section{PALEONTOLOGY/MICROPALEONTOLOGY}

A Major Unconformity Between Upper Ordovician and Lower Devonian Strata in the Nanook Limestone, Shublik Mountains, Northeastern Brooks Range

Robert B. Blodgett, David M. Rohr, Anita G. Harris, and Rong Jia-yu 18

A Late Silurian Age Determination for the Limestone of the Lost Creek Unit, Livengood

C-4 Quadrangle, East-Central Alaska

Robert B. Blodgett, Ning Zhang, Allen R. Ormiston, and Florence R. Weber 54

Megafossils (Buchia) Indicate Late Jurassic Age for Part of Kelp Bay Group on Baranof Island, Southeastern Alaska

David A. Brew, Susan M. Kar1, and John W. Miller 147

Ostracode and Molluscan Assemblages from the Late Neogene Nuwok Member of the Sagavanirktok Formation, North Slope

El isabeth M. Brouwers and Louie Marincovich, Jr. 24

Nearshore Marine Environments of the Alaskan Beaufort Sea During Deposition of the Flaxman Member of the Gubik Formation

L. David Carter, Elisabeth M. Brouwers, and Louie Marincovich, Jr. 27

Off-Platform Silurian Sequences in the Ambler River Quadrangle

Julie A. Dumoulin and Anita G. Harris 35

\section{PETROLEUM GEOLOGY}

A Thermal Cross Section for the Permafrost and Hydrate Stability Zones in the Kuparuk and Prudhoe Bay Oil Fields

Arthur H. Lachenbruch, S. Peter Galanis, Jr., and Thomas H. Moses, Jr. 48

Hydrocarbon Source Potential and Thermal Maturity of the Sanctuary Formation (Middle Miocene), Northern Foothills of the Alaska Range

Richard G. Stanley 117

\section{PETROLOGY - IGNEOUS}

Middle Pennsylvanian Plutonic Rocks Along the Southern Margin of the Wrangellia Terrane John N. Aleinikoff, George Plafker, and Warren J. Nokleberg 110

Major-Element Geochemistry of Metabasalts of the Juneau-Haines Region, Southeastern Alaska Arthur B. Ford and David A. Brew 150

Petrogenesis of the Crooked Mountains Pluton, Bethel Quadrangle: A Preliminary Report Thomas P. Frost, James P. Calzia, Ronald W. Kistler, and Davison V. Vivit 126 
New K-Ar Ages for Plutons on Western Chichagof Island and on Yakobi Island

Susan M. Kar 1, Bruce R. Johnson, and Marvin A. Lanphere 164

Ultramafic Rocks of the Livengood Terrane

Robert A. Loney and Glen R. Himmelberg 68

Geochemistry and Petrography of Lamprophyre Dike Rocks in the Coast Mountains, Southeastern Alaska John S. Lull and George Plafker 169

\section{PETROLOGY - METAMORPHIC}

Relative Timing of Porphyroblast Growth, Foliation Development, and Ductile Shear in Pelitic Metamorphic Rocks from the Juneau Area, Southeastern Alaska 138

Robert L. Bauer, Glen R. Himmelberg, David A. Brew, and Arthur B. Ford

Geologic Setting and Petrography of the Phyllite and Metagraywacke Thrust Panel, North-Central Alaska John M. Murphy and W.W. Patton, Jr. 104

\section{PETROLOGY - SEDIMENTARY}

A Comparative Petrologic Study of Sandstone from the Wilber Creek, Cascaden Ridge, and Wickersham Units in the Livengood Quadrangle L.D. Gergen, J.E. Decker, and George Plafker 57

Petrography of Sandstones of the Orca Group from the Southern Trans-Alaskan Crustal Transect (TACT) Route and Montague Island

L.D. Gergen and George Plafker 156

\section{QUATERNARY GEOLOGY}

Nearshore Marine Environments of the Alaskan Beaufort Sea During Deposition of the Flaxman Member of the Gubik Formation

L. David Carter, Elisabeth M. Brouwers, and Louie Marincovich, Jr. 27

Late Wisconsin Eolian Activity and Related Alluviation, Central Kobuk River Valley

Thomas D. Hamilton, John P. Galloway, and Eduard A. Koster 39

Glacial Geologic History of the Salmon Lake Area, Seward Peninsula

Darrell S. Kaufman, David M. Hopkins, and Parker E. Calk in 91

Advance of Hubbard Glacier and Closure of Russell Fiord, Alaska--Environmental Effects and Hazards in the Yakutat Area

Lawrence R. Mayo 4

Source of the Sanford Volcanic Debris Flow, South-Central Alaska

Donald H. Richter, Henry R. Schmoll, and Dana J. Bove 114

\section{SEDIMENTOLOGY}

Construction of an Arctic Barrier Island by Alternating Sea-Ice Pileup and Overwash

P.W. Barnes and Erk Reimnitz 180

A Major Unconformity Between Upper Ordovician and Lower Devonian Strata in the Nanook Limestone, Shublik Mountains, Northeastern Brooks Range Robert B. Blodgett, David M. Rohr, Anita G. Harris, and Rong Jia-yu 18

A Late Silurian Age Determination for the Limestone of the Lost Creek Unit, Livengood

C-4 Quadrangle, East-Central Alaska

Robert B. Blodgett, Ning Zhang, Allen R. Ormiston, and Florence R. Weber 54

Stromatolite- and Coated-Grain-Bearing Carbonate Rocks of the Western Brooks Range Julie A. Dumoulin 31

Off-Platform Silurian Sequences in the Ambler River Quadrangle Julie A. Dumoul in and Anita G. Harris 35 
Stratigraphy, Sedimentology, and Structure of the Wickersham Terrane in the Cache Mountain Area, EastCentral Alaska

Thomas E. Moore and Warren J. Nokleberg 75

\section{STRATIGRAPHY}

A Major Unconformity Between Upper Ordovician and Lower Devonian Strata in the Nanook Limestone, Shublik Mountains, Northeastern Brooks Range Robert B. Blodgett, David M. Rohr, Anita G. Harris, and Rong Jia-yu 181

A Late Silurian Age Determination for the Limestone of the Lost Creek Unit, Livengood

C-4 Quadrangle, East-Central Alaska Robert B. Blodgett, Ning Zhang, Allen R. Ormiston, and Florence R. Weber 54

A Reexamination of the Contacts and other Features of the Gravina Belt, Southeastern Alaska David A. Brew and Susan M. Karl 143

Stromatolite- and Coated-Grain-Bearing Carbonate Rocks of the Western Brooks Range Julie A. Dumoulin 31

Off-Platform Silurian Sequences in the Ambler River Quadrangle Julie A. Dumoulin and Anita G. Harris 35

Tertiary Gold-Bearing Gravel at Livengood, Alaska

Susan M. Kar 1, Thomas A. Ager, Karl Hanneman, and Steve D. Teller 61

Right-Lateral Offset Solution for the Iditarod-Nixon Fork Fault, Western Alaska Marti L. Miller and Thomas K. Bundtzen 99

Stratigraphy, Sedimentology, and Structure of the Wickersham Terrane in the Cache Mountain Area, EastCentral Alaska Thomas E. Moore and Warren J. Nokleberg 75

Geologic Setting and Petrography of the Phyllite and Metagraywacke Thrust Panel, North-Central Alaska John M. Murphy and W.W. Patton, Jr. 104

Hydrocarbon Source Potential and Thermal Maturity of the Sanctuary Formation (Middle Miocene), Northern Foothills of the Alaska Range

Richard G. Stanley 117

\section{STRUCTURAL/TECTONICS}

Relative Timing of Porphyroblast Growth, Foliation Development, and Ductile Shear in Pelitic Metamorphic Rocks from the Juneau Area, Southeastern Alaska Robert L. Bauer, Glen R. Himme lberg, David A. Brew, and Arthur B. Ford 138

A Reexamination of the Contacts and other Features of the Gravina Belt, Southeastern Alaska David A. Brew and Susan M. Karl 143

Megafossils (Buchia) Indicate Late Jurassic Age for Part of Kelp Bay Group on Baranof Island, Southeastern Alaska

David A. Brew, Susan M. Karl, and John W. Miller 147

Decollements in the Endicott Mountains Allochthon, North-Central Brooks Range

J.S. Kelley and Diedra Bohn 44

Right-Lateral Offset Solution for the Iditarod-Nixon Fork Fault, Western Alaska

Marti L. Miller and Thomas K. Bundtzen 99

Stratigraphy, Sedimentology, and Structure of the Wickersham Terrane in the Cache Mountain Area, EastCentral Alaska

Thomas E. Moore and Warren J. Nokleberg 75 


\section{VOLCANOLOGY}

Lahar Deposit in the Iditarod Voleanics, Southwestern Iditarod Quadrangle Robert G. McGimsey and Marti L. Miller 95

Source of the Sanford Volcanic Debris Flow, South-Central Alaska Donald H. Richter, Henry R. Schmol1, and Dana J. Bove 114 


\section{Author Index}

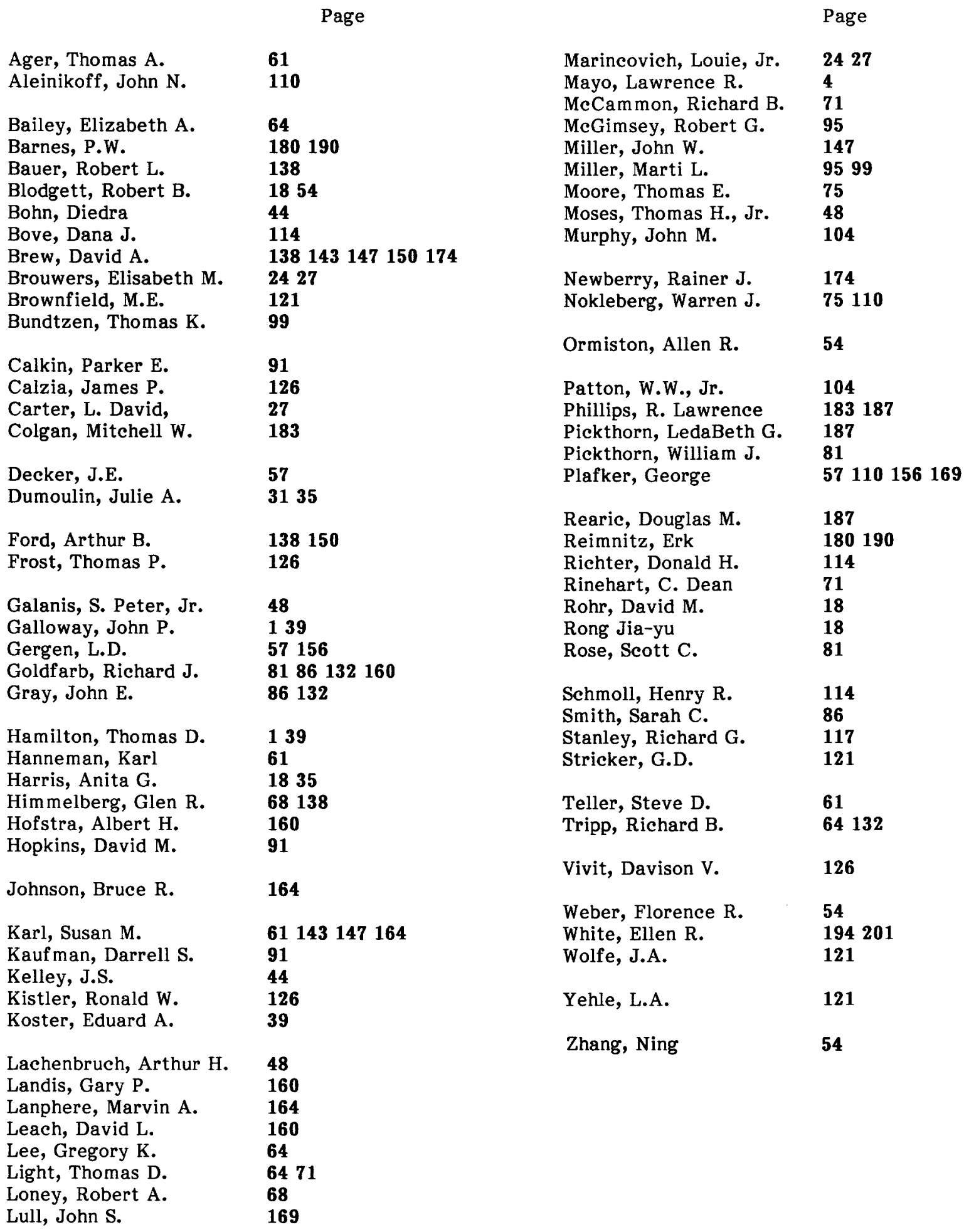




\section{Authors' Addresses}

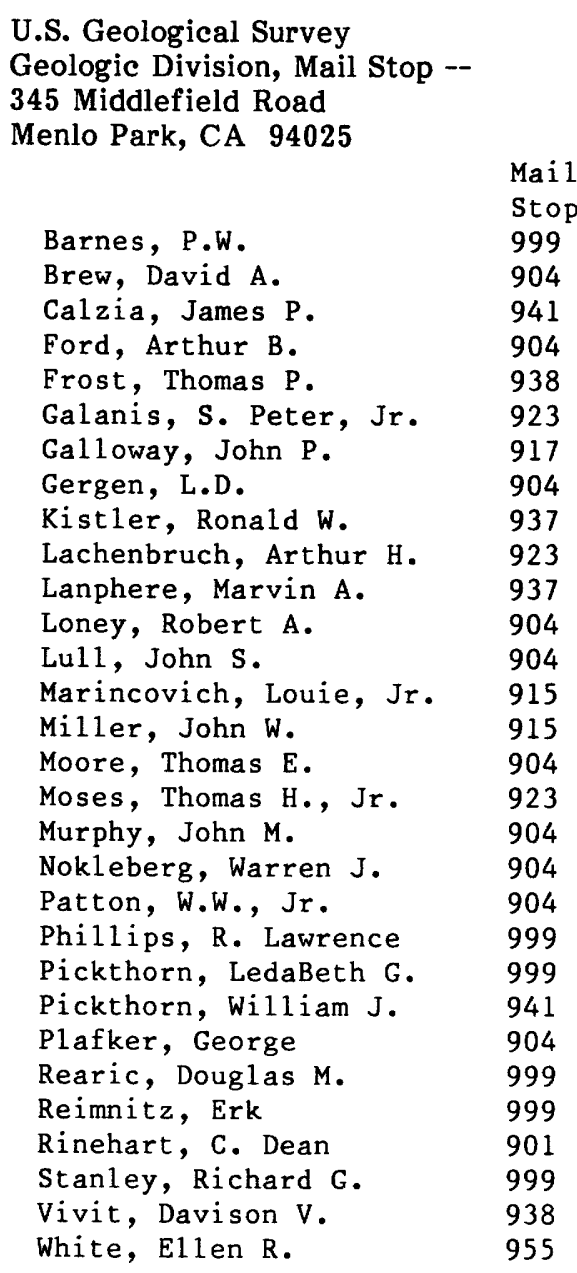

\footnotetext{
U.S. Geological Survey

Branch of Alaskan Geology 4200 University Drive Anchorage, AK 99508-4667

Bailey, Elizabeth A. Bohn, Diedra

Carter, L. David

Dumoulin, Julie A.

Hamilton, Thomas D.

Kelley, J.S.

Light, Thomas D.

McGimsey, Robert G.

Miller, Marti L.
}

\author{
U.S. Geological Survey \\ Branch of Alaskan Geology \\ PO Box 80586 \\ Fairbanks, AK 99708 \\ Karl, Susan M. \\ Weber, Florence R. \\ U.S. Geological Survey \\ Geologic Division, Mail Stop -- \\ Box 25046, DFC \\ Denver, CO 80225

$\begin{array}{ll} & \text { Mail } \\ \text { Stop } & 963 \\ \text { Aleinikoff, John N. } & 905 \\ \text { Bove, Dana J. } & 919 \\ \text { Brouwers, Elisabeth M. } & 972 \\ \text { Brownfield, M.E. } & 973 \\ \text { Goldfarb, Richard J. } & 973 \\ \text { Gray, John E. } & 973 \\ \text { Hofstra, Albert H. } & 972 \\ \text { Johnson, Bruce R. } & 905 \\ \text { Landis, Gary P. } & 973 \\ \text { Leach, David L. } & 973 \\ \text { Lee, Gregory K. } & 973 \\ \text { Rose, Scott C. } & 972 \\ \text { Schmoll, Henry R. } & 973 \\ \text { Smith, Sarah C. } & 972 \\ \text { Stricker, G.D. } & 973 \\ \text { Tripp, Richard B. } & 972 \\ \text { Wolfe, J.A. } & 919 \\ \text { Yehle, L.A. } & \end{array}$

U.S. Geological Survey

National Center, Mail Stop -12201 Sunrise Valley Drive

Reston, VA 22092

$\begin{array}{ll} & \text { Mail } \\ & \text { Stop } \\ \text { Ager, Thomas A. } & 970 \\ \text { McCammon, Richard B. } & 920\end{array}$

U.S. Geological Survey

Museum Natural History E-503

Washington, D.C. 20560

Harris, Anita G. 


\section{U.S. Geological Survey}

Water Resources Divison

Cold Regions Hydrology Project Office

800 Yukon Drive

Fairbanks, AK 99775-5150

Mayo, Lawrence $\mathrm{R}$.

\section{U.S. Geological Survey}

Box 79

Winston, NM 87943

Richter, Donald H.

Alaska Division of Geological and Geophysical Surveys 794 University Avenue

Fairbanks, AK 99709

Bundtzen, Thomas $\mathrm{K}$.

Decker, J.E.

Alaska Placer Development Inc.

Fairbanks, AK 99708

Hanneman, Kar1

Amoco Production Company

Research Center

4502 E. 41st Street

P.O. Box 3385

Tulsa, OK 74102

Ormiston, Allen R.

Geographical Institute

University of Utrecht

Heidelberglaan 2

3584 CS Utrecht

The Netherlands

Koster, Eduard A.

Nanjing Institute of Geology and Paleontology

Academia Sinica

Chi-Ming-Ssu

Nanjing, People's Republic of China

Rong Jia-yu
Oregon State University

Department of Geology

Corvallis, OR 97331

Blodgett, Robert B.

Zhang, Ning

State University of New York at Buffalo

Department of Geology

4240 Ridge Lea Road

Buffalo, NY 14226

Calkin, Parker E.

Sul Ross State University

Department of Gelogy

Alpine, TX 79832

Rohr, David M.

University of Alaska

Department of Geology and Geophysics

Fairbanks, AK 88775-0760

Hopkins, David M.

Newberry, Rainer J.

Teller, Steve D.

University of Colorado

Institute of Arctic and Alpine Research

Campus Box 450

Boulder, CO 80309

Kaufman, Darrel1 s.

University of Missouri

Department of Geology

Columbia, MO 65211

Bauer, Robert L.

Himmelberg, Glen $\mathrm{R}$.

University of Santa Cruz

Earth Sciences Board

Santa Cruz, CA 95064

Colgan, Mitchell W. 

